\title{
New Bern Biomass to Energy Project Phase I: Feasibility Study
}

Stone \& Webster, Weyerhauser, Amoco, and Carolina Power \& Light

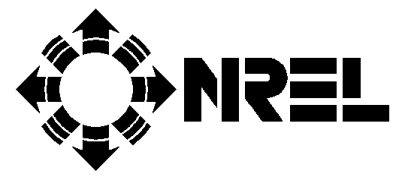

National Renewable Energy Laboratory 1617 Cole Boulevard Golden, Colorado 80401-3393

A national laboratory of the U.S. Department of Energy Managed by Midwest Research Institute for the U.S. Department of Energy under contract No. DE-AC36-83CH10093 


\section{New Bern Biomass to Energy Project Phase I: Feasibility Study}

Stone \& Webster, Weyerhauser, Amoco, and Carolina Power \& Light

NREL Technical Monitors:

F. Parson, R. Bain

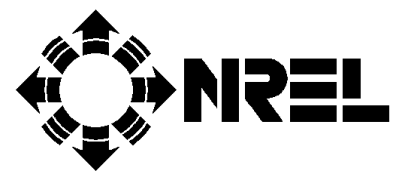

National Renewable Energy Laboratory 1617 Cole Boulevard Golden, Colorado 80401-3393

A national laboratory of the U.S. Department of Energy Managed by Midwest Research Institute for the U.S. Department of Energy under contract No. DE-AC36-83CH10093

Prepared under Subcontract No. RCA-3-13326

October 1995 
This publication was reproduced from the best available copy

Submitted by the subcontractor and received no editorial review at NREL

\section{NOTICE}

This report was prepared as an account of work sponsored by an agency of the United States government. Neither the United States government nor any agency thereof, nor any of their employees, makes any warranty, express or implied, or assumes any legal liability or responsibility for the accuracy, completeness, or usefulness of any information, apparatus, product, or process disclosed, or represents that its use would not infringe privately owned rights. Reference herein to any specific commercial product, process, or service by trade name, trademark, manufacturer, or otherwise does not necessarily constitute or imply its endorsement, recommendation, or favoring by the United States government or any agency thereof. The views and opinions of authors expressed herein do not necessarily state or reflect those of the United States government or any agency thereof.

Available to DOE and DOE contractors from:

Office of Scientific and Technical Information (OSTI)

P.O. Box 62

Oak Ridge, TN 37831

Prices available by calling (423) 576-8401

Available to the public from:

National Technical Information Service (NTIS)

U.S. Department of Commerce

5285 Port Royal Road

Springfield, VA 22161

(703) 605-6000 or (800) 553-6847

or

DOE Information Bridge

http://www.doe.gov/bridge/home.html 


\title{
Final Report
}

presented to
National Renewable Energy Laboratory and
Electric Power Research Institute

\section{New Bern Biomass to Energy Project Phase 1 Feasibility Study}

\author{
Response to NREL Contract No. LOI No. RCA-3-13326 \\ National Renewable Energy Laboratory \\ Technical Monitors: Frankie Parson, Richard Bain
}

Prepared by:

A. Stone \& Webster

A Weyerhaeuser

Amoco

ene1 Carolina Power \& Light 


\section{Disclaimer of Warranties and Limitation of Liabilities}

This report was prepared by the organization(s) named below as an account of work cosponsored by the National Renewable Energy Laboratory (NREL) and the Electric Power Research Institute, Inc. (EPRI). Neither NREL, EPRI, any member of NREL or EPRI, the organization(s) named below, nor any person acting on behalf of any of them:

(A) Makes any warranty or representation whatsoever, expressed or implied, (I) with respect to the use of any information, apparatus, method, process, or similar items disclosed in this report, including merchantability and fitness for a particular purpose, or (II) that such use does not infringe on or interfere with privately owned rights, including any party's intellectual property, or (III) that this report is suitable to any particular user's circumstance; or

(B) Assumes responsibility for any damages or other liability whatsoever (including any consequential damages, even if NREL, EPRI, or the organizations named below has been advised of the possibility of such damages) resulting from your selection or use of this report or any information, apparatus, method, process, or similar item disclosed in this report.

Organization(s) that prepared this report:

Weyerhaeuser Company

Amoco

Carolina Power \& Light Company

Stone \& Webster Engineering Corporation 


\begin{abstract}
Weyerhaeuser, together with Amoco and Carolina Power \& Light, performed a detailed evaluation of biomass gasification and enzymatic processing of biomass to ethanol. This evaluation assesses the potential of these technologies for commercial application to determine which technology offers the best opportunity at this time to increase economic productivity of forest resources in an environmentally sustainable manner. The work performed included preparation of site-specific plant designs that integrate with the Weyerhaeuser New Bern, North Carolina pulp mill to meet overall plant energy requirements, cost estimates, resource and product market assessments, and technology evaluations. The Weyerhaeuser team was assisted by Stone \& Webster Engineering Corporation and technology vendors in developing the necessary data, designs, and cost information used in this comparative study.

Based on the information developed in this study and parallel evaluations performed by Weyerhaeuser and others, biomass gasification for use in power production appears to be technically and economically viable. Options exist at the New Bern mill which would allow commercial scale demonstration of the technology in a manner that would serve the practical energy requirements of the mill. A staged project development plan has been prepared for review. The plan would provide for a low-risk and cost demonstration of a biomass gasifier as an element of a boiler modification program and then allow for timely expansion of power production by the addition of a combined cycle cogeneration plant.

Although ethanol technology is at an earlier stage of development, there appears to be a set of realizable site and market conditions which could provide for an economically attractive woody-biomass-based ethanol facility. The market price of ethanol and the cost of both feedstock and enzyme have a dramatic impact on the projected profitability of such a plant. Additional process and project development work is required to reduce uncertainties and perceived risks before proceeding with such a project.
\end{abstract}




\section{Executive Summary}

Driven by process changes that are making pulp and paper mills increasingly dependent on purchased electric power, the industry is motivated to search for more economic technology alternatives for the production of co-generated power from its biomass residuals. Recent emphasis by the U.S. Department of Energy (DOE) in the area of renewables has provided an unusual window of opportunity for the industry to syndicate the risk of moving to a new more efficient energy generation technology. This window of opportunity comes at a time when the age of greater than 50 percent of the industry's power generation equipment will need major alternation or replacement within the next 15 years.

Two technologies that can have a profound impact on the industry's energy self sufficiency-even to substantially increasing the capability for exporting electric power-have evolved to the point of commercial readiness. These technologies are biomass gasification combined cycle (BGCC) and black liquor gasification combined cycle. A third technology, ethanol production from biomass, although not as advanced in its commercial readiness, is also of increasing interest driven by recent advances in fermentation technology and significantly increased market opportunity as a result of the environmental driver for gasoline additives.

Black liquor gasification is being actively pursued by Weyerhaeuser and others and is not considered here. This report compares, for an integrated pulp mill situation, the operating and economic realities of BGCC and biomass-to-ethanol technologies. As partners in the project, Amoco supplied the ethanol production technology input and marketing analysis; Stone \& Webster Engineering Corporation provided the cost estimating and economic analysis; and Carolina Power \& Light provided the power market information pertinent to North Carolina.

Detailed economics presented in this study include sensitivities to heat rate, discount rate, capacity factor, tax credits, export power prices, feedstock price, DOE capital support, and in the case of ethanol, additional sensitivities to ethanol price and enzyme cost. Analysis of all these sensitivities indicates that in the case of ethanol, the market price and enzyme cost are by far the most influential in determining the project viability. Enzyme costs less than $\$ 4 /$ gallon of enzyme and/or ethanol prices over $\$ 1.40 /$ gallon of ethanol appear necessary to move the ethanol concept as presented here into a economically interesting range. It should be noted, however, that the state of development of biomass to ethanol is clearly precommercial at this time and that a number of design improvements are possible that would significantly change this picture. Also, if a high-value marketable product can be developed for the lignin by-product stream, this would have a significant positive impact.

After discussing biomass gasification combined cycle options with seven potential suppliers, Tampella and TPS were selected for in-depth analysis - the results of which are presented in this report. The ability to work with these two suppliers provided an excellent opportunity to contrast a pressurized system (represented by the Tampella technology) with an atmospheric system (represented by the TPS technology). Given the degree of accuracy of this study, the capital cost of the two technologies investigated were sufficiently similar that no clear preference of one over the other could be determined based on the capital cost factor alone. However, since the operating efficiency of the pressurized technology was better, the Tampella case was taken forward for detailed economic analysis. It should be noted, however, that the pressurized system is not practical for producing fuel gas for firing in a boiler which would be the first step of a preferred staged implementation approach at the New Bern facility.

Based on the analysis of sensitivities with respect to gasification, again capital cost - and in this case, the value of export power - have by far the most significant impact on BGCC economics. Given a 50 percent shared cost for first commercial plants, a positive economic result is achievable for the plant size 
studied herein at export power prices of $5 \mathrm{c} / \mathrm{kWh}$ and above. It is Weyerhaeuser's belief that this conclusion - in light of the future possibilities of integrating this technology with black liquor gasification combined cycle, the probability of a mature BGCC technology having 20-30 percent less capital cost, and anticipated trends in electricity prices - make biomass gasification combined cycle a viable and exciting future option which merits government support to encourage early commercialization.

As mentioned above, in order to advance this technology with a minimum amount of risk, a staged approach is considered preferable. Based on the results reported here, a detailed implementation plan is currently being developed for the New Bern facility which will include as a first phase an atmospheric indirect gasification plant coupled with back-pressure and condensing electric power generation. As a second phase to be implemented early in the next decade, the gas cleaning and gas turbine cycle will be added in conjunction with a black liquor combined cycle technology. With shared cost through DOE's commercialization programs (similar to the current request for proposals advanced in the Biomass Power for Rural Development solicitation), BGCC should find an early home in the forest product industry, contributing to the country's energy self sufficiency from renewable resources and improving the industry's global competitiveness.

As a final point, it should be mentioned that advancing this technology is widely supported by the industry and is consistent with the intent of the "compact" signed between the DOE and the industry in October of 1994, which is based on the industry's vision as put forth in Agenda 2020. 


\section{Contents}

$\underline{\text { Page }}$

Abstract $\quad$ i

Executive Summary $\quad$ ii

$1.0 \quad$ Project Concept $\quad 1-1$

1.1 Background $1-1$

1.2 Review of Gasification Technologies $\quad 1-4$

1.2.1 Evaluation Approach $\quad 1-4$

1.2.2 General Discussion of Biomass Gasification $1-4$

$\begin{array}{lr}\text { 1.2.3 Synopsis of Candidate Technologies } & 1-7\end{array}$

1.2.4 Weyerhaeuser Visits to Gasification Facilities $1-13$

1.2.5 Gasification Technology Selection 1-14

$\begin{array}{ll}1.3 & \text { Design Basis } \\ & 1-15\end{array}$

1.3.1 Biomass Gasification Combined Cycle (BGCC) 1-15 Cogeneration Plant

$\begin{array}{ll}\text { 1.3.2 Ethanol Plant } & 1-16\end{array}$

$2.0 \quad$ Preliminary Design and Cost $\quad 2-1$

2.1 TPS Studsvik Biomass Gasification Combined Cycle 2-1 Cogeneration Plant Design

2.2 Tampella Biomass Gasification Combined Cycle 2-10

Cogeneration Plant Design

2.3 Biomass to Ethanol Plant Design 2-23

2.4 Material Handling Systems $\quad 2-52$

$\begin{array}{ll}2.5 & \text { Plot Plans and Balance of Plant }\end{array}$

$\begin{array}{llr}2.5 .1 & \text { BGCC } & 2-79\end{array}$

$\begin{array}{ll}\text { 2.5.2 Ethanol Plant } & 2-83\end{array}$

$\begin{array}{llr}2.6 & \text { Plant Performance } & 2-90\end{array}$

2.6.1 BGCC Cogen Plants $2-90$

$\begin{array}{lr}\text { 2.6.2 Ethanol Cases } & 2-92\end{array}$ 


\section{Contents (Cont)}

$2.7 \quad$ Cost Estimates $\quad 2-98$

2.7.1 Capital Cost Estimates 2-104

2.7.2 Operating and Maintenance Cost Estimates 2-108

$2.8 \quad$ Project Schedule $\quad 2-127$

3.0 Regional Biomass Supply System

3.1 Scope and Objectives

3.2 Findings $\quad 3-1$

3.3 Approach 3-1

3.4 Strategy 1: Capture existing volumes of residuals $3-5$ available to the company

3.5 Strategy 2: Incorporate mill residuals that are currently going to landfill or lagoon disposal sites

3.6 Strategy 3: Capture existing and/or potential wood chips both whole tree final harvest and plantation thinning chips

3.7 Strategy 4: Grow Biomass by maximizing pine volumes per acre without giving up solid wood value

3.8 Strategy 5: Grow maximum pine/hardwood biomass per acre trying to hold costs

3.9 Strategy 6: Grow maximum biomass per acre with a dedicated short rotation plantation and using mill residuals and process water and/or other nutrient and water sources locally available

4.0 Preliminary Business Assessment for the Integrated

Enterprise

4.1 Economic Evaluation Method 4-1

4.2 Analysis Input 4-2

4.3 BGCC Plant Economic Analysis $\quad$ 4-5

4.4 BGCC/Ethanol Plant Economic Analysis $\quad 4-6$ 


\section{Contents (Cont)}

4.5 Ethanol Plant Economic Analysis

4.6 Comparison of BGCC, BGCC/Ethanol, and Ethanol to the Base Case Boiler Retrofit Project

4.7 Sensitivity Analysis

5.0 Environmental Monitoring Plan $\quad$ 5-1

5.1 Timberlands Environmental Monitoring 5-1

5.2 Environmental Stewardship

5.3 New Bern Mill Environmental Monitoring 5-7

6.0 Market Issues $\quad$ 6-1

6.1 Market for Electric Power 6-1

6.2 Fuel/Ethanol Market $\quad$ 6-8

6.3 New Bern BGCC Plant Ownership Options 6-17

7.0 Socioeconomic and Environmental Evaluation $7-1$

8.0 Plan for Phase II $\quad$ 8-1 


\section{List of Tables}

1-1 Information Request - Biomass Gasification Technology Qualifications

1-2 Evaluation Criteria

1-3 BGCC Plant Design Basis

1-4 Water Analyses from Existing System at New Bern Pulp Mill

1-5 Advanced Biomass Cellulose to Ethanol Plant Design Basis

2-1 Material Balance - TPS BGCC (Flue Gas Dryer)

2-2 Equipment List - TPS BGCC (Flue Gas Dryer)

2-3 Material Balance - Tampella BGCC (Flue Gas Dryer)

2-4 Material Balance - Tampella BGCC (Steam Dryer)

2-5 Equipment List - Tampella BGCC (Flue Gas Dryer)

2-6 Equipment List - Tampella BGCC (Steam Dryer)

2-7 Material Balance - Amoco Ethanol Plant

2-8 Equipment List - Amoco Ethanol Plant

2-9 Equipment List - Feed Preparation System - TPS BGCC (Flue Gas Dryer)

2-10 Equipment List - Dolomite Receiving, Bed Sand, and Ash Removal Systems - TPS BGCC (Flue Gas Dryer)

2-11 Equipment List - Feed Preparation System - Tampella BGCC (Flue Gas Dryer)

2-12 Equipment List - Dolomite, Ash Handling Systems - Tampella BGCC (Flue Gas Dryer)

2-13 Equipment List - Feed Preparation System - Tampella BGCC (Steam Dryer)

2-14 Equipment List - Dolomite, Ash Handling Systems - Tampella BGCC (Steam Dryer)

2-15 Equipment List - Feed Preparation Stillage Handling Systems - Tampella BGCC (Flue Gas Dryer)

2-16 Equipment List - Dolomite Receiving, Ash Handling Systems - Amoco Ethanol Plant and Tampella BGCC (Flue Gas Dryer)

2-17 TPS BGCC (FGD) - Electrical Summary

2-18 TPS BGCC (No Extraction Air) - Electrical Summary

2-19 Tampella BGCC (FGD) - Electrical Summary

2-20 Tampella BGCC (Steam Dryer) - Electrical Summary

2-21 Tampella BGCC/Ethanol (FGD) - Electrical Summary

2-22 Estimate Summary - Tampella BGCC (Flue Gas Dryer)

2-23 Estimate Summary - Tampella BGCC (Steam Dryer)

2-24 Estimate Summary - TPS BGCC (Flue Gas Dryer)

2-25 Estimate Summary - Ethanol Plant

2-26 Estimate Summary - BGCC/Ethanol Combined Plant 


\section{List of Tables (Cont)}

Tampella BGCC Flue Gas Dryer Design O\&M Cost Summary Tampella BGCC Steam Dryer Design O\&M Cost Summary TPS BGCC Flue Gas Dryer Design O\&M Cost Summary

\section{Ethanol Piant O\&M Cost Summary}

$$
\text { Integrated BGCC - Ethanol Plant O\&M Cost Summary }
$$

$$
\text { Base Case (Refurbished Bark Boiler) O } \dot{\&} \text { M Cost Summary }
$$

Total Biomass Fuel Resource - Units - kBDT per year

Weyerhaeuser Mill Residuals

Unused External Mill Residuals

All Mill Residual (kBDT)/Year)

Forest Residuals

Final Harvest Biomass

$$
\text { First Thinning Biomass }
$$

Inter-row Planting

\section{Short Rotation Pine Plantation}

Economic Input Table - Biomass to Energy

Master Input Table

Incremental Plant (Alternate - Base) [A \& B]

Incremental Plant (Alternate - Base) (Flue Gas Dryer) (see Flue Gas Dryer plus Ethanol Plant) [A \& B]

$$
\text { Incremental Plant (Alternate - Base) Bark Boiler Retrofit plus Ethanol Plant }
$$

U.S. Fuel Ethanol Plants and Capacity

Selected Capacity Studies for U.S. Fuel Ethanol Plant

Companion of New Bern Ethanol Plant Capacity Statistics

New Bern Ethanol Plant Model Market Area

Ethanol Plant Model Market Area Fuel Demand

New Bern Ethanol Transportation Cost Model

New Bern Biomass to Ethanol Plant Market Model

Summary of Selected Historical Fuel Ethanol Prices (1992-1994)

1992 Ethanol Prices for Selected Markets

1993 Ethanol Prices for Selected Markets

1994 Ethanol Prices for Selected Markets 


\section{List of Figures}

Figure 2-1 Process Flow Diagram - TPS BGCC (Flue Gas Dryer)

Figure 2-2 Process Flow Diagram - Tampella BGCC (Flue Gas Dryer)

Figure 2-3 Process Flow Diagram - Tampella BGCC (Steam Dryer)

Figure 2-4 Block Flow Diagram - Amoco Ethanol Plant

Figure 2-5 Process Flow Diagram - Pretreatment

Figure 2-6 Process Flow Diagram - SSF Fermentation

Figure 2-7 Process Flow Diagram - Fermentation Yeast Propagation

Figure 2-8 Process Flow Diagram - Distillation and Dehydration

Figure 2-9 Process Flow Diagram - Alcohol Storage

Figure 2-10 Process Flow Diagram - Stillage Handling

Figure 2-11 Process Flow Diagram - CIP \& Nutrients

Figure 2-12 Process Flow Diagram - Chemical Storage

Figure 2-13 BGCC Retrofit Fuel/Ash Handling System Tampella Steam Dryer Case - Sheet 1 of 3

Figure 2-14 BGCC Retrofit Fuel/Ash Handling System Tampella Steam Dryer Case - Sheet 2 of 3

Figure 2-15 BGCC Retrofit Fuel/Ash Handling System Tampella Steam Dryer Case - Sheet 3 of 3

Figure 2-16 BGCC Retrofit Fuel/Ash Handling System Tampella Flue Gas Dryer Case Sheet 1 of 3

Figure 2-17 BGCC Retrofit Fuel/Ash Handling System Tampella Flue Gas Dryer Case Sheet 2 of 3

Figure 2-18 BGCC Retrofit Fuel/Ash Handling System Tampella Flue Gas Dryer Case Sheet 3 of 3

Figure 2-19 BGCC Retrofit Fuel/Ash Handling System TPS Options - Sheet 1 of 3

Figure 2-20 BGCC Retrofit Fuel/Ash Handling System TPS Options - Sheet 2 of 3

Figure 2-21 BGCC Retrofit Fuel/Ash Handling System TPS Options - Sheet 3 of 3

Figure 2-22 BGCC/Ethanol Retrofit Fuel/Ash Handling System Tampella Flue Gas Dryer Case Sheet 1 of 4

Figure 2-23 BGCC/Ethanol Retrofit Fuel/Ash Handling System Tampella Flue Gas Dryer Case Sheet 2 of 4

Figure 2-24 BGCC/Ethanol Retrofit Fuel/Ash Handling System Tampella Flue Gas Dryer Case Sheet 3 of 4

Figure 2-25 BGCC/Ethanol Retrofit Fuel/Ash Handling System Tampella Flue Gas Dryer Case Sheet 4 of 4

Figure 2-26 Mill Plot Plan (Mill Storm Water Collection System)

Figure 2-27 Plot Plan - BGCC Retrofit

Figure 2-28 Plot Plan - BGCC/Ethanol Retrofit

Figure 2-29 Block Flow Diagram - TPS BGCC (Flue Gas Dryer) 


\section{List of Figures (Cont)}

Figure 2-30 Block Flow Diagram - TPS BGCC (No Extraction Air)

Figure 2-31 - Block Flow Diagram - Tampella BGCC (Flue Gas Dryer)

Figure 2-32 Block Flow Diagram - Tampella BGCC (Steam Dryer)

Figure 2-33 Ethanol Plant Overall Material Balance and Mill Interfaces

Figure 2-34 Block Flow Diagram - Ethanol Plant with Tampella BGCC (Flue Gas Dryer)

Figure 2-35 BGCC Project Schedule

Figure 3-1 Map of External Forest kBDT Residuals

Figure 3-2 Chart of Residual Biomass Fuel Resource

Figure 3-3 Chart of Total Biomass Fuel Resource

Figure 3-4 Map of Unused Mill Residuals/BDT

Figure 3-5 Map of Total Mill Residuals/kBDT

Figure 4-1 Option 3 - BGCC/Ethanol vs. Bark Boiler Retrofit NPV as a Function of Biomass and Enzyme Costs

Figure 4-2 Option 4 - Ethanol Plant vs. Bark Boiler Retrofit NPV as a Function of Biomass and Enzyme Costs

Figure 4-3 Sensitivity of Incremental Plant's NPV to Capital Support

Figure 4-4 Sensitivity of Incremental Plant's NPV to the Power Price

Figure 4-5 Sensitivity of Incremental Plant's NPV to Ethanol Price

Figure 4-6 Sensitivity of Incremental Plant's Price to Lignin Sales Price

Figure 4-7 Sensitivity of Incremental Plant's NPV to the Enzyme Cost

Figure 4-8 Sensitivity of Incremental Plant's NPV to Tax Credits

Figure 4-9 Sensitivity of Incremental Plant's NPV to the Export Power Capacity Factor

Figure 4-10 Sensitivity of Incremental Plant's NPV to Biomass Escalation Rate

Figure 4-11 Sensitivity of Incremental Plant's NPV to Initial Biomass Price 


\section{List of Figures (Cont)}

Figure 4-12 Sensitivity of Incremental Plant's NPV to Energy Plant Capacity Factor

Figure 4-13 Sensitivity of Incremental Plant's NPV to Performance

Figure 4-14 Sensitivity of Incremental Plant's NPV to Discount Rate

Figure 4-15 Sensitivity of Incremental Plant's NPV to Capital Cost

Figure 4-16 BGCC NPV Minus New Boiler NPV vs. Power Sales Price

Figure 4-17 BGCC NPV Minus New Boiler NPV Over Project Life (Power Sales @ \$0.05/kWh)

Figure 4-18 BGCC NPV Minus New Boiler NPV over Project Life (Power Sales@ @ $\quad$ 0.07/kWh)

Figure 6-1 BGCC - No DOE Contribution

Figure 6-2 With DOE Contribution

Figure 8-1 Alternatives for a Sustained Competitive Future with Government Funding 


\section{Section 1}

\section{Project Concept}

The concept of this project is to define a specific dedicated feedstock supply system (DFSS) for serving an advanced biomass to energy conversion process located at Weyerhaeuser's market pulp mill in New Bern, North Carolina. This project is a feasibility study of the capital cost, operating economics, and regional impact of two technologies - biomass gasification combined cycle and biomass to ethanol.

\subsection{Background}

\section{An Energy Profile of the Pulp and Paper Industry}

The U.S. pulp and paper industry is the fourth largest consumer of energy among all segments of American industrial activity-and the third largest if the fuels industry itself is excepted. The manufacture of pulp and paper products in the U.S. consumes over 2,600 trillion Btu of energy annually. This large use of heat and power is exceeded among process industry manufacturers only by that of U.S. chemical plants and primary metal mills. In spite of this fact, the industry can make a claim that no other can come close to-it is over 57 percent energy self-sufficient. According to the American Forest \& Paper Association (AF\&PA), the industry currently derives about 40 percent of its energy needs from the burning of black liquor and around 17 percent from the burning of forest biomass and mill solid wastes. In both of these cases, the generation of steam and power is accomplished through technology that lacks efficiency in its energy conversion compared to emerging new methods.

\section{The Uncertainty of Purchased Energy Costs}

On the fuel front, the uncertainty of forces influencing prices is providing the pulp and paper industry with increased motivation to look more seriously than ever at biomass as a replacement for fossil fuels. Although the price of coal promises to be reasonably stable, the price of fuel oil and natural gas have proven impossible to predict. However, it seems unlikely that they should decrease, and many believe that natural gas prices will reach a parity with oil prices in the not-too-distant future.

Increasing American dependence on foreign oil supplies is a continuing national concern, and environmentally, the pressure to use less fossil fuel is unrelenting. The pulp and paper industry is uniquely positioned to respond positively to these converging forces.

\section{The Opportunity for Renewable Fuels}

Many U.S. pulp and paper companies generate significant quantities of alternative fuel as a natural consequence or residual of their raw material harvesting and manufacturing processes. Forest biomass and manufacturing residuals have always played an important part in mill energy generation and can easily play an even bigger part in the pulp and paper mills of the future.

The industry can increase its production of energy from renewable sources in two ways. The first is to increase the amount of biomass utilized, and the second is to increase the efficiency of the energy conversion to high pressure steam and electricity. Increasing the amount of biomass utilized can result partially from collecting more of the residuals from harvesting. Much of the limbs and trimmings now left in the forest can be delivered to the mill for use as fuel while maintaining the soils for sustainable forestry. It is further likely that the nation's commercial forests can be managed to significantly increase 
yield of biomass on a sustainable basis, both for primary product and energy use. As a result, many pulp and paper mills of the future will begin to see their woodlands in terms of both fiber and fuel.

\section{Converging Events Demand Changes}

There are changes on the energy horizon. In fact, the convergence of several events may well provide a unique opportunity for the pulp and paper industry to make yet another significant step in selfsufficiency.

- Dependence on Purchased Electric Power

Although the pulp and paper industry is currently No. 1 in the industrial generation of electricity, there is a clear movement towards more and more dependence on purchased electrical power. This undeniable trend is the result of a combination of changes in the industry's manufacturing processes. To remain competitive and satisfy stricter environmental requirements, mills are undergoing modernization and process optimization with a resulting decrease in built-in capacity for cogeneration of electricity. However, as co-generation capacity decreases, electrical energy requirements are increasing. Added environmental control equipment, primarily scrubbers and precipitators; create greater electrical demand. Alternatives to chlorine bleaching sequences, involving on-site oxygen/ozone generation, and an industry trend towards more thermo-mechanical pulp also contribute to increased demand. Recycling is having electric power consequences, since using recycled fiber adds to electrical demand (except in TMP fiber replacement). Another consequence of recycling is that it leaves no appreciable amount of residue, as wood does, that can be used as fuel.

- The Aging of Black Liquor and Biomass Boilers

As a result of industry expansion and rebuild strategies during the decades of the 60's and 70's, nearly 70 percent of the industry's recovery boilers were built or underwent major rebuilds between 1963 and 1980 . Given that statistically significant data indicates the useful life of these units is around 30 years, most will need major attention or replacement over the next 15 to 20 years. A similar, although slightly less compelling, situation exists for the industry's biomass boilers. Potentially this situation represents a window of opportunity in a 30-year cycle for the introduction of more energy-efficient technology.

- Constraints on Air Emissions

Although the industry has had an impressive record of air emissions reductions, further improvements will be necessary as we proceed into the next century. These changes will also provide challenges for the industry's processing equipment and motivation for technological change. All mills must also factor in both the capital and operating costs of continually tightening air emissions regulations.

- Capitalization

In all that has been said to this point, the impact on capitalization must be kept in perspective. Currently, the pulp and paper industry is twice as capital intensive as the average for the industrial sector-and this capitalization is increasing at a rate of 2.7 percent per year as compared with 1.6 percent per year for all manufacturing. Any new technology introduced must provide an opportunity for reducing capital requirements per ton of product produced. 
According to the U.S. Department of Energy (DOE), in 1995 the total biomass-based energy (measured in quads or $\left(10^{15} \mathrm{Btu}\right)$ ) production in the U.S. will be just under 4 quads. The nation currently uses about 82 quads of energy in total. Because of its ready supply of bark and residuals (including lignin in black liquor), the pulp and paper industry is responsible for 90 percent of the national total of energy from renewable sources. DOE predicts, however, that by 2010 the national renewable energy production from biomass will rise to over 5 quads annually-and to over 15 quads by 2030 . At projected growth rates of genetically improved species, the land required to achieve this 2030 objective will be over 100 million acres at the current conversion efficiency of biomass to electricity. Therefore, it will be essential, even if only a significant fraction of this goal is achieved, that biomass-to-useful-energy conversion processes be as efficient as possible.

- Biomass-to-Energy Conversion Technologies

Conversion efficiency can be increased through innovations in drying biomass before conversion to useful energy, but will be attained primarily through advances in conversion technology. The Dutchoven boiler of the 1950's operated at less than 15 percent overall thermal conversion efficiency to electricity with a condensing turbine. It is expected that the advanced biomass gasification combined cycle (BGCC) technologies now emerging will produce three times as much electrical energy from the same amount of biomass, operating at close to 45 percent efficiency. If these technologies can be shown to be cost-competitive, they will become the technologies of choice over the next 10 to 15 years. Biomass and black liquor will not be delivered to furnace cavities, but rather to gasifiers. The gases exiting the gasifier will be cleaned and used to fuel gas turbine combustors and the lime kiln. Steam will be produced in heat recovery steam generators downstream of the gas turbines. This steam will be used for further power generation and for process steam. The result will be a significant technology shift for many of the industry's manufacturing facilities, from highsteam/moderate-electricity operation to lower-steam/higher-electricity operating designs. BGCC systems will be an important part of that technology shift.

We are entering an era where considerably increased attention is going to be focused on biomass as an energy source. Because of such focus, technology advancement in growing, harvesting and conversion of biomass to energy will likely occur. This is happening at a time when much of the technology for gasification combined cycle has been developed as a result of the last decade's intense funding by the DOE of the clean coal program - and when mills need the capability for more electric power generation, air emissions regulations are becoming more stringent, the industry's black liquor and biomass boilers are maturing, and the need for lower capital technologies is clear.

All these factors present a challenging but strategically advantageous opportunity to transform many of the American pulp and paper industry's operating facilities from net power consumers into balanced producer/consumers, or even net power producers.

It is for these reasons that Weyerhaeuser-in partnership with Amoco, Carolina Power and Light (CP\&L) and Stone \& Webster-applied for and received from NREL and EPRI shared support to undertake this feasibility study. The compelling reasons for including an evaluation of the biomass-to-ethanol technology contributed by Amoco were the realization that export power may not always be the most attractive marketable product from an integrated facility and that the advances being made by developers of biomass-to-ethanol processes are nearing the point where this technology must be considered as a serious alternative. It is believed that this feasibility study represents a first attempt to compare biomass gasification combined cycle technology with biomass to ethanol at a real site-specific operating market pulp mill. 


\subsection{Review of Gasification Technologies}

The first major decision point of the Phase I Feasibility Study was to select the biomass gasification technology that would be the basis for the preliminary engineering and costing of the New Bern Mill retrofit project.

\subsubsection{Evaluation Approach}

Available biomass gasification technologies were identified from Weyerhaeuser and Stone \& Webster experience and from the literature. The developers or licensors of these technologies were then contacted to determine if they wished to be considered for the Weyerhaeuser New Bern Biomass to Energy Demonstration Project. The candidate technologies were as follows:

- Bioflow (Ahlstrom/Sydkraft)

- Enviropower (Tampella Power)

- HTW (high temperature Winkler, licensed by Lurgi)

- TPS Termiska Processer

- Lurgi CFB Gasification Process

- Battelle Low Inlet Velocity Gasification Process (licensed by FERCO)

- MTCI Steam Reforming Process (ThermoChem)

- American Carbons Inc. Pyrolysis/Carbonization Process

To obtain the latest information on the technology, its state of development and the capabilities of the owner/licensor, each owner/licensor was sent a "Request for Qualifications" which included the information request presented in Table 1-1. After responses were received, meetings were scheduled to allow the project team to ask follow up questions. The meetings were attended by Stone \& Webster, Weyerhaeuser and Amoco team members and NREL observers. Prior to the meetings the project team developed evaluation criteria which are given in Table 1-2.

To further assess the state of development of the technologies, Weyerhaeuser personnel toured several research, pilot and commercial gasification facilities subsequent to the technology supplier interviews.

\subsubsection{General Discussion of Biomass Gasification}

In the gasification process the biomass is heated to vaporize water and volatile compounds. Heavier organic compounds are cracked into lower molecular weight compounds and several chemical reactions involving carbon, carbon monoxide, steam, hydrogen, low molecular weight hydrocarbons and oxygen occur. The heat required to maintain the required gasification temperature is usually provided through the combustion of a portion of the carbon to carbon dioxide which means a controlled amount of air is introduced into the gasifier. The resulting fuel gas will therefore be diluted with nitrogen and steam and will have a heating value of about $150 \mathrm{Btu} / \mathrm{standard}$ cubic foot (scf). Alternatively the heat for gasification can be provided indirectly which avoids production of carbon dioxide through combustion and introduction of nitrogen with the air stream. In these indirect designs, the resulting fuel gas will have a heating value in the range of 400 to $500 \mathrm{Btu} / \mathrm{scf}$. The MTCI and Battelle processes involve indirect heating approaches. 
Table 1-1: Information Request Biomass Gasification Technology Qualifications

\begin{tabular}{|c|c|}
\hline 1. & $\begin{array}{l}\text { Provide any company/corporate information you consider pertinent to this project and include a copy } \\
\text { of your latest annual report }\end{array}$ \\
\hline $2^{-}$ & $\begin{array}{l}\text { Describe in as much detail as possible your biomass gasification technology and how it can be } \\
\text { utilized to provide fuel gas for a gas turbine/combined cycle cogeneration plant, your approach to } \\
\text { dealing with gas cleanup, and clearly explain the boundaries/battery limits/interfaces of the } \\
\text { technology you would provide; i.e., the scope of your responsibility. Describe the usefulness of any } \\
\text { by-product the technology may produce. Also discuss the environmental impacts of the technology. }\end{array}$ \\
\hline 3. & $\begin{array}{l}\text { Explain the ownership rights to the technology including all its parts as provided by patents, licensing } \\
\text { agreements, etc. }\end{array}$ \\
\hline 4. & $\begin{array}{l}\text { Are there any unresolved legal actions regarding ownership of or rights to the technology or any part } \\
\text { of it? }\end{array}$ \\
\hline 5. & $\begin{array}{l}\text { Explain your business plans with respect to this technology, including any applicable license and/or } \\
\text { royalty fees, e.g., will license technology only and provide a process design package; will design } \\
\text { fabricate and supply major equipment; will furnish and erect complete scope of the technology; etc. }\end{array}$ \\
\hline 6. & Explain guarantees offered. \\
\hline 7. & $\begin{array}{l}\text { Discuss the state of development of the technology; include bench scale, pilot scale, demonstration } \\
\text { and commercial facilities planned, under construction or built; to the extent possible, for each facility } \\
\text { provide location, date in service, size (capacity) and biomass feedstock(s). For pilot scale and larger } \\
\text { facilities, we are interested in operating hours logged to date and longest continuous run. For } \\
\text { demonstration and commercial plants, annual on-stream factors (actual annual production divided by } \\
\text { theoretical production if operated at full capacity for the entire year) is of importance. }\end{array}$ \\
\hline 8. & $\begin{array}{l}\text { What experience regarding biomass feedstocks have you had? Discuss feed preparation requirements } \\
\text { and allowable variability. For each feedstock that you have experience with, we would appreciate any } \\
\text { available process heat and material balances including compositions of input and output streams. }\end{array}$ \\
\hline 9. & $\begin{array}{l}\text { We are interested in your opinion as to the ability to design a plant to handle multiple feedstocks } \\
\text { such as harvested biomass, bark, sawdust and pulp mill sludge. What testing would be required to } \\
\text { establish a design basis? Where would this testing be performed, and what would be your estimate of } \\
\text { the cost? }\end{array}$ \\
\hline 10. & $\begin{array}{l}\text { State capacity (in million Btu(s) per hour of product gas) of the largest single gasifier which you } \\
\text { would be willing to offer and your basis for scale up. }\end{array}$ \\
\hline 11. & $\begin{array}{l}\text { Discuss your perspective of maintenance requirements for your technology, including frequency } \\
\text { intervals and planned maintenance outage duration. For demonstration and commercial plants for } \\
\text { which you have experience, provide to the degree possible any annual forced outage rates and major } \\
\text { causes of unplanned or forced outages. }\end{array}$ \\
\hline 12. & $\begin{array}{l}\text { We are also interested in your view of operating requirements (labor, skill level, utilities, etc.), ease } \\
\text { of operation, turndown capability, start-up and shut-down considerations and safety issues that } \\
\text { distinguish your technology from that of competitors. }\end{array}$ \\
\hline 13. & $\begin{array}{l}\text { Please describe any previous experience in working in or designing systems to be compatible with the } \\
\text { pulp and paper operating environment; e.g., process steam systems, process integration, mass/energy } \\
\text { considerations relative to host mill, environmental benefits/impacts, etc. }\end{array}$ \\
\hline 14. & Please indicate if you are willing to offer any cost sharing to participate in the demonstration. \\
\hline
\end{tabular}


Table 1-2: Evaluation Criteria

\begin{tabular}{|c|c|}
\hline Commercial readiness of technology & $\begin{array}{ll}\text { - } & \text { Hours of operation (Pilot/Commercial) } \\
\text { - } & \text { Longest continuous operating time } \\
\text { - } & \text { Ownership } \\
\text { - } & \text { Guarantees } \\
\text { - } & \text { Reliability } \\
\text { - } & \text { Identified technical and operating hurdles/issues } \\
\text { - } & \text { Demonstrated reliability of data } \\
\text { - } & \text { engineering evaluation completed (existing } \\
\text { - } & \text { Cost to develop } \\
\text { - } & \text { Development schedule }\end{array}$ \\
\hline Supplier Profile & $\begin{array}{l}\text { - } \quad \text { Manufacturing capability } \\
\text { - } \quad \text { Tredibility of cost estimating/scale-up } \\
\text { - Technical support capabilities } \\
\text { - } \quad \text { Prack record of process design/scale-up } \\
\text { - } \quad \text { Financial viability of company } \\
\text { - Experience with forest products industry } \\
\text { - Commitment to product line } \\
\text { - Installation list for related technologies } \\
\text { - Scope of supply }\end{array}$ \\
\hline $\begin{array}{l}\text { Suitability for BGCC application in pulp and } \\
\text { paper environment }\end{array}$ & $\begin{array}{ll}\text { - } & \text { Process steam opportunity } \\
\text { - } & \text { Degree of process integration } \\
\text { - } & \text { Useful by-product } \\
\text { - } & \text { Mass/energy considerations relative to host mill } \\
\text { - } & \text { Environmental benefits/impacts } \\
\end{array}$ \\
\hline Operation and control considerations & $\begin{array}{ll}\text { - } & \text { Number of operations } \\
\text { - } & \text { Control loops and philosophy } \\
\text { - } & \text { Maintenance } \\
\text { - } & \text { Availability } \\
\text { - Start-up/shutdown } \\
\text { - } & \text { Size considerations (how big) } \\
\text { - } & \text { Ease of operation } \\
\text { - } & \text { Safety } \\
\text { - } & \text { Material of construction } \\
\end{array}$ \\
\hline Opportunity for competitive advantage & $\begin{array}{ll}\text { - } & \text { Concessions/license } \\
\text { - } & \text { Shared risk } \\
\text { - } & \text { Thert/operational economics } \\
\text { - } & \text { Market potential } \\
\text { - } & \text { Marketing/sales capacity } \\
\end{array}$ \\
\hline Adaptability to changing feedstocks & $\begin{array}{l}\text { - } \quad \text { Experience with biomass feedstocks } \\
\text { - } \quad \text { Ceedstock flexibility } \\
\text { - } \quad \text { Operational cost impact }\end{array}$ \\
\hline
\end{tabular}


The TPS, Lurgi CFB, MTCI, Battelle, and American Carbons processes operate at near atmospheric pressure and therefore the fuel gas must be compressed for gas turbine applications. The Bioflow (Ahlstrom), Tampella, and HTW processes are being developed specifically for integrated gas turbine combined cycle applications. These processes operate at a sufficient pressure (above $300 \mathrm{psig}$ ) such that the fuel gas product can be fed to the selected combustion turbine without additional compression.

The elements of a complete gasification plant include the fuel processing system, the gasifier vessel, the ash removal system and fuel gas cooling and cleanup systems. Pressurized gasification processes require more complex feed and ash removal systems. The most critical part of the process is the cleanup system. Proven cleanup systems include bag filters and scrubbers.

To minimize cooling of the fuel gas and avoid decreasing the overall efficiency of the gasification power plant, Ahlstrom and Tampella employ hot gas cleanup technology which consists of developmental ceramic candle filters. One advantage of the hot gas cleanup approach is that the gasification plant produces no wastewater.

Fluidized bed gasifiers operate at conditions which with many biomass feeds will result in a fuel gas containing a small, but potentially troublesome quantity of heavy organic compounds called tars. These tars condense upon cooling of the fuel gas and may cause plugging and fouling problems. The tars can be removed with water scrubbing, but this reduces the overall efficiency of the process and increases the wastewater treatment requirements. Limestone or dolomite has been shown to catalyze the cracking of tars to trouble-free lower molecular weight compounds.

Air blown fluidized bed gasifiers produce a fuel gas with a significant ammonia content which would result in high nitrogen oxides $\left(\mathrm{NO}_{x}\right)$ emissions upon combustion of the fuel gas. Cold gas cleanup approaches can incorporate acid scrubbers to remove the ammonia. However, the more efficient hot gas cleanup processes requires post combustion selective catalytic reduction to meet $\mathrm{NO}_{\mathrm{x}}$ standards.

The proposed biomass feed is approximately 50 percent by weight water. In order to produce a fuel gas with a minimum acceptable heating value for gas turbine applications, the air blown gasifiers typically require a maximum moisture content of about 20 percent by weight thus requiring the inclusion of a dryer. A dryer increases capital costs, requires a heat source that can impact the overall biomass to power efficiency, and adds the potential for air emissions from the dryer exhaust.

For the Ahlstrom and Tampella technologies employing dry, hot gas clean up, removing alkali compounds from the hot raw fuel gas is an important consideration. For these technologies the fuel gas must be cooled to a low enough temperature to condense the alkali compounds. These compounds condense on particulate matter present and are then captured by the hot gas filter. If the proper conditions for this to occur-are not provided, the turbine fuel specification may be violated.

\subsubsection{Synopsis of the Candidate Technologies}

Tampella

Tampella Power Corporation is developing a pressurized, air blown, hot gas cleanup, integrated gasification combined cycle technology. The gasifier is a spouting type fluidized bed which was developed by the Institute of Gas Technology (IGT) for solid fuels including coal, biomass, peat, and petroleum coke. Tampella purchased licenses for these technologies (U-Gas for coal and RENUGAS for biomass) in 1989. Tampella established a new subsidiary, Enviropower Inc. to pursue and demonstrate the application of the technology. 
For biomass feeds, dolomite is injected into the gasifier to control tar formation and to provide additional particulate matter on which alkalis can condense prior to removal in a ceramic candle filter.

Tampelia designed and built a 15 megawatt thermal (MWt) pilot plant in Finland based on the licensed technology. The pilot plant through November, 1993 had gasified approximately 265 tons of hardwood (trūnk-wood with bark), 1900 tons of hardwood and softwood mixtures, and 1450 tons of hardwood, softwood, and saw-mill residue mixtures. Wood feedstocks tested include Spruce, Larch, Pines, Birch, and Alder. During the test runs the gasifier was operated at capacities ranging from $50-60 \mathrm{MBtu} / \mathrm{hr}$. The heating value of the product gas ranged from $135-160 \mathrm{Btu} / \mathrm{scf}$, suitable fuel for a gas turbine generator. The hot gas cleanup system performed to expectations: no tars; particulates below detection limits ( $<5 \mathrm{ppmw})$; and acceptable alkalis (.01-.1 ppmw). The ammonia content of the product gas ranged from 650 to 2,000 ppmw. During December,1994, a 50/50 mixture of 22 tons of Danish straw and Columbian coal were successfully run. In February, 1995, 700 tons composed of mixtures of 50 percent Finnish hardwood and softwood and 50 percent mill wastes (bark, sludge, saw residues, paper, wood residue and plastics) were gasified without any difficulty.

In addition to a license for the use of the technology, Tampella would expect to provide as a minimum the process and engineering design for the proprietary components of the gasification island. Tampella would consider furnishing the gasification island on a turnkey basis. Tampella's preferred battery limits for the gasification island are downstream of the gasification system and upstream of the gas turbine inlet control valve. Included within these limits are feed systems, the gasifier, gas cooling, hot gas cleanup, solids removal, and participation in the design of the heat recovery steam generator (HRSG).

Tampella is not prepared to offer commercial guarantees on the technology prior to a commercial scale demonstration. Tampella is ready to design a single gasifier to feed a gas turbine as large as the General Electric Frame 6FA. The resulting biomass gasification combined cycle plant would have a net power output of 105 MWe.

Based on pilot plant operations, Potential Problems Analysis (PPA) and other safety studies performed by Tampella/Enviropower for the gasifier system, 15 to 25 percent unscheduled outages are anticipated for the commercial demonstration. For follow on projects Tampella expects the unscheduled down time to drop to 10 percent to 15 percent. Coupled with scheduled downtime the mature technology is expected to have an availability of 82 percent to 88 percent.

\section{Battelle}

The Battelle Low Inlet Velocity Gasification (LIVG) process is an indirectly heated, atmospheric pressure, circulating fluid bed gasifier. The feed is brought to gasification temperature by mixing with hot sand. The gasifier is fluidized with either steam or recycle fuel gas. Since no air is used in the reaction vessel, the process produces a medium Btu heating value fuel gas without the use of oxygen. The gasifier is operated to achieve incomplete carbon conversion and as a result the medium Btu gas leaves the gasifier with sand and char. The char and sand are separated and fed into a separate circulating fluidized bed combustor where the char is burned and reheats the sand which is collected and fed back to the gasifier inlet.

Battelle began developing the process in 1977 and built a process research unit (PRU) in 1980. The PRU gasifier was initially 6-inch diameter, but has since been replaced with a 10-inch diameter gasifier which has a maximum capacity of about $3 \mathrm{MWt}$ with wood feed. 
Battelle has accumulated over 20,000 hours of testing in the PRU. A wide range of materials have been tested including hardwood and softwood chips, shredded bark, sawdust, whole tree chips, shredded stump material, refuse-derived fuel (RDF), hybrid poplar and switchgrass.

The longest continuous run in the PRU has been 96 hours. Battelle reports that since its inception, the PRU has operated very reliably.

Battelle has published several papers publicizing the advantages of the process, but the papers do not detail the complete process requirements. The papers show no dolomite injection for tar control. The fuel gas is cleaned of particulate matter using a water scrubber. The flue gas from the combustor vessel is used in a biomass feed dryer. It is not clear whether additional cleanup of both the fuel gas (to meet gas turbine requirements) and the flue gas to meet emission limits will be required.

In late 1992 Battelle granted Future Energy Resources Corporation (FERCO) rights to the technology, FERCO with the help of Zurn Nepco is currently developing projects based on the technology. They have a contract to build a demonstration facility at the existing wood-fired McNeil power station in Burlington, Vermont. The plant is scheduled to be operational in 1996. The gasifier will have a capacity of 200 tons per day (TPD) of dry feed (about $25 \mathrm{MWt}$ ). The gas will be initially fired in the existing boiler, but the plan is to add a $1600 \mathrm{~kW}$ gas turbine later.

Depending on the customer's preference, FERCO will either license the technology and provide a process design package or provide a complete turnkey project covering the gasification island or the complete gasification power plant. FERCO will provide guarantees once the demonstration project in Burlington has been successful.

\section{TPS Termiska Processer (TPS)}

TPS is an independent Swedish company specializing in energy and environmental process research and technology development. TPS's research and development on biomass gasification began in the late 1970s. During the early 1980s they focused on the development of MINO pressurized oxygen blown biomass gasifier and built a 2.5 MWt pilot plant. Beginning in 1985 TPS in cooperation with ABB-Flakt of Sweden developed a bark-fueled air-blown circulating fluid bed gasifier to produce a low Btu gas for firing in lime kilns in kraft pulp mills. A $2 \mathrm{MWt}$ pilot plant was built and research and pilot plant test work focused on the air-blown atmospheric pressure process and its application to the thermal processing of biomass and waste fuels. Wood chips, wood pellets, pelletized industrial waste, pelletized RDF, and more recently Brazilian eucalyptus have been tested in the pilot plant.

TPS believes a separate tar cracker vessel following the gasifier is required to control tar formation. The tar cracker is a fluidized bed of dolomite. The process includes cold gas cleanup of the fuel gas consisting of a bag filter and an acid scrubber to remove ammonia.

Two $15 \mathrm{MWt}$ RDF-fueled gasifiers have been built in Italy providing fuel for a boiler and a cement factory. The first unit began operation in November 1991 and the second unit in September 1992. Most of the problems in the plant have been associated with equipment outside of the gasification system. During tests in April 1992 availabilities of more than 85 percent were recorded. TPS is currently studying the feasibility of a $50 \mathrm{MWt}$ cogeneration project in Sweden. TPS is one of two gasifiers being considered for the Brazilian Biomass Gasification Combined Cycle Demonstration Project.

TPS is willing to scale up a single gasifier to $100 \mathrm{MWt}$ capacity. TPS will license the technology and provide engineering and services and startup assistance. TPS would consider providing a performance guarantee. 


\section{$\underline{\mathrm{HTW}}$}

The HTW gasification process is a pressurized version of the atmospheric pressure Winkler coal gasifier which was widely applied until the 1960s. Rheinbraun AG, a German coal company, began developing the HTW process in 1974 in order to utilize German brown coal. The process can be operated with either air to produce a low Btu heating value gas or with oxygen to produce a medium Btu heating value gas.

In 1979, Rheinbraun commissioned a 25 to 40 ton per day (TPD) pilot plant in Germany which operates at $146 \mathrm{psi}$. In 1985 the first commercial size plant was started up in Germany. The plant capacity is 730 dry TPD of brown coal. It used oxygen and produces a synthesis gas which is converted to methanol.

In 1988, an HTW plant in Finland began operation. The unit was recently shut down. It was designed for $27 \mathrm{TPH}$ of dry peat (about $90 \mathrm{MWt}$ ), but the actual feed was a mixture of 60 percent peat and 40 percent wood. The plant operated at pressures as high as $190 \mathrm{psi}$, was oxygen blown, and produced a synthesis gas which was converted to ammonia.

In 1989, Rheinbraun started up a pilot plant in Germany for gasification tests at pressures up to 365 psi. This pilot plant has a capacity of 160 TPD of dry German brown coal (about $30 \mathrm{MWt}$ ).

Rheinbraun reports that the above plants have been very reliable.

For projects based on the HTW technology, Rheinbraun will provide a license for one time use of the technology. Rheinbraun has entered into an exclusive arrangement with Lurgi and Uhde, two German engineering firms. The two companies will provide each licensor with an engineering package (conceptual/preliminary design) and furnish proprietary equipment. The technology scope or gasification process island will cover the biomass dryer to the inlet of the gas turbine. Typical process guarantees will be provided covering biomass throughput, gas production, gas composition, power and utilities consumption, as well as pertinent environmental performance.

Based on information provided by Lurgi, the process scheme for biomass includes dry particulate control using candle filters and does not include dolomite injection for tar control. The ash withdrawn from the bottom of the gasifier contains about 60 to 70 percent carbon or char by weight and could be used as fuel for a boiler.

\section{$\underline{\mathrm{MTCI}}$}

MTCI refers to its gasification process as steam reforming technology because it is an indirectly heated fluidized bed gasifier using steam instead of air to fluidize the bed. Heat exchanger tubes in the bed provide the heat necessary to sustain the gasification reactions. The heat source inside the tubes is flue gas generated by combusting a portion of the product gas. Since air is not used, a medium Btu heating value gas is produced.

The key to the technology is the pulsed combustor developed by $\mathrm{MTCI}$. The pulsing action enhances the heat transfer from the flue gas through the tubes to the bed of feed being gasified.

MTCI has built a $33 \mathrm{lb} / \mathrm{hr}$ pilot unit and during 1985 and 1986 under a DOE program tested biomass feeds including pistachio shells, wood chips, rice hulls, recycle paper mill sludge, Kraft mill sludge, RDF, and municipal solid waste. A larger pilot plant $(200 \mathrm{lb} / \mathrm{hr})$ was built and from 1987 to 1989 was used to test paper mill wastes and black liquor. In 1990 EPA sponsored tests using municipal solid waste and RDF. 
In 1992 MTCI built a 1 ton per hour (TPH) paper mill sludge gasifier at an Inland Container Corporation plant in California. Testing of the unit began in May 1992. A successful 500 hour extended duration test was conducted during July 1993. A total of 138 tons of as-received sludge was gasified. The gasifier and pulsed combustor heat exchanger were 100 percent available during this test run. However, the actual availability of the unit was 85 percent due to problems with the sludge feeder and utility supply.

The Inland Container unit was shut down and relocated to MTCI's Baltimore facility where it is used for large scale pilot testing. About 23 tons of wood chips and 20 tons of wheat straw were recently tested in the unit. MTCI has reportedly sold a 60 TPD black liquor gasifier in India, a 120 TPD distillery spent wash gasifier in India and a 1 TPH black liquor gasifier in Spain. These units were built during 1992 and 1993. A 120 TPD black liquor gasifier was built with DOE support at the Weyerhaeuser pulp mill in New Bern, North Carolina. The unit was started up in the spring of 1994. About 2 months into the startup an internal cyclone in the gasifier broke away from its support and damaged some of the in bed heat exchanger tubes. Repairs are being made.

To date MTCI has focused on applications directly coupled to an existing boiler. They have provided conceptual schemes for integration with a combustion turbine which state that a venturi scrubber is one of the options for removing particulates from the fuel gas. They do not discuss tar formation and do not show injection of dolomite.

MTCI has created a subsidiary company called ThermoChem to market the technology. For each project ThermoChem intends to form a joint venture company with an engineer/procure/construct (EPC) contractor to provide a turnkey installation including the power generation equipment. They will also operate the unit. The permitting and operation and maintenance will be sub-contracted to Ogden Environmental Services. Licenses, royalties and guarantees are subject to negotiation.

\section{$\underline{\text { Lurgi CFB }}$}

Lurgi is a major supplier of circulating fluid bed (CFB) boilers. A 1.7 MWt pilot plant in Frankfurt was used to develop an atmospheric pressure CFB process. Lurgi states that the process can be operated with either air or oxygen, but all the experience to date appears to be with air. Petcoke, coal, lignite, anthracite culm, wood, tree bark, waste wood, straw, RDF, rubber waste and pulp mill sludges have been tested in the pilot plant.

In 1987, a $25 \mathrm{MWt}$ gasifier was placed in service at a pulp and paper mill in Austria. The gasifier produces low Btu gas fuel for a lime kiln. This plant was designed for tree bark, wood waste and up to 20 percent paper mill sludge. Lurgi states that the only problems with the plant has been due to the biomass dryer. The dryer was designed to dry feeds ranging from 15 percent to 50 percent moisture. The feeds tested however have exceeded $\mathbf{5 0}$ percent moisture content. The plant has successfully tested straw.

A $100 \mathrm{MWt}$ gasifier is currently under construction in Germany. The gasifier is designed for a mixture of lignite, demolition wood waste, RDF, and rubber waste. The low Btu gas produced will be fired in a cement kiln.

Lurgi has provided a scheme for gas turbine application which shows a fuel gas cleanup system that comprises a secondary cyclone, a dry filter (the filter type is not specified) and a two stage scrubber. Particulates are removed in the cyclone and filter and undesired inorganic (ammonia, hydrogen cyanide, hydrochloric acid, etc.) and organic (phenols, fatty acids, oil, i.e. the tars) are removed in a two stage scrubbing system. Particulates captured in the cyclone and filter are recycled to the gasifier. The only 
outlet for ash is from the bottom of the gasifier and Lurgi states that this ash is very low in carbon content.

For each project based on the CFB gasifier, Lurgi will provide a license for one time use of the technology. As part of the licensing agreement, there will be requirements that Lurgi provide as a minimum a process design package, technical assistance for the detail design, startup and initial operation and supply of all proprietary equipment. The technology boundary is from the biomass dryer to the inlet of the gas turbine. Lurgi will provide typical process guarantees covering biomass throughput, gas production, gas composition, power and utilities consumption, as well as pertinent environmental performance.

\section{Bioflow}

In the early 1980s, A. Ahlstrom Corporation of Finland, well known for its circulating fluid bed boilers, developed an air blown, atmospheric pressure biomass gasifier to provide a fuel gas for lime kilns. The first commercial unit was installed in 1983 at a Finnish mill. To date Ahlstrom has supplied three more of these gasifiers.

In mid 1991, Ahistrom and Sydkraft AB, the largest private utility company in Sweden, agreed to jointly develop integrated biomass gasification combined cycle (IGCC) technology based on a pressurized version of the Ahlstrom CFB gasifier. Ahlstrom built a $7 \mathrm{MWt}$ pressurized gasifier pilot plant in Finland and tested waste wood chips, bark and sawdust.

Based on the pilot plant test results, the companies began developing an $18 \mathrm{MWt}$ IGCC cogeneration demonstration project in Varnamo, Sweden. In 1992 the two companies formed a joint venture company, Bioflow LTD., to market the technology.

The Bioflow process includes dolomite injection to the gasifier and hot gas cleanup using ceramic candle filters.

The Varnamo demonstration plant uses waste wood chips. The gasification portion of the plant started up in 1993 and has operated favorably. The gas turbine combined cycle portion of the plant was started up using oil in June, 1994. In October, 1994, the plant integration of the gasification and combined cycle was scheduled to occur. The gas turbine is a $4.8 \mathrm{MWt}$ unit supplied by European Gas Turbines.

In early 1994, Bioflow performed a feasibility study for a $60 \mathrm{MWt}$ biomass IGCC plant to be located at a pulp mill in Finland. The results of the feasibility study are being evaluated.

The pressurized Bioflow technology is being evaluated against the atmospheric pressure TPS technology for application in a $30 \mathrm{MWt}$ biomass gasification combined cycle demonstration plant in Brazil.

Bioflow will license the technology and be responsible for design from the biomass dryer to the inlet of the gas turbine. Ahlstrom will supply the gasifier. Bioflow will likely provide guarantees once the Varnamo demonstration plant has been successfully operated.

\section{American Carbons, Inc. (ACI)}

American Carbons, Inc's. (ACI) technology is pyrolytic conversion of carbonaceous materials into carbon products, oil, and gas. The process was developed by American Can Company from 1960 through 1978 and was called the Tech-Air process. ACI licensed the technology in 1979 and acquired all the rights to the technology in 1988. In the early 1980s ACI continued technology development and patented 
process called GRPP Technology. A non-exclusive license was issued to the Kingsford Company in 1982. A license, exclusive for Hawaii and certain Caribbean locations, was granted to Carbon Group Limited in 1986.

The pyrolysis or carbonization process takes place in a vertical packed bed reactor which converts the biomass into a solid char (carbon), a low Btu heating value fuel gas and a single phase low molecular weight organic emulsion (oil). About 32 percent by weight of the feed is converted to char, about 20 percent to oil and the remainder to gas.

To provide only a fuel gas, two options are possible. The char can be recycled in the pyrolyzer and the liquid product can be gasified in a separate gasifier or the char and the liquid feed can be gasified in a separate gasifier.

In developing the pyrolysis process, many different pilot units up to 50 TPD capacity were built. A prototype pyrolyzer was operated from 1973 to 1979 and is reported to have had an 83 percent availability. A $7500 \mathrm{lb} / \mathrm{hr}$ (dry basis) unit for the production of a high volatile content carbon was built in California and operated from 1983 to 1989 . The plant shut down in 1989 because it was ruined by a fire in the product storage area. Based on this experience $\mathrm{ACI}$ expects to be able to achieve a 90 percent availability factor.

ACI plans to limit a unit size to $12,500 \mathrm{lb} / \mathrm{hr}$ of bone dry feed (which will result in a pyrolyzer vessel plan area of about 55 square feet) and simply offer parallel trains to achieve the desired capacity. The feed would be dried to less than 20 percent moisture and the fuel gas should range from 125 to $150 \mathrm{Btu} / \mathrm{scf}$.

ACI has formed a joint venture with ICF Kaiser International to commercialize and further develop the technology. The joint venture intends to provide process design, fabrication, procurement and construction of a complete gasification and power generating facility. They may also license the technology. ICF Kaiser is willing to provide process guarantees for the basic pyrolysis unit, but not to the broader full-scale gasification application.

\subsubsection{Weyerhaeuser Visits to Gasification Facilities}

The following gasification facilities were visited by Weyerhaeuser personnel:

- The dual $15 \mathrm{MWt}$ atmospheric recirculating fluid bed gasifiers designed by TPS and built by Ansaldo in Greve-in-Chianti, Italy

- The 2 MWt atmospheric pilot facility at TPS in Studsvik, Sweden

- The VTT (Technical Research Center of Finland) pilot facilities in Espoo, Finland

- The $15 \mathrm{MWt}$ internally recirculating pressurized fluid bed gasifier pilot facility built by TampellaEnviropower and located in Tampere, Finland

- The pressurized steam dryer system pilot facility built by Imatron Voima Oy (IVO) and located at Jyvaskyla, Finland

- The $15 \mathrm{MWt}$ pressurized externally recirculating fluid bed gasifier and integrated combined cycle commercial plant, built by Ahlstrom and operated by Bioflow in Varnamo, Sweden

Based on these plant visits and discussions, Weyerhaeuser identified some areas of primary importance to successful commercialization and operation of BGCC technology including: 
- Materials handling - particularly feed systems for pressurized gasifiers and dryers. Operating availability of lockhopper or piston feeders is still questionable and the inert gas requirements of the lockhopper systems is an operating issue.

- Appropriate bed material (dolomite, limestone, etc.) for the recirculating systems that will both achieve the necessary "catalytic cracking" of the tars and maintain acceptable levels of carryover and attrition. . Progress has been made and the concept has been proven, but optimum materials have not yet been found.

- For the hot gas cleanup designs, operating conditions or operating windows are currently being optimized that will achieve the necessary tar cracking without sintering, provide for removal of alkali metals, and protect the operation of both the hot gas filter and the gas turbine.

- Although recent experience with candle filters looks promising, long term operating results are as yet unavailable for biomass gasification systems.

- For the atmospheric systems in particular, the cracking and removal of organic compounds, principally naphtha, must be dealt with in a long term, acceptable manner.

- Acceptable and economic methods of dealing with the ammonia formed in the gasification process and its impact on gas turbine nitrogen oxides emissions need analysis. The approaches are greatly different between atmospheric and pressurized systems.

- Methods of handling mill load swings must be determined. Depending upon the design of the BGCC cogeneration plant, supplemental firing of the HRSG with biogas may be required to follow mill steam demand while keeping the gas turbine base loaded.

- Both flue gas and integrated steam drying technologies are being considered by the different suppliers of gasification systems. However, most of these suppliers would likely prefer to limit their scope of supply to the gasification, gas cleaning and turbine systems. The dryer integration will have a significant impact on BGCC economics.

The plant visits were conducted under secrecy agreements and therefore details of the plant tours can not be published. It was noted that based on the level of effort being expended on this technology, commercial operation of a BGCC plant should be achievable in two to three years.

\subsubsection{Gasification Technology Selection}

Upon completion of the evaluation of candidate gasification technologies, MTCI and ACI were eliminated from further consideration-MTCI because of the fact that Weyerhaeuser and DOE are already gaining experience with this technology through a black liquor gasification project also being implemented at the New Bern mill. The ACI technology was considered to be extremely interesting, but it did not clearly fit the criteria set forth for BGCC and the scale up to the size anticipated for the New Bern project was deemed to be a high risk at this time.

The team believed there was an insufficient basis for selecting among the remaining technologies. Consequently, it was decided to find out which technology suppliers would be willing to provide specific design information to proceed with the conceptual engineering and costing of the New Bern BGCC Demonstration Project. Each of the vendors was given a design basis and asked to respond with information.

Bioflow (Ahlstrom) said that they could not respond at this time because all their energies were focused on the Varnamo plant start up. FERCO advised that they had established a design/construct relationship with Zurn-Nepco; however Zurn-Nepco advised that their resources were directed at the Burlington demonstration project. Consequently, they offered to provide information directly to Weyerhaeuser at a later time which could be compared to the Phase I feasibility results. For the HTW and its own CFB 
gasification process, Lurgi was only willing to provide an overall summary material balance and total estimated price for the gasification island.

Only Tampella and TPS agreed to closely interface with Stone \& Webster and Weyerhaeuser in order to develop a detailed heat and material balance suitable for determining plant performance and a basis for preparing a reasonable capital cost estimate. As a result, these two technologies were utilized in the study, providing an excellent basis for comparing the benefits and issues of an atmospheric and a pressurized gasification system integrated with the needs of a bleached kraft market pulp mill.

\subsection{Design Basis}

\subsubsection{Biomass Gasification Combined Cycle (BGCC) Cogeneration Plant}

The New Bern Pulp Mill generates process steam and electricity using a black liquor recovery boiler, a power boiler, and an extraction backpressure steam turbine generator. The power boiler, although designed to burn mill residuals (rejected or waste biomass), is currently able to fire only oil as a result of emissions limitations. The power boiler is also referred to as a bark boiler or a hog-fuel boiler. Weyerhaeuser is considering life extending (modifying) the power boiler and retrofitting emission controls which would allow it to once again burn biomass. The BGCC cogeneration plant is an alternative to the bark boiler retrofit project (which is referred to in this report as the Base Case Mill).

A general Electric Frame 6B gas turbine was selected as the basis for the BGCC plant since a biomass gasifier firing the 6B gas turbine with a heat recovery steam generator (HRSG) is of the right size to meet the steam requirements of the mill following the completion of a fiber-line modernization project planned for start-up in late 1997.

With maximum throttle steam flow, the mill's extraction/backpressure steam turbine generates $29 \mathrm{MWe}$. The mill's electricity consumption is $34.5 \mathrm{MWe}$, so $5.6 \mathrm{MWe}$ is purchased. The turbine extraction provides 155 psig process steam and the turbine exhaust supplies 55 psig process steam. The throttle steam conditions are $850 \mathrm{psig} / 825^{\circ} \mathrm{F}$. Because of the backpressure design, if the mill need for $55 \mathrm{psig}$ steam drops, either the throttle flow to the turbine must be reduced accordingly or the excess 55 psig steam must be vented. The practice is to decrease the throttle flow which results in less electric generation and increased outside power purchases. To eliminate this problem, a $10 \mathrm{MWe}$ condensing steam turbine generator (with the same throttle conditions as the existing turbine) is included as part of the Base Case Mill (bark boiler retrofit project) and the BGCC retrofit project.

The pulp mill and associated saw mill produce approximately 129,000 bone dry tons (BDT)/year of biomass wastes. The BGCC project will require additional biomass feed which will be supplied from forest management thinnings and other sources which are discussed in detail in Section 3.

Table 1-3 provides the overall design basis for the BGCC plant. The major requirement as of June 1994 based on a predicted steam demand after fiber line modernization is that the BGCC plant reliably supply $156,000 \mathrm{lb} / \mathrm{hr}$ of $850 \mathrm{psig} / 825^{\circ} \mathrm{F}$ steam and $45,000 \mathrm{lb} / \mathrm{hr}$ of $155 \mathrm{psig}$ saturated steam. The mill is planning to convert its existing once-through cooling system to a mechanical draft cooling tower. The cooling load of the BGCC plant will be added to the mill cooling water load and the incremental cooling tower cost included in the BGCC plant cost estimate. Deaerated boiler feed water will be provided to the BGCC plant from the existing mill turbine-driven boiler feed pumps. The analyses of boiler feedwater, process water and potable water which are available from the existing systems are given in Table 1-4. Wastewater streams will be treated in the existing mill wastewater treatment system. The mill 
is planning to install a stripping system for gas streams containing trace amounts of volatile organic compounds. This system will also be available for BGCC plant use.

\subsubsection{Ethanol Plant}

Much of the residual biomass generated at the mill site is bark which is high in lignin and not a suitable feed to the ethanol plant. Therefore, the ethanol plant feed will be trucked in biomass (wood chips from forest thinnings and other sources discussed in Section 3). The ethanol plant overall design basis is given in Table 1-5. The plant is sized to process 1000 BDT per day of biomass. This feed still contains lignin which becomes a byproduct of the ethanol process. If the ethanol plant is sited with the Base Case Mill (refurbished bark boiler), the lignin will be sold as fuel. Since the Base Case Mill can only supply the mill process steam needs, the ethanol plant design considered here includes an oil-fired packaged boiler to satisfy its steam requirements.

The ethanol plant can also be included as part of a BGCC retrofit project. In that scenario, the BGCC plant would provide the ethanol plant steam needs in addition to replacing the bark fired boiler's steam supply. The ethanol plant lignin byproduct will be used as part of the BGCC plant feed. 


\section{Site Data}

- Location: New Bern, North Carolina

- Elevation: 12 feet $\mathrm{msl}$

- Wind Load: $110 \mathrm{mph}$

- Seismic Zone 1

- $\quad$ Pile foundations for major structures

\section{Utilities}

- Cooling tower with river water makeup

- Cooling water inlet temperature $90^{\circ} \mathrm{F}$

- Demineralized (boiler feedwater) water available

- Process water available

- Potable water available

\section{Other Infrastructure}

- Primary and secondary wastewater treatment systems and condensate stripping systems are available

\section{Power Island}

- Existing pulp mill power complex includes a black liquor recovery boiler and a bark boiler which supply steam to a single extraction backpressure steam turbine. The BGCC plant will replace the bark boiler. The HRSG must provide the following steam to the pulp mill to meet the steam requirements of the mill following the completion of a fiber-line modification project planned for start-up in late 1997.

$156,000 \mathrm{lb} / \mathrm{hr} @ 850 \mathrm{psig} / 825^{\circ} \mathrm{F}$

$45,000 \mathrm{lb} / \mathrm{hr}$ of $155 \mathrm{psig}$ saturated

- BGCC plant will be based on a single General Electric Frame 6B gas turbine capable of firing either low Btu fuel gas or distillate oil; $\mathrm{NO}_{x}$ control approach to be determined

- Gas turbine performance at inlet air temperature $59^{\circ} \mathrm{F}, 60 \%$ relative humidity. 
Table 1-3: BGCC Plant Design Basis (Cont)

\section{Gasification Island}

- Feed-mixture of harvesting and thinning residuals and sawmill waste

TPS

$842 \mathrm{BD}$ tons per day

1,685 tons per day (wet basis)

Tampella

913 BD tons per day

1826 tons per day (wet basis)

- Feed as received ultimate analysis (average)

Moisture $\quad 50.0$

Carbon 25.1

Hydrogen $\quad 2.7$

Nitrogen $\quad 0.1$

Oxygen $\quad 20.1$

Ash $\quad 2.0(0.35 \%$ soluble, $1.65 \%$ acid insoluble $)$

- $\quad$ Feed HHV 8800 Btu/lb (dry basis)

- Feed bulk density, uncompacted $6.8 \mathrm{lb} /$ cubic foot

- $\quad$ Feed as received size distribution

Williams Classification

$\begin{array}{lr}+29 \mathrm{~mm} & 7.9 \% \\ +22 \mathrm{~mm} & 14.6 \% \\ +16 \mathrm{~mm} & 23.0 \% \\ +10 \mathrm{~mm} & 26.3 \% \\ +5 \mathrm{~mm} & 15.9 \% \\ \text { pan } & 12.3 \%\end{array}$

- $\quad$ Dryer to be designed for $55 \%$ moisture feed

\section{Air Emissions Limits}

- New Source Performance Standards (NSPS)

\section{Sparing Philosophy}

- Consistent with achieving high availability ( $95 \%)$ (e.g., online spares for rotating and severe service equipment)

\section{Sizing Philosophy}

- Since there are only a few gas turbine offerings with biomass produced gas that provide acceptable guarantees based on a sound testing program, the plant size was forced to match the fuel needs of the turbine selected - the GE Frame 6B. This resulted in somewhat different feed mass flows for each BGCC alternative and the ethanol plant. 
Table 1-4: Water Analyses from Existing Systems at New Bern Pulp Mill

\begin{tabular}{|c|c|c|c|}
\hline & Potable Water & Process Water & Boiler Feedwater \\
\hline $\mathrm{pH}$ & 8.15 & 6.55 & 6.05 \\
\hline Specific Conductance, $25^{\circ} \mathrm{C}$, UMHOS & 560. & 128.4 & 2.65 \\
\hline Alkalinity, "P" as $\mathrm{CACO}_{3}$, ppm & $\mathbf{0}$ & 0.4 & 0.4 \\
\hline Alkalinity, "M" as $\mathrm{CACO}_{3}$, ppm & 258. & 22.4 & 2.0 \\
\hline Sulfur, Total, as $\mathrm{SO}_{4}$, ppm & 10. & 18.05 & 0.5 \\
\hline Chloride, as CL, ppm & 24. & 12.1 & 0.5 \\
\hline Hardness, Total, as $\mathrm{CACO}_{3}$, ppm & 179.5 & 29.4 & 0.1 \\
\hline $\begin{array}{l}\text { Calcium Hardness, Total, as } \mathrm{CACO}_{3} \text {, } \\
\text { ppmo }\end{array}$ & 106. & 19.6 & 0.05 \\
\hline $\begin{array}{l}\text { Magnesium Hardness, Total as } \mathrm{CACO}_{3} \text {, } \\
\text { ppm }\end{array}$ & 73. & 9.2 & 0.05 \\
\hline Copper, Total, as CU, ppm & 0.05 & 0.05 & 0.005 \\
\hline Iron, Total, as FE, ppm & 0.365 & 1.15 & 0.005 \\
\hline Sodium, as NA, ppm & 55.5 & 12.75 & 0.055 \\
\hline Manganese, Total as MN, ppm & 0.03 & 0.07 & \\
\hline Phosphate, Total, as $\mathrm{PO}_{4}$, $\mathrm{ppm}$ & 0.4 & 0.4 & 0.4 \\
\hline Phosphate, Total Inorganic, as $\mathrm{PO}_{4}$, ppm & 0.2 & 0.25 & \\
\hline Phosphate, Ortho- as $\mathrm{PO}_{4}$, ppm & 0.2 & 0.25 & \\
\hline Silica, Total, as $\mathrm{SIO}_{2}$, ppm & 25.5 & 8.0 & 0.05 \\
\hline
\end{tabular}


Table 1-5: Advanced Biomass Cellulose to Ethanol Plant Design Basis

\begin{tabular}{|c|c|c|}
\hline Feed Stock & $\begin{array}{l}\text { Chipped harvesting and thinning residt } \\
\text { BDT } 2083 \text { tons per day (wet basis) } \\
\text { Composition } \\
\text { Cellulose } \\
\text { Hemicellulose } \\
\text { Lignin } \\
\text { Sol. Solids/inerts } \\
\text { Insol. solids/inerts } \\
\text { Water } \\
\text { Chip Size Distribution } \\
+29 \mathrm{~mm} \\
+22 \mathrm{~mm} \\
+16 \mathrm{~mm} \\
+10 \mathrm{~mm} \\
+5 \mathrm{~mm} \\
\ll 5 \mathrm{~mm}\end{array}$ & $\begin{array}{l}\text { is from southern pine plantations } 1000 \\
\\
\text { WT \% } \\
18.4 \\
11.75 \\
12.31 \\
4.79 \\
0.75 \\
52.00 \\
\\
\% \\
8.0 \\
14.6 \\
23.0 \\
26.3 \\
15.9 \\
12.3\end{array}$ \\
\hline Product & $\begin{array}{l}\text { Anhydrous fuel grade ethanol (undena } \\
79,000 \text { gallons per day } \\
26,860 ; 000 \text { gallons per year }\end{array}$ & red) \\
\hline By-products & $\begin{array}{l}\text { Lignin based residual solids (stillage) } \\
614 \text { tons per day ( } 45 \% \text { moisture) }\end{array}$ & \\
\hline Chip Storage & 21 days & \\
\hline Pretreatment & $\begin{array}{l}\text { Proprietary Amoco dilute acid prehyd } \\
\text { Temperature } \\
\text { Pressure } \\
\text { Conversions: } \\
\text { Cellulose to glucose } \\
\text { Hemicellulose to Hexose and Xylose } \\
\text { Hemicellulose to Furfural: Grouped i }\end{array}$ & $\begin{array}{l}\text { lysis reactor: } \\
489^{\circ} \mathrm{F} \\
615 \text { PSIA } \\
\\
10 \% \\
90 \% \\
\text { oluble solid }\end{array}$ \\
\hline Flash Tanks (F.T.) & $\begin{array}{l}\text { First F.T. Insoluble Solids Conc. } \\
\text { Second F.T. Insoluble Solids Conc. } \\
\text { Residence Time } \\
\text { First F.T. Pressure } \\
\text { Second F.T. Pressure } \\
\end{array}$ & $\begin{array}{l}30 \text { WT\% } \\
33 \text { WT\% } \\
5 \text { minutes } \\
24 \text { PSIA } \\
3 \text { PSIA }\end{array}$ \\
\hline Neutralization & $\begin{array}{l}\text { Neutralizing Agent } \\
\text { Residence Time } \\
\text { Dosage: }\end{array}$ & $\begin{array}{l}17 \% \text { Lime Slurry } \\
5 \text { minutes } \\
\text { Over Lime to pH } 7.5\end{array}$ \\
\hline
\end{tabular}


Table 1-5: Advanced Biomass Cellulose to Ethanol Plant Design Basis (Cont)

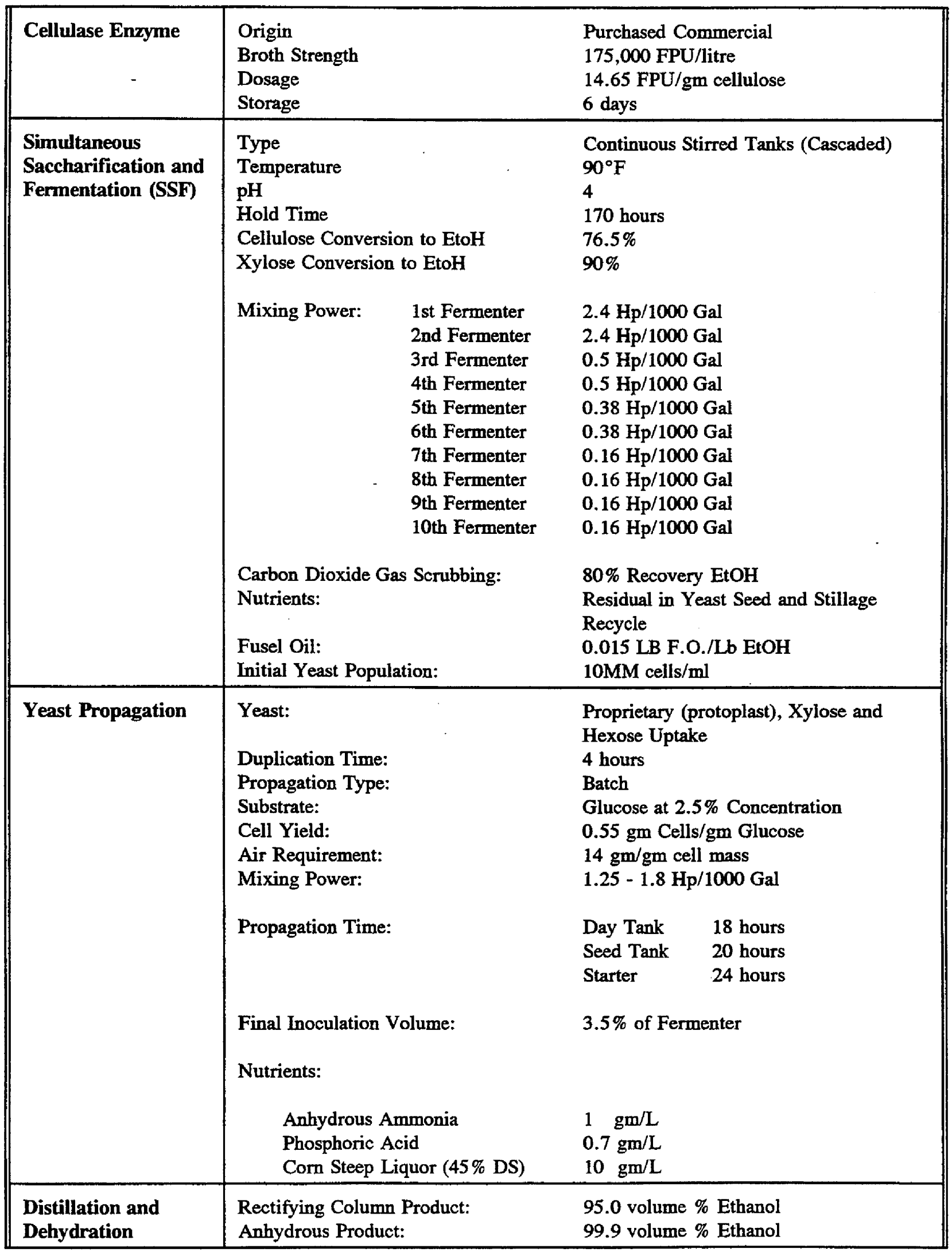


Table 1-5: Advanced Biomass Cellulose to Ethanol Plant Design Basis (Cont)

\begin{tabular}{||l|ll||}
\hline Stillage Handling & Centrifugation: & \\
& Cake: & $35 \%$ Solids \\
Recovery: & $64 \%$ of Solids \\
& Rotary Vacuum Filter: & \\
& Cake: & $55 \%$ Solids \\
& Recovery: & $92 \%$ of Solids \\
\hline Utilities & Steam: & 610 PSIG Sat'd \\
& & 155 PSIG Sat'd \\
& Chilled Water: & \\
& Supply & $45^{\circ} \mathrm{F}$ \\
& Return & $65^{\circ} \mathrm{F}$ \\
& Cooling Water: & $90^{\circ} \mathrm{F}$ \\
& Supply & $110^{\circ} \mathrm{F}$ \\
\hline Retu m
\end{tabular}




\section{Section 2}

\section{Preliminary Design and Cost}

At the start of the project, Stone \& Webster requested design and cost information for the proposed Weyerhaeuser New Bern biomass gasification combined cycle plant (BGCC) from several gasifier vendors and design and requested cost information for an integrated ethanol-from-biomass plant from Amoco. All of the vendors were given the Basis of Design (Section 1.3) and asked to provide a complete preliminary design package. Only two gasification vendors (TPS and Tampella) responded with sufficient information. Consequently, only these technologies were evaluated.

Using the TPS, Tampella, and Amoco information, Stone \& Webster developed system designs and cost estimates for three BGCC cases and two ethanol cases (integrated with BGCC and stand-alone). One of the BGCC cases is based on the TPS atmospheric gasification system, and two cases use the Tampella (EnviroPower) pressurized gasification system. All produce sufficient fuel gas to power a General Electric Company (GE) Frame 6B gas turbine. Each of the BGCC designs supplies 100 percent of the existing mill's power needs as well as excess power for sale to the area electric utility. In addition, process steam needs above that required by the recovery boiler are satisfied by the BGCC system. The ethanol plant integrated with the BGCC supplies lignin feed to the gasifier and the BGCC returns process steam to the ethanol process. In the stand-alone case, the lignin is sold as fuel or used in the existing bark boiler and an auxiliary boiler provides the ethanol plant process steam requirements.

Biomass gasification design packages provided by TPS and Tampella included process descriptions, heat and material balances, and installed equipment cost information, but did not supply base equipment costs for the gasification island which, therefore, required clarification and adjustment. The Amoco ethanol package included block flow diagrams, material balances, some kinetic data, and some stream property data. Amoco also provided the cost of the proprietary pretreatment "black box."

Stone \& Webster worked closely with TPS, Tampella, and Amoco to develop a detailed process flow diagram and heat and material balance for the overall BGCC cogeneration plant and ethanol plant configurations. In-house process simulation software was used to confirm the vendor-provided heat and material balances for the gasifiers, gas coolers, and heat recovery steam generator (HRSG) systems. In addition, the fuel gas specifications and gas turbine performance data were submitted to GE for verification.

For the TPS system, Stone \& Webster redesigned and prepared cost estimates for the gas cooling and scrubbing systems. Stone \& Webster also sized and costed all of the non-proprietary equipment for the Amoco ethanol process. For both BGCC technologies and the ethanol plant, major equipment items in the material handling and power systems were sized by Stone \& Webster and submitted to vendors for pricing. Most of the costs for the balance-of-plant systems and structures were estimated using factors except for major equipment items such as the cooling tower and flare.

The results of the design and cost estimating activities are presented in the following sections.

\subsection{TPS Studsvik Biomass Gasification Combined Cycle Cogeneration Plant Design}

The TPS system uses an atmospheric pressure gasification vessel to convert dried biomass into a low-Btu fuel gas. TPS believes that uncracked tars and hydrocarbons would foul the biogas cooler and condense in the biogas scrubber. Therefore, an additional tar cracker atmospheric vessel is employed downstream 
of the gasifier to catalytically break down tars and heavy hydrocarbons into lower molecular weight compounds. Without this feature, the condensed tars would increase wastewater treatment requirements and reduce the carbon conversion efficiency of the plant. Because of the tar cracking vessel and large degree of gas cooling, the TPS process can use conventional gas cleaning equipment such as bag filters and scrubbers.

TPS was given the option of specifying the moisture content of the biomass feed to the gasifier and had originally decided upon a 10 weight percent feed moisture content. The project team, however, had concerns regarding the feasibility of drying wood chips of the specified size range to such a low moisture value. Since other vendors were recommending a 20 percent moisture content (by weight) basis, TPS was asked to provide a revised design based on 20 percent for the sake of consistency.

The original TPS design did not account for the fact that the New Bern mill would supply heated boiler feed water to the BGCC plant. Stone \& Webster therefore redesigned the gas cooler and biogas water scrubber to account for the reduced requirements for low-level heat recovery. To be consistent with the TPS design, Stone \& Webster designed the biogas water scrubber and biogas absorption tower as separate systems. Consolidating the two towers into one packed column tower could reduce capital cost and should be investigated prior to detailed design.

When firing low-Btu gas, the combined flow of fuel gas and combustion air would exceed the design limits of the gas turbine expander. Air is therefore bled from the compressor discharge to prevent surging. TPS had developed a cost-effective concept to let down the high pressure turbine extraction air for use in the gasifier and tar cracker. However, since additional development work was required to adapt the TPS integration scheme to the Frame $6 \mathrm{~B}$ gas turbine, it was decided to use a conventional expander-compressor system. This equipment provides the 20 psig air for gasification and generates an additional 1.2 MW of electricity.

Alteratively, one could throttle the gas turbine compressor inlet guide vanes in order to eliminate the need for extraction air. In this design, gasification air requirements are provided by a separate compressor. This option was also investigated and is discussed within the performance section of this report (Section 2.3.2).

Due to the significant cooling of the biogas, more steam is generated by the TPS design BGCC plant than is required by the mill. The additional steam flow is utilized in the auxiliary steam turbine to produce about $2.9 \mathrm{MW}$ of power. Consequently, the proposed standby $10 \mathrm{MW}$ condensing steam turbine was oversized by about $3 \mathrm{MW}$.

\section{System Description}

A process flow diagram of the biomass gasification system for the TPS design is shown in Figure 2-1, a material balance is provided in Table $2-1$, and an equipment list is provided in Table 2-2. Dried biomass from the dry fuel day bin is fed to the gasifier by the biomass feed, weigh hopper, conveyor system. This system is designed to function as two trains operating in parallel. Each line consists of a live bottom fuel bin with an extraction screw that doses the fuel onto a weigh belt conveyor. Since the gasifier operates at slight pressure, two pressurized rotary valves are required to prevent the backflow of combustible gases. Downstream of the rotary valves, a screw conveyor for each line feeds the fuel to the gasifier. Bed sand, used to initially charge the gasifier bed, is also fed manually to the gasifier on this conveyor system. Typically, the bed sand flow is zero during normal operating conditions. 
The gasifier is a cylindrical refractory-lined steel vessel. It operates in two regimes; the lower part of the gasifier contains a "dense-phase" fluidized bed, while the upper part of the gasifier operates as a "fast" fluidized bed.

As biomass is fed to the gasifier, it immediately falls into the lower level dense bed. The dense-phase fluidized bed processes coarser fuel particles and provides sufficient residence time for the gasification reactions. Preheated primary air enters the gasifier near the base of the gasifier vessel and maintains fluidization of the dense bed material. Without the dense bed, large particles would fall directly onto the air distributor plate and cause clinkering. Secondary air is added above the dense bed to increase the upward gas velocity to produce a "fast" fluidized bed. In this phase, the fuel is fully pyrolyzed and gasified by the combined action of heat, air and gas components. Gas exiting the top of the gasifier enters the primary and secondary solids separation cyclones. The separated particles are recirculated back to the dense bed in order to maximize carbon conversion. Ash is continually drained from the bottom of the vessel. Rotary valves in the ash removal system are required to prevent gas leakage. The bottom ash is cooled by two gasifier ash cooling screw conveyors operating in parallel.

Hot fuel gas from the secondary cyclone enters the fluidized bed tar cracker vessel. The main function of this vessel is to crack or convert tars and heavy hydrocarbons into more volatile organics. If not cracked, these tars would foul the biogas cooler, plug the fabric filter, and increase wastewater loads from the scrubber. Dolomite, a catalyst, is added to the bed to reduce nitrogen compounds to ammonia which can be easily removed by the downstream towers. The dolomite feed system consists of a single bin with discharge screw, two rotary feeders, and shutoff valve.

Unlike the gasifier, the tar cracker operates as a circulating fluidized bed without a dense bed at the bottom. The biogas is introduced at the bottom of the vessel to provide for good contact between the product gas and dolomite bed material. Tar conversion is dependent on the fluidizing gas velocity, temperature, and solid-gas contact time. The higher operating temperature of the cracker also serves to gasify any carbon particles remaining in the fuel gas. Gas exiting the top of the cracker enters the primary and secondary solids separation cyclones. The separated particles are recirculated back to the cracker. Because the dolomite is continuously broken down to finer particles which exit with the fuel gas, a continuous supply of fresh dolomite is required.

High efficiency cyclones are important to the operation of both the gasifier and tar cracker. In the case of the gasifier, the cyclones maximize carbon conversion and minimize ash transport to the tar cracker. In the tar cracker, the cyclones reduce the loss of dolomite catalyst and impact the size distribution of dust in the fuel gas.

Product gas from the tar cracker cyclones is cooled from $1,688^{\circ} \mathrm{F}$ to $347^{\circ} \mathrm{F}$ in the biogas cooler. The biogas cooler consists of an economizer section and an evaporator section. Boiler feed water entering the economizer at $303^{\circ} \mathrm{F}$ is heated to $527^{\circ} \mathrm{F}$. The economized water is combined with economized water from the HRSG and fed to the biogas cooler evaporator to produce high pressure saturated steam ( $880 \mathrm{psig}$, $533^{\circ} \mathrm{F}$ ). A continuous blowdown of approximately one percent of the steam flow is taken from the biogas cooler steam drum and sent to the blowdown flash tank. This controls the accumulation of impurities in the steam drum.

Particulate matter entrained in the product gas is removed by bag filters. As the biogas is cooled, alkali metals condense and attach to particulate matter in the gas stream. These compounds are subsequently removed by the filter. A nitrogen pulse is used to periodically shake the captured ash off the fabric filters. Filter ash collects at the bottom of the filter vessel and is discharged by a screw conveyor and a multiple rotary valve lock system. 
After dust removal, the gas is cooled to $100^{\circ} \mathrm{F}$ by a direct cooling condensing scrubber. Water and some residual hydrocarbons are condensed and removed from the product gas. A significant amount of ammonia is also removed by the condensing water. The gas is then washed in the biogas absorption tower by a recirculating dilute sulfuric acid stream for further ammonia removal. The combined activity of the scrubber and absorption tower provide for over 95 percent ammonia removal. The removal of ammonia prior to combustion of the biogas in the gas turbine precludes the need for selective catalytic reduction of nitrogen oxides $\left(\mathrm{NO}_{\mathrm{x}}\right)$ in the HRSG. The purge streams from both towers are sent to the mill's existing wastewater treatment system.

Biogas from the absorption tower passes through a knockout drum to remove entrained water prior to compression in the gas booster compressor. The gas is compressed from atmospheric pressure to the required inlet pressure of the gas turbine fuel skid (238 psig).

Atmospheric air, compressed by the gas turbine compressor, is combined with biogas in the gas turbine combustor. The hot gases from combustion are expanded in the turbine section to produce about $43.0 \mathrm{MW}$ of power. The combustion system is designed to fire both biogas and backup No. 2 distillate oil. The gas turbine package includes a lubrication and hydraulic oil system, generator package, fire detection and suppression system, and control system.

The extraction air from the gas turbine compressor at $148 \mathrm{psig}$ and $659^{\circ} \mathrm{F}$ is expanded in the expander section of the expander/compressor/generator. The expansion of the extraction air provides sufficient shaft energy to compress an additional amount of air to gasification requirements and to generate $1.2 \mathrm{MW}$ of power in the generator. The combined air flow is heated in the HRSG and sent to the gasification island.

Hot exhaust gas at $1,010^{\circ} \mathrm{F}$ from the gas turbine is ducted to the inlet of the HRSG. Although the HRSG direct burner system is designed to fire low-Btu gas for improved control and operability, the amount of supplemental firing is normally zero. The HRSG consists of two pressure levels, 155 psig and $850 \mathrm{psig}$. Low pressure (LP) boiler feedwater from the mill is heated to $350^{\circ} \mathrm{F}$ in the LP economizer section. This water is then evaporated at $155 \mathrm{psig}$ and $368^{\circ} \mathrm{F}$ in the LP evaporator section and sent to the mill for process uses. High pressure (HP) feedwater from the mill is fed to the HP economizer in the HRSG and to the HP economizer in the biogas cooler and heated to $509^{\circ} \mathrm{F}$. A portion of the heated water exiting the HRSG HP economizer is sent to the biogas cooler, combined with biogas cooler economized water and evaporated. The remaining HRSG economized water is evaporated in the HP evaporator section of the HRSG. The saturated steam flow from the biogas cooler and the HRSG HP evaporator are combined and superheated in the HRSG HP superheater section to $825^{\circ} \mathrm{F}$. About $26,000 \mathrm{lb} / \mathrm{hr}$ of superheated steam is sent to the auxiliary condensing steam turbine to produce $2.9 \mathrm{MW}$ of power. The remaining 156,000 $\mathrm{lb} / \mathrm{hr}$ is sent to the mill's existing steam turbine.

A continuous blowdown of about one percent of the steam flow is taken from the HRSG steam drums and the biogas cooler steam drum. Blow down from the two high pressure blow down tanks are let down to $155 \mathrm{psig}$. The resulting steam from the drums are sent to the 155 psig steam header. The remaining water at $155 \mathrm{psig}$ is combined with blowdown from the low pressure steam drum and letdown in the low pressure blow-off tank. Steam is released to the atmosphere and residual water is pumped to the cooling tower (refer to cooling tower description in Section 2.5.1).

The flue gas leaving the HRSG at $464^{\circ} \mathrm{F}$ is ducted to the biomass dryer (refer to material handling description in Section 2.4). The HRSG is provided with a stack for operation with backup distillate oil when the gasifier is out of service. A continuous emissions monitoring system is located in the ductwork upstream of the branch connections to the HRSG stack and dryer duct. 
Table 2-1: Material Balance - TPS BGCC (Flue Gas Dryer)

\begin{tabular}{|c|c|c|c|c|c|c|c|c|c|c|}
\hline NODE & 1 & 2 & 18 & 4 & 6 & 3 & 9 & 8 & 9 & 10 \\
\hline $\begin{array}{l}\text { STREAM } \\
\text { PRESSURE (PSIO) } \\
\text { TEMPERATURE (F) } \\
\text { TOTAL FLOW (LBIHR) } \\
\text { ORY FLOW (LEMHR) }\end{array}$ & $\begin{array}{l}\text { BIOMASS FEED } \\
\text { TO DRYER } \\
0 \\
59 \\
140,400 \\
70,200\end{array}$ & \begin{tabular}{|r|} 
DRIED BIOMASS \\
TO GASIFIER \\
0 \\
140 \\
87,800 \\
70,200
\end{tabular} & $\begin{array}{r}\text { ASH FROM } \\
\text { GASIFIER } \\
0 \\
392 \\
\\
-\quad 2,200 \\
-\quad\end{array}$ & $\begin{array}{cr}\begin{array}{c}\text { BED SAND } \\
\text { FEED }\end{array} & \\
& 0 \\
& 59 \\
& 0 \\
- & \end{array}$ & \begin{tabular}{cr}
\multicolumn{1}{c|}{$\begin{array}{c}\text { DOLOMITE } \\
\text { FEED }\end{array}$} \\
\\
\\
\\
$-\quad 2,300$ \\
$-\quad$
\end{tabular} & $\begin{array}{l}\text { BIOGAS TO } \\
\text { COOLER } \\
\\
1,688 \\
188,800\end{array}$ & \begin{tabular}{l} 
BIOGAS TO \\
FILTER \\
\multicolumn{1}{|l}{$\begin{array}{r}347 \\
188,800\end{array}$} \\
\end{tabular} & $\begin{array}{l}\text { ASH FROM } \\
\text { FILTER } \\
\\
\\
\\
\\
\\
-\quad 3,200 \\
-\end{array}$ & \begin{tabular}{r}
\multicolumn{2}{c|}{ FILTER } \\
CLEANING N2 \\
50 \\
\\
59 \\
$-\quad 700$ \\
$-\quad$
\end{tabular} & $\begin{array}{r}\text { BIOGAS TO } \\
\text { SCRUBBER } \\
3 \\
347 \\
186,300 \\
-\quad\end{array}$ \\
\hline NODE & 11 & 12 & 13 & 14 & 16 & 16 & 17 & 18 & 19 & 20 \\
\hline $\begin{array}{l}\text { STREAM } \\
\text { PRESSURE (PSIO) } \\
\text { TEMPERATURE (F) } \\
\text { TOTAL FLOW (LERHR) } \\
\text { DRY FLOW (LEHAR) }\end{array}$ & $\begin{array}{c}\text { COND. FROM } \\
\text { SCRUBBER } \\
0 \\
110 \\
11,400 \\
-\end{array}$ & $\begin{array}{r}\text { ACID WATER } \\
\text { TO ABS. TWR. } \\
30 \\
90 \\
8,200\end{array}$ & $\begin{array}{l}\text { ABS. TWR. } \\
\text { BLEED } \\
\\
15 \\
100 \\
8,500\end{array}$ & $\begin{array}{r}\text { BIOGAS TO GAS } \\
\text { COMPRESSOR } \\
1.5 \\
100 \\
174,600 \\
-\quad\end{array}$ & $\begin{array}{l}\text { BIOGAS TO } \\
\text { DUCT FIRING } \\
\begin{array}{rr}1.5 \\
& 100 \\
& 0 \\
. & \end{array}\end{array}$ & $\begin{array}{r}\text { BIOGAS TOG.T. } \\
245 \\
311 \\
174,600 \\
-\end{array}$ & $\begin{array}{l}\text { AIR TO G.T. } \\
\begin{array}{r}0 \\
59 \\
1,081,800 \\
-\quad\end{array}\end{array}$ & $\begin{array}{l}\text { EXTRACTION AIR } \\
\text { FROM G.T. }\end{array}$ & $\begin{array}{l}\text { G.T. EXHAUST } \\
\text { TO HRSG } \\
\begin{array}{r}1 \\
1,010 \\
1,193,500 \\
-\end{array}\end{array}$ & $\begin{array}{l}\text { FLUEGAS } \\
\text { TO DRYER } \\
1 \\
464 \\
1,193,500 \\
-\quad\end{array}$ \\
\hline NODE: & 21 & 22 & 23 & 24 & 26 & 26 & 27 & 28 & $29+\circ$ & 30 \\
\hline $\begin{array}{l}\text { STREAM } \\
\text { PRESSURE (PSIO) } \\
\text { TEMPERATURE (F) } \\
\text { TOTAL FLOW (LB/HR) } \\
\text { ORY FLOW (LB/HR) }\end{array}$ & \begin{tabular}{l} 
FLUEGAS TO \\
STACK \\
\multicolumn{2}{|c|}{0} \\
$1,246,100$ \\
$\cdots$
\end{tabular} & $\begin{array}{c}\text { AIR FROM } \\
\text { COMPRESSOR }\end{array}$ & $\begin{array}{l}\text { AIR FROM } \\
\text { EXPANDER }\end{array}$ & $\begin{array}{l}\text { GASIFICATION AIR } \\
\text { TO AIR HEATER }\end{array}$ & $\begin{array}{l}\text { GASIFICATION } \\
\text { AIR TO GASIFIER }\end{array}$ & $\begin{array}{r}\text { BFW TO LP } \\
\text { ECONOMIZER } \\
165 \\
303 \\
45,500 \\
--\end{array}$ & $\begin{array}{l}\text { LP STEAM } \\
\text { TO MILL } \\
\\
\\
\\
\\
\\
-\quad 455,000 \\
-\quad\end{array}$ & $\begin{array}{l}\text { HP BFW } \\
\text { FROM MILL } \\
900 \\
303 \\
183,800\end{array}$ & \begin{tabular}{|r|} 
BFW TO \\
BIOGAS COOLER \\
900 \\
303 \\
66,500 \\
$-\quad$
\end{tabular} & $\begin{array}{r}\text { BFW TOHP } \\
\text { ECONOMIZER } \\
900 \\
303 \\
117,300 \\
-\quad\end{array}$ \\
\hline NOOE & 31 & 32 & 33 & 34 & 35 & 36 & 37 & $38:$ & 39 & \\
\hline $\begin{array}{l}\text { STREAM } \\
\text { PRESSURE (PSIO), } \\
\text { TEMPERATURE (F) } \\
\text { TOTAL FLOW (LBAHR) } \\
\text { DRY FLOW (LBARR) }\end{array}$ & \begin{tabular}{r|} 
ECON. H2O TO \\
BIOGAS COOLER \\
890 \\
527 \\
42,400 \\
..
\end{tabular} & $\begin{array}{r}\text { STEAM FROM } \\
\text { BIOGAS COOLER } \\
880 \\
533 \\
107,800 \\
-\end{array}$ & $\begin{array}{l}\text { ECON. H2O TO } \\
\text { HP EVAP. } \\
890 \\
527 \\
74,900 \\
. .\end{array}$ & $\begin{array}{l}\text { STEAM FROM } \\
\text { HP EVAP. } \\
880 \\
533 \\
-\quad 74,200 \\
-\quad\end{array}$ & $\begin{array}{l}\text { HP SH STEAM } \\
\text { FROM HRSG } \\
850 \\
825 \\
182,000 \\
-\quad\end{array}$ & $\begin{array}{l}\text { HP STEAM } \\
\text { TO MILL } \\
850 \\
825 \\
156,000\end{array}$ & \begin{tabular}{|r} 
HP STEAM TO AUX \\
STEAM TURBIINE \\
850 \\
825 \\
26,000 \\
$-\quad$
\end{tabular} & $\begin{array}{r}\text { HP MILL STEAM TO } \\
\text { STEAM TURBIINE } \\
850 \\
825 \\
\\
- \\
-\end{array}$ & $\begin{array}{r}\text { CONDEN. FROM } \\
\text { STEAM TURBIINE } \\
2 \\
140 \\
26,000\end{array}$ & \\
\hline
\end{tabular}

NOTE:

1. BASED ON TPS PRELIMINARY MASS AND ENERGY BALANCE TRANSMITTED 9/21/94. ADJUSTED FOR GE GAS TURBINE PERFORMANCE PROVIDED BY GE ON NOV. 22, 1994.

2. REFERENCE DRAWING NO. 04996.00-DJ-0001-1. 
Table 2-1: Material Balance - TPS BGCC (Flue Gas Dryer)

\begin{tabular}{|c|c|c|c|c|c|c|c|}
\hline NOOE & 6 & 10 & 14 & 16 & 19 & 20 & 21 \\
\hline STREAM & $\begin{array}{l}\text { BIOGAS TO } \\
\text { COOLER }\end{array}$ & $\begin{array}{l}\text { BIOGAS TO } \\
\text { SCRUBBER }\end{array}$ & $\begin{array}{l}\text { BIOGAS TO GAS } \\
\text { COMPRESSOR }\end{array}$ & BIOGAS TO G.T. & $\begin{array}{l}\text { G.T. EXHAUST } \\
\text { TO HRSG }\end{array}$ & $\begin{array}{l}\text { FLUEGAS } \\
\text { TO DRYER }\end{array}$ & $\begin{array}{l}\text { FLUEGAS TO } \\
\text { STACK }\end{array}$ \\
\hline $\begin{array}{l}\text { PRESSUURE (PSIO) } \\
\text { TEMPERATURE (F) }\end{array}$ & $\begin{array}{r}5 \\
1,688\end{array}$ & $\begin{array}{r}3 \\
347\end{array}$ & & & $1,010^{1}$ & & $\begin{array}{r}0 \\
230\end{array}$ \\
\hline TOTAL FLOW (LBIHR) & 188,800 & 186,300 & 174,600 & 174,600 & $4,193,500$ & $1,193,500$ & $1,246,100$ \\
\hline COMPONENTS & & & & & & & \\
\hline (VOL\%) & $0.04 \%$ & $0.04 \%$ & $0.04 \%$ & $0.04 \%$ & $0.00 \%$ & $0.00 \%$ & $0.00 \%$ \\
\hline (VOL\%) & $1.13 \%$ & $1.13 \%$ & $1.25 \%$ & $1.25 \%$ & $0.00 \%$ & $0.00 \%$ & $0.00 \%$ \\
\hline CH4 & $3.08 \%$ & $3.08 \%$ & $3.39 \%$ & $3.39 \%$ & $0.00 \%$ & $0.00 \%$ & $0.00 \%$ \\
\hline २०० NOL\% & $19.47 \%$ & $19.47 \%$ & $21.42 \%$ & $21.42 \%$ & $0.00 \%$ & $0.00 \%$ & $0.00 \%$ \\
\hline (NOL $\%)$ & $11.46 \%$ & $11.46 \%$ & $12.61 \%$ & $12.61 \%$ & $6.90 \%$ & $6.90 \%$ & $6.61 \%$ \\
\hline (VOL\%) & $15.15 \%$ & $15.15 \%$ & $16.67 \%$ & $16.67 \%$ & $0.00 \%$ & $0.00 \%$ & $0.00 \%$ \\
\hline NOL\%: & $13.57 \%$ & $13.57 \%$ & $5.02 \%$ & $5.02 \%$ & $6.20 \%$ & $6.20 \%$ & $10.16 \%$ \\
\hline (VOL\%) & $35.82 \%$ & $35.82 \%$ & $39.59 \%$ & $39.59 \%$ & $74.10 \%$ & $74.10 \%$ & $70.95 \%$ \\
\hline NOL\%) & $0.00 \%$ & $0.00 \%$ & $0.00 \%$ & $0.00 \%$ & $12.80 \%$ & $12.80 \%$ & $12.26 \%$ \\
\hline ७ै (PPMV) & 2800 & 2800 & 80 & 80 & 0 & 0 & 0 \\
\hline H2S, ?, (PPMV) & 0 & 0 & 0 & 0 & $\mathbf{0}$ & 0 & 0 \\
\hline MOX $(P P M V D)(16 \% 02)$ & 0 & 0 & 0 & 0 & 25 & 25 & 24 \\
\hline $\mathrm{CO}$ & 0 & 0 & D. & 0 & 10 & 10 & 10 \\
\hline 20 (PPMV) & 0 & 0 & 0 & 0 & 7 & 7 & 7 \\
\hline (PPMWT) & 0 & 0 & 은 & 0 & 0 & $\mathbf{0}$ & 118 \\
\hline (PPMWT) & 0 & 0 & 0 & 0 & 4 & 4 & 42 \\
\hline ४ै। TOTAL & $100.00 \%$ & $100.00 \%$ & $100.00 \%$ & $100.00 \%$ & $100.00 \%$ & $100.00 \%$ & $100.00 \%$ \\
\hline
\end{tabular}

NOTE:
1. BASED ON TPS PRELIMINARY MASS AND ENERGY BALANCE TRANSMITIED 9/21/94. ADJUSTED FOR GE GAS TURBINE PERFORMANCE PROVIDED BY GE ON NOV. 22, 1994.

2. REFERENCE DRAWING NO. 04996.00-DJ-0001-1. 
Table 2-2: Equipment List - TPS BGCC (Flue Gas Dryer)

\begin{tabular}{|c|c|c|c|}
\hline Item No. & Description & Qty & Remarks \\
\hline A-201 & Biogas Water Scrubber & 1 & $\begin{array}{l}\text { Tray Tower 13'4" I.D. x 48'2", } \\
\text { Material-316 SS }\end{array}$ \\
\hline A-202 & Biogas Absorption Tower & 1 & $\begin{array}{l}\text { Tray Tower } 13^{\prime} 4^{\prime \prime} \text { I.D. x } 48^{\prime} 2 " \\
\text { Material }=316 \mathrm{SS}\end{array}$ \\
\hline G-201 & Gas Turbine Frame 6B & 1 & $43.0 \mathrm{MW}$ \\
\hline G-202 & Expander/compressor/generator & 1 & Includes generator for $1.2 \mathrm{MW}$ \\
\hline G-206 & Auxiliary Steam Turbine & 1 & $13 \mathrm{MW}$ \\
\hline G-207 & Bag Filter & 1 & Sized by TPS \\
\hline L-202 & Circulating Fluidized Bed Gasifier & 1 & Sized by TPS \\
\hline L-205 & Tar Cracker & 1 & Sized by TPS \\
\hline M-203 & Gasifier Primary Cyclone & 1 & Sized by TPS \\
\hline M-204 & Gasifier Secondary Cyclone & 1 & Sized by TPS \\
\hline M-206 & Tar Cracker Primary Cyclone & 1 & Sized by TPS \\
\hline M-207 & Tar Cracker Secondary Cyclone & 1 & Sized by TPS \\
\hline M-208 & Biogas Knock-out Drum & 1 & $\begin{array}{l}\text { 5'-0" Diameter, } 15^{\prime}-0 " \text { Length, } \\
\text { Material = } 316 \text { SS }\end{array}$ \\
\hline$M-212$ & Biogas Cooler Continuous Blowdown Tank* & 1 & $\begin{array}{l}5 '-2 " \text { x 0'-6" } 175 \text { psig design } \\
\text { (Vertical) }\end{array}$ \\
\hline M-213 & HRSG Continuous Blowdown Tank* & 1 & $\begin{array}{l}\text { 4'-10" x 0'-6" } 175 \text { psig design } \\
\text { (Vertical) }\end{array}$ \\
\hline M-214 & Blowoff Tank* & 1 & $\begin{array}{l}4^{\prime}-0^{\prime \prime} \times 1{ }^{\prime}-0^{\prime \prime} \text { atmospheric } \\
\text { design }\end{array}$ \\
\hline M-220 & Bed Sand Storage Hopper & 1 & Sized by TPS \\
\hline $\mathrm{P}-201 \mathrm{~A} / \mathrm{B}$ & Blowoff Transfer Pump* & 2 & $3.8 \mathrm{gpm}$ DELTA $P=50 \mathrm{psi}$ \\
\hline P-202A/B & Condensate Pump* & 2 & $200 \mathrm{gpm}$ at $90 \mathrm{psig}$ \\
\hline $\mathrm{P}-210 \mathrm{~A} / \mathrm{B}$ & Biogas Water Scrubber Recycle Pump & 2 & $\begin{array}{l}3,000 \mathrm{gpm}, \text { head }=30 \mathrm{psi} \\
\text { material = rubber lined CS }\end{array}$ \\
\hline $\mathrm{P}-211 \mathrm{~A} / \mathrm{B}$ & Biogas Absorber Recycle Pump & 2 & $\begin{array}{l}3,000 \mathrm{gpm}, \text { head }=30 \mathrm{psi}, \\
\text { material = rubber lined CS }\end{array}$ \\
\hline $\mathrm{R}-201$ & Gas Booster Compressor & 1 & $10.4 \mathrm{MW}$ \\
\hline $\begin{array}{l}\mathrm{T}-201 \mathrm{~A}, \mathrm{~B} \\
\mathrm{C}, \mathrm{D}\end{array}$ & Biomass Dryer & 4 & Flue gas dryer to $20 \%$ moisture \\
\hline $\mathrm{T}-202$ & Biogas Cooler & 1 & $\begin{array}{l}98 \mathrm{mmBtu} / \mathrm{hr} \text { Steam generator, } \\
\text { HRSG }\end{array}$ \\
\hline
\end{tabular}


Table 2-2: Equipment List - TPS BGCC (Flue Gas Dryer) continued

\begin{tabular}{|l|l|c|l|}
\hline \multicolumn{1}{|c|}{ Item No. } & \multicolumn{1}{|c|}{ Description } & Qty & \multicolumn{1}{|c|}{ Remarks } \\
\hline T-205 & HRSG & 1 & $\begin{array}{l}\text { Two pressure level system (850 } \\
\text { psig \& 155 psig) }\end{array}$ \\
\hline T-206 & Auxiliary Steam Turbine Condenser & 1 & $\begin{array}{l}130.5 \text { mmBtu/hr, 19,900 sq ft } \\
\text { incl. ejector package and two } \\
\text { mechanical vacuum pumps }\end{array}$ \\
\hline T-211 & Biogas Water Scrubber Cooler & 1 & $\begin{array}{l}\text { 22 mmBtu/hr Materials }= \\
\text { Tubes: 316 SS; Shell: CS }\end{array}$ \\
\hline W-204A/B & Gasifier Ash Cooling Screw Conveyor & 2 & Sized by TPS \\
\hline W-205 & Biogas Filter Ash Screw Conveyor & 1 & Sized by TPS \\
\hline W-206A/B & Gasifier Ash System & 2 & Sized by TPS \\
\hline W-207 & Filter Ash System & 1 & Sized by TPS \\
\hline W-211 & Dolomite Feed Weigh Hopper Conveyor System & 1 & Sized by TPS \\
\hline W-213A/B & Biomass Feed Weigh Hopper Conveyor System & 2 & Sized by TPS \\
\hline
\end{tabular}

*Not shown on PFD 


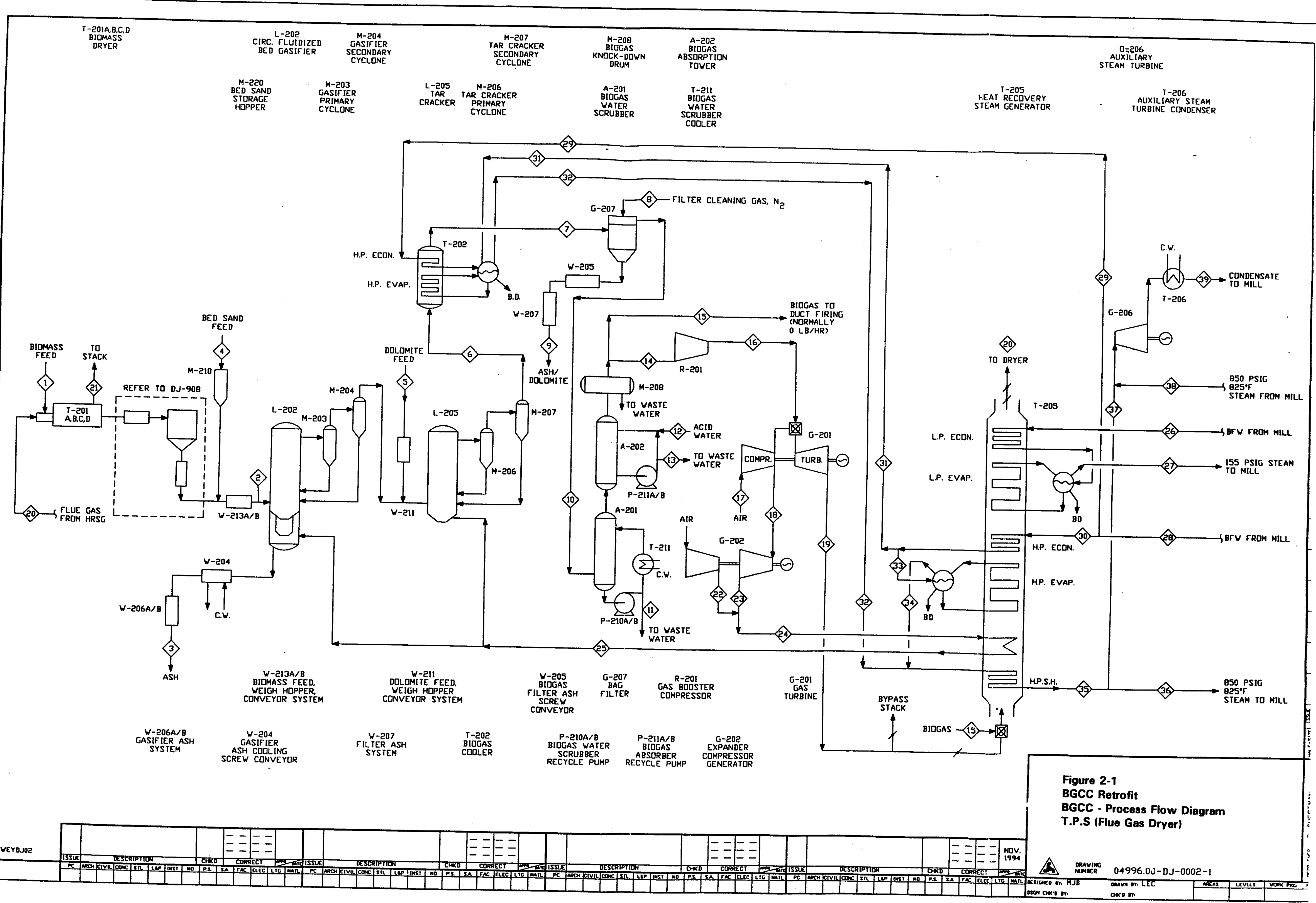


This page is intentionally left blank 


\subsection{Tampella Biomass Gasification Combined Cycle Cogeneration Plant Design}

The Tampella system features a pressurized gasification vessel to convert biomass into a low Btu fuel gas. The main advantage of the pressurized system is that it generates a fuel gas at a pressure sufficient to enter the gas turbine directly, therefore avoiding the need for a fuel gas compressor. The Tampella system employs a hot gas cleaning system which allows a large portion of the sensible heat in the fuel gas to be utilized by the gas turbine. Hot gas cleanup also reduces the gas cooling equipment duty and reduces the amount of wastewater produced. To meet gas turbine fuel quality requirements, the gas must be cooled to a temperature low enough to condense alkali vapors onto particulate matter for removal in the hot gas filter. This is accomplished in the biogas cooler by cooling the gas to $1,020^{\circ} \mathrm{F}$.

Tampella provided two design options for the drying of the biomass. In one case, flue gas from the HRSG dries the wet biomass feed to 20 percent (by weight) moisture. The other case uses steam raised in the HRSG for use in a steam dryer. In this option, the HRSG must be supplementary fired to produce the additional steam requirement. Both Tampella options are described below with the major differences being noted.

The Steam Dryer Case requires slightly superheated, medium pressure steam for use in the dryer. A medium pressure superheater section was therefore added to the HRSG. Since the dryer steam pressure requirement was only slightly higher than that for the mill process steam, the mill process steam was generated along with the steam dryer steam and then let down and desuperheated to meet the mill requirements.

Since the Tampella design does not allow for ammonia control prior to the gas turbine, an SCR system was added to the HRSG in both Tampella designs.

\section{System Description}

Process flow diagrams for the Tampella flue gas dryer and steam dryer cases are shown in Figure 2-2 and Figure 2-3. Material balances are provided in Table 2-3 and 2-4. Equipment lists for each case are provided in Tables 2-5 and 2-6. Dried biomass (20 percent moisture) is fed to the gasifier through three parallel trains of weigh hoppers, lock hoppers and screw feeder systems. Dolomite is fed to the gasifier using a single weigh hopper, lock hopper system. Nitrogen is used for lock hopper pressurization. Steam and air are used as the bed fluidizing agent.

In the fluidized bed, biomass carbon reacts with air and steam at approximately $1,625^{\circ} \mathrm{F}$. The operating pressure is $260 \mathrm{psig}$. High pressure superheated steam $\left(850 \mathrm{psig}, 825^{\circ} \mathrm{F}\right)$ from the HRSG is let down to $375 \mathrm{psig}$ and fed to the gasifier vessel. The fluidizing medium of steam and air are fed into the gasifier via a distributor plate at the bottom of the bed. The gasifier is a spouting bed design which provides high internal circulation rates and thorough mixing of the bed. This feature results in longer residence times and higher carbon conversion. Longer residence times and high operating temperatures also serve to minimize the formation of tars and ammonia.

Inert materials such as sand, stones, ash and dolomite collect at the bottom of the gasification vessel. The bed depth height is maintained by the bottom ash discharge system. This system consists of a watercooled screw conveyor and a depressurizing lock-hopper system.

Fines, ash, and other particulates are removed from the fuel gas in a single cyclone system. The collected solids are returned to the base of the gasification vessel to ensure high carbon conversion. The product 
gas (consisting of carbon monoxide, carbon dioxide, methane, hydrogen, water vapor, and small amounts of tars and ammonia) is sent to the gas conditioning system.

The raw biogas from the gasifier is cooled from $1,625^{\circ} \mathrm{F}$ to $1,020^{\circ} \mathrm{F}$ in the biogas cooler by evaporating high pressure economized water $\left(890 \mathrm{psig}, 509^{\circ} \mathrm{F}\right)$ to high pressure saturated steam $\left(880 \mathrm{psig}, 533^{\circ} \mathrm{F}\right)$. A continuous blowdown of approximately one percent of the steam flow is taken from the biogas cooler steam drum.

Particulate matter in the product gas is removed by the high temperature high pressure (HTHP) filter. The filter is composed of numerous ceramic candles. As the biogas is cooled, alkali metals condense and attach to particulate in the gas stream and are subsequently removed by the filter. High pressure heated nitrogen is used to clean the filter elements on line. Nitrogen from the nitrogen system is stored at 565 psig in the cleaning gas tank. The gas is maintained at approximately $400^{\circ} \mathrm{F}$ with steam lines to minimize thermal stresses in the ceramic candles. A backflow of nitrogen is pulsed to each of the candle filters to remove the accumulated filter cake. The filter ash collects at the bottom of the filter vessel and is removed by the filter ash removal system. The ash is transported in a jacketed screw conveyor. Cooling water cools the ash to $450^{\circ} \mathrm{F}$. The filter ash is depressurized in the ash/dolomite surge/lock hopper system and pneumatically conveyed to the filter ash silo.

Clean fuel gas is sent to the gas turbine combustor and mixed with combustion air from the gas turbine compressor. The hot combustion gases are expanded in the turbine section to produce about $42.8 \mathrm{MW}$ of power (42.2 MW in the Steam Dryer Case). The gas turbine is designed to fire both biogas and No. 2 distillate oil. The system includes a lubrication and hydraulic oil system, generator package, fire detection and suppression system, and control system. The hot exhaust gases exit the gas turbine at $1,018^{\circ} \mathrm{F}$ and are ducted to the HRSG.

When firing low-Btu gas, a portion of the compressed air flow must be bled from the air compressor discharge to avoid surging in the turbine expander section. The extraction air is utilized in the gasifier. A booster compressor is used to compress the extraction air from 157 psig to 345 psig in order to meet the required feed pressure of the gasifier. The gas turbine extraction air is cooled in a series of heat exchangers prior to compression by the booster compressor. The first heat exchanger is regenerative and also heats the air after compression before it enters the gasifier.

The HRSG is provided with a duct burner system designed to deliver low-Btu gas. In the flue gas dryer case, the amount of supplemental firing is normally zero. The duct burner, however, is designed to fire 20 percent of the HRSG heat input for improved control and operability. In the steam dryer case, approximately $20,000 \mathrm{lb} / \mathrm{hr}$ of biogas is fed to the HRSG duct burners to generate the additional steam required by the dryer.

The HRSG generates steam at two pressure levels, 155 psig ( 203 psig for the steam dryer case) and 850 psig. In the flue gas dryer case, LP boiler feedwater from the mill is heated to $350^{\circ} \mathrm{F}$ in the LP economizer section and evaporated at $155 \mathrm{psig}$ in the LP evaporator section and sent to the mill. In the steam dryer case, superheated steam at 203 psig and $428^{\circ} \mathrm{F}$ is generated for the dryer. A portion of the saturated steam flow is let down and desuperheated to $155 \mathrm{psig}$ for process use in the mill. In both cases, high pressure feedwater from the mill is fed to the HP economizer and heated to $509^{\circ} \mathrm{F}$. A portion of this flow is sent to the biogas cooler where it is evaporated. The remainder is evaporated in the HP evaporator section of the HRSG. The two HP saturated steam flows are combined and superheated to $825^{\circ} \mathrm{F}$ in the HP superheater section. A small portion of this flow is sent to the gasifier while the remainder is sent to the existing mill steam turbine. 
A continuous blowdown of one percent of the steam flow is taken from the two HRSG steam drums and the biogas cooler steam drum. Blowdown from the two high pressure blowdown tanks are let down to 155 psig. The resulting steam from the drums is sent to the 155 psig steam header. The remaining water at 155 psig is combined with blowdown from the low pressure HRSG steam drum and letdown in the low pressure blow-off tank. Steam is released to the environment and residual water is pumped to the cooling tower.

For the flue gas dryer design, the exhaust gases leaving the HRSG at $471^{\circ} \mathrm{F}$ are ducted to the biomass dryer (refer to material handling description in Section 2.4). For the steam dryer case the flue gas exits the HRSG at $342^{\circ} \mathrm{F}$ and is discharged through the HRSG stack.

In the flue gas dryer design, a continuous emissions monitor is located in the HRSG discharge ductwork upstream of branch connections to the biomass dryer and to the HRSG stack. In this case, the HRSG stack is used when the gasifier is out of service and the gas turbine fires distillate oil. For the steam dryer design, the continuous emissions monitor is located in the HRSG stack. 
Table 2-3: Materlal Balance - Tampella BGCC (Flue Gas Dryer)

\begin{tabular}{|c|c|c|c|c|c|c|c|c|c|c|}
\hline HOOE & 1 & 2 & 3 & 3 & 8 & 6 & It & 8 & 9 & 10 \\
\hline $\begin{array}{l}\text { STREAMT } \\
\text { PRESSURE (PSIO) } \\
\text { TEMPERATURE (F) } \\
\text { TOTAL FLOW (LBAR) } \\
\text { ORY FLOW }(\mathrm{LB} / \mathrm{HR})\end{array}$ & $\begin{array}{c}\text { BIOMASS FEED } \\
\text { TO DRYER } \\
0 \\
59 \\
152,200 \\
76,100\end{array}$ & $\begin{array}{r}\text { DRIED BIOMASS } \\
\text { TO GASIFIER } \\
280 \\
140 \\
95,200 \\
76,100\end{array}$ & $\begin{array}{l}\text { DOLOMITE } \\
\text { FEED } \\
280 \\
\\
59 \\
400 \\
400\end{array}$ & $\begin{array}{l}\text { N2 FEED TO } \\
\text { GASIFIER } \\
565 \\
59 \\
5,600 \\
-\end{array}$ & $\begin{array}{r}\text { ASH FROM } \\
\text { GASIFIER } \\
40 \\
450 \\
3,200 \\
-\end{array}$ & $\begin{array}{r}\text { BIOGAS TO } \\
\text { COOLER } \\
273 \\
1,625 \\
212,300 \\
-\end{array}$ & $\begin{array}{r}\text { BIOGAS TO } \\
\text { FILTER } \\
268 \\
1,020 \\
212,300 \\
-\end{array}$ & $\begin{array}{r}\text { FILTER } \\
\text { CLEANING N2 } \\
565 \\
400 \\
800 \\
-\end{array}$ & $\begin{array}{lr}\begin{array}{l}\text { ASH FROM } \\
\text { FILTER }\end{array} \\
\\
450 \\
1,100 \\
\\
\\
\end{array}$ & $\begin{array}{r}\text { BIOGAS TO G.T. } \\
260 \\
1,020 \\
212,000\end{array}$ \\
\hline HODE & 11 & 12 & 13 & 14 & 16 & 16 & 17 & 18 & 18 & 20 \\
\hline $\begin{array}{l}\text { STREAM } \\
\text { PRESSURE (PSIO) } \\
\text { TEMPERATURE (F) } \\
\text { TOTAL FLOW (LBHR) } \\
\text { DRY FLOW (LBIHR) }\end{array}$ & $\begin{array}{l}\text { BIOGAS TO } \\
\text { DUCT FIRING } \\
260 \\
1,020 \\
0 \\
-\end{array}$ & $\begin{array}{r}\text { AIR TO G.T. } \\
0 \\
59 \\
1,082,300 \\
-\end{array}$ & \begin{tabular}{|r|} 
AIR TO BOOSTER \\
COMPRESSOR \\
157 \\
662 \\
112,500 \\
-
\end{tabular} & \begin{tabular}{|r|} 
G.T. EXHAUST \\
TO DUCT BURNER \\
1 \\
1,018 \\
$1,181,800$
\end{tabular} & $\begin{array}{r}\text { EXHAUST GAS } \\
\text { TO HRSG } \\
1 \\
1,018 \\
1,181,800\end{array}$ & $\begin{array}{l}\text { FLUE GAS TO } \\
\text { DRYER } \\
\begin{array}{r}0 \\
471 \\
1,182,050 \\
-\end{array}\end{array}$ & $\begin{array}{l}\text { FLUE GAS TO } \\
\text { STACK } \\
0 \\
233 \\
1,239,050 \\
-\end{array}$ & $\begin{array}{r}\text { COMPR. AIR } \\
\text { TO GASIFIER } \\
345 \\
650 \\
112,500 \\
\end{array}$ & $\begin{array}{r}\text { BFW TO LP } \\
\text { ECONOMIZER } \\
165 \\
303 \\
45,500\end{array}$ & $\begin{array}{l}\text { LP STEAM } \\
\text { TO MILL } \\
155 \\
368 \\
45,000 \\
-\end{array}$ \\
\hline NODE & 21 & 22 & 23 & 24 & 268 & 26 & 27 & 28 & 29 & १ै। \\
\hline $\begin{array}{l}\text { STREAM } \\
\text { PRESSURE (PSIO) } \\
\text { TEMPERATURE }(F) \\
\text { TOTAL FLOW }(L B / H R) \\
\text { DRY FLOW (LBHR) }\end{array}$ & $\begin{array}{r}\text { BFW TO HP } \\
\text { ECONOMIZER } \\
900 \\
303 \\
159,300 \\
-\end{array}$ & \begin{tabular}{|r} 
ECON. H2O TO \\
BIOGAS COOLER \\
890 \\
509 \\
69,600
\end{tabular} & \begin{tabular}{|r|} 
STEAM FROM \\
BIOGAS COOLER \\
880 \\
533 \\
68,900 \\
$-\cdot$
\end{tabular} & $\begin{array}{l}\text { ECON. H20 TO } \\
\text { HP EVAP. } \\
890 \\
509 \\
89,700 \\
-\end{array}$ & $\begin{array}{r}\text { STEAM FROM } \\
\text { HP EVAP. } \\
880 \\
533 \\
88,900 \\
-\end{array}$ & \begin{tabular}{|r|} 
STEAM FROM HP \\
SUPERHEATER \\
880 \\
533 \\
157,800 \\
-
\end{tabular} & $\begin{array}{r}\text { SH STEAM TO } \\
\text { GASIFIER } \\
375 \\
825 \\
1,800\end{array}$ & $\begin{array}{l}\text { SH STEAM } \\
\text { TO MILL } \\
850 \\
825 \\
156,000 \\
-\end{array}$ & $\begin{array}{l}\text { AQ. AMMONNIA } \\
\text { TO SCR } \\
50 \\
59 \\
250\end{array}$ & ' \\
\hline
\end{tabular}

NOTE:

1. BASED ON TAMPELLA PRELIMINARY MASS AND ENERGY BALANCE TRANSMITTED 10/21/94. ADJUSTED FOR GE GAS TURBINE PERFORMANCE PROVIDED BY GE ON NOV. 22, 1994.

2. REFERENCE DRAWING NO. 04996.00-DJ-0003-1. 
Table 2-3: Materlal Balance - Tampella BGCC (Flue Gas Dryer)

\begin{tabular}{|c|c|c|c|c|c|}
\hline HODE & 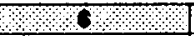 & 1 & 14 & 16 & 17 \\
\hline STREAM & $\begin{array}{l}\text { BIOGAS TO } \\
\text { COOLER }\end{array}$ & BIOGAS TO G.T. & G.T. EXHAUST & $\begin{array}{c}\text { FLUE GAS TO } \\
\text { DRYER }\end{array}$ & $\begin{array}{l}\text { FLUE GAS TO } \\
\text { STACK }\end{array}$ \\
\hline PRESSURE (PSIO) & 273 & 260 & & 0 & \\
\hline TEMPERATURE (F) & 1,625 & 1,020 & 1,018 & 471 & 233 \\
\hline TOTAL FLOW (LBAR) & 212,300 & 212,000 & $1,181,800$ & $1,182,050$ & $1,239,050$ \\
\hline \multicolumn{6}{|l|}{ COMPONENTS } \\
\hline (NOL\%) & $0.02 \%$ & $0.02 \%$ & $0.00 \%$ & $0.00 \%$ & $0.00 \%$ \\
\hline Not\% & $0.69 \%$ & $0.69 \%$ & $0.00 \%$ & $0.00 \%$ & $0.00 \%$ \\
\hline NOL & $7.50 \%$ & $7.50 \%$ & $0.00 \%$ & $0.00 \%$ & $0.00 \%$ \\
\hline NoL\%) & $12.30 \%$ & $12.30 \%$ & $0.00 \%$ & $0.00 \%$ & $0.00 \%$ \\
\hline Nol\%) & $15.90 \%$ & $15.90 \%$ & $7.28 \%$ & $7.28 \%$ & $6.94 \%$ \\
\hline NOL\% & $8.50 \%$ & $8.50 \%$ & $0.00 \%$ & $0.00 \%$ & $0.00 \%$ \\
\hline ৮ै & $14.30 \%$ & $14.30 \%$ & $7.69 \%$ & $7.69 \%$ & $11.94 \%$ \\
\hline NOL\%) & $40.70 \%$ & $40.70 \%$ & $73.14 \%$ & $73.16 \%$ & $69.79 \%$ \\
\hline NOLYS & $0.00 \%$ & $0.00 \%$ & $11.87 \%$ & $11.87 \%$ & $11.32 \%$ \\
\hline (PPMV & 900 & 900 & 0 & 0 & 0 \\
\hline १/ (PPMV & & & 0 & 0 & 0 \\
\hline (PPMVO) $15 \%$ O2) & & & 133 & 13 & 19 \\
\hline (PPMVD) & & & 10 & 10 & 15 \\
\hline (PPMV) & & & -7 & 7 & 10 \\
\hline (PPMWT & & & $\overline{0}$ & $\overline{0}$ & 0 \\
\hline (PPMWTI) & & & 4 & 4 & 65 \\
\hline TOTAL & $100.00 \%$ & $100.00 \%$ & $100.00 \%$ & $100.00 \%$ & $100.00 \%$ \\
\hline
\end{tabular}

NOTE:

1. BASED ON TAMPELLA PRELIMINARY MASS AND ENERGY BALANCE TRANSMITTED 10/21/94. ADJUSTED FOR GE GAS

TURBINE PERFORMANCE PROVIDED BY GE ON NOV. 22, 1994.

2. REFERENCE DRAWING NO. 04996.00-DJ-0003-1. 
Table 2-4: Material Balance - Tampella BGCC (Steam Dryer)

\begin{tabular}{|c|c|c|c|c|c|c|c|c|c|c|}
\hline NODE & 1 & 2 & 3 & 4 & 6 & 0 & 1 & $8 \%$ & 9 & 10 \\
\hline $\begin{array}{l}\text { STREAM } \\
\text { PRESSURE (PSIG) } \\
\text { TEMPERATURE (F) } \\
\text { TOTAL FLOW (LBHR) } \\
\text { DRY FLOW (LBAR) }\end{array}$ & $\begin{array}{r}\text { BIOMASS FEED } \\
\text { TO DRYER } \\
0 \\
59 \\
165,700 \\
82,850\end{array}$ & $\begin{array}{r}\text { DRIED BIOMASS } \\
\text { TO GASIFIER } \\
280 \\
212 \\
103,500 \\
82,850\end{array}$ & \begin{tabular}{cr|} 
DOLOMITE \\
FEED \\
\\
280 \\
\\
59 \\
440 \\
440
\end{tabular} & $\begin{array}{l}\text { N2 FEED TO } \\
\text { GASIFIER } \\
565 \\
59 \\
6,000 \\
-\end{array}$ & $\begin{array}{r}\text { ASHFROM } \\
\text { GASIFIER } \\
0 \\
450 \\
3,440 \\
-\end{array}$ & $\begin{array}{r}\text { BIOGAS TO } \\
\text { COOLER } \\
273 \\
1,625 \\
230,850 \\
-\end{array}$ & $\begin{array}{l}\text { BIOGAS TO } \\
\text { FILTER } \\
268 \\
1,020 \\
230,850 \\
-\end{array}$ & $\begin{array}{r}\text { FILTER } \\
\text { CLEANING N2 } \\
565 \\
400 \\
900 \\
-\end{array}$ & $\begin{array}{cr}\text { ASH FROM } \\
\text { FILTER } \\
\\
\\
\\
450 \\
1,500 \\
\\
\end{array}$ & $\begin{array}{r}\text { BIOGAS TO G.T. } \\
260 \\
1,020 \\
210,250 \\
-\end{array}$ \\
\hline NODE & 11 & 12 & 13 & 14 & 16 & 16 & 17 & 18 & 19 & 200 \\
\hline $\begin{array}{l}\text { STREAM } \\
\text { PRESSURE } \\
\text { TEMSIG) } \\
\text { TOTARAL FLOWE }(\mathrm{FB}) \\
\text { DRY FLOW }(\mathrm{CBAHR})\end{array}$ & $\begin{array}{r}\text { BIOGAS TO } \\
\text { DUCT FIRING } \\
260 \\
1,020 \\
20,000 \\
-\end{array}$ & $\begin{array}{r}\text { ARR TO G.T. } \\
0 \\
59 \\
1,082,700 \\
-\end{array}$ & $\begin{array}{r}\text { AIR TO BOOSTER } \\
\text { COMPRESSOR } \\
155 \\
659 \\
122,450 \\
-\end{array}$ & $\begin{array}{r}\text { G.T. EXHAUST } \\
\text { TO DUCT BURNER } \\
1 \\
1,019 \\
1,170,500 \\
-\end{array}$ & $\begin{array}{r}\text { EXHAUST GAS } \\
\text { TOHRSG } \\
1 \\
1,135 \\
1,190,500 \\
-\end{array}$ & $\begin{array}{l}\text { FLUE GAS TO } \\
\text { TO STACK } \\
0 \\
342 \\
1,190.750 \\
-\end{array}$ & $\begin{array}{r}\text { COMPR. AIR } \\
\text { TO GASIFIER } \\
345.0 \\
650 \\
122,450 \\
-\end{array}$ & $\begin{array}{r}\text { BFW TOLP } \\
\text { ECONOMIZER } \\
223 \\
303 \\
135,000 \\
-\end{array}$ & $\begin{array}{r}\text { BFW TO LP } \\
\text { DESUPERHEATER } \\
223 \\
303 \\
200 \\
-\end{array}$ & $\begin{array}{r}\text { BFW TO LP } \\
\text { ECONOMIZER } \\
233 \\
303 \\
134,800 \\
-\end{array}$ \\
\hline NODE $/$ $/ 1$ & $21 \%$ & 22 & 23 & 21 & 20 & 28 & 27 & 28 & 29 & 30 \\
\hline $\begin{array}{l}\text { STREAM } \\
\text { PRESSURE (PSIG) } \\
\text { TEMPERATURE (F) } \\
\text { TOTAL FLOW (LBHR) } \\
\text { DRY FLOW (LBHR) }\end{array}$ & $\begin{array}{r}\text { LP STEAM } \\
\text { FROM EVAP. } \\
223 \\
397 \\
133,300 \\
-\end{array}$ & $\begin{array}{r}\text { LP STEAM TO } \\
\text { SUPERHEATER } \\
223 \\
397 \\
88,500 \\
-\end{array}$ & $\begin{array}{lr}\text { LP STEAM } & \\
\text { TOMLL } & \\
& 155 \\
& 368 \\
45,000 & -\end{array}$ & $\begin{array}{r}\text { LP STEAM } \\
\text { TO DRYER } \\
203 \\
428 \\
88,500 \\
--\end{array}$ & $\begin{array}{r}\text { DRYER } \\
\text { CONDENSATE } \\
43 \\
290 \\
78,500 \\
-\end{array}$ & $\begin{array}{r}\text { LP STEAM } \\
\text { FROM DRYER } \\
43 \\
307 \\
72,200 \\
-\end{array}$ & $\begin{array}{r}\text { BFW TO HP } \\
\text { ECONOMIZER } \\
900 \\
303 \\
159,500 \\
-\end{array}$ & $\begin{array}{r}\text { ECON. H2O TO } \\
\text { BIOGAS COOLER } \\
990 \\
509 \\
75,400 \\
-\end{array}$ & \begin{tabular}{|r|} 
STEAM FROM \\
BIOGAS COOLER \\
880 \\
533 \\
74,700 \\
-
\end{tabular} & $\begin{array}{r}\text { ECON. H2O TO } \\
\text { HP EVAP } \\
890 \\
509 \\
84.100 \\
-\end{array}$ \\
\hline NODE & \31 & 332 & 33 & 34 & 36 & & २र & & & \\
\hline $\begin{array}{l}\text { STREAM } \\
\text { PRESSURE (PSIG) } \\
\text { TEMPERATURE (F) } \\
\text { TOTAL FLOW (LBHR) } \\
\text { DRY FLOW (LBMTR) }\end{array}$ & $\begin{array}{r}\text { STEAM FROM } \\
\text { HP EVAP. } \\
880 \\
533 \\
83,200 \\
-\end{array}$ & $\begin{array}{r}\text { STEAM TO HP } \\
\text { SUPERHEATER } \\
880 \\
533 \\
157,900 \\
-\end{array}$ & $\begin{array}{r}\text { SH STEAM TO } \\
\text { GASIFIER } \\
375 \\
825 \\
1,900 \\
-\end{array}$ & $\begin{array}{l}\text { SH STEAM } \\
\text { TO MILL } \\
850 \\
825 \\
156,000 \\
-\end{array}$ & $\begin{array}{l}\text { AQ. AMMONIA } \\
\text { TO SCR } \\
\\
50 \\
80 \\
250 \\
-\end{array}$ & & & & & \\
\hline
\end{tabular}

NOTE: 1 BASED ON TAMPELLA PRELIMINARY MASS AND ENERGY BALANCE TRANSMITTED 10/18/94. ADJUSTED FOR GE GAS TURBINE PERFORMANCE PROVIDED BY GE ON NOV. 22 , 1994.

2. REFERENCE DRAWING NO. 04996.00-DJ-0004-1. 
Table 2-4: Material Balance - Tampella BGCC (Steam Dryer)

\begin{tabular}{|c|c|c|c|c|}
\hline NODE & 6 & 10 & 14 & 16 \\
\hline STREAM & $\begin{array}{l}\text { BIOGAS TO } \\
\text { COOLER }\end{array}$ & BIOGAS TO G.T. & $\begin{array}{l}\text { G.T. EXHAUST } \\
\text { TO DUCT BURNER }\end{array}$ & $\begin{array}{l}\text { FLUE GAS TO } \\
\text { TO STACK }\end{array}$ \\
\hline PRESSURE (PSIG) & 273 & 260 & & \\
\hline $\begin{array}{l}\text { TEMPERATURE (F) } \\
\text { TOTAL FLOW (LBHR) }\end{array}$ & $\begin{array}{r}1,625 \\
230,850\end{array}$ & $\begin{array}{r}1,020 \\
210,250\end{array}$ & $\begin{array}{r}1,019 \\
1,170,500\end{array}$ & $\begin{array}{r}342 \\
1,190,750\end{array}$ \\
\hline COMPONENTS & & & & \\
\hline $\mathrm{C} 2 \mathrm{HB} \quad \square$ & $0.02 \%$ & $0.02 \%$ & $0.00 \%$ & $0.00 \%$ \\
\hline $\mathrm{C} 2 \mathrm{HH}$ & $0.69 \%$ & $0.69 \%$ & $0.00 \%$ & $0.00 \%$ \\
\hline $\mathrm{CH} 4 \mathrm{O} \ \checkmark$ & $7.50 \%$ & $7.50 \%$ & $0.00 \%$ & $0.00 \%$ \\
\hline (VOL $\%)$ & $12.30 \%$ & $12.30 \%$ & $0.00 \%$ & $0.00 \%$ \\
\hline (VOL\%) & $15.90 \%$ & $15.90 \%$ & $7.48 \%$ & $8.07 \%$ \\
\hline (VOL\%) & $8.50 \%$ & $8.50 \%$ & $0.00 \%$ & $0.00 \%$ \\
\hline (VOL\%) & $14.30 \%$ & $14.30 \%$ & $7.87 \%$ & $8.23 \%$ \\
\hline (VOL\%) & $40.70 \%$ & $40.70 \%$ & $72.98 \%$ & $72.73 \%$ \\
\hline (VOL\%) & $0.00 \%$ & $0.00 \%$ & $11.65 \%$ & $10.97 \%$ \\
\hline (PPMV) & 900 & 900 & 0 & 0 \\
\hline H2S & & & 0 & 0 \\
\hline $\mathrm{NOX}$ (PPMVDK15\%,O2) & & & 133 & 13 \\
\hline OP (PPMVD) & & & 10 & 10 \\
\hline UNH & & & 7 & 7 \\
\hline (PPMWT) & & & 0 & $\underline{\mathbf{0}}$ \\
\hline (PPMWT) & & & 4 & 4 \\
\hline WQ TOTAL & $100.00 \%$ & $100.00 \%$ & $100.00 \%$ & $100.00 \%$ \\
\hline
\end{tabular}

NOTE: 1 BASED ON TAMPELLA PRELIMINARY MASS AND ENERGY BALANCE TRANSMITTED 10/18/94. ADJUSTED FOR GE GAS TURBINE PERFORMANCE PROVIED BY GE ON NOV. 22, 1994.

2. REFERENCE DRAWING NO. 04996.00-DJ-0004-1. 
Table 2-5: Equipment List - Tampella BGCC (Flue Gas Dryer)

\begin{tabular}{|c|c|c|c|}
\hline Item No. & Description & Oty & Remarks \\
\hline G-301 & Gas Turbine Frame 6B & 1 & $42.8 \mathrm{MW}$ \\
\hline L-302 & Pressurized Circulating Fluidized Bed Gasifier & 1 & $\begin{array}{l}\text { Sized by Tampella; includes compr., } \\
\mathrm{CW} \text { pump, and heat exchanger and } \\
\text { startup heater }\end{array}$ \\
\hline M-302 & AQ. Ammonia Tank* & 1 & $316 \mathrm{SS}$ \\
\hline M-303 & Gasifier Cyclone & 1 & Sized by Tampella \\
\hline M-305 & Air Receiver Tank & 1 & Sized by Tampella \\
\hline M-307 & Cleaning Gas Pulse Tank - N2 & 1 & Sized by Tampella \\
\hline M-308 & Continuous Blowdown Tank* C.S. & 1 & $\begin{array}{l}\text { 4'-5" x } 0 \text { 0'-6" } \\
75 \text { psig design (Vertical) }\end{array}$ \\
\hline$M-310$ & HP Continuous Blowdown Tank* & 1 & 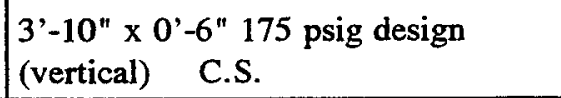 \\
\hline P-301A/B & Cooling Circuit Pumps* & 2 & Sized by Tampella \\
\hline $\mathrm{P}-302 \mathrm{~A} / \mathrm{B}$ & Condensate Pump* & 2 & $200 \mathrm{gpm}$ at $90 \mathrm{psig}$ \\
\hline $\mathrm{P}-303 \mathrm{~A} / \mathrm{B}$ & Blowoff Transfer Pump* & 2 & $3.2 \mathrm{gpm}$ DELTA $P=50$ psi C.S. \\
\hline $\mathrm{P}-304 \mathrm{~A} / \mathrm{B}$ & AQ. Ammonia Pump* & 2 & $.75 \mathrm{gpm}$, DELTA $P=50 \mathrm{psi}, 316 \mathrm{SS}$ \\
\hline $\mathrm{R}-301$ & Booster Compressor & 1 & Sized by Tampella \\
\hline $\begin{array}{l}\mathrm{T}-301 \mathrm{~A}, \mathrm{~B} \\
\mathrm{C}, \mathrm{D}\end{array}$ & Biomass Dryer & 4 & Flue gas dryer to $20 \%$ moisture \\
\hline $\mathrm{T}-302$ & Product Gas Cooler with Steam Drum & 1 & Sized by Tampella \\
\hline $\mathrm{T}-303$ & Booster Compressor Air/Air Heat Exchanger & 1 & Sized by Tampella \\
\hline $\mathrm{T}-304$ & Booster Compressor Feed Cooler & 1 & Sized by Tampella \\
\hline $\mathrm{T}-305$ & HRSG & 1 & \\
\hline $\mathrm{T}-306$ & Auxiliary Steam Turbine Condenser* & 1 & $87 \mathrm{mmBtu} / \mathrm{hr}$ \\
\hline $\mathrm{T}-307$ & Component Cooler Heat Exchanger* & 1 & Sized by Tampella \\
\hline $\mathrm{V}-302$ & SCR Unit & 1 & $90 \% \mathrm{NO}_{\mathrm{x}}$ reduction \\
\hline$V-305$ & H.T.H.P. Candle Filter & 1 & Sized by Tampella \\
\hline $\mathrm{V}-311$ & Blowoff Tank* & 1 & $\begin{array}{l}4^{\prime}-3 " \text { " } \times 0^{\prime}-6^{\prime \prime} \text { atmospheric design } \\
\text { (vertical) }\end{array}$ \\
\hline $\mathrm{W}-303 \mathrm{~A} / \mathrm{B}$ & Gasifier Ash Cooling Screw Conveyor & 2 & Sized by Tampella \\
\hline W-304 & Biogas Filter Ash Screw Conveyor & 1 & Sized by Tampella \\
\hline W-306 & Filter Ash/Dolomite Surge, Lock Hopper System & 1 & Sized by Tampella \\
\hline
\end{tabular}


Table 2-5: Equipment List - Tampella BGCC (Flue Gas Dryer) (continued)

\begin{tabular}{|l|l|c|l|}
\hline Item No. & Description & Qty & Remarks \\
\hline W-307A,B/C & $\begin{array}{l}\text { Biomass Feed Weigh, Lock, Surge Hopper } \\
\text { System }\end{array}$ & 3 & Sized by Tampella \\
\hline W-308 & $\begin{array}{l}\text { Dolomite Feed Weigh, Lock, Surge Hopper } \\
\text { System }\end{array}$ & 1 & Sized by Tampella \\
\hline W-311A/B & Bottom Ash Surge, Lock Hopper System & 2 & Sized by Tampella \\
\hline
\end{tabular}

* Not shown on PFD 
Table 2-6: Equipment List - Tampella BGCC (Steam Dryer)

\begin{tabular}{|c|c|c|c|}
\hline Item No. & Description & Oty & Remarks \\
\hline G-401 & Gas Turbine Frame 6B & 1 & $42.2 \mathrm{MW}$ \\
\hline $\mathrm{L}-402$ & Pressurized Circulating Fluidized Bed Gasifier & 1 & $\begin{array}{l}\text { Sized by Tampella; Includes compr., } \\
\text { CW pump, and heat exchanger and } \\
\text { startup heater }\end{array}$ \\
\hline $\mathrm{M}-40 \overline{2}$ & AQ. Ammonia Tank* & 1 & $316 \mathrm{SS}$ \\
\hline$M-403$ & Gasifier Cyclone & 1 & Sized by Tampella \\
\hline$M-405$ & Air Receiver Tank & 1 & Sized by Tampella \\
\hline$M-407$ & Cleaning Gas Pulse Tank - N2 & 1 & Sized by Tampella \\
\hline$M-408$ & Continuous Blowdown Tank* & 1 & $\begin{array}{l}\text { 4'-5" x. 0’-6" (Vertical) } 175 \text { psig } \\
\text { design C.S. }\end{array}$ \\
\hline M-410 & HP Continuous Blowdown Tank* & 1 & $\begin{array}{l}\text { 3'-10" x 0'-6" } 175 \text { psig design } \\
\text { (vertical) } \\
\text { C.S. }\end{array}$ \\
\hline $\mathrm{P}-401 \mathrm{~A} / \mathrm{B}$ & Cooling Circuit Pumps* & 2 & Sized by Tampella \\
\hline $\mathrm{P}-402 \mathrm{~A} / \mathrm{B}$ & Condensate Pump* & 2 & $200 \mathrm{gpm}$ at $90 \mathrm{psig}$ \\
\hline $\mathrm{P}-403 \mathrm{~A} / \mathrm{B}$ & Blowoff Transfer Pump* & 2 & 3.2 gpm DELTA $P=50$ psi C.S. \\
\hline $\mathrm{P}-404 \mathrm{~A} / \mathrm{B}$ & AQ. Ammonia Pump* & 2 & $.75 \mathrm{gpm}$, DELTA $P=50 \mathrm{psi}, 316 \mathrm{SS}$ \\
\hline $\mathrm{R}-401$ & Booster Compressor & 1 & Sized by Tampella \\
\hline $\begin{array}{l}\mathrm{T}-401 \mathrm{~A}, \mathrm{~B} \\
\mathrm{C}, \mathrm{D}\end{array}$ & Biomass Dryer & 4 & Steam dryer to $20 \%$ moisture \\
\hline $\mathrm{T}-402$ & H.R.S.G. & 1 & 2 Pressure levels \\
\hline $\mathrm{T}-402$ & Product Gas Cooler with Steam Drum & 1 & Sized by Tampella \\
\hline $\mathrm{T}-403$ & Booster Compressor Air/Air Heat Exchanger & 1 & Sized by Tampella \\
\hline $\mathrm{T}-404$ & Booster Compressor Feed Cooler & 1 & Sized by Tampella \\
\hline $\mathrm{T}-404$ & Component Cooler Heat Exchanger* & 1 & Sized by Tampella \\
\hline $\mathrm{T}-405$ & H.R.S.G. & 1 & 2 pressure levels \\
\hline $\mathrm{T}-406$ & Auxiliary Steam Turbine Condenser* & 1 & $87 \mathrm{mmBtu} / \mathrm{hr}$ \\
\hline $\mathrm{V}-402$ & SCR Unit & 1 & $90 \% \mathrm{NO}_{\mathrm{x}}$ reduction \\
\hline$V-405$ & H.T.H.P. Candle Filter & 1 & Sized by Tampella \\
\hline$V-411$ & Blowoff Tank* & 1 & $\begin{array}{l}4^{\prime}-3 " \text { " } \times 0^{\prime}-6 " \text { atmospheric design } \\
\text { (vertical) }\end{array}$ \\
\hline $\mathrm{W}-403 \mathrm{~A} / \mathrm{B}$ & Gasifier Ash Cooling Screw Conveyor & 2 & Sized by Tampella \\
\hline W-404 & Biogas Filter Ash Screw Conveyor & 1 & Sized by Tampella \\
\hline$W-406$ & Filter Ash/Dolomite Surge, Lock Hopper System & 1 & Sized by Tampella \\
\hline
\end{tabular}


Table 2-6: Equipment List - Tampella BGCC (Steam Dryer) (continued)

\begin{tabular}{|l|l|c|l|}
\hline Item No. & Description & Qty & Remarks \\
\hline W-407A,B/C & $\begin{array}{l}\text { Biomass Feed Weigh, Lock, Surge Hopper } \\
\text { System }\end{array}$ & 3 & Sized by Tampella \\
\hline W-408 & $\begin{array}{l}\text { Dolomite Feed Weigh, Lock, Surge Hopper } \\
\text { System }\end{array}$ & 1 & Sized by Tampella \\
\hline W-411A/B & Bottom Ash Surge, Lock Hopper System & 2 & Sized by Tampella \\
\hline
\end{tabular}

* Not shown on PFD. 


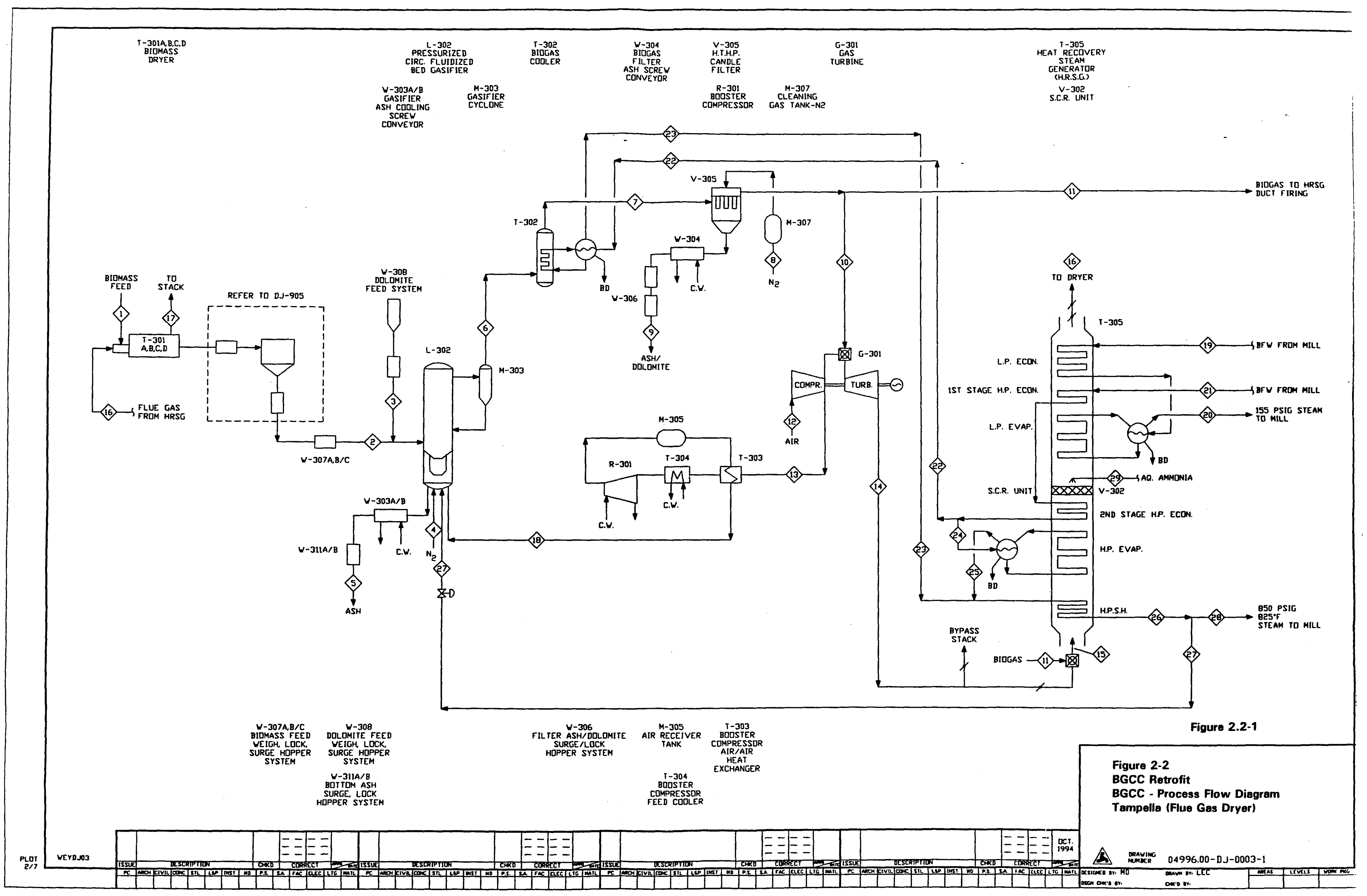




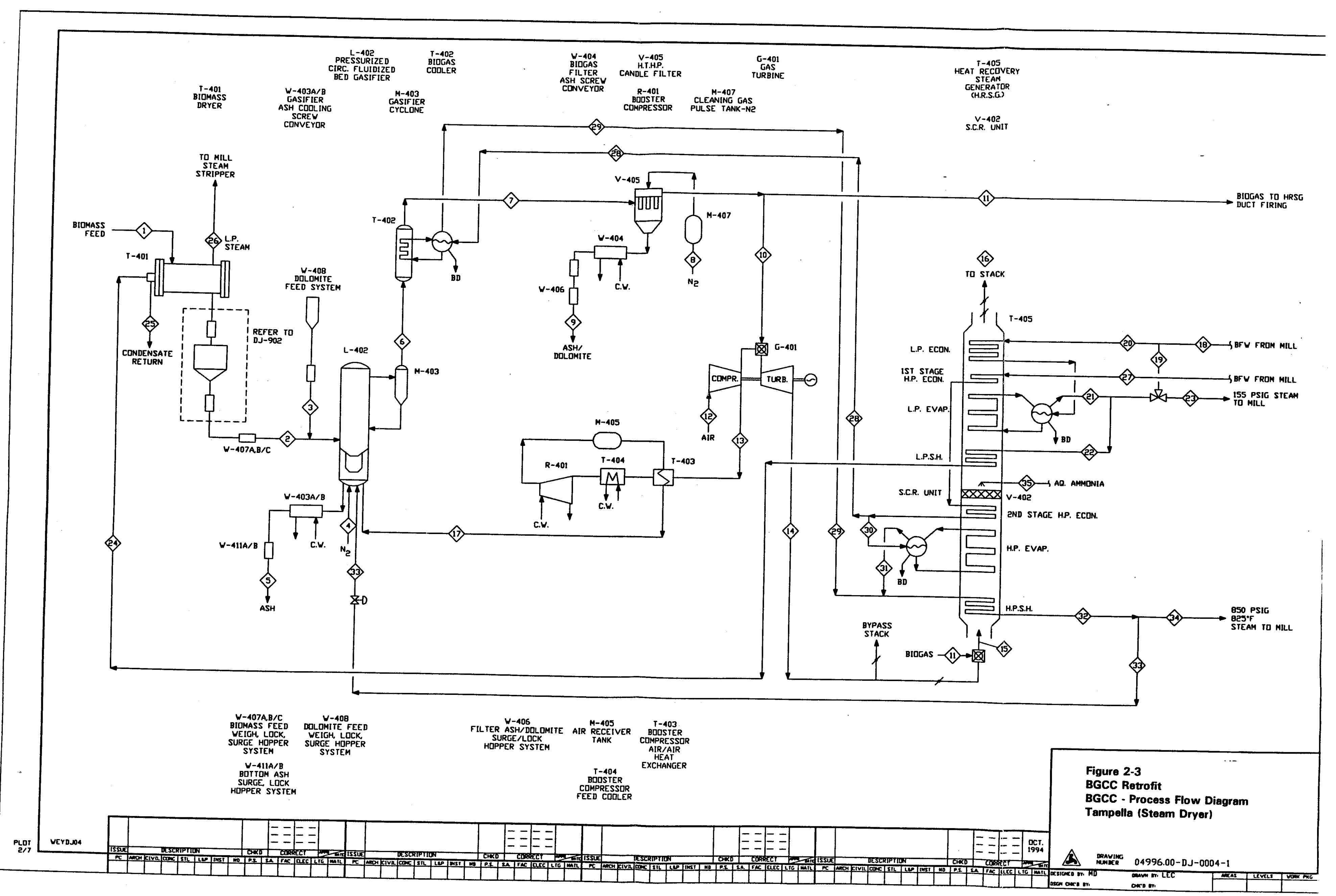




\subsection{Biomass to Ethanol Plant Design}

Amoco provided preliminary process information for its proprietary biomass to ethanol plant to be located adjacent to the Weyerhaeuser mill in New Bern, NC. The data were not obtained in an integrated manner, but were taken from pilot studies done by Amoco on several different hardwood feedstocks. A large portion of the proposed residuals feedstock is immature softwood thinnings which have a composition similar to hardwood. It was assumed that these thinnings would react to the enzyme in the same manner as hardwood.

Using the Amoco information, Stone \& Webster developed a process flow sheet, sized equipment list, and heat and material balance to support a budgetary capital cost estimate and an operating and maintenance $(O \& M)$ cost estimate. The basis of design for this facility is described in Section 1.3.

The Amoco biomass-to-ethanol technology uses a proprietary yeast that is capable of fermenting both hexose and pentose sugars. The process also includes a proprietary pretreatment step that hydrolizes the raw wood chip feed while minimizing by-product formation. These two process improvements distinguish the Amoco ethanol process from other biomass to ethanol processes. Amoco provided cost information for the proprietary hydrolyzer and yeast and a range of enzyme costs.

The following sections provide descriptions of the main sections of the Amoco cellulose-to-ethanol plant. Each section also has a corresponding process flow sheet. The overall heat and material balance for the process is shown in Table 2-7. A process equipment list, organized by plant section, is provided in Table 2-8.

\section{System Description}

The overall block flow diagram for the Amoco Ethanol process is shown in Figure 2-4. When integrated with a BGCC plant, lignin from the filtration is fed to the gasifier. For a stand-alone ethanol plant, the lignin may be sold as a fuel or fed to the existing mill bark boiler.

The following sections describe the pretreatment SSF fermentation, distillation, stillage handling, and chemical storage sections of the plant. On the block flow diagram, the pretreatment section includes fuel handling, chip preheat, pretreatment, first and second stage flashes, and chemical additions prior to fermentation. The distillation section includes beer distillation; flash recovery and molecular sieve dehydration. The centrifuge and filtration steps are described in the stillage handling section, where yeast propagation is included in the SSF fermentation section.

\section{Pretreatment}

Area 200 of the biomass-to-ethanol plant is shown on Figure 2-5, Process Flow Diagram - Pretreatment. Whole tree wood chips conveyed from the wood chip storage pile reclaim enter the chip bin which provides short-term surge capacity for the process. The chip meter measures the flow rate of chips to the chip preheater. The chips are preheated using both a portion of the high pressure flash vapor and low pressure flash condensate prior to pretreatment hydrolysis. Preheated chips and sufficient acid are fed into the proprietary pretreatment hydrolyzer where high pressure steam raises the temperature to $489^{\circ} \mathrm{F}$. The pretreated wood substrate flashes to $237^{\circ} \mathrm{F}$. Flash vapor preheats the chip feed stream and provides vapor to the beer column in the distillation system. Lime slurry is added to the wood substrate to raise the $\mathrm{pH}$ to 7.5 and this mixture is further flash cooled to $140^{\circ} \mathrm{F}$ in the LP flash tank. Flash vapor is condensed and used to preheat the chip feed. A vacuum pump maintains the vacuum required at the LP flash condenser. The wood substrate is mixed with process water and recycle stillage, which are added 
to dilute and cool the substrate to $97^{\circ} \mathrm{F}$, and is conveyed to the first stage fermenter. To reduce the substrate temperature, the process water and recycle stillage are cooled to $65^{\circ} \mathrm{F}$ using chilled water.

\section{SSF Fermentation}

Area 300 of the biomass to ethanol plant is shown in Figures 2-6 and 2-7. The acidity of the diluted wood substrate leaving the pretreatment section is adjusted to $\mathrm{pH} 4$ with the addition of sulfuric acid. The SSF feed conveyor then conveys the substrate into the first fermenter of a series of cascade flow fermenters. An ethanol recycle stream from the anhydrous molecular sieve unit regeneration cycle is added to the first fermenter. Enzyme substrate and propagated yeast inoculum are also added to the first fermenter. Simultaneous saccharification and fermentation reactions proceed while the wood substrate flows through the fermenter vessels.

The first seven fermenters are equipped with external pumped fermenter cooling heat exchangers used to maintain the fermenting substrate at $90^{\circ} \mathrm{F}$. Chilled water is used as the cooling medium. An air blower sparges air into the recirculating substrate, primarily in the first three fermenters where yeast growth is required. Carbon dioxide gas collected from all fermenters passes through the carbon dioxide scrubber where process water scrubs residual ethanol from the gas and is pumped to the beer well. The scrubbed gas vents to atmosphere.

The fermented substrate flows into the beer well which acts as a final fermenter and surge tank for feed to the distillation system.

Proprietary yeast, capable of fermenting both hexose and pentose sugars, is grown from laboratory culture and propagated to concentrations required for fermenter inoculation. The culture is propagated in diluted glucose with the necessary nutrients, such as corn steep liquor, phosphoric acid, and ammonia.

Yeast culture is grown in successive vessel sizes starting with the yeast starter tank. The contents of this tank are used to inoculate one of two seed tanks from which the contents are used to inoculate one of three yeast day tanks. Once the yeast population has been reached in the yeast day tanks, its contents are pumped to the first fermenter on a continuous basis.

Each of these vessels is continuously agitated, cooled with chilled water in cooling jackets, and sparged with the necessary air required for optimal yeast growth. Each of these vessels is operated in batch mode. Each cycle of operation includes clean in place (CIP) cleaning with caustic solution followed by water rinse. Once cleaned, the vessels are filled with glucose and nutrients and the propagation cycle is repeated.

\section{Distillation and Dehydration}

Distillation and dehydration of the fermented substrate (Area 400) is shown in Figure 2-8. The product storage (Area 400) is shown in Figure 2-9. Fermented substrate, termed "beer," is pumped through the beer preheater and beer heater and fed onto the top tray of the beer column. This column operates at atmospheric pressure. Alcohol is stripped from the beer into the overhead vapor which is directed into the base of the rectifying column. The alcohol is concentrated to 95 percent by volume. A portion of the overhead vapor from the rectifying column is condensed by preheating the beer feed. The condensate is returned as reflux. The product portion of the vapor is fed to the dehydration unit with the balance of the remaining vapor condensed in the rectifying column condenser. A fusel oil stream is drawn off the rectifying column and fed to the washer column in which process water is used to extract an aqueous alcohol layer from the fusel oil layer. The aqueous alcohol layer is returned to the rectifying column. 
Fusel oil is stored in the fusel oil tank and pumped to alcohol storage for product blending. Dilute alcohol from the base of the rectifying column is pumped to the beer column for reflux.

The stillage issuing from the base of the column is flash cooled in the stillage flash tank. Flash vapor is drawn into a steam ejector and combined with the ejector motive steam for direct addition to the beer column.

This vapor, together with flash vapor from the wood chip pretreatment section, provides the necessary boil-up energy for distillation. Stillage is pumped through the beer heater, for further cooling by preheating the beer feed, to the stillage handling area.

Ethanol vapor from the rectifying column is superheated with the steam and blown into one of two molecular sieve bed vessels. One bed operates while the other regenerates using a portion of the anhydrous vapor product. The regeneration results in a diluted alcohol steam which is collected in the regeneration tank and pumped back to the first fermenter. Anhydrous ethanol product is condensed and flows to alcohol storage.

Two day tanks are provided to collect the daily alcohol production and to verify quality. If quality is unacceptable, the alcohol is pumped back to the rectifying column with the re-run pump.

Before the alcohol is pumped to the alcohol storage tank, the alcohol concentration is reduced to the minimum specification by adding fusel oil and denaturant gasoline is blended into the product. One truck loading arm and three rail car loading arms are provided for product loading.

\section{Stillage Handling}

Stillage handling recovers lignin cake for use as feedstock in the BGCC plant. There is insufficient information available on the dewaterability of the stillage. The design presented herein has not been tested. Optimization of this plant section could have a major impact (either positive or negative) on the ethanol plant capital and operating costs.

Figure 2-10 shows the stillage handling (Area 500) section of the ethanol plant. Stillage from the bottom of the beer column enters the stillage tank which provides 30 minutes of surge capacity. Stillage is pumped through the stillage cooler to reduce the temperature to $150^{\circ} \mathrm{F}$ and fed to three parallel centrifuges. Lignin based cake at 25 percent solids is conveyed to three parallel rotary filters for further dewatering to 55 percent total solids. The filtered lignin cake is conveyed to the BGCC plant where it is used as fuel.

A portion of the centrifuge liquid is fed to the recycle stillage tank and from there pumped through the recycle cooler to reduce the temperature to $65^{\circ} \mathrm{F}$ using chilled water. The recycle stillage is added to the pretreated wood substrate before fermentation. The balance of the centrifuge liquid is added to the filter liquid in the waste liquid tank. This liquid is pumped to the existing liquid waste treatment facility on site.

\section{Chemical Storage}

Area 600, the clean-in-place (CIP) and Nutrient preparation and chemical storage sections of the ethanol plant are shown in Figures 2-11 and 2-12. Dilute caustic solution is prepared in the CIP tank using 50 percent caustic from the caustic storage tank. The dilute caustic is pumped to the yeast propagation and fermentation vessels for CIP cleaning as required. This solution is returned to the spent CIP tank after 
the wash and reused for further cleaning cycles until the detergent action is reduced and then slowly drained to the liquid waste treatment facility.

The steep liquor tank and syrup tank are provided with steam coils to maintain desired storage temperatures. Glucose syrup is diluted with process water, pumped through the in-line mixer and on to one of the yeast vessels. Steep liquor, phosphoric acid, and aqueous ammonia are batch mixed in the nutrient mix tank and pumped to a yeast vessel in quantities as required.

Lime is stored in the lime storage silo and conveyed to the lime mix tank. Batch quantities of lime and water are mixed and the lime slurry is pumped to pretreatment as required.

\section{Plant Design Review}

This section addresses questions about assumptions and approach raised during reviews of the preliminary design and discusses information which became available after the design was completed. This will provide a basis for future design development and optimization efforts.

\section{Aeration in SSF}

The proprietary yeast selected for SSF is capable of fermenting hexose and pentose sugars and is not microaerophilic. For the purpose of yeast propagation and SSF inoculation cell mass development, it was assumed to have similar characteristics to Saccharomyces Cerevisiae and the aeration requirements were calculated accordingly. Recent discussions with Amoco indicate that aeration in the SSF fermentation system may not be required for the proprietary yeast because sufficient inoculation cell mass levels may be achieved in the yeast propagation system to satisfy the fermentation requirements.

\section{Solids Conveying System}

The solids conveying system following the pretreatment step has not been optimized. The solids conveying system utilized is a conservative engineering approach for the transport of material whose properties are as yet not well defined. A more complete understanding of material properties, together with suitable design refinements may permit the use of slurry pumps to move the material from the pretreatment to the SSF stage, which would enhance system operability. Other alternatives include the use of an inclined conveying system. Any future design changes are not expected to have a significant impact on the capital cost.

\section{Xylanase Activity}

The enzyme used in the ethanol process shows both cellulose and xylose hydrolysis activity. In the material balance, non-hydrolyzed C5 material has been lumped into a single category labeled "xylan" and has been carried throughout the balance as an inert. This "lumping" approach afforded a convenience to handling the material balance and should not be misconstrued to imply that xylan material does not convert at all. The material balance reflects laboratory data for C5 hydrolysis and fermentation activity.

\section{Fermentation Byproducts}

The material balance includes fusel oil which is a major byproduct of fermentation. Fusel oil is shown to be separated in the distillation system and later available to be recombined with the ethanol product to the limit allowed by the purity specification. Fusel oil consists of propyl, butyl and amyl alcohols. 
Other byproducts of fermentation such as aldehydes, esters and organic acids (acetic, succinic) are at low concentration levels and were not specifically identified and accounted for in the material balance.

\section{Flash Systems}

The pretreatment technology employed in the design basis is a highly selective hydrolysis process which minimizes the formation of degradation products such as furfural and HMF. Laboratory data show the yield of these two degradation by-products during hydrolysis is less than 0.5 percent. Off-gas handling systems for the degradation products were not fully engineered. However, given the small quantity of furfural and HMF produced in the pretreatment, it is unlikely the capital costs associated with their handling will be material. Subsequent phases of biomass-to-ethanol development will address the off gas handling requirements.

\section{Gypsum Formation}

The ethanol plant design material balance tracks gypsum formation following acid hydrolysis and lime addition in the material category labeled "soluble solids." Gypsum formation was folded into this category for two reasons. First, the quantity of gypsum formed is small, amounting to no more than 130 pounds per hour. Second, the formed gypsum is well below the concentration levels which will foster its precipitation. However, it is recognized that gypsum precipitation is likely to occur in the beer still bottom where temperatures are higher than elsewhere in the system. Whether or not scaling produced in the beer still bottom will be problematic is an issue for later phases of biomass-to-ethanol engineering development.

\section{Agitation}

Agitation costs and power requirements are very high. The agitation requirements were developed by a major vendor based on limited laboratory viscosity data.

\section{Materials of Construction}

Fermentation vessel costs are based on tile-lined, concrete construction. Although the "industry standard" is stainless steel, Stone \& Webster had recent costs for concrete tile-lined vessels developed for a sulfite liquor ethanol plant. Based on the current cost of stainless steel, installed costs for concrete tile-lined vessels may be less expensive. There is a potential for increased contamination with the tile-lined design due to the difficulty in cleaning the grouting. The cost and risk trade-offs would be carefully considered in final engineering.

\section{Feedstock Reactivity}

A large portion of the proposed residuals feedstock is immature softwood thinnings which have a composition similar to hardwood. It was assumed that these thinnings would react to the enzyme in the same manner as hardwood. Subsequent testing in pilot facilities indicates that the thinnings behave more like softwood and are not a viable feedstock with present pretreatment technology. 


\section{Lignin (Stillage) Dewatering}

Lignin dewatering characteristics are dependent on feedstock and processing. Unfortunately, samples of lignin from the pilot processing of the proposed feedstock were not available for examination and testing. Alternative dewatering designs utilizing combinations of anaerobic digestion pretreatment to improve dewaterability, centrifugation, evaporation, and various filtration types were considered. The centrifuge/rotary vacuum filter combination was selected based on discussions with vendors. This design is realistic both in terms of technical viability and cost. 
Table 2-7 Material Balance - Amoco Ethanol Plant

\begin{tabular}{|c|c|c|c|c|c|c|c|c|c|c|c|c|}
\hline Node,$\ldots$ & Wood Chips & $\frac{10}{\%}$ & Flast vapor & $\frac{12}{\text { Heated }}$ & $\frac{13}{\mathrm{H}^{2 \mathrm{SO}}}$ & $\frac{14}{\text { Steam }}$ & Digested & $\frac{16}{15 t \text { Flash }}$ & 1st Flash & $\frac{18}{\text { Lime }}$ & $\frac{19}{2 n d F l a s h}$ & 2ndFlash \\
\hline & $\begin{array}{l}\text { Wood Chips } \\
1000 \text { ODT/d }\end{array}$ & composition & Recycle & $\begin{array}{l}\text { Heated } \\
\text { Chips }\end{array}$ & $\begin{array}{c}\text { acid } \\
\text { act }\end{array}$ & & Chips & $\begin{array}{l}\text { St rlasn } \\
\text { vapor } \\
\end{array}$ & Bottoms & Slurry & Condensate & $\begin{array}{l}\text { 2nd Flash } \\
\text { Bottoms }\end{array}$ \\
\hline cellulose. & 31,945 & 18.40 & & 31,945 & & & 28,751 & & 28,751 & & & 28,751 \\
\hline glucose & & & & & & & 15,529 & & 15,529 & & & 15,529 \\
\hline hemicellitose: & 20,407 & 11.75 & & 20,407 & & & 2,041 & & 2,041 & & & 2,041 \\
\hline xylose & & & & & & & 5,218 & & 5,218 & & & 5,218 \\
\hline ignin & 21,373 & 12.31 & & 21,373 & & & 21,373 & & 21,373 & & & 21,373 \\
\hline carbon dioxide & & & & & & & & & & & & \\
\hline soluble solids finets & 8,308 & 4.79 & & 8,308 & 347 & & 11,671 & & 11,671 & 174 & & 11,845 \\
\hline insoluble solids/inerts & 1,300 & 0.75 & & 1,300 & & & 1,300 & & 1,300 & & & 1,300 \\
\hline ethanol & & & & & & & & & & & & \\
\hline enzyme & & & & & & & & & & & & \\
\hline spent enzyme & & & & & & & & & & & & \\
\hline yeast & & & & & & & & & & & & \\
\hline yeast residue & & & & & & & & & & & & \\
\hline bir & & & & & & & & & & & & \\
\hline Iusel of & & & & & & & & & & & & \\
\hline water & 90,278 & 52.00 & 7,156 & 112,538 & 26 & 70,671 & 181,033 & 56,864 & 124,169 & 879 & 15,104 & 109,944 \\
\hline total flow (bohr) & 173,611 & 100.00 & 7,156 & 195,871 & 373 & 70,671 & 266,916 & 56,864 & 210,052 & 9,052 & 15,104 & 196,000 \\
\hline & & & & & & & & & & & & \\
\hline \% total solids & 48.00 & & & 42.55 & 93.00 & & 32.18 & & 40.89 & 16.50 & & 43.91 \\
\hline$\%$ solids insol \& fiber: & 45.39 & & & 40.00 & & & 22.80 & & 30.10 & & & 32.72 \\
\hline temp deg. $(F)$ & 60 & & 237 & 124 & 75 & 490 & 489 & 237 & 237 & 75 & 140 & 140 \\
\hline pressure (psia) & atm & & 38 & & & 622 & 615 & 24 & & & 3 & \\
\hline enthaloy (Bturtir) & $3,461,111$ & & $8,297,255$ & $13,389,588$ & 7,096 & $85,034,724$ & $98,431,407$ & $65,934,384$ & $32,497,024$ & 40,765 & $1,631,221$ & $15,591,548$ \\
\hline heating value (Btuni) & & & 1,160 & & & 1,203 & & 1,160 & & & 1,122 & \\
\hline comments & & & & & & & & & & & & \\
\hline
\end{tabular}

\begin{tabular}{|c|c|c|c|c|c|c|c|c|c|c|c|c|}
\hline Node & 21. & 22, & 23 & 224 & 25 & 26 & 27 & 28 & 29 & 30 & 31 & 32 \\
\hline Stréam & $\begin{array}{c}\text { Dilution } \\
\text { Water-PW }\end{array}$ & $\begin{array}{c}\begin{array}{c}\text { H2SO4 } \\
\text { acid }\end{array} \\
\end{array}$ & $\begin{array}{l}\text { Recycle } \\
\text { Stillage }\end{array}$ & $\begin{array}{c}\text { 1st Flash } \\
\text { Vapor Excess }\end{array}$ & $\begin{array}{l}\text { Diluted } \\
\text { Feed }\end{array}$ & $\begin{array}{l}\text { Elthanol } \\
\text { Recycle }\end{array}$ & $\begin{array}{l}\text { Cellulase } \\
\text { Enzyme }\end{array}$ & SPARE & SSF Feed & Beer & $\mathrm{CO} 2$ vent & Waler \\
\hline collulose & & & 155 & & 28,906 & & & & 28,906 & 7,548 & & \\
\hline glucose & & & 45 & & 15,575 & & & & 15,625 & 385 & & \\
\hline hemicellulose & & & 43 & & 2,083 & & & & 2,083 & 2,083 & & \\
\hline xylose & & & 62 & & 5,280 & & & & 5,280 & 528 & & \\
\hline ligniin & & & 449 & & 21,822 & & & & 21,822 & 21,822 & & \\
\hline Carbon dioxide & & & & & & & & & & & 20,946 & \\
\hline soluble solids interts & & 69 & 1,564 & & 13,478 & & 24 & & 13,553 & 13,553 & & \\
\hline insoluble solids-inents & & & 27 & & 1,327 & & & & 1,327 & 1,327 & & \\
\hline ethand & & & 30 & & 30 & 5,419 & & & 5,450 & 27,337 & 10 & \\
\hline enzyme & & & & & & & 73 & & 74 & 74 & & \\
\hline spent enzyme & & & 2 & & 2 & & & & & & & \\
\hline yeast _ـ & & & & & & & & & 121 & 1,000 & & \\
\hline yeast residue & & & 21 & & 21 & & & & & & & \\
\hline air $\lcm{ }$ & & & & & & & & & & & 7,000 & \\
\hline Iusel oil & & & & & & & & & & & & \\
\hline water & 147,626 & 5 & 49,209 & 49,708 & 306,784 & 3,322 & 2,320 & & 320,425 & 332,675 & 377 & 7,817 \\
\hline total fow (b/h) & 147,626 & 75 & 51,607 & 49,708 & 395,308 & 8,741 & 2,417 & & 414,666 & 408,332 & 28,333 & 7,817 \\
\hline & & & & & & & & & & & & \\
\hline \% total solids & & 93.00 & 4.65 & & 22.39 & 62.00 & 4.00 & & 21.41 & 11.83 & & \\
\hline \% solids insol \& fiber & & & 1.35 & & 15.00 & & & & 14.45 & 8.97 & & \\
\hline Lemp deg (F) & 65 & 75 & 65 & 237 & 97 & 185 & 75 & & 96 & 90 & 90 & 75 \\
\hline pressure (psia) & & & 150 & 24 & & & & & & & & \\
\hline enthalpy (Btu/ht) & $4,871,664$ & 1,419 & $1,654,855$ & $57,637,128$ & $22,119,486$ & 508,206 & $100,17 \overline{6}$ & & $22,727,868$ & $20,391,271$ & & 336,118 \\
\hline heating value (Bku/b) & & & & 1160 & & & & & & & & \\
\hline comments & & & & & & & \#1enzyme & & & & \#3-air & \\
\hline
\end{tabular}


Table 2-7 Material Balance - Amoco Ethanol Plant

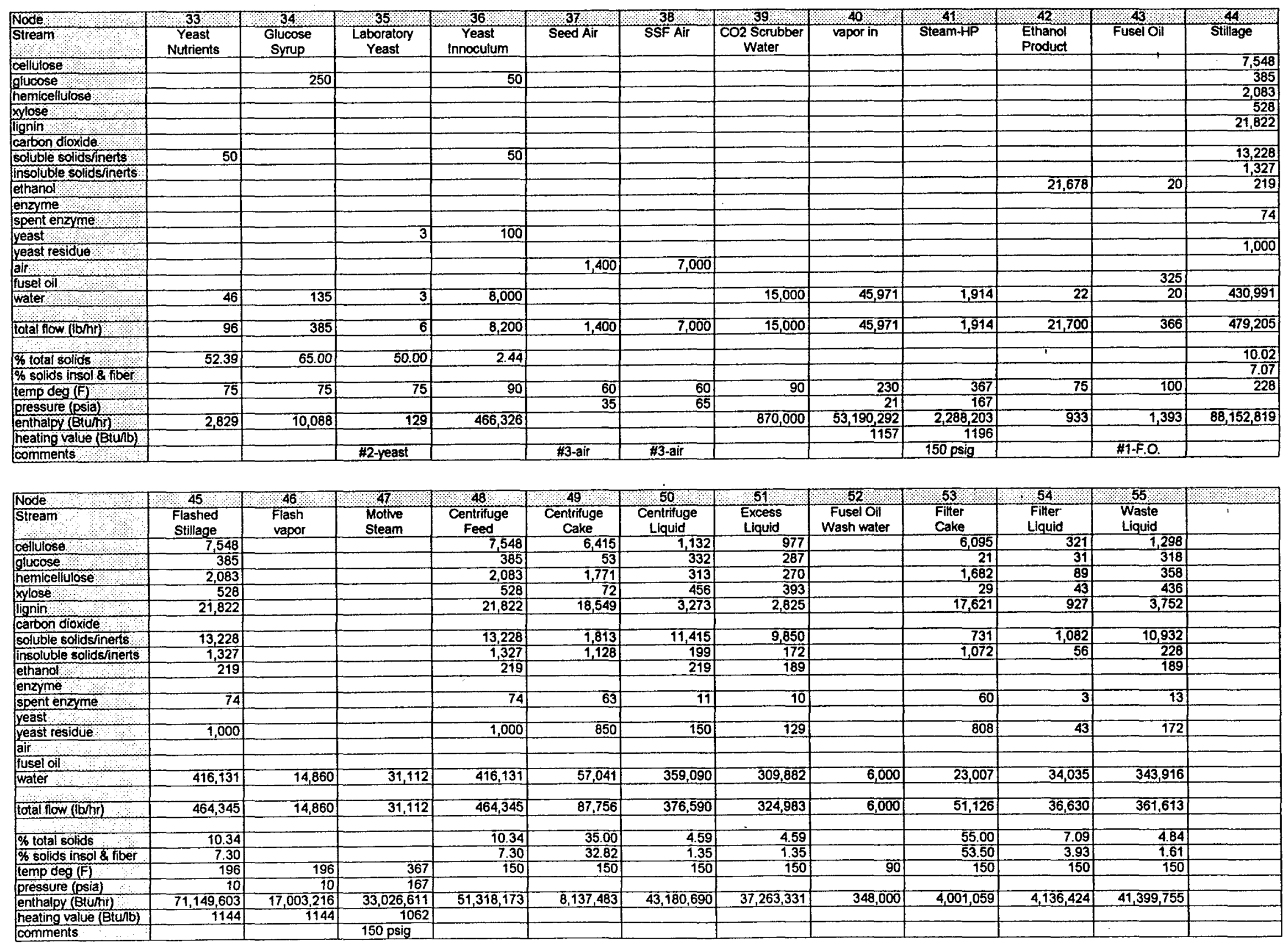


Table 2-8: Equipment List - Amoco Ethanol Plant

\begin{tabular}{|c|c|c|c|c|}
\hline Qty. & Equipment & \multicolumn{2}{|c|}{ Description } & HP \\
\hline \multicolumn{5}{|c|}{200 Area: Pretreatment } \\
\hline 1 & $\frac{\text { T-201 }}{\text { LP Flash Condenser }}$ & $\begin{array}{l}\text { Shell \& tu } \\
\text { Floating h } \\
\text { Surf. area: } \\
\text { Material: } \\
\text { DP: }\end{array}$ & $\begin{array}{l}\text { ger } \\
2,840 \mathrm{ft}^{2} \\
\text { SS } 316 \\
100 \text { psig/Full vacuum }\end{array}$ & \\
\hline 1 & $\frac{\mathrm{T}-202}{\text { Process Water Cooler }}$ & $\begin{array}{l}\text { Plate type } \\
\text { Surf. area: } \\
\text { Material: } \\
\text { DP: }\end{array}$ & $\begin{array}{l}750 \mathrm{ft}^{2} \\
\text { SS } 316 \text { plates } \\
100 \text { psig }\end{array}$ & \\
\hline 1 & $\frac{\text { V-201 }}{\text { Chip Meter }}$ & $\begin{array}{l}\text { Capacity: } \\
\text { Material: }\end{array}$ & $\begin{array}{l}90 \text { ton } / \mathrm{hr} \\
\text { Carbon steel }\end{array}$ & \\
\hline 1 & $\frac{\text { V-202 }}{\text { Chip Feeder }}$ & $\begin{array}{l}\text { Low press } \\
\text { Cap: } \\
\text { Material: }\end{array}$ & $\begin{array}{l}90 \text { ton } / \mathrm{hr} \\
\text { SS } 316\end{array}$ & 40 \\
\hline 1 & $\frac{\text { V-203 }}{\text { Chip Preheater }}$ & $\begin{array}{l}\text { Cap: } \\
\text { Material: }\end{array}$ & $\begin{array}{l}104 \text { ton } / \mathrm{hr} \\
48^{\prime \prime} \text { dia. } \times 15^{\prime} \text { length } \\
\text { SS } 316\end{array}$ & 75 \\
\hline 1 & $\frac{\text { V-204 }}{\text { Hydrolyzer Feeder }}$ & $\begin{array}{l}\text { High press } \\
\text { Cap: } \\
\text { Material: }\end{array}$ & $\begin{array}{l}104 \text { ton } / \mathrm{hr} \\
\text { SS } 316\end{array}$ & 75 \\
\hline 1 & $\frac{\mathrm{V}-205}{\text { Pretreatment Hydrolyzer }}$ & $\begin{array}{l}\text { Package ur } \\
\text { - See Amo }\end{array}$ & tails. & $4830 \mathrm{~kW}$ \\
\hline 1 & $\frac{\text { V-206 }}{\text { LP Flash Feeder }}$ & $\begin{array}{l}\text { High press } \\
\text { Cap: } \\
\text { Material: }\end{array}$ & $\begin{array}{l}103 \text { ton } / \mathrm{hr} \\
\text { SS } 316\end{array}$ & 75 \\
\hline 1 & $\frac{\text { V-207 }}{\text { Conveyor Feeder }}$ & $\begin{array}{l}\text { Low press } \\
\text { Cap: } \\
\text { Material: }\end{array}$ & $\begin{array}{l}100 \text { ton } / \mathrm{hr} \\
\text { SS } 316\end{array}$ & 40 \\
\hline 1 & $\frac{\mathrm{W}-201}{\text { Pretreatment Conveyor }}$ & Cap: & $\begin{array}{l}100 \text { ton } / \mathrm{hr} \\
36^{\prime \prime} \text { dia. } \times 20 \text { ' length }\end{array}$ & 75 \\
\hline 1 & $\frac{\mathrm{W}-202}{\text { SSF Feed Elevator }}$ & Cap: & 100 ton $/ \mathrm{hr}$ & 30 \\
\hline 1 & $\frac{\text { P-201 }}{\text { Flash Condensate Pump }}$ & $\begin{array}{l}\text { Centrifuga } \\
\text { Cap: } \\
\text { Head: } \\
\text { Material: }\end{array}$ & $\begin{array}{l}30 \mathrm{gpm} \\
150 \mathrm{ft} \\
\mathrm{SS} 316\end{array}$ & 5 \\
\hline 1 & $\frac{\text { P-202 }}{\text { Vacuum Pump }}$ & $\begin{array}{l}\text { Liquid rin } \\
\text { Cap: } \\
\text { C/W separ }\end{array}$ & $\begin{array}{l}300 \mathrm{cfm} \text { air } \\
\text { skid assembly }\end{array}$ & 20 \\
\hline
\end{tabular}


Table 2-8: Equipment List - Amoco Ethanol Plant (Cont)

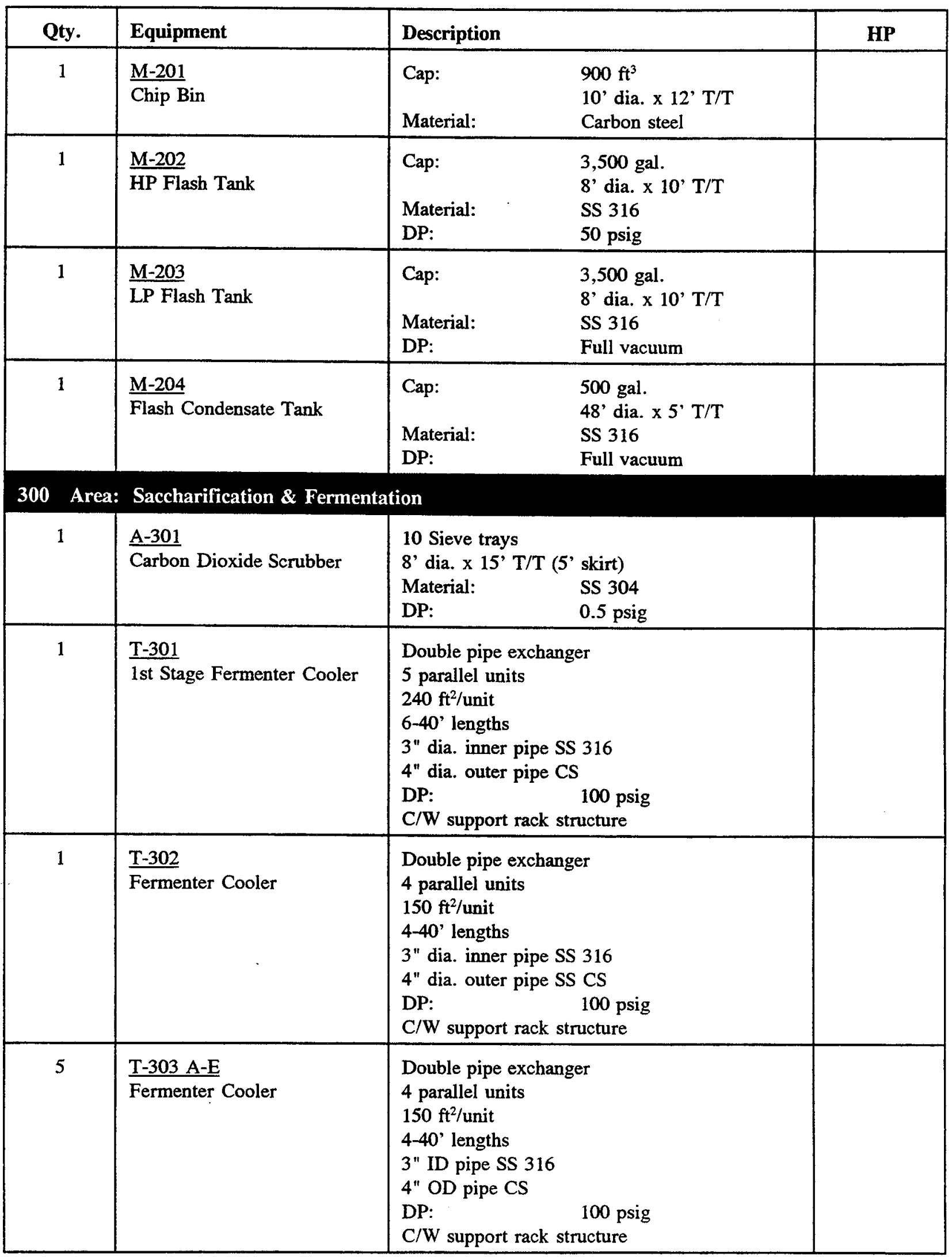


Table 2-8: Equipment List - Amoco Ethanol Plant (Cont)

\begin{tabular}{|c|c|c|c|}
\hline Qty. & Equipment & Description & HP \\
\hline 1 & $\frac{\text { W-301 }}{\text { SSF Feed Conveyor }}$ & $\begin{array}{l}\text { Screw conveyor } \\
\text { 30" dia. - 60' length } \\
\text { Material: SS } 316 \\
\text { C/W removable cover }\end{array}$ & 50 \\
\hline 3 & $\frac{\text { V-301 A,B,C }}{\text { SSF Agitators }}$ & $\begin{array}{l}\text { M-301A, top mounted agitators } \\
\text { Lightnin } 784 \mathrm{Q} 350 \\
\text { Wetted parts SS } 316\end{array}$ & 350 (ea) \\
\hline 3 & $\frac{\text { V-302 A,B,C }}{\text { SSF Agitators }}$ & $\begin{array}{l}\text { M-301B, top mounted agitators } \\
\text { Lightnin } 784 \text { Q350 } \\
\text { Wetted parts SS } 316\end{array}$ & 350 (ea) \\
\hline 3 & $\frac{\mathrm{V}-303 \text { A,B,C }}{\text { Fermenter Agitators }}$ & $\begin{array}{l}\text { M-303A, top mounted agitators } \\
\text { Lightnin 783Q150 } \\
\text { Wetted parts SS } 316\end{array}$ & $150(\mathrm{ea})$ \\
\hline 3 & $\frac{\text { V-304 A,B,C }}{\text { Fermenter Agitators }}$ & $\begin{array}{l}\text { M-303B, top mounted agitators } \\
\text { Lightnin 783Q150 } \\
\text { Wetted parts SS } 316\end{array}$ & $150(\mathrm{ea})$ \\
\hline 3 & $\frac{\mathrm{V}-305 \mathrm{~A}, \mathrm{~B}, \mathrm{C}}{\text { Day Tank Agitator }}$ & $\begin{array}{l}\text { Top mounted agitator } \\
\text { Wetted parts SS } 304\end{array}$ & 20 (ea) \\
\hline 2 & $\frac{\mathrm{V}-306 \mathrm{~A}, \mathrm{~B}}{\text { Seed Tank Agitator }}$ & $\begin{array}{l}\text { Top mounted agitator } \\
\text { Wetted parts SS } 304\end{array}$ & 3 (ea) \\
\hline 1 & 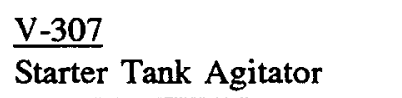 & $\begin{array}{l}\text { Top entry agitator } \\
\text { Wetted parts SS } 304\end{array}$ & 0.5 \\
\hline 2 & $\mathrm{~V}-308 \mathrm{~A}, \mathrm{~B}$ & $\begin{array}{l}\text { M-303C \& D, top mounted agitator } \\
\text { Lightnin 784Q350 } \\
\text { Wetted parts SS } 316\end{array}$ & 350 (ea) \\
\hline 4 & V-309A-D & $\begin{array}{l}\text { M-303E, F, G, \& M-304, top mounted agitator } \\
\text { Lightnin } 783 Q 150 \\
\text { Wetted parts SS } 316\end{array}$ & 150 (ea) \\
\hline 1 & $\frac{\text { P-301 }}{\text { Fermenter Cooler Pump }}$ & $\begin{array}{ll}\text { Heavy duty centrifugal pump } \\
\text { Cap: } & 1300 \mathrm{gpm} \\
\text { Head: } & 200 \mathrm{ft} \\
\text { Material: } & \text { SS } 317 \\
\end{array}$ & 150 \\
\hline 1 & $\frac{\text { P-302 }}{\text { Enzyme Pump }}$ & $\begin{array}{ll}\text { Centrifugal pump } & \\
\text { Cap: } & 5 \mathrm{gpm} \\
\text { Head: } & 75 \mathrm{ft} \\
\text { Material: } & \text { SS } 316 \\
\end{array}$ & 2 \\
\hline 1 & $\frac{\mathrm{P}-303}{\text { Enzyme Unloading Pump }}$ & $\begin{array}{l}\text { Centrifugal pump } \\
\text { Cap: } \\
\text { Head: } \\
\text { Material: }\end{array}$ & 7.5 \\
\hline
\end{tabular}


Table 2-8: Equipment List - Amoco Ethanol Plant (Cont)

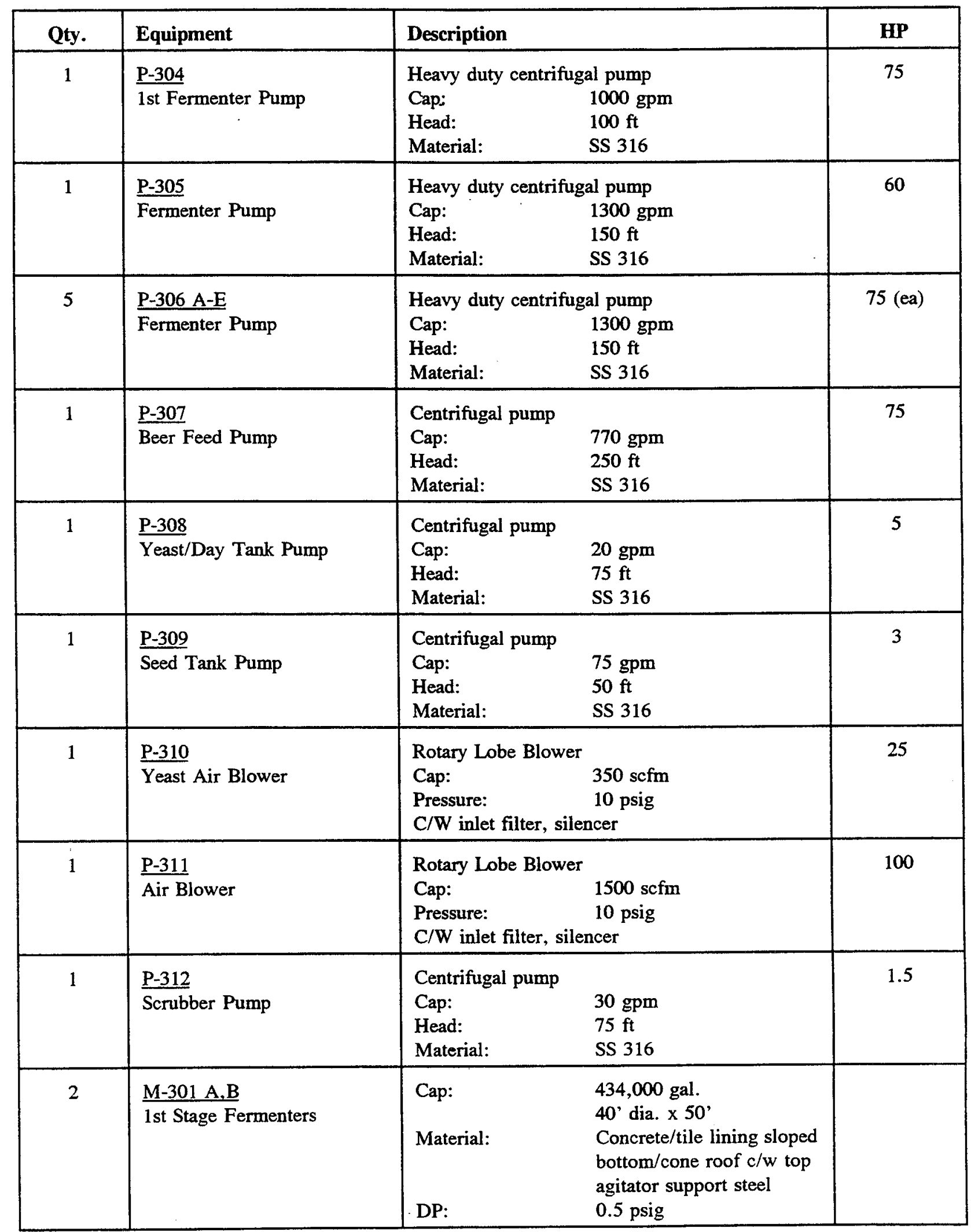


Table 2-8: Equipment List - Amoco Ethanol Plant (Cont)

\begin{tabular}{|c|c|c|c|c|}
\hline Qty. & Equipment & Description & & HP \\
\hline 1 & $\frac{\mathrm{M}-302}{\text { Enzyme Storage Tank }}$ & $\begin{array}{l}\text { Cap: } \\
\text { Material: } \\
\text { DP: }\end{array}$ & $\begin{array}{l}40,000 \text { gal. } \\
16^{\prime} \text { dia. } \times 26^{\prime} \mathrm{T} / \mathrm{T} \\
\text { SS } 304 \\
\text { Atmospheric }\end{array}$ & . \\
\hline 7 & $\frac{M-303 A-G}{\text { Fermenters }}$ & $\begin{array}{l}\text { Cap: } \\
\text { Material: } \\
\text { DP: }\end{array}$ & $\begin{array}{l}921,000 \text { gal. } \\
56^{\prime} \text { dia. } \times 50^{\prime} \mathrm{T} / \mathrm{T} \\
\text { Concrete/tile lining sloped } \\
\text { bottom } \\
0.5 \mathrm{psig}\end{array}$ & \\
\hline 1 & $\frac{\text { M-304 }}{\text { Beer Well }}$ & $\begin{array}{l}\text { Cap: } \\
\text { Material: } \\
\text { DP: }\end{array}$ & $\begin{array}{l}921,000 \text { gal. } \\
56 \text { ' dia. x 50' T/T } \\
\text { Concrete/tile lining sloped } \\
\text { bottom } \\
0.5 \mathrm{psig}\end{array}$ & \\
\hline 1 & $\frac{\mathrm{M}-305}{\text { Yeast Starter Tank }}$ & $\begin{array}{l}\text { Cap: } \\
\text { Material: } \\
\text { C/W: } \\
\text { DP: }\end{array}$ & $\begin{array}{l}160 \text { gal. } \\
30 " \text { dia. } \times 48 " \mathrm{~T} / \mathrm{T} \\
\text { SS } 304 \\
\text { Air sparger, cooling } \\
\text { jacket } \\
\text { Atmospheric }\end{array}$ & \\
\hline 2 & $\frac{\text { M-306 A,B }}{\text { Seed Tank }}$ & $\begin{array}{l}\text { Cap: } \\
\text { Material: } \\
\text { C/W: } \\
\text { DP: }\end{array}$ & $\begin{array}{l}\text { 1,600 gal. } \\
\text { 5'6" dia. x 9' T/T } \\
\text { SS } 304 \\
\text { Air sparger, cooling } \\
\text { jacket } \\
\text { Atmospheric }\end{array}$ & \\
\hline 3 & $\frac{\text { M-307 A,B,C }}{\text { Day Tanks }}$ & $\begin{array}{l}\text { Cap: } \\
\text { Material: } \\
\text { C/W: } \\
\text { DP: }\end{array}$ & $\begin{array}{l}16,000 \text { gal. } \\
12 \text { dia. } \times 19^{\prime} \mathrm{T} / \mathrm{T} \\
\text { SS } 304 \\
\text { Air sparger, cooling } \\
\text { jacket } \\
\text { Atmospheric }\end{array}$ & \\
\hline 400 & Distillation \& Alcoho & & & \\
\hline 1 & $\frac{A-401}{\text { Beer Column }}$ & $\begin{array}{l}11^{\prime} \text { dia. } x 52 \text { ' } \\
30 \text { Sieve trays } \\
\text { Material: } \\
\text { DP: }\end{array}$ & $\begin{array}{l}\text { SS } 304 \\
14 \text { psig }\end{array}$ & \\
\hline 1 & $\frac{A-402}{\text { Rectifying Column }}$ & $\begin{array}{l}\text { 11' dia. } \times 45^{\prime} \mathrm{F} / \mathrm{T} \\
35 \text { Sieve trays } \\
\text { Material: } \\
\text { DP: }\end{array}$ & $\begin{array}{l}\text { SS } 304 \\
14 \text { psig }\end{array}$ & \\
\hline 1 & $\frac{\mathrm{A}-403}{\text { Washer Column }}$ & $\begin{array}{l}3^{\prime} \text { dia. } \times 6^{\prime} \mathrm{T} / \mathrm{T} \\
\text { Material: } \\
\mathrm{C} / \mathrm{W} \text { packing }\end{array}$ & SS 304 & \\
\hline
\end{tabular}


Table 2-8: Equipment List - Amoco Ethanol Plant (Cont)

\begin{tabular}{|c|c|c|c|c|}
\hline Qty. & Equipment & \multicolumn{2}{|l|}{ Description } & HP \\
\hline 1 & $\frac{T-401}{\text { Beer Heater }}$ & \multicolumn{2}{|c|}{ 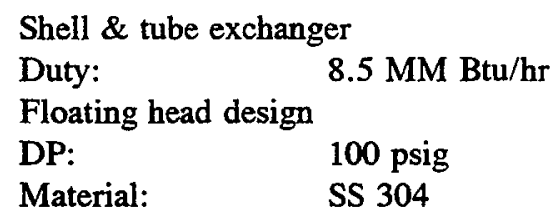 } & \\
\hline 1 & $\frac{\mathrm{T}-402}{\text { Beer Preheater }}$ & \multicolumn{2}{|c|}{$\begin{array}{l}\text { Shell \& tube exchanger } \\
\text { Duty: } \quad 17 \mathrm{MM} \mathrm{Btu} / \mathrm{hr} \\
\text { Floating head design } \\
\begin{array}{ll}\text { DP: } & 100 \mathrm{psig} \\
\text { Material: } & \text { SS } 304\end{array}\end{array}$} & \\
\hline 1 & $\begin{array}{l}\frac{T-403}{\text { Rectifying Column }} \\
\text { Condenser }\end{array}$ & \multicolumn{2}{|c|}{$\begin{array}{l}\text { Shell \& tube exchanger } \\
\text { Duty: } 40 \mathrm{MM} \mathrm{Btu} / \mathrm{hr} \\
\text { Floating head design } \\
\text { SS } 304 \text { tubes/CS shell }\end{array}$} & \\
\hline 1 & $\frac{T-404}{\text { Steam Ejector }}$ & Capacity: & $\begin{array}{l}40,000 \mathrm{lb} / \mathrm{hr} \\
\text { Motive steam }\end{array}$ & \\
\hline 1 & $\frac{\mathrm{T}-405}{\text { Vapour Superheater }}$ & $\begin{array}{l}\text { Shell \& tube } \\
\text { Duty: } \\
\text { SS } 304 \text { tube }\end{array}$ & $2 \mathrm{MM} \mathrm{Btu} / \mathrm{hr}$ & . \\
\hline 1 & $\frac{\mathrm{T}-406}{\text { Regeneration Condenser }}$ & $\begin{array}{l}\text { Shell \& tube } \\
\text { Duty: } \\
\text { SS } 304 \text { tube }\end{array}$ & $4 \mathrm{MM} \mathrm{Btu} / \mathrm{hr}$ & \\
\hline 1 & $\frac{T-407}{\text { Product Condenser }}$ & $\begin{array}{l}\text { Shell \& tube } \\
\text { Duty: } \\
\text { SS } 304 \text { tube }\end{array}$ & $10 \mathrm{MM} \mathrm{Btu} / \mathrm{hr}$ & \\
\hline 1 & $\frac{\text { P-401 }}{\text { Stillage Pump }}$ & $\begin{array}{l}\text { Centrifugal } \\
\text { Cap: } \\
\text { Head: } \\
\text { Material: }\end{array}$ & $\begin{array}{l}900 \mathrm{gpm} \\
200 \mathrm{ft} \\
\text { SS } 316\end{array}$ & 75 \\
\hline 1 & $\frac{P-402}{\text { Reflux Pump }}$ & $\begin{array}{l}\text { Centrifugal } \\
\text { Cap: } \\
\text { Head: } \\
\text { Material: }\end{array}$ & $\begin{array}{l}110 \mathrm{gpm} \\
100 \mathrm{ft} \\
\text { SS } 316\end{array}$ & 7.5 \\
\hline 1 & $\frac{\text { P-403 }}{\text { Wash Pump }}$ & $\begin{array}{l}\text { Centrifugal } \\
\text { Cap: } \\
\text { Head: } \\
\text { Material: }\end{array}$ & $\begin{array}{l}20 \mathrm{gpm} \\
100 \mathrm{ft} \\
\text { SS } 316\end{array}$ & 3 \\
\hline 1 & $\frac{\text { P-404 }}{\text { Fusel Oil Pump }}$ & $\begin{array}{l}\text { Centrifugal } \\
\text { Cap: } \\
\text { Head: } \\
\text { Material: }\end{array}$ & $\begin{array}{l}10 \mathrm{gpm} \\
50 \mathrm{ft} \\
\text { SS } 316\end{array}$ & 2 \\
\hline
\end{tabular}


Table 2-8: Equipment List - Amoco Ethanol Plant (Cont)

\begin{tabular}{|c|c|c|c|c|}
\hline Qty. & Equipment & Description & & HP \\
\hline 1 & $\frac{\text { P-405 }}{\text { Vapour Blower }}$ & $\begin{array}{l}\text { Rotary blower } \\
\text { Cap: } \\
\text { Discharge: }\end{array}$ & $\begin{array}{l}4000 \mathrm{cfm} \\
5 \mathrm{psig}\end{array}$ & 30 \\
\hline 1 & $\frac{\text { P-406 }}{\text { Regeneration Blower }}$ & $\begin{array}{l}\text { Rotary blower } \\
\text { Cap: } \\
\text { Discharge: }\end{array}$ & $\begin{array}{l}1000 \mathrm{cfm} \\
5 \mathrm{psig}\end{array}$ & 10 \\
\hline 1 & $\frac{\text { P-407 }}{\text { Regeneration Pump }}$ & $\begin{array}{l}\text { Centrifugal } \\
\text { Cap: } \\
\text { Head: } \\
\text { Material: }\end{array}$ & $\begin{array}{l}20 \mathrm{gpm} \\
75 \mathrm{ft} \\
\text { SS } 316\end{array}$ & 1.5 \\
\hline 1 & $\frac{\text { P-408 }}{\text { Rerun Pump }}$ & $\begin{array}{l}\text { Centrifugal } \\
\text { Cap: } \\
\text { Head: } \\
\text { Material: }\end{array}$ & $\begin{array}{l}10 \mathrm{gpm} \\
100 \mathrm{ft} \\
\text { Carbon steel }\end{array}$ & 3 \\
\hline 1 & $\frac{\text { P-409 }}{\text { Alcohol Transfer Pump }}$ & $\begin{array}{l}\text { Centrifugal } \\
\text { Cap: } \\
\text { Head: } \\
\text { Material: }\end{array}$ & $\begin{array}{l}200 \mathrm{gpm} \\
75 \mathrm{ft} \\
\text { Carbon steel }\end{array}$ & 7.5 \\
\hline 3 & $\frac{\text { P-410 A,B,C }}{\text { Alcohol Loading Pump }}$ & $\begin{array}{l}\text { Centrifugal } \\
\text { Cap: } \\
\text { Head: } \\
\text { Material: }\end{array}$ & $\begin{array}{l}300 \mathrm{gpm} \\
100 \mathrm{ft} \\
\text { Carbon steel }\end{array}$ & 15 (ea) \\
\hline 1 & $\frac{\text { P-411 }}{\text { Denaturant Pump }}$ & $\begin{array}{l}\text { Centrifugal } \\
\text { Cap: } \\
\text { Head: } \\
\text { Material: }\end{array}$ & $\begin{array}{l}6 \mathrm{gpm} \\
75 \mathrm{ft} \\
\text { Carbon steel }\end{array}$ & 5 \\
\hline 1 & $\frac{\mathrm{P}-412}{\text { Denaturant Unloading Pump }}$ & $\begin{array}{l}\text { Centrifugal } \\
\text { Cap: } \\
\text { Head: }\end{array}$ & $\begin{array}{l}150 \mathrm{gpm} \\
50 \mathrm{ft}\end{array}$ & 5 \\
\hline 1 & $\frac{\mathrm{M}-401}{\text { Stillage Flash Tank }}$ & $\begin{array}{l}\text { Cap: } \\
\text { Material: } \\
\text { DP: }\end{array}$ & $\begin{array}{l}6000 \text { gal. } \\
9^{\prime} \text { dia. } \times 13^{\prime} \mathrm{T} / \mathrm{T} \\
\text { SS } 304 \\
\text { Full vacuum }\end{array}$ & \\
\hline 1 & $\frac{\mathrm{M}-402}{\text { Fo. Wash Tank }}$ & $\begin{array}{l}\text { Cap: } \\
\text { Material: } \\
\text { DP: }\end{array}$ & $\begin{array}{l}300 \text { gal. } \\
42 " \text { dia. x 54" T/T } \\
\text { SS } 304 \\
\text { Atmospheric }\end{array}$ & \\
\hline 1 & $\frac{\mathrm{M}-403}{\text { Fusel Oil Tank }}$ & $\begin{array}{l}\text { Cap: } \\
\text { Material: } \\
\text { DP: }\end{array}$ & $\begin{array}{l}1100 \text { gal. } \\
\text { 5' dia. x } 8, \mathrm{~T} / \mathrm{T} \\
\text { Carbon steel } \\
\text { Atmospheric }\end{array}$ & \\
\hline
\end{tabular}


Table 2-8: Equipment List - Amoco Ethanol Plant (Cont)

\begin{tabular}{|c|c|c|c|c|}
\hline Qty. & Equipment & \multicolumn{2}{|c|}{ Description } & \multirow[t]{2}{*}{$\mathbf{H P}$} \\
\hline 2 & $\frac{\text { M-404 A \& B }}{\text { Mol Sieve Beds }}$ & $\begin{array}{l}\text { Cap: } \\
\text { Material: } \\
\text { C/W inter } \\
\text { DP: }\end{array}$ & $\begin{array}{l}600 \mathrm{ft}^{3} \\
7{ }^{\prime} \text { dia. } \times 18, \mathrm{~T} / \mathrm{T} \\
\text { Carbon steel } \\
\text { ators \& support trays } \\
14 \mathrm{psig}\end{array}$ & \\
\hline 1 & $\frac{\text { M-405 }}{\text { Regeneration Tank }}$ & $\begin{array}{l}\text { Cap: } \\
\text { Material: } \\
\text { DP: }\end{array}$ & $\begin{array}{l}1000 \text { gal. } \\
5^{\prime} \text { dia. } \times 7 \text { T/T } \\
\text { SS } 304 \\
\text { Atmospheric }\end{array}$ & \\
\hline 2 & $\frac{\text { Q-401 A \& B }}{\text { Alcohol Day Tanks }}$ & $\begin{array}{l}\text { Cap: } \\
\text { Material: } \\
\text { DP: }\end{array}$ & $\begin{array}{l}80,000 \text { gal. } \\
20^{\prime} \text { dia. } \times 34^{\prime} \mathrm{T} / \mathrm{T} \\
\text { Carbon steel } \\
\text { Atmospheric }\end{array}$ & \\
\hline 1 & $\frac{\mathrm{Q}-402}{\text { Alcohol Storage Tank }}$ & $\begin{array}{l}\text { Cap: } \\
\text { Material: } \\
\text { DP: }\end{array}$ & $\begin{array}{l}800,000 \text { gal. } \\
55 \text { dia. x } 45, \mathrm{~T} / \mathrm{T} \\
\text { Float roof design } \\
\text { Carbon steel } \\
\text { Atmospheric }\end{array}$ & \\
\hline 1 & $\frac{\mathrm{Q}-403}{\text { Denaturant Tank }}$ & $\begin{array}{l}\text { Cap: } \\
\text { Material: } \\
\text { DP: }\end{array}$ & $\begin{array}{l}40,000 \text { gal. } \\
16^{\prime} \text { dia. } \times 26^{\prime} \mathrm{T} / \mathrm{T} \\
\text { Carbon steel } \\
\text { Atmospheric }\end{array}$ & \\
\hline 1 & $\frac{V-401}{\text { In-line Mixer }}$ & \multicolumn{2}{|c|}{$\begin{array}{l}\text { Static Mixer } \\
\text { 6" dia. x 4' length }\end{array}$} & \\
\hline \multicolumn{5}{|c|}{ D Area: Stillage Handling } \\
\hline 1 & $\frac{\mathrm{V}-501}{\text { Stillage Tank Agitator }}$ & \multicolumn{2}{|c|}{$\begin{array}{l}\text { Side mounted agitator } \\
\text { Wetted parts SS } 304\end{array}$} & 25 \\
\hline 3 & $\frac{\mathrm{V}-502 \mathrm{~A}, \mathrm{~B}, \mathrm{C}}{\text { Centrifuges }}$ & \multicolumn{2}{|c|}{$\begin{array}{l}\text { Alfa laval super-d-canter SG-16 } \\
\text { Cap: } \quad 300 \text { gpm }\end{array}$} & 250 (ea) \\
\hline 3 & $\frac{\text { V-503 A,B,C }}{\text { Rotary Filters }}$ & \multicolumn{2}{|c|}{$\begin{array}{l}\text { Rotary vacuum filter } \\
\text { C/W auxiliary systems }\end{array}$} & 25 (ea) \\
\hline 1 & $\begin{array}{l}\frac{\text { V-504 }}{\text { Recycle Stillage Tank }} \\
\text { Agitator }\end{array}$ & \multicolumn{2}{|c|}{$\begin{array}{l}\text { Side mounted agitator } \\
\text { Wetted parts SS } 304\end{array}$} & 3 \\
\hline 1 & 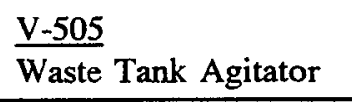 & \multicolumn{2}{|c|}{$\begin{array}{l}\text { Side mounted agitator } \\
\text { Wetted parts SS } 304\end{array}$} & 5 \\
\hline 1 & $\frac{\mathrm{W}-501 \mathrm{~A}, \mathrm{~B}, \mathrm{C}}{\text { Filter Conveyors }}$ & Cap: & 9 ton $/ \mathrm{hr}$ & 10 (ea) \\
\hline 1 & $\frac{\text { W-502 }}{\text { Cake Belt Conveyor }}$ & $\begin{array}{l}\text { Belt Con } \\
\text { Cap: }\end{array}$ & $\begin{array}{l}26 \mathrm{ton} / \mathrm{hr} \\
250 \mathrm{ft} \text { length }\end{array}$ & 15 \\
\hline
\end{tabular}


Table 2-8: Equipment List - Amoco Ethanol Plant (Cont)

\begin{tabular}{|c|c|c|c|c|}
\hline Qty. & Equipment & \multicolumn{2}{|l|}{ Description } & HP \\
\hline 3 & $\frac{\mathrm{W}-503 \mathrm{~A}, \mathrm{~B}, \mathrm{C}}{\text { Centrifugal Conveyors }}$ & Cap: & 15 ton $/ \mathrm{hr}$ & $15(e a)$ \\
\hline 1 & $\frac{\text { P-501 }}{\text { Filter Feed Pump }}$ & $\begin{array}{l}\text { Centrifugal } \\
\text { Cap: } \\
\text { Head: } \\
\text { Material: }\end{array}$ & $\begin{array}{l}900 \mathrm{gpm} \\
100 \mathrm{ft} \\
\text { SS } 316\end{array}$ & 40 \\
\hline 1 & $\frac{\text { P-502 }}{\text { Filtrate Pump }}$ & $\begin{array}{l}\text { Centrifugal } \\
\text { Cap: } \\
\text { Head: } \\
\text { Material: }\end{array}$ & $\begin{array}{l}80 \mathrm{gpm} \\
150 \mathrm{ft} \\
\mathrm{SS} 316\end{array}$ & 10 \\
\hline 1 & $\frac{\text { P-503 }}{\text { Recycle Stillage Pump }}$ & $\begin{array}{l}\text { Centrifugal } \\
\text { Cap: } \\
\text { Head: } \\
\text { Material: }\end{array}$ & $\begin{array}{l}100 \mathrm{gpm} \\
150 \mathrm{ft} \\
\text { SS } 316\end{array}$ & 10 \\
\hline 3 & $\frac{\text { P-504 A,B,C }}{\text { Filter Vacuum Pumps }}$ & $\begin{array}{l}\text { Liquid ring } \\
\text { Cap: } \\
\text { C/W separ: }\end{array}$ & $\begin{array}{l}\text { pump } \\
600 \mathrm{cfm} \\
\text { skid assembly }\end{array}$ & 400 (ea) \\
\hline 1 & $\frac{\text { P-505 }}{\text { Waste Liquid Pump }}$ & $\begin{array}{l}\text { Centrifugal } \\
\text { Cap: } \\
\text { Head: } \\
\text { Material: }\end{array}$ & $\begin{array}{l}800 \mathrm{gpm} \\
150 \mathrm{ft} \\
\text { SS } 316\end{array}$ & 40 \\
\hline 1 & $\frac{\mathrm{T}-501}{\text { Stillage Cooler }}$ & $\begin{array}{l}\text { Shell \& tub } \\
\text { Surf. area: } \\
\text { Material: } \\
\text { DP: }\end{array}$ & $\begin{array}{l}\text { ser } \\
1,350 \mathrm{ft}^{2} \\
\text { SS } 304 \text { tubes/CS shell } \\
100 \mathrm{psig}\end{array}$ & \\
\hline 1 & $\frac{\mathrm{T}-502}{\text { Recycle Cooler }}$ & $\begin{array}{l}\text { Shell \& tub } \\
\text { Surf. area: } \\
\text { Material: } \\
\text { DP: }\end{array}$ & $\begin{array}{l}850 \mathrm{ft}^{2} \\
\text { SS } 304 \text { tubes/CS shell } \\
100 \mathrm{psig}\end{array}$ & \\
\hline 1 & $\frac{\text { M-501 }}{\text { Stillage Tank }}$ & $\begin{array}{l}\text { Cap: } \\
\text { Material: } \\
\text { DP: }\end{array}$ & $\begin{array}{l}25,000 \text { gal. } \\
15^{\prime} \text { dia. } \times 20^{\prime} \mathrm{T} / \mathrm{T} \\
\text { SS } 304 \\
\text { Atmospheric }\end{array}$ & \\
\hline 1 & $\frac{\text { M-502 }}{\text { Recycle Stillage Tank }}$ & $\begin{array}{l}\text { Cap: } \\
\text { Material: } \\
\text { DP: }\end{array}$ & $\begin{array}{l}5,000 \text { gal. } \\
8, \text { dia. } \times 13, T / T \\
\text { SS } 304 \\
\text { Atmospheric }\end{array}$ & \\
\hline 1 & $\frac{\text { M-503 }}{\text { Waste Liquid Tank }}$ & $\begin{array}{l}\text { Cap: } \\
\text { Material: } \\
\text { DP: }\end{array}$ & $\begin{array}{l}12,000 \text { gal. } \\
11^{\prime} \text { dia. } \times 17 \text { 'T/T } \\
\text { SS } 304 \\
\text { Atmospheric }\end{array}$ & \\
\hline
\end{tabular}


Table 2-8: Equipment List - Amoco Ethanol Plant (Cont)

\begin{tabular}{|c|c|c|c|c|}
\hline Qty. & Equipment & \multicolumn{2}{|l|}{ Description } & \multirow[t]{2}{*}{$\mathbf{H P}$} \\
\hline \multicolumn{4}{|c|}{0 Area: chemicals \& CIP } & \\
\hline 1 & $\frac{\mathrm{V}-601}{\text { Spent }}$ CIP Agitator & $\begin{array}{l}\text { Side mounte } \\
\text { Material: }\end{array}$ & SS 316 wetted parts & 5 \\
\hline 1 & $\frac{\mathrm{V}-602}{\text { CIP Tank Agitator }}$ & $\begin{array}{l}\text { Side mounte } \\
\text { Material: }\end{array}$ & SS 316 wetted parts & 10 \\
\hline 1 & $\frac{\mathrm{V}-603}{\text { Nutrient Mix Tank Agitator }}$ & $\begin{array}{l}\text { Top entry aq } \\
\text { Material: }\end{array}$ & SS 316 wetted parts & 5 \\
\hline 1 & $\frac{\mathrm{V}-604}{\text { In-line Mixer }}$ & $\begin{array}{l}\text { Static mixed } \\
2^{\prime \prime} \text { diameter } \\
\text { Material: }\end{array}$ & SS 304 & \\
\hline 1 & $\frac{\mathrm{V}-605}{\text { Lime Tank Agitator }}$ & $\begin{array}{l}\text { Bottom side } \\
\text { Material: }\end{array}$ & $\begin{array}{l}\text { agitator } \\
\text { Carbon steel }\end{array}$ & 5 \\
\hline 1 & $\frac{\mathrm{W}-601}{\text { Lime Conveyor }}$ & $\begin{array}{l}\text { Screw Conv } \\
4^{\text {" diameter }} \\
\text { Material: }\end{array}$ & $\begin{array}{l}\text { Igth } \\
\text { Carbon steel } \\
\end{array}$ & 1.5 \\
\hline 1 & $\frac{\mathrm{W}-602}{\text { Lime Unloading Elevator }}$ & $\begin{array}{l}\text { Bucket eleva } \\
\text { 30' height } \\
\text { Material: }\end{array}$ & $\begin{array}{l}\text { On/hr } \\
\text { Carbon steel }\end{array}$ & 3 \\
\hline 1 & $\frac{\text { P-601 }}{\text { CIP Pump }}$ & $\begin{array}{l}\text { Centrifugal } \\
\text { Cap: } \\
\text { Head: } \\
\text { Material: } \\
\end{array}$ & $\begin{array}{l}300 \mathrm{gpm} \\
150 \mathrm{ft} \\
\text { SS } 316 \\
\end{array}$ & 20 \\
\hline 1 & $\frac{\text { P-602 }}{\text { Caustic Pump }}$ & $\begin{array}{l}\text { Centrifugal } \\
\text { Cap: } \\
\text { Head: } \\
\text { Material: }\end{array}$ & $\begin{array}{l}50 \mathrm{gpm} \\
50 \mathrm{ft} \\
\text { Carbon steel }\end{array}$ & 20 \\
\hline 1 & $\frac{\mathrm{P}-603}{\text { Caustic Unloading Pump }}$ & $\begin{array}{l}\text { Centrifugal } \\
\text { Cap: } \\
\text { Head: } \\
\text { Material: }\end{array}$ & $\begin{array}{l}150 \mathrm{gpm} \\
50 \mathrm{ft} \\
\text { Carbon steel } \\
\end{array}$ & 3 \\
\hline 1 & $\frac{\text { P-604 }}{\text { Nutrient Pump }}$ & $\begin{array}{l}\text { Centrifugal } \\
\text { Cap: } \\
\text { Head: } \\
\text { Material: }\end{array}$ & $\begin{array}{l}10 \text { gpm } \\
75 \mathrm{ft} \\
\text { SS } 316\end{array}$ & 2 \\
\hline 1 & $\frac{\text { P-605 }}{\text { Steep Liquor Pump }}$ & $\begin{array}{l}\text { Centrifugal } \\
\text { Cap: } \\
\text { Head: } \\
\text { Material: } \\
\end{array}$ & $\begin{array}{l}50 \mathrm{gpm} \\
50 \mathrm{ft} \\
\text { SS } 316 \\
\end{array}$ & 1.5 \\
\hline
\end{tabular}


Table 2-8: Equipment List - Amoco Ethanol Plant (Cont)

\begin{tabular}{|c|c|c|c|c|}
\hline Qty. & Equipment & Description & & HP \\
\hline 1 & $\begin{array}{l}\frac{\text { P-606 }}{\text { Steep Liquor Unloading }} \\
\text { Pump }\end{array}$ & $\begin{array}{l}\text { Centrifugal } \\
\text { Cap: } \\
\text { Head: } \\
\text { Material: }\end{array}$ & $\begin{array}{l}150 \mathrm{gpm} \\
50 \mathrm{ft} \\
\text { SS } 316\end{array}$ & 3 \\
\hline 1 & $\frac{\text { P-607 }}{\text { Syrup Pump }}$ & $\begin{array}{l}\text { Centrifugal } \\
\text { Cap: } \\
\text { Head: } \\
\text { Material: }\end{array}$ & $\begin{array}{l}50 \mathrm{gpm} \\
75 \mathrm{ft} \\
\text { Carbon steel }\end{array}$ & 2 \\
\hline 1 & $\frac{\text { P-608 }}{\text { Phosphoric Acid Pump }}$ & $\begin{array}{l}\text { Metering pump } \\
\text { Cap: } \\
\text { Material: }\end{array}$ & $\begin{array}{l}1 \mathrm{gpm} \\
\text { Carbon steel }\end{array}$ & 0.5 \\
\hline 1 & $\frac{\text { P-609 }}{\text { Ammonia Pump }}$ & $\begin{array}{l}\text { Metering pump } \\
\text { Cap: } \\
\text { Material: }\end{array}$ & $\begin{array}{l}1 \mathrm{gpm} \\
\text { Carbon steel }\end{array}$ & 0.5 \\
\hline 1 & $\frac{\text { P-610 }}{\text { Ammonia Unloading Pump }}$ & $\begin{array}{l}\text { Centrifugal } \\
\text { Cap: } \\
\text { Head: } \\
\text { Material: }\end{array}$ & $\begin{array}{l}150 \mathrm{gpm} \\
50 \mathrm{ft} \\
\text { Carbon steel }\end{array}$ & 3 \\
\hline 1 & $\frac{\text { P-611 }}{\text { Sulphuric Acid Pump }}$ & $\begin{array}{l}\text { Metering pump } \\
\text { Cap: } \\
\text { Material: }\end{array}$ & $\begin{array}{l}0.75 \mathrm{gpm} \\
\text { Carbon steel }\end{array}$ & 0.5 \\
\hline 1 & $\frac{\text { P-612 }}{\text { Acid Unloading Pump }}$ & $\begin{array}{l}\text { Centrifugal } \\
\text { Cap: } \\
\text { Head: } \\
\text { Material: }\end{array}$ & $\begin{array}{l}150 \mathrm{gpm} \\
50 \mathrm{ft} \\
\text { Carbon steel }\end{array}$ & 3 \\
\hline 1 & $\frac{\text { P-613 }}{\text { Lime Slurry Pump }}$ & $\begin{array}{l}\text { Centrifugal } \\
\text { Cap: } \\
\text { Head: } \\
\text { Material: }\end{array}$ & $\begin{array}{l}3 \mathrm{gpm} \\
100 \mathrm{ft} \\
\text { Carbon steel }\end{array}$ & 2 \\
\hline 1 & $\frac{\text { P-614 }}{\text { Syrup Unloading Pump }}$ & $\begin{array}{l}\text { Centrifugal } \\
\text { Cap: } \\
\text { Head: } \\
\text { Material: }\end{array}$ & $\begin{array}{l}150 \mathrm{gpm} \\
50 \mathrm{ft} \\
\text { Carbon steel }\end{array}$ & 3 \\
\hline 1 & $\frac{Q-601}{\text { Spent CIP Tank }}$ & $\begin{array}{l}\text { Cap: } \\
\text { Material: } \\
\text { DP: }\end{array}$ & $\begin{array}{l}6,000 \text { gal. } \\
\text { 9' dia. } \times 12, \mathrm{~T} / \mathrm{T} \\
\text { SS } 304 \\
\text { Atmospheric }\end{array}$ & \\
\hline 1 & $\frac{\text { Q-602 }}{\text { CIP Tank }}$ & $\begin{array}{l}\text { Cap: } \\
\text { Material: } \\
\text { DP: }\end{array}$ & $\begin{array}{l}6,000 \mathrm{gal} . \\
9^{\prime} \text { dia. } \times 12^{\prime} \mathrm{T} / \mathrm{T} \\
\text { Carbon steel } \\
\text { Atmospheric }\end{array}$ & \\
\hline
\end{tabular}


Table 2-8: Equipment List - Amoco Ethanol Plant (Cont)

\begin{tabular}{|c|c|c|c|c|}
\hline Qty. & Equipment & \multicolumn{2}{|c|}{ Description } & HP \\
\hline 1 & $\frac{\text { Q-603 }}{\text { Caustic Storage Tank }}$ & $\begin{array}{l}\text { Cap: } \\
\text { Material: } \\
\text { DP: }\end{array}$ & $\begin{array}{l}7,500 \text { gal. } \\
10^{\prime} \text { dia. } \times 13^{\prime} \mathrm{T} / \mathrm{T} \\
\text { Carbon steel } \\
\text { Atmospheric }\end{array}$ & \\
\hline 2 & $\frac{\mathrm{M}-604}{\text { Nutrient Mix Tank }}$ & $\begin{array}{l}\text { Cap: } \\
\text { Material: } \\
\text { DP: }\end{array}$ & $\begin{array}{l}1,500 \text { gal. } \\
\text { 5'-6" dia. x 9' T/T } \\
\text { SS } 304 \\
\text { Atmospheric }\end{array}$ & \\
\hline 1 & $\frac{\text { Q-605 }}{\text { Steep Liquor Tank }}$ & $\begin{array}{l}\text { Cap: } \\
\text { Material: } \\
\text { DP: } \\
\text { C/W inter }\end{array}$ & $\begin{array}{l}15,000 \text { gal. } \\
12 \text { ' dia. x } 18^{\prime} \mathrm{T} / \mathrm{T} \\
\text { SS } 316 \\
\text { Atmospheric } \\
\text { coil }\end{array}$ & \\
\hline 1 & $\frac{0-606}{\text { Syrup Tank }}$ & $\begin{array}{l}\text { Cap: } \\
\text { Material: } \\
\text { DP: } \\
\text { C/W inter }\end{array}$ & $\begin{array}{l}15,000 \text { gal. } \\
12 \text { ' dia. } \times 18, \mathrm{~T} / \mathrm{T} \\
\text { Carbon steel } \\
\text { Atmospheric } \\
\text { coil }\end{array}$ & \\
\hline 1 & $\frac{\mathrm{Q}-607}{\text { Aqueous Ammonia Tank }}$ & $\begin{array}{l}\text { Cap: } \\
\text { Material: } \\
\text { DP: } \\
\text { C/W wate } \\
\text { 12" dia. }\end{array}$ & $\begin{array}{l}6,000 \text { gal. } \\
\text { 9' dia. } \times 12 \text { ' T/T } \\
\text { Carbon steel } \\
5 \text { psig } \\
\text { ne scrubber }\end{array}$ & \\
\hline 1 & $\frac{\text { Q-608 }}{\text { Acid Tank }}$ & $\begin{array}{l}\text { Cap: } \\
\text { Material: } \\
\text { DP: }\end{array}$ & $\begin{array}{l}\text { 6,000 gal. } \\
\text { 9' dia. x 12' T/T } \\
\text { 1,000 BTM core } \\
\text { Carbon steel } \\
\text { Atmospheric }\end{array}$ & \\
\hline 1 & $\frac{\text { M-609 }}{\text { Lime Mix Tank }}$ & $\begin{array}{l}\text { Cap: } \\
\text { Material: } \\
\text { DP: }\end{array}$ & $\begin{array}{l}3,000 \text { gal. } \\
8 \text { ' dia. } \times 8 \text { ' T/T } \\
\text { Carbon steel } \\
\text { Atmospheric }\end{array}$ & \\
\hline 1 & $\frac{\mathrm{M}-610}{\text { Lime Storage Silo }}$ & $\begin{array}{l}\text { Cap: } \\
\text { Material: } \\
\text { DP: }\end{array}$ & $\begin{array}{l}1,200 \text { cubic } \mathrm{ft} \\
10^{\prime} \text { dia. } \times 15^{\prime} \mathrm{T} / \mathrm{T} \\
\text { Carbon steel } \\
\text { Atmospheric }\end{array}$ & \\
\hline
\end{tabular}




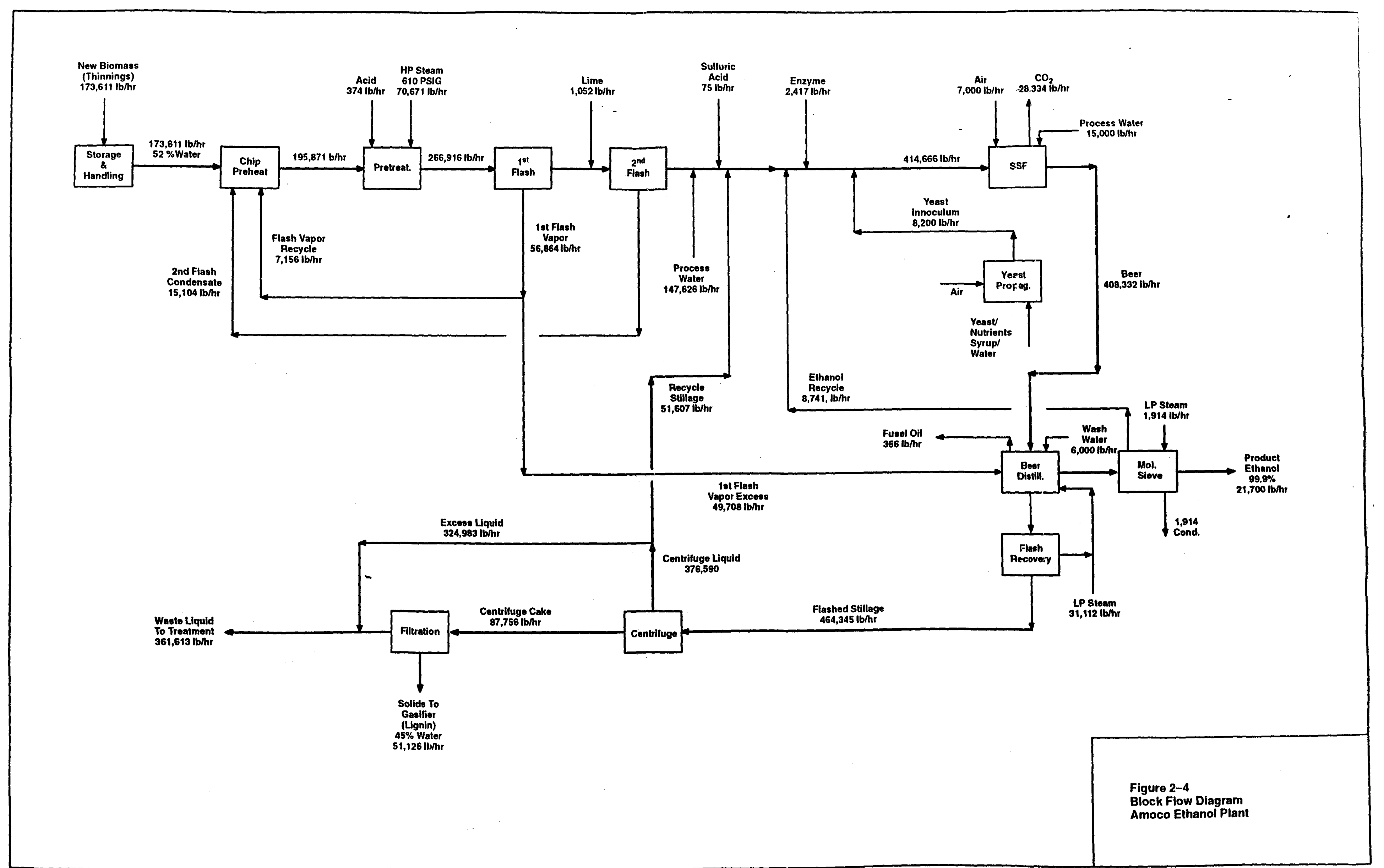




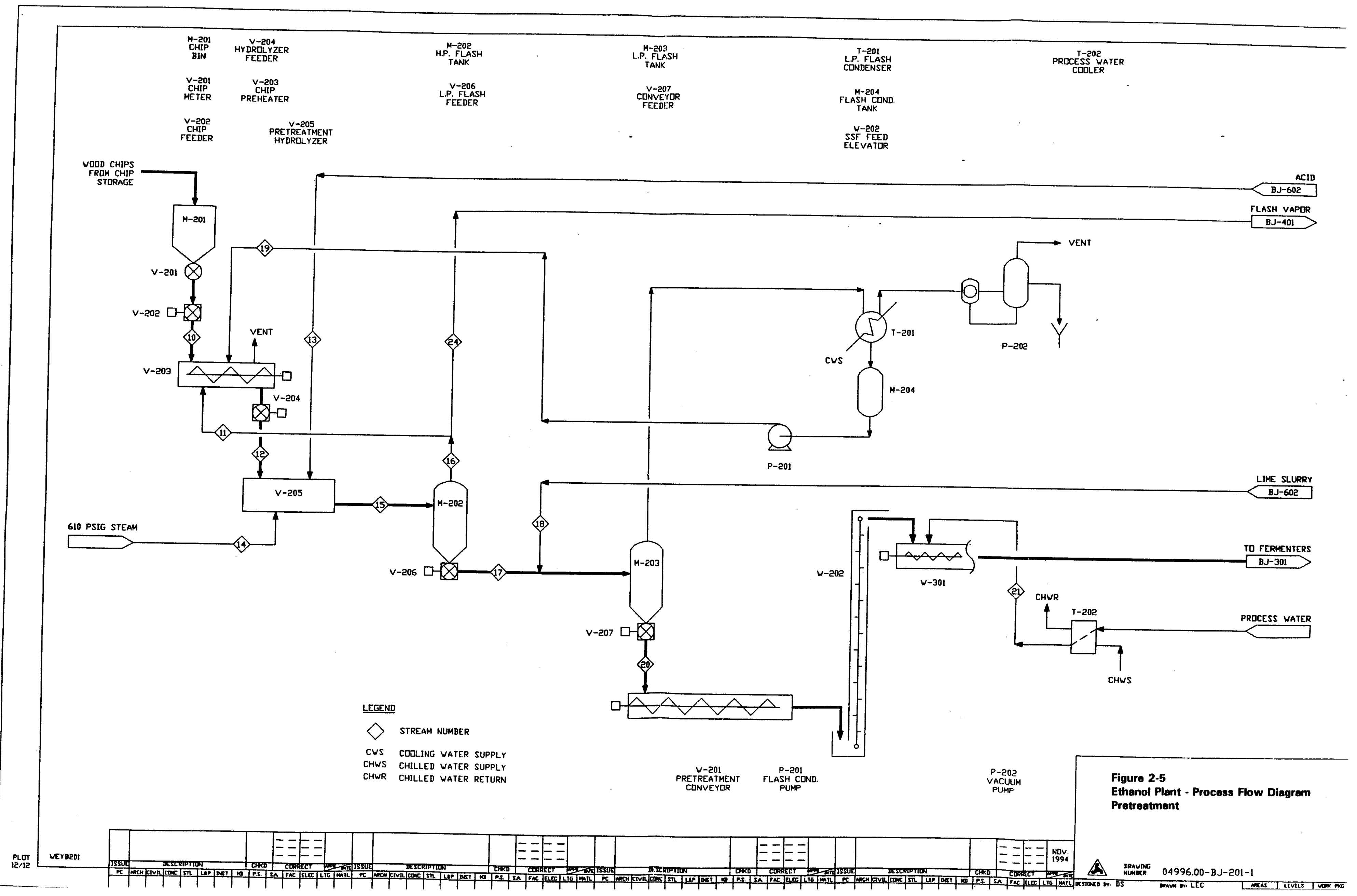




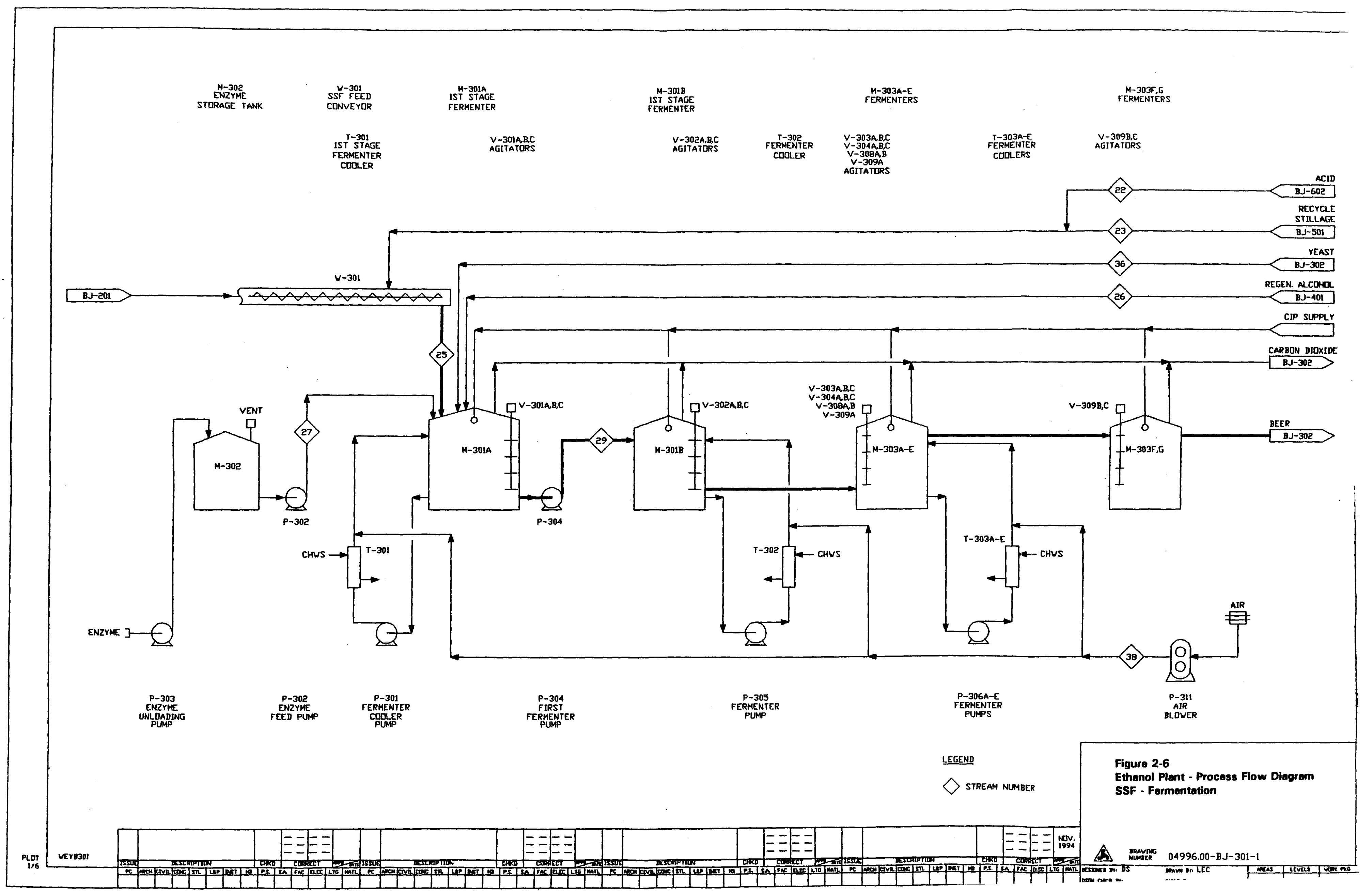




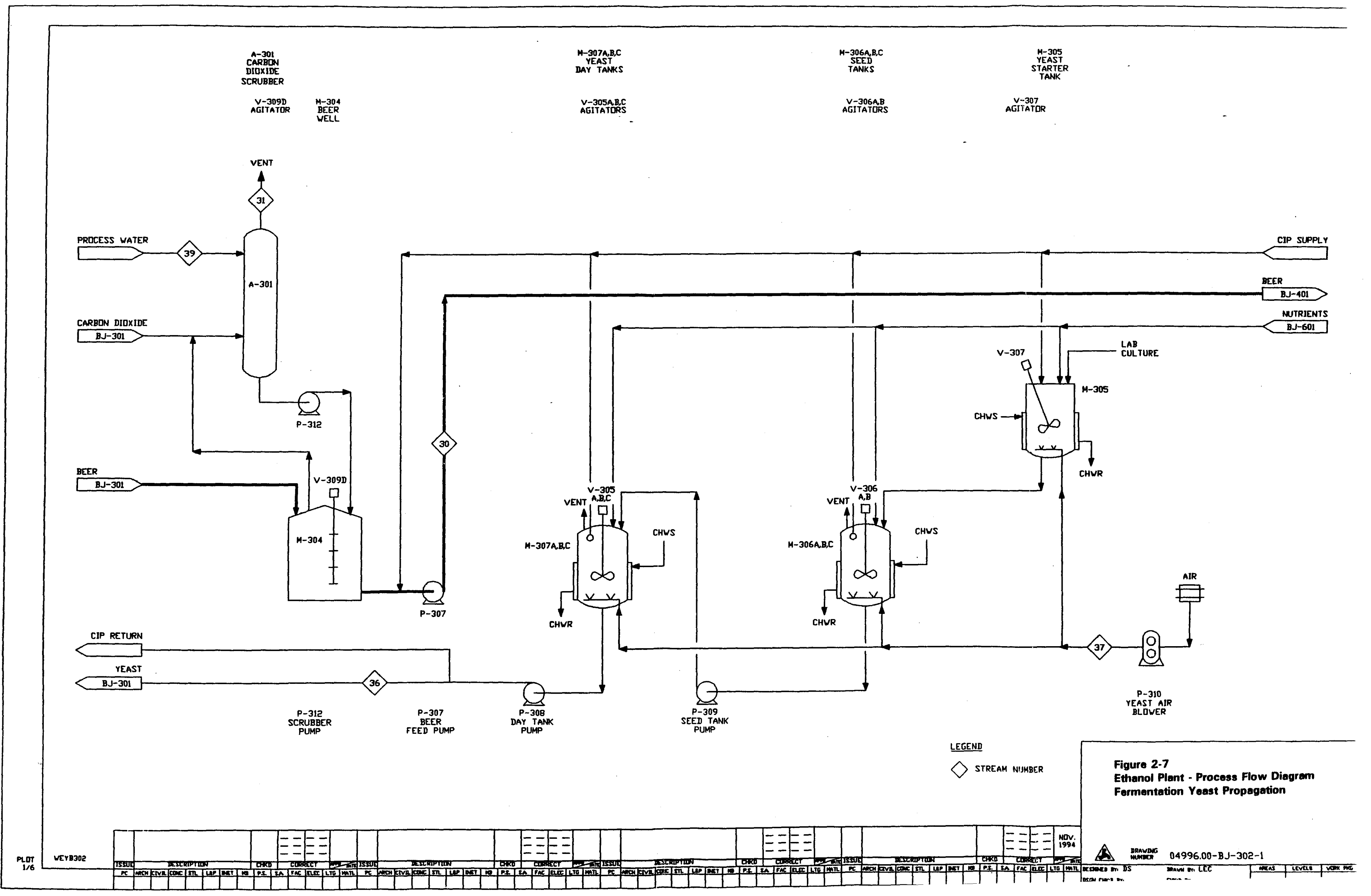




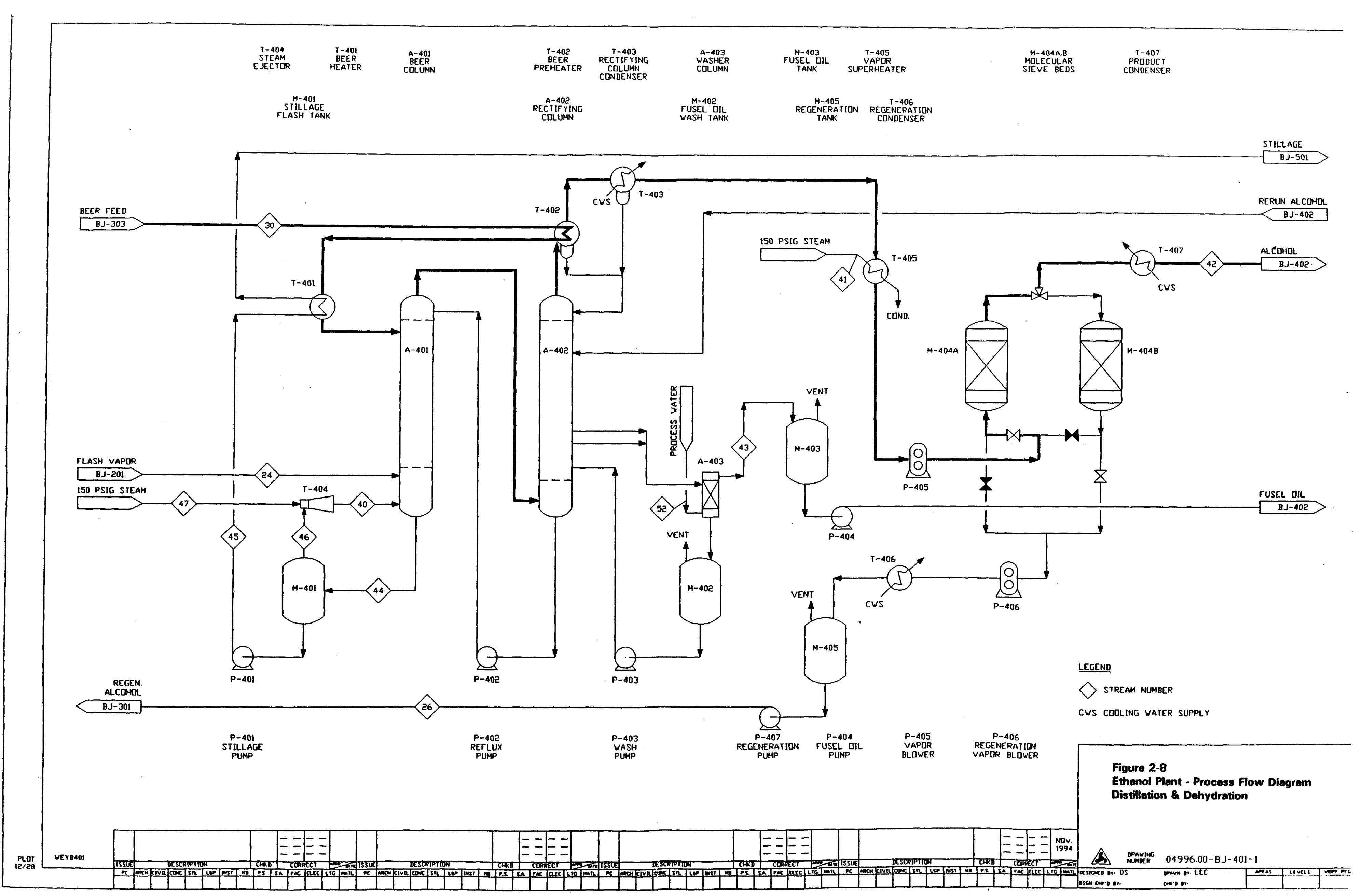




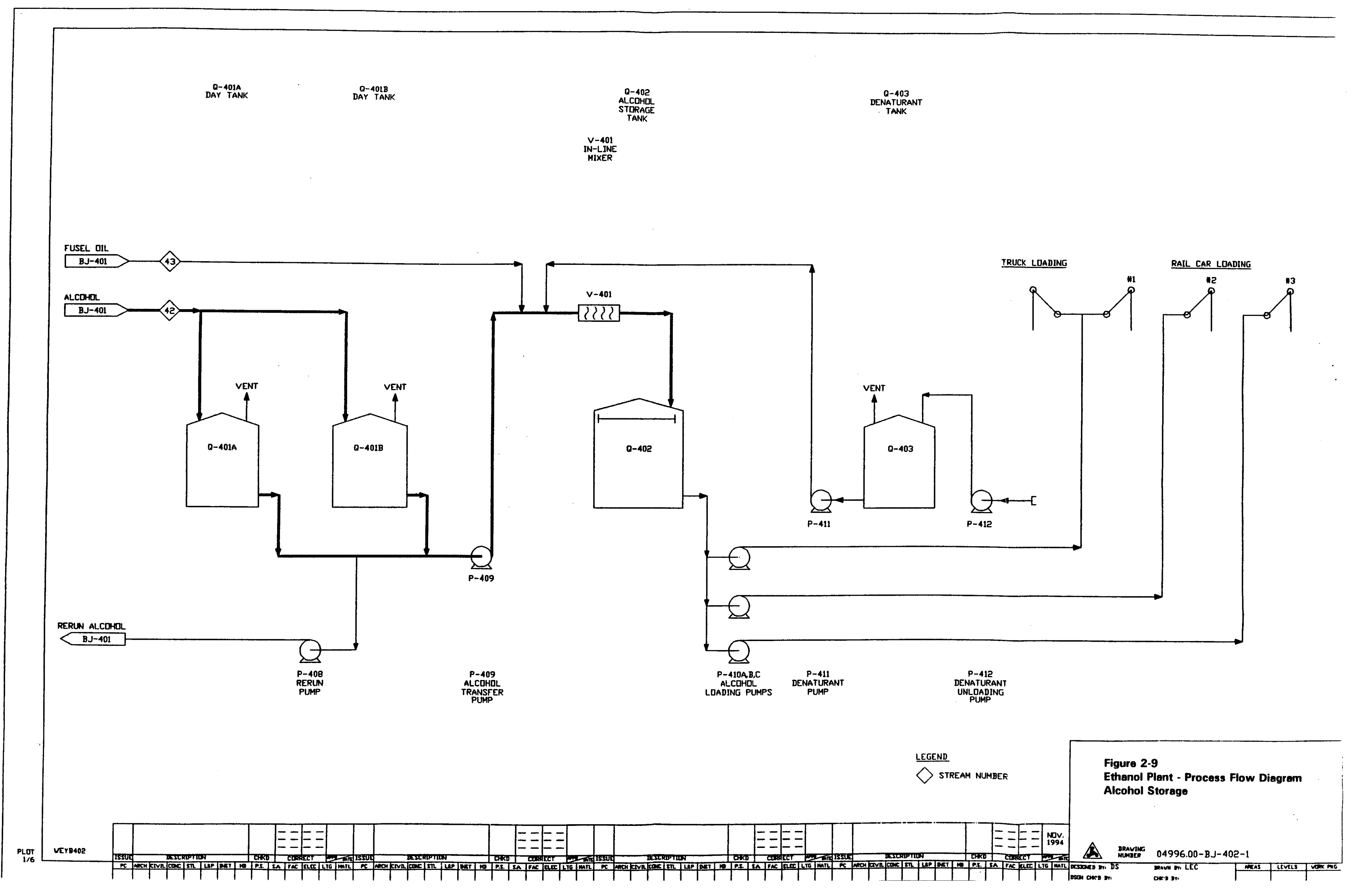




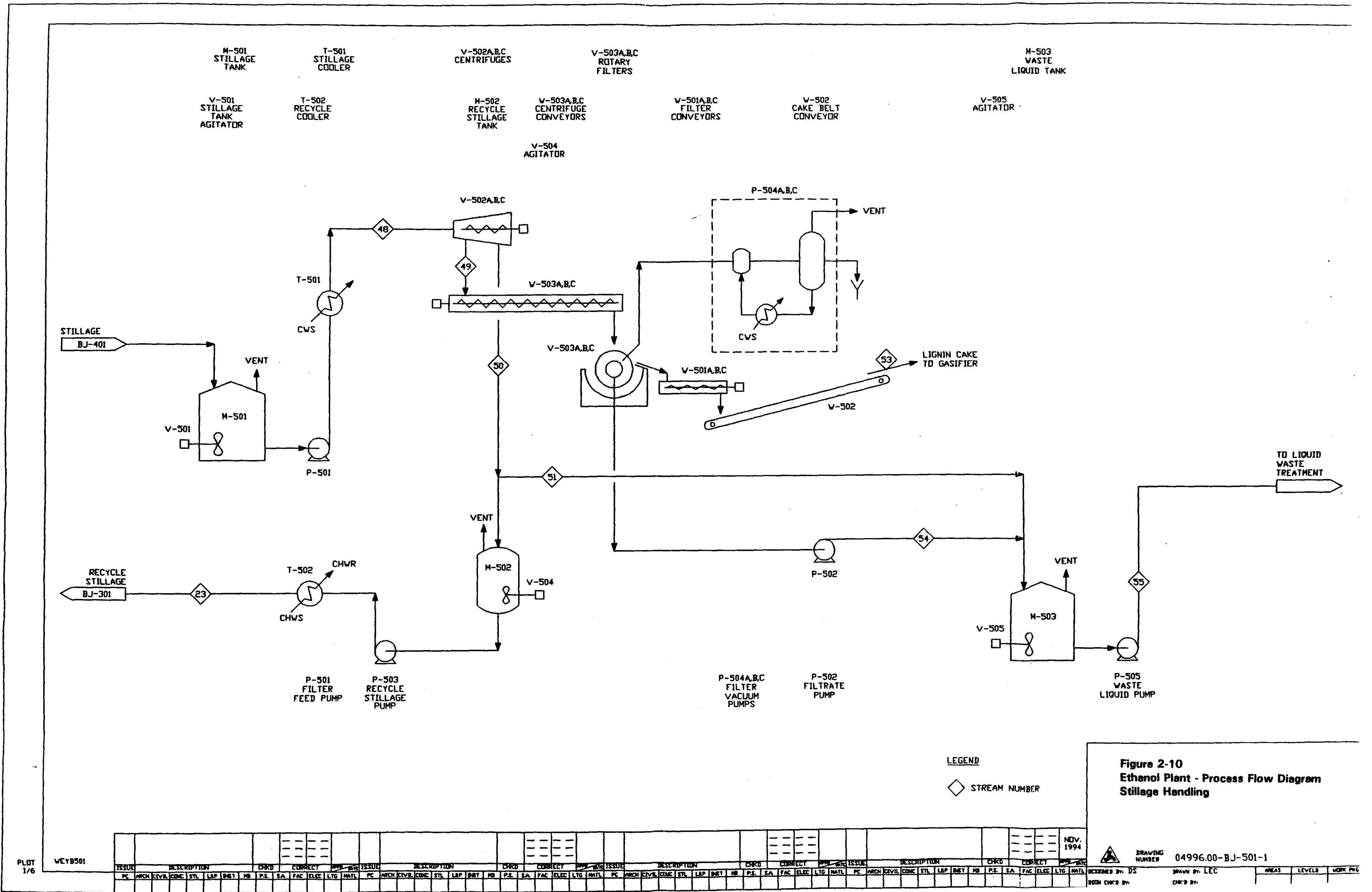




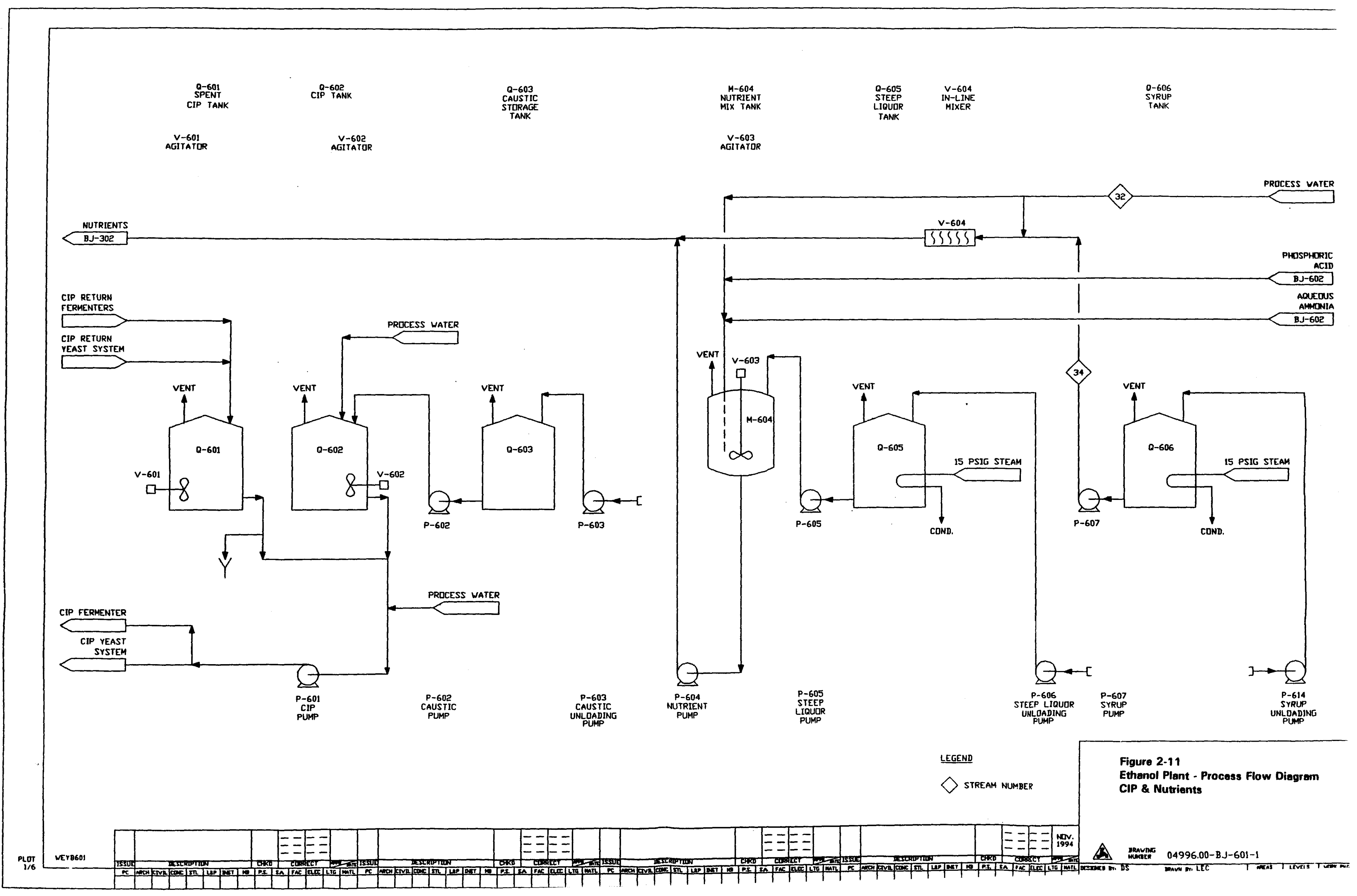




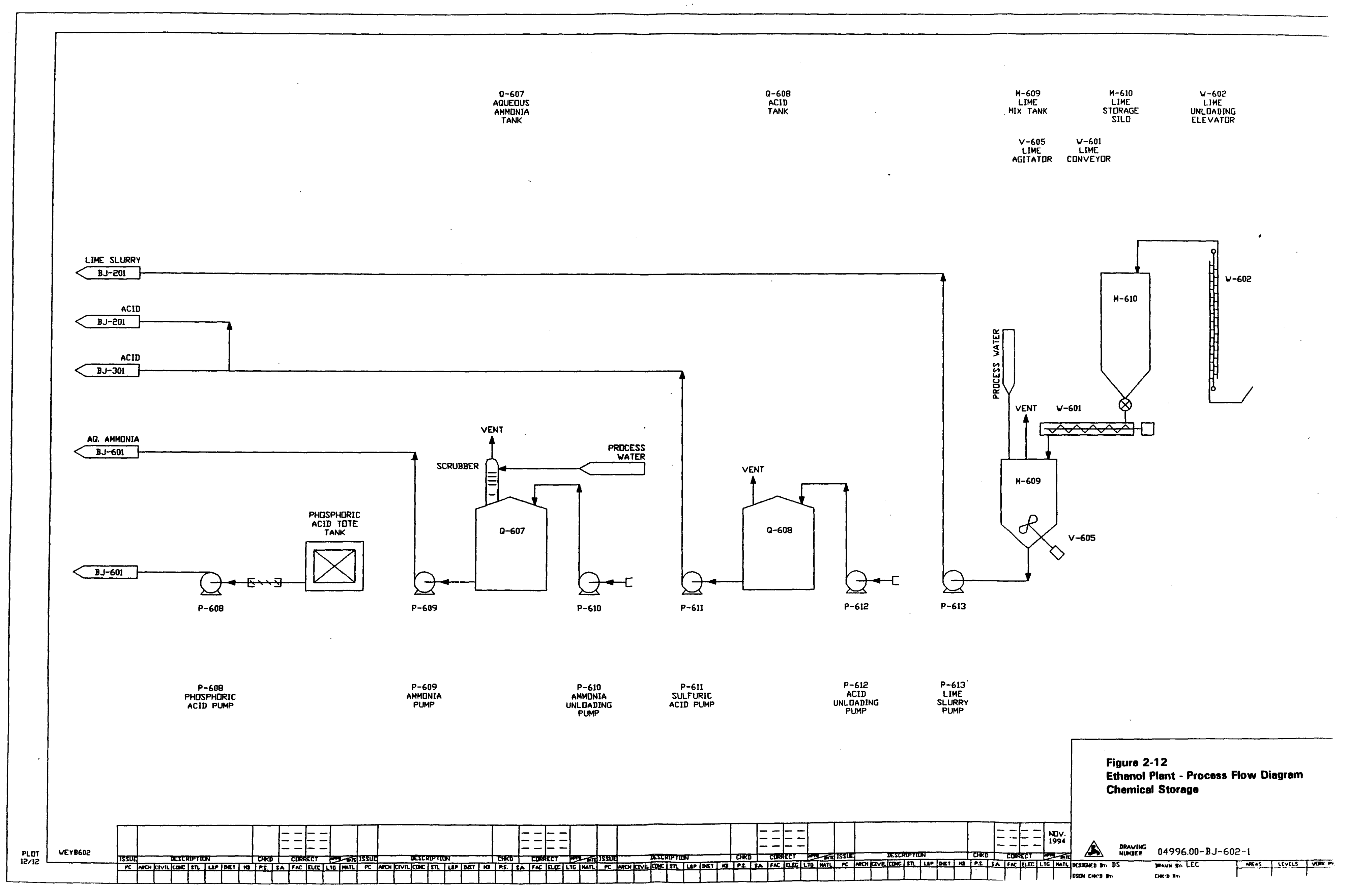


This page is intentionally left blank 


\subsection{Material Handling Systems}

Neither TPS, Tampella, nor Amoco included material handling in the scopes of supply. Therefore, Stone \& Webster worked with Weyerhaeuser and equipment vendors to lay out and estimate the cost of the material handling equipment. The material handling systems receive, store, and handle the raw biomass feed as well as the dolomite, ash, stillage, and bed sand as each particular case requires. For the most part, the feedstock handling systems for all of the cases are identical and differ predominately in the capacities of the systems. Other differences in the feedstock handling result from specific details in the feed arrangements for the dryers, gasifier, or ethanol feedstock pretreatment system.

This section provides the design philosophies used to size and cost the material handling equipment for the Tampella Flue Gas Drying and Steam Drying BGCC designs, the TPS BGCC design and the ethanol plant combined with a Tampella BGCC plant. Equipment lists are provided in Table 2-9 through Table 2-16. Using this information, costs were subsequently developed for a "stand alone" ethanol plant (i.e., without a BGCC plant).

The proposed material handling systems for the BGCC plant at the New Bern Mill integrate the existing hogged fuel handling equipment with new equipment required for the receiving, storing, handling and drying of biomass feedstock. As shown on Figure 2-27 of Section 2.5, Plot Plan - BGCC Retrofit, the material handling equipment occupies a large area in the vicinity of the BGCC plant.

Similarly, the material handling equipment associated with the ethanol plant dominates the site plan as shown on Figure 2-28 of Section 2.5, Plot Plan - BGCC/Ethanol Retrofit. As shown on this plot plan, the ethanol plant is located on the south side of the New Bern Mill site, approximately 1,500 feet from the existing hog boiler and proposed BGCC plant site. Since the majority of the new material to be trucked in from off site is consumed in the ethanol plant, the new receiving stations are located close to the ethanol plant. A 1,900 foot long belt conveyor carries some of the new feedstock along with the lignin waste stream to the existing hogged fuel pile or the proposed BGCC plant.

The following functions are provided by the material handling systems to support operation of the BGCC or ethanol plants independently, or in combination with each other:

- Transfer of hogged fuel produced by the mill's existing system to the BGCC plant's wet storage pile.

- Weighing and receiving of new feedstock trucked in from remote sources.

- $\quad$ Removal of metal objects, screening and hogging of new feedstock.

- Transfer of lignin stillage material from the ethanol plant to BGCC or hog fuel boiler storage pile.

- Mixing of material from the existing mill bark handling system with new processed wet fuel (for BGCC only).

- Storage for sufficient amounts of wet feedstock to allow for interruption in the supply of feedstock from outside sources.

- Reclaim and transfer of feedstock to the BGCC dryers or ethanol plant pretreatment area.

- $\quad$ Drying of feedstock while controlling fines and dust.

- Sufficient dry fuel storage to allow for constant dry fuel feed to the gasifier.

- Transfer of dry fuel to gasifier fuel inlet weigh hoppers.

- Storage and transfer dolomite to the tar cracker.

- $\quad$ Removal of cooled ash and dust and storage for transfer off-site. 


\section{System Descriptions}

\section{Feedstock Preparation Systems}

The BGCC plants receive wood biomass feedstock from two sources. The first source is the bark, rejects, sawdust, and associated material produced in the existing mill complex and is consolidated in the existing hog fuel processing area flow via a belt conveyor from the existing sizing station to the proposed wet fuel storage pile (See Figures 2-13, 2-16, 2-19, and 2-22). The existing bark sizing station must be relocated to allow proper alignment of conveyors. The second source, raw biomass, arrives from off-site via 20ton trucks. All of the feedstock for the ethanol plant, however, is received from offsite in the form of chipped harvesting and thinning residuals that are brought in by truck.

During normal operation, trucks arrive at a scale facility, are weighed, and then proceed to one of two (one of three in the ethanol case) hydraulic truck dumpers with above grade, live bottom 5,600 cu feet receiving hoppers at the $B G C C$ plant area. The two dumpers receive up to nine trucks per hour and tip the trucks, while still coupled to the cab, into the receiving hoppers. The BGCC plants receive trucks eight hours per day. At the ethanol plant three truck dumpers receive up to 16 trucks per hour. The ethanol plant receives trucks 10 hours per day. Empty trucks return to the scale facility for weighing out on separate and dedicated scales. A belt conveyor reclaims and transfers feedstock from the receiving hoppers to the process building (See Figures 2-13, 2-16, 2-19, and 2-22). In the process building, the material falls onto a reversing conveyor. A magnetic metal detection device, mounted in the conveyor, senses metal contamination in the feedstock and reverses the conveyor to dump rejects to the ground. Dumped material is periodically removed by a front end loader and discarded.

The process building contains a disk scalping screen. Material passing through the screen collects on a belt conveyor and transferred to the storage pile. The oversized reject material passing over the screen is directed to a hammer-type hog. Material processed through the hog falls onto the conveyor transferring material to the storage piles. In the ethanol plant case, an additional conveyor is provided to divert some of the flow to the BGCC plant or hog boiler. This belt conveyor discharges onto the lignin feed belt conveyor sending material back to the BGCC area (See Figures 2-22 and 2-23).

The sized biomass storage consists of a radial stacker and reclaimer system that combines the BGCC feedstock streams from the process building, existing sizing station and ethanol lignin and stores it on a pile. A bulldozer works the pile on a continuous basis to ensure complete mixing. The sized biomass storage pile servicing the ethanol plant contains only chipped harvesting and thinning residuals. The reclaimer system includes two redundant drag chain reclaimers which feed the sized biomass to the biomass dryer feed belt conveyor or biomass ethanol feed belt conveyor that delivers chips to the pretreatment area (Figure 2-23). The biomass dryer feed belt conveyor transfers the feedstock to a drag chain distribution conveyor. This conveyor distributes the feedstock to each of the four flue-gas dryer feed surge hoppers on a continuous basis. Each dryer inlet hopper is sized for approximately 10 minutes of full capacity operation. If all dryer inlet hoppers are full, the dryer feed belt conveyor will stop. From the hoppers, the feedstock is then fed into each dryer through an inlet rotary valve by dryer feed screw conveyors presented within Figures 2-16, 2-19, and 2-22. However, in the steam dryer case, biomass dryer feed belt conveyor delivers the biomass to a single steam dryer. Tampella selected a Niro steam dryer for this service. The dryer inlet hopper is sized for about 10 minutes of full-capacity operation. Wet fuel is fed to the dryer inlet rotary valve by the dryer feed screw conveyor. From the rotary valve biomass enters the dryer through a screw conveyor furnished with the dryer (See Figure 2-13). 
The four biomass flue gas dryers are rotary drum type and use the flue gas from the discharge of the HRSG as the drying medium. The performance of the dryers is controlled by bleeding ambient air into the flue gas stream through a temperature-controlled damper on the inlet of the dryer. The biomass is dried to the required moisture content ( 20 weight percent) in a single pass. Coarse biomass exits the dryer through an outlet dropout box rotary valve into a dryer discharge screw conveyor. The flue gas, carrying fine material, is drawn through a system of four parallel cyclone dust collectors where particles are separated and discharged through rotary valves to the previously mentioned dryer discharge screw conveyor. Fine material then mixes with coarse biomass in the dryer discharge screw conveyor and falls onto the dry fuel silo belt conveyor. The flue gas exits the dryers through two stacks provided to serve the four dryer trains.

The steam dryer is a pressurized circulating fluidized bed type which uses super heated steam as a drying medium. The drying stream is actually evaporated moisture from the wet biomass which is recirculated to the dryer core and superheated by contact with heat exchanger tubes containing medium pressure superheated steam ( $203 \mathrm{psig}, 428^{\circ} \mathrm{F}$ ) provided from the HRSG. Wet biomass and steam are circulated by a $1,100 \mathrm{~kW}$ circulating fan. The wet biomass is fed into the first of 16 cells on the perimeter of the dryer. The particles pass thereafter through the cells clockwise around the perimeter driven by steam flow through a baffle configuration which creates a rotating movement. The larger particles stay in the lower part of the cells and pass from one cell to the next. The smaller particles are blown to the upper (conical) part of the cells. Here the steam passes between incline plates which distribute it in a larger cross section. With the reduction of steam velocity in upper regions, particles fall onto plates and slide downwards, through a set of perforated plates and rails. The dryer is designed to move particles around the perimeter as they become progressively dryer and lighter. Steam leaving the top of each cell carries dust which must be separated in the top of the dryer. The steam passes between stationary blades that create a cyclone effect in the top cylinder. The dust hits the cylinder walls and eventually passes through a slot in the cylinder wall into a smaller internal cyclone that drops it back down into the last cell for mixing with coarse dried material and discharge from the dryer.

Steam evaporated from the feed particles is added to the circulating flow of steam. Therefore, a corresponding amount of steam is discharged through a pipe in the top of the dryer. This contaminated steam is used in a proposed mill stripper. Dust free steam recirculates back through the core of the dryer. The saturated condensate from the heating steam exits through a flash tank. A small portion of the clean condensate flashes to steam and is routed to the dirty steam line. The remaining clean condensate is returned to the mill condensate system.

Dried fuel with fine and coarse particles uniformly mixed is discharged through a rotary valve onto the dry fuel silo feed belt conveyor. The dry fuel silo feed belt conveyor conveys the biomass from the dryer discharge to the two dry fuel silos. Live bottom screws control the discharge of biomass from each dry fuel silo onto the biomass feed belt conveyor. The major configuration difference between the TPS and Tampella biomass feedstock preparation systems is that the Tampella system interfaces with three gasifier feed systems, whereas the TPS feed preparation system interfaces with only two feed systems.

In the TPS gasifier, the material falls onto a reversing conveyor which distributes the feed to one of two dried fuel feed hoppers provided with the gasifier. In the Tampella gasifier, the biomass flow splits into three streams for delivery to the gasifier. A diverter gate directs flow either to a reversing shuttle conveyor or to a chute which goes directly to one of the biomass weigh hoppers furnished with the gasifier. The reversing shuttle conveyor transfers flow to either of two additional biomass feed transfer conveyors. These conveyors discharge into the remaining two biomass weigh hoppers furnished with the gasifier. The system is designed to alternate flow to the three inlets on a uniform basis. Each flow path is sized to handle the full biomass feed rate. This biomass delivery system is similar for both the Tampella steam dryer case and the flue gas dryer case, although flow rates are slightly different. 


\section{Dolomite Receiving}

Dolomite is delivered to the BGCC site in self-unloading 20 ton trucks. A silo in the yard adjacent to the gasifier structure stores enough dolomite for four days of full-capacity operation. A pneumatic conveyor carries dolomite to the dolomite feed hopper furnished with the gasifiers (See Figures 2-14, 2-17, 2-20, and 2-24).

\section{Ash Removal}

In the TPS BGCC plant, ash exits the bottom of the fluid bed gasifier and is cooled in the ash cooling screw conveyor provided with the gasifier island. Ash from the bag filter also collects in a filter ash screw conveyor. A pneumatic conveyor carries bottom ash from rotary valves furnished with the gasifier to a storage silo in the yard. This silo is sized for two days of full-capacity operation. An integral discharge system can empty the ash in approximately two hours into a truck for transportation to Weyerhaeuser plantations for land application. A pneumatic conveyor carries filter ash from rotary valves furnished with the bag filter to a storage silo in the yard. Like the bottom ash silo, this silo is sized for two days of full-capacity operation. An integral discharge system can empty the ash in approximately two hours into a truck for transportation to Weyerhaeuser plantations for land application for treatment as described above. A fluidization system is provided with the filter ash storage silo to prevent bridging of the lighter, less dense fly ash to allow for smooth discharge of material into ash receiving trucks.

In the Tampella BGCC plant, each of two pneumatic conveyors carries bottom ash from lock hoppers furnished with the gasifier to storage silo in the yard. Ash temperature is about $450^{\circ} \mathrm{F}$. This silo is sized for two days of full-capacity operation and is emptied by an integral discharge system in approximately two hours into a truck for transportation to Weyerhaeuser plantations for land application for treatment as described above. A pneumatic conveyor carries filter ash from rotary valves furnished with the gasifier to a storage silo in the yard. This silo also is sized for two days of full-capacity operation and is emptied into a truck for disposal by an integral discharge system in approximately two hours. As in the TPS system, a fluidization system is provided with the filter ash storage silo to prevent bridging and allow for smooth discharge of material into ash receiving trucks.

\section{Stillage Handling}

Lignin storage waste from the ethanol plant mixed with processed wood chips that have bypassed the ethanol plant are conveyed to the BGCC feed system. Lignin stillage is deposited on the lignin waste transfer conveyor by the ethanol plant stillage cake belt conveyor (See Figure 2-23). At an intermediate point on the waste transfer conveyor, bypassed wood chips are added to the flow by the bypass conveyor. The combined flow of lignin cake and chips is discharged on the wet fuel storage pile (See Figure 2-22). At this location, it is well mixed with the mill waste bark by a bulldozer. From here, the material is handled by the BGCC feed preparation and handling system as previously described.

\section{Bed Sand Receiving}

Bed sand is added to the TPS gasifier only during startup before sufficient ash has built up in the system to sustain the fluidized bed. The gasifier island includes a bed sand inlet weigh hopper. Bags of bed sand are loaded on pallets and transported to the gasifier area for manual loading into the inlet weigh hopper. 


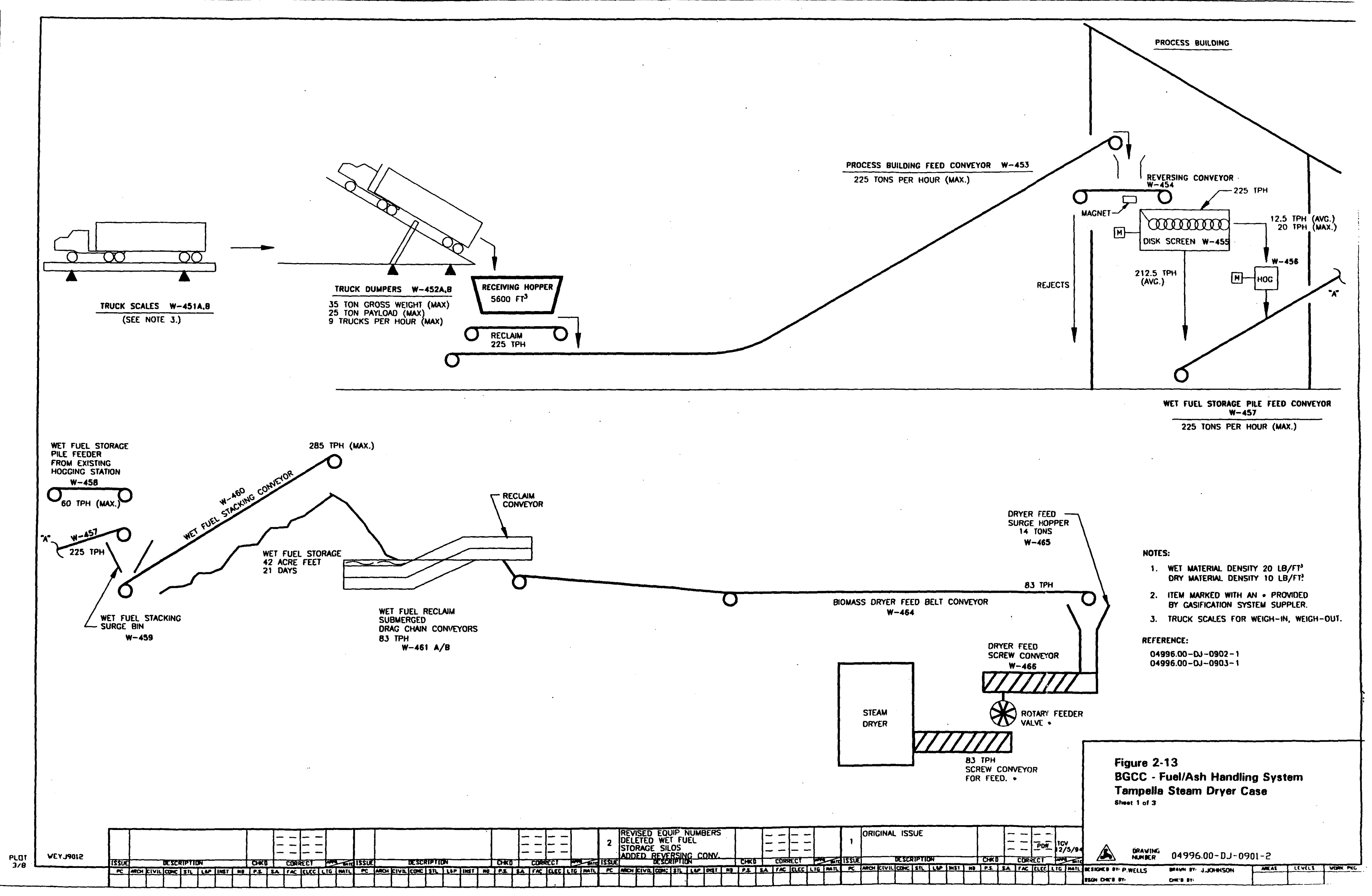




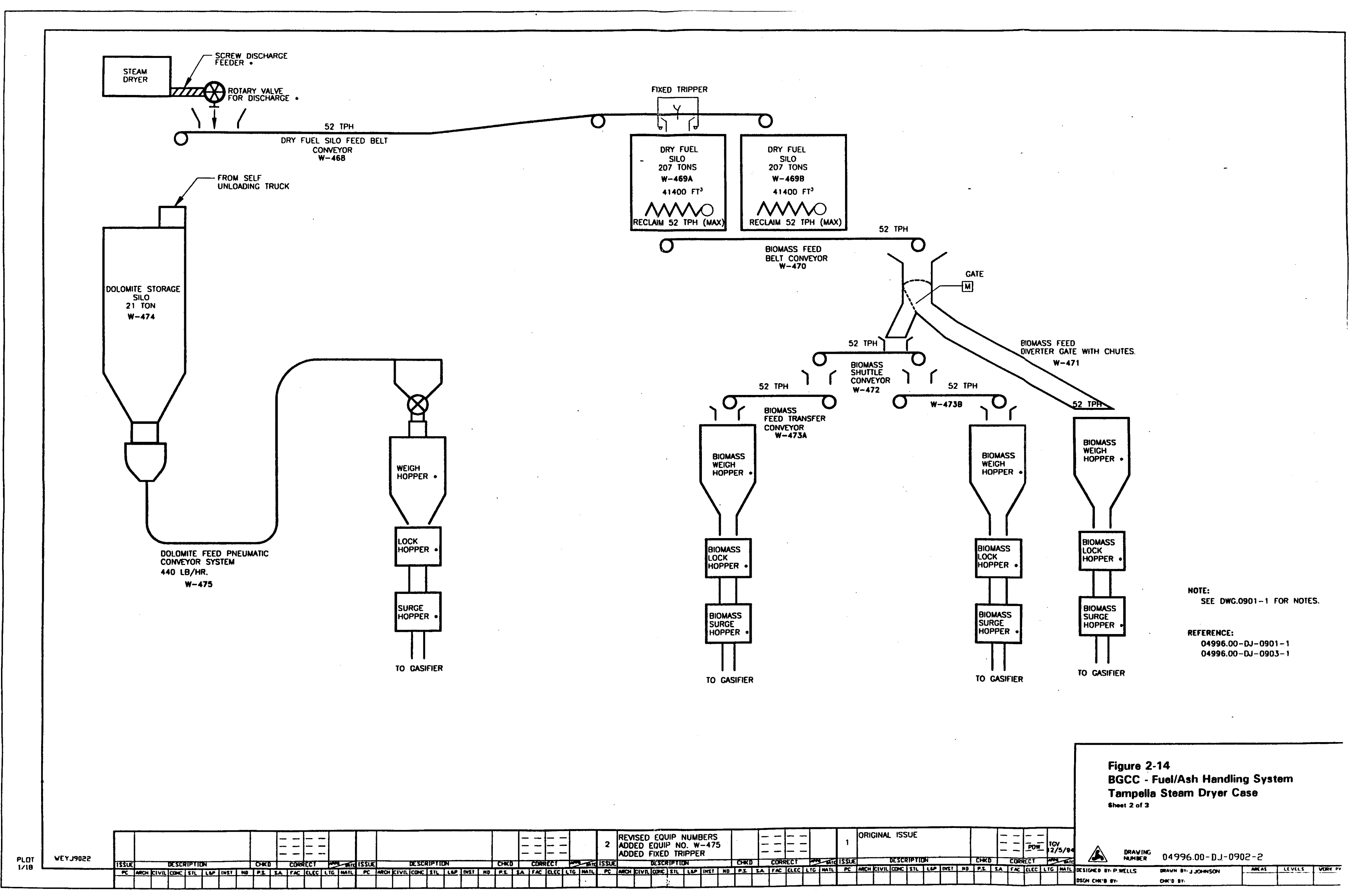




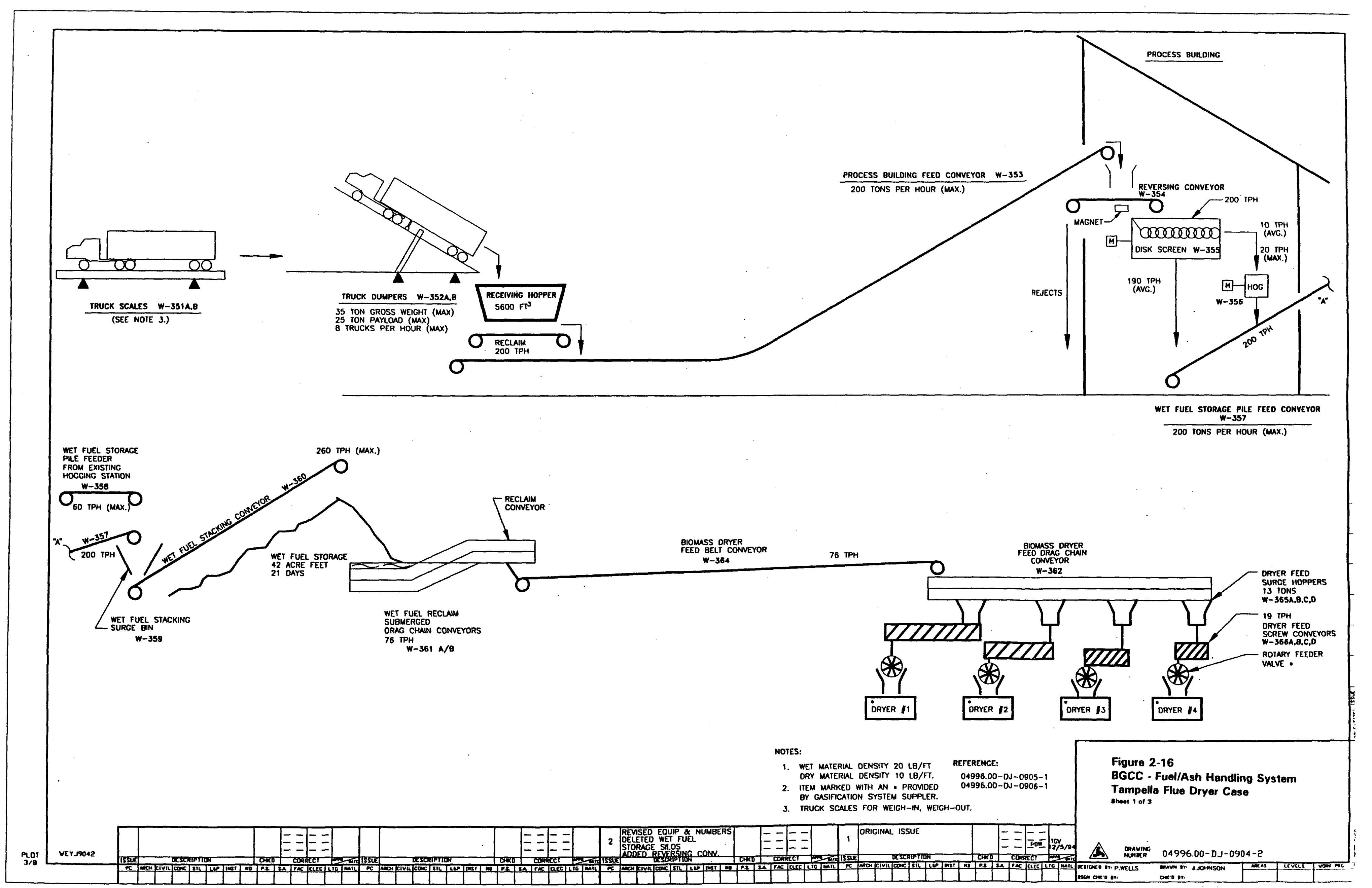




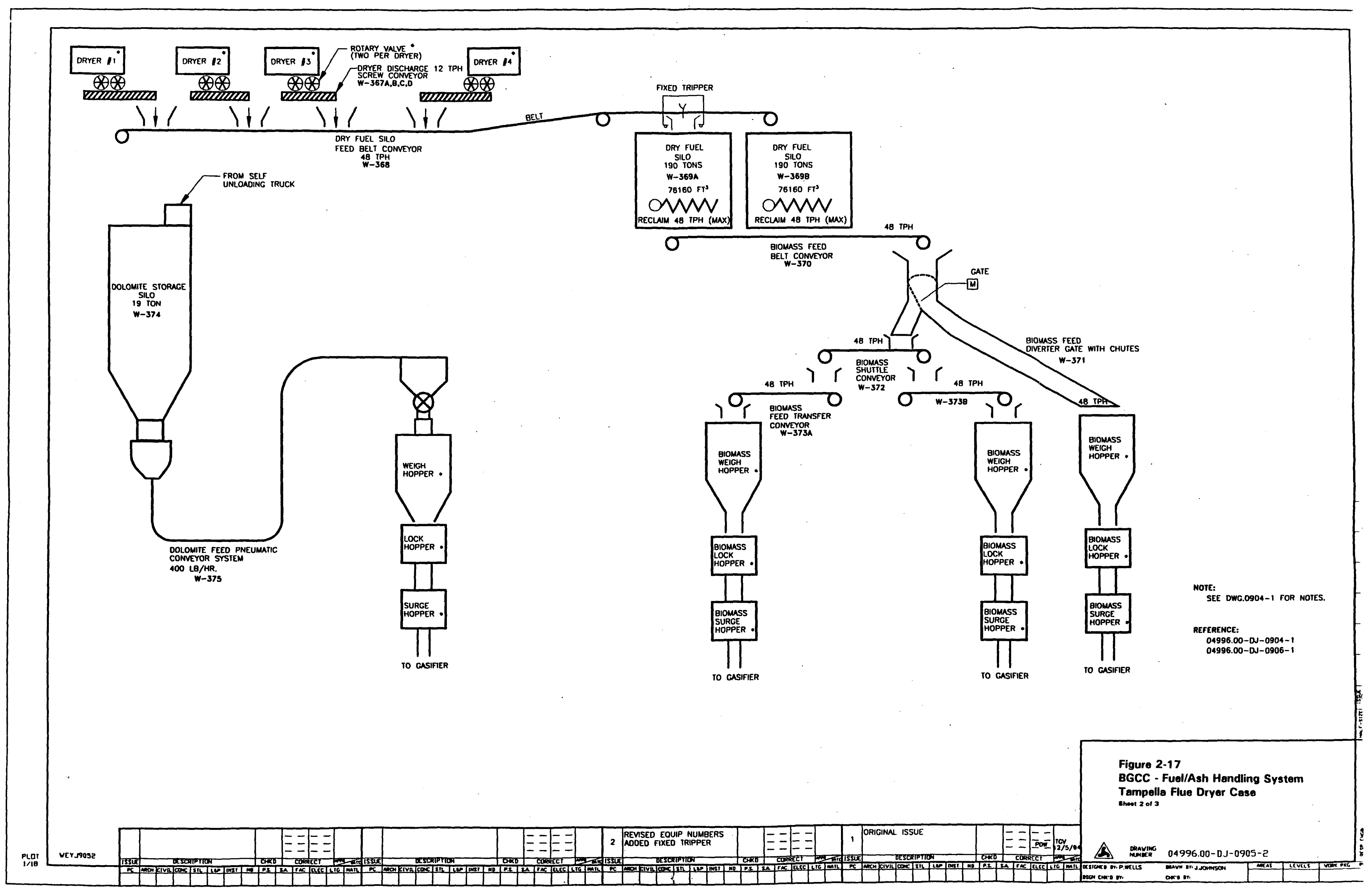




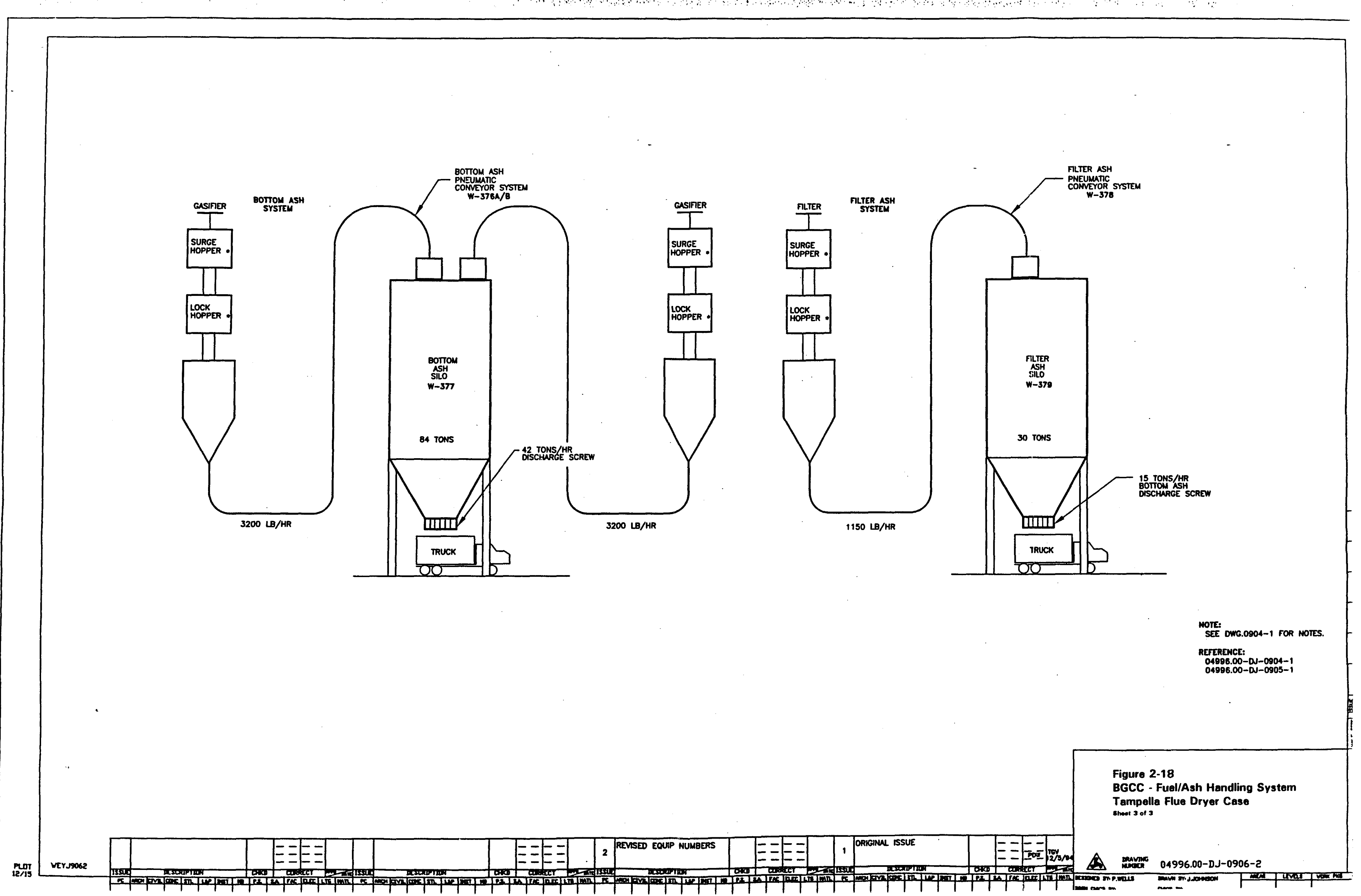




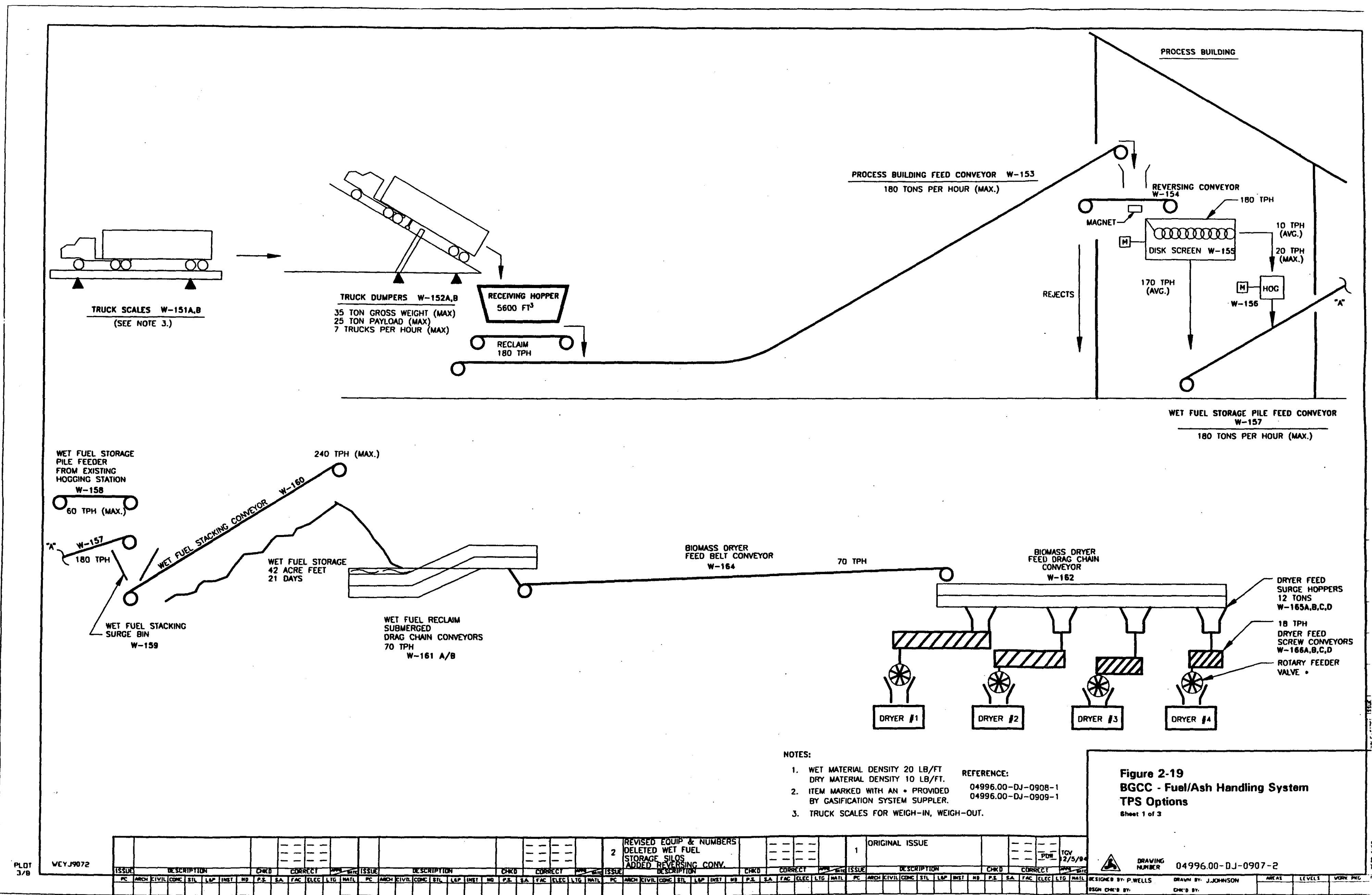




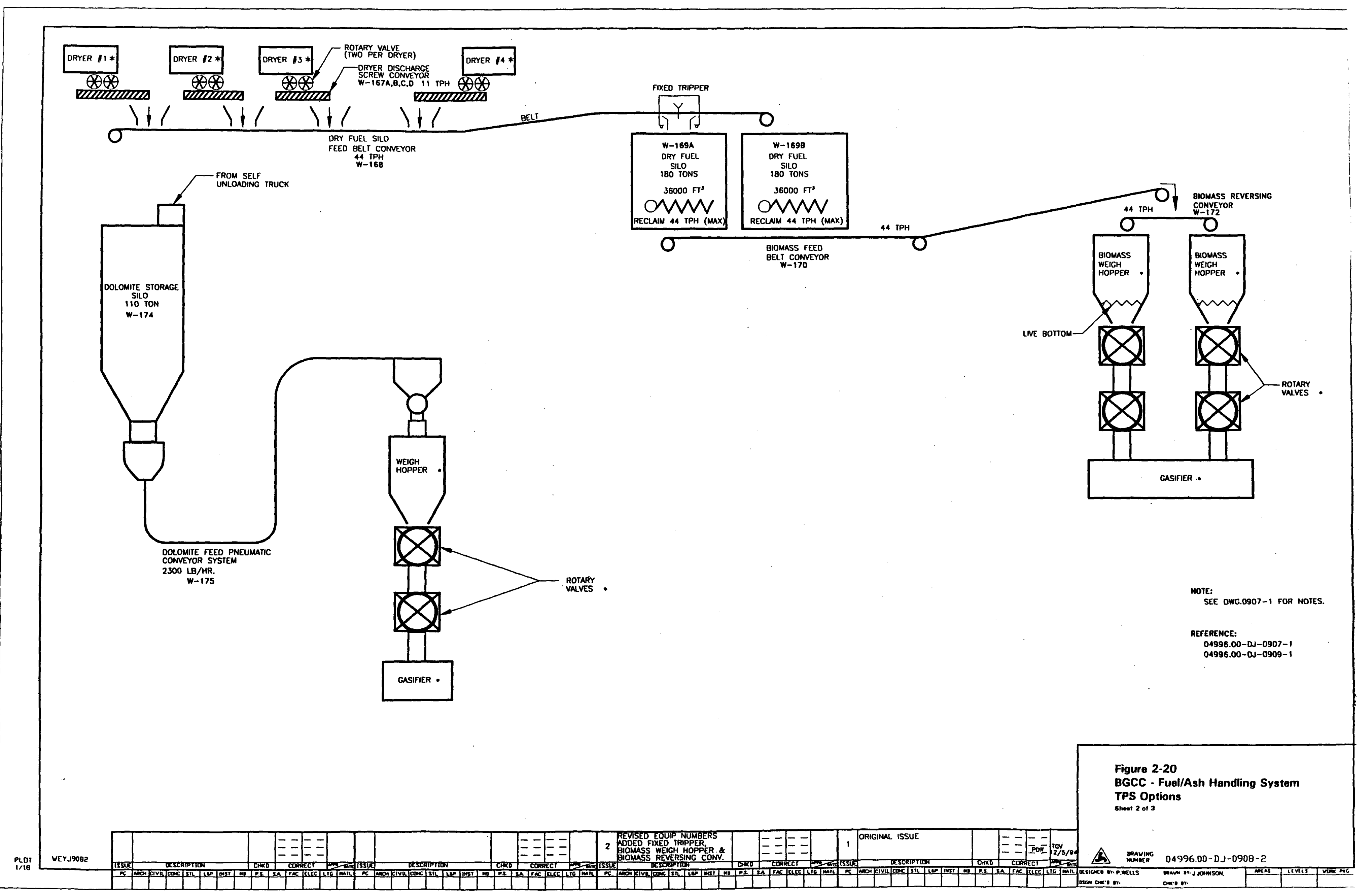




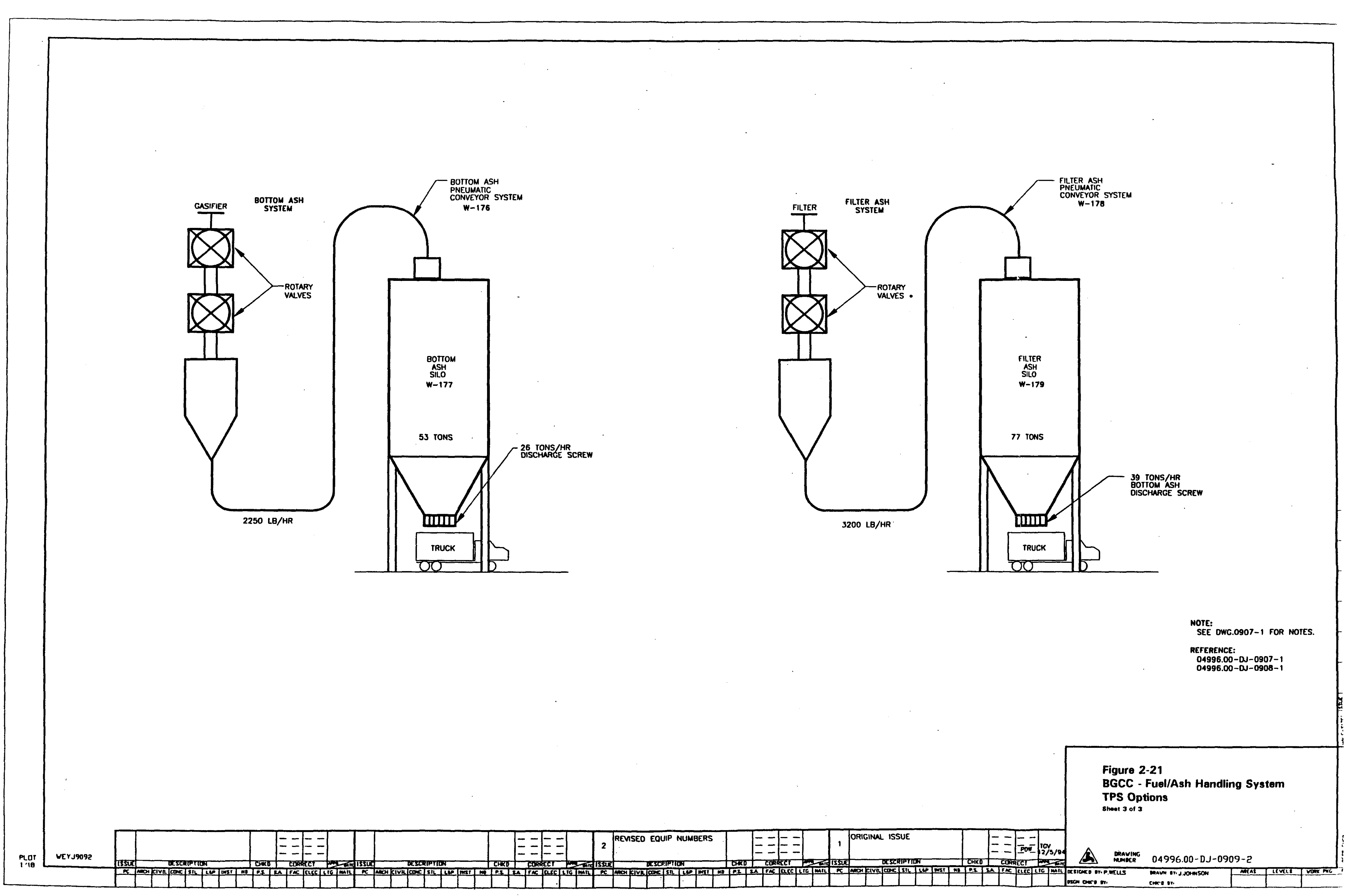




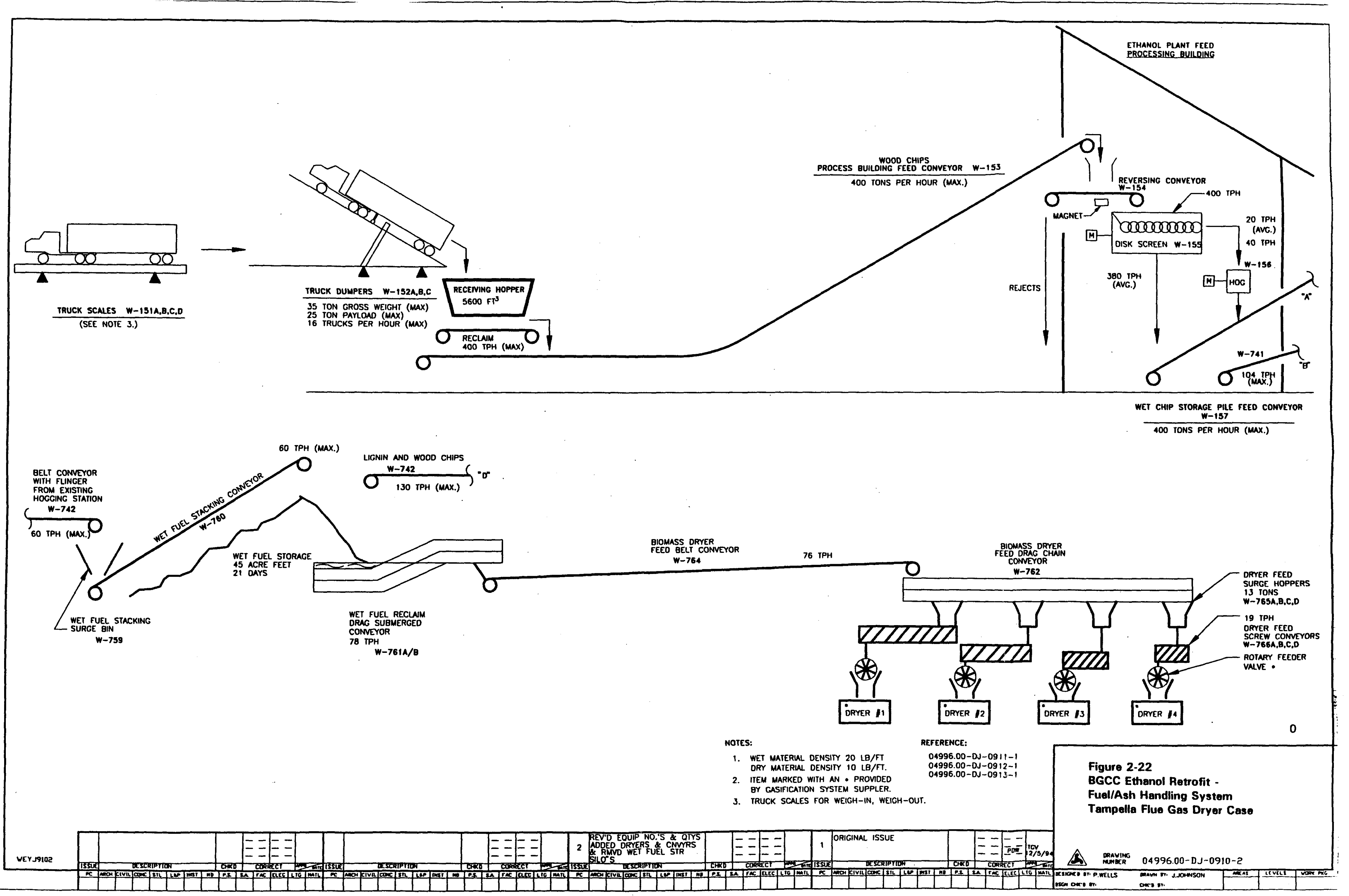




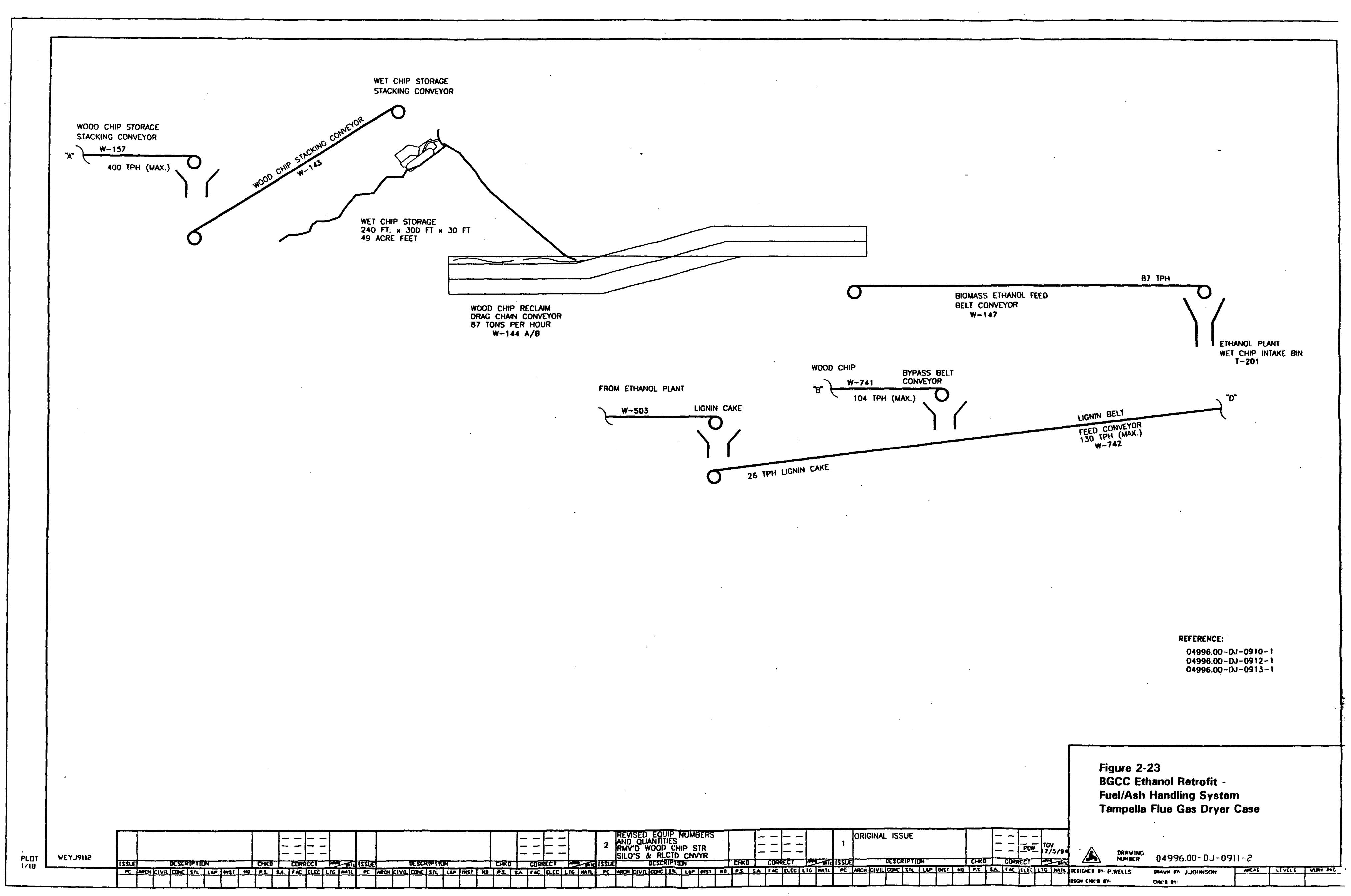




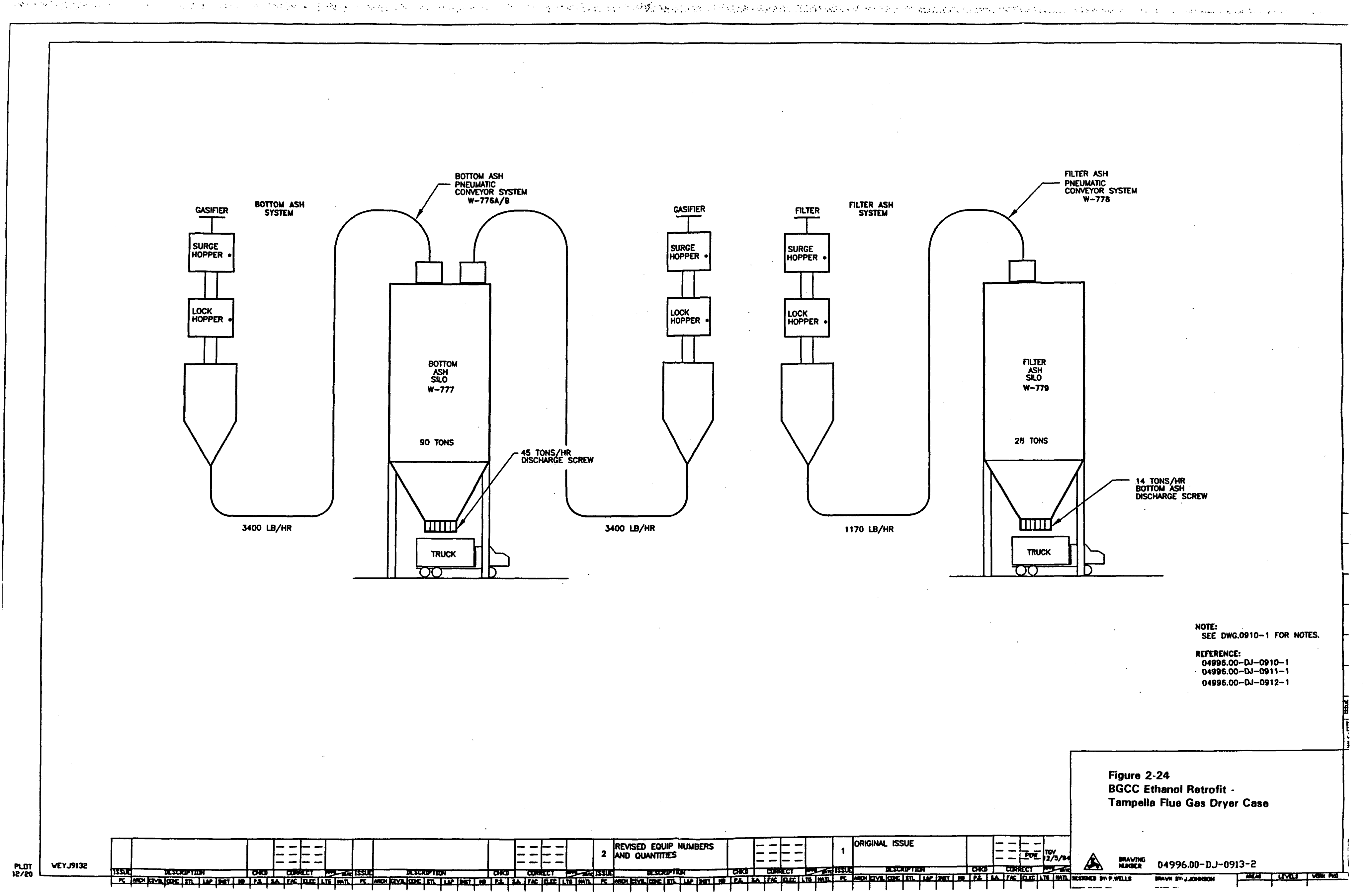




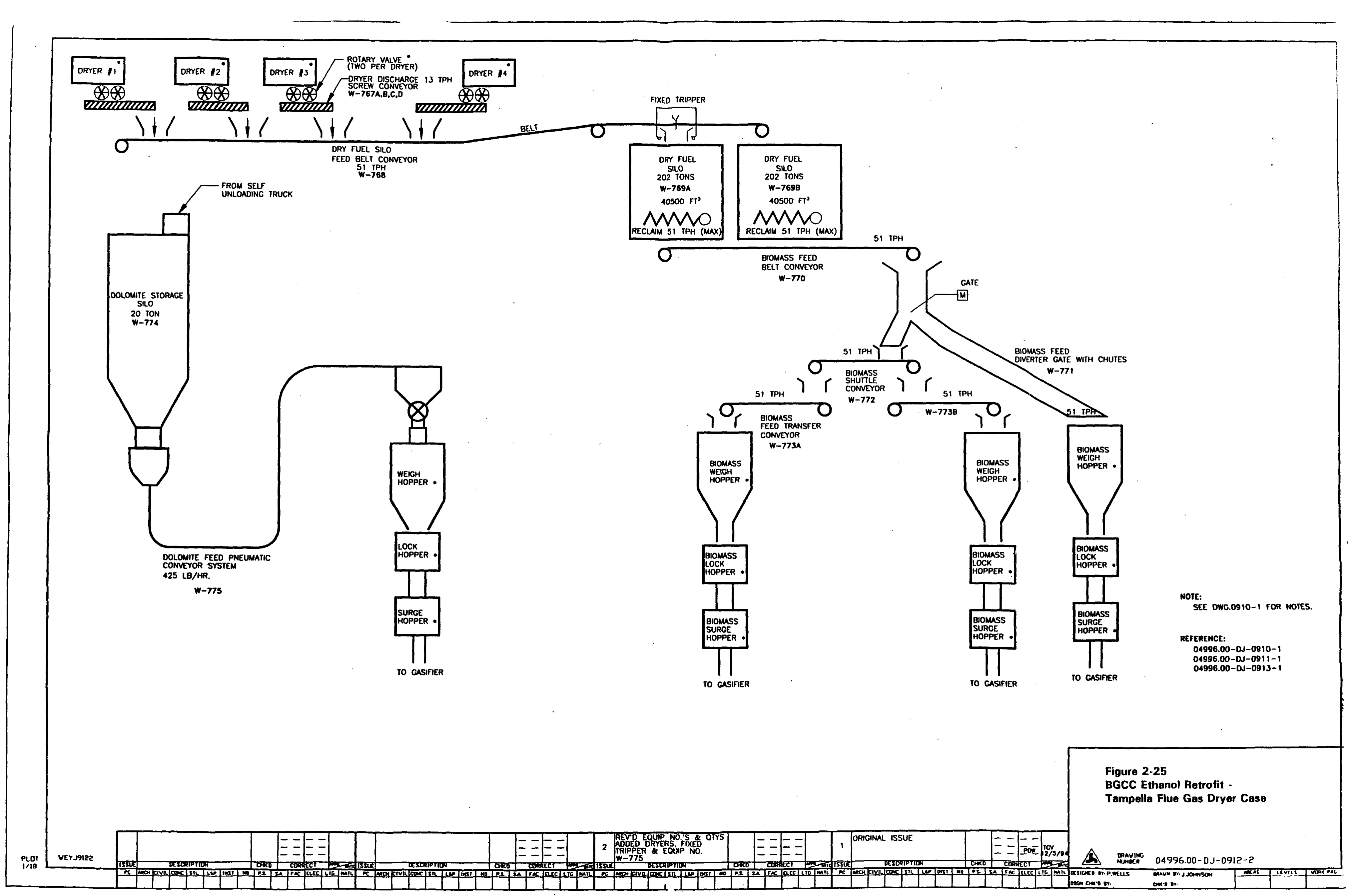


Table 2-9: Equipment List - Feed Preparation System (TPS BGCC)

\begin{tabular}{|c|c|c|c|c|c|c|c|}
\hline Item No. & Description & $\begin{array}{c}\text { Capacity } \\
\text { (tons/TPH) }\end{array}$ & $\begin{array}{l}\text { Width } \\
\text { (in.) }\end{array}$ & $\begin{array}{l}\text { Speed } \\
(\mathrm{fpm})\end{array}$ & $\begin{array}{l}V C D^{1} \\
(\mathrm{ft})\end{array}$ & $\begin{array}{c}H C D^{2} \\
(\mathrm{ft}) \\
\end{array}$ & Remarks \\
\hline $\mathrm{W}-151 \mathrm{~A}, \mathrm{~B}$ & Truck Scales & 35 & & & & & \multirow{2}{*}{$\begin{array}{l}8 \text { hr operation for } \\
\text { Item W-151 thru W- } \\
160\end{array}$} \\
\hline $\mathrm{W}-152 \mathrm{~A}, \mathrm{~B}$ & Truck Dumper Reclaimer with Hopper and Belt Reclaimer & $5,600 \mathrm{cu} \mathrm{ft}$ & Chain & 100 & & & \\
\hline $\mathrm{W}-153$ & Process Building Feed Conveyor & 180 & 48 & 250 & 45 & 250 & \multirow{2}{*}{$\begin{array}{l}24 \mathrm{hr} \text { operation } \\
\text { for all other items }\end{array}$} \\
\hline $\mathrm{W}-154$ & Reversing Conveyor with Magnetic Metal Detector & 180 & 48 & 250 & 0 & 30 & \\
\hline $\mathrm{W}-155$ & Disk Screen & 180 & & & & & \\
\hline $\mathrm{W}-156$ & Wet Fuel Hog & 20 & & & & & $\begin{array}{l}5 \text { to } 10 \text { percent of } \\
\text { flow }\end{array}$ \\
\hline$W-157$ & Wet Fuel Storage Pile Feed Conveyor & 180 & 48 & 250 & 45 & 250 & \\
\hline $\mathrm{W}-158$ & Wet Fuel Storage Pile Feeder from Existing Hogging Station & 60 & 24 & 250 & 50 & 750 & \\
\hline W-159 & Wet Fuel Stacking Surge Bin & 65 tons & & & & & \\
\hline$W-160$ & Wet Fuel Stacking Conveyor & 240 & 48 & 276 & 30 & 100 & , \\
\hline W-161 & Wet Fuel Reclaim Submerged Drag Chain Conveyor & 72 & 54 & 75 & 20 & 70 & \\
\hline W-162 & Biomass Dryer Feed Chain Distribution Conveyor & 76 & 54 & 75 & $\mathbf{0}$ & 80 & \\
\hline W-164 & Biomass Dryer Feed Belt Conveyor & 76 & 30 & 250 & 60 & 700 & \\
\hline W-165A,B,C,D & Dryer Feed Surge Hopper & 12 tons & & & & & $12 \mathrm{ft}$ dia $\times 11 \mathrm{ft}$ high \\
\hline W-166A,B,C,D & Dryer Feed Screw Conveyor & 18 & & & 1 down & 10 & \\
\hline W-167A,B,C,D & Dryer Discharge Screw Conveyor & 10 & & & 3 down & 25 & \\
\hline$W-168$ & Dry Fuel Silo Feed Belt Conveyor & 40 & 30 & 240 & 60 & 400 & \\
\hline W-169A,B & Dry Silo with Live Bottom Reclaim & $158 / 40$ & & & & & $30 \mathrm{ft}$ dia $\times 45 \mathrm{ft} \mathrm{high}$ \\
\hline$W-170$ & Biomass Feed Belt Conveyor & 40 & 30 & 240 & 155 & 700 & \\
\hline W-172 & Biomass Feed Reversing Belt Conveyor & 40 & 30 & 240 & 0 & 45 & \\
\hline
\end{tabular}

Vertical Center Dimension

${ }^{2}$ Horizontal Center Dimension 
Table 2-10: Equipment List

Dolomite Receiving, Bed Sand, and Ash Removal Systems for TPS Gasifier

\begin{tabular}{|l|l|c|c|c|c|}
\hline $\begin{array}{l}\text { Item } \\
\text { No. }\end{array}$ & \multicolumn{1}{|c|}{ Description } & $\begin{array}{c}\text { Capacity } \\
\text { Tons/TPH }\end{array}$ & $\begin{array}{c}\text { VCD } \\
\mathrm{ft}\end{array}$ & $\begin{array}{c}\mathrm{HCD}^{2} \\
\mathrm{ft}\end{array}$ & Remarks \\
\hline W-174 & Dolomite Storage Silo with Live Bottom & 115 & & & \\
\hline W-175 & $\begin{array}{l}\text { Dolomite Feed Pneumatic Conveyor } \\
\text { System }\end{array}$ & 2,400 & 100 & 80 & \\
\hline W-176 & Bottom Ash Pneumatic Conveyor System & 1,150 & 50 & 80 & \\
\hline W-177 & Bottom Ash Silo with Discharge Screw & $30 / 15$ & & & \\
\hline W-178 & Filter Ash Pneumatic Conveyor System & 2,600 & 60 & 80 & \\
\hline W-179 & Filter Ash Silo with Discharge Screw & $62 / 31$ & & & \\
\hline
\end{tabular}

${ }^{1}$ Vertical Center Dimension

${ }^{2}$ Horizontal Center Dimension 
Table 2-11: Equipment List - Feed Preparation System (Tampella BGCC/Flue Gas Dryer)

\begin{tabular}{|c|c|c|c|c|c|c|c|}
\hline Item No. & Description & $\begin{array}{l}\text { Capacity } \\
\text { Tons/TPH }\end{array}$ & $\begin{array}{l}\text { Width } \\
\text { in. }\end{array}$ & $\begin{array}{c}\text { Speed } \\
\text { fpm }\end{array}$ & $\begin{array}{c}\text { VCD } \\
\mathrm{ft}\end{array}$ & $\begin{array}{c}\mathrm{HCD}^{1} \\
\mathrm{ft}\end{array}$ & Remarks \\
\hline W-351A, B & Truck Scales & 35 & & & & & \multirow{2}{*}{$\begin{array}{l}8 \mathrm{hr} \text { operation for } \\
\text { Item W-351 thru W-360 }\end{array}$} \\
\hline W-352A, B & Truck Dumper Reclaimer with Hopper and Belt Reclaimer & $4,000 \mathrm{cu} \mathrm{ft}$ & CHAIN & 100 & & & \\
\hline W-353 & Process Building Feed Conveyor & 200 & 48 & 250 & 45 & 250 & \multirow{2}{*}{$\begin{array}{l}24 \mathrm{hr} \text { operation for } \\
\text { all other items }\end{array}$} \\
\hline W-354 & Reversing Conveyor with Magnetic Metal Detector & 200 & 48 & 250 & $\mathbf{0}$ & 30 & \\
\hline W-355 & Disk Screen & 200 & & & & & \\
\hline W-356 & Wet Fuel Hog & 20 & & & & & 5 to 10 percent of flow \\
\hline W-357 & Wet Fuel Storage Pile Feed Conveyor & 200 & 48 & 250 & 45 & 250 & \\
\hline W-358 & Wet Fuel Storage Pile Feeder from Existing Hogging Station & 60 & 24 & 250 & 50 & 750 & \\
\hline W-359 & Wet Fuel Stacking Surge Bin & 65 tons & & & & & \\
\hline $\mathrm{W}-360$ & Wet Fuel Stacking Conveyor & 260 & 48 & 276 & 30 & 100 & \\
\hline W-361 & Wet Fuel Reclaim Submerged Drag Chain Conveyor & 76 & 54 & 75 & 20 & .70 & \\
\hline$W-362$ & Biomass Dryer Feed Chain Distribution Conveyor & 76 & 54 & 75 & 0 & 80 & \\
\hline W-364 & Biomass Dryer Feed Belt Conveyor & 76 & 30 & 250 & 60 & 700 & \\
\hline $\begin{array}{l}\text { W-365A, } \\
\text { B,C,D }\end{array}$ & Dryer Feed Surge Hopper & 13 tons & & & & & $12 \mathrm{ft}$ dia $\times 11 \mathrm{ft}$ high \\
\hline $\begin{array}{l}\text { W-366A, } \\
\text { B,C,D }\end{array}$ & Dryer Feed Screw Conveyor & 19 & & & 1 down & 10 & \\
\hline $\begin{array}{l}\text { W-367A, } \\
\text { B,C,D }\end{array}$ & Dryer Discharge Screw Conveyor & 12 & & & 3 down & 25 & \\
\hline $\mathrm{W}-368$ & Dry Fuel Silo Feed Belt Conveyor & 48 & 30 & 240 & 60 & 400 & \\
\hline W-369A,B & Dry Silo with Live Bottom Reclaim & $190 / 48$ & & & & & $30 \mathrm{ft}$ dia $\times 45 \mathrm{ft}$ high \\
\hline $\mathrm{W}-370$ & Biomass Feed Belt Conveyor & 48 & 30 & 240 & 155 & 700 & \\
\hline W-371 & Biomass Feed Diverter Gate with Chutes & 48 & & & & & \\
\hline W-372 & Biomass Feed Reversing Shuttle Belt Conveyor & 48 & 30 & 240 & 0 & 45 & \\
\hline
\end{tabular}


Table 2-11: Equipment List - Feed Preparation System (Tampella BGCC/Flue Gas Dryer) (Continued)

\begin{tabular}{|c|c|c|c|c|c|c|c|}
\hline Item No. & Description & $\begin{array}{c}\text { Capacity } \\
\text { Tons/TPH }\end{array}$ & $\begin{array}{l}\text { Width } \\
\text { in. }\end{array}$ & $\begin{array}{c}\text { Speed } \\
\text { fpm }\end{array}$ & $\begin{array}{c}V C D^{1} \\
\mathrm{ft}\end{array}$ & $\begin{array}{c}H C D^{1} \\
\mathrm{ft}\end{array}$ & Remarks \\
\hline W-373A,B & Biomass Feed Transfer Conveyor & 48 & 30 & 240 & $\mathbf{0}$ & 45 & \\
\hline
\end{tabular}

${ }^{1}$ Vertical Center Dimension

${ }^{2}$ Horizontal Center Dimension 
Table 2-12: Equipment List

Dolomite, Ash Handling Systems (Tampella BGCC/Flue Gas Dryer)

\begin{tabular}{|c|l|c|c|c|c|}
\hline $\begin{array}{c}\text { Item } \\
\text { No. }\end{array}$ & \multicolumn{1}{|c|}{ Description } & $\begin{array}{c}\text { Capacity } \\
\text { Tons/tph }\end{array}$ & $\begin{array}{c}\text { VCD' } \\
\text { Ft }\end{array}$ & $\begin{array}{c}\text { HÇD } \\
\text { Ft }\end{array}$ & Remarks \\
\hline W-374 & $\begin{array}{l}\text { Dolomite Storage Silo with Live } \\
\text { Bottom }\end{array}$ & 19 & & & \\
\hline W-375 & $\begin{array}{l}\text { Dolomite Feed Pneumatic Conveyor } \\
\text { System }\end{array}$ & 400 & 100 & 80 & \\
\hline W-376 & $\begin{array}{l}\text { Bottom Ash Pneumatic Conveyor } \\
\text { System }\end{array}$ & 3,200 & 50 & 80 & \\
\hline W-377 & $\begin{array}{l}\text { Bottom Ash Silo with Discharge } \\
\text { Screw }\end{array}$ & $84 / 42$ & & & \\
\hline W-378 & $\begin{array}{l}\text { Filter Ash Pneumatic Conveyor } \\
\text { System }\end{array}$ & 1,150 & 60 & 80 & \\
\hline W-379 & Filter Ash Silo with Discharge Screw & $30 / 15$ & & & \\
\hline
\end{tabular}

${ }^{1}$ Vertical Center Dimension

${ }^{2}$ Horizontal Center Dimension 
Table 2-13: Equipment List - Feed Preparation System (Tampella BGCC/Steam Dryer)

\begin{tabular}{|c|c|c|c|c|c|c|c|}
\hline Item No. & Description & $\begin{array}{l}\text { Capacity } \\
\text { Tons/tph }\end{array}$ & $\begin{array}{c}\text { Width } \\
\text { in. }\end{array}$ & $\begin{array}{c}\text { Speed } \\
\text { fpm }\end{array}$ & $\begin{array}{c}\text { VCp } \\
\mathrm{ft}\end{array}$ & $\begin{array}{c}H C D^{2} \\
\mathrm{ft} \\
\end{array}$ & Remarks \\
\hline W-451A, B & Truck Scales & 35 & & & & & $8 \mathrm{hr}$ operation for \\
\hline W-452A,B & Truck Dumper Reclaimer with Hopper and Belt Reclaimer & $4,000 \mathrm{cu} \mathrm{ft}$ & Chain & 100 & & & $\begin{array}{l}\text { Item W-451 thru } \\
\text { W-460 }\end{array}$ \\
\hline W-453 & Process Building Feed Conveyor with Magnetic Separator & 225 & 48 & 250 & 45 & 250 & 24 hour operation for \\
\hline W-454 & Reversing Conveyor with Magnetic Metal Detector & 225 & 48 & 250 & 0 & 30 & all other items \\
\hline$W-455$ & Disk Screen & 225 & & & & & \\
\hline$W-456$ & Wet Fuel Hog & 20 & & & & & $\begin{array}{l}5 \text { to } 10 \text { percent of } \\
\text { flow }\end{array}$ \\
\hline$W-457$ & Wet Fuel Storage Pile Feed Conveyor & 225 & 48 & 250 & 45 & 250 & \\
\hline$W-458$ & $\begin{array}{l}\text { Wet Fuel Storage Pile Feeder from Existing Hogging } \\
\text { Station }\end{array}$ & 60 & 24 & 250 & 50 & 750 & \\
\hline$\dot{W}-459$ & Wet Fuel Stacking Surge Bin & 65 tons & & & & & \\
\hline$W-460$ & Wet Fuel Stacking Conveyor & 285 & 48 & 276 & 30 & 100 & \\
\hline W-461 & Wet Fuel Reclaim Submerged Drag Chain Conveyor & 83 & 54 & 75 & 20 & 70 & \\
\hline W-464 & Biomass Dryer Feed Belt Conveyor & 83 & 30 & 250 & 60 & 700 & \\
\hline $\mathrm{W}-465 \mathrm{~A}, \mathrm{~B}, \mathrm{C}, \mathrm{D}$ & Dryer Feed Surge Hopper & 14 tons & & & & & $12 \mathrm{ft}$ dia $\times 11 \mathrm{ft}$ high \\
\hline W-466 & Dryer Feed Screw Conveyor & 18 & & & 1 down & 10 & \\
\hline$W-468$ & Dry Fuel Silo Feed Belt Conveyor & 52 & 30 & 240 & 60 & 400 & \\
\hline W-469A,B & Dry Silo with Live Bottom Reclaim & $207 / 52$ & & & & & $30 \mathrm{ft}$ dia $\times 45 \mathrm{ft}$ high \\
\hline $\mathrm{W}-470$ & Biomass Feed Belt Conveyor & 52 & 30 & 240 & 155 & 700 & See Note A \\
\hline $\mathrm{W}-471$ & Biomass Feed Diverter Gate with Chutes & 52 & & & & & \\
\hline W-472 & Biomass Feed Reversing Shuttle Belt Conveyor & 52 & 30 & 240 & $\mathbf{0}$ & 45 & \\
\hline$W-473 A, B$ & Biomass Feed Transfer Conveyor & 52 & 30 & 240 & $\mathbf{0}$ & 45 & \\
\hline
\end{tabular}

Vertical Center Dimension ${ }^{2}$ Horizontal Center Dimension 
Table 2-14: Equipment List

Dolomite, Ash Handling Systems (Tampella BGCC/Steam Dryer)

\begin{tabular}{|c|l|c|c|c|c|}
\hline Item No. & \multicolumn{1}{|c|}{ Description } & $\begin{array}{c}\text { Capacity } \\
\text { Tons/tph }\end{array}$ & $\begin{array}{c}\text { VCD } \\
\text { Ft }\end{array}$ & $\begin{array}{c}\text { HCD } \\
\text { Ft }\end{array}$ & Remarks \\
\hline W-474 & $\begin{array}{l}\text { Dolomite Storage Silo with Live } \\
\text { Bottom }\end{array}$ & 21 & & & \\
\hline W-475 & $\begin{array}{l}\text { Dolomite Feed Pneumatic } \\
\text { Conveyor System }\end{array}$ & 440 & 100 & 80 & \\
\hline W-476 & $\begin{array}{l}\text { Bottom Ash Pneumatic Conveyor } \\
\text { System }\end{array}$ & 3,400 & 50 & 80 & \\
\hline W-477 & $\begin{array}{l}\text { Bottom Ash Silo with Discharge } \\
\text { Screw }\end{array}$ & $91 / 45$ & & & \\
\hline W-478 & $\begin{array}{l}\text { Filter Ash Pneumatic Conveyor } \\
\text { System }\end{array}$ & 1,500 & 60 & 80 & \\
\hline W-479 & $\begin{array}{l}\text { Filter Ash Silo with Discharge } \\
\text { Screw }\end{array}$ & $36 / 18$ & & & \\
\hline
\end{tabular}

${ }^{1}$ Vertical Center Dimension

${ }^{2}$ Horizontal Center Dimension 
Table 2-15: Equipment List - Feed Preparation and Stillage Handling Systems for Amoco Ethanol Plant (Tampella BGCC/Flue Gas Dryer)

\begin{tabular}{|c|c|c|c|c|c|c|c|}
\hline Item No. & Description & $\begin{array}{c}\text { Capacity } \\
\text { (tons/tph) }\end{array}$ & $\begin{array}{l}\text { Width } \\
\text { (in.) }\end{array}$ & $\begin{array}{l}\text { Speed } \\
\text { (fpm) }\end{array}$ & $\begin{array}{c}V C D^{1} \\
\text { (ft) }\end{array}$ & $\begin{array}{c}H C D^{2} \\
(f t)\end{array}$ & Remarks \\
\hline W-741 & Wood Chip Bypass Belt Conveyor & 104 & 30 & 250 & 40 & 250 & \\
\hline$W-742$ & Lignin Feed Belt Conveyor & 130 & 30 & 250 & 50 & 1900 & \\
\hline$W-143$ & Wood Chip Stacking Conveyor & 400 & 54 & 360 & 30 & 100 & \\
\hline $\mathrm{W}-144 \mathrm{~A} / \mathrm{B}$ & Wood Chip Reclaim Drag Chain Conveyor (two each) & 87 & 54 & 75 & 18 & 60 & \\
\hline W-147 & Biomass Ethanol Feed Belt Conveyor & 87 & 30 & 250 & 80 & 350 & \\
\hline W-151A, B,C,D & Truck Scales (two each for weigh in and weigh out) & 35 & & & & & \multirow{2}{*}{$\begin{array}{l}8 \mathrm{hr} \text { operation for } \\
\text { Item W-141 thru } \\
W-760\end{array}$} \\
\hline $\mathrm{W}-152 \mathrm{~A}, \mathrm{~B}, \mathrm{C}$ & Truck Dumper Reclaimer with Hopper and Belt Reclaimer & $5,600 \mathrm{cu} \mathrm{ft}$ & Chain & 125 & & & \\
\hline$W-153$ & Process Building Feed Conveyor & 400 & 48 & 250 & 45 & 250 & \multirow{2}{*}{$\begin{array}{l}24 \mathrm{hr} \text { operation for } \\
\text { all other items }\end{array}$} \\
\hline W-154 & Reversing Conveyor with Magnetic Metal Detector & 400 & 48 & 250 & 0 & 30 & \\
\hline W-155 & Disk Screen & 400 & & & & & \\
\hline W-156 & Wet Fuel Hog & 40 & & & & & 5 to 10 percent of flow \\
\hline W-157 & Wet Fuel Storage Pile Feed Conveyor & 400 & 48 & 250 & 45 & 250 & \\
\hline W-758 & Wet Fuel Storage Pile Feeder from Existing Hogging Station & 60 & 24 & 250 & 50 & 750 & \\
\hline$W-759$ & Wet Fuel Stacking Surge Bin & 65 tons & & & & & \\
\hline W-760 & Wet Fuel Stacking Conveyor & 60 & 48 & 276 & 30 & 100 & \\
\hline W-761 & Wet Fuel Reclaim Submerged Drag Chain Conveyor & 78 & 54 & 75 & 20 & 70 & \\
\hline$W-762$ & Biomass Dryer Feed Chain Distribution Conveyor & 78 & 54 & 75 & 0 & 80 & \\
\hline W-764 & Biomass Dryer Feed Belt Conveyor & 78 & 30 & 250 & 60 & 700 & \\
\hline W-765A,B,C,D & Dryer Feed Surge Hopper & 13 tons & & & & & $12 \mathrm{ft}$ dia $\times 11 \mathrm{ft}$ high \\
\hline W-766A, B,C,D & Dryer Feed Screw Conveyor & 19 & & & 1 down & 10 & \\
\hline
\end{tabular}


Table 2-15: Equipment List - Feed Preparation and Stillage Handling Systems for Amoco Ethanol Plant (Tampella BGCC/Flue Gas Dryer) (Continued)

\begin{tabular}{|c|c|c|c|c|c|c|c|}
\hline Item No. & Description & $\begin{array}{c}\text { Capacity } \\
\text { (tons/tph) }\end{array}$ & $\begin{array}{c}\text { Width } \\
\text { (in.) }\end{array}$ & $\begin{array}{l}\text { Speed } \\
(\mathrm{fpm})\end{array}$ & $\begin{array}{c}V C D^{1} \\
\text { (ft) }\end{array}$ & $\begin{array}{c}H C D^{2} \\
(\mathrm{ft})\end{array}$ & Remarks \\
\hline W-767A,B,C,D & Dryer Discharge Screw Conveyor & 13 & & & 3 down & 25 & \\
\hline W-768 & Dry Fuel Silo Feed Belt Conveyor & 51 & 30 & 240 & 60 & 400 & \\
\hline W-769A,B & Dry Silo with Live Bottom Reclaim & $202 / 51$ & & & & & $30 \mathrm{ft}$ dia $\times 45 \mathrm{ft}$ high \\
\hline W-770 & Biomass Feed Belt Conveyor & 51 & 30 & 240 & 155 & 700 & \\
\hline W-771 & Biomass Feed Diverter Gate with Chutes & 51 & & & & & \\
\hline $\mathrm{W}-772$ & Biomass Feed Reversing Shuttle Belt Conveyor & 51 & 30 & 240 & 0 & 45 & \\
\hline $\mathrm{W}-773 \mathrm{~A}, \mathrm{~B}$ & Biomass Feed Transfer Conveyor & 51 & 30 & 240 & 0 & 45 & \\
\hline
\end{tabular}

${ }^{1}$ Vertical Center Dimension

${ }^{2}$ Horizontal Center Dimension 
Table 2-16: Equipment List

Dolomite Receiving, Ash Handling (Amoco Ethanol Plant and Tampella BGCC/Flue Gas Dryer)

\begin{tabular}{|c|l|c|c|c|c|}
\hline Item No. & \multicolumn{1}{|c|}{ Description } & $\begin{array}{c}\text { Capacity } \\
\text { (tons/tph) }\end{array}$ & $\begin{array}{c}\text { VCD } \\
\text { (ft) }\end{array}$ & $\begin{array}{c}\text { HCD } \\
\text { (ft) }\end{array}$ & Remarks \\
\hline W-774 & $\begin{array}{l}\text { Dolomite Storage Silo with Live } \\
\text { Bottom }\end{array}$ & 20 & & & \\
\hline W-775 & $\begin{array}{l}\text { Dolomite Feed Pneumatic Conveyor } \\
\text { System }\end{array}$ & 425 & 100 & 80 & \\
\hline W-776 & $\begin{array}{l}\text { Bottom Ash Pneumatic Conveyor } \\
\text { System }\end{array}$ & 3,400 & 50 & 80 & \\
\hline W-777 & $\begin{array}{l}\text { Bottom Ash Silo with Discharge } \\
\text { Screw }\end{array}$ & $90 / 45$ & & & \\
\hline W-778 & $\begin{array}{l}\text { Filter Ash Pneumatic Conveyor } \\
\text { System }\end{array}$ & 1,170 & 60 & 80 & \\
\hline W-779 & $\begin{array}{l}\text { Filter Ash Silo with Discharge } \\
\text { Screw }\end{array}$ & $28 / 14$ & & & \\
\hline
\end{tabular}

${ }^{1}$ Vertical Center Dimension

${ }^{2}$ Horizontal Center Dimension 


\subsection{Plot Plans and Balance of Plant}

Stone \& Webster developed preliminary plot plans, building descriptions, and balance of plant descriptions to support the estimating effort. Because the BGCC and ethanol plants use several of the mill's existing utility systems, the balance of plant requirements are reduced.

This section describes the generic plot plan for the BGCC plant and ethanol plant, the balance of plant systems for both plants, and the buildings associated with both plants.

\subsubsection{BGCC}

\section{Plot Plan}

The location and orientation of major buildings and components forms the basis for the design of the material handling systems and the layout of interconnecting piping systems. The starting point for development of the plan was Figure 2-26, Drawing No. 090-09-007 Revision 2, New Bern Mill Storm Water Collection System Plan, provided by Weyerhaeuser, since it provided the best readily available "as-built" information.

Placement of the BGCC plant requires relocating the existing bark pile as shown on Figure 2-26, to a new location northeast of the powerhouse. The new location is shown on Figure 2-27, Plot Plan - BGCC Retrofit (Drawing No. 05996.00-EM-1A). This provides adequate space for location of the Frame 6B combustion turbine and HRSG without affecting existing roadways and railroad tracks. Pipe racks carry steam, feedwater, condensate and other piping over roadways and railroad tracks to the mill powerhouse.

The flue gas biomass dryers are located to the east of the HRSG flue gas discharge. The four dryers are oriented with centerlines running north-south. Flue gas and feedstock biomass enter on the south end and discharge on the north end. Two stacks are provided for the four dryer trains. The steam dryer (not shown) would also be placed here.

The bark pile is located approximately 600 feet from the dryers to the east. This spacing is required to keep conveyor sloping to less than 15 degrees. The truck dumping station and feedstock process building are located on the east end of the bark pile. The stacker with inlet hopper is located on the north side of the bark pile and can receive feedstock via belt conveyor from the process building and from the existing bark sizing system. The existing bark hogging station is being relocated slightly to allow for alignment of these conveyors.

Dry fuel silos are located on the northwest corner of the proposed bark pile and are aligned to provide sufficient horizontal distance to receive dry fuel by belt conveyor from the dryer discharge and to send dry fuel to the gasifier area. A horizontal distance of 700 feet is necessary for the discharge of the conveyor to push the inlet of the gasifier which is anticipated to be 155 feet above grade. Electrical and mechanical equipment buildings are located adjacent to the gasifier building. The nitrogen system area and fuel oil day tank with emergency dike are also located in this area.

Dolomite and ash silos are placed west of the gasifier structure and allow for easy access by truck.

The auxiliary condensing steam turbine is located south of the existing railroad tracks and east of pipe racks. This placement accommodates tie-in of steam and condensate piping from the pipe racks as well as minimizing water piping to and from the planned mill cooling tower which will service mill process 
cooling needs as well as those of the proposed BGCC complex. This cooling tower is located east of the existing powerhouse and south of the railroad tracks.

\section{Utility and Balance of Plant Systems}

Thê balance of plant items for both the TPS and Tampella design cases are similar. Where applicable, differences in capacity and design requirements are described.

Control System. A distributed control system is provided for the BGCC plant. The system, including five video display units (VDU) will be located in the existing mill powerhouse control room.

Electrical System. The following electrical system design was used as the basis for costing for the electrical system:

- $\quad$ Tie-ins will be made to the mill's existing $13.8 \mathrm{kV}$ system.

- Motors above 1,000 horsepower will draw power from the $13.8 \mathrm{kV}$ bus. Motors 250 to 1,000 horsepower will draw power from the $4.16 \mathrm{kV}$ bus, and motors $1 / 2$ horsepower to 250 horsepower will draw power from the $480 \mathrm{~V}$ bus. Motors below $1 / 2$ horsepower will draw power from $110 \mathrm{~V}$ distribution panels.

The GE Frame 6B Gas turbine and the auxiliary steam turbine will feed the $13.8 \mathrm{kV}$ bus that is tied into the mill's existing electrical distribution system. The fuel gas booster compressor required in the TPS system will be fed from the $13.8 \mathrm{kV}$ bus. A step-up transformer is provided to tie into the $115 \mathrm{kV}$ grid for export of power. A stepdown transformer is provided to feed a $4.16 \mathrm{kV}$ bus that will power large motors including process air compressors, dryer induced draft (ID) fans, and dryer circulators. A stepdown transformer will be provided to feed a $480 \mathrm{~V}$ system to feed remaining loads. Load centers, switchgear, and motor control centers will be housed in an electrical equipment building, located in the BGCC plant area.

Boiler Feedwater and Condensate System. The mill has a common boiler feedwater system to serve the recovery boiler and the existing bark boiler. Since the BGCC plant would replace the bark boiler, the existing feedwater system will simply be repiped to serve the HRSG. The system is capable of delivering deaerated boiler feedwater to the BGCC plant at $303^{\circ} \mathrm{F}$ and 900 psig. A 6-inch Schedule 40 carbon steel line with appropriate valving will be routed from the existing mill powerhouse on a pipe rack over railroad tracks to the BGCC area. This pipe rack will also be used to carry steam and condensate lines back from the HRSG and from the auxiliary steam turbine. Two 100 percent capacity pumps are provided to return condensate from the auxiliary steam turbine. Pressure of the condensate at the discharge from the Tampella steam dryer is expected to be adequate for return to the mill condensate system. Condensate lines will be 4 -inch Schedule 40 carbon steel. Rough quantities of piping in these systems were estimated and served as input for establishing the bulk material factor for piping, and valves.

Cooling Water System. The cooling water system removes heat from the following components associated with the BGCC plant:

- $\quad$ Combustion Turbine

- $\quad$ Auxiliary Steam Turbine

- $\quad$ Auxiliary steam turbine condenser (only TPS case provides BGCC steam to this turbine)

- Bottom ash discharge water cooled screw conveyors

- Filter ash discharge water cooled screw conveyor 
- $\quad$ Process air compressor jacket cooling system (Tampella cases)

- Process air precooling heat exchanger upstream of the process air compressor (Tampella cases)

- Biogas water scrubber cooler (TPS case)

The Tampella BGCC plant requires $1300 \mathrm{gpm}$ of cooling water. The TPS BGCC requires an additional $6,000 \mathrm{gpm}$ split between biogas water scrubber cooler and the auxiliary steam turbine condenser.

The New Bern mill plans to install a new forced draft cooling tower to meet its process cooling needs and is defining the cooling tower design with the Marley Company. Marley was contacted to obtain an incremental cost for an additional cooling tower cell to serve the BGCC project. This value has been included in the capital cost estimate. Rough quantities of piping in this system were estimated and served as input for establishing the bulk material factor for piping.

Flare System. The flare system safely disposes of intermittent flows of combustible gases from various relief and bypass lines in the BGCC plant fuel gas processing train. It is designed to handle the entire flow from the gasification system in the event of an emergency shutdown of the gas turbine when operating at full-capacity. Complete combustion of the gas flow is required and must be accomplished in a safe, reliable manner.

The purge gas line (from the gasifier section) and the fuel line (from the gas turbine) are connected to the flare gas header system. Each header is continuously purged with nitrogen to prevent air from entering the system. The headers are connected to the flare gas inlet pipe which enter the flare knockout drum. The gas leaving the knockout drum enters the flare stack and is ignited by pilot flares. A nitrogen purge line also connects to the flare stack. Plant air, clean fuel gas, and auxiliary fuel gas (propane) are connected to the ignitor and to the pilot flares. Liquid, collected in the flare knockout drum, is pumped by the two process condensate pumps to the mill's secondary wastewater treatment system.

Nitrogen System. The nitrogen distribution system for the BGCC plant provides high pressure nitrogen for filter pulse cleaning, inerting, purging and blanketing of the plant equipment. The Tampella cases require a substantial amount for charging of lock and surge hoppers associated with biomass and dolomite feed to the gasifier, and discharge of bottom ash and filter ash. Nitrogen is purchased from a supplier who will provide an onsite generation system sized for the continuous nitrogen requirements. For the Tampella design, the nitrogen supplier will also include a liquid nitrogen storage tank and high volume vaporizer for rapid inerting of the gasifier in the event of an emergency shutdown.

The continuous nitrogen system supplies the Tampella system with a total of about 7,000 lb/hr of nitrogen at $600 \mathrm{psig}$. The TPS gasifier requires a continuous flow of approximately $700 \mathrm{lb} / \mathrm{hr}$.

Service Air and Instrument Air System. This system provides air to the BGCC plant for operating maintenance equipment, and for powering air operated valves and dampers, and for other instrumentation needs. A $150 \mathrm{hp}$ air compressor is sized for $580 \mathrm{scfm}$ at $100 \mathrm{psig}$. This compressor will feed a 1,060 gallon (142 cubic feet) service air receiver. From this receiver, service air piping is routed throughout the BGCC plant for use in maintenance activities. Instrument air is processed through a prefilter, dryer, and after-filter before being routed to various instrument needs. The sizing of this system was based on estimated needs provided by Tampella. It was assumed that the TPS gasifier design would be comparable.

Fuel Oil System. The fuel oil system provides No. 2 distillate fuel oil to the gas turbine for startup and backup when the gasifier is out of service. Fuel oil is also required for initial heating of the gasifier refractory lined vessels. The fuel oil day tank is sized for eight hour operation of the combustion turbine. 
Bulk quantities of fuel oil are delivered from off site by truck to existing on-site storage tanks located south of the powerhouse building. A positive displacement fuel oil transfer pump will take $30 \mathrm{gpm}$ of fuel oil through a 2-inch diameter supply to the 25,000 gallon fuel oil day tank located in the BGCC area. The fuel oil day tank is surrounded by an emergency dike approximately 30 feet in diameter by 6 feet high. A positive displacement pump feeds fuel oil to the combustion turbine and to the gasifier as required.

Fire Protection Systems. The BGCC fire protection systems are fed by existing yard fire protection systems in the vicinity. An allowance has been made in the capital cost estimate for additional yard piping, including three new deluge water systems to serve transformers, dry fuel storage silos and dryers, and six hose stations for general response to area fires. A high pressure local application carbon dioxide suppression system is supplied with the combustion turbine.

Potable Water System. Potable water is provided to hose bibs in the BGCC area for wash downs, and to eye wash stations and emergency showers provided for personnel safety. This piping system carries water from the mill potable water system.

Sanitary Water System. This system routes sanitary drain water from the BGCC plant to the mill sanitary sewer. An allowance for sanitary water system piping has been provided as input for establishing the bulk material factor for piping.

Waste Water System. Waste water streams such as effluent from blow down tanks, SCR unit discharge, biogas absorption tower discharge, and biogas water scrubber discharge are routed to the existing mill waste water treatment system. An allowance for waste water system piping of 600 feet of 4-inch diameter ductile iron piping has been provided as input for establishing the bulk material factor for piping. The waste water system is tied into the existing mill system.

Storm Water Runoff System. The system collects and disposes storm water runoff from the BGCC plant areas. An allowance for storm water drain system improvements has been incorporated into site improvements. The storm water drain system is connected to the existing mill system.

\section{Buildings and Structures}

The climate at the New Bern mill is mild. Therefore, the main components of the BGCC plant such as the gasifier, combustion turbine and HRSG are not enclosed in buildings. This is typical of installations of this type of equipment in similar climates. Enclosures are provided for electrical components and high maintenance mechanical equipment to provide protection from dust contamination. Structures are provided to support system components and provide access for inspections and maintenance. Personnel access and egress must alșo be provided in accordance with applicable life safety codes, and standards (i.e., OSHA, NFPA 101).

Structures will be similar for all BGCC plant cases.

Gasifier Structure. The gasifier structure is approximately 60 feet by 60 feet by 180 feet tall. It is an open structure with a roof designed to house the gasifier system and provide access for inspection and maintenance. The structure is a steel frame with grating on each level. Two stair towers are provided in the structure. Major components are serviced using mobile cranes and hoists as required. The foundation is on piles. This structure provides the support for all gasifier components as well as material handling system components including biomass feed, dolomite feed and ash removal system. All floors, 
platforms, railings, and stairs are designed in accordance with OSHA requirements for personnel access and safety.

Compressor Enclosure. The compressor enclosure abuts the north wall of the gasifier structure and houses the booster air compressors providing makeup air to the gasifier. This one story structure, approximately 60 feet by 40 feet by 28 feet in height, is a pre-engineered building with steel framing and siding. The compressor enclosure is ventilated with roof exhaust fans and inlet louvers with filters. Heating is provided with steam unit heaters. The foundation of this structure is integrated with the gasifier structure.

Service Building. This is a one story pre-engineered, metal-sided building, approximately 40 feet by 60 feet, with a spread-footing foundation. The building will contain miscellaneous mechanical equipment including the service and instrument air compressors. The building is ventilated with roof exhaust fans and associated inlet louvers. Heating is provided with steam unit heaters.

Electrical Building. This building is a pre-engineered building similar to the mechanical buildings described above. Ventilation consists of roof mounted heating and ventilation units with filters and direct expansion air conditioning. The building will contain electrical cabinets, instrument racks, motor control centers (MCCs) and switchgear. The building is slightly pressurized to prevent the intrusion of dust.

Nitrogen Skid Area. The continuous nitrogen generation system and the liquid nitrogen storage and vaporization equipment are located on a slab with spread footings.

Gas Turbine. The gas turbine is provided with a weatherproof enclosure. The foundation rests on piles.

Biomass Dryers. Biomass dryers and associated equipment including induced draft fans, primary and secondary separators, hoppers and screw feeding equipment are located on a slab with spread footings.

Auxiliary Steam Turbine Building. The auxiliary steam turbine will be housed in a pre-engineered structure with removable panels to facilitate maintenance. This building is approximately 70 feet long by 30 feet wide by 40 feet high. The building is ventilated with roof exhaust fans and inlet louvers and heated with steam unit heaters. The foundation for this building rests on piles.

Condenser Enclosure. The condenser enclosure abuts the south wall of the auxiliary turbine building and houses the condenser and its accessories. This is a once-story pre-engineered building approximately 40 feet by 30 feet high with steel framing and siding. The condenser enclosure will be ventilated with roof exhaust fans and inlet louvers and heated with steam unit heaters. The foundation of this structure is integrated with the auxiliary steam turbine building.

Process Building. The process building houses disk screening and hogging equipment. This structure is engineered and supplied by the biomass handling equipment vendor. No heating or ventilation is required for this building.

\subsubsection{Ethanol Plant}

\section{Plot Plan}

The development of the plot plan for the ethanol plant was started from an existing as-built New Bern Mill drawing previously mentioned as Figure 2-26. Figure 2-27, Plot Plan - BGCC/Ethanol Retrofit 
Drawing No. 04996.00-EM-1B, superimposes a plot plan for the BGCC plant and the ethanol plant on the mill drawing.

The extreme south end of the mill site appeared to be the best location for the ethanol plant. Adequate space is available for feedstock receiving and storage, as well as the main ethanol plant process systems, structures, and components. This location wilt allow the ethanol plant to operate with little if any impact on the mill activities.

Three feedstock truck dumping stations are located on the northern most end of the ethanol plant complex. These stations feed a single conveyor system which transports feedstock through a processing building and then to a 21-day wood chip storage pile. The BGCC plant associated with the ethanol plant does not include new feedstock receiving and processing equipment, because all new feedstock for the BGCC system is processed through the ethanol plant receiving system.

Feedstock is carried from the wood chip storage pile directly to the pretreatment building 350 feet to the south. Wood chips are conveyed to the chip bin at the top of the pretreatment building (el. $80 \mathrm{ft}$ ). The processed wood flows downward as it moves from the chip preheater through the hydrolyzer, to flash cooling stages at grade level. The material is then conveyed to the first of 10 fermenters located outdoors to the south of the pretreatment building.

The fermenting slurry flows through the fermenters in a cascading mode starting with smaller fermenters located nearest the pretreatment building and ending at the final larger vessel (beer well) located at the south west point. These vessels have been arranged with adequate spacing to locate fermenter coolers adjacent to each serviced fermenter.

Fermented beer is pumped from the last vessel (beer well) to the distillation unit located outdoors on the west side of the pretreatment building.

The stillage handling building, located next to the west end of the distillation system, processes the distillation residue or bottoms. The chiller building which houses the chilled water system and the service and instrument air systems is located south of the stillage building and west of the fermenters.

The yeast building, east of the pretreatment building, contains all vessels and equipment necessary to propagate yeast for fermentation. The chemical mix building, next to yeast preparation, contains the vessels for CIP and lime slurry preparation. The chemical storage tanks are located outdoors in a diked area adjacent to the chemical mix building. Truck unloading roadway space is provided along side of the diked area.

Alcohol storage tanks and denaturant storage are located in diked areas between the rail line and the ethanol plant ring road. The rail spur has been extended and rail car loading facilities are located close to alcohol storage.

A 1,900 foot long belt conveyor carries lignin stillage and bypassed wood chip feedstock to the BGCC plant. The structure carrying this belt can also be used to run steam, cooling water and other balance of plant system piping. 


\section{Utility and Balance of Plant Systems}

The existing mill firewater, sanitary sewer, wastewater sewer, stormwater sewer, potable water, and process water systems will be extended into the ethanol plant area. The ethanol plant consumes approximately $364 \mathrm{gpm}$ of process water and produces about $726 \mathrm{gpm}$ of wastewater.

The remaining support systems for the ethanol plant include the following

Control System. A distributed control system is provided for the ethanol plant. The system with video display units will be located in the pretreatment building.

Electrical System. A $4.16 \mathrm{kV}$ feeder from the BGCC plant will serve the ethanol plant.

Service Air and Instrument Air. A packaged system is provided to supply $200 \mathrm{scfm}$ of air at $100 \mathrm{psig}$ to the ethanol plant users.

Steam and Condensate. High pressure and medium pressure steamlines are provided from the BGCC plant to the ethanol plant. Condensate is returned to the existing mill deaerator.

Cooling Water System. The ethanol plant has the following cooling water requirements:

$\begin{array}{lr} & \begin{array}{c}\text { Rate } \\ \text { gpm }\end{array} \\ \text { LP Flash Condenser (T-201) } & 1,531 \\ \text { Distillation and Dehydration } & 6,500 \\ \text { Stillage Cooler (T-501) } & 948 \\ \text { Filter Vacuum Pumps (P-504) } & \underline{150} \\ & 9,129\end{array}$

This additional load was added to the planned mill cooling tower (along with the cooling load of the BGCC plant) and the incremental cost to accommodate the ethanol plant requirements was estimated by the cooling tower vendor. This value has been included in the capital cost estimate. Rough quantities of piping in this system were estimated and served as input for establishing the bulk material factor for piping.

Chilled Water System. The ethanol plant requires chilled water at a supply temperature $45^{\circ} \mathrm{F}$ with a return temperature of $65^{\circ} \mathrm{F}$ for process cooling. The total duty is 1,961 tons of refrigeration corresponding to a chilled water flow rate of $2,476 \mathrm{gpm}$, distributed among users as follows: 


$\begin{array}{lcrr} & \begin{array}{l}\text { Load } \\ \text { MM Btu/hr }\end{array} & \begin{array}{c}\text { Rate } \\ \text { gpm }\end{array} & \begin{array}{r}\text { Refrigeration } \\ \text { Tons }\end{array} \\ \text { Process Water Cooler (T-201) } & 3.7 & 492 & 308 \\ \text { Recycle Cooler (T-502) } & 4.3 & 426 & 355 \\ \text { Fermenter Coolers } & 13.0 & 1,518 & 1,265 \\ \text { Yeast Propagation } & \underline{0.4} & \underline{40} & \underline{33} \\ & 21.4 & 2,476 & 1,961\end{array}$

An ammonia chiller is provided to supply the chilled water. The chiller system includes a shell and tube evaporator and screw compressor on a skid to be located in the chiller building along with associated chilled water pumps and piping. An air cooled evaporative condenser is mounted on the chiller building roof.

\section{Buildings and Structures}

Chiller Building. The compressor/evaporator and chilled water pumps are located on grade in this building with the condenser located on the roof of the structure. The service air and instrument air system for the ethanol plant are also located in this building. The building is a pre-engineered, metalsided design with dimensions of 30 by 50 feet. A pile-supported slab foundation is required.

Pretreatment Building. The pretreatment building is a 50 feet by 50 feet by 80 feet high steel-framed structure with siding and stairwells. This building contains four levels to house the chip bin, chip preheater, hydrolyzer, and flash cooling stages of the process. The building is ventilated by exhaust fans on the upper level. Heating is provided with steam unit heaters. The ethanol plant control room containing the distributed control system (DCS) equipment is also located in this building. Air conditioning and lavatory facilities are provided for the control room. The foundation is a slab supported on piles.

Yeast Building. The yeast building is a pre-engineered building 40 feet by 50 feet by 40 feet high. The building is ventilated by roof exhaust fans. Heating is provided with steam unit heaters. The foundation is a slab on grade.

Chemical Mixing Building. The chemical mixing building is a pre-engineered building 25 feet by 50 feet by 20 feet high. The building is ventilated by roof exhaust fans and heated with steam unit heaters. The foundation is a slab on grade.

Stillage Handling Building. The stillage handling building is a pre-engineered type building 100 feet by 100 feet by 30 feet high, containing heavy rotary vacuum filters and centrifuges. The building is ventilated by roof exhaust fans and heated with steam unit heaters. The foundation is a slab supported on piles. 


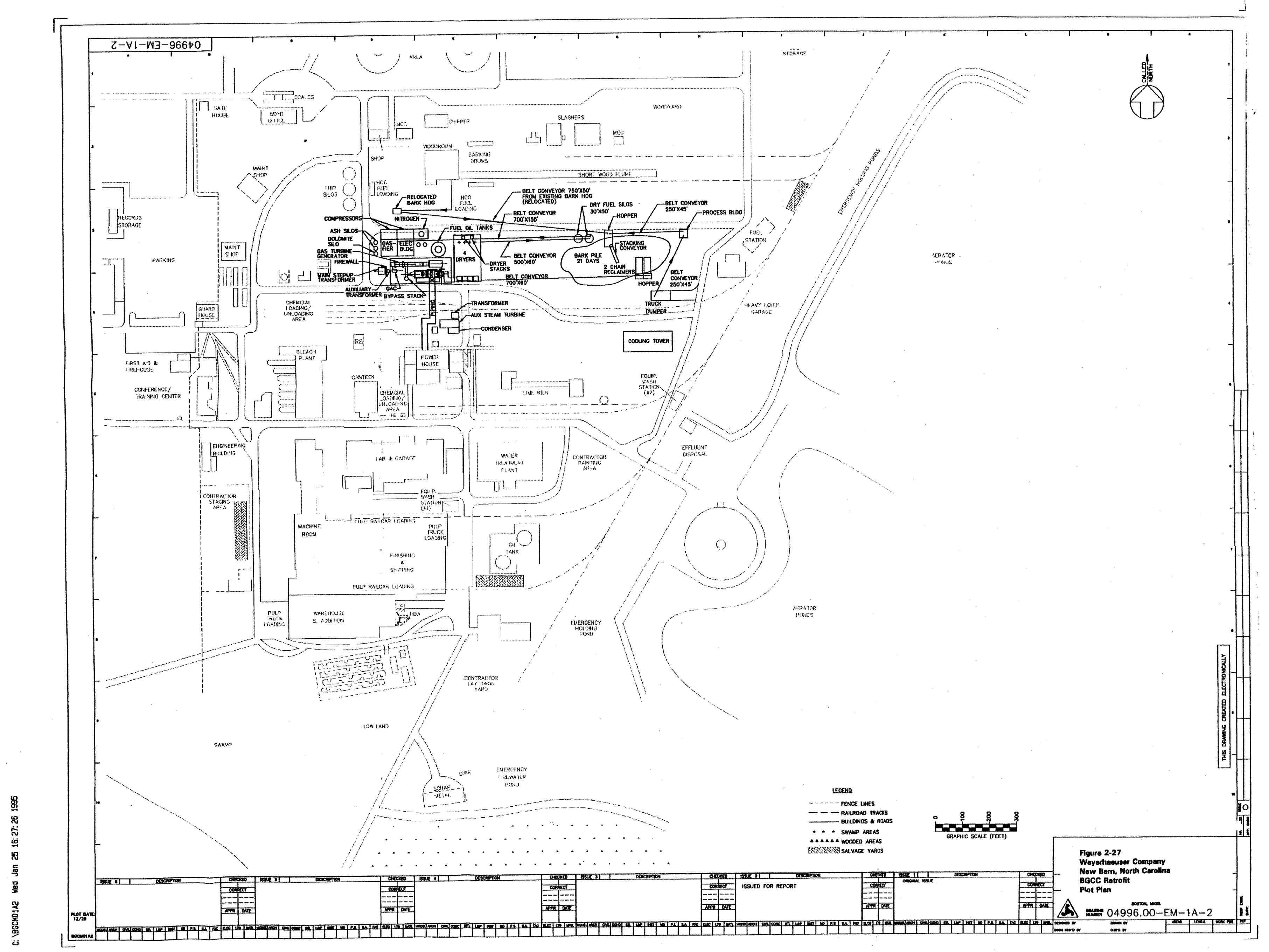




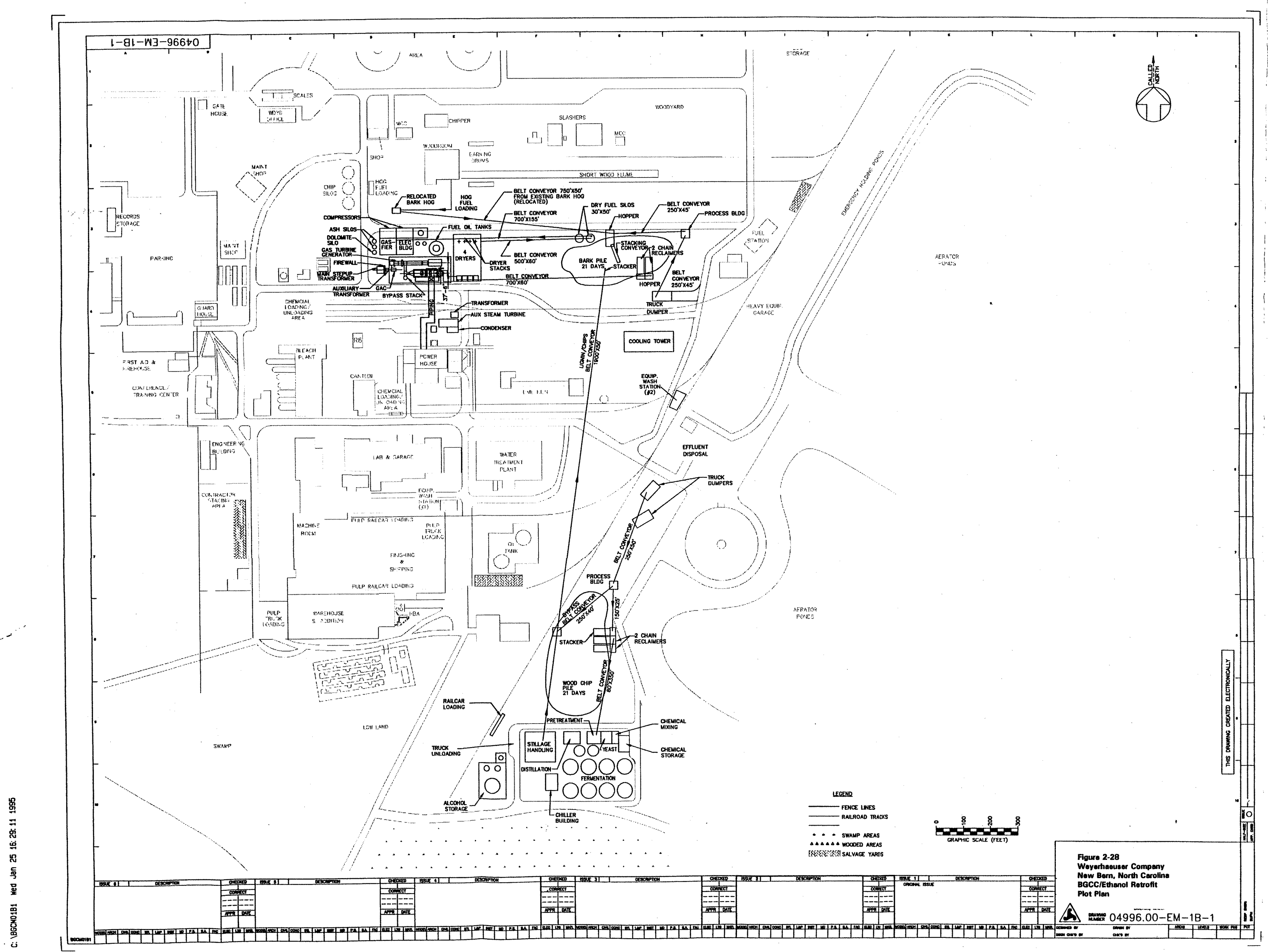


This page is intentionally left blank 


\subsection{Plant Performance}

\subsubsection{BGCC Cogen Plants}

Since the steam needs of the mill are fixed in all cases, the BGCC plant performance is measured by the biomass fuel consumption, the gross power generation and the auxiliary or internal power consumption. These values define the plant net output and its efficiency. The efficiency of a power plant is usually expressed in terms of net heat rate which is the fuel heat input in Btu/hr divided by the net output in kilowatts. For cogeneration plants, this calculation results in a high and misleading value because it does not take into consideration the steam produced for process use.

One approach for developing a meaningful efficiency for cogeneration plants is to determine that portion of the fuel heat input chargeable to electric generation. This allows the calculation of a fuel chargeable to power (FCP) heat rate. The thermal credit for process steam production is calculated by assuming the steam is generated in a separate natural gas or oil fired boiler with a typical efficiency (e.g., 87.5 percent). From the quality and quantity of the steam and the boiler efficiency, the fuel heat input in $\mathrm{Btu} / \mathrm{hr}$ required to produce the steam is calculated and subtracted from the total heat input to the cogen plant to determine the fuel heat input used to generate the electric power. This FCP heat rate calculation is used to compare the various BGCC alternatives.

For the BGCC cogen plant at the New Bern Mill, the fuel heat input which would be required to produce the steam sent to the mill is as follows:

Fuel Heat Input for Steam Production, $10^{6} \mathrm{Btu} / \mathrm{hr}$

202.5

47.4

\section{Process Steam}

$156,000 \mathrm{lb} / \mathrm{hr}\left(825^{\circ} \mathrm{F}, 850 \mathrm{psig}\right)$

$45,000 \mathrm{lb} / \mathrm{hr}\left(155 \mathrm{psig}\right.$, sat'd) $^{\prime}$

The total fuel heat input attributable to steam production is $249.9 \times 10^{6} \mathrm{Btu} / \mathrm{hr}$. Therefore, for each of the BGCC design cases, the FCP heat rate is calculated as follows:

Biomass Feed Heat Input, Btu/hr - $249.9 \times 10^{6} \mathrm{Btu} / \mathrm{hr}$

net kilowatt output

Figures 2-29 through 2-32 present summary energy and material balances and performance calculations for the BGCC cases. Figure 2-29 is the TPS gasification-based design presented in Section 2.1. Figure 2-30 presents a modified TPS design (no air extraction) suggested for study by Dr. Erich Larson of Princeton University. The modified design is based on performance information provided by General Electric for throttling the gas turbine compressor using the inlet guide vanes to prevent surge due to the large low Btu fuel gas volumetric flow instead of extracting air from the compressor discharge. For atmospheric gasifiers, extracting high pressure air from the gas turbine compressor to prevent surge and using it to satisfy the low pressure air requirements of the gasifier is a severe energy penalty. To minimize this penalty, instead of throttling to the pressure required by the gasifier, an expander was provided in the TPS BGCC design to generate some additional electricity (refer to Section 2.1 for a description of the expander-compressor-generator). The modified TPS design answers the question of whether throttling the gas turbine compressor to prevent surge is less of an energy penalty than air extraction. 
As indicated in Figures 2-29 and 2-30, the heat rate of the air extraction case at $10,885 \mathrm{Btu} / \mathrm{kWh}$ is slightly lower than the heat rate of the no air extraction case $(11,000 \mathrm{Btu} / \mathrm{kWh})$. However, the expandercompressor-generator cost for the air extraction case may be too high to justify a $115 \mathrm{Btu} / \mathrm{kWh}$ improvement in heat rate. TPS has developed a cost-effective air integration design for a smaller gas turbine which should be adaptable to the Frame 6B. The integration issue should be resolved in a design optimization study.

Figures 2-31 and 2-32 depict the pressurized Tampella Gasification-based BGCC plants with a flue gas biomass dryer and with a biomass dryer using steam. The flue gas biomass dryer design, although slightly higher in capital cost (refer to Section 2.7-1), has a better heat rate of $10,764 \mathrm{Btu} / \mathrm{kWh}$ versus $12,319 \mathrm{Btu} / \mathrm{kWh}$ for the steam dryer case. This difference is due to the fact that to provide the steam for the dryer the HRSG must be supplementary fired with biogass. With the steam dryer case, the steam evaporated from the biomass may be used in a planned mill steam stripper. This steam would reduce the mill steam requirements and should improve the steam dryer case heat rate.

Comparing the TPS case using flue gas to dry the biomass shown in Figure 2-29 and the Tampella Flue Gas Dryer Case shown in Figure 2-30 indicates the pressurized gasifier has a slightly better heat rate than the atmospheric gasifier. However, considering the level of accuracy of the preliminary design, it is only fair to conclude that the heat rates for the Frame 6B size BGCC plant are about the same.

The BGCC heat rate compares favorably with:

- a conventional biomass-fueled fluid bed boiler system of similar capacity $\sim 14,000 \mathrm{Btu} / \mathrm{kWh}$

- a new coal-fired power plant $300 \mathrm{MW}$ in size $\sim 10,500-11,000$

- $\quad$ typical utility system overall heat rates

Tables 2-17 through 2-20 are the electrical (motor) load lists for the four BGCC cases which were used to calculate the auxiliary power consumption.

The performance of the four BGCC cases can be summarized as follow:

\begin{tabular}{|c|c|c|c|c|c|}
\hline Case & $\begin{array}{r}\text { Biomass } \\
\text { lb/hr (wet) }\end{array}$ & $\begin{array}{l}\text { Consumption } \\
\text { Tons/Yr (Dry) }\end{array}$ & $\begin{array}{l}\text { Net Output, } \\
\underline{\mathbf{k W}}\end{array}$ & $\begin{array}{l}\text { Power } \\
\text { Sales, } \\
\underline{\mathbf{k W}}\end{array}$ & $\begin{array}{c}\text { FCP Heat } \\
\text { Rate, } \\
\text { Btu/kWh }\end{array}$ \\
\hline $\begin{array}{l}\text { TPS (Flue Gas } \\
\text { Dryer) }\end{array}$ & 140,400 & 261,355 & 33,800 & 28,200 & 10,885 \\
\hline $\begin{array}{l}\text { TPS (No Air } \\
\text { Extraction) }\end{array}$ & 146,800 & 273,268 & 36,000 & 30,400 & 11,000 \\
\hline $\begin{array}{l}\text { Tampella (Flue } \\
\text { Gas Dryer) }\end{array}$ & 152,200 & 283,320 & 39,000 & 33,400 & 10,764 \\
\hline $\begin{array}{l}\text { Tampella (Steam } \\
\text { Dryer) }\end{array}$ & 165,700 & 308,450 & 38,900 & 33,300 & 12,319 \\
\hline
\end{tabular}

The biomass consumption is based on an 85 percent capacity factor for the BGCC plant. 


\subsubsection{Ethanol Cases}

The ethanol plant can be located at the New Bern Mill with or without a BGCC plant. For the case without a BGCC plant, Figure 2-33 shows the overall ethanol plant material balance and interfaces with the mill. The mill provides process water, boiler feedwater and cooling water to the ethanol plant and treats the wastewater stream. The ethanol plant must be provided with a packaged boiler to satisfy its steam needs. To reduce the requirement for outside (trucked in) biomass, the "stand alone" ethanol plant would use some of the mill residuals which are of sufficient quality.

This "stand alone" ethanol plant, converts $19,466 \mathrm{lb} / \mathrm{hr}(9,733 \mathrm{lb} / \mathrm{hr}$ dry basis $)$ of waste biomass from the mill plus $154,134 \mathrm{lb} / \mathrm{hr}(77,067 \mathrm{lb} / \mathrm{hr}$ dry basis) of new biomass (chipped thinnings from forest management) to $21,700 \mathrm{lb} / \mathrm{hr}(3,292 \mathrm{gal} / \mathrm{hr})$ of anhydrous fuel grade ethanol. The plant also produces $51,126 \mathrm{lb} / \mathrm{hr}(28,119 \mathrm{lb} / \mathrm{hr}$ dry $)$ of a lignin by-product which can be used as fuel in the mill or sold as fuel.

The ethanol plant is capable of a 94 percent annual onstream factor. This translates to a biomass consumption of 357,373 tons/yr of bone dry (or BDT/yr) biomass which is converted to 89,343 tons/yr of ethanol. This is a conversion efficiency of 25 percent.

The ethanol energy requirements are $13.2 \mathrm{MW}$ of electricity and $114 \times 10^{6} \mathrm{Btu} / \mathrm{hr}$ of fuel oil used to produce the ethanol plant steam requirements in a packaged boiler.

The most significant ethanol plant chemical usage is the enzyme which is used in fermentation. The impact of the enzyme cost on the ethanol plant economics is discussed in Section 4.

Figure 2-34 shows the ethanol plant integrated with a Tampella-based BGCC plant design with a flue gas biomass dryer. The integration with the BGCC plant is very simple. The BGCC plant provides steam to the ethanol plant (in addition to supplying steam to the mill previously supplied by the bark boiler) and the ethanol plant lignin by-product is used to offset a portion of the new (outside) biomass used to fuel the BGCC plant. The BGCC plant also provides electricity to the mill and to the ethanol plant and provides 19.4 MWe of export power to the grid.

The motor load list for the ethanol and BGCC plants is given in Table 2-21. 
Table 2-17: Electrical Summary - TPS BGCC (Flue Gas Dryer)

\begin{tabular}{|c|c|c|c|c|c|c|}
\hline \multicolumn{2}{|c|}{ DETAILED ELECTRICAL SUMMARY } & \multicolumn{3}{|c|}{ ISSUE 1} & \multicolumn{2}{|l|}{\begin{tabular}{|c|}
$\begin{array}{c}\text { J.O. NO. } \\
04996.00\end{array}$ \\
SHEET \\
1 OF 1 \\
\end{tabular}} \\
\hline \multicolumn{3}{|c|}{$\begin{array}{l}\text { SERMCE } \\
\text { TPS BGCC (Flue Gas Dryer) }\end{array}$} & DLS & $\begin{array}{r}\text { CHECKED } \\
\text { PDW }\end{array}$ & 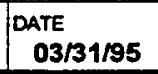 & \\
\hline \multirow[t]{3}{*}{ TEMNO. } & \multirow[t]{2}{*}{ SERVCE } & \multirow[t]{2}{*}{ NOTES } & \multirow[t]{2}{*}{ BHP } & \multirow{2}{*}{ POWER } & \multirow{2}{*}{\multicolumn{2}{|c|}{ REV. }} \\
\hline & & & & & & \\
\hline & GASIFIER ISLAND & & & 320.0 & & \\
\hline G. 201 & COMBUSTLON TURBINE AUXILLARIES & & & 143.0 & & \\
\hline G- 202 & EXPANDERKCOMPRESSOR AUXILIARIES & & & 50.0 & & \\
\hline G. 203 & STEAM TURBINE AUXILLARIES & & 110.0 & 86.3 & & \\
\hline G. $264 \mathrm{~A}, \mathrm{~B}$ & INCREMENTAL COOLING TOWER \& PUMPING & 2 & 30.2 & 23.7 & & \\
\hline G. $276 \mathrm{~A}$ & GAS TURBINE FUEL OIL PUMP & 1 & 10.0 & 7.8 & & \\
\hline G- $278 \mathrm{~A}$ & LOCAL BOILER WATER TREATMENT & & 1.0 & 0.8 & & \\
\hline P. 201A & BLOW-OFF TRANSFER PUMP & & 1.0 & 0.8 & & \\
\hline P. $202 \mathrm{AB}$ & CONDENSATE PUMP & & & 10.0 & & \\
\hline P. 253 & FLARE PROCESS CONDENSATE PUMP & 1 & 5.0 & 3.9 & & \\
\hline P- $254 \mathrm{~A}$ & FUEL OIL SUPPLY PUMP & 1 & 10.0 & 7.8 & & \\
\hline R- 201 & FUEL GAS BOOSTER COMPRESSOR & & & 12.530 .0 & & \\
\hline $\mathrm{R}: 251 \mathrm{AB}$ & SERVCE \& INSTRUMENT AIR COMPRESSOR (60\%) & & 100.0 & 78.5 & & \\
\hline T. $201 A-D$ & BIOMASS DRYER (FLUE GAS) & & $2,250.0$ & $1,766.1$ & & \\
\hline$W-252 \mathrm{AB}$ & TRUCK DUMPER WILNE BOTTOM RECEMING HOPPER & & 130.0 & 102.0 & & \\
\hline W- 253 & PROCESS BUILDING FEED CONVEYOR & & 30.0 & 23.5 & & \\
\hline W- 254 & REVERSING CONVEYOR WITH MAGNETIC METAL DETECTOR & & 20.0 & 15.7 & & \\
\hline W- 255 & DISK SCREEN & & 15.0 & 11.8 & & \\
\hline W. 256 & WET FUEL HOG & & 300.0 & 235.5 & & \\
\hline W. 257 & WETFUEL STORAGE PLLE FEED CONVEYOR & & 30.0 & 23.5 & & \\
\hline W- 258 & WETFUEL STORAGE PILE FEEDER FROM EXISTING HOGGING STATION & & 25.0 & 19.6 & & \\
\hline$W-260$ & WETFUEL STACKING CONVEYOR & & 30.0 & 23.5 & & \\
\hline W- 261AVB & WETFUEL CHAIN RECLAIMER & & 100.0 & 78.5 & & \\
\hline W- 262 & BIOMASS DRYER FEED CHAN DISTRIBUTHON CONVEYOR & & 50.0 & 39.2 & & \\
\hline W- 264 & BIOMASS DRYER FEED CONVEYOR & & 40.0 & 31.4 & & \\
\hline W. 266A,B,C,D & DRYER FEED SCREW CONVEYOR & & 60.0 & 47.1 & & \\
\hline W. 267A,B,C,D & DRYER DISCHARGE SCREW CONVEYOR & & 60.0 & 47.1 & & \\
\hline$W-268$ & DRY FUEL SILO FEED CONVEYOR & & 15.0 & 11.8 & & \\
\hline$W-269 A, B$ & DRY FUEL SILO WITH LIVE BOTTOM RECLAIM & & 115.0 & 90.3 & & \\
\hline$W-270$ & BIOMASS FEED BELT CONVEYOR & & 25.0 & 19.6 & & \\
\hline$W-272$ & BIOMASS FEED REVERSING BELT CONVEYOR & & 15.0 & 11.8 & & \\
\hline W. 274 & DOLOMITE STORAGE SILO WITH LNE BOTTOM & & 1.0 & 0.8 & & \\
\hline$W-275$ & DOLOMITE FEED PNEUMATIC CONVEYOR SYSTEM & & 40.0 & 31.4 & & \\
\hline$W-276$ & BOTTOM ASH PNEUMATKC CONVEYOR SYSTEM & & 40.0 & 31.4 & & \\
\hline$w-277$ & BOTTOM ASH SILO WITH DISCHARGE SCREW & & 1.0 & 0.8 & & \\
\hline W. 278 & FILTER ASH PNEUMATIC CONVEYOR SYSTEM & & 45.0 & 35.3 & & \\
\hline W- 279 & FILTER ASH SILO WITH DISCHARGE SCREW & & 1.0 & 0.8 & & \\
\hline N/A & LIGHTING AND MISC BUILDING LOADS & & & 50.0 & & \\
\hline मा & TOTAL CONNECTED POWER LOAD REQUUREMENTS & + & 4 & 15,9918 & & \\
\hline & TOTAL ONLINE POWER CONSUMPTION ( $83 \%$ CONNECT) & & & 13.273 .2 & & \\
\hline NOTES & & & & & & \\
\hline 1) INTERMIT & TENT SERVICE, NOT INCLUDED IN TOTAL & & & & & \\
\hline 2) COOLING & SYSTEM AND CONDENSATE SYSTEM INCLUDES ADDITIONAL LOAD FOF & CON & S STEA & ZBINE & & \\
\hline
\end{tabular}


Table 2-18: Electrical Summary - TPS BGCC (No Extraction Air Case)

\begin{tabular}{|c|c|c|c|c|c|c|}
\hline \multirow{2}{*}{\multicolumn{2}{|c|}{ DETAILED ELECTRICAL SUMMARY }} & \multicolumn{3}{|c|}{ ISSUE 1} & \multirow{2}{*}{\multicolumn{2}{|c|}{\begin{tabular}{|c|}
$\begin{array}{c}\text { J.O. NO. } \\
04996.00\end{array}$ \\
SHEET \\
1 OF 1 \\
\end{tabular}}} \\
\hline & & & & & & \\
\hline \multicolumn{3}{|c|}{$\begin{array}{l}\text { SERVCE } \\
\text { TPS BGCC (No Extraction Air Case) }\end{array}$} & ${ }^{B Y}$ DLS & $\begin{array}{r}\text { CHECKED } \\
\text { PDW }\end{array}$ & $\begin{array}{l}\text { DATE } \\
\text { O3/31/95 }\end{array}$ & \\
\hline \multirow[t]{2}{*}{ TEM NO. } & \multirow[t]{2}{*}{ SERVICE } & \multirow[t]{2}{*}{ NOTES } & \multirow[t]{2}{*}{ BHP } & POWER & \multirow{2}{*}{\multicolumn{2}{|c|}{ REV. }} \\
\hline & & & & kw & & \\
\hline & GASIFIER ISLAND & & & 330.0 & & \\
\hline G- 201 & COMBUSTION TURBINE AUXILLARIES & & & 143.0 & & \\
\hline G- 203 & STEAM TURBINE AUXILLARIES & & $\$ 45.0$ & 113.8 & & \\
\hline G. $264 A, B$ & INCREMENTAL COOLING TOWER \& PUMPING & 2 & 46.0 & 36.1 & & \\
\hline G. $276 \mathrm{~A}$ & GAS TURBINE FUEL OIL PUMP & 1 & 10.0 & 7.8 & & \\
\hline G. $278 \mathrm{~A}$ & LOCAL BOILER WATER TREATMENT & & 1.0 & 0.8 & & \\
\hline P- 201A & BLOW-OFF TRANSFER PUMP & & 1.0 & 0.8 & & \\
\hline P. $202 \mathrm{AB}$ & CONDENSATE PUMP & & & 13.2 & & \\
\hline P. 253 & FLARE PROCESS CONDENSATE PUMP & 1 & 5.0 & 3.9 & & \\
\hline P. $254 \mathrm{~A}$ & FUEL OIL SUPPLY PUMP & 1 & 10.0 & 7.8 & & \\
\hline R. 201 & FUEL GAS BOOSTER COMPRESSOR & & & $13,085.0$ & & \\
\hline R. 202 & GASIFICATION AR FEED COMPRESSOR & & & $2,000.0$ & & \\
\hline R. $251 \mathrm{AB}$ & SERVCE \& INSTRUMENT ARR COMPRESSOR (60\%) & & 100.0 & 78.5 & & \\
\hline T- $201 A-D$ & BIOMASS DRYER (FLUE GAS) & & $2,350.0$ & $1,844.6$ & & \\
\hline$W-252 \mathrm{AB}$ & TRUCK DUMPER W/LNE BOTTOM RECEMNG HOPPER & & 130.0 & 102.0 & & \\
\hline w. 253 & PROCESS BUILDING FEED CONNEYOR & & 30.0 & 23.5 & & \\
\hline w. 254 & REVERSING CONVEYOR WITH MAGNETIC METAL DETECTOR & & 20.0 & 15.7 & & \\
\hline W- 255 & DISK SCREEN & & 15.0 & 11.8 & & \\
\hline$W-256$ & WET FUEL HOG & & 300.0 & 235.5 & & \\
\hline W. 257 & WETFUEL STORAGE PILE FEED CONVEYOR & & 30.0 & 23.5 & & \\
\hline W- 258 & WETFUEL STORAGE PILE FEEDER FROM EXISTING HOGGING STATION & & 25.0 & 19.6 & & \\
\hline W- 260 & WETFUEL STACKING CONVEYOR & & 30.0 & 23.5 & & \\
\hline W- 261AB & WETFUEL CHAIN RECLAMMER & & 100.0 & 78.5 & & \\
\hline w- 262 & BIOMASS DRYER FEED CHAIN DISTRIBUTION CONVEYOR & & 50.0 & 39.2 & & \\
\hline W- 264 & BIOMASS DRYER FEED CONVEYOR & & 40.0 & 31.4 & & \\
\hline$W-2664, B, C, D$ & DRYER FEED SCREW CONVEYOR & & 60.0 & 47.1 & & \\
\hline$W-267 A, B, C, D$ & DRYER DISCHARGE SCREW CONVEYOR & & 60.0 & 47.1 & & \\
\hline$w-268$ & DRY FUEL SILO FEED CONVEYOR & & 15.0 & 11.8 & & \\
\hline W- 269AB & DRY FUEL SILO WITH LNE BOTTOM RECLAIM & & 115.0 & 90.3 & & \\
\hline$w-270$ & BIOMASS FEED BELT CONVEYOR & & 25.0 & 19.6 & & \\
\hline$W-272$ & BIOMASS FEED REVERSING BELT CONVEYOR & & 15.0 & 11.8 & & \\
\hline$w-274$ & DOLOMITE STORAGE SLLO WITH LIVE BOTTOM & & 1.0 & 0.8 & & \\
\hline W- 275 & DOLOMITE FEED PNEUMATIC CONVEYOR SYSTEM & & 40.0 & 31.4 & & \\
\hline$W-276$ & BOTTOM ASH PNEUMATIC CONVEYOR SYSTEM & & 40.0 & 31.4 & & \\
\hline w- 277 & BOTTOM ASH SILO WITH DISCHARGE SCREW & & 1.0 & 0.8 & & \\
\hline W- 278 & FILTER ASH PNEUMATIC CONVEYOR SYSTEM & & 45.0 & 35.3 & & \\
\hline$W-279$ & FILTER ASH SILO WITH DISCHARGE SCREW & & 1.0 & 0.8 & & \\
\hline NA & LIGHTING AND MISC. BUILDING LOADS & & & 50.0 & & \\
\hline मे & TTOTAL CONNECTED POWER LOAO REQUIREMENTS & & & $18,628.3$ & & \\
\hline & TOTAL ONLINE POWER CONSUMPTION ( $83 \%$ CONNECT) & & & 15.461 .5 & & \\
\hline NOTES & & & & & & \\
\hline 1) INTERMITI & TENT SERVICE, NOT INCLUDED IN TOTAL & & & & & \\
\hline 2) COOLING & SYSTEM AND CONDENSATE SYSTEM INCLUDES ADDITIONAL LOAD FOR & VCONDE & ING STEAM & TURBINE & & \\
\hline
\end{tabular}


Table 2-19: Electrical Summary - Tampella BGCC (Flue Gas Dryer)

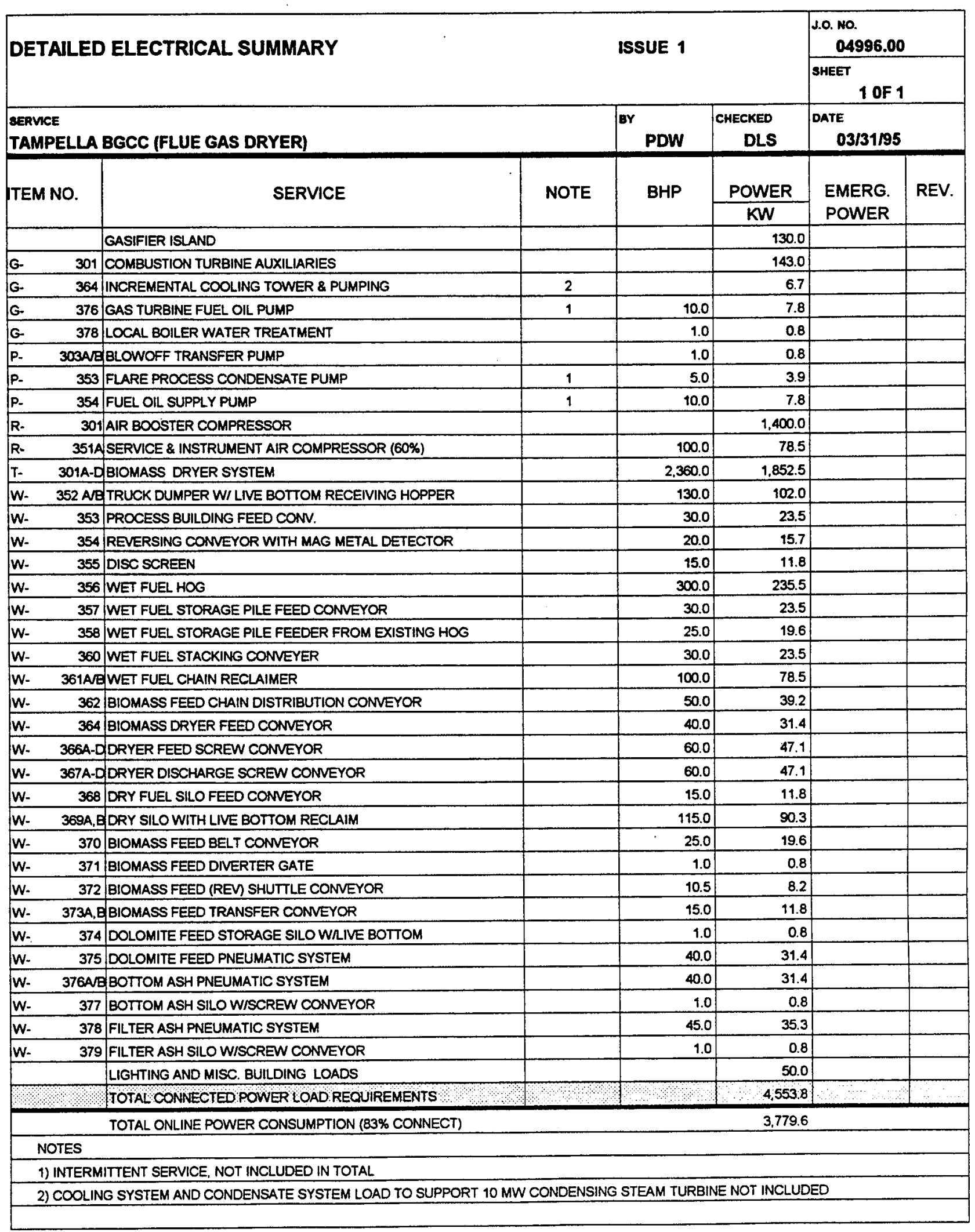


Table 2-20: Electrical Summary - Tampella BGCC (Steam Dryer)

\begin{tabular}{|c|c|c|c|c|c|c|}
\hline \multicolumn{2}{|c|}{ DETAILED ELECTRICAL SUMMARY } & & \multirow{2}{*}{\multicolumn{2}{|c|}{\begin{tabular}{|l|}
$\begin{array}{l}\text { J.O. NO. } \\
\text { O4996.00 }\end{array}$ \\
SHEET \\
\\
1 OF 1
\end{tabular}}} \\
\hline \multicolumn{3}{|c|}{ - } & \multicolumn{2}{|l|}{ ISSUE 1} & & \\
\hline \multicolumn{3}{|c|}{$\begin{array}{l}\text { SERMCE } \\
\text { TAMPELLA BGCC (STEAM DRYER) }\end{array}$} & ${ }^{\mathrm{BY}}$ PDW & $\begin{array}{r}\text { CHECKED } \\
\text { DLS }\end{array}$ & 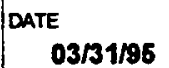 & \\
\hline \multirow[t]{2}{*}{ TEM NO. } & \multirow[t]{2}{*}{ SERVICE } & \multirow[t]{2}{*}{ NOTES } & \multirow[t]{2}{*}{ BHP } & POWER & & \multirow[t]{2}{*}{ REV. } \\
\hline & & & & $\mathrm{KW}$ & & \\
\hline & GASIFIER ISLAND & & & 141.5 & & \\
\hline 401 & COMBUSTION TURBINE AUXILIARIES & & & 143.0 & & \\
\hline 464. & INCREMENTAL COOLING TOWER \& PUMPING & 2 & & 7.3 & & \\
\hline 476 & GAS TURBINE FUEL OIL PUMP & 1 & 10.0 & 7.8 & & \\
\hline 478 & LOCAL BOILER WATER TREATMENT & & 1.4 & 1.1 & & \\
\hline 403 & BLOWOFF TRANSFER PUMP & & 1.4 & 1.1 & & \\
\hline 453 & FLARE PROCESS CONDENSATE PUMP & 1 & 5.0 & 3.9 & & \\
\hline 454 & FUEL OIL SUPPLY PUMP & 1 & 10.0 & 7.8 & & \\
\hline 401 & AIR BOOSTER COMPRESSOR & & & $1,523.8$ & & \\
\hline 451A & SERVICE \& INSTRUMENT AIR COMPRESSOR (60\%) & & 100.0 & 78.5 & & \\
\hline 401 & BIOMASS STEAM DRYER SYSTEM & & & $1,060.0$ & & \\
\hline 452AVB & TRUCK DUMPER WIIVE BOTTOM RECEIVING HOPPER & & 130.0 & 1020 & & \\
\hline 453. & PROCESS BUILDING FEED CONW. & & 30.0 & 23.5 & & \\
\hline 454 & REVERSING CONVEYOR WITH MAG. METAL DETECTOR & & 20.0 & 15.7 & & \\
\hline 455 & DISC SCREEN & & 15.0 & 11.8 & & - \\
\hline 456 & WET FUEL HOG & & 300.0 & 235.5 & & \\
\hline 457 & WET FUEL STORAGE PILE FEED & & 30.0 & 23.5 & & \\
\hline 458 & WET FUEL STORAGE PILE FEEDER FROM EXISTING HOG & & 25.0 & 19.6 & & \\
\hline 460 & WET FUEL STACKING CONVEYER & & 30.0 & 23.5 & & \\
\hline 461AVB & WET FUEL CHAIN RECLAIMER & & 100.0 & 78.5 & & \\
\hline 462 & BIOMASS FEED CHAIN DISTRIBUTION CONVEYOR & & 50.0 & 39.2 & & \\
\hline 464 & BIOMASS DRYER FEED CONVEYOR & & 40.0 & 31.4 & & \\
\hline 466A-D & DRYER FEED SCREW CONVEYOR & & 60.0 & 47.1 & & \\
\hline W. 467A-D & DRYER DISCHARGE SCREW COMVYOR & & 60.0 & 47.1 & & \\
\hline 468 & DRY FUEL SILO FEED CONVEYOR & & 15.0 & 11.8 & & \\
\hline W. $469 \mathrm{~A}, \mathrm{~B}$ & DRY SILO WITH LIVE BOTTOM RECLAIM & & 145.0 & 90.3 & & \\
\hline 470 & BIOMASS FEED BELT CONVEYOR & & 25.0 & 19.6 & & \\
\hline 471 & BIOMASS FEED DIVERTER GATE & & 1.0 & 0.8 & & \\
\hline 472 & BIOMASS FEED (REV) SHUTTLE CONVEYOR & & 10.5 & 8.2 & & \\
\hline $473 A, B$ & BIOMASS FEED TRANSFER CONVEYOR & & 15.0 & 11.8 & & \\
\hline 474 & DOLOMITE FEED STORAGE SILO WIIVE BOTTOM & & 1.0 & 0.8 & & \\
\hline 475 & DOLOMITE FEED PNEUMATIC SYSTEM & & 40.0 & 31.4 & & \\
\hline 476AVB & BOTTOM ASH PNEUMATIC SYSTEM & & 40.0 & 31.4 & & \\
\hline 477 & BOTTOM ASH SILO WISCREW COAVEYOR & & 1.0 & 0.8 & & \\
\hline 478 & FILTER ASH PNEUMATIC SYSTEM & & 45.0 & 35.3 & & \\
\hline 479 & FILTER ASH SILO WISCREW CONVEYOR & & 1.0 & 0.8 & & \\
\hline & LIGHTING AND MISC. BUILDING LOADS & & & 50.0 & & \\
\hline & TOTAL CONNECTEO POWER LOAD REQUIREMENTS & & & $3,947: 9$ & & \\
\hline & TOTAL ONLINE POWER CONSUMPTION (83\% CONNECT) & & & $3,276.8$ & & \\
\hline NOTES & & & & & & \\
\hline 1) INTERI & MITTENT SERVICE, NOT INCLUDED IN TOTAL & & & & & \\
\hline 2) $\mathrm{COOLI}$ & ING SYSTEM AND CONDENSATE SYSTEM LOAD TO SUPPOF & $O \mathrm{MW}$ CON & ENSING STEAM & A TURBINE NOT & I INCLUDED & \\
\hline
\end{tabular}


Table 2-21: Electrical Summary - Tampella BGCC/Ethanol Plant (Flue Gas Dryer)

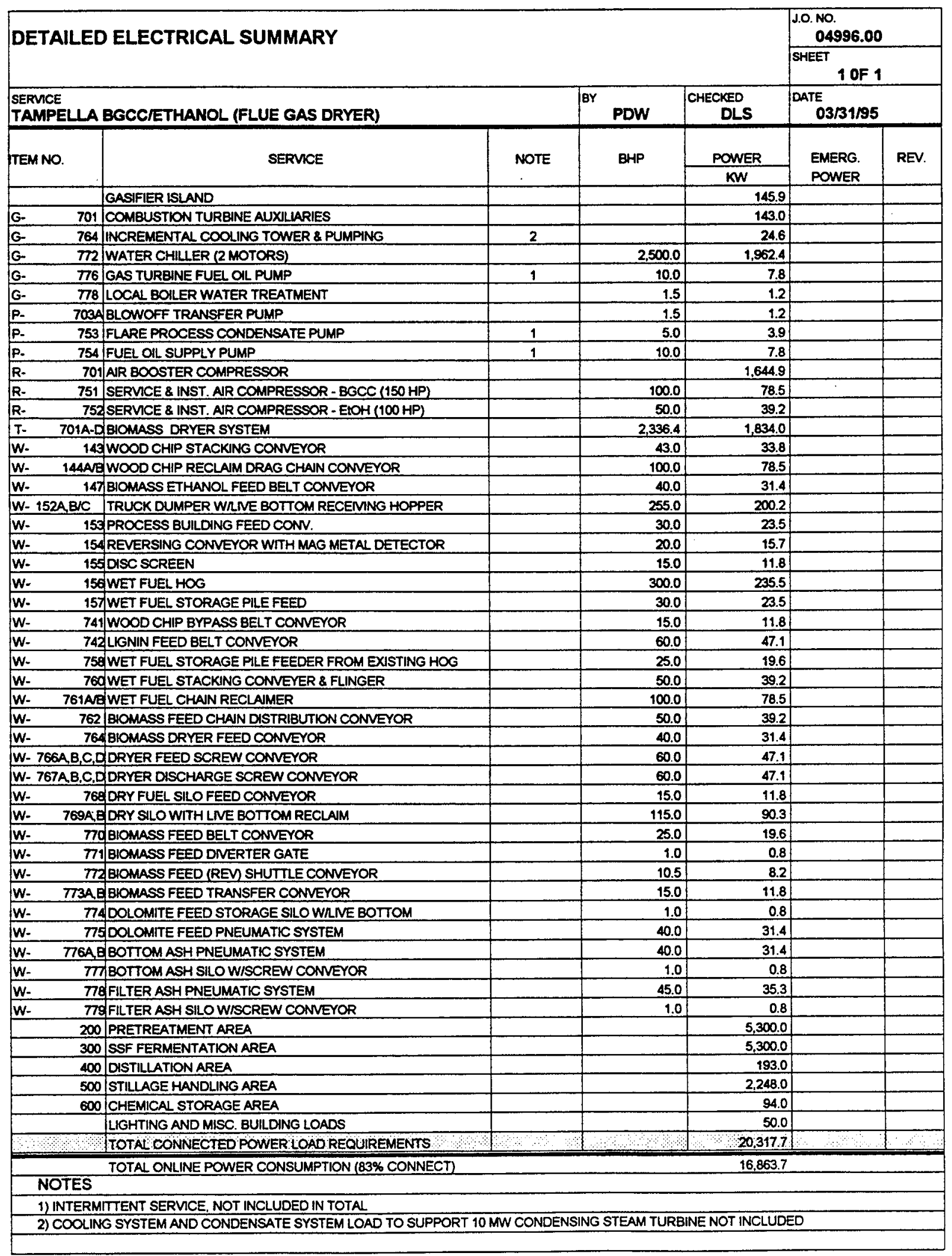




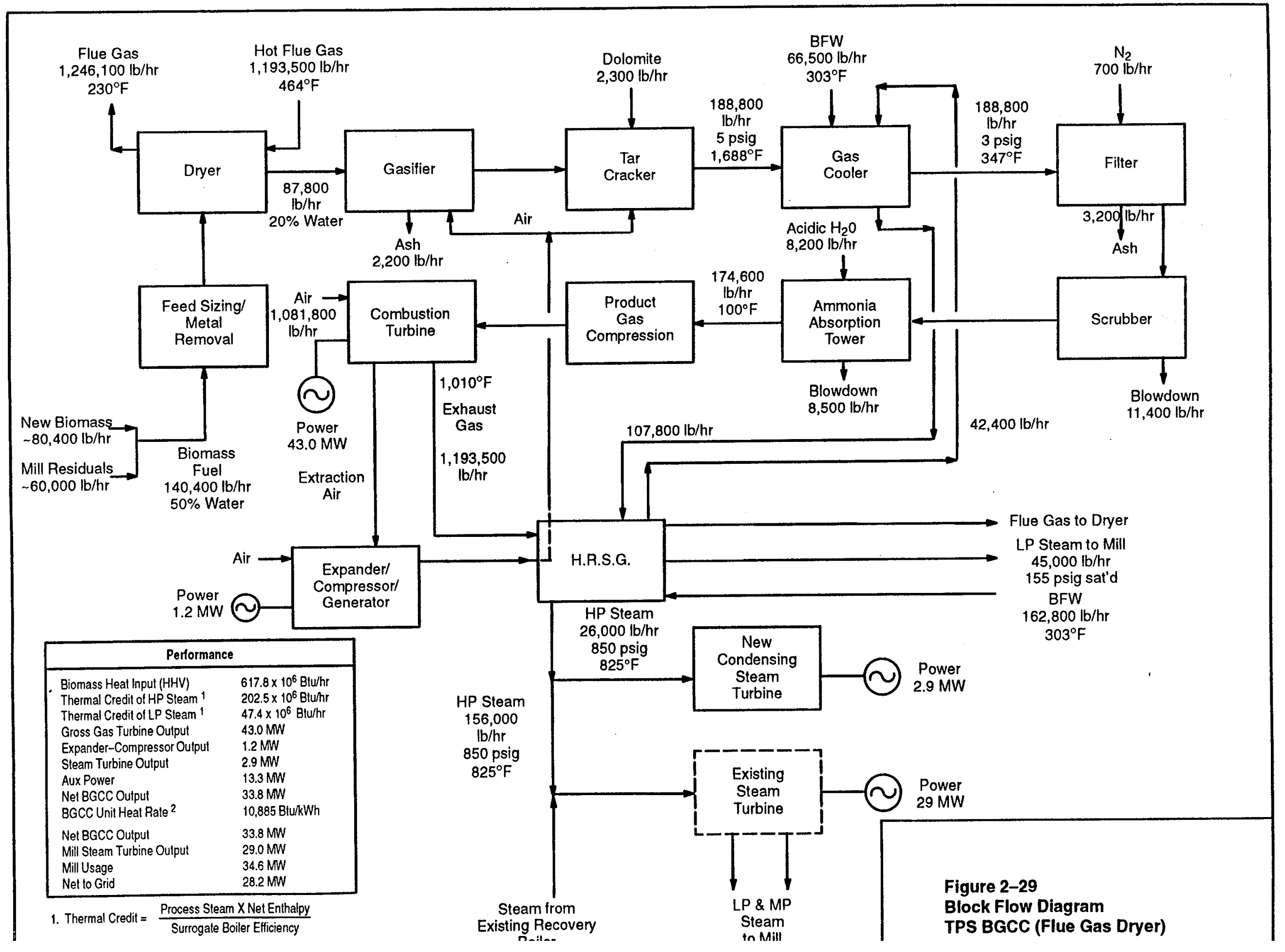




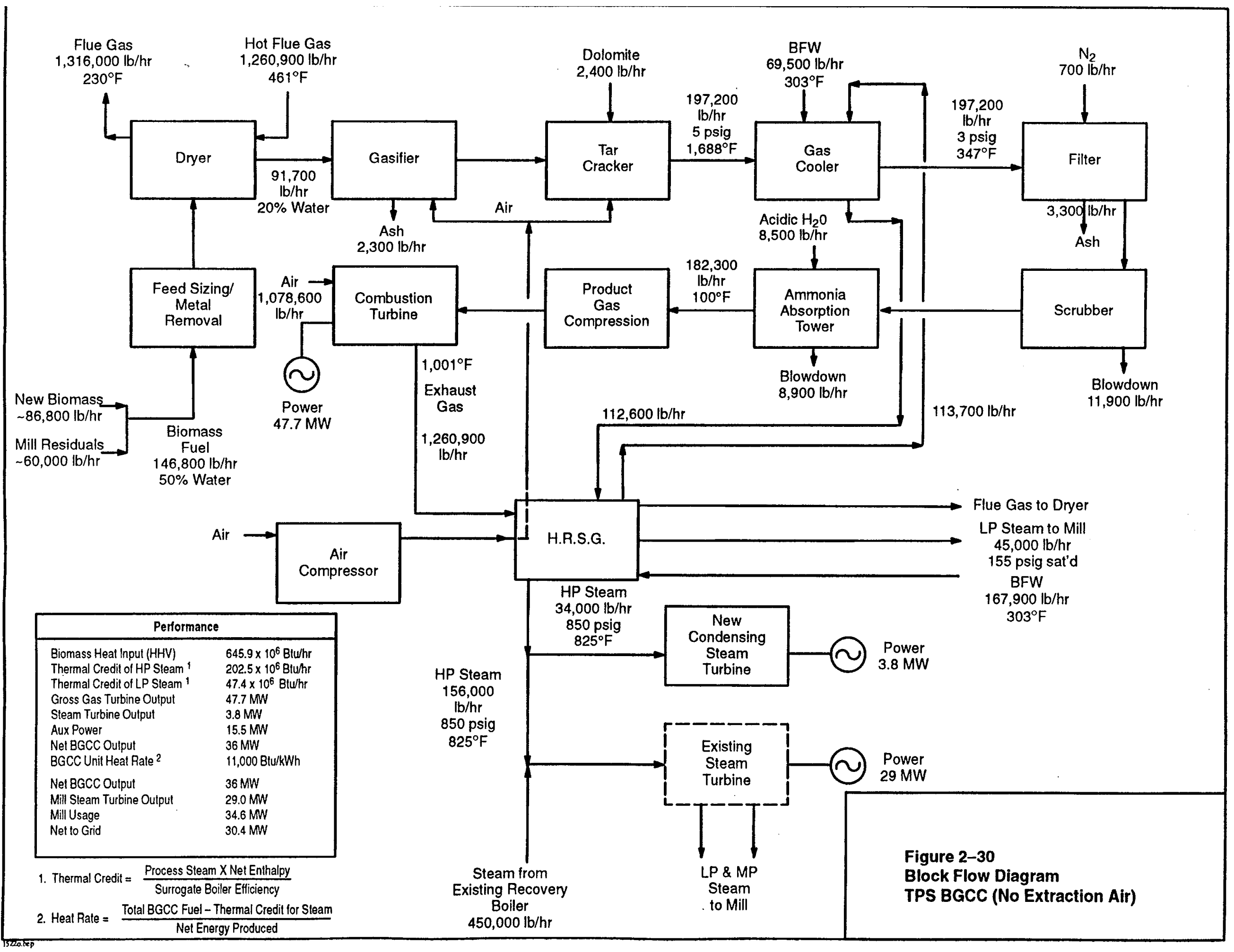




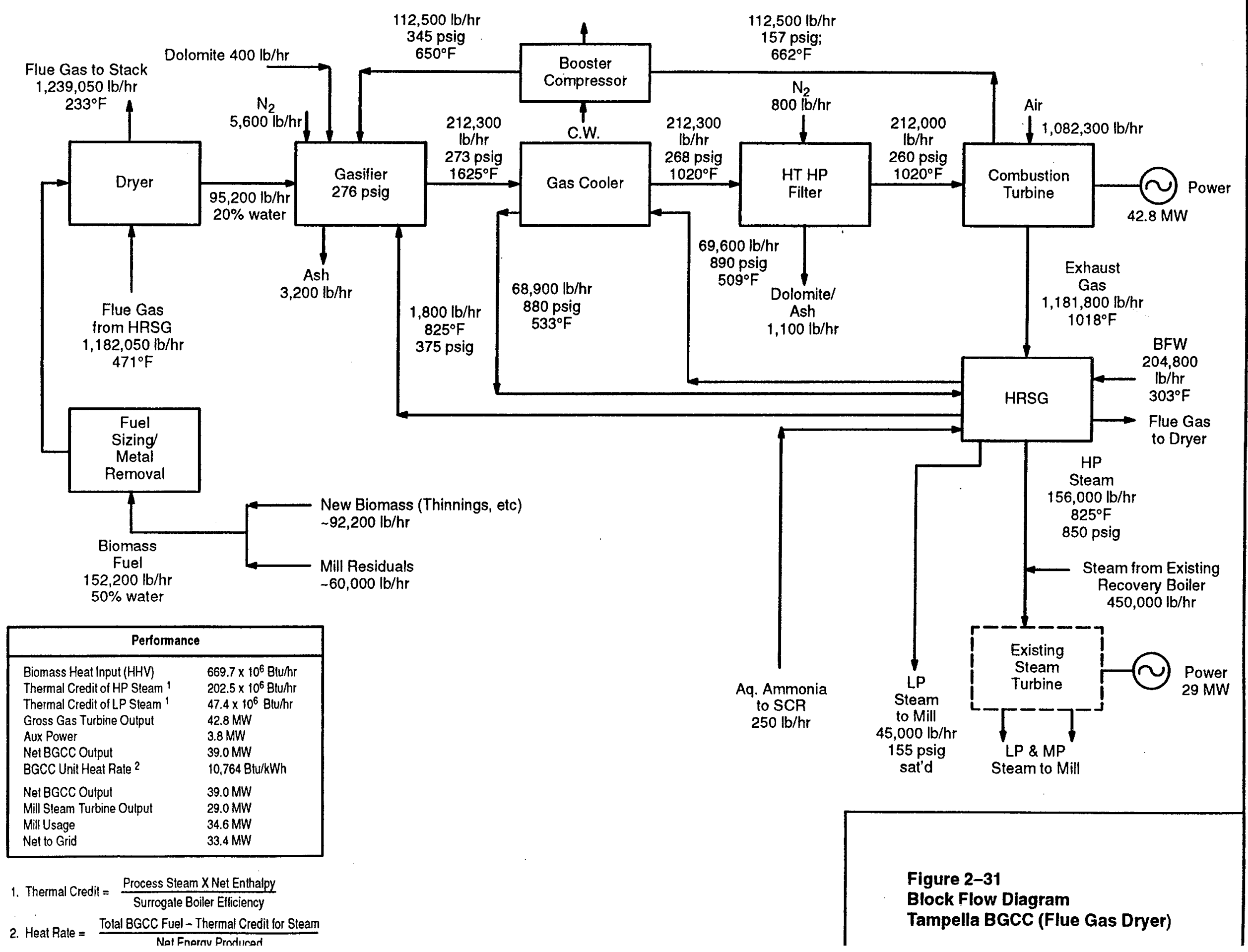




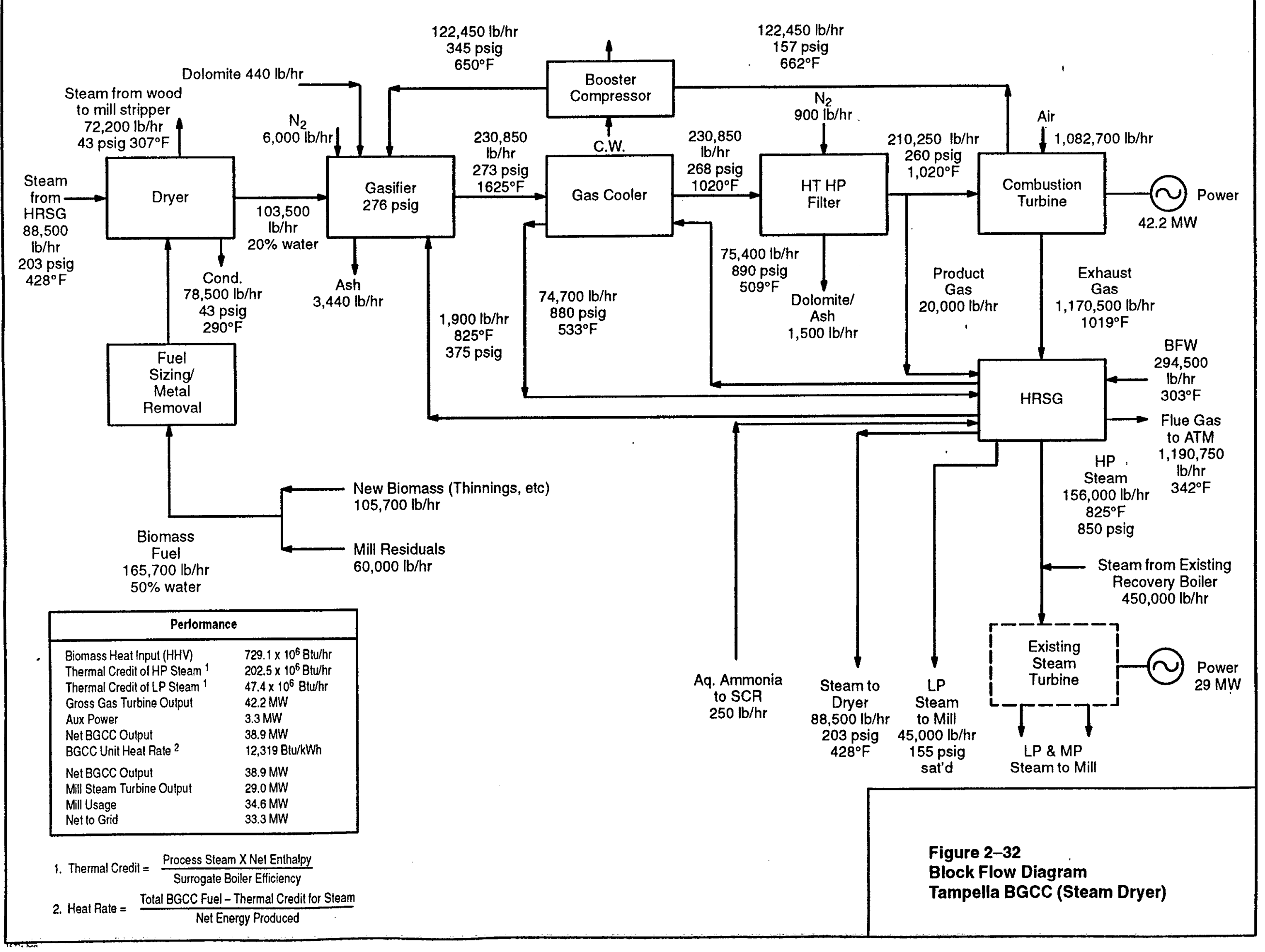




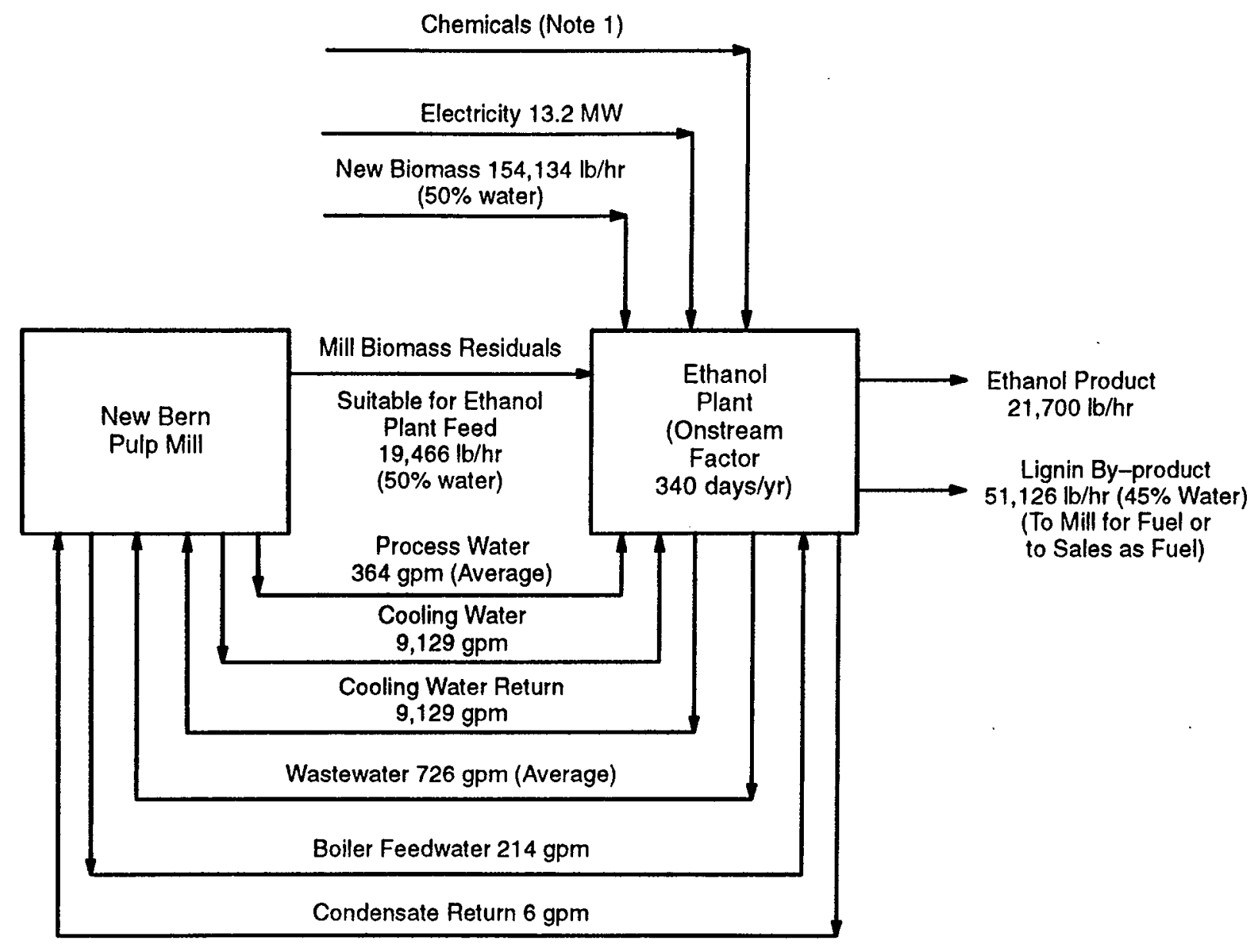

Note 1

Chemicals Summary:

Average

Hourly Requirement

Cellulase Enzyme (Wet Basis)

$$
\begin{gathered}
290 \mathrm{gal} \\
450 \mathrm{lbs} \\
27.5 \mathrm{lbs} \\
83.3 \mathrm{lbs} \\
5.8 \mathrm{lbs} \\
175 \mathrm{lbs} \\
15 \mathrm{lbs} \\
41.7 \mathrm{lbs} \\
67.2 \mathrm{gal} \\
760.5 \mathrm{gal}
\end{gathered}
$$




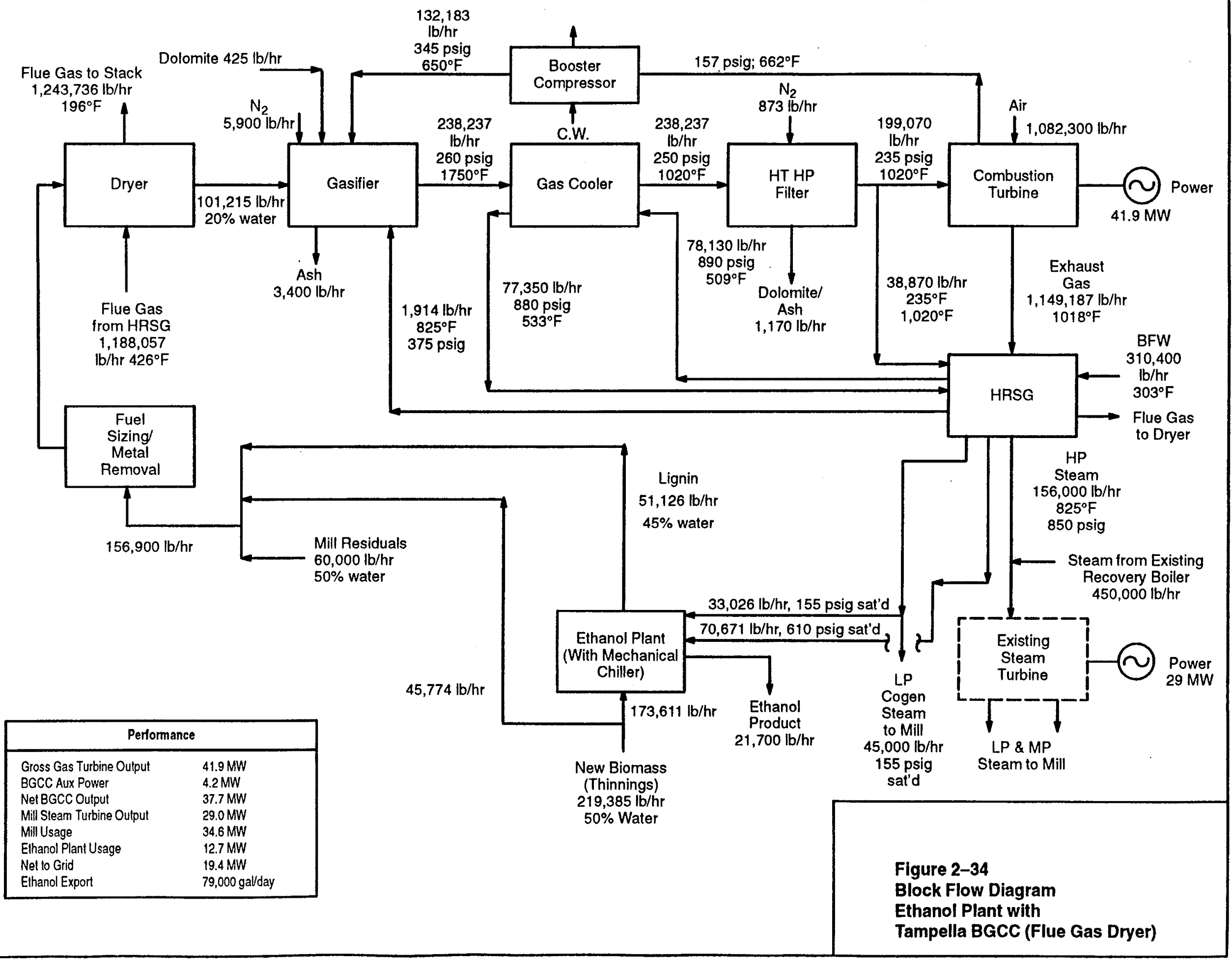




\subsection{Cost Estimates}

Stone \& Webster prepared capital cost estimates and operating and maintenance cost estimates for the BGCC cogeneration plants and for the ethanol plant. Weyerhaeuser provided corresponding cost information for a "Base Case" which is refurbishment of the existing bark boiler to extend its life and to allow it once again to burn mill residuals in compliance with emission limits. For all cases, including the Base Case, Stone \& Webster included the cost for the $10 \mathrm{MW}$ condensing steam turbine to allow the mill steam production to remain constant during most swings in mill steam usage and to eliminate reductions in electrical generation.

\subsubsection{Capital Cost Estimates}

The approach for developing the capital cost estimates for the BGCC cases was as follows:

- Gasification technology suppliers were requested to provide costs for major equipment within the gasification island.

- $\quad$ Stone \& Webster reviewed and checked pricing provided by gasification technology suppliers. The costs provided by Tampella included all the piping within the gasifier island. TPS submitted installed costs for the gasifier and tar cracker, including support steel and auxiliaries such as fuel and dolomite feed systems, cyclones, ash removal, and local instrumentation and control. TPS also provided "ball park" costs for the dryer, fuel gas compressor, fuel gas particulate filter (baghouse), water scrubber, and ammonia scrubber. Stone \& Webster obtained actual quotes for the dryer and the TPS fuel gas compressor. Stone \& Webster also priced the air supply system for TPS and designed and costed the TPS water scrubber and ammonia absorption tower.

- Stone \& Webster obtained pricing for major equipment/systems required for material handling, the cogeneration unit (power block), cooling water, service and instrument air, flare, distillate oil storage and supply, and overall plant control.

- Stone \& Webster estimated the costs of buildings and structures based on dimensions and materials of construction.

- Material costs for civil/structural, instruments and controls (with the exception of the distributed control system and the continuous emission monitoring system which were priced), electrical, piping and valves, insulation, fire protection and painting, and site improvements were calculated as percentages of total equipment costs based on factors Stone \& Webster developed from detailed estimates of gasification plants and combined cycle plants. These factors were adjusted to compensate for piping included in the Tampella-provided costs and support steel and instrumentation and controls in the TPS-provided costs.

- Installation (labor) costs for major equipment were based on a combination of vendor recommendations and Stone \& Webster experience.

- Installation labor for bulk materials was based on usual material/labor splits.

- Head office (engineering, procurement, other project services, and field support) costs and construction management costs were calculated as a percentage of the total direct cost based on Stone \&.Webster experience. 
- A 10 percent allowance for indeterminate (AFI) was added to arrive at the total installed plant cost. AFI covers items not yet defined at this stage of engineering.

Stone \& Webster believes that the accuracy of the installed cost estimate is \pm 30 percent. Prepaid royalties, preproduction (startup) costs, spare parts, working capital and the initial fill of catalyst and chemicals costs must be added to obtain a totat "overnight" capital cost. The initial process charge of catalyst and chemicals is small and was ignored. The other items were estimated based on the following procedure from the "Technical Assessment Guide" published by the Electric Power Research Institute:

- Prepaid royalties at 0.5 percent of the process capital.

- Preproduction (startup costs) totalling one month fixed operating cost, three months variable operating cost, 25 percent of full capacity fuel cost for one month and 2 percent of total installed cost.

- Working (inventory) capital equivalent to 30 days' supply of fuel plus consumables.

- Spare parts at 0.5 percent of the total installed cost.

The estimate summaries for the Tampella flue gas dryer-based BGCC plant, the Tampella steam dryerbased BGCC plant, and the TPS (flue gas dryer-based) BGCC plant are given in Tables 2-22, 2-23, and $2-24$.

Two ethanol plant estimates were prepared. The first estimate is for an ethanol plant which would be added to the Base Case (the mill with the refurbished bark-fired boiler). An oil-fired packaged boiler is included in the ethanol plant to supply the ethanol plant steam requirements and the stillage or lignin waste from the ethanol plant is sold as fuel. The second estimate is for an ethanol plant integrated with a BGCC plant at the mill. In this case, the BGCC plant is sized to replace the mill's bark-fired boiler and provide steam to the ethanol plant. The lignin from the ethanol plant satisfies a portion of BGCC plant feed requirement.

Stone \& Webster was given sufficient process information to size and cost all of the equipment in the ethanol plant with the exception of the pretreatment section. Amoco, the technology licensor, provided a lump sum estimated cost for the pretreatment step. Stone \& Webster applied recent in-house experience from two other biomass-to-ethanol projects in developing some equipment costs and in establishing factors for bulk materials and labor. The majority of the equipment costs were based on new quotes.

Indirect costs were developed as follows:

- Head office (engineering, procurement, other project services, and field support) costs and the cost for construction management were calculated as a percentage of the total direct cost based on Stone \& Webster experience.

- A 10 percent allowance for indeterminates (AFI) was added to cover items not yet defined at this stage of engineering design.

- Estimates for prepaid royalties, spare parts, working capital and preproduction (startup) were developed using the approach given in the "Technical Assessment Guide" (TAG) published by the Electric Power Research Institute. Prepaid royalties are assumed to be 0.5 percent of the process capital. The spare parts allowance is 0.5 percent of the total installed cost. Working capital covers 30 days' supply of feedstock plus consumables. Start-up costs for the ethanol plant 
were assumed to be equal to the sum of one month fixed operating costs (to cover training), 25 percent of the full capacity biomass feed cost for one month (to account for inefficient operation) and 2 percent of the total installed cost (to cover modifications needed to bring the unit to full capacity). Normally, one to three months variable operating cost is included in the startup cost estimate. However, as discussed in Section 2.7.2, the ethanol plant variable cost is high due to the assumed cost of the proprietary enzyme. Since the enzyme cost is uncertain, adding variable cost to the start-up cost estimate was considered to be unreasonable.

The cost estimate summary for the ethanol plant (excluding the cost of the Base Case mill's refurbished bark-fired boiler and new condensing steam turbine) is shown in Table 2-25. The cost estimate summary for the integrated BGCC-ethanol plant is given in Table 2-26. Stone \& Webster believes the accuracy of the estimates is \pm 30 percent. The estimates are present day overnight costs (no escalation or interest during construction) and do not include permitting costs.

The Base Case capital cost was developed as follows:

Cost to Refurbish Bark-Fired Boiler

Installed Cost for New Condensing Steam

Turbine, Auxiliaries, and Associated Equipment

Total Installed Cost

Startup

Spare Parts

Working Capital

Total (Overnight) Capital Cost
$\$ 14.0$ million

$\$ 6.2$ million

20.2 million

0.6 million

0.1 million

$\underline{0.2 \text { million }}$

$\$ 21.1$ million

The total capital cost for all of the cases studied are as follows:

Case

Tampella BGCC (Flue Gas Dryer Design)

Tampella BGCC (Steam Dryer Design)

TPS BGCC (Flue Gas Dryer Design)

Base Case Mill

Ethanol Plant

Base Case Mill plus Ethanol Plant

Integrated BGCC-Ethanol Plant
Overnight

Capital Cost

$\$ 97,930,000$

$\$ 97,689,000$

$\$ 106,470,000$

$\$ 21,100,000$

$\$ 96,830,000$

$\$ 117,930,000$

$\$ 189,802,000$

The economic analyses in Section 4 compare the Base Case mill, the Tampella (flue gas dryer design) BGCC plant, the Base Case mill with the ethanol plant, and the integrated BGCC/ethanol plant.

It must be emphasized that the above costs for the BGCC and ethanol plants are not exactly comparable to greenfield plants. The design and costs of the BGCC plants and the ethanol plant were impacted by mill integration. The integration benefitted from usage of the existing mill demineralized, service, potable boiler feedwater and cooling water systems and both the ethanol plant and the TPS BGCC Plant have 
wastewater which is sent to the mill wastewater treatment system. In addition, although a steam turbine was included for the BGCC plants, it is smaller than would have been required for a greenfield BGCC power plant.

Although the capital cost estimates show the TPS BGCC cogen plant capital cost being 10 percent higher than the Tampella BGCC plant, the accuracy of the cost estimating of the gasifier area is insufficient to substantiate this difference. The only conclusion that can be reached is that the capital cost of the atmospheric and pressurized BGCC designs at the $60 \mathrm{MW}$ equivalent plant size are very close.

Extrapolating from the data developed for the New Bern BGCC Cogen retrofit, a greenfield BGCC power plant (no cogeneration) based on the General Electric Frame 6B gas turbine would have the following cost and performance:

- Total Plant Investment - \$1,750/kW

- $\quad$ Net Output - $59 \mathrm{MW}$

- Biomass to Net Electricity Conversion Efficiency - 30 percent

EPRI provided the following cost and performance information for a BGCC power plant based on an advanced General Electric 6FA gas turbine:

- Total Plant Investment - $\$ 1,765 / \mathrm{kW}$

- Net Output - $100 \mathrm{MW}$

- $\quad$ Efficiency $-35.5 \%$

By capacity factoring from the New Bern data, Stone \& Webster would have expected the capital cost for a $100 \mathrm{MW}$ BGCC power plant to be $\$ 1,535 / \mathrm{kW}$, which is slightly lower than EPRI's cost. The higher efficiency of the $100 \mathrm{MW}$ plant is attributable to the advanced gas turbine.

The BGCC plant cost, especially for the advanced pressurized gasifier, hot gas cleanup designs, is expected to decrease as the technology matures. Reductions can occur as a result of the following:

- Reduction in contingencies, due to increased confidence

- $\quad$ Competitive pressures

- $\quad$ Reduction in manufacturing costs for the advanced technology components, e.g., hot gas filters

- Reduction in engineering costs due to standardization

- Improvements in constructability

- Design improvements which reduce equipment costs or sparing requirements

It is interesting to note that the development of coal gasification combined cycle technology focused on maximizing efficiency and not minimizing capital cost. The developers have now turned their attention to reducing capital cost and have identified several innovations which should produce cost reductions on the order of 20 percent without any significant decrease in efficiency. BGCC technology affords the same opportunity for cost reduction.

As discussed in Section 2.3, the ethanol plant design is conservative in many areas due to lack of physical data on process streams. Also the mild climate in New Bern required a sizeable chilled water system. 
Further process development and design optimization studies have the potential to yield significant cost reductions.

\subsubsection{Operating and Maintenance Cost Estimates}

Operating and maintenance costs were calculated for the Base Case, each of the three BGCC cases, the ethanol plant, and the BGCC/ethanol plant. The costs are comprised of fixed and variable operating costs which are divided as follows:

a. Fixed Operating Costs (independent of production)

- Permanent plant operating and maintenance staff including supervision and administration.

- Maintenance performed on a regular schedule, not specifically tied to the quantity of fuel or feed consumption; this includes materials and any purchased (contract) labor in addition to the permanent maintenance staff.

b. Variable Operating Costs (related to production)

- Consumables such as water, chemicals, and catalysts

- Ash disposal.

- Combustion turbine maintenance including materials and any purchased (contract) labor.

- Credits for sales of by-products.

The total annual operating and maintenance cost is the fixed cost plus the variable cost. Since the variable cost is dependent on the annual plant output, the anticipated capacity factor must be defined in order to calculate the annual variable cost. The capacity factor is the actual annual production divided by the theoretical annual production if the plant operated continuously at full capacity. An 85 percent capacity factor was used for the BGCC plant based on Tampella's recommendation. A 92 percent capacity factor was used for the ethanol plant, although fermentation plants should be able to achieve a capacity factor of 94 percent.

The biomass fuel or feedstock cost is not included in the total annual operating and maintenance cost.

The operating and maintenance costs were calculated using a spreadsheet program which clearly shows the basis for the calculation. The spreadsheet outputs for the cases are presented in Tables 2-27 through 2-32.

The results compare as follows:

Case

Tampella BGCC (Flue Gas Dryer)

Tampella BGCC (Steam Dryer)

TPS BGCC (Flue Gas Dryer)

Ethanol Plant

BGCC/Ethanol Plant

Base Case Mill

\section{Annual Fixed O\&M Cost, $\$$ \\ Hourly Variable \\ O\&M Cost, $\$$}

$\$ 3.7$ million

$\$ 3.7$ million

$\$ 3.7$ million

$\$ 3.3$ million

$\$ 6.6$ million

$\$ 1.7$ million
$\$ 199$

$\$ 212$

$\$ 132$

$\$ 3,040$

$\$ 2,556$

$\$ 23$
Total Annual

O\&M Cost

$\$ 5.2$ million

$\$ 5.3$ million

$\$ 4.7$ million

$\$ 27.8$ million

$\$ 27.1$ million

$\$ 1.9$ million 
The difference between the Tampella and TPS BGCC plants operating and maintenance costs is due to consumables. Tampella uses more nitrogen and requires ammonia and catalyst for the selective catalytic reduction (SCR) $\mathrm{NO}_{x}$ control unit in the heat recovery steam generator. Since ammonia is removed from the TPS fuel gas prior to combustion, an SCR unit should not be necessary.

The ethanol plant operating and maintenance cost is dominated by the cost of the proprietary enzyme. The enzyme was assumed to cost $\$ 2 /$ liter which, by itself, results in an hourly variable cost of $\$ 2,195$. A comparison of the ethanol plant cost with and without the enzyme cost is as follows:

\section{With Enzyme Cost Without Enzyme Cost}

Fixed Annual O\&M

Variable Hourly O\&M

Total Annual O\&M
$\$ 3.3$ million

$\$ 3,040$

$\$ 27.8$ million
$\$ 3.3$ million

$\$ 845$

$\$ 10.1$ million

Approximately 65 percent of the annual operating and maintenance cost of the ethanol plant (excluding the cost of the biomass feed) is contributed by the enzyme cost at $\$ 2 /$ liter. Enzyme cost is one of the major parameters affecting ethanol plant economics and its impact is studied in Section 4.

For the ethanol plant alone which would be combined with the Base Case Mill costs, it is assumed that the lignin waste (stillage) from the ethanol plant is sold as fuel for $\$ 0.96 /$ million Btu (HHV basis). In the case of the integrated BGCC/ethanol plant, the lignin is used as fuel in the BGCC plant, reducing the outside biomass purchases. In this instance, a credit is not given for the lignin by-product in the O\&M cost estimate. 
Table 2-22 Estimate Summary - Tampelia BGCC (Flue Gas Drying)

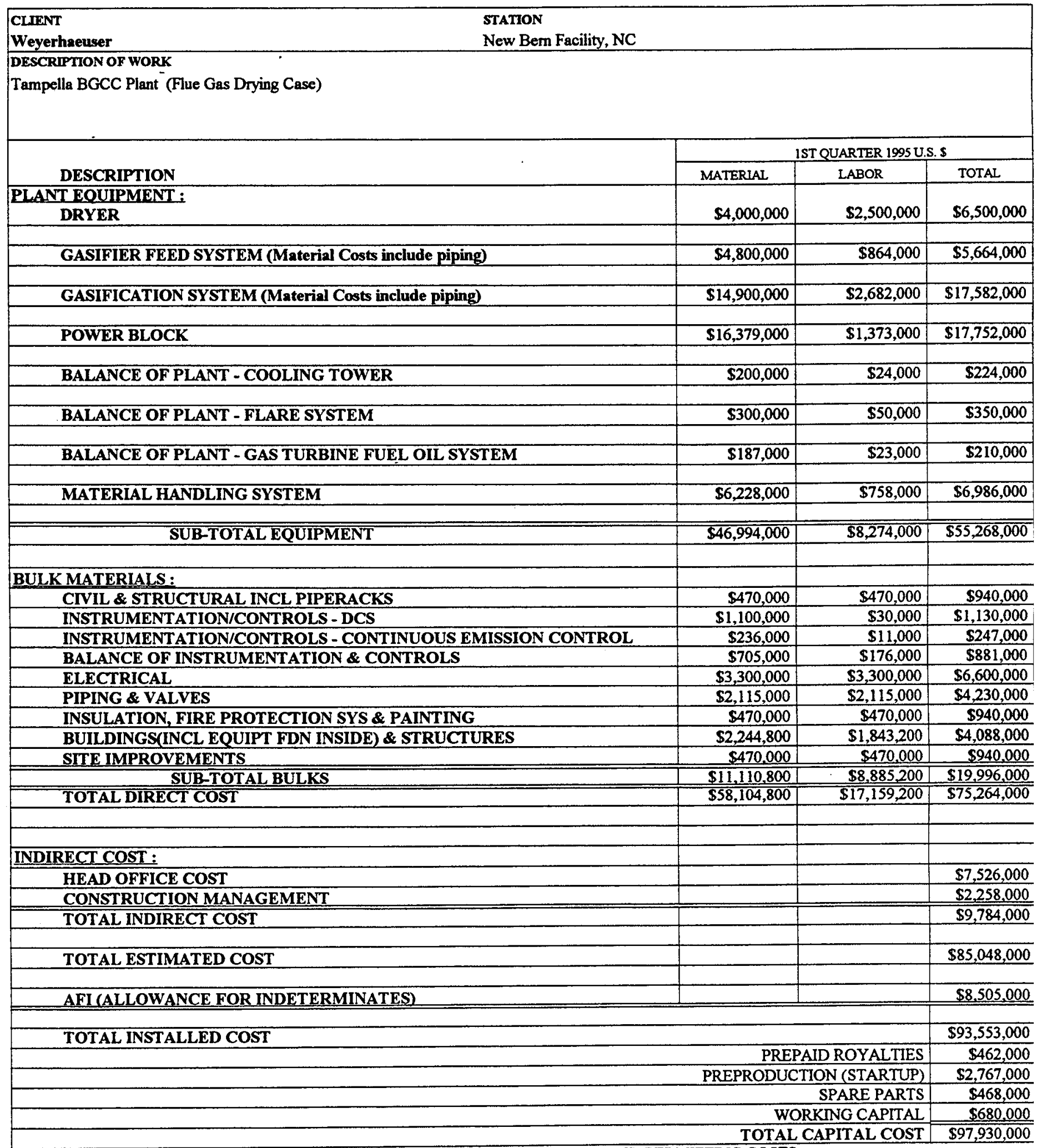

NOTE: EXCLUDES ESCALATION,INTEREST DURING CONSTRUCTION, AND PERMITTING COSTS 
Table 2-23 Estimate Summary - Tampella BGCC (Steam Drying)

\begin{tabular}{|c|c|c|c|}
\hline $\begin{array}{l}\text { STATION } \\
\text { New Bern Facility, NC }\end{array}$ & & & \\
\hline \multicolumn{4}{|l|}{$\begin{array}{l}\text { DESCRIPTION OF WORK } \\
\text { Tampella BGCC Plant (Steam Drying Case) }\end{array}$} \\
\hline & \multicolumn{3}{|c|}{ IST QUARTER 1995 U.S. \$ } \\
\hline DESCRIPTION & MATERIAL & LABOR & TOTAL \\
\hline$\frac{\text { PLANT EQUIPMENT: }}{\text { DRYER }}$ & $\$ 5,000,000$ & $\$ 3,000,000$ & $\$ 8,000,000$ \\
\hline GASIFIER FEED SYSTEM (Material Costs include piping) & $\mathbf{S 4 , 8 0 0 , 0 0 0}$ & $\$ 864,000$ & $\$ 5,664,000$ \\
\hline GASIFICATION SYSTEM (Material Costs include piping) & $\$ 15,800,000$ & $\$ 2,844,000$ & $\$ 18,644,000$ \\
\hline POWER BLOCK & $\$ 14,422,000$ & $\$ 1,261,000$ & $\$ 15,683,000$ \\
\hline BALANCE OF PLANT - COOLING TOWER & $\$ 200,000$ & $\$ 24,000$ & $\$ 224,000$ \\
\hline BALANCE OF PLANT - FLARE SYSTEM & $\$ 300,000$ & $\$ 50,000$ & $\$ 350,000$ \\
\hline BALANCE OF PLANT - GAS TURBINE FUEL OIL SYSTEM & $\$ 187,000$ & $\$ 23,000$ & $\$ 210,000$ \\
\hline MATERIAL HANDLING SYSTEM & $\$ 5,595,000$ & $\$ 682,000$ & $\$ 6,277,000$ \\
\hline SUB-TOTAL EQUTPMENT & $\$ 46,304,000$ & $\$ 8,748,000$ & $\$ 55,052,000$ \\
\hline BULKMATERIALS: & & & \\
\hline CIVIL \& STRUCTURAL INCL PIPERACKS & $\$ 463,000$ & $\$ 463,000$ & $\$ 926,000$ \\
\hline INSTRUMENTATION/CONTROLS - DCS & $\$ 1,100,000$ & $\$ 30,000$ & $\$ 1,130,000$ \\
\hline INSTRUMENTATION/CONTROLS - CONTINUOUS EMISSION CONTROL & $\$ 236,000$ & $\$ 11,000$ & $\$ 247,000$ \\
\hline BALANCE OF INSTRUMENTATION \& CONTROLS & $\$ 695,000$ & $\$ 174,000$ & $\$ 869,000$ \\
\hline ELECTRICAL & $\$ 3,300,000$ & $\$ 3,300,000$ & $\$ 6,600,000$ \\
\hline PIPING \& VALVES & $\$ 2,084,000$ & $\$ 2,084,000$ & $\$ 4,168,000$ \\
\hline INSULATION, FIRE PROTECTION SYS \& PAINTING & $\$ 463,000$ & $\$ 463,000$ & $\$ 926,000$ \\
\hline BUILDINGS(INCL EQUIPT FDN INSIDE) \& STRUCTURES & $\$ 2,244,800$ & $\$ 1,843,200$ & $\$ 4,088,000$ \\
\hline SITE IMPROVEMENTS & $\$ 463,000$ & $\$ 463,000$ & $\$ 926,000$ \\
\hline SUB-TOTAL BULKS & $\$ 11,048,800$ & $\$ 8,831,200$ & $\$ 19,880,000$ \\
\hline TOTAL DIRECT COST & $\$ 57,352,800$ & $\$ 17,579,200$ & $\$ 74,932,000$ \\
\hline INDIRECT COST: & & & \\
\hline HEAD OFFICE COST & & & $\$ 7,493,000$ \\
\hline CONSTRUCTION MANAGEMENT & & & $\$ 2,248,000$ \\
\hline TOTAL INDIRECT COST & & & $\$ 9,741,000$ \\
\hline TOTAL ESTIMATED COST & & & $\$ 84,673,000$ \\
\hline AFI (ALLOWANCE FOR INDETERMINATES) & & & $\$ 8,467,000$ \\
\hline TOTAL INSTALLED COST & & & $\$ 93,140,000$ \\
\hline & PREPA & ID ROYALTIES & $\$ 460,000$ \\
\hline & PREPRODUCTI & ON (STARTUP) & $\$ 2,806,000$ \\
\hline & & SPARE PARTS & $\$ 466,000$ \\
\hline & WORK & KING CAPITAL & $\$ 817,000$ \\
\hline & TOTAL C & APITAL COST & $\$ 97,689,000$ \\
\hline
\end{tabular}

NOTE: EXCLUDES ESCALATION, INTEREST DURING CONSTRUCTION, AND PERMITTING COSTS 
Table 2-24 Estimate Summary - TPS BGCC (Flue Gas Drying)

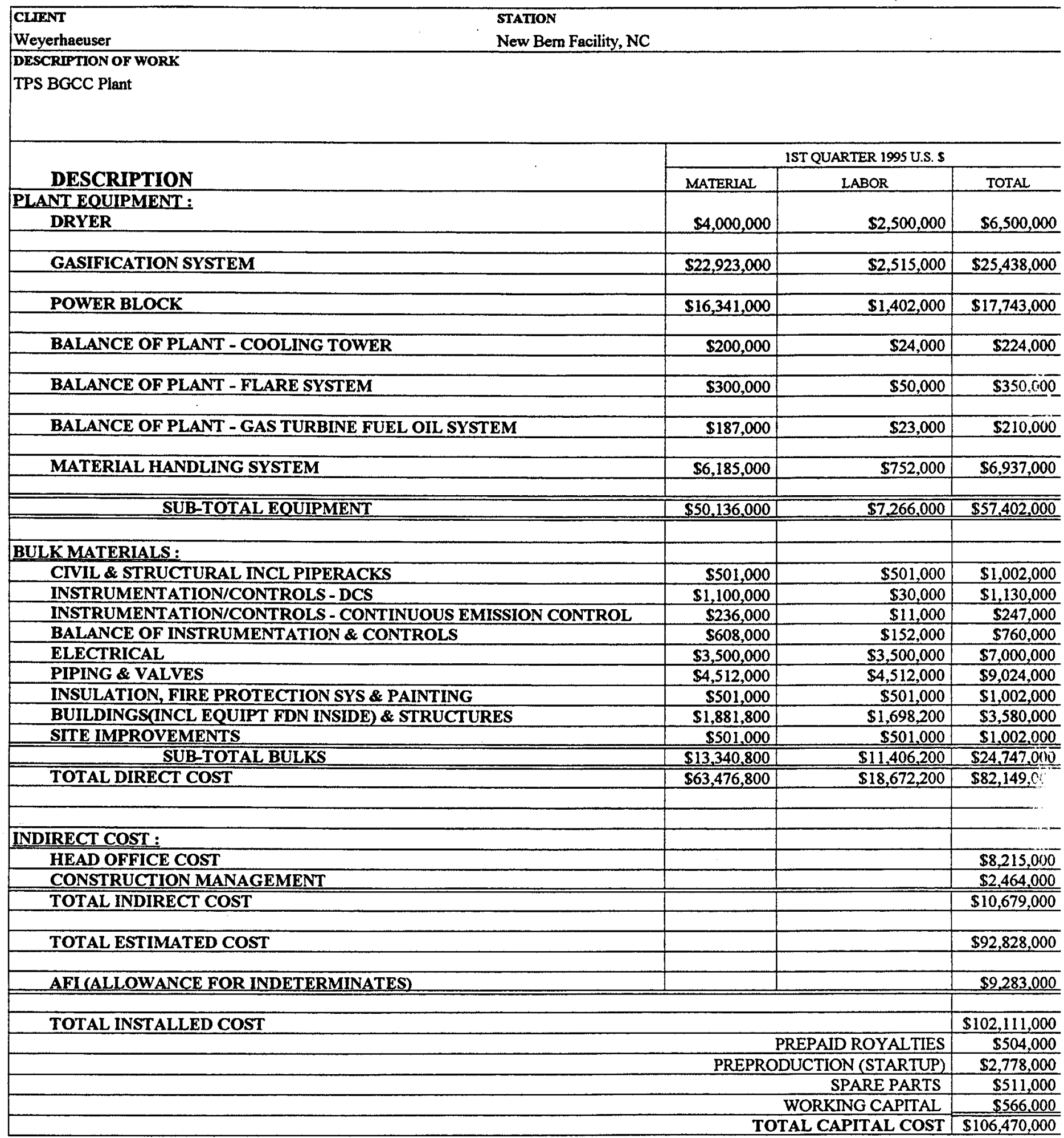

NOTE: EXCLUDES ESCALATION, INTEREST DURING CONSTRUCTION, AND PERMITTING COSTS. 


\begin{tabular}{|c|c|c|c|}
\hline $\begin{array}{l}\text { STATION } \\
\text { New Bern Facility, NC }\end{array}$ & & & \\
\hline \multicolumn{4}{|l|}{$\begin{array}{l}\text { DESCRIPTION OF WORK } \\
\text { Ethanol Plant }\end{array}$} \\
\hline & \multicolumn{3}{|c|}{ IST QUARTER 1995 U.S.S } \\
\hline DESCRIPTION & MATERIAL & LABOR & TOTAL \\
\hline \multicolumn{4}{|l|}{ ETHANOL PLANT OEXCLURING UTI TIEST } \\
\hline TOWERS & $\$ 880,000$ & $\$ 44,000$ & $\$ 924,000$ \\
\hline DRUMSIVESSELS & $\$ 6,140,000$ & $\$ 245,600$ & $\$ 6,385,600$ \\
\hline PUMPS & $\$ 1,920,000$ & $\$ 230,400$ & $\$ 2,150,400$ \\
\hline STORAGE TANKS & $\$ 1,140,000$ & $\mathbf{S 5 7 , 0 0 0}$ & $\$ 1,197,000$ \\
\hline HEAT EXCHANGERS & $\$ 1,430,000$ & $\$ 42,900$ & $\$ 1,472,900$ \\
\hline SPECIAL EQUIPMENT & $\$ 19,466,000$ & $\$ 1,621,920$ & $\$ 21,087,920$ \\
\hline SOLIDS HANDLING EQUIPMENT & $\$ 3,685,000$ & $\$ 267,950$ & $\$ 3,952,950$ \\
\hline $\begin{array}{l}\text { SUB-TOTAL EQUIPMENT } \\
\end{array}$ & $\$ 34,661,000$ & $\$ 2,509,770$ & $\$ 37,170,770$ \\
\hline \multicolumn{4}{|l|}{ BULKINSTALLATION MATERIALS } \\
\hline CIVIL \& STRUCTURAL & $\mathbf{S 2 , 2 3 1 , 1 9 8}$ & $\mathbf{S 3 , 6 4 0 , 3 7 6}$ & $\$ 5,871, \$ 73$ \\
\hline INSTRUMENTATION AND CONTROLS & $\$ 4,272,618$ & $\$ 1,942,099$ & $\$ 6,214,717$ \\
\hline ELECTRICAL & $\$ 2,034,936$ & $\$ 2,817,604$ & $\$ 4,852,540$ \\
\hline PIPING \& VALVES & $\$ 4,825,951$ & $\$ 7,755,992$ & $\$ 12,581,943$ \\
\hline INSULATION, FIRE PROTECTION SYS AND PAINTING & $\$ 430,274$ & $\$ 956,166$ & $\$ 1,386,440$ \\
\hline BUILDINGS & $\$ 1,784,500$ & $\$ 1,215,500$ & $\mathbf{s 3 , 0 0 0 , 0 0 0}$ \\
\hline SITE IMPROVEMENTS & $\$ 82,416$ & $\$ 659,329$ & $\$ 741,745$ \\
\hline RAIL SPUR EXTENSION & $\$ 53,333$ & $\$ 66,667$ & $\$ 120,000$ \\
\hline SUB-TOTAL BULKS & $\$ 15,715,227$ & $\$ 19,053,732$ & $\$ \$ 34,768,959$ \\
\hline DIRECT COST & $\$ 50,376,227$ & $\$ 21,563,502$ & $\$ 71,939,729$ \\
\hline \multicolumn{4}{|l|}{ ETHANOL PLANT UTHITIES } \\
\hline POWER BLOCK PACKAGE BOIER & $\$ 900,000$ & $\$ 100,000$ & $\$ 1,000,000$ \\
\hline BALANCE OF PLANT - COOLING TOWER & $\mathbf{\$ 2 5 0 , 0 0 0}$ & $\$ 30,000$ & $\$ 280,000$ \\
\hline BALANCE OF PLANT - FLARE SYSTEM AND CERLER & $\$ 520,000$ & $\$ 112,000$ & $\$ 632,000$ \\
\hline \begin{tabular}{|c} 
SUB-TOTAL EQUIPMENT \\
\end{tabular} & $\$ 770,000$ & $\$ 152,000$ & $\$ 1,912,000$ \\
\hline \multicolumn{4}{|l|}{ BULK MATERIALS : } \\
\hline CIVIL \& STRUCTURAL INCL PIPERACKS & $\$ 8,000$ & $\$ 8,000$ & $\$ 16,000$ \\
\hline BALANCE OF INSTRUMENTATION \& CONTROLS & $\$ 12,000$ & $\$ 3,000$ & $\mathbf{S 1 5 , 0 0 0}$ \\
\hline ELECTRICAL & $\$ 23,000$ & $\$ 23,000$ & $\$ 46,000$ \\
\hline PIPING \& VALVES & $\$ 35,000$ & $\$ 35,000$ & $\$ 70,000$ \\
\hline INSULATION, FIRE PROTECTION SYS \& PAINTING & $\$ 8,000$ & $\mathbf{\$ 8 , 0 0 0}$ & $\$ 16,000$ \\
\hline STTE IMPROVEMENTS & $\$ 8,000$ & $\$ 8,000$ & $\$ 16,000$ \\
\hline SUB-TOTAL BULKS & $\$ 94,000$ & $\$ 85,000$ & $\$ 179,000$ \\
\hline DIRECT COST & $\$ 864,000$ & $\$ 237,000$ & $\$ 2,091,000$ \\
\hline DIRECT COST - ETHANOL PLANT & & & $\$ 71,940,000$ \\
\hline DIRECT COST - UTHITIES SUPPORT & & & $\$ 2,091,000$ \\
\hline TOTAL DIRECT COST & & & $\$ 74,031,000$ \\
\hline HEAD OFFICE COST & & & $\$ 7,403,000$ \\
\hline CONSTRUCTION MANAGEMENT & & & $\$ 2,221,000$ \\
\hline TOTAL INDIRECT COST & & & $\$ 9,624,000$ \\
\hline TOTAL ESTMMATED COST & & & $\$ 83,655,000$ \\
\hline AFI (ALLOWANCE FOR INDETERMINATES) & & & $\$ 8,366,000$ \\
\hline TOTAL INSTALLED COST & & & $\$ 90,925,000$ \\
\hline & PREPAID & ROYALTIES & $\$ 455,000$ \\
\hline & PREPRODUCTIO & (STARTUP) & $\$ 2,312,000$ \\
\hline & & ARE PARTS & $\$ 460,000$ \\
\hline & WORKII & G CAPITAL & $\$ 2,678,000$ \\
\hline & TOTAL CA & PITAL COST & $\$ 96,830,000$ \\
\hline
\end{tabular}


Table 2-26 Estimate Summary - Tampella BGCC/Ethanol Plant

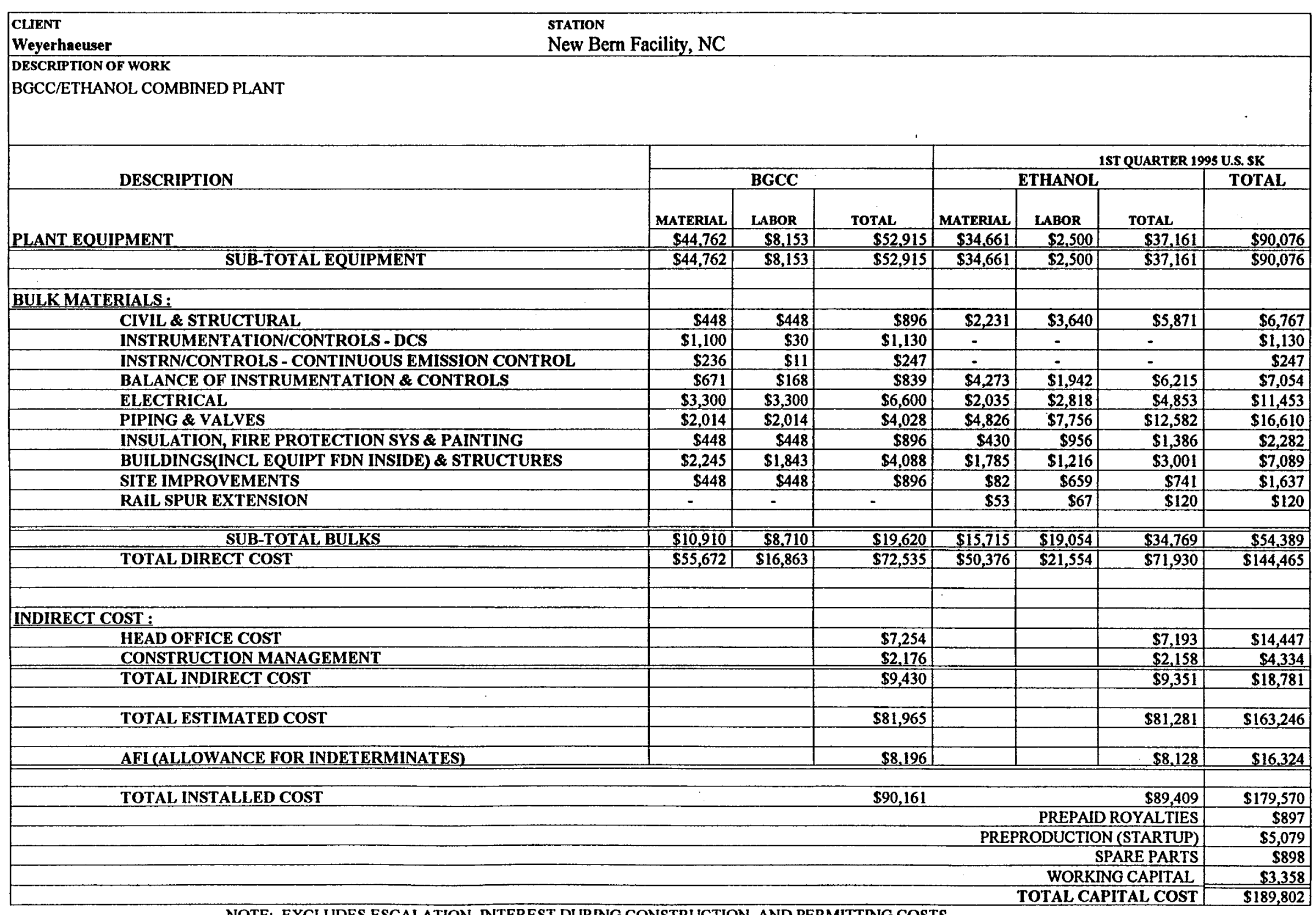




\section{TAMPELLA BGCC FLUE GAS DRYER DESIGN}

\section{O\&M COST SUMMARY EXCLUDING BIOMASS COST} ACETDESCRIPTION

TOTAL O\&M

$5155 \mathrm{ks} / \mathrm{yr}$

FIXED OBM

Fixod mat' O\&M

Fixed labor O\&N

VARIABLE O\&M

Variable labor O\&M

Variable mat'I O\&M

\begin{tabular}{|c|c|}
\hline 3,656 & $k s / y$ \\
\hline$\frac{1.305}{2.351}$ & {$\left[\begin{array}{l}k \leqslant / y \\
k \leqslant / y\end{array}\right.$} \\
\hline 1.499 & 1 \\
\hline $\begin{array}{r}98 \\
1,401\end{array}$ & \\
\hline
\end{tabular}

Basis for calculation of O\&M costs:

Plant Capital Cost \%

Full load heat input m. Biomass 10^6 Btu/hr HHV basis

Capacity factor

Annual operation 7.446 hrs per year at full load

Operating labor rate 6 grosols \$/hr (salary)

Stan maint labor rate

Labor Supervision $/$.

Overhead \% of labor \& supervision

Contract labor rate.

Contract Supervision

FIXED O\&M

Operating stafi $6.25 *$ workers at site per shift (4 shitts)

Truck Unloading

Wood Pite

Gasifier

Cntrl Rm Ops-BGCC

Roving Ops - BGCC

Cntrl Rm Ops-EtOH

Roving Ops - EtOH

Operating labor cost

Supervision

Labor overhead

Total oporating labor cost

Maintenance stafi Maint labor cost Supervision

Labor overhead Total fixed maint labor cost

\begin{tabular}{|c|c|}
\hline & 25 \\
\hline & 40 \\
\hline & 2 \\
\hline 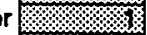 & 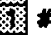 \\
\hline 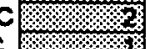 & 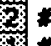 \\
\hline & 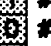 \\
\hline & 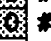 \\
\hline 1.040 & \\
\hline 312 & \\
\hline 406 & \\
\hline 1.758 & \\
\hline & 3 \\
\hline & 24 \\
\hline 37 & 37 \\
\hline 158 & \\
\hline
\end{tabular}

Hours per wook

* workers managing wood pile per shith

* workers operating gasifier per shit

* workers in BGCC control room per shit

* operators roving BGCC plant per shift

* workers in EtOH control room per shift

* operators roving EtOH plant per shift

$\mathrm{kS} / \mathrm{yr}$ [ $6.25 \times 2080 \mathrm{hr} / \mathrm{yr} \times 4$ shifts $\times 20 \mathrm{~s} / \mathrm{hr} / 1000$ ]

$\mathrm{ks} / \mathrm{yr}$ [ 30/100 $x$ operating labor cost]

ks/yt [ 30/100 $\times$ (operating + supervision costs)]

58 \$k/yr [total of labor cost, supervision, and overhead]

Maintenance materials and contract labor

\begin{tabular}{|c|c|c|c|c|c|c|}
\hline Major equipment maintenance & $\begin{array}{l}\text { Period } \\
\text { months }\end{array}$ & $\begin{array}{l}\text { Materials } \\
\$ k\end{array}$ & $\begin{array}{c}\text { Contract } \\
\text { Labor } \\
\text { hours }\end{array}$ & $\begin{array}{c}\text { Contract } \\
\text { Labor } \\
\text { \$k }\end{array}$ & $\begin{array}{l}\text { Average } \\
\text { Cost } \\
\text { Materials } \\
\text { S K /yr }\end{array}$ & $\begin{array}{c}\text { Average } \\
\text { Cost } \\
\text { Labor } \\
\$ \mathrm{kJyr}\end{array}$ \\
\hline Gasifier Packago & 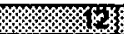 & \% scts & \% & 436 & 1,005 & 436 \\
\hline HRSG & 2 & 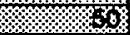 & $\vee \%$ & 0 & 50 & 0 \\
\hline Stm turbine - major & 80 & 80 & 林 & $\mathbf{0}$ & 0 & 0 \\
\hline Stm turbine - minor & 18 & 10 & 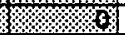 & 0 & o & 0 \\
\hline Ethanol Plant & 83 & 8 & 8 & 0 & o & 0 \\
\hline B.O.P. - major & 60 & 80 & 0 & 0 & 0 & 0 \\
\hline B.O.P. - minor & 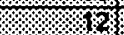 & 250 & 0 & 0 & 250 & 0 \\
\hline & & & & & & 36 \\
\hline
\end{tabular}

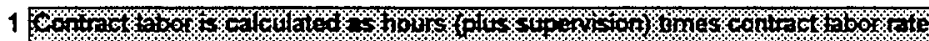

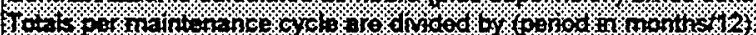

2 noj

SUMMARY OF FIXED O\&M

Operating labor

Maintenance labor

Contract labor

Maintenance materials

Total fixed O\&M materials

Total fixed O\&M labor

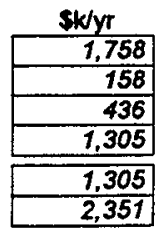

Note: Shaded cells are for spreadsheet inputs; clear cells are calculated 
VARIABLE OBM

Consumables

Process water

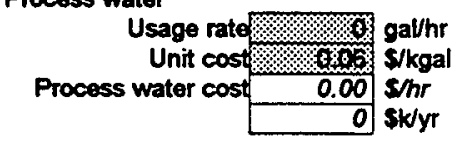

Cooling system makeup

Usage rate

costs.

Raw water cost $\quad 0.10$ S/hr

Demineralized water for feedwater makeup

Usage rate/ $\%$ gallhr

Raw water unit costi...

Demineralization unit cost 1 . .

Dermin water cost $0.36 \mathrm{~s} / \mathrm{hr}$

3 skyr

Catalysts and chemicals

\begin{tabular}{|c|c|c|c|c|c|}
\hline Item & Usage Rate & SUnit & Units & S/hr & kSTyr \\
\hline Dolomite & $\%$ o 20 TPH & 7,25 & \% 1818 & 5 & 37 \\
\hline Continuous N2 & K 3 TPH & 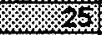 & \% & 74 & 549 \\
\hline Liquid N2 & \% TPY & 15 & Koins & 1 & 11 \\
\hline Aqueous NH3 & 25 PPH & $11 \%$ & Hons & 22 & 166 \\
\hline SCR Catalyst & \& Lot & 160 & $160 \%$ & 9 & 75 \\
\hline Enzyme & 3 GPD & 62 & $\mathrm{E}_{\mathrm{ter}}$ & 0 & 0 \\
\hline Sulfuric Acid & O TPD & 61 & 6 & $\overline{0}$ & o \\
\hline Glucose Syrup & OT:TPD & 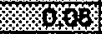 & 66 & 0 & 0 \\
\hline Denaturant & O GPD & 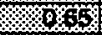 & 69 & 0 & 0 \\
\hline Pkgd Boiler Fuel Oil & SMBTU/Hr & 836 & Mist & $\overline{0}$ & 0 \\
\hline Misc. & B 6 O Hrs & 18 & 8 & 5 & 44 \\
\hline & & & & 116 & 882 \\
\hline
\end{tabular}

Total consumables $\quad 886$ \$ $\$$ Kyr

Other Variable O\&M Costs

Ash Disposal

$$
\begin{aligned}
& \text { Production Rate. } \\
& \text { Disposal Cost/2 } 1 \text { of \$/ton } \\
& 26 \mathrm{~S} / \mathrm{hr}
\end{aligned}
$$

Incremental Maintenance on Combustion Turbine

Number of CTs:

Cost of Maintenance and Overhauls per CT

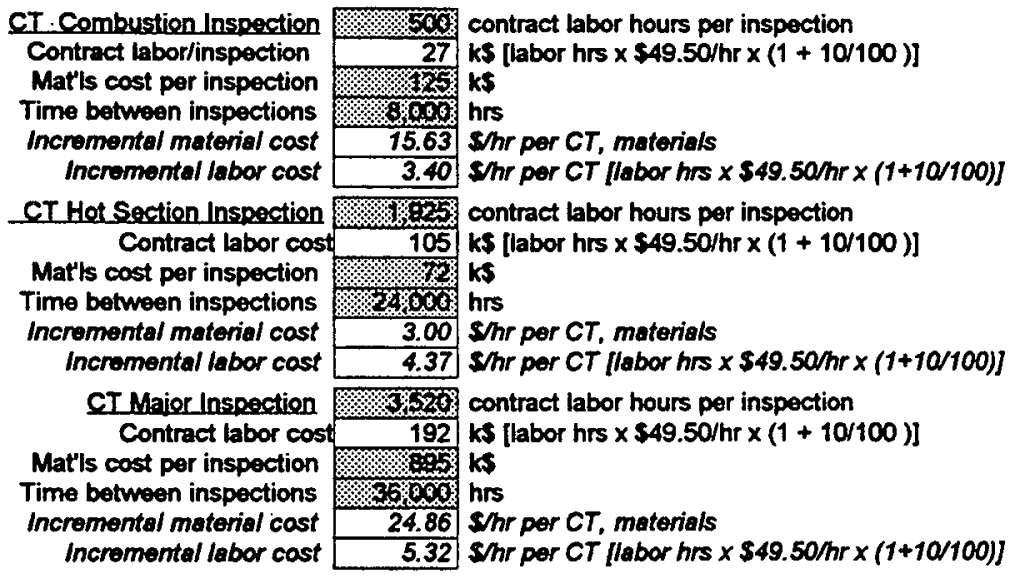

Total incremental mat'l cost Total incremental labor cost

43.49 $\mathrm{S} / \mathrm{hr}$ [ total of above materials $\times$ number of CT's] $13.09 \mathrm{~S} / \mathrm{hr}$ [ total of above labor $x$ number of CT's ]

SUMMARY OF VARIABLE O\&M

Consumables

Other Variable OSM Costs

CT Maintenance materials

Total variable O\&M material Total variable O\&M labor
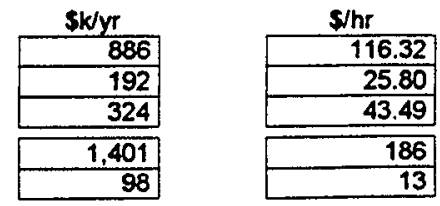
TAMPELLA BGCC STEAM DRYER DESIGN

\section{O\&M COST SUMMARY EXCLUDING BIOMASS COST} ACETDESCRIPTION TOTAL OSM

$5256 \mathrm{k} \$ \mathrm{yr}$

FIXED O\&M

Fixed mat' OsM

Fixed labor O\&M

VARIABLE O\&M

Variable labor OSM

Variable mat'l OsM

Basis for calculation of O8M costs:

Plant Capital Cost

Full load heat input

Capacity factor

Annual operation

Operating labor rate

Staff maint tabor rate

Labor Supervision Overhead

Contract labor mate

Contract Supervision

$3.656 \mathrm{ks} / \mathrm{yr}$

$1,305 \mathrm{k} \$ \mathrm{yr}$

$2,351 \mathrm{ks} / \mathrm{yr}$

$1,599 \mathrm{ks} / \mathrm{yr}$

$98 \mathrm{ks} / \mathrm{yr}$ $1,502] \mathrm{ks} / \mathrm{yr}$

Based on Capacity Factor of $85 \%$

FIXED O\&M

Operating staf Truck Unloading Wood Pile Gasifier

Cntr Rm Ops-BGCC

Roving Ops - BGCC

Cntr Rm Ops-EtOH

Roving Ops - EtOH

Operating labor cost Supervision

Labor overhead

Tatal operating labor cost

Maintenance stafi

Maint labor cost

Supervision

Labor overheac

府

$M \$$

Biomass $10^{4} 6$ Btu/hr HHV basis

7.46

7.446 hrs per year at full load

0.295 SMBtu HHV

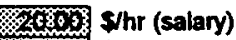

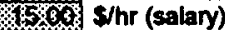

36. \% of labor

$\$$ to $\$ / h$

\% of contract labor

Hours per woek

7 workers managing wood pite per shitt

\% * workers operating gasifier per shith

\% workers in BGCC control room per shitt

* operators roving BGCC plant per shitt

73) * workers in EtOH control room per shitt

* operators roving EtOH plant per shil

$1.040 \mathrm{ks} / \mathrm{yr}[6.25 \times 2080 \mathrm{hr} / \mathrm{yr} \times 4$ shifts $\times 20 \mathrm{~s} / \mathrm{hr} / 1000$ ]

$312 \mathrm{k} \$ \mathrm{yr}$ [ $30 / 100 \times$ operating labor cost]

$406 \mathrm{~K} \$ / \mathrm{yr}$ [ $30 / 100 \times$ (operating + supervision costs)]

1.758 \$K/yr [total of labor cost, supervision, and overhead]

\% * workers at site (1 shith only)

94 Sk/yr

28 Skyr

$3 \times 2080 \mathrm{hr} / \mathrm{yr} \times$

$15 \mathrm{~S} / \mathrm{hr} / 1000$ ]

37 \$k/yr

$30 / 100 \times$ maintenance labor cost ]

$30 / 100 \times$ (maint labor + supervision) ]

Totel fixed maint labor cost 158 sk/yr [total of labor cost, supervision, and overhead]

Maintenance materials and contract labor

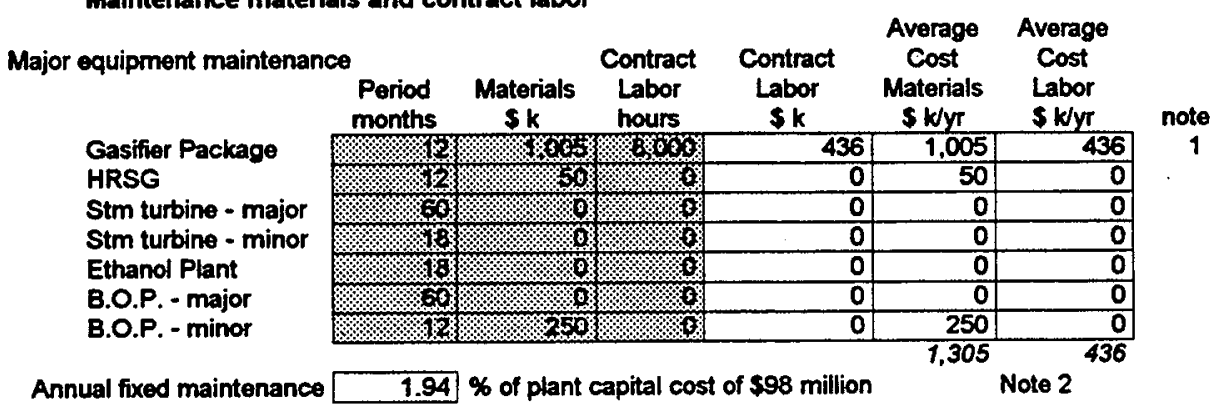

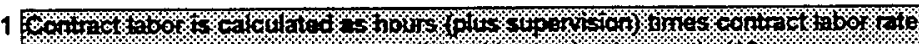

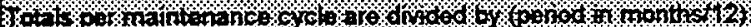

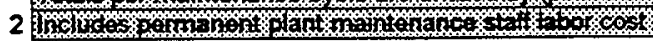

SUMMARY OF FIXED O\&M

Operating labor

Maintenance labor

Contract labor

Maintenance materials

Total fixed O\&M materials

Total fixed O\&M labor

\begin{tabular}{|r|}
\multicolumn{1}{c}{$\mathbf{S k} / \mathbf{y}$} \\
\hline 1,758 \\
\hline 158 \\
\hline 436 \\
\hline 1,305 \\
\hline 1,305 \\
\hline 2,351 \\
\hline
\end{tabular}

Note: Shaded cells are for spreadsheet inputs; clear cells are calculated 


\section{VARIABLE OSM}

Consumables

Process water

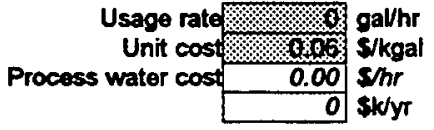

Cooling system makeup

Usage rate

Raw water unit cost t.

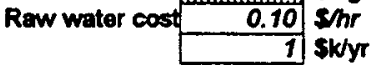

Demineralized water for feectwater makeup

Usage rate.

Raw water unit costí

Demineralization unit cost W.

Demin water cost $2.51 \mathrm{~s} / \mathrm{hr}$

19 skyr

Catalysts and chemicals

\begin{tabular}{|c|c|c|c|c|c|}
\hline Item & Usage $\quad$ Rate & SUnit & Units & \$hr & $\mathrm{kS} / \mathrm{yr}$ \\
\hline Dolomite & $10 \angle D$ TPH & \% Z5 & Yows $~ ₹$ & 6 & 41 \\
\hline Continuous N2 & \%. TPH & 5 & 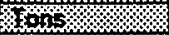 & 81 & 601 \\
\hline Liquid N2 & X TPY & 150 & Kons & 1 & 11 \\
\hline Aqueous NH3 & K5 PPH & 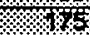 & Stots & 22 & 166 \\
\hline SCR Catalyst & X L Lot & 15000 & 160 & 9 & 75 \\
\hline Enzyme & G:GPD & $1 \% 2$ & $\frac{1}{6 t}$ & 0 & 0 \\
\hline Sulfuric Acid & OTPD & 35 & \% & $\overline{0}$ & 0 \\
\hline Glucose Syrup & S: TPD & 8083 & 88 & 0 & 0 \\
\hline Denaturant & 0 GPD & 6065 & 809 & 0 & $\overline{0}$ \\
\hline Pkgd Boiler Fuel Oil & S:MBTU/Hr & 866 & $M E T B$ & 0 & $\overline{0}$ \\
\hline Misc. & 86 Hrs & \% & s.m & 5 & 44 \\
\hline & & & & 123 & 938 \\
\hline
\end{tabular}

Total consumables 957 skyr

\section{Other Variable OsM Costs}

Ash Disposal

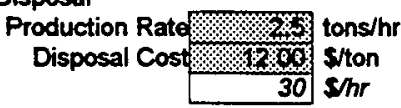

Incremental Maintenance on Combustion Turbine

\begin{tabular}{|c|c|c|}
\hline $\begin{array}{l}\text { CT Combustion Inspection } \\
\text { Contract labor/inspection } \\
\text { Mat'ls cost per inspection } \\
\text { Time between inspections } \\
\text { Incremental material cost } \\
\text { Incremental labor cost }\end{array}$ & 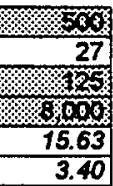 & $\begin{array}{l}\text { contract labor hours per inspoction } \\
k \$[\text { labor hrs } \times \$ 49.50 / \mathrm{hr} \times(1+10 / 100)] \\
\mathrm{k} \$ \\
\mathrm{hrs} \\
\$ / \mathrm{hr} \text { per CT, matorials } \\
\mathrm{s} / \mathrm{hr} \text { per Cr llabor hrs } \times \$ 49.50 \mathrm{hr} \times(1+10 / 100)]\end{array}$ \\
\hline $\begin{array}{l}\text { CT Hot Section Inspection } \\
\text { Contract labor cost } \\
\text { Mat'ls cost per inspection } \\
\text { Time between inspections } \\
\text { Incremental material cost } \\
\text { Incremental labor cost }\end{array}$ & 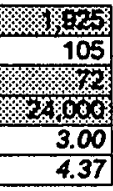 & $\begin{array}{l}\text { contract labor hours per inspection } \\
k \$ \text { [labor hrs } \times \$ 49.50 / \mathrm{hr} \times(1+10 / 100)] \\
\mathrm{ks} \\
\mathrm{hrs} \\
\$ \mathrm{~h} / \mathrm{hr} \text { por CT, meteriels } \\
\mathrm{s} / \mathrm{hr} \text { per CT [labor hrs } \times \$ 49.50 / \mathrm{hr} \times(1+10 / 100) \text { ] }\end{array}$ \\
\hline $\begin{array}{l}\text { CT Majer inspection } \\
\text { Contract labor cost } \\
\text { Mat'ls cost per inspection } \\
\text { Time between inspections } \\
\text { Incremental material cost } \\
\text { Incremental labor cost }\end{array}$ & 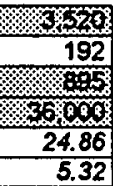 & $\begin{array}{l}\text { contract labor hours per inspection } \\
\text { k\$ [labor hrs } \times \$ 49.50 / \mathrm{hr} \times(1+10 / 100) \text { ] } \\
\text { ks } \\
\text { hrs } \\
\$ \mathrm{hr} \text { per CT, materials } \\
\text { s/hr per CT llabor hrs } \times \$ 49.50 \mathrm{hr} \times(1+10\end{array}$ \\
\hline & & of CT's J \\
\hline
\end{tabular}

Number of CT's:

Cost of Maintenance and Overhauls per CT

$13.09 \mathrm{~S} / \mathrm{hr}$ [ total of above labor $x$ number of CT's ]

SUMMARY OF VARIABLE O\&M

Consumables

Other Variable O\&M Costs

CT Maintenance materials

Total variable O\&M material

Total variable O\&M labor
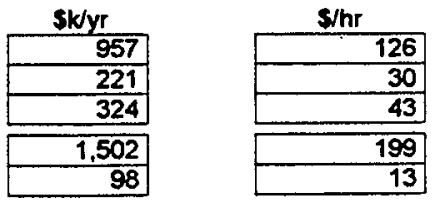
TABLE 2-29: OsM Cost Summary - TPS BCCCfFlue Cas Dryer) Page 1 of 2

TPS BGCC FLUE GAS DRYER DESIGN

O\&M COST SUMMARY EXCLUDING BIOMASS COST

ACCTDESCRIPTION

TOTAL O\&M

$4694 \mathrm{ks} / \mathrm{yr}$

Based on Capacity Factor of $85 \%$

FIXED O\&M

$3,703 \mathrm{kS} / \mathrm{yr}$

Fixed matl O\&M $1,347 \mathrm{ks} / \mathrm{yr}$

Fixed labor O\&M $2,356 \mathrm{ks} / \mathrm{yr}$

VARIABLE O\&M $\quad 990$ k\$y

Variable labor O\&M $98 \mathrm{kS} / \mathrm{yr}$

Variable matl O\&M 893 kS/yr

0.215 SMBtu HHV

Basis for calculation of OsM costs:

\begin{tabular}{|c|c|c|}
\hline $\begin{array}{l}\text { Plant Capital Cost } \\
\text { Full load heat input }\end{array}$ & 36 & $\begin{array}{l}\text { MS } \\
\text { Biomass } 1046 \text { Btwhr HHV basis }\end{array}$ \\
\hline $\begin{array}{l}\text { Capacity factor } \\
\text { Annual operation }\end{array}$ & 7.446 & $\begin{array}{l}\% \\
\text { hrs per year at full load }\end{array}$ \\
\hline $\begin{array}{l}\text { Operating labor rate } \\
\text { tafl maint labor rate } \\
\text { Labor Supervision } \\
\text { Overhead } \\
\text { Contract labor rate } \\
\text { Contract Supervision }\end{array}$ & \%orat & $\begin{array}{l}\text { S/hr (salary) } \\
\text { S/hr (salary) } \\
\% \text { of labor } \\
\% \text { of labor \& supervision } \\
\text { S/hr } \\
\% \text { of contract labor }\end{array}$ \\
\hline
\end{tabular}

FIXED O\&M

Operating stafi 6.25 * workers at site per shilt (4 shifts)

Truck Unloading $\%$ Hours por wook

Wood Pile 3 *orkers managing wood pile per shift

Gasifier 1 workers operating gasifier per shift

Cntr Rm Ops-BGCC $\%$ workers in BGCC control room per shit

Roving Ops - BGCC $\%$ operators roving BGCC plant per shith

Cntrl Rm Ops-EtOH \% workers in EtOH control room per shift

Roving Ops - EtOH

Operating labor cost $1.040 \mathrm{ks} / \mathrm{yr}[6.25 \times 2080 \mathrm{hr} / \mathrm{yr} \times 4 \mathrm{shifts} \times 20 \mathrm{~s} / \mathrm{hr} / 1000]$

Supervision 312 k\$ $\$$ /yr [ $30 / 100 \times$ operating labor cost]

Labor overhead 406 K\$/Yr [ 30/100 x (operating + supervision costs)]

Total operating labor cost 1,758 Skyr [total of labor cost, supervision, and overhead]

Maintenance staff

Maint labor cost $\quad 94 \mid$ Sklyr [ $\quad 3 \times 2080 \mathrm{hr} / \mathrm{yr} \times \quad 15 \mathrm{~s} / \mathrm{hr} / 1000$ ]

Supervision 28 Sk/yr [ $30 / 100 \times$ maintenance labor cost]

Labor overhead 37 Sk/yr [ $\quad 30 / 100 \times$ (maint labor + supervision) ]

Total fixed maint labor cost 158 \$kyr [total of labor cost, supervision, and overhead]

Maintenance materials and contract labor

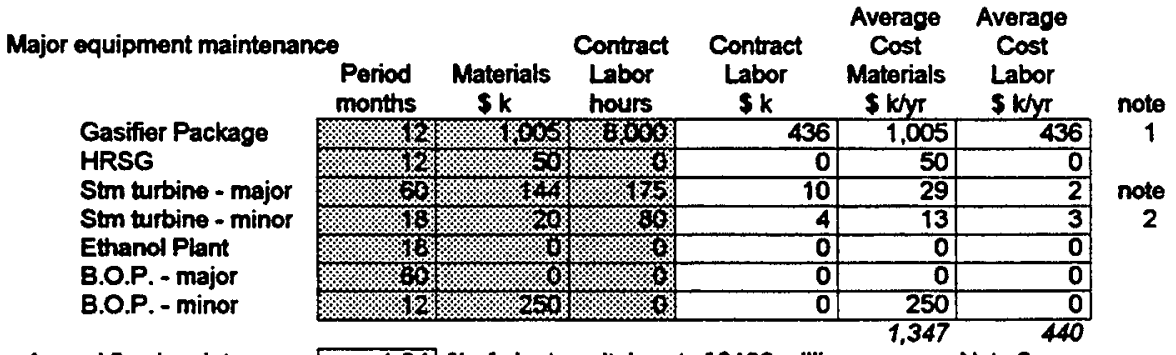

Annual fixed maintenance

$1.84 \%$ of plant capital cost of $\$ 106$ million

Note 3

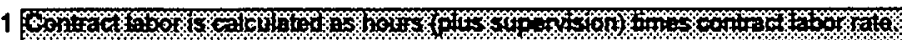

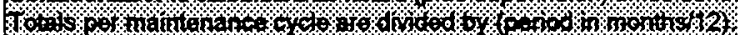

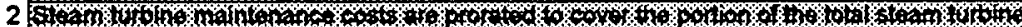

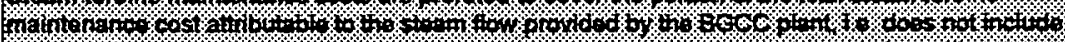

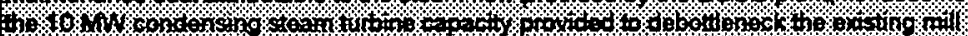

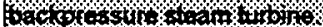

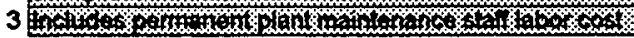

SUMMARY OF FIXED O\&M

Operating labor

Maintenance labor

Contract labor

Maintenance materials

Sklyr

Total fixed O\&M materials

Total fixed OsM labor

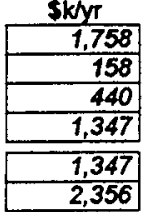

Note: Shaded cells are for spreadsheet inputs; clear cells are calculated 
VARIABLE ORM

Consumables

Process water

Usage rate $\times$ galhr

Unit cost.

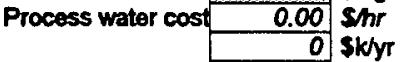

Cooling system makeup

Usage rate

Raw water unit cost woigs s/kgal

Raw water cose $0.40 \mathrm{shr}$

Demineralized water for feectwater makeup

Usago ratef of gal/hr

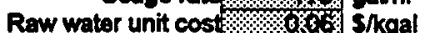

Demineralization unit cost 1 \% $\$$ kgal

Demin water cost $0.26 \mathrm{~s} / \mathrm{hr}$

Catalysts and chemicals

\begin{tabular}{|c|c|c|c|c|c|}
\hline Item & Usage $\quad$ Rate & \$/Unit & Units & $\$ \mathrm{hr}$ & $\overline{k S / y T}$ \\
\hline Dolomite & $\%$ W TPH & $\% 25$ & \% & 29 & 214 \\
\hline Continuous N2 & OOA TPH & 25 & 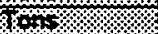 & 9 & 65 \\
\hline Liquid N2 & OITPY & $83 ; 3$ & 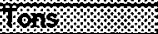 & 0 & 0 \\
\hline Aqueous NH3 & PPH & 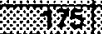 & 3 Bof & o & 0 \\
\hline SCR Catalyst & Lot & 350301 & $6 \%$ & 0 & 0 \\
\hline Enzyme & Q GPD & $\%$ & H & 0 & 0 \\
\hline Sulfuric Acid & Q TPD & 6 & on & 0 & 0 \\
\hline Glucose Syrup & OTD & 0 & 16 & 0 & $\overline{0}$ \\
\hline Denaturant & Oे GPD & OS5 & $6 \%$ & o & $\overline{0}$ \\
\hline Pkgd Boiler Fuel Oil & / OMBTU $\mathrm{Hr}$ & 26 & Utots & 0 & 0 \\
\hline Misc. & 6 6 Hrs & 3. & 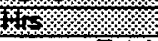 & 5 & 44 \\
\hline & & & & 43 & 323 \\
\hline
\end{tabular}

Total consumables 328 Skyr

\section{Other Variable OsM Costs}

Ash Disposal

$$
\begin{array}{ll}
\text { Production Rate } & \text { tons/hr } \\
\text { Disposal Cost } & \text { S/ton } \\
& \text { Shr }
\end{array}
$$

Incremental Maintenance on Combustion Turbine

Number of CTs

Cost of Maintenance and Overhauls per CT

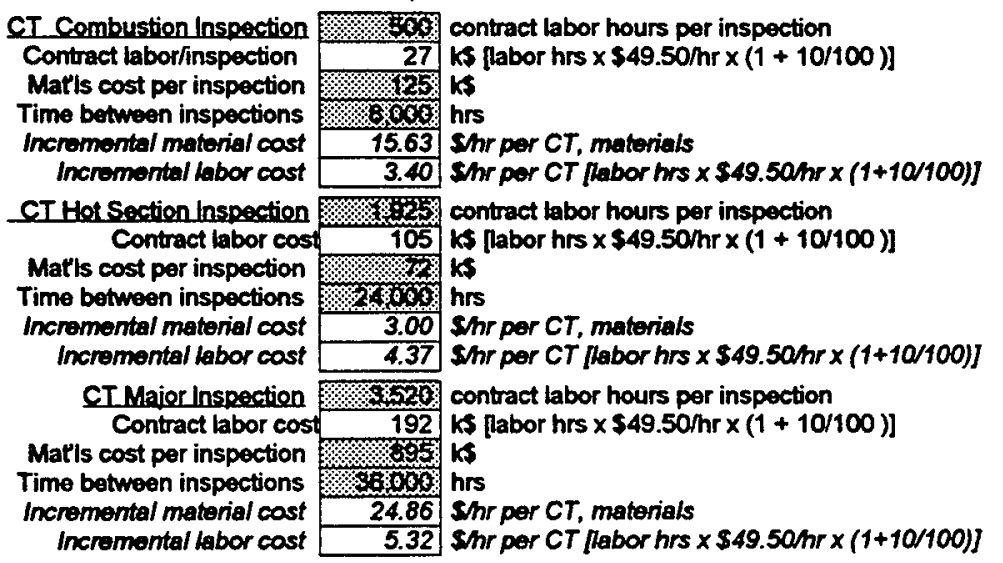

Total incremental matl cast $\quad 43.49 \mathrm{shr}$ [ total of above meterials $\times$ number of CT's] Total incremental labor cast $13.09 \mathrm{Shr}$ ( total of above labor $x$ number of CT's]

SUMMARY OF VARIABLE OBM Consumables

Other Variable O\&M Costs

CT Maintenance materials

Total variable O\&M material

Total variable O\&M labor
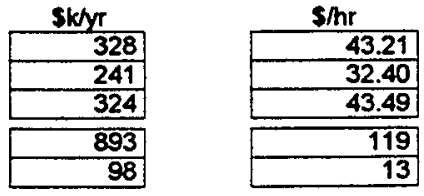
TABLE 2-30: O\&M Cost Summary - Ethanol Plant Page 1 of 2

ETHANOL PLANT

\section{O\&M COST SUMMARY EXCLUDING BIOMASS COST}

ACCTDESCRIPTION

TOTAL O\&M

$27829 \mathrm{k} \$ \mathrm{yr}$

FIXED O\&M

Fixed matl O\&M

Fixed labor O\&M

VARIABLE O\&M
$3,294 \mathrm{k} \$ \mathrm{yr}$

1,300

$1,994 \mathrm{k} \$ / \mathrm{yr}$

$24,535 \mathrm{k} \$ \mathrm{yr}$
Based on Capacity Factor of $92 \%$

3.986 S/MBtu HHV of feed

\section{Basis for calculation of O\&M costs:}

\begin{tabular}{|c|c|c|}
\hline $\begin{array}{l}\text { Plant Capital Cost } \\
\text { Feed heat input }\end{array}$ & 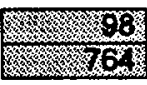 & $\begin{array}{l}\text { M\$ } \\
\text { Biomass } 10^{\wedge} 6 \text { Btu/hr HHV basis }\end{array}$ \\
\hline $\begin{array}{l}\text { Capacity factor } \\
\text { Annual operation }\end{array}$ & 8,059 & $\begin{array}{l}\% \\
\text { hrs per year at full load }\end{array}$ \\
\hline $\begin{array}{r}\text { Operating labor ra } \\
\text { Staff maint labor ra } \\
\text { bor Supervision } \\
\text { Overhead } \\
\text { Contract labor rate } \\
\text { Contract Supervision }\end{array}$ & $\frac{2000}{3.200}$ & $\begin{array}{l}\$ / \mathrm{hr} \text { (salary) } \\
\$ / \mathrm{hr} \text { (salary) } \\
\% \text { of labor } \\
\% \text { of labor \& supervision } \\
\$ / \mathrm{hr} \\
\% \text { of contract labor }\end{array}$ \\
\hline
\end{tabular}

\section{FIXED O\&M}

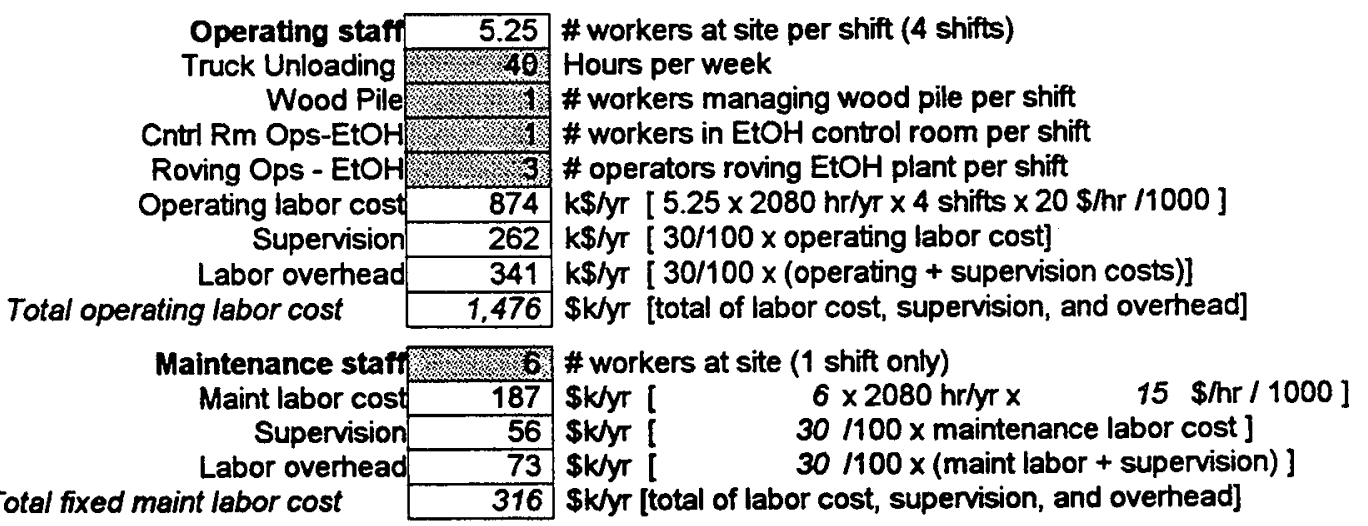

Maintenance materlals and contract labor

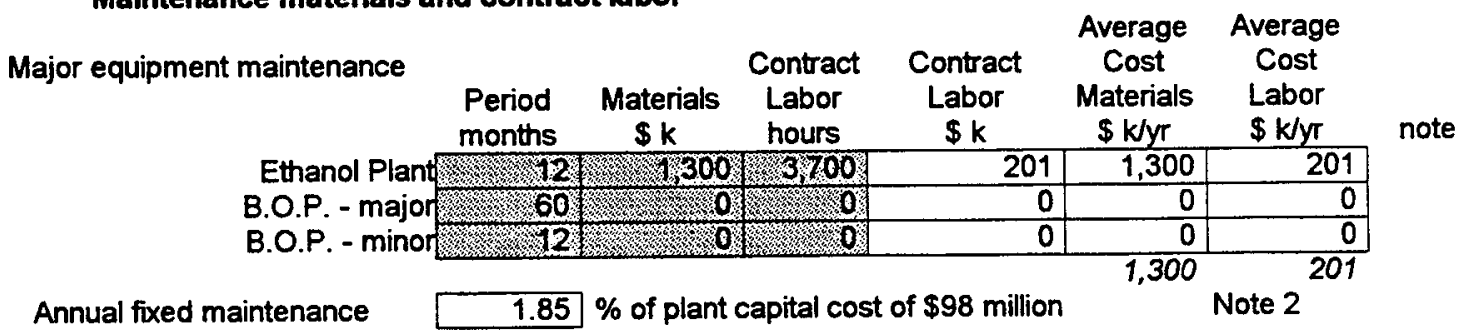

1 Cortract ab or is calculated as hours (pils supenision) fimes contract labor rate.

Totals per maintenance cycle are orvided by (penod in monthsi12)

2 Foludes permanent plant maintenance staiflabor cost

\begin{tabular}{|c|c|}
\hline $\begin{array}{l}\text { SUMMARY OF FIXED O\&M } \\
\text { Operating labor } \\
\text { Maintenance labor } \\
\text { Contract labor } \\
\text { Maintenance materials }\end{array}$ & $\begin{array}{r}\$ \mathrm{k} / \mathrm{yr} \\
1,476 \\
316 \\
201 \\
1,300 \\
\end{array}$ \\
\hline $\begin{array}{l}\text { Total fixed O\&M materials } \\
\text { Total fixed O\&M labor }\end{array}$ & $\frac{1,300}{1,994}$ \\
\hline
\end{tabular}

Note: Shaded cells are for spreadsheet inputs; clear cells are calculated 
VARIABLE O\&M

Consumables

Process water

$$
\begin{aligned}
& \text { Usage rate 27,800 gal/hr } \\
& \text { Unit cost } 0.06 \text { \$/kgal } \\
& \text { Process water cost } 1.20 \text { \$/hr - }
\end{aligned}
$$

Cooling system makeup

Usage rate

Raw water unit cost

CT MU water cost

6 Sk/yr

Demineralized water for feedwater makeup

Usage rate 2,72 gal/hr

Raw water unit cost,

Demineralization unit cost \$/kgal

Demin water cost 19.16 \$/hr

\begin{tabular}{|c|c|c|}
\hline $\begin{array}{l}\text { Usage rate } \\
\text { Elect unit cost }\end{array}$ & $\begin{array}{r}3,200 \\
405 \\
660 \\
5,319\end{array}$ & $\begin{array}{l}\text { kWhr/hr } \\
\text { \$/KWhr } \\
\text { \$/hr } \\
\text { \$k/rr }\end{array}$ \\
\hline
\end{tabular}

Electricity

154 \$klyr

\begin{tabular}{|c|c|c|c|c|c|}
\hline Item & Usage Rate & \$/Unit & Units & $\$ / h r$ & $\mathbf{k} \mathbf{S / \mathbf { T }}$ \\
\hline Enzyme & 6960 GPD & 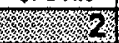 & Atter & 2195 & 17688 \\
\hline Sulfuric Acid & X6' 5 TPD & 5 & Kon & 16 & 126 \\
\hline Glucose Syrup & \% 5 TPD & 008 & W & 33 & 269 \\
\hline Denaturant & 1612 GPD & 0.65 & Ga & $\overline{44}$ & 352 \\
\hline Pkgd Boiler Fuel Oil & TS MBTU/HR & 3 & MBTE & 328 & 2646 \\
\hline Misc. & 8760 Hrs & 50 & SIs & 50 & 438 \\
\hline & & & & 2666 & 21518 \\
\hline
\end{tabular}

Catalysts and chemicals

Total consumables 27,007 \$kyr

Other Variable O\&M Costs

Credit for Lignin (stillage) Byproduct Sales (for fuel)

Production Rate 25.56: tons/hr

Sales Price

Credit $307 \mathrm{~S} / \mathrm{hr}$

SUMMARY OF VARIABLE O\&M

Consumables

Other Variable O\&M Costs

Total variable O\&M \$klyr

27,007

$(2,472)$

24,535
$\$ / \mathrm{hr}$

3,347

(307)

3,040 
TABLE 2-31: OeM Cost Summary - Tempella BCCCrEthanol Plant Page 1 of 2

INTEGRATED BGCCETHANOL PLANT

OBM COST SUMMARY EXCLUDING BIOMASS COST ACCTDESCRIPTION

TOTAL O\&M

27090 ks/yr

Based on Capacity Factor of $92 \%$

FIXED OBM

$6,599 \mathrm{ks} / \mathrm{yr}$

Fixed marl 08M $2.605 \mathrm{ks} / \mathrm{yr}$

Fixed labor O8M 3,994 ksSyr

VARIABLE O\&M $20,491 \mathrm{kS} / \mathrm{yr}$

Variable labor O\&M $106 \mathrm{kSYyr}$

Variable mat' O8M 20,385 ks/yr

2.065 S/MBtu HHN

Basis for calculation of Osm costs:

Plant Capital Cost \%m

Biomass heat input \% $10^{4} 6$ Btumr HHV basis

Capacity factor\% $\%$ \% (BGCC CF on biomass is 85\%; GT fired with No.2 oil for $613.2 \mathrm{hrs}$ )

Annual operation 8.059 hrs per year at full load

Operating labor rate \% स

Staff maint labor rate $\%$ S/hr (salary)

Labor Supervision $\%$ of labor

Overtea \% \% of labor \& supervision

Contract labor rate

FIXED OEM

Contract Supervision. \% $\%$ of contract labor

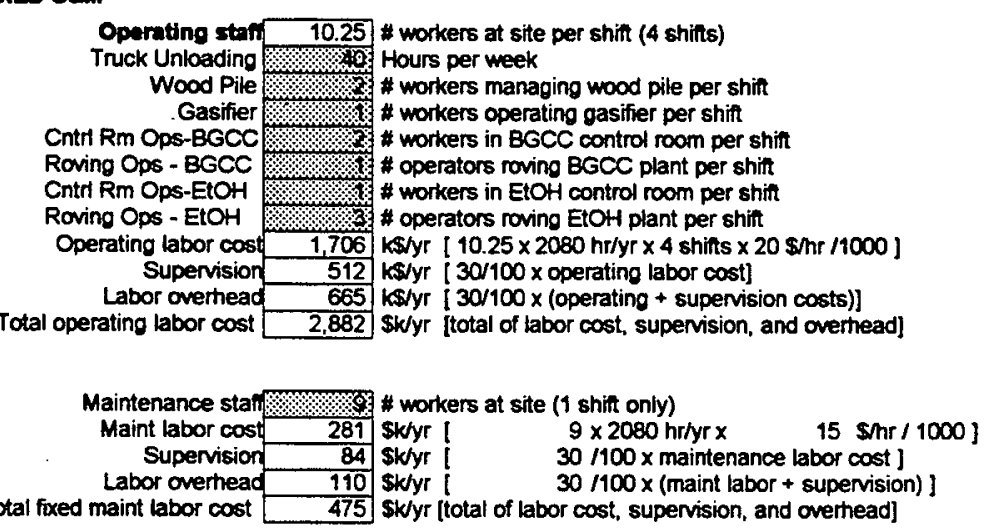

Maintenance materials and contract labor

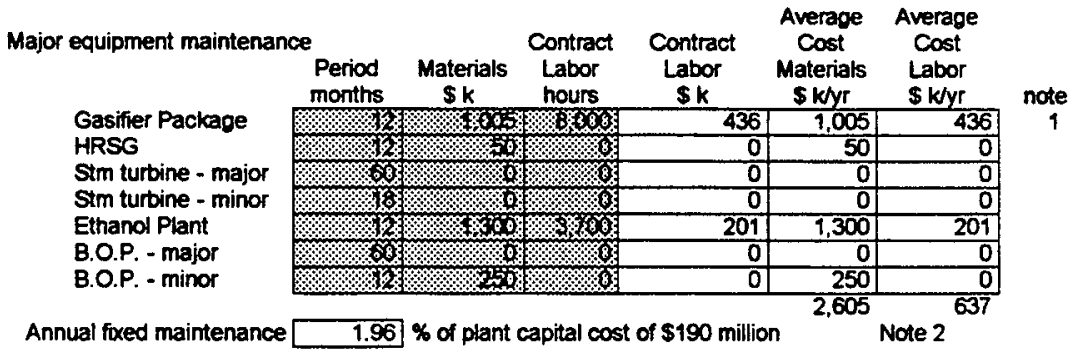

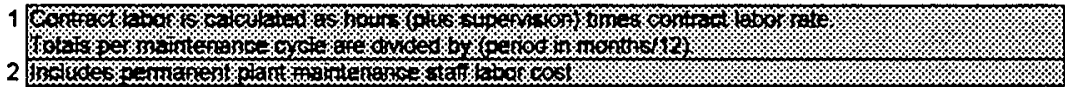

SUMMARY OF FIXED O\&M

Operating labor

Maintenance labor

Contract labor

Maintenance materials

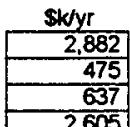

Total fixed O\&M materials

Total fixed O\&M Labor

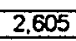

3,994

Note: Shaded cells are for spreadsheet inputs; clear cells are calculated 
VARIABLE O\&M

Consumables

Process water

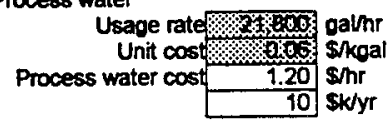

Cooling system makeup

Usage rate \%कso: $\mathrm{opm}$

Raw water unit cost

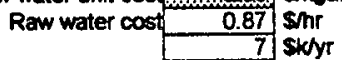

Demineralized water for feecwater makeup

Usage rate $\%$ gal/

Raw water unit cost

Demineralization unit cost \%..... \$ \$

Demin water cost $19.16 \mathrm{~S} / \mathrm{hr}$

154 Sklyr

\begin{tabular}{|c|c|c|c|c|c|}
\hline ltem & Usage Rate & SMnit & Units & $\$ \mathrm{Shr}$ & ksyr \\
\hline Dolomite & $2+17$ TPH & Fras & torsom & 5 & 42 \\
\hline Continuous N2 & \% TPH & 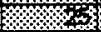 & oos & 79 & 633 \\
\hline Liquid N2 & \% 2 TPY & 8 & 00 & 1 & 11 \\
\hline Aqueous NH3 & KI PPH & 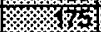 & Sos & 28 & 74 \\
\hline SCR Catalyst & K Lot & Bxtsos & 180 & 9 & 75 \\
\hline Enzyme & GPD & W & 38 & 2187 & 17622 \\
\hline Sulfuric Acid & I TPD & $\%$ & No3 & 16 & 126 \\
\hline Glucose Synup & $\%$ TPD & OOH & 36 & 33 & 269 \\
\hline Denaturant & OXS GPD & 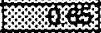 & 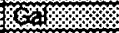 & 44 & 352 \\
\hline Pkod Boiler Fuel Oil & gMBTU/Hr & 3 & 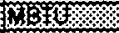 & 0 & 0 \\
\hline Misc. & Hrs & 8 & 80 & 50 & 438 \\
\hline & & & & 2450 & 19641 \\
\hline
\end{tabular}

Total consumables 19,813 sk/yr

\section{Other Variable O\&M Costs}

Ash Disposal

Production Rate

Disposal Cost \%

28 s $5 / \mathrm{hr}$

Incremental Maintenance on Combustion Turbine

Number of CTs:

Cost of Maintenance and Overhauls per CT

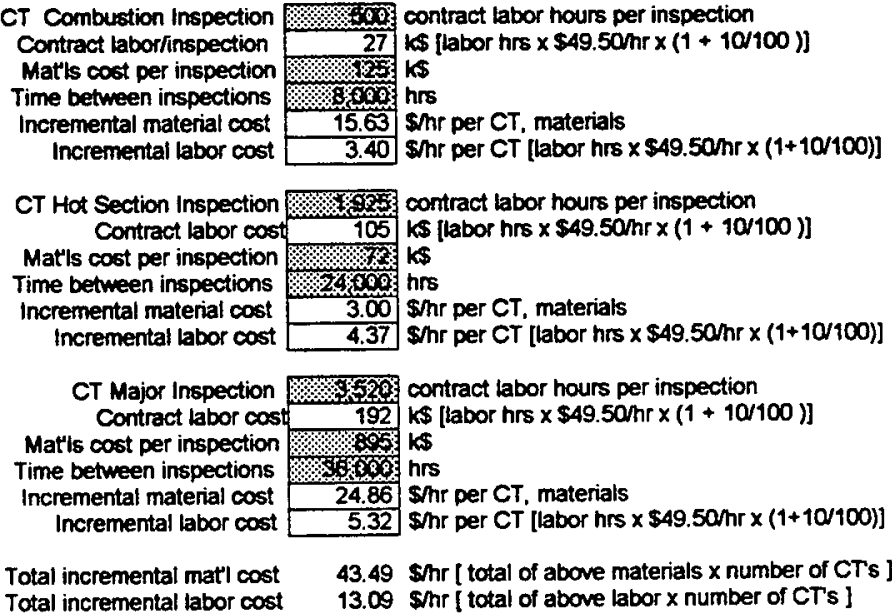

CT Combustion Inspection $\%$ contract labor hours per inspection

Contract labor/inspection 27 k\$ [labor hrs $\times \$ 49.50 \mathrm{hr} \times(1+10 / 100)$ ]

Mat's cost per inspection $\%$

Time between inspections $\%$ greo hrs

Incremental material cost $15.63 \mathrm{~s} / \mathrm{hr}$ per $\mathrm{CT}$, materials

Incremental labor cost 3.40 S/hr per CT [labor hrs $\times \$ 49.50 \mathrm{mr} \times(1+10 / 100)$ ]

CT Hot Section Inspection 1 contract labor hours per inspection

Contract labor cost 105 ks [labor hrs $\times \$ 49.50 \mathrm{mr} \times(1+10 / 100)$ ]

Mat'ls cost per inspection KS

Time between inspections $\%$ grop hrs

Incremental material cost 3.00 \$ \$ $/ \mathrm{hr}$ per CT, materials

Incremental labor cost 4.37 \$/hr per CT [labor hrs $\times \$ 49.50 \mathrm{hr} \times(1+10 / 100)]$

CT Major Inspection

Contract labor cost 192 is [labor hrs $\times \$ 49.50 \mathrm{hr} \times(1+10 / 100)]$

Mat'is cost per inspection 1 .

Time between inspections hrs

Incremental material cost 24.86 S/hr per CT, materials

Incremental labor cost $\quad 5.32$ S/hr per CT [labor hrs $\times \$ 49.50 / \mathrm{hr} \times(1+10 / 100)$ ]

Total incremental mat'l cost $\quad 43.49 \mathrm{~S} / \mathrm{hr}$ [ total of above materials $\mathrm{x}$ number of CT's ]

Total incremental labor cost $\quad 13.00 \mathrm{~S} / \mathrm{hr}$ [ total of above labor $x$ number of CTs ]

SUMMARY OF VARIABLE O\&M

Consumables

Other Variable O\&M Costs

CT Maintenance materials
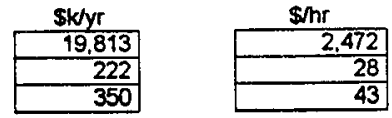

Total variable O\&M material

Total variable O\&M labor 


\section{BASE CASE (MODIFIED BARK BOILER)}

\section{O\&M COST SUMMARY EXCLUDING BIOMASS COST ACCTDESCRIPTION \\ TOTAL O\&M \\ $1903 \mathrm{ks} / \mathrm{yr}$ \\ Based on Capacity Factor of $92 \%$ \\ FIXED O\&M \\ $1,711 \mathrm{k} \$ / \mathrm{yr}$ \\ Fixed mat"l O\&M $500 \mathrm{k} \$ \mathrm{yr}$ \\ Fixed labor O\&M $1,211 \mathrm{k} \$ \mathrm{yr}$ \\ VARIABLE O\&M $192 \mathrm{k} / \mathrm{yr}$ \\ 0.070 \$/MBtu HHV}

Basis for calculation of O\&M costs:

Full load heat input $10^{\wedge} 6$ Btu/hr HHV basis

Capacity factor

Annual operation 8,059 hrs per year at full load

Operating labor rate $\$ / \mathrm{hr}$ (salary)
Staff maint labor rate
Labor Supervision
Overhead
Contract labor rate
Contract Supervision

FIXED O\&M

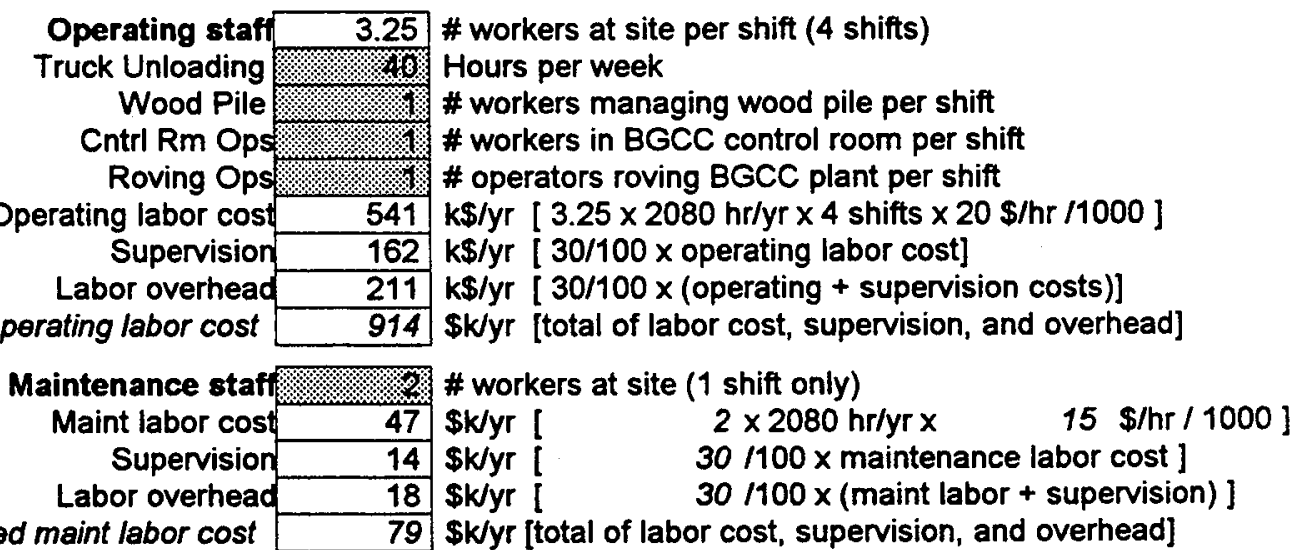

Total fixed maint labor cost

79 \$k/yr [total of labor cost, supervision, and overhead]

Maintenance materials and contract labor

\begin{tabular}{|c|c|c|c|c|c|c|}
\hline Major equipment maintenance & $\begin{array}{l}\text { Period } \\
\text { months }\end{array}$ & $\begin{array}{c}\text { Materials } \\
\$ \mathrm{k}\end{array}$ & $\begin{array}{l}\text { Contract } \\
\text { Labor } \\
\text { hours }\end{array}$ & $\begin{array}{c}\text { Contract } \\
\text { Labor } \\
\$ k\end{array}$ & $\begin{array}{c}\text { Average } \\
\text { Cost } \\
\text { Materials } \\
\$ \mathrm{KJyr} \\
\end{array}$ & $\begin{array}{c}\text { Average } \\
\text { Cost } \\
\text { Labor } \\
\$ \mathrm{k} / \mathrm{yr} \\
\end{array}$ \\
\hline Boiler & $1 \% 28$ & $1 \%<00$ & $1 \% \$ 00$ & 218 & 500 & 218 \\
\hline
\end{tabular}

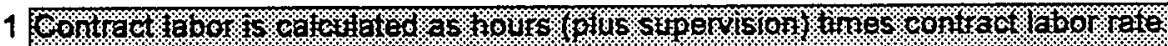

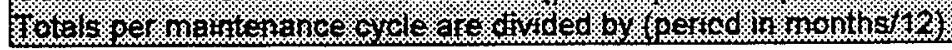

SUMMARY OF FIXED O\&M

Operating labor

Maintenance labor

Contract labor

Maintenance materials

Total fixed O\&M materials

Total fixed O\&M labor
$\$ \mathrm{kJyr}$

\begin{tabular}{|r|}
\hline 914 \\
\hline 79 \\
\hline 218 \\
\hline 500 \\
\hline 500 \\
\hline 1,211 \\
\hline
\end{tabular}

Note: Shaded cells are for spreadsheet inputs; clear cells are calculated 
VARIABLE O\&M

Consumables

Process water

\begin{tabular}{|c|c|c|}
\hline Usage rate & 80 & \\
\hline Unit cost & 206 & \\
\hline Process water cost & 0.00 & \\
\hline
\end{tabular}

Cooling system makeup

Usage rate

Raw water unit cost/\%.

Raw water cost $0.00 \mathrm{~S} / \mathrm{hr}$

o $\$ k / y r$

Demineralized water for feedwater makeup

Usage rate

Raw water unit cost

Demineralization unit cost $\%$. $\$$ \$ $\$$ / $\mathrm{kgal}$

Demin water cost 0.36 S/hr

Catalysts and chemicals

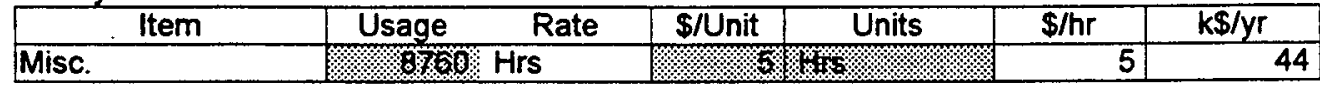

Total consumables 47 \$kyr

\section{Other Variable O\&M Costs}

Ash Disposal

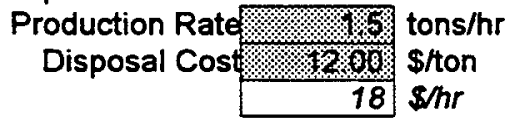

SUMMARY OF VARIABLE O\&M

Consumables

Other Variable O\&M Costs

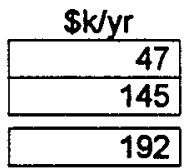

$\$ / \mathrm{hr}$

Total variable O\&M material 


\subsection{Project Schedule}

Figure 2-35 presents the proposed schedule for implementing a BGCC cogeneration plant at the New Bern Mill. The schedule allows 9 to 12 months for the gasification technology supplier to test the specific New Bern biomass feed and develop a process design for the gasification island

Consistent with Weyerhaeuser practice, $a \pm 10$ percent project cost estimate must be completed in order to request corporate funding for the project.

Authorization to proceed with procurement and construction could be received as early as September, 1996.

The in-service date for the project is February 3, 1999.

For the ethanol plant several process design issues must be resolved regarding agitation requirements and stillage (lignin) dewatering before the technology is ready for large-scale demonstration. Consequently, additional time will be required before the ethanol process will be ready for specific feedstock testing and preparation of the process design package. However, once these issues are resolved the overall duration of the engineering/procurement and construction schedule should be similar to that of the BGCC plant (i.e., about three years). 


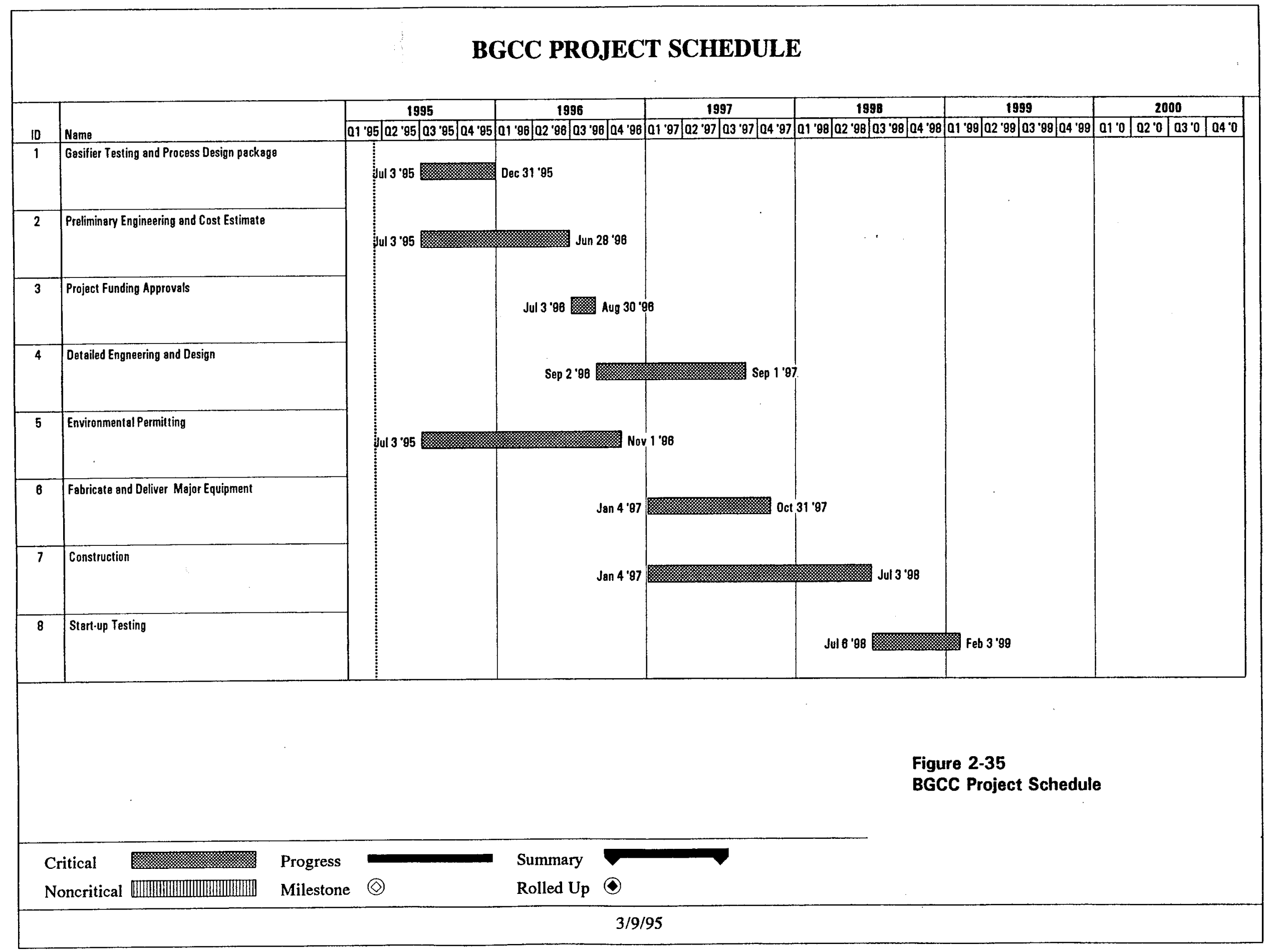




\section{Section 3}

\section{Regional Biomass Supply System}

\subsection{Scope and Objectives}

The objectives of this task included developing a description of the fuel supply and fuel costs for the BGCC and ethanol plants. To address both existing and potential supplies, six strategies were developed to account for alternative sources, future costs, and environmental benefits. The strategies have been developed sufficiently to address real costs and benefits, in dollars, fuel supply, and sustainable forest management practices.

\subsection{Findings}

There is sufficient biomass fuel available from the feedstock system surrounding New Bern to satisfy the range of feedstock needs of the various BGCC and ethanol alternatives considered in this study $(294,700$ bone dry tons (BDT)/year to 350,000 BDT/year) at an average cost of $\$ 20$ to \$24/BDT. This biomass is made up of Weyerhaeuser mill residuals and woods residuals from the final harvest of natural stands and is all within a 60 mile transportation radius of New Bern. Residual resources are presented in Figure 3-1 and Figure 3-2. A requirement of 600,000 BDT raises the average cost to $\$ 26 / \mathrm{BDT}$, increases the transportation distance to about 80 miles and adds residuals from Plymouth wood products, plantations, and non-Weyerhaeuser mills. A requirement of 900,000 BDT is available and it raises the average cost to $\$ 28 / \mathrm{BDT}$, increases the transportation distance to 100 miles and adds residuals to each of the above components (Figures 3-2 and 3-3).

The predominant residual component available to New Bern is that available from final harvest as it accounts for more than 65 percent of the more than 900,000 BDT available. The least cost and most readily committed components are the residuals available from the New Bern sawmill, pulp mill and chip mill and these amount to 120,000 BDT (see Table 3-1). If poultry-house residuals can be utilized, average costs can be reduced significantly (by $\$ 3$ to $\$ 4 / B D T$ ).

\subsection{Approach}

Availability and costs for volume from Weyerhaeuser forests and facilities were obtained from historical records and knowledgeable people in the company who have the responsibility for managing the forests and supplying the raw material for the mills. Information on plantation growth and economics was backed up by strategic planners and researchers who utilized computer runs on Weyerhaeuser's proprietary financial models. These models rely on extensive information collected and verified over many years on volume, growth and field operations. Estimates for items such as harvesting, collecting, transporting, site prepping, and planning were based on data from actual experience modified for the specific situation. Cost, volume, and growth estimates were generally modified towards optimism in an attempt to include a particular component such as biomass from plantations or from short rotation forestry. However, when it was apparent that inclusion of the component was not feasible, conservative estimates (those tending to reduce the quantity) were used to identify the quantity actually available for use in an energy facility (Tables 3-1 through 3-7, Figures 3-1 through 3-5.) 


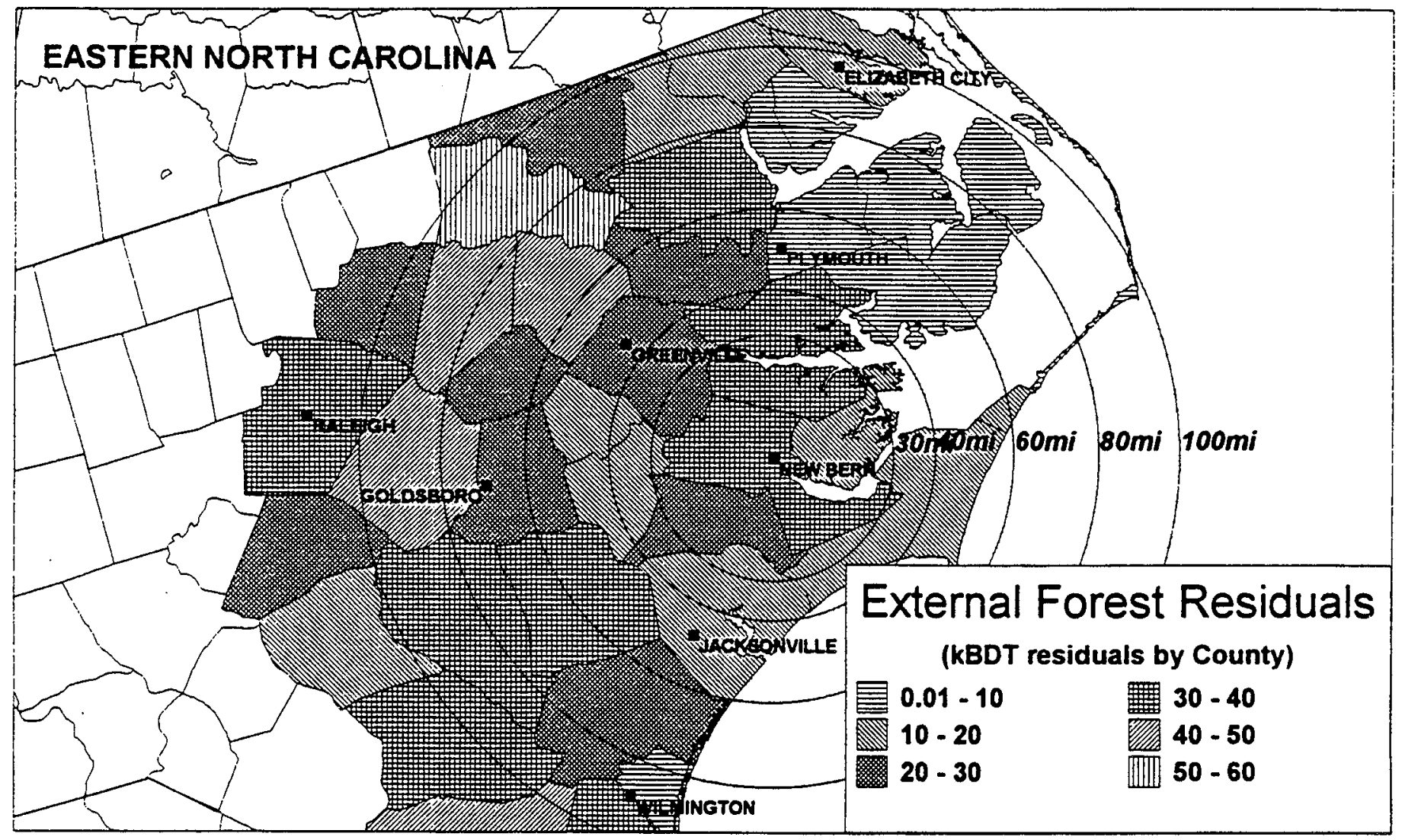

Figure 3-1: Map of External Forest Residuals

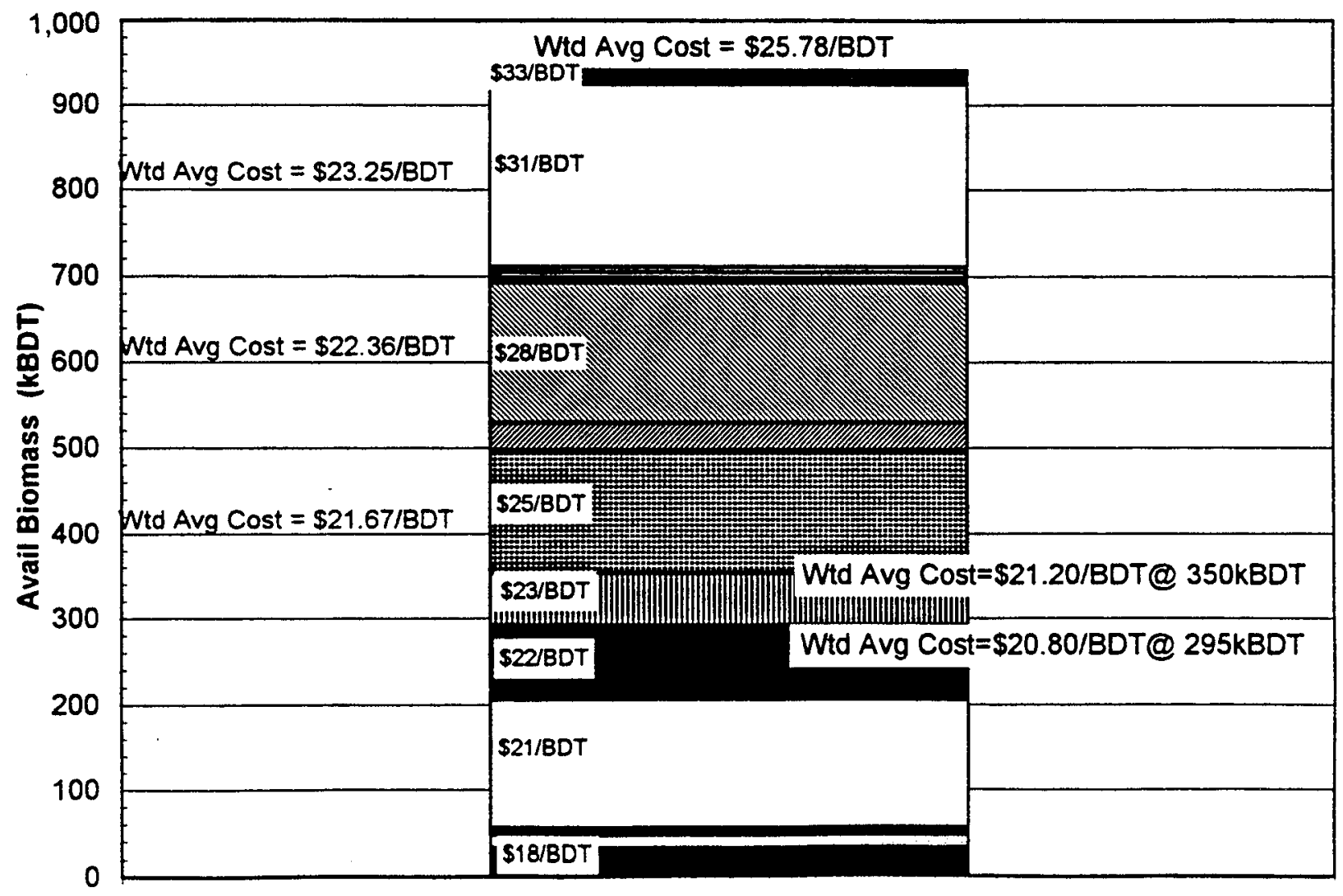

Figure 3-2: Chart of Residual Biomass Fuel Resource 


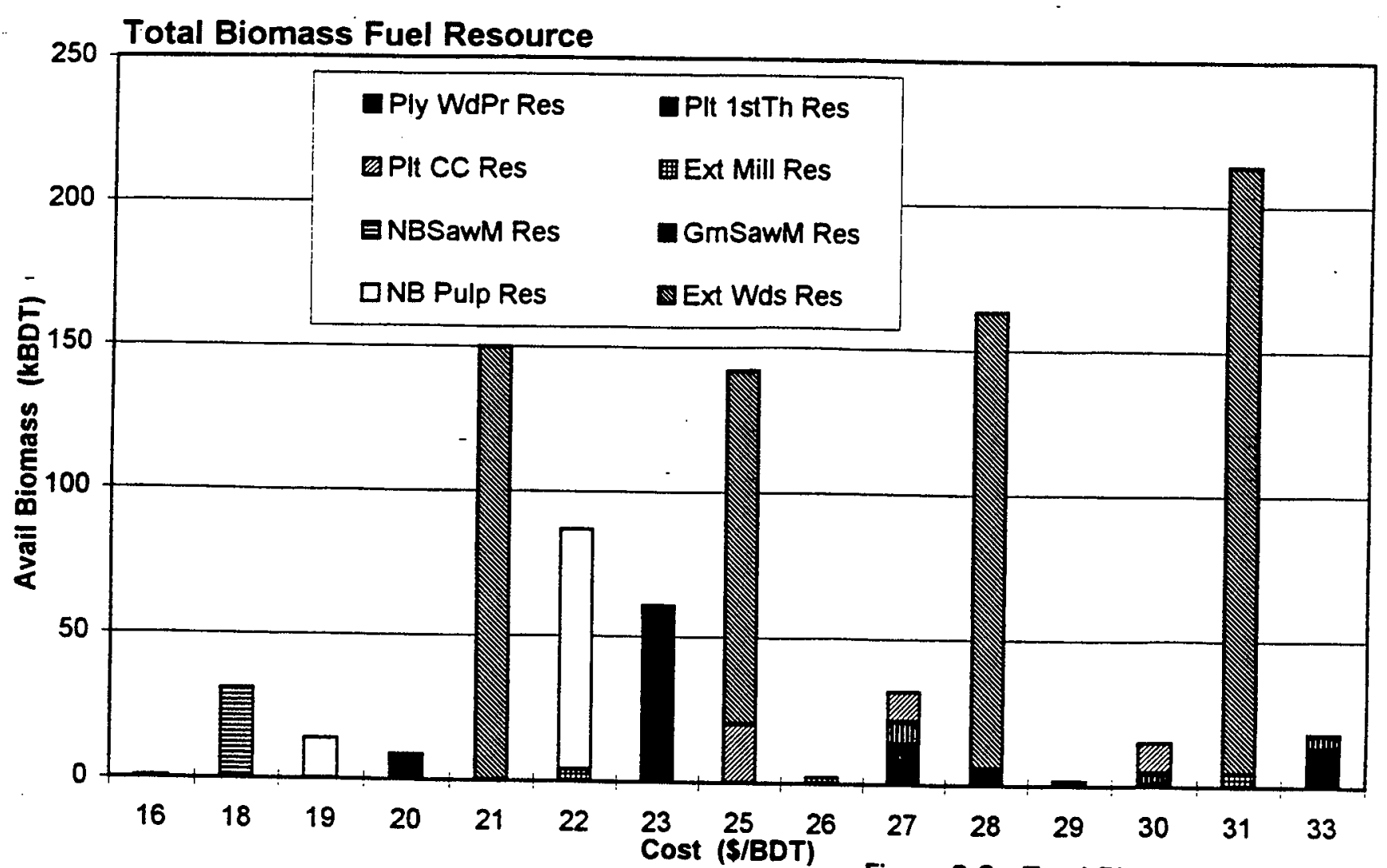

Figure 3-3: Total Biomass Fuel Resource

Table 3-1: Total Biomass Fuel Resource - Units - BDT per year

\begin{tabular}{|c|c|c|c|c|c|c|c|c|c|c|}
\hline \multirow[b]{3}{*}{$\begin{array}{l}\text { Fuel Cost* } \\
\text { (\$/BDT) }\end{array}$} & \multicolumn{6}{|c|}{ Weyerhaeuser Operations } & \multirow{2}{*}{\multicolumn{2}{|c|}{$\begin{array}{l}\text { Non-Weyerhaeuser } \\
\text { Operations }\end{array}$}} & \multirow{3}{*}{$\begin{array}{l}\text { Total } \\
\text { Res. } \\
\text { Fuel }\end{array}$} & \multirow{3}{*}{$\begin{array}{c}\text { Accm. } \\
\text { Res. } \\
\text { Fuel }\end{array}$} \\
\hline & \multicolumn{2}{|c|}{ Plantation Residuals } & \multicolumn{4}{|c|}{ Mill Residuals } & & & & \\
\hline & $\begin{array}{l}\text { Clear } \\
\text { Cut }\end{array}$ & $\begin{array}{c}\text { First } \\
\text { Thinning }\end{array}$ & $\begin{array}{c}\text { New Bern } \\
\text { Sawmill }\end{array}$ & $\begin{array}{l}\text { New Bern } \\
\text { Pulp Mill }\end{array}$ & $\begin{array}{c}\text { Greenville } \\
\text { Sawmill }\end{array}$ & $\begin{array}{l}\text { Plymouth } \\
\text { Wd Prod }\end{array}$ & $\begin{array}{l}\text { Woods } \\
\text { Residuals }\end{array}$ & $\begin{array}{c}\text { Mill } \\
\text { Residuals }\end{array}$ & & \\
\hline 16 & & & 1 & & & & & & 1 & 1 \\
\hline 18 & & & 31 & & & & & & 31 & 32 \\
\hline 19 & & & & 14 & & & & & 14 & 46 \\
\hline 20 & & & & & 9 & & 92 & & 101 & 147 \\
\hline 22 & & & & 83 & & & 58 & 4 & 15 & 292 \\
\hline 23 & & & & & 61 & & & & 61 & 353 \\
\hline 25 & 20 & & & & & & 122 & & 142 & 495 \\
\hline 27 & 10 & 8 & & & & 14 & & 2 & 34 & 529 \\
\hline 28 & & & & & & 6 & 157 & & 163 & 692 \\
\hline 30 & 10 & 5 & & & & & & 2 & 17 & 709 \\
\hline 31 & & & & & & & 209 & & 209 & 918 \\
\hline 33 & & 5 & & & & & & 5 & 10 & 928 \\
\hline 34 & & & & & & 13 & & & 13 & 941 \\
\hline $\begin{array}{l}\text { Source } \\
\text { Total }\end{array}$ & 40 & 18 & 32 & 97 & 70 & 33 & 638 & 13 & 941 & \\
\hline
\end{tabular}

*Delivered to New Bern 


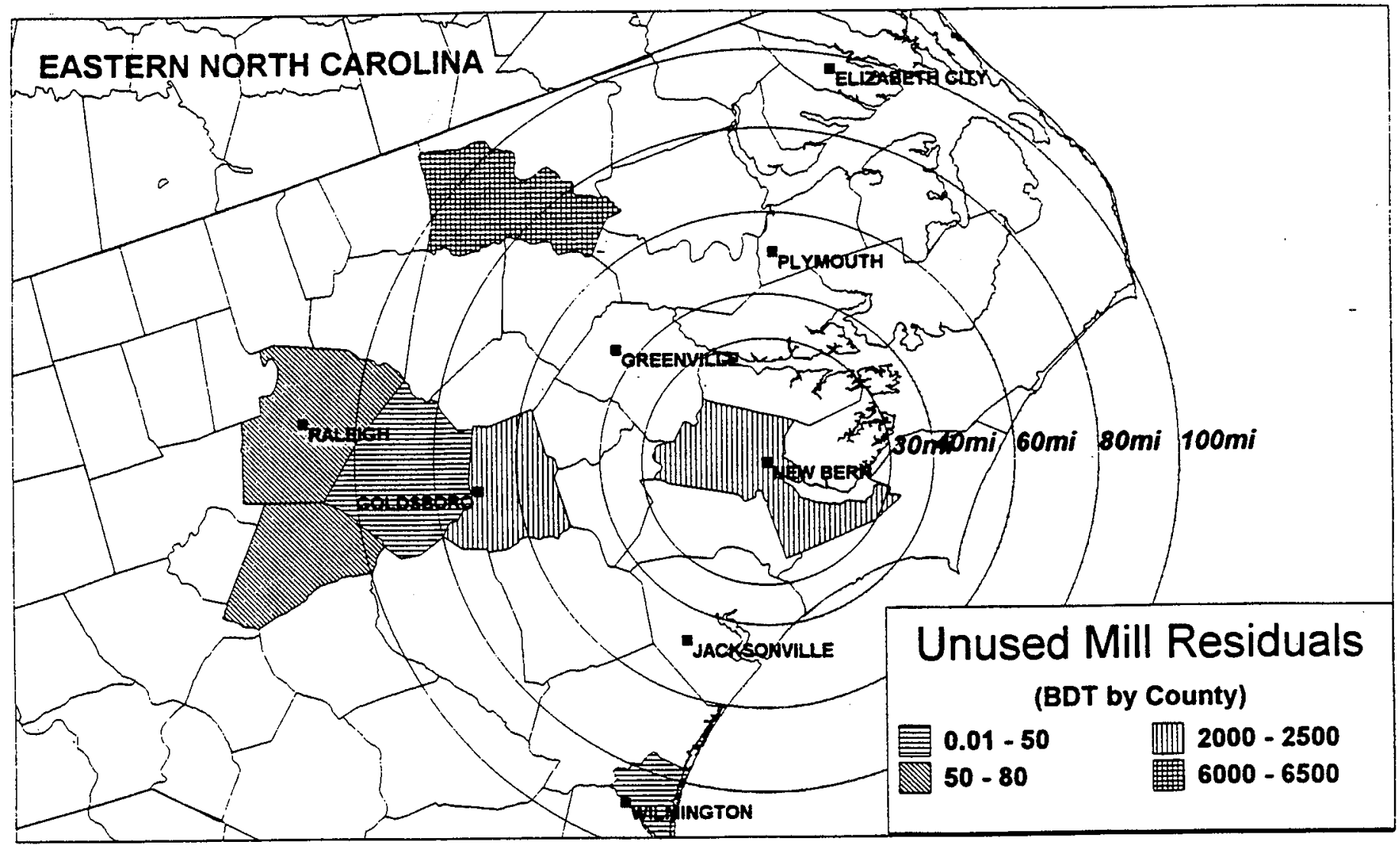

Figure 3-4: Map of Unused Mill Residuals

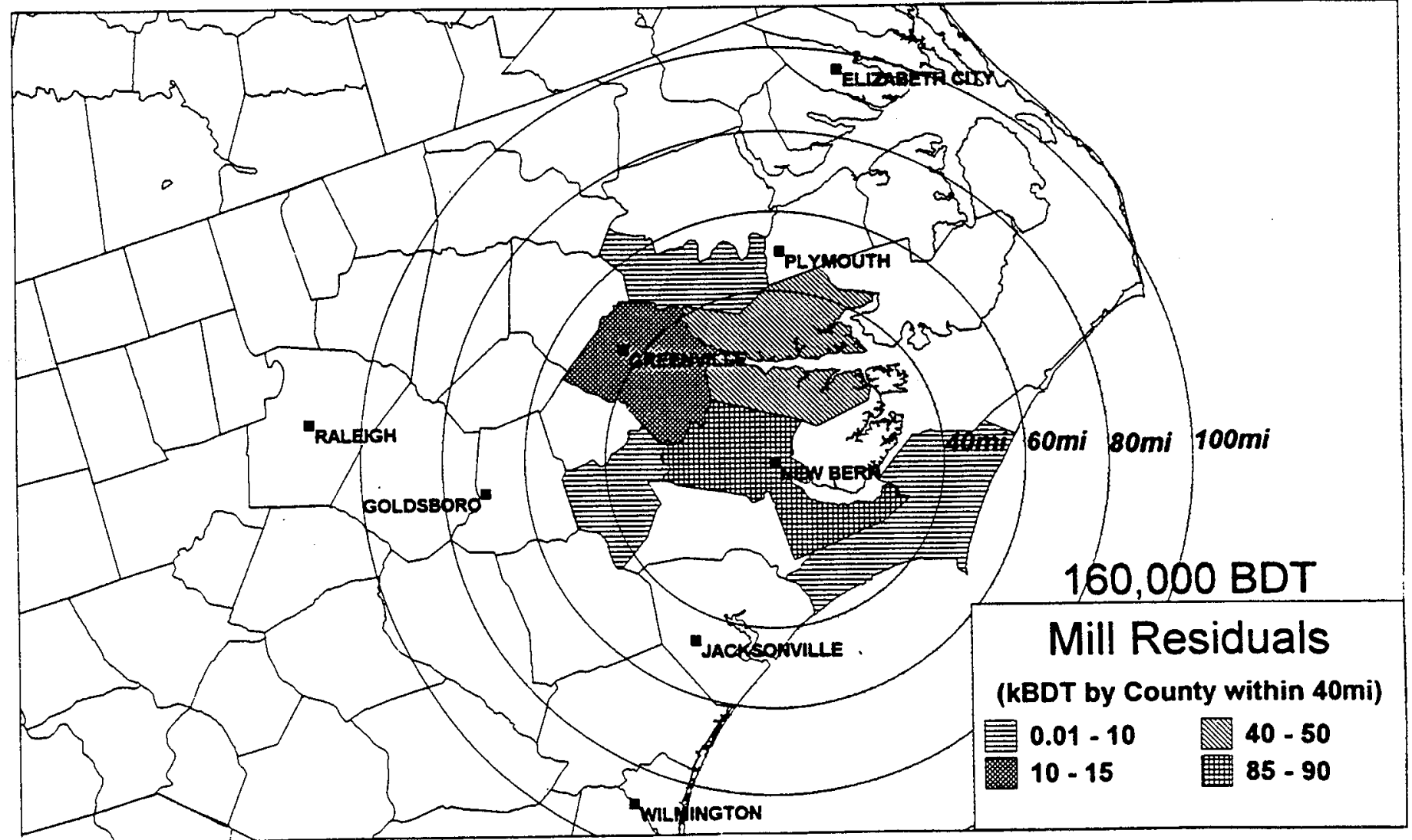

Figure 3-5: Map of Total Mill Residuals 
Data for residual material available from external sources was obtained primarily from resource bulletins published by the Southeastern Forest Experiment Station, United States Department of Agriculture (Resource Bulletins SE-111, SE-113, SF-120, and SE-142). The Forest Experiment Station researchers and writers of the bulletins (in particular Tony Johnson) were especially helpful in interpreting the data in the bulletins and in making a special run to collate the mill residual data on a county by county basis. The quantity in each country was roughly proportioned on the basis of each county's map area within mileage circles around New Bern.

The forest residue quantity available from lands not owned by Weyerhaeuser was determined on a countyby-county basis and then allocated to mileage circles as discussed above. A recoverable residual biomass to merchantable growing stock ratio was determined on a full state basis since this was the lowest level that individual biomass component information was available (Resource Bulletin SE-142). This ratio was then applied to the merchantable growing stock for each county (from Resource Bulletins SE-111 and SE113) to determine the recoverable residual by county (see Figure 3-1). In addition, several Weyerhaeuser people knowledgeable about raw materials assessed the quantity information on each component of forest biomass from the bulletin and estimated the amount of each component that would be recoverable and the portion of forests that would be accessible. This was compared with Weyerhaeuser experience and found to be conservatively low.

The data on residual material available from wood product facilities was examined in great detail and in several different ways. In the final analysis the primary data source for both the quantity generated and the disposal options was again the Southeastern Forest Experiment Station (SFES) bulletins. The amount available (unused mill residuals) by county was proportioned on a mileage circle basis as discussed above (see Figure 3-4 and Figure 3-5).

The bulletins contain information on mill residuals from mill surveys conducted every two years on all wood product facilities in the state. These surveys develop data on the quantity and form of residuals generated and their disposal and use. Initially it appeared there might be more residual material available for use than what the bulletins identified as unused. This led to an independent evaluation on specific mill usage supported by information supplied by the TVA Southeastern Regional Biomass office. This data included 118 specific industrial facilities in North Carolina that utilize some form of biomass. The data was screened for wood-residue users within 150 miles of New Bern and compared against the material generated. After deducting the quantity used from that generated and reviewing this quantity with local residual purchasers and comparing it with the SFES bulletin information, there appeared to be an inordinate amount available. The disparity was attributed to changes over the 10 years since the TVA data was developed. Wood-residue usage had increased as poultry bedding, mulch, fuel, furnish, and for pulp, paper, and particle/strandboard.

With the above information, six potential strategies were evaluated as possible approaches for supplying the needed biomass for the projects. These strategies are summarized below.

\subsection{Strategy \#1 - Capture existing volumes of residuals available to Weyerhaeuser that are available at hog fuel (or lower) values.}

\section{Weyerhaeuser Mill Residuals}

Weyerhaeuser processes predominantly pine into bleached market pulp and lumber at the New Bern, Greenville and Plymouth locations. The New Bern wood yard also debarks and chips 200,000 BDT per year of hardwood of which a small portion $(21,000 \mathrm{BDT})$ is used internally for pulp. The major portion 
of the chips are sold for local mill use and for export. These operations also generate residuals that cannot currently be used for the final product of these facilities and is now being sold to non-company users as fuel.

New Bern pulp, New Bern sawmill, and Greenville sawmill generate almost 200,000 BDT per year of bark, sawdust, screenings and hogged waste wood at values of $\$ 10$ to $\$ 20 /$ BDT, FOB generating plant. Greenville furnishes about 70,000 BDT of residual material which has an incremental handling and transportation cost of $\$ 7$ to $\$ 10 /$ BDT (see Table 3-2). At the present time most of this material is sold to Craven Hydraco, a private electricity generating facility utilizing wood residuals, with some small portion going to the Plymouth wood waste boiler on a supplemental basis.

Table 3-2: Weyerhaeuser Mill Residuals

\begin{tabular}{|c|c|c|c|c|}
\hline \multirow[b]{2}{*}{$\begin{array}{l}\text { Fuel } \\
\text { Cost* } \\
\text { (\$/BDT) }\end{array}$} & \multicolumn{4}{|c|}{ Mill Residuals (kBDT) } \\
\hline & $\begin{array}{c}\text { New Bern } \\
\text { Sawmill }\end{array}$ & $\begin{array}{l}\text { New Bern } \\
\text { Pulp Mill }\end{array}$ & $\begin{array}{c}\text { Greenville } \\
\text { Sawmill }\end{array}$ & $\begin{array}{l}\text { Plymouth } \\
\text { Wood } \\
\text { Products }\end{array}$ \\
\hline 16 & 1 & & & \\
\hline 18 & 31 & & & \\
\hline 19 & - & 14 & & \\
\hline 20 & & & 9 & \\
\hline 22 & & 83 & & \\
\hline 23 & & & 61 & \\
\hline 27 & & & & 14 \\
\hline 28 & & & & 6 \\
\hline 34 & & & & 13 \\
\hline Total & 32 & 97 & 70 & 33 \\
\hline
\end{tabular}

*Delivered to New Bern

An additional 33,000 BDT of residual material is available from the Plymouth plywood and sawmill facilities at a value of $\$ 16$ to $\$ 25 / \mathrm{BDT}$, and having an incremental transportation cost of $\$ 9$ to $\$ 11 / \mathrm{BDT}$ (Table 3-2).

The wood products facilities at New Bern and Greenville also generate about 10,000 BDT of dry planer shavings. This material was not included as a source for fuel because of its very high value (\$34/BDT) as poultry bedding and furnish for engineered panels.

The obvious benefit of using the mill residuals as fuel is the large volume of low value material already owned by Weyerhaeuser, and in the case of New Bern, that is already on site. The handling costs are the only incremental costs and the existing value is what other people are willing to pay for fuel less transportation cost. Craven Hydraco has communicated their intent to substantially reduce their use of Weyerhaeuser mill residuals as they convert to a source of shipped cross ties. This reduction could leave the New Bern residual fuel without a viable market. Using this source of material for a new New Bern power plant provides a dedicated Weyerhaeuser supplier/consumer; a reliable flow of fuel; an opportunity 
to reduce current handling, marketing, and disposal costs; and the opportunity to add value to existing products.

\section{Weyerhaeuser Log Storage Yard Waste}

Before processing logs for mill usage many small logs are broken and accompanying limbs, chunks, and bark are removed during the storage and handling of logs. In the past, because of a fairly high level of dirt and rocks, this material was collected and hauled to landfill for disposal. However in 1994 approximately $2000 \mathrm{BDT}$ of this material from the New Bern and Greenville sawmills was collected, ground and sold as fuel for energy. If the fuel facility being considered has the capability to handle the higher level of dirt and rocks, this component would add about $1400 \mathrm{BDT} /$ year at $\$ 19$ to \$22/BDT and about $2500 \mathrm{BDT} / \mathrm{year}$ at $\$ 26$ to $\$ 30 / \mathrm{BDT}$. This was not included in the following summaries.

\section{Non-Weyerhaeuser Plant Residuals}

Based on the mill surveys conducted by the Southeast Forest Experiment Station, only 88,000 BDT (1.8 percent of total mill residuals) of the mill residue generated in North Carolina in 1989 was not used. This was reduced even further to only 62,000 BDT (1.4 percent of total mill residual) in 1991 . In 1989, based on a breakdown of this survey data by counties, about 18,000 BDT was unused within a 100 mile radius of New Bern and 50 percent of that was more than 60 miles away from New Bern. Although the 1991 data was not available by county, if it is assumed that the unused residuals distribution was the same as in 1989, there would have been only 13,000 BDT available within 100 miles in 1991 (Table 3-3 and Figure 3-4). Because of proximity to New Bern and the associated lower transportation costs, there is a high probability that some portion of the 433,000 BDTs of mill residuals within a 40 mile radius currently being utilized by others would be available to a New Bern facility (Figure 3-5). Because of the speculative nature of the quantity and cost of this material it has not been included in any of the tables, however as a facility comes on stream, this component could help increase the locally available material and reduce the subsequent cost. Continued efficiency improvements in wood product plants and increases in residual uses will reduce somewhat the amount available from this resource in the 1998 and beyond time frame.

Table 3-3: Unused External Mill Residuals

\begin{tabular}{|l|r|r:r:r|r|}
\hline Distance from New Bern (miles) & 30 & 40 & 60 & 80 & 100 \\
\hline Unused mill resid. (kBDT/year) & 3.2 & 0.8 & 2.2 & 1.8 & 4.6 \\
\hline Cost at mill (\$/BDT) & 18 & 18 & 18 & 18 & 18 \\
\hline Transportation Cost (\$/BDT) & 4 & 4 & 8 & 11 & 15 \\
\hline Total Cost (\$/BDT) & 22 & 22 & 26 & 29 & 33 \\
\hline
\end{tabular}

\section{Poultry House Waste}

Dry planer shavings from Weyerhaeuser and other sawmills are being purchased at a high value ( $\$ 30$ to $\$ 34 / \mathrm{BDT}$ ) and utilized as bedding material in the burgeoning North Carolina poultry business. After use, the material is reclaimed from the poultry houses and some of it is spread on farm fields as mulch and fertilizer. One of the larger users, Goldsboro Milling, uses approximately 90,000 tons of shavings annually to which the poultry adds about 25,000 tons. Today there is a cost to Goldsboro Milling to reclaim,load, haul and spread the material in the fields as well as a problem with winter time disposals when the fields are too wet to spread. Goldsboro is very interested in alternative disposals and it was assumed that this material would be available for the cost of transportation or $\$ 8$ to $\$ 12 / \mathrm{BDT}$. Since it 
was not known if the fuel facility could handle this material it was not included in the following summaries. However if $110,000 \mathrm{BDT}$ could be delivered for $\$ 12 / \mathrm{BDT}$ the weighted average cost for the amount of feedstock required to fuel the facilities discussed in this study would be lowered to $\$ 17-20 /$ BDT.

\section{Summary Strategy \#1:}

Mill residuals from Weyerhaeuser mills are an obvious first choice for fuel as they are readily available, can be committed to internal use, and for the most part, are the lowest cost (Table 3-4). Unused residuals from external mills are not a significant quantity (Table 3-4), but with a closer facility some local mills would probably sell to Weyerhaeuser instead of transporting their residuals a longer distance. The use of poultry house residuals could reduce the average cost of fuel significantly. 
Table 3-4: All Mill Residuals (kBDT/year)

\begin{tabular}{|c|c|c|c|c|c|c|c|c|}
\hline \multirow[b]{2}{*}{$\begin{array}{l}\text { Fuel Cost } \\
\text { (\$/BDT) }\end{array}$} & \multirow{2}{*}{$\begin{array}{c}\text { Dist. from } \\
\text { N.B. } \\
\text { (miles) }\end{array}$} & \multicolumn{4}{|c|}{ Weyerhaeuser Mill Residuals } & \multirow{2}{*}{$\begin{array}{c}\text { Non-Wey. } \\
\text { Mill } \\
\text { Residuals }\end{array}$} & \multirow{2}{*}{$\begin{array}{c}\text { Total } \\
\text { Mill } \\
\text { Residual }\end{array}$} & \multirow{2}{*}{$\begin{array}{c}\text { Accm. } \\
\text { Mill } \\
\text { Residual }\end{array}$} \\
\hline & & $\begin{array}{c}\text { New Bern } \\
\text { Sawmill }\end{array}$ & $\begin{array}{l}\text { New Bern } \\
\text { Pulp Mill }\end{array}$ & $\begin{array}{c}\text { Greenville } \\
\text { Sawmill }\end{array}$ & $\begin{array}{l}\text { Plymouth } \\
\text { Wd Prod }\end{array}$ & & & \\
\hline 16 & 0 & 1 & \multirow{4}{*}{14} & \multirow[b]{4}{*}{9} & & & 1 & 1 \\
\hline 18 & 0 & 31 & & & & & 31 & 32 \\
\hline 19 & 0 & & & & & & 14 & 46 \\
\hline 20 & 50 & & & & & & 9 & 55 \\
\hline 22 & 0 & & \multirow[t]{3}{*}{83} & \multirow{3}{*}{61} & \multirow[b]{3}{*}{14} & \multirow[t]{2}{*}{4} & 87 & 142 \\
\hline 23 & 50 & & & & & & 61 & 203 \\
\hline 27 & $\begin{array}{l}\text { 40; Ply } \\
\text { (60) }\end{array}$ & & & & & 2 & 16 & 219 \\
\hline 28 & 60 & & & & \multirow[b]{4}{*}{13} & & 6 & 225 \\
\hline 30 & 60 & & & & & 2 & 2 & 227 \\
\hline 33 & 80 & & & & & 5 & $\mathbf{5}$ & 232 \\
\hline 34 & 60 & & & & & & 13 & 245 \\
\hline $\begin{array}{c}\text { Source } \\
\text { Total }\end{array}$ & & 32 & 97 & 70 & 33 & 13 & 245 & \\
\hline
\end{tabular}

\subsection{Strategy \#2 - Incorporate mill residuals that currently are going to landfill or lagoon disposal sites at a net cost and potential liability to the Company.}

New Bern Pulp currently sends sludge (23,850 wet tons) to an old landfill as $10-15$ percent solids at about a $\$ 4.00 /$ ton handling cost (est.). New landfill space would have a much higher cost. Probability of permitting additional landfill construction beyond the current space is difficult and would require significant capital.

The landfill and the treatment lagoons at New Bern have many tons of material that could be recovered as a fuel source. The lagoons may have to be dredged in the near future with expensive disposal alternatives. Combustion under controlled temperature is a potential remediation process. Plymouth has a system in place to dry dredged sludge for burning, but does not have the capacity to dry and burn all their lagoon sludge if further cleanout is required. A system designed with the temperature requirements of sludge burning at New Bern could be a desirable home for this material. The mill residuals included in this discussion are generally not net contributors to an energy balance due to their high moisture levels ( 85 percent to 90 percent moisture content). However, the use by the energy facility would have a significant benefit to the mill site in the form of reduced operating cost for disposal. There may be qualities that discourage their use as a fuel source. Use in an energy system would capture some benefit from materials that are currently direct costs. Landfill or lagoon storage have been low cost options, but creation of new space will continue to increase in cost with significant regulatory barriers that may prevent long term continuation without changes and significant costs. Thermal conversion in a gasifier or combustion system may become an attractive alternative.

\section{Summary Strategy \#2:}

Requires suitable drying technology, regulatory driven, some risk, and not a significant Btu source. 


\subsection{Strategy \#3 - Capture existing and/or potential woods residual chips from final harvest and plantation thinning, that are available at hog fuel prices plus transportation.}

\section{Non-Weyerhaeuser Forest Residuals}

Recovery of forest logging residuals at the time of final harvest for roundwood is already a significant and reliable source of biomass fuel for the Weyerhaeuser wood residue boilers in Plymouth. Its contribution has ranged from 10 percent to 35 percent of the Plymouth wood fuel source over the last six years. Although higher in cost than the mill residual increment by $\$ 4$ to $\$ 7 / B D T$ it is available in significant quantities within a 100 mile hauling distance of New Bern.

Every four to six years the South Eastern Forest Experiment Station of the U.S. Forest Service conducts a survey of the North Carolina standing forest inventory and of operational logging sites. Based on the 1989 survey, 8 percent of the merchantable growing stock (6 percent softwood, 10 percent hardwood) in harvested areas is left in the woods as logging residue. In addition unmerchantable material, composed primarily of small stems, 1-inch to 5-inch diameter at breast height (dbh), and tops and limbs, but with a portion of salvageable dead trees, rough trees, and partially rotten trees, is not currently recovered. The total unmerchantable material is an increment about 25 percent greater than the merchantable growing stock for softwood and about 55 percent greater than the merchantable growing stock for hardwood.

After several knowledgeable people assessed each unmerchantable component for recoverability, it was determined that approximately 40 percent of the unmerchantable pine and 35 percent of the unmerchantable hardwood would be recoverable from those stands selected for residual harvest. It was also assumed that residual recovery would not be attempted on 50 percent of the stands due to small stand size, inaccessibility, operability constraints, low volume per acre, and a future shift from natural stands to more plantations for Weyerhaeuser and other large forest products companies. The increment to the merchantable growing stock removal amounts to 16 percent (about 7 BDT/acre) for softwood and 31 percent (about 13 BDT/acre) for hardwood. Residual availability was determined for each county and then each county was proportioned on the basis of map area and portions assigned to specific mileage zones around New Bern (see Figure 3-5). Residual availability and costs were determined for mileage zones from 40 to 100 miles in 20 mile increments (see Table 3-5).

Table 3-5: Forest Residuals

\begin{tabular}{|l|r:r:r:r|r|}
\hline Dist. from New Bern (miles) & 30 & 40 & 60 & 80 & 100 \\
\hline Material Avail (BDT) & 92 & 58 & 122 & 157 & 209 \\
\hline Recovery cost (\$/BDT) & 17 & 17 & 17 & 17 & 17 \\
\hline Transportation Cost (\$/BDT) & 4 & 4 & 8 & 11 & 15 \\
\hline \hline Total Cost (\$/BDT) & 21 & 21 & 25 & 28 & 31 \\
\hline
\end{tabular}

For more than 6 years Weyerhaeuser has experienced a residual recovery of 10 to 15 BDT/acre on natural pine stands, which is about 50 percent greater than the estimate above and should verify the assumption as conservative. Logging contractors have developed efficient systems for residual recovery over the more than six years of producing fuel for Weyerhaeuser and are now realizing incremental harvest costs which range from $\$ 14$ to $\$ 18 /$ BDT with transportation and handling costs an additional $\$ 8$ to $\$ 12 /$ BDT with hauling distances of 40 to 70 miles. 
The lower costs of regeneration behind harvest operations utilizing a woods chipper to remove more biomass provides a competitive advantage for purchase of stumpage from some small private landowners. While this type of advantage may be difficult to assign a value to, as competition for timber increases, it may be the difference in being competitive for this timber stumpage.

\section{Plantation Final Harvest}

Merchantable volume from final harvest of plantations will continue to increase until about the year 2000 and then level off at that amount into the foreseeable future. Based on projected quantities of limbs and tops and the residual recovery results from early plantation harvests there appears to be 16 to 25 percent increment of residual biomass available for fuel. This is composed of non-merchantable, hardwood ingrowth, pine tops and large limbs, landing scraps, long butts and lily pads. With an identified need and improved values this could be increased slightly through the use of harvesting heads which could cut off the stem at or slightly below ground level. Assuming that 50 percent of the available material would be recoverable in 1998 and with improving technology and production efficiencies this would improve steadily to 70 percent by 2008 . This would provide about 25,000 BDT of residuals for fuel in 1998 increasing to almost 80,000 BDT in 2008 as presented in Table 3-6.

Table 3-6: Final Harvest Biomass

\begin{tabular}{|c|c|c|}
\hline $\begin{array}{c}\text { Harvest } \\
\text { Year }\end{array}$ & $\begin{array}{c}\text { \% } \\
\text { Recovered }\end{array}$ & $\begin{array}{c}\text { kBDT } \\
\text { Produced }\end{array}$ \\
\hline $\mathbf{1 , 9 9 8}$ & $50 \%$ & 26 \\
$\mathbf{1 , 9 9 9}$ & $52 \%$ & 30 \\
$\mathbf{2 , 0 0 0}$ & $54 \%$ & 26 \\
$\mathbf{2 , 0 0 1}$ & $56 \%$ & 42 \\
\hline $\mathbf{2 , 0 0 2}$ & $58 \%$ & 49 \\
$\mathbf{2 , 0 0 3}$ & $60 \%$ & 53 \\
$\mathbf{2 , 0 0 4}$ & $62 \%$ & 57 \\
$\mathbf{2 , 0 0 5}$ & $64 \%$ & 62 \\
\hline $\mathbf{2 , 0 0 6}$ & $66 \%$ & 67 \\
$\mathbf{2 , 0 0 7}$ & $68 \%$ & 72 \\
$\mathbf{2 , 0 0 8}$ & $70 \%$ & 77 \\
\hline
\end{tabular}

\section{First Thinning}

Market conditions will dictate the stocking level of future plantations in North Carolina. Depending on the value of chips and fuel at first thinning in relation to the value of diameter at final harvest, there may be some options to increase chip and/or fuel harvest removals in the first thin. Projections do not favor losing final harvest diameter.

At the present time with New Bern pulp requiring high specific gravity material and much of the first thin material below the specification, a large quantity of first thinning material has been whole tree chipped in the woods and all of it sold as fuel. However higher expected future demand for chips from already planted plantations is expected to shift the existing first thinning activity from fuel production to pulp and paper chip production for export and domestic sales. 
Although the total volume for fuel from this source will decrease, if these operations utilize woods chipping with flail debarking then about 5 tons/acre of flailed bark, limbs and tops can be recovered for fuel as a byproduct of the chips at a recovery (grind and load) cost of $\$ 15$ to $\$ 20 / \mathrm{BDT}$. This will provide about 20,000 BDT of residual fuel annually during the 1998 to 2006 time frame (see Table 3-7).

Table 3-7: First Thinning Biomass

\begin{tabular}{|c|c|c|}
\hline \multirow{2}{*}{$\begin{array}{c}\text { Harvest } \\
\text { Year }\end{array}$} & \multicolumn{2}{|c|}{ Biomass (kBDT) } \\
\cline { 2 - 3 } & $\begin{array}{c}\text { 20\% Avail. } \\
\text { Flail \& Chip }\end{array}$ & $\begin{array}{c}\text { Produced } \\
\text { on 60\% std }\end{array}$ \\
\hline $\mathbf{1 , 9 9 8}$ & 30 & 18 \\
$\mathbf{1 , 9 9 9}$ & 51 & 31 \\
$\mathbf{2 , 0 0 0}$ & 30 & 18 \\
$\mathbf{2 , 0 0 1}$ & 29 & 17 \\
\hline $\mathbf{2 , 0 0 2}$ & 28 & 17 \\
$\mathbf{2 , 0 0 3}$ & 37 & 22 \\
$\mathbf{2 , 0 0 4}$ & 26 & 16 \\
$\mathbf{2 , 0 0 5}$ & 36 & 21 \\
\hline & $10 \%$ Avail. & Produced \\
& Flail \& Chip & on $40 \%$ std \\
\hline $\mathbf{2 , 0 0 6}$ & 31 & 19 \\
$\mathbf{2 , 0 0 7}$ & 16 & 6 \\
$\mathbf{2 , 0 0 8}$ & 16 & 6 \\
\hline
\end{tabular}

First thinning on already planted more heavily stocked plantations is expected to be completed by 2006 when the wider spacing and fewer trees of the new regime will start to be thinned and overall removal volume and residual volume will be significantly reduced. The new planting regime would only yield about 1 to 2 tons/acre of residuals from thinning and because of low volume (requires coverage of up to 24 acres for each truckload) could only be applied to the highest volume stands (assumed to be applicable to 40 percent of available stands), which would make it costly to recover. This would only provide 5,000 to 8,000 BDT per year (see Table 3-7).

Weyerhaeuser North Carolina timberlands operations is also considering an alternative to the woods chipping approach for first thinning in both time frames which removes the thinning material in roundwood log form from the forest and processes the stems at a chip plant. This would still recover the bark at the chip plant but since the chipping or grinding process would need to be brought to the woods specifically for the small increment of fuel from the limbs and tops (less than 1 ton/acre or more than 24 acres required per truckload) the costs would probably be prohibitive for either of the above plantation time frames.

\section{Second Thinning Residuals}

Cut to length harvesters will be utilized for second thinning and this process removes the limbs and tops and leaves them at the stump while recovering all of the stem to the terminal bud. Recovering these limbs and tops would be more difficult than first thinning or final harvest residual recovery because, in addition to being a very low volume (less than $1 \mathrm{BDT} / \mathrm{acre}$ ), the harvest costs would be considerably higher since 
they would have to be independently collected at the stump and transported to roadside. This would make the costs considerably higher (\$5 - \$7/BDT) than any of the alternative biomass fuel options and would also require incremental fertilization to offset the limbs and tops nutrient contribution.

\section{Site Preparation Residuals}

The initial V-shear operation produces a roll of biomass on each side of the blade even with a fairly clean logging job. This material consists of stump lillypads, non-merchantable stems, understory, and soil litter. After the V-shear pass for slash disposal behind clearcut harvest, a flail-type chipper on a Hydroax with a collection system (silage chopper concept), could be used to collect the residual biomass. However, there is a value in this material to the long term organic matter levels on mineral soils. In addition, there is a question about how much of this shearing will be done long term if the EPA/Corps continues their present direction. Given the regulatory risk, soil organic matter impact, harvesting cost, and other options, this should not rank very high on the list of biomass options.

\section{Summary Strategy \#3:}

Though not the lowest cost, the woods-residual component from natural stand clear cuts is the largest single source of biomass for fuel identified in this study. Based on the conservative assumptions above it amounts to at least $600,000 \mathrm{BDT}$ and based on Weyerhaeuser's experience of 10 to $15 \mathrm{BDT} /$ acre could run as high as 900,000 BDT within a 100 mile radius of New Bern.

\subsection{Strategy \#4 - Grow biomass by maximizing pine volumes per acre without giving up solid wood values, and trying to hold costs to hog fuel values plus transportation.}

\section{Pine Inter-row Planting}

The most cost effective (most tons of biomass produced) approach to increase available biomass would be to plant more trees, make more frequent thinning entries, leave more trees at each entry, lengthen the rotation and forego some diameter growth. An option to achieve this is to plant an additional row of pine between the rows of the existing current prescription and then remove all of the trees in the extra row plus some in the normal rows to reach the desired 200 trees per acre after thinning. If the final harvest values are assumed to be unaffected by this additional row even though current forest growth and financial models indicate that the smaller trees would be worth less, then the incremental site preparation cost must be offset by the value of the additional material removed in the thinning. In order to earn, for example, 8 percent real after tax on the additional site preparation and planting investment, the thinning material must have a value of \$90/BDT if thinned at 14 years and \$120/BDT if thinned at 10 years (refer to Table 3-8, Option 1). There is a possibility that the loss of value from having a smaller log (due to the heavier initial stocking) might be offset by a benefit from the smaller low value juvenile log core and smaller limbs/knots. If a higher final harvest stand value of about 10 percent is assumed then since the thinning provides a offsetting benefit the total required return for thinning and the resulting fuel value can be reduced by 50 percent (refer to Table 3-8, Option 2). This requires a high fuel value of $\$ 45$ to $\$ 60 / B D T$. However, if 80 percent of the material is allocated to the higher value of chips (with an optimistically high chip price of $\$ 50 / \mathrm{BDT}$ ) then the fuel would only need a value of $\$ 35$ to $\$ 40 / \mathrm{BDT}$ for ages 14 to 12 , respectively (see Table $3-8$, Option 3 ). 


\begin{tabular}{|c|c|c|c|c|c|}
\hline \multicolumn{6}{|c|}{ Table 3-8: Inter-row Planting } \\
\hline \multicolumn{6}{|c|}{ ( 450 and 800 trees/acre) } \\
\hline Thin Age & 10 & 11 & 12 & 13 & 14 \\
\hline $\begin{array}{l}\text { Option 1: } \\
\text { All merch and Residuals to fuel } \\
\qquad \text { Required fuel Value (\$/BDT) }\end{array}$ & 120 & 100 & 95 & 90 & 90 \\
\hline $\begin{array}{l}\text { Opiton 2: } \\
\text { "Assumed" } 10 \% \text { Higher Final Stand Value } \\
\text { Required fuel Value (\$/BDT) }\end{array}$ & 60 & 50 & 45 & 45 & 45 \\
\hline $\begin{array}{l}\text { Option 3: } \\
\text { Option 2 with } 80 \% \text { of bole to chips } \\
\qquad \text { Required fuel Value (\$/BDT) }\end{array}$ & 85 & 50 & 40 & 35 & 35 \\
\hline
\end{tabular}

The incremental costs of almost doubling the site preparation and planting costs for the current values of fuel or even optimistically high future values do not appear to be warranted for the harvest of fuel alone, however if chip prices for pulp and paper increase significantly (above \$50/BDT) and if an increase in final harvest values can be validated then a higher planting level with subsequent thinning chips and fuel could be justified.

Early fertilization on responsive stands has been shown to provide the option to increase first thin removal at age 12 by 3 to 4 BDT and still leave larger diameters on crop trees. While this approach does not minimize DOS (unpruned, low value core), the combination of values from a single lift prune, chip harvest, and growing to a larger final diameter may be a net benefit.

\section{Summary Strategy \#4:}

Biologically feasible, low volumes, high plantation establishment and carrying costs.

\subsection{Strategy \#5 - Grow maximum pine/hardwood biomass per acre trying to hold costs to hog fuel plus transportation.}

\section{Hardwood Sprouting Between Rows}

The next increment of volume would come from a strategy that intentionally grew biomass fuel as opposed to using residuals from other processes. A low-investment approach within the existing solidwood strategy could use the current 18 foot bed spacing to advantage. Most of the Weyerhaeuser sites have an understory component of red maple, pepperbush, sweetgum, bay, etc. that is not killed with the $\mathrm{V}$-streaking for the $18 \mathrm{ft}$ beds. This is heavier in natural stands, but plantations can have a significant component. With early thinning, more thinning entries, and wider row spacing, the understory is heavier. North Carolina has not used brush control like the rest of the South. However, brush control between rows might be needed to reduce competition with the pine, but would only be done if the competition level was severe. Energy harvest could replace a brush control on these sites. One of the options for this brush control would be a mechanical chopping or mowing which would replace part of the harvesting cost of an energy operation. 
Seeding between the rows is an option, but most of the native species would have a high seed cost compared to planting. The plantation would then be fertilized, bedded and planted with weed control directly on the top of the bed. The materials between rows could be re-harvested just before second thinning or final harvest or when volume justified with a yet to be developed silage chopper concept. This regrowth material would be sweetgum, red maple, pepperbush, and switchcane. With present technology the harvest costs associated with this biomass harvest would be higher than standard round wood harvest or woods chipping costs. There is an additional cost associated with this strategy that is less apparent. The understory material has a higher concentration of nutrients than pine bark and stem wood. The nutrient concentration increases with increases in the percentage of leaves and non-woody material. Most of eastern North Carolina has soils that are nutrient limited, with much of the available nutrient supply tied up in vegetation. Natural additions to the nutrient pool are limited and would not compensate for removals associated with intensive biomass harvesting of the understory. Thus, nutrient replacement is essential to insure long term sustainability of this type of system. An option for this nutrient replacement is to spread the residual ash from the biomass boiler back across the harvested acres. Research done by the Integrated Waste Management group has shown the costs and values associated with this process. Operational land application of wood ash from the Plymouth boilers is scheduled to begin this year. Estimated application costs are less than costs of new landfill space, so replacement of nutrient removals from biomass harvesting could be limited to nitrogen and phosphorus replacement. There is always the potential for new harvest technologies that would separate leaves and small pieces from the larger pieces and return these to the forest floor with a resulting reduction in this nitrogen and phosphorus replacement cost.

There are values associated with soil organic matter related to water movement, soil structure, root penetration, slow release of nutrients, maintenance of microbial populations, and nutrient retention in the upper soil profile that are extremely difficult to quantify. A conceptual example is the comparison of an old field plantation with a stand on a woods site. The woods site may or may not exhibit the greater productivity of pine, but the greater ecosystem diversity and buffering capacity results in a greater total productivity. The old field site is more comparable to row crop agriculture in relation to the requirement of nutrient additions in excess of removals to maintain long term productivity potential. Another issue in this type of system is the amount of traffic over the soil with heavy harvesting equipment. Rutting and compaction seriously impact the surface rooting volume of most soils and subsequent tree growth. Amelioration during site preparation can alleviate some impacts.

\section{Hardwood Inter-row Planting}

The next increment of volume (and cost) would be to plant sweetgum or red maple in a row between the rows of pines. A nitrogen-fixing tree species that was not very competitive with the pine crop trees would be desirable for this use. There is not a native species available. Wax myrtle is an arborescent shrub that has some potential. Black locust has been used in mine reclamation for this purpose, but is not native or particularly adapted to eastern North Carolina. This row would be chipped at first thinning entry and resprouting encouraged. The sprouts could be harvested whenever volume justified reentry. The incremental costs associated with this approach are primarily the planting stock and planting labor.

\section{Summary Strategy \#5:}

Biologically feasible, high risk, low volumes, high plantation establishment and carrying costs and high harvest costs with current harvest technology. 


\subsection{Strategy \#6 - Grow maximum biomass per acre with a dedicated short rotation plantation using mill residuals and process water and/or other nutrient and water sources locally available to increase the wood and biomass volume produced.}

\section{Dedicated Short Rotation Plantation}

Weyerhaeuser foresters believe that for the Eastern North Carolina region the lower cost fast growth tree crop to grow is a Loblolly Pine plantation. With the addition of the sludge discussed below, it was assumed that the site index could be increased to an 85 site index. For a harvest age of 10 years, it appears that 800 trees per acre initial planting is a good balance between site preparation and planting costs and maximum biomass growth. As with strategy 4 above, the harvested material should have a value high enough to earn 8 percent real after tax on the site preparation and planting investment. Based on projections of growth and volume and expected planting, site preparation, and harvesting cost, fuel value would have to reach about $\$ 50 / B D T$ in order to achieve the required return (see Option 1, Alternative A, Table 3-9). If site preparation and planting costs could be reduced by about 20 percent, then fuel values would only have to reach about \$45/BDT (see Option 1, Alternative B, Table 3-9) and if they could be dramatically reduced by 75 percent, then fuel values would only have to be \$30/BDT (see Option 1, Alternative C, Table 3-9).

Table 3-9: Short Rotation Pine Plantation

\begin{tabular}{|l|r|r|r|}
\hline \multicolumn{1}{|c|}{ Alternative } & \multicolumn{1}{c|}{ A } & \multicolumn{1}{c|}{ B } & C \\
\hline Site Index & 85 & 85 & 85 \\
Initial trees (trees/acre) & 800 & 800 & 800 \\
Final Harvest Age & 10 & \multicolumn{1}{c|}{10} & 10 \\
Site Prep \& Planting Cost & Normal & $\mathbf{8 0 \%}$ & $\mathbf{2 5 \%}$ \\
\hline Option 1: All Merchantable and Residuals to Fuel & & & \\
Total Required Return (\$/BDT) & 50 & 45 & 30 \\
\hline Option 2: Merchantable to chips \& Residuals to fuel & & & \\
Fuel price to return 8\% on site prep (\$/BDT) & 60 & 30 & \\
\hline
\end{tabular}

Though it would reduce the amount of biomass for fuel, a more feasible, though still optimistic, alternative would be to harvest for fuel and for pulp and paper chips. Fuel costs would only have to reach \$30/acre with a 20 percent reduction in site preparation and planting costs (see Option 2, Alternative B, Table 3-9). The above scenarios all assume an optimistically low harvest and transport cost and a relatively high chip price for a very high site with no incremental cost for the application of sludge to achieve the high productivity site.

\section{Increase Biomass through Application of Sludge}

This strategy combines the objective of growing biomass for a fuel source and land application of residuals from a manufacturing process as an alternative to landfill or lagoon storage. The pulp and paper industry generates waste water that must be treated and returned to the environment. Treatment of this process water requires considerable investment and operating costs, regulatory accommodation, and 
seasonal limitation depending on normal riverflows. An alternative to river discharge is irrigation of grass crops or tree crops that have a high level of water use. These crops are able to transpire or evaporate surplus water, as well as incorporate water into biomass. The water has to have suitable chemistry for land application and plant use. A system designed to maximize plant growth, maximize water use, and control risks within reasonable limits will probably require nutrient additions to balance the additions in the process water. The net effect would be a system driven by the need to recycle water using land application and a biomass crop. This system maintains the crop near maximum growth rate to minimize the costs of having a larger area under irrigation. Harvest of the crop transports water and nutrients off the site. With tree crops frequent thinning entries could be used to maintain the stand between full site occupancy and adequate room to grow at maximum rates. Trees grown under this type of regime may not have the wood qualities required for standard lumber and pulp products, thus fuel options may provide a viable use. The costs associated with this approach are not realistic with current sources of fuel unless the inputs are subsidized, possibly with less charged for disposal of wastewater and sludges. Hardwood or pine plantations that are fertilized and watered with mill process water, papermill sludges, hoghouse effluent, municipal waste water or sewage sludges have the potential to maximize biomass production while serving to recycle nutrients and water that needs treatment and disposal. While land application of these materials has not been the traditional low cost option, current regulatory pressures, particularly in nutrient sensitive watersheds, are requiring serious consideration of land application systems. With this type of system in use at various sites around the South and eastern North Carolina, the feasibility is proven. Biologically and operationally it is feasible to grow high yields of desirable biomass fuels on dedicated sites while utilizing waste nutrients and water in environmentally sound systems. Potential yields are at least 10 tons/acre/year.

The City of New Bern is currently land applying municipal sludges on agricultural land and seriously pursuing land application options with Weyerhaeuser for waste water. The Neuse River is nutrient sensitive and options to river discharge are being sought. Since Weyerhaeuser's New Bern pulp mill uses and returns water to this river a short distance upstream from New Bern's sewage plant, there is considerable interest from all parties in maintaining economically feasible solutions to the regulatory limits. Weyerhaeuser as a major forest land owner in many North Carolina counties, is the first option for most municipalities considering land application. There is currently a region team developing a unified policy for dealing with these issues. It seems probable that land application will become the disposal method of choice and may offer an opportunity to grow biomass fuels at subsidized costs.

\section{Summary Strategy \#6:}

Sludge application for high valued crops is double, regulatory driven, may be least cost solution to disposal issues, requires dedicated site and significant investment, some risk of liability issues. Short rotation tree crops dedicated to fuel would require dramatic reductions in site preparation, planting, and harvesting costs in order to achieve a reasonable return on plantation investment even with a significant improvement in growth from sludge application. Short rotation crops for fuel and pulp could be feasible with small improvements in site preparation, planting, and harvesting costs if juvenile wood chips would reach a high enough value. 


\section{Section 4}

\section{Preliminary Business Assessment for the Integrated Enterprise}

\subsection{Economic Evaluation Methodology}

The purpose of this economic analysis is to evaluate the business potential of the biomass-to-energy project concepts which have been studied for New Bern and to identify the economically preferred project. The energy project must be integrated into the New Bern mill, satisfying the mill's need for thermal and electric energy and all other operational requirements. The evaluation process has to consider the New Bern Mill's energy needs and to compete. with any other feasible project which satisfies those needs.

All biomass-to-energy options identified for this economic evaluation supply the required thermal and electrical energy to the mill with the exception of the Base Case Mill (Boiler Modification) Project which would still require the mill to purchase some electricity. Section 2 presents the project description, energy balances, capital costs, and operating and maintenance costs. Because the costs and efficiency of the BGCC technology options are similar, the Tampella flue gas biomass dryer design, which resulted in a slightly lower capital cost and higher efficiency, is used in the economic analysis. Each of the following New Bern Mill project options, with the exception of the Bark Boiler Modification, also produces one or more additional products for sale:

Option No.$$
1
$$

2

$$
3
$$

\section{Additional Product}

\author{
None \\ 33.4 MW power \\ 19.5 MW power $+79,000 \mathrm{GPD}$ ethanol \\ 79,000 GPD ethanol +25.75 tons/hr lignin
}

The basis used for this economic evaluation is to determine the incremental net present value of each of the options studied by calculating each option's total net present value and subtracting from this number the base case's present value. This provides a measure of the incremental benefit of the option. The entity being evaluated in each comparison is the energy project option integrated with the New Bern Mill. Only cash flows between this entity and outside parties are material to this analysis. The base case utilized is a modified power boiler where all cash flows are expenditures. A Weyerhaeuser goal is to minimize the present value of these expenditures.

An incremental project for each option is defined as the total project minus the base case which satisfies the mill's energy needs through the utilization of biomass and oil in the existing boiler. It is the incremental portion of the project which produces other marketable products. If the present value of the incremental plant is positive, then the present value of the total project is greater than the Boiler Modification project, and the option is preferred to the Boiler Modification project. The project with the highest positive incremental present value is the preferred project, which may best meet Weyerhaeuser's goal of minimizing the cost of supplying the mill with the required thermal and electrical energy. The evaluation presented here is focused on the three incremental project options. 
A discounted cash flow (DCF) analysis was used to develop the economic assessment for the incremental projects by deducting a DCF analysis of the Boiler Modification from a DCF analysis of the Option. The economic criteria, as described above, is the net present value (NPV) of the incremental plant's after-tax, pre-finance cash flow. The discount rate used to determine the present value is 12 percent. The evaluation was performed using expected values for all input parameters; the effect of uncertainties in the inputs was determined through sensitivity analyses. The discount rate was one of the variables subjected to a sensitivity analysis.

\subsection{Analysis Input}

Input required for economic analysis of the alternative projects include the following:

\begin{tabular}{ll} 
- & \multicolumn{2}{l}{ Common Input: } \\
- & Schedule \\
- & Inflation and Escalation Projections \\
- & Tax Data \\
- & Unit Prices \\
Option Data: \\
$-\quad$ Performance \\
$-\quad$ Capital Cost \\
$-\quad$ Operating Cost \\
Economic Development Incentives \\
$-\quad$ Capital Grants \\
$-\quad$ Tax Credits
\end{tabular}

Most of the common and economic development incentives input data is summarized on Table 4-1.

The project development schedule is presented in Section 2.8. Schedule information important to the economic evaluation includes the present day reference date for escalating prices, the start of construction, and the in-service date. A 20-year operating life was assumed.

A long-term general inflation rate of 3.5 percent was assumed for the analysis. This rate agrees with the inflation projection being used by Carolina Power \& Light (CP\&L) in its assessment of the market value of power in its region. For escalation rates, most expenditures are expected to escalate with inflation except for waste disposal and fuel oil. Waste disposal escalation is expected to run slightly ahead of inflation; a real escalation rate of 0.5 percent was assumed. The average, long-term real escalation projection of 3.0 percent for fuel oil is based on data published in "Energy Price Indices and Discount Factors for Life-Cycle Cost Analysis - 1995," by the U.S. Department of Commerce (Publication No. NISTIR 85-3273-9). This reference also verified that electricity prices are expected to closely follow inflation over the long term. Weyerhaeuser expects the feedstock price escalation to be somewhere between -1 to +2 percent in real terms over the long term. For the design basis evaluation, feedstock is expected to escalate with inflation. The effect of feedstock price escalation on the economic results will be addressed in the sensitivity analysis.

Tax data includes the following:

- Income Tax:

- Federal tax rate is 35 percent of taxable income.

- Weyerhaeuser's effective state income tax rate for plants located in North Carolina is assumed to be 3 percent and is deductible for Federal Income Tax computation. 
- Tax depreciation rate for the biomass-to-energy projects is 5 year, 200 percent declining balance.

- $\quad$ Property Tax:

- Property tax rate is 0.66 percent of book value.

- Book value declines 7 percent per year until 25 percent of the original value is reached.

The State of North Carolina offers several tax credits which may apply to some or all of the options being considered. The possible credits include:

- Construction of Cogenerating Power Plant

- For purchase and installation of the electrical or mechanical power generating equipment of a cogenerating power plant.

- $\quad$ Credit equals 10 percent of the installed cost.

- $\quad$ The credit may not exceed the taxpayer's North Carolina tax liability.

- Ten-year carryover period.

- The combustion equipment that uses residual oil, middle distillate oil, gasoline, natural gas, or LPG does not qualify for the credit.

- If the total credit for all applicants exceeds $\$ 5,000,000$ during a calendar year, the credit will be prorated among all eligible applicants.

- Conversion of Industrial Boiler to Wood Fuel

- For modification or replacement of an oil or gas-fired boiler or kiln and associated fuel and residue handling equipment with one that is capable of burning wood.

- One-time credit equals 15 percent of the equipment and installation cost of conversion.

- No carryover.

- The credit may not exceed the taxpayer's North Carolina tax liability.

- Fuel Ethanol Distillery

For the construction of a distillery to make ethanol from forestry products

Only applicable to costs incurred during taxable years beginning prior to January 1, 1996.

- Credit equals 20 percent of the installation and construction costs, plus an additional 10 percent if the distillery is powered by an alternative fuel source.

- The credit may not exceed the taxpayer's North Carolina's tax liability.

- The excess, if any, may be carried forward for the next ten years. 
- If the total tax credit from all eligible taxpayers exceeds $\$ 5,000,000$ and/or $\$ 2,500,000$ for all eligible corporations, the credit will be limited.

Use of these credits is limited either by Weyerhaeuser's effective state tax rate or by possible competition for the credits by other applicants. The effect of including any one of these three possible tax credit was not evaluated for the design basis evaluation at this time. The credits, when applicable, were utilized in a sensitivity calculation and in this calculation were assumed to be used in their entirety in the first year of operation, offsetting other Weyerhaeuser state tax liability. In the sensitivities, the cogeneration and wood fuel credits were used for Option 2, and the ethanol credit was used for Options 3 and 4.

Biomass gasification is eligible for a federal tax credit based on a barrel-of-oil equivalent, adjusted annually for inflation (1994 credit rate per barrel was about $\$ 5.85$ ). However, the following conditions apply:

- Credit is allowed to the producer of gas from biomass if the gas is sold to an unrelated person.

- The facility must be placed in service before January 1,1997 , pursuant to a binding written contract in effect before January 1, 1996.

- Credits can not be used against the minimum tax.

- Credit can be phased out if oil prices exceed certain levels (1994 level is about $\$ 45.75$ per barrel).

- $\quad$ Credit expires on January 1, 2008.

Since a BGCC project at New Bern could not meet the January 1, 1996, date (refer to Figure 2.8-1, Project Schedule in Section 2.8), this federal tax credit was not considered in the economic analysis. There is a federal tax credit available to ethanol producers whose production capacity does not exceed 30 million gallons in a tax year. The credit is ten cents per gallon for up to 15 million gallons of production. This credit is scheduled to expire on January 1, 2001. An alcohol plant at the New Bern mill would qualify for this credit. However, since the ethanol process requires additional development before a project of the size proposed at New Bern could be initiated, by the time the plant is commissioned the tax credit would be expiring in a year or so. It is, of course, possible that the tax credit would be extended. Therefore, the impact of the tax credit is considered in the economic sensitivity studies.

An alcohol fuel credit is also allowed by the Federal government. However, this credit accrues to the person who actually uses or sells the alcohol for fuel. This credit is discussed in the ethanol market assessment presented in Section 6.2. It is used to develop the expected price at which ethanol would be sold by the New Bern facility to a blender/retailer such as Amoco.

Unit prices used to determine operating costs are presented in Section 2.7. The market price of feedstock is uncertain so the effect of varying feedstock prices on the economic results was tested in the sensitivity analysis. Prices for marketable products are as follows:

- Export power: CP\&L has determined the current market value of the power from the BGCC options to be less than $\$ 0.03 / \mathrm{kWh}$ initially and $\$ 0.038 / \mathrm{kWh}$ levelized over 20 years, based on their avoided cost curve, shown on Figure 6-1. However, a need for baseload power by other utilities in the region in the early years of the next decade may offer market opportunities for export power. Therefore, a range of power sales prices from $\$ 0.03$ to $\$ 0.07 / \mathrm{kWh}$ has been 
assumed to assess the economic impact associated with varying power price levels. CP\&L has indicated that the value of export power may be affected by the unit dispatchability. Therefore, the capacity factor of the export power portion of the plant is treated separately from the rest of the energy plant. The export power capacity factor will never exceed that of the energy plant but may be less, thus affecting revenues.

- $\quad$ Ethanol: The market price for ethanol was assumed to be $\$ 1.17 /$ gallon based on the average market price over the last 3 years, which is supported by the market assessment Amoco presented in Section 6.2. The market price has varied between $\$ 0.94$ /gallon and $\$ 1.45 /$ gallon during that period, and does not appear to be trending up or down but staying level. The ethanol project feasibility is sensitive to the sales price, therefore alcohol price is a variable used for a sensitivity analysis.

- Lignin: Lignin is a useful byproduct of the ethanol process. The lignin will be either used in the gasification process (Option 3), or sold commercially as an alternative to mill biomass residues (Option 4). The market value adjusted for boiler efficiency losses is assumed to be $\$ 12 /$ ton or $\$ 21.82 /$ BDT.

Data on the performance of each option is presented in Section 2.6. The performance parameters of interest include amount and type of feedstock required, and amount of each product generated. These data are provided on a "per operating hour" basis. For those times when the project may be out of service and unable to provide the needed energy to the mill, backup thermal energy is provided by a No.6 oil-fired boiler and backup power is provided by purchases from the utility. The capacity factor of the energy plant is another variable in the sensitivity analysis.

Capital and operating costs developed for each option have been presented in Section 2.7. The capital costs are presented in January 1995 dollars. For the economic evaluation, escalation and interest during construction (IDC) were added to arrive at a total in-service date investment. Escalation was included from the present day reference date to the centroid of expenditure, assumed to occur mid-way through construction. IDC was calculated from the centroid of expenditure to the in-service date, assuming 100 percent debt at short-term interest, which was assumed to be 9 percent. The operating costs include fixed costs, which are incurred whether or not the facility runs as many hours each year as projected, and variable costs, which are incurred only when the facility runs. The estimated capital costs are variables tested in the sensitivity analysis. Of the O\&M costs, only feedstock price, feedstock price escalation, feedstock consumption rate, and enzyme cost are tested in the sensitivity analysis.

Capital grants may be available for the BGCC and BGCC/Ethanol options. The federal funding will help mitigate a portion of the capital risk in an integrated system. A maximum of 50 percent of the plant cost may be available as capital support. The projects, however, are evaluated with and without capital support to assess the federal funding required for commercialization.

\subsection{BGCC Plant Economic Analysis}

The technical and cost input for this option is presented on Table 4-2 and incorporates the total energy project, including that portion which serves the mill's thermal and power requirements. The mill is expected to operate 336 days/year at equivalent full-load, but the BGCC plant is expected to be available for only 310 days/year. Backup steam and power are needed for the mill during those additional days. For this evaluation the Bark Boiler Retrofit is assumed to operate 336 days/year at equivalent full-load. A separate capacity factor is incorporated for the export power portion of the BGCC plant to account for some amount of dispatching which CP\&L may value more highly than a fully dispatched generator. 
Capacity factor for both the energy plant and for the export power portion of the plant are variables to be tested in the sensitivity analysis.

The discounted cash flow for the incremental plant is presented on Table 4-3. The "boxed-in" data along the left side of the cash flow statement highlights important input such as the market price of power used in the analysis which is $\$ 0.05 / \mathrm{kWh}$, the cost of feedstock, capital cost, and support and tax credits. The highlighted capital cost is the present day cost without escalation and IDC to the in-service date; the capital support shown is based on the total in-service date cost of $\$ 118,300,000$ including escalation and IDC. With these assumptions, the NPV at the end of the 20th year of operation, at a 12 percent discount rate, is $+\$ 28$ million, indicating that the BGCC plant is preferred over the Boiler Modification project.

\subsection{BGCC/Ethanol Plant Economic Analysis}

The economic analysis input for this option is presented on Table 4-2 and incorporates the total energy project, including that portion which serves the mill's thermal and power requirements. The mill is expected to operate at equivalent full-load for 336 days/year, but the BGCC/Ethanol plant is expected to be available for only 310 days/year. Backup steam and power are needed for the mill during those additional days. A separate capacity factor is incorporated for the export power portion of the BGCC/Ethanol plant to account for some amount of dispatching which CP\&L may value more highly than a base loaded generator. Capacity factor for both the energy plant and for the export power portion of the plant are variables to be tested in the sensitivity analysis.

A selected discounted cash flow for the incremental plant is shown in Table 4-4. Important input data has been "boxed-in" as was done for the BGCC case. Important input data includes the ethanol market price assumption of $\$ 1.17 /$ gallon and the power price of $\$ 0.05 / \mathrm{kWh}$. The highlighted capital cost includes the alternative's present day cost of $\$ 189,300,000$ and the capital support of $\$ 114,650,000$, based on the in-service date cost of $\$ 229,300,000$ which includes escalation and IDC. The NPV of the net cash flow discounted at 12 percent per year at the end of the twentieth year of plant operation is shown in Figure 4-1 as a function of biomass and enzyme cost, the two most costly inputs to the combined Ethanol/BGCC facility.

The figure shows that under the assumed economic environment, the combined Ethanol/BGCC facility can be an attractive option to the bark boiler retrofit over a range of selected biomass and enzyme costs. With biomass costs of $\$ 10.00$ per wet ton, enzyme costs below about $\$ 5.70 /$ gallon will produce a positive NPV versus the bark boiler retrofit. At biomass costs of $\$ 20.00$ per wet ton, enzyme costs below $\$ 1.80 /$ gallon will produce a positive NPV versus the bark boiler retrofit. At the centroid biomass cost of $\$ 14.00$ per wet ton, enzyme costs below about $\$ 4.20$ will produce a positive NPV. The BGCC/Ethanol plant option will return the same NPV as the BGCC option with biomass costs at $\$ 14.00$ per wet ton and enzyme costs of about $\$ 2.40 /$ gallon.

For a purchase decision on enzyme today, the $\$ 7.57 /$ gallon used in the economic calculations is considered realistic. The sensitivity to enzyme costs would indicate that an improved method of enzyme production or on-site production should be investigated as a way to significantly decrease the cost of ethanol. An April 30, 1993 report entitled "The Cost of Ethanol Production from Lignocellulosic Biomass - A Comparison of Selected Alternative Processes" prepared by the Michigan Biotechnology Institute for the United States Department of Agriculture (Specific Cooperative Agreement No. 58-1935-2050) includes costs for onsite enzyme production which illustrate the large cost reduction potential. 


\subsection{Ethanol Plant Economic Analysis}

The economic analysis input for this option is presented on Table 4-2 and incorporates the total plant, including that portion which serves the mill's thermal and power requirements. The Ethanol plant is expected to operate at least as much as the mill which is expected to operate 336 days/year. Operating cost associated with the provision for backup steam and power are zero, but the backup capability is included in the design. The capacity factor for the energy plant is a variable to be tested in the sensitivity analysis.

A selected discounted cash flow for the incremental plant is shown in Table 4-5. Important input data has been "boxed-in" as was done for the BGCC case. Important input data includes the ethanol market price assumption of $\$ 1.17 /$ gallon and the lignin sales price of $\$ 12$ per ton or $\$ 0.96 / \mathrm{MBtu}$. The highlighted capital cost includes the alternative's present day cost of $\$ 117,900,000$ and the capital support of $\$ 71,250,000$, based on the in-service date cost of $\$ 142,500,000$ which includes escalation and IDC. The NPV of the net cash flow discounted at 12 percent per year at the end of the twentieth year of plant operation is shown in Figure 4-2 as a function of biomass and enzyme cost.

The figure shows that under the assumed economic environment, the Ethanol facility can be an attractive option to the bark boiler retrofit over a range of selected biomass and enzyme costs. With biomass costs of $\$ 10.00$ per wet ton, enzyme costs below about $\$ 3.50 /$ gallon will produce a positive NPV versus the bark boiler retrofit. At biomass costs of $\$ 20.00$ per wet ton, enzyme costs below about $\$ 0.80 /$ gallon will produce a positive NPV versus the bark boiler retrofit. At the centroid biomass cost of $\$ 14.00$ per wet ton, enzyme costs below about $\$ 2.50$ will produce a positive NPV. The Ethanol plant option will return the same NPV as the BGCC option with biomass costs at $\$ 14.00$ per wet ton and enzyme costs of $\$ 1.00 /$ gallon.

\subsection{Comparison of BGCC, BGCC/Ethanol, and Ethanol to the New Bern Mill Modification Project}

All three options to the bark boiler retrofit are expected to return the same positive NPV of about $\$ 28$ million under the following primary conditions, assuming a power market value of $\$ 0.05 / \mathrm{kWh}$ and an ethanol market value of $\$ 1.17 /$ gallon:

$\begin{array}{lcc}\begin{array}{c}\text { Option vs } \\ \text { Bark Boiler Retrofit }\end{array} & \begin{array}{c}\text { Biomass Cost } \\ \text { \$/Wet Ton }\end{array} & \begin{array}{c}\text { Enzyme Cost } \\ \text { \$/Gallon }\end{array} \\ \text { BGCC } & 14.00 & \text { Not Applicable } \\ \text { BGCC/Ethanol } & 14.00 & 2.40 \\ \text { Ethanol } & 14.00 & 1.00\end{array}$

Please note that all projects except the Bark Boiler Retrofit assume 50\% capital support as may be available under the Bimoass Power Program.

\subsection{Sensitivity Analysis}

Sensitivity analyses of the NPV for each incremental project option to the following parameters were performed in order to provide development guidance for future phases of the biomass to liquid fuels and electricity program:

- Amount of capital support - from 0\% to $50 \%$

- Export power price - from $\$ 0.03 / \mathrm{kWh}$ to $\$ 0.07 / \mathrm{kWh}$

- Ethanol price - from $\$ 0.94 /$ gallon to $\$ 1.45 /$ gallon 
- Lignin price - from $\$ 0 /$ ton to $\$ 12 /$ wet ton

- $\quad$ Enzyme cost - from $\$ 1 /$ gallon to $\$ 8 /$ gallon

- State and federal tax credits - applicable or not

- Export power capacity factor - from $50 \%$ to $92 \%$

- Biomass escalation rate - from $-1 \%$ to $2 \%$ real

- Biomass cost - from $\$ 10$ /ton to $\$ 20$ /ton for new biomass (mill residual cost is approximately $43 \%$ of new)

- $\quad$ Energy plant capacity factor - from $65 \%$ to $92 \%$

- Performance - fuel consumption from $80 \%$ to $130 \%$ of estimated. Note that output stays constant.

- Discount rate - from $10 \%$ to $15 \%$

- Capital cost - from $50 \%$ to $150 \%$ of estimated cost without capital support

The results are presented on Figures 4-3 through 4-15.

Based on the above listed sensitivity analyses, it is apparent that the ethanol projects are sensitive to project capital cost, lignin sales price, and biomass and enzyme cost. Figures 4-1 and 4-2 demonstrate the wide range of biomass and enzyme costs over which the production of ethanol from woody biomass through enzymatic processing can be economically attractive versus the bark boiler retrofit case. Issues related to plant design, plant performance, and enzyme costs are items which should be investigated in future phases of biomass-to-liquid fuels technology development. Enhancement of the lignin byproduct value is another fertile area for improving ethanol production economics. The results of this feasibility study are especially encouraging because the ethanol plant options have not been optimized, nor have they been demonstrated on the scale that BGCC has.

The BGCC technology is a more mature technology than ethanol manufacture from woody biomass and, therefore, has near term commercialization potential at New Bern. Given the projected value of power in the region and the fact that a BGCC plant could serve a mill need being defined, the results of this study demonstrate that the BGCC has the potential for achieving improved mill operation and biomass efficiency in a cost competitive manner today.

An examination of three of the sensitivity curves is supportive of this conclusion. Figures 4-4 and 4-9 show the large effect of export power price and capacity factor. Figure 4-15 shows the equally large impact of capital cost. It is evident from these curves that an economically viable BGCC project integrated with a market pulp mill may ultimately be feasible (without subsidy) if the capital cost can be reduced by at least $20 \%$, the export power can be sold for a minimum of 5 cents $/ \mathrm{kWh}$ and the facility can achieve a capacity factor over $80 \%$ The first few plants will have to demonstrate the ability to achieve these goals. The biggest challenges are to reduce the capital cost and demonstrate availability.

The EPRI Technical Assessment Guide (TAG) points out that the cost of the first commercial unit is often higher than expected, but the cost gradually decreases with each of the next three or four units. The cost of the "mature" technology can be lower than the cost predicted prior to the first unit. The commercialization of fluidized bed combustion power plants generally followed this pattern, although the capital cost increased significantly after the first units and then gradually decreased. This was due to the technology owners anxiousness to increase sales rapidly. They designed the initial plants for low capital cost, but they encountered operational problems. Solutions to these operating problems resulted in higher costs for subsequent units. However, less expensive solutions were developed as the technology matured reducing capital cost and the technology has flourished. 
Reasons why capital cost reductions can be anticipated as a technology matures are discussed in Section 2.7.1. Gasification combined cycle technology affords much greater opportunity for cost reduction than was available to fluidized bed combustion.

It is important to note that there are many pulp mills much larger than New Bern. BGCC projects at these larger mills can accommodate larger more efficient gas turbines. Increasing from the 40 MW GE Frame 6B gas turbine to the $70 \mathrm{MW} 6 \mathrm{FA}$ gas turbine should result in an economy of scale capital cost reduction of over $10 \%$.

The objective of this study was to evaluate BGCC for application to the New Bern mill. As such the BGCC project was compared against the mill's plan to retrofit the existing bark boiler. However, a clearer picture of BGCC competitiveness is seen by comparing the BGCC project to a new bark-fired boiler project.

Weyerhaeuser obtained a cost for a new biomass boiler which would replace the steam generation of the existing bark boiler plus generate additional steam which would be used in a new condensing steam turbine to generate the extra electricity required to make the mill self-sufficient. The condensing steam turbine is oversized to debottleneck the existing backpressure steam turbine as discussed in Section 1.3. This project compares to the BGCC project as follows:

$\begin{array}{lll} & \text { BGCC } & \text { New Biomass Boiler } \\ \text { Capital Cost } & \$ 98 \text { million } & \$ 60.3 \text { million } \\ \text { Annual O\&M Cost (excl. fuel) } & \$ 5.2 \text { million } & \$ 2.2 \text { million } \\ \text { Biomass Consumed, MBtu/hr } & 669.7 & 422.4 \\ \text { Export Power, MW } & 33.4 & 0\end{array}$

The BGCC project has a higher capital cost and higher annual O\&M and fuel cost than the new biomass boiler, but the BGCC project produces $33.4 \mathrm{MW}$ for sale to the grid. The electricity sale price will determine whether the additional costs of the BGCC project are justified. In Figure 4-16, the BGCC incremental net present value (the difference between the net present value of the BGCC project without any subsidy or capital cost support and the net present value of the new biomass boiler project) is plotted against the price at which the export power can be sold. The incremental net present value is greater than zero at an electricity sales price of $\$ 0.035 / \mathrm{kWh}$. This means that over the project 20 year life, the BGCC project begins to compete with a new biomass boiler if the electricity could be sold today for at least $\$ 0.035 / \mathrm{kWh}$. Of course, the greater the electricity sales price the quicker payback on the increased BGCC costs. In Figure 4-17 the BGCC incremental net present value which would result if the present day power sales price were $\$ 0.05 / \mathrm{kWh}$ is plotted against years of project life. The figure shows that after 8 years of operation the initial higher capital cost of the BGCC project pays off. At a current electricity sales price of $\$ 0.07 / \mathrm{kWh}$, the payback period is reduced to about 4.5 years as is evident in Figure 4-18.

It is important that a result of this nature appears achievable. If all future projects required a subsidy to proceed it would be difficult to justify the development dollars to commercialize the technology. However, given this analysis and the potential of the technology as discussed in other sections of this report, DOE support of BGCC technology commercialization appears well justified. 
Table 4-1: Economic Input Table

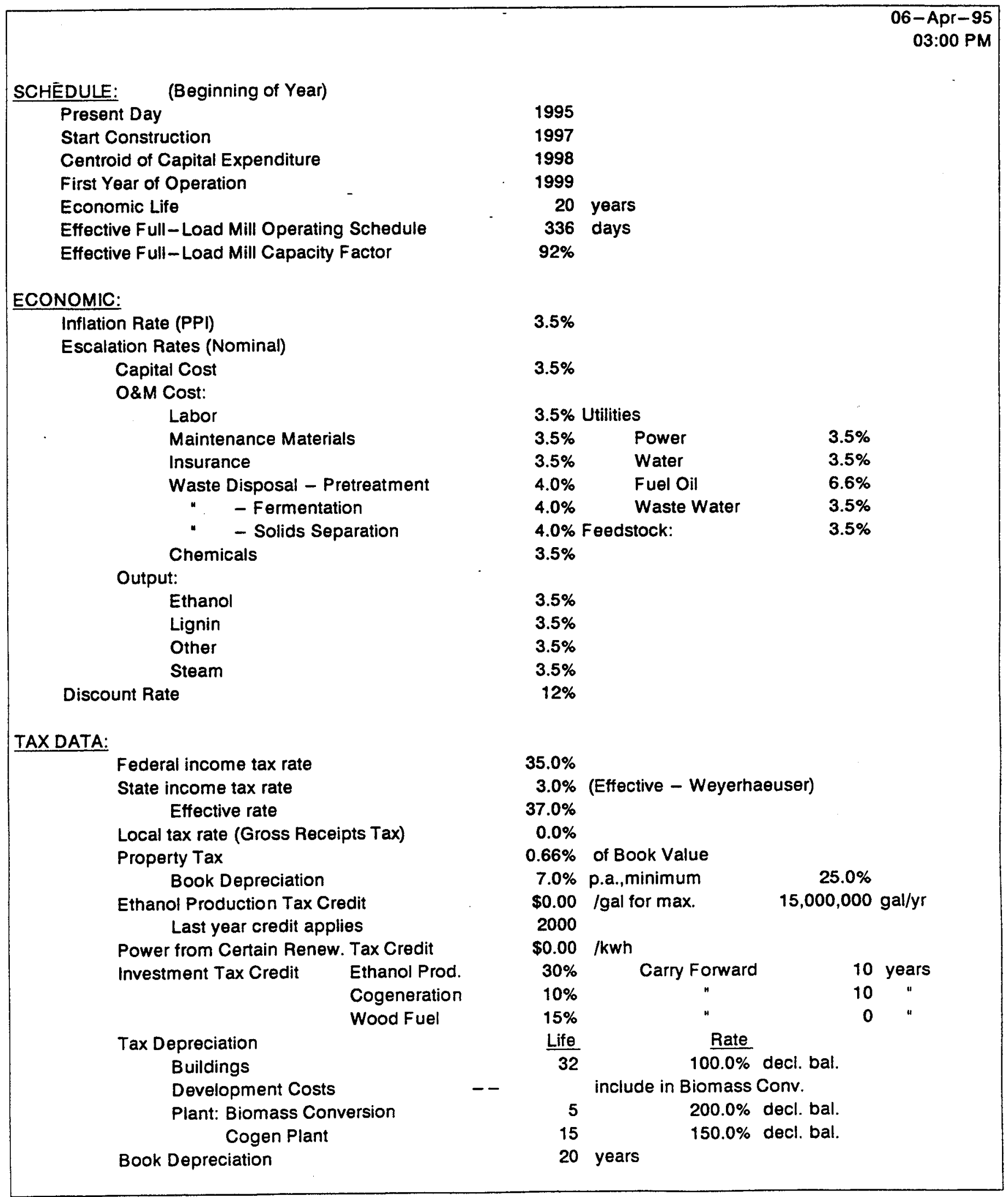


Table 4-2: Master Input Table

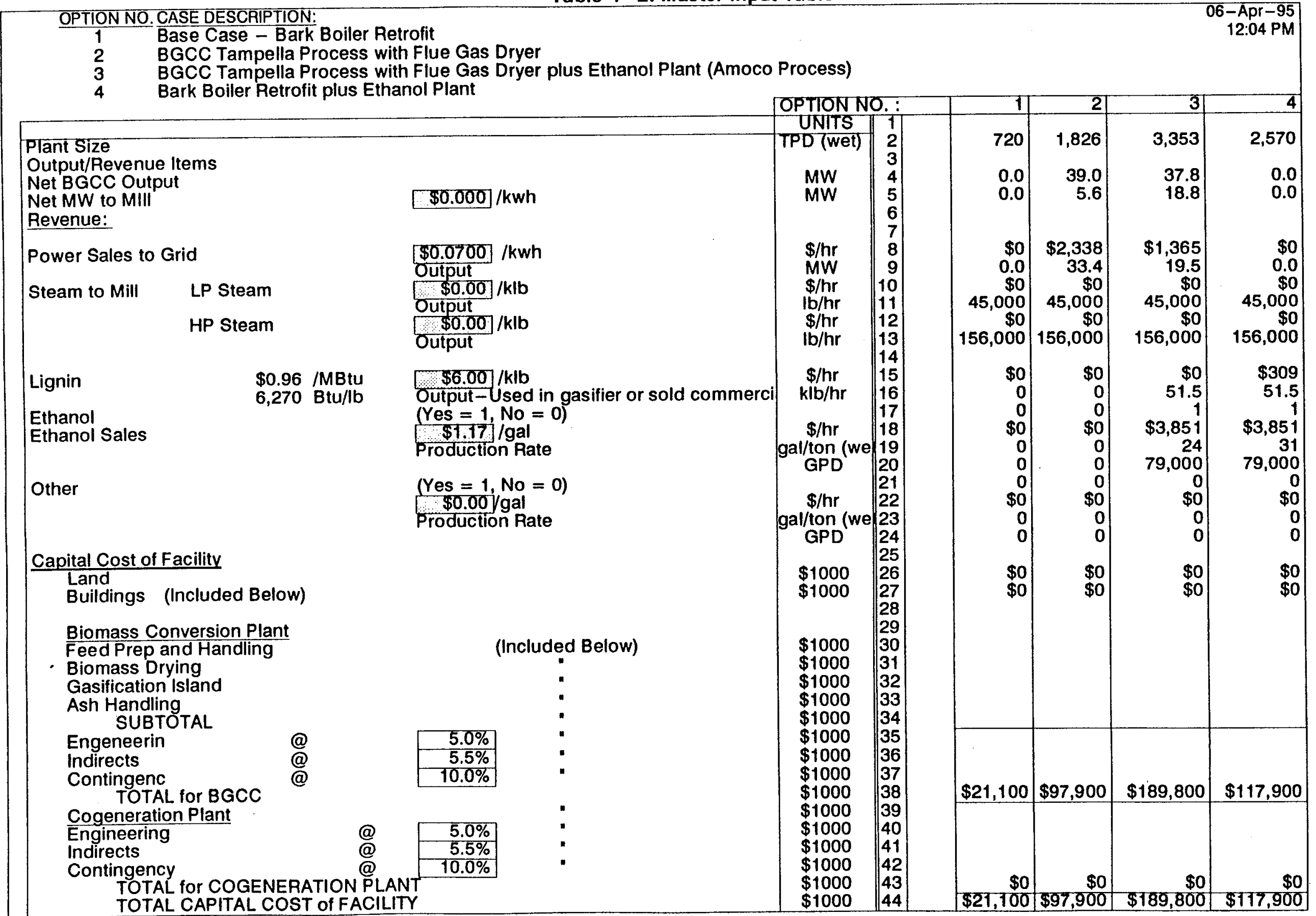


Table 4-2: Master Input Table

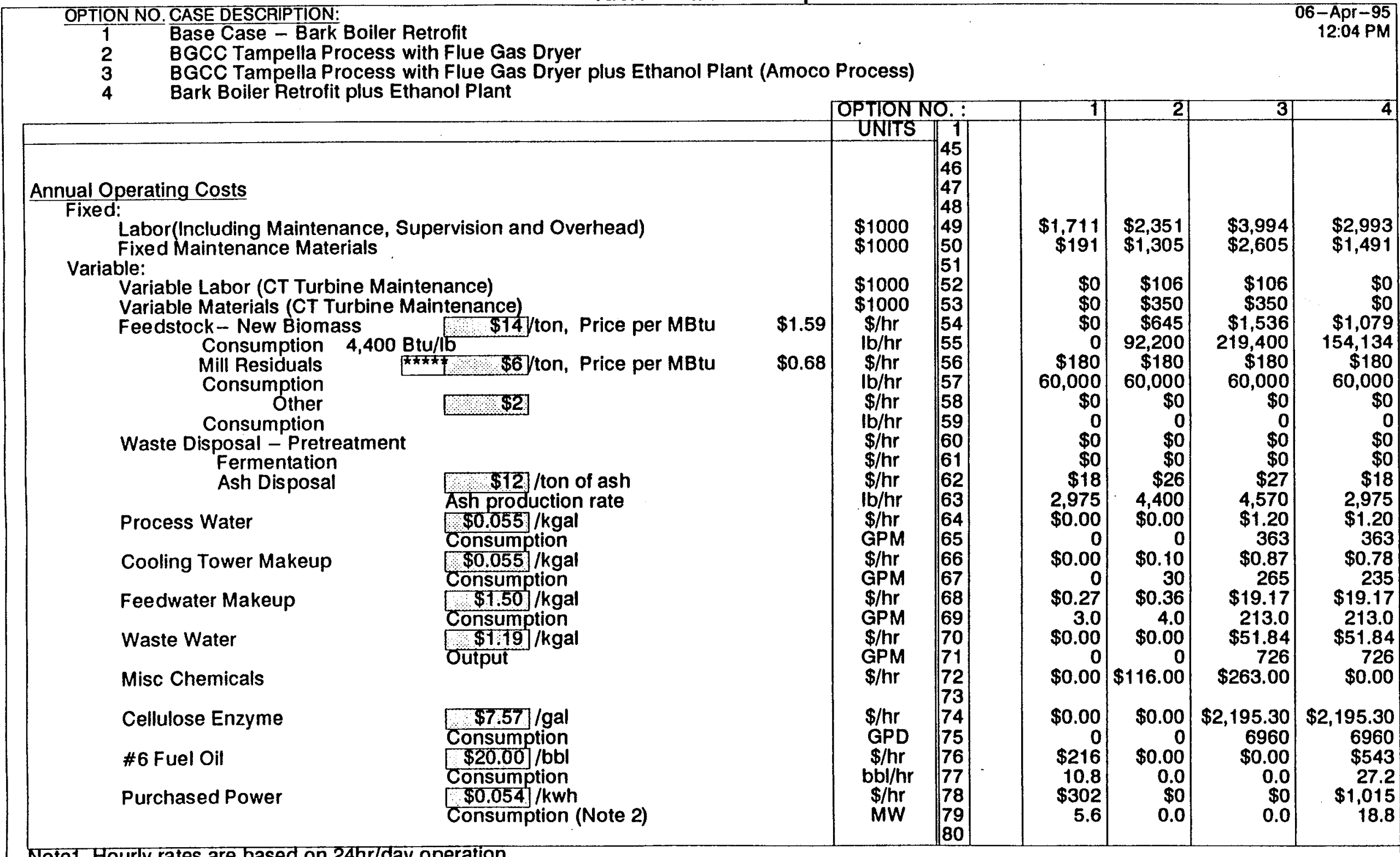

Noter. Hourly rates are based on 24 hr/day operation

2. Mill purchases power during all operating hours under Option 1 only; power is purchased from utility during Energy Plant downtimes for all other options. 
Table 4 - 3 A

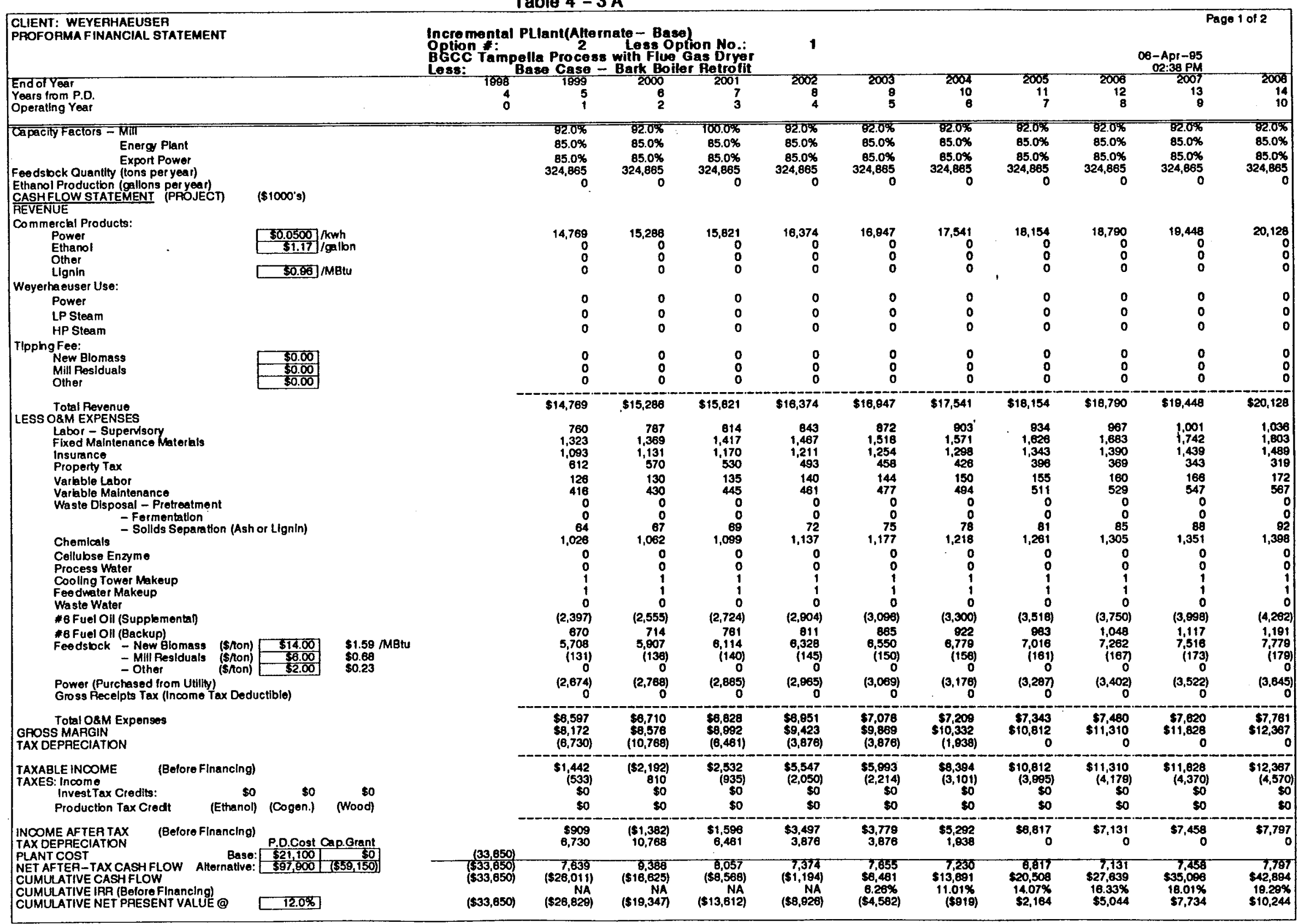


Table 4 - 3 B

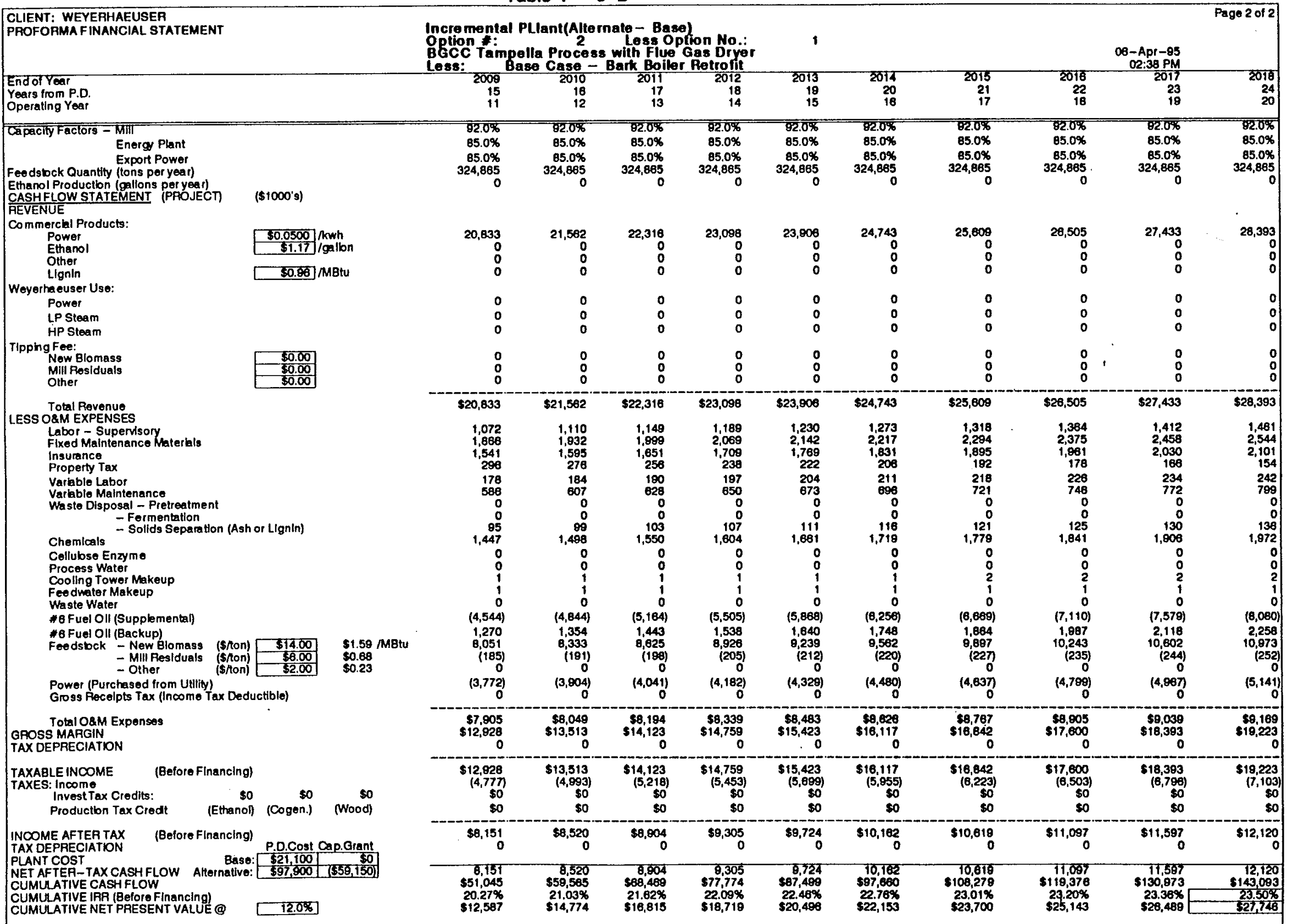


Table 4 - 4A

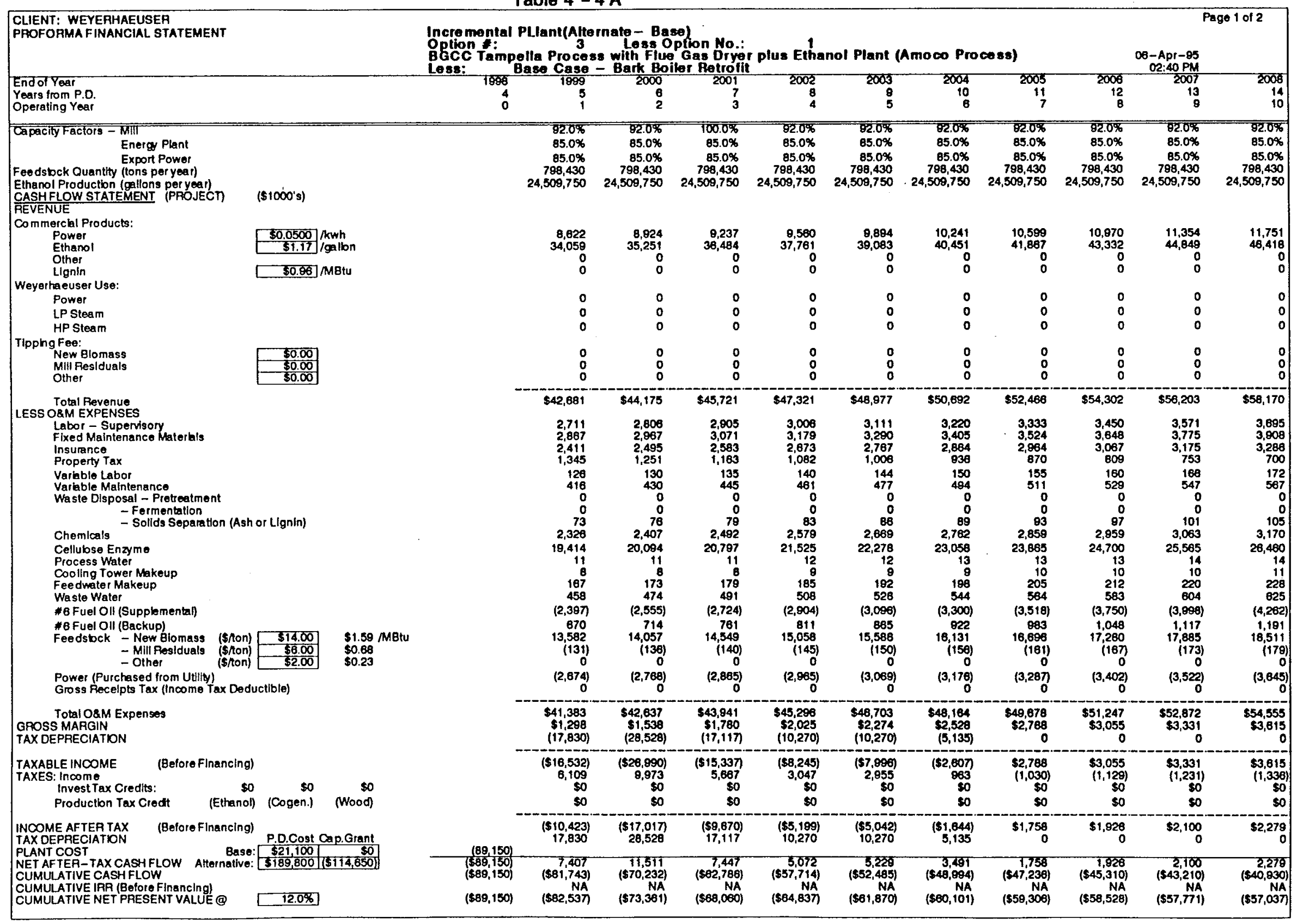


Table 4- 4 B

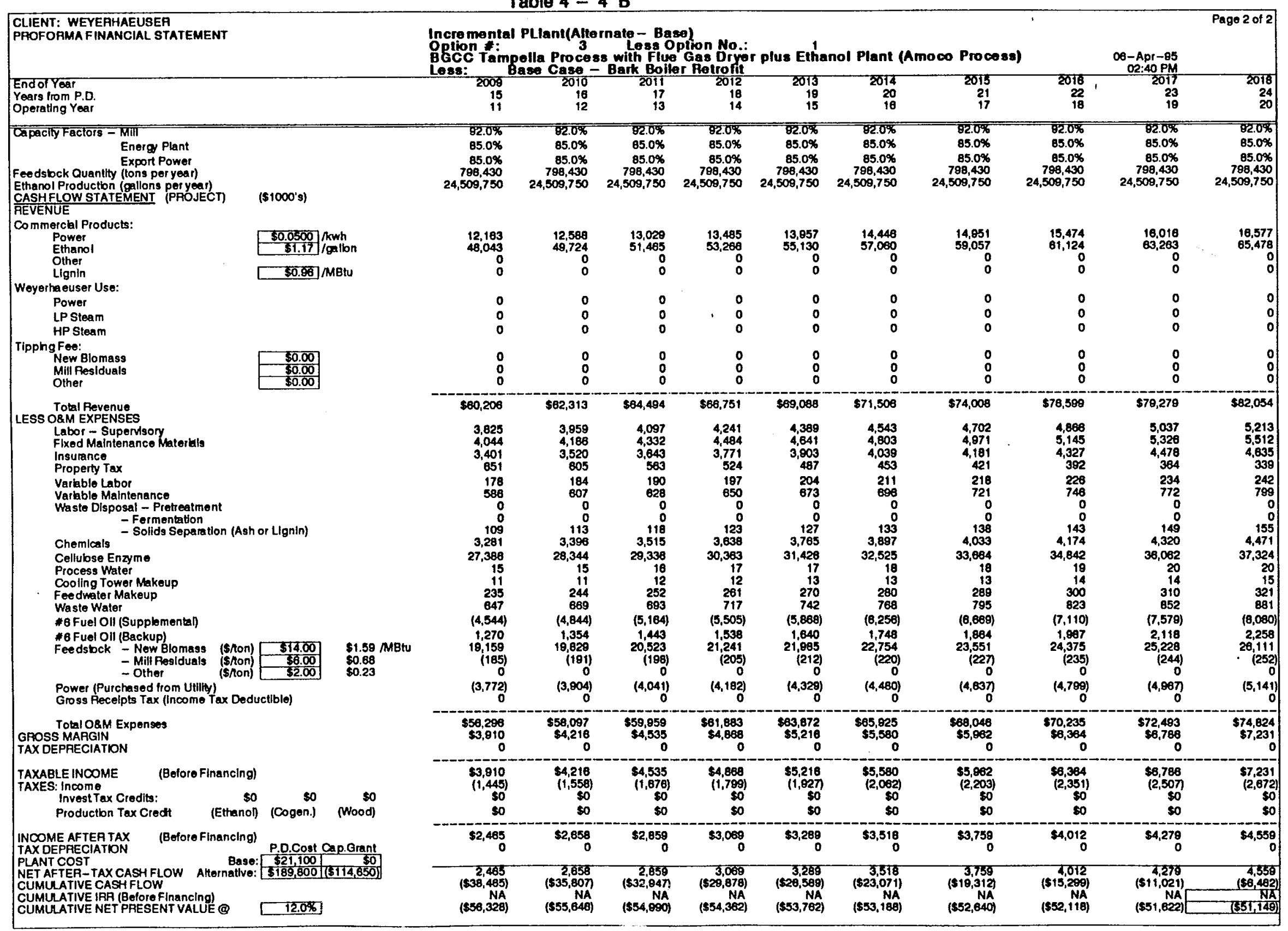


Table 4 - 5 A

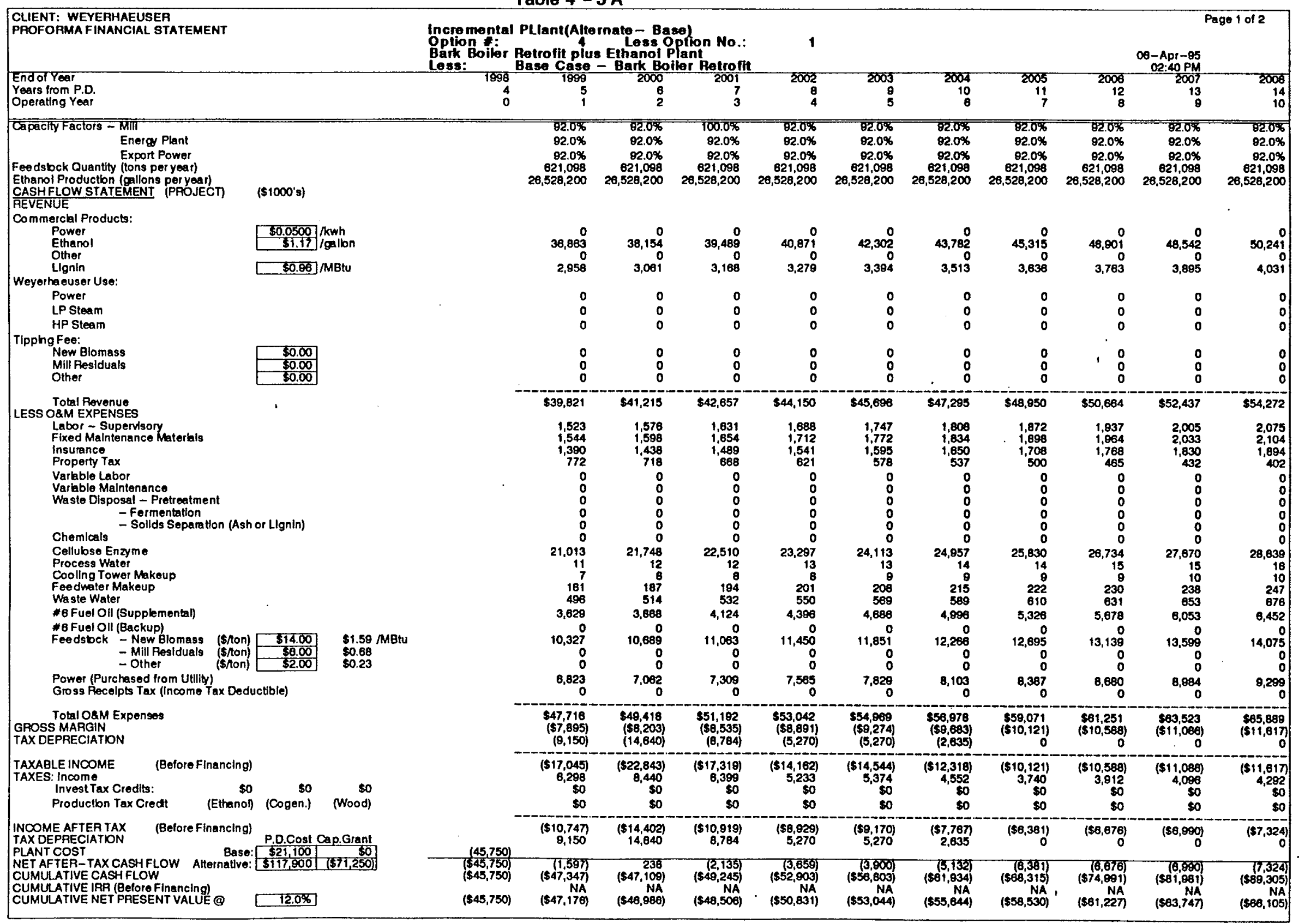


Table 4 - 5 B

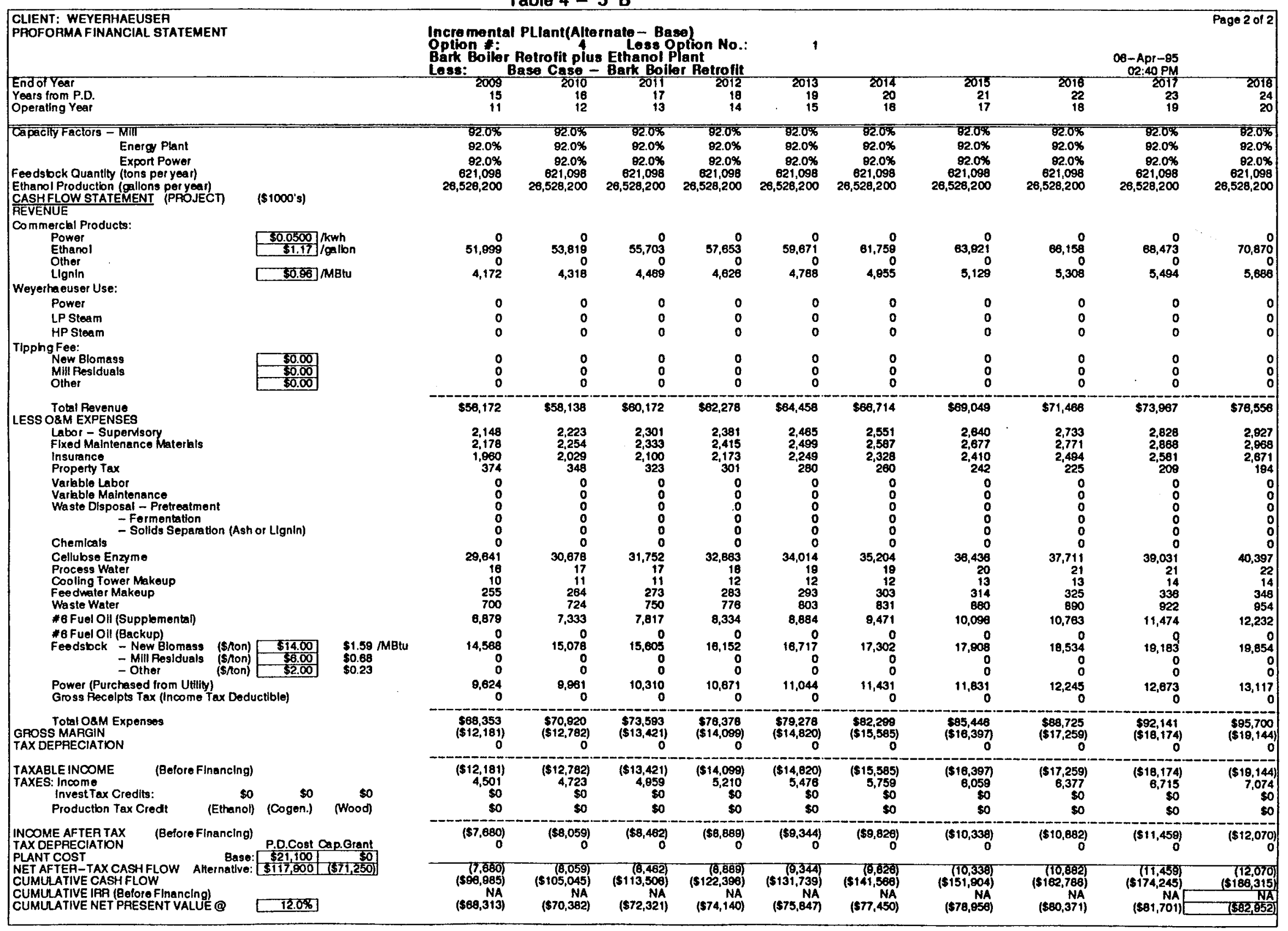




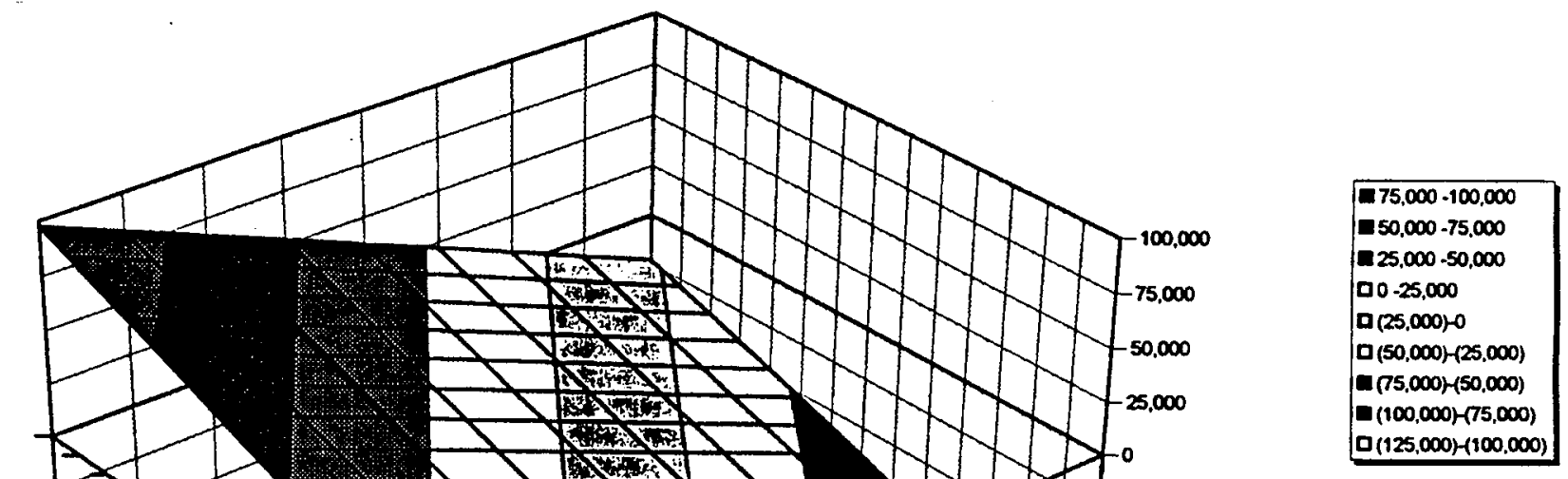

MPN12, 2000

8

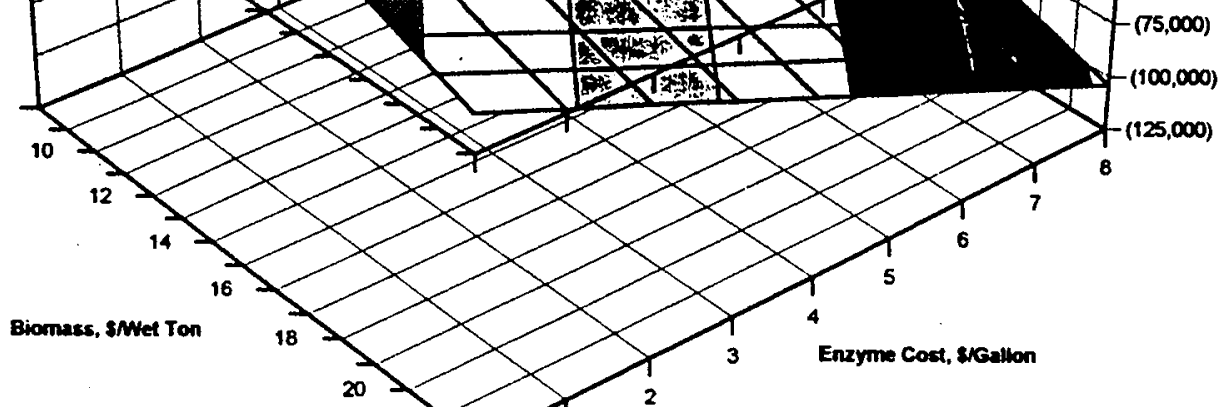

Power: 5.0 Cents/kWh

Ethanol: \$1.17/Galion

Discount Rate: $12 \%$

Capital Support: $\mathbf{5 0 \%}$

Figure 4-1: Option 3 - BGCC/Ethanol Plant vs Bark Boiler Retrofit Net Present Value (NPV) as a Function of Biomass and Enzyme Cost

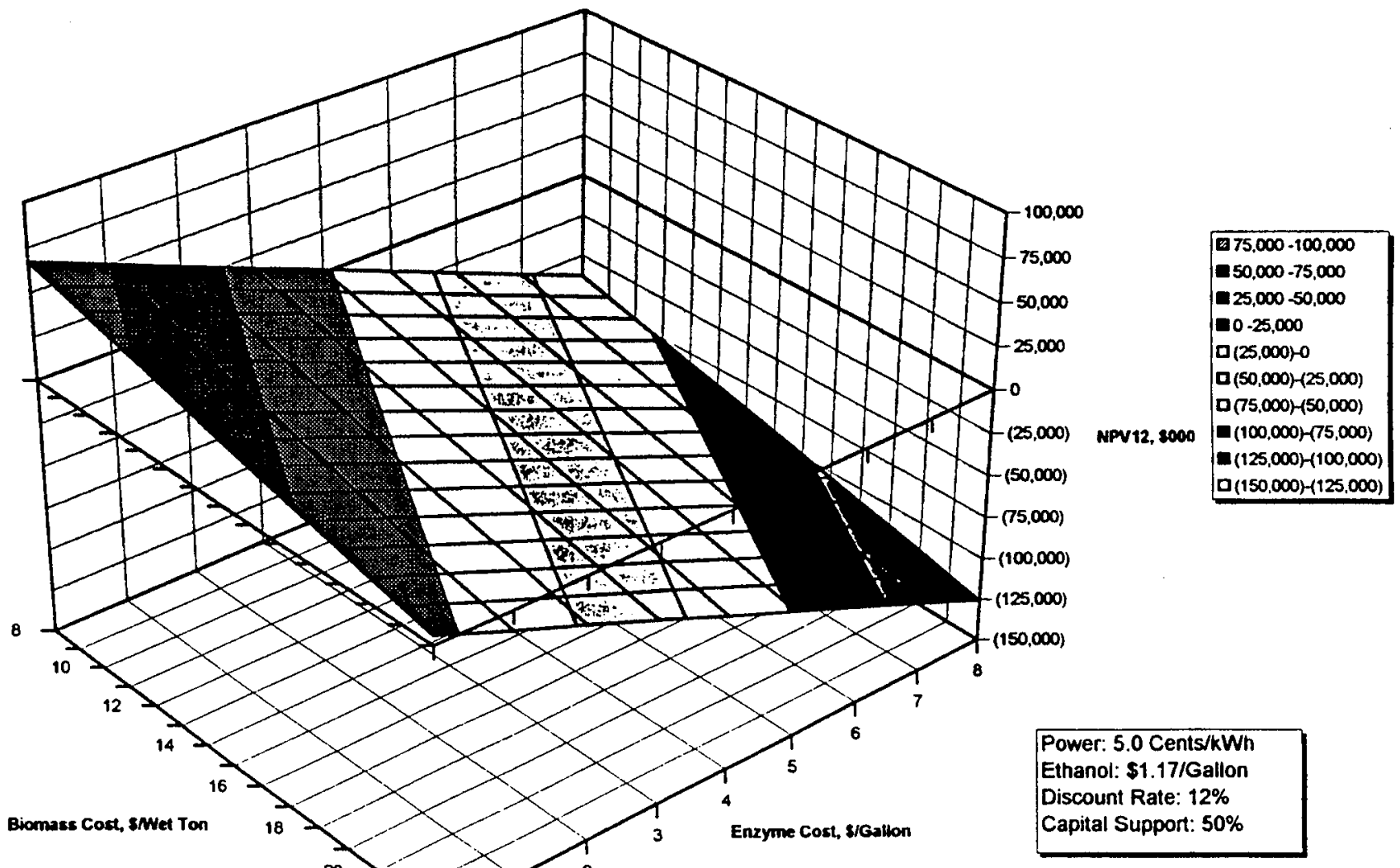

Figure 4-2: Option 4 - Ethanol Plant vs Bark Boiler Retrofit Net Present Value (NPV) as a Function of Biomass and Enzyme Costs 


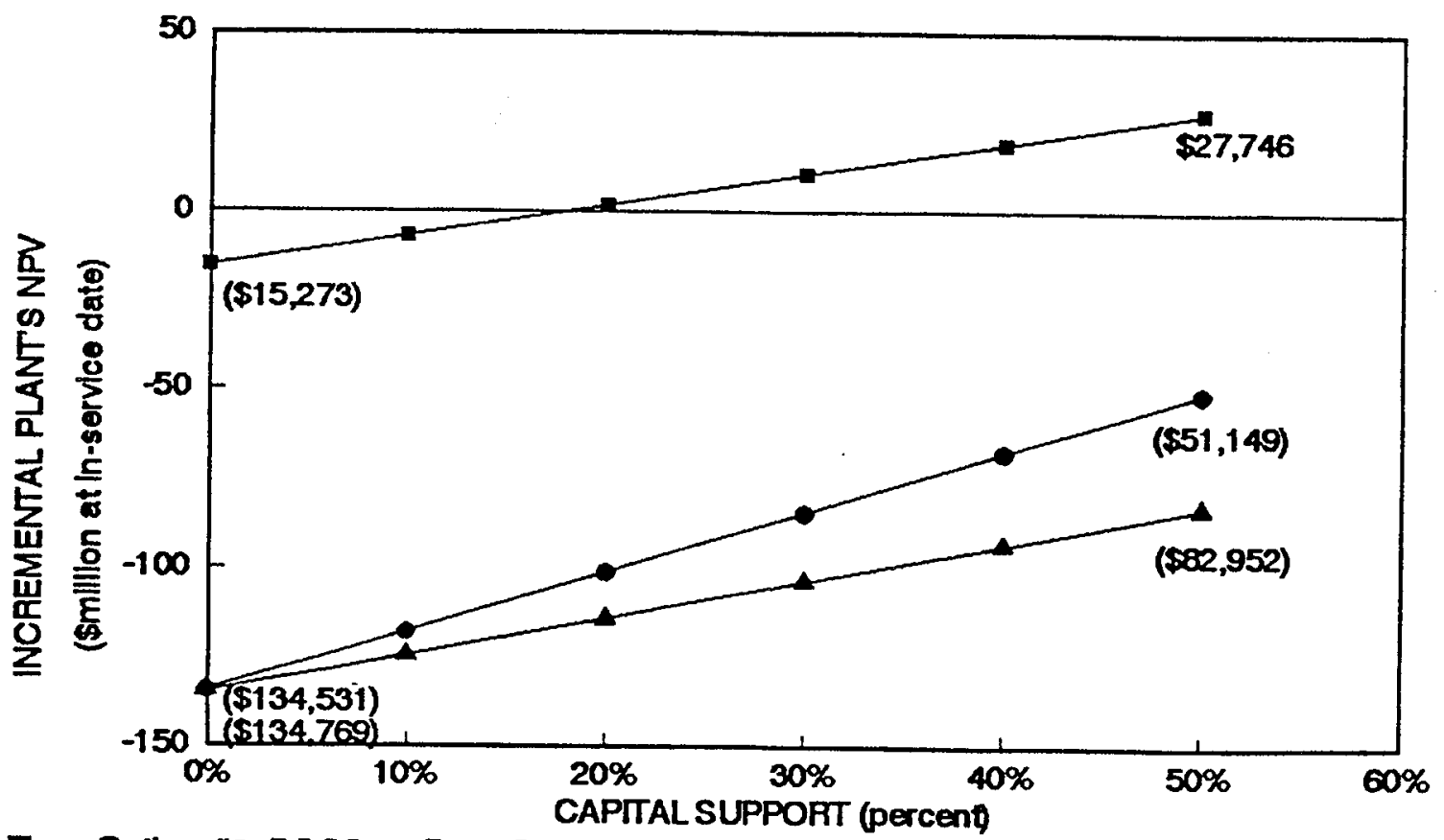

-1- Option \#2: BGCC vs. Base Case

-- Option \#3: BGCC+Ethanol Plant vs. Base Case.

- Option \#4: Boiler Retrofit + Ethanol Plant vs. Base Case

NPV - Net Present Value

Figure 4-3

Sensitivity of Incremental Plant's NPV to the Capital Support

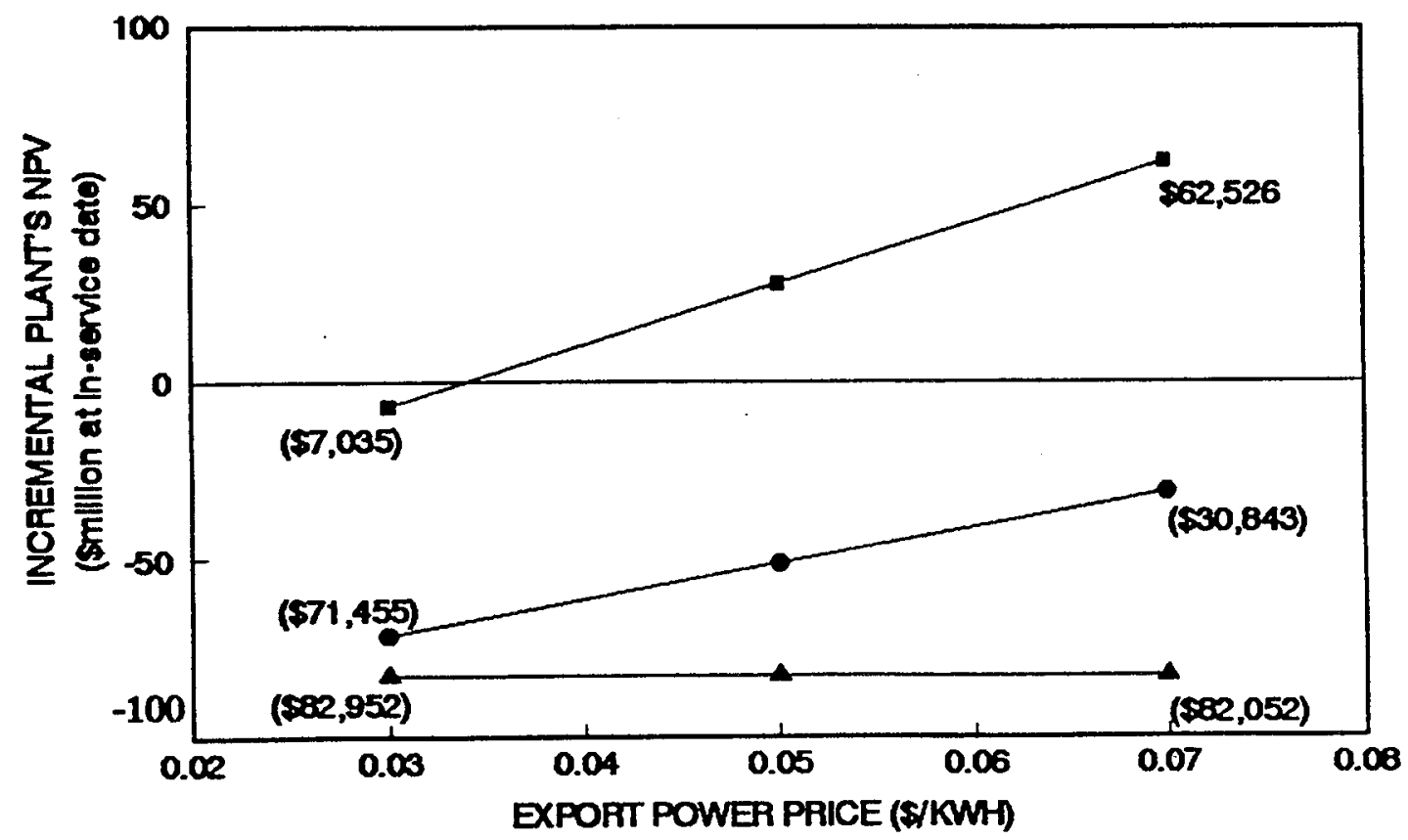

- Option \#2: BGCC vs. Base Case

-O- Option \#3: BGCC+Ethand Plant vs.Base Case

- Option *4: Boiler Rotrofit + Ethand Plant vs. Base Case NPV - Net Present Vahue
Figure 4-4

Sensitivity of Incremental Plant's NPV to the Power Price 


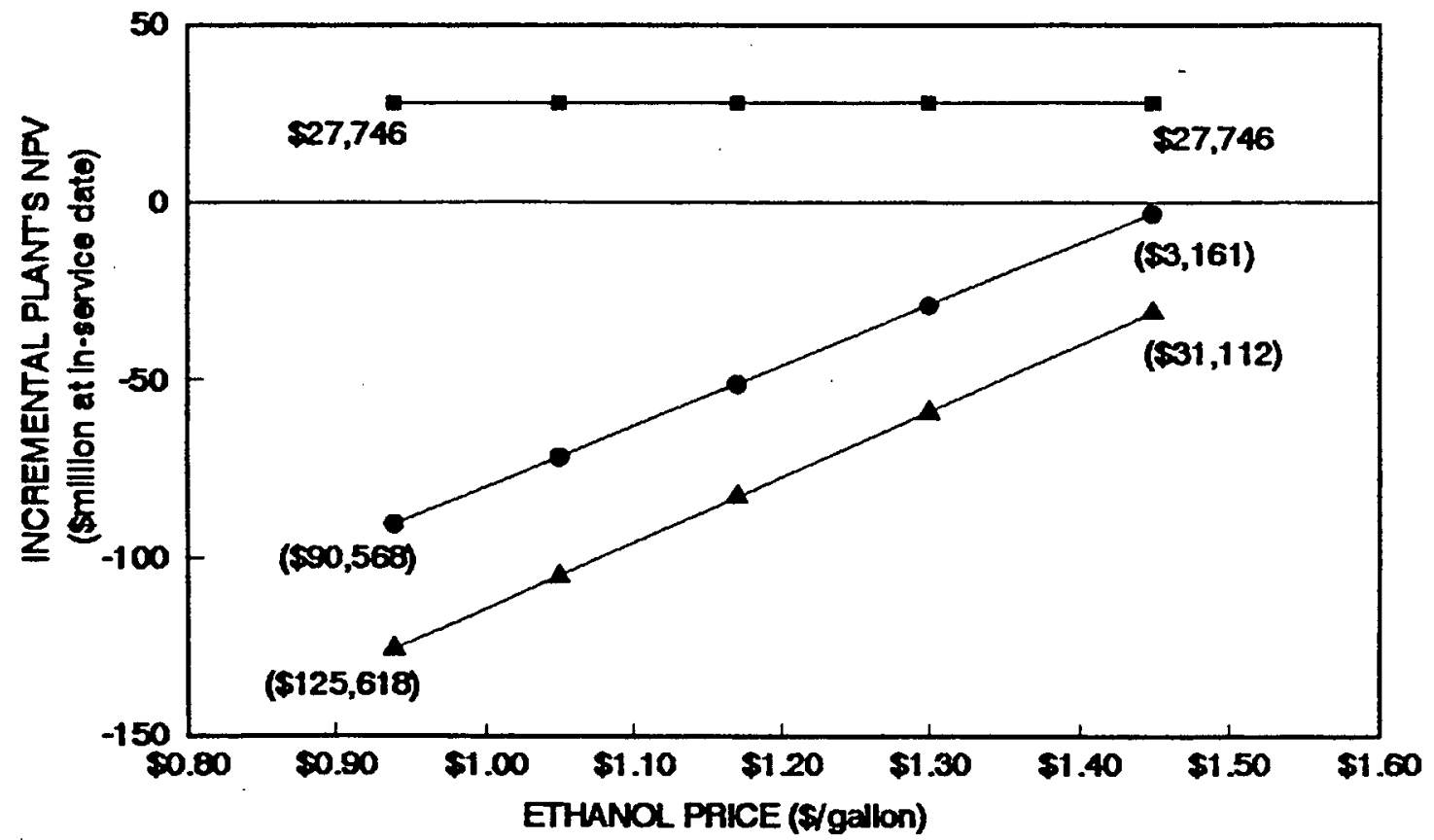

$\rightarrow$ - Option 12: BGCC vs. Base Case

-- Option *3: BGCC + Ethanol Plant vs. Base Case

- Option *4: Boiler Retrofit + Ethanol Plant vs. Base Case

Figure 4-5

NPV - Not Present Value

Seneilivity of Incromental Plant's NPV to the Ehand Price

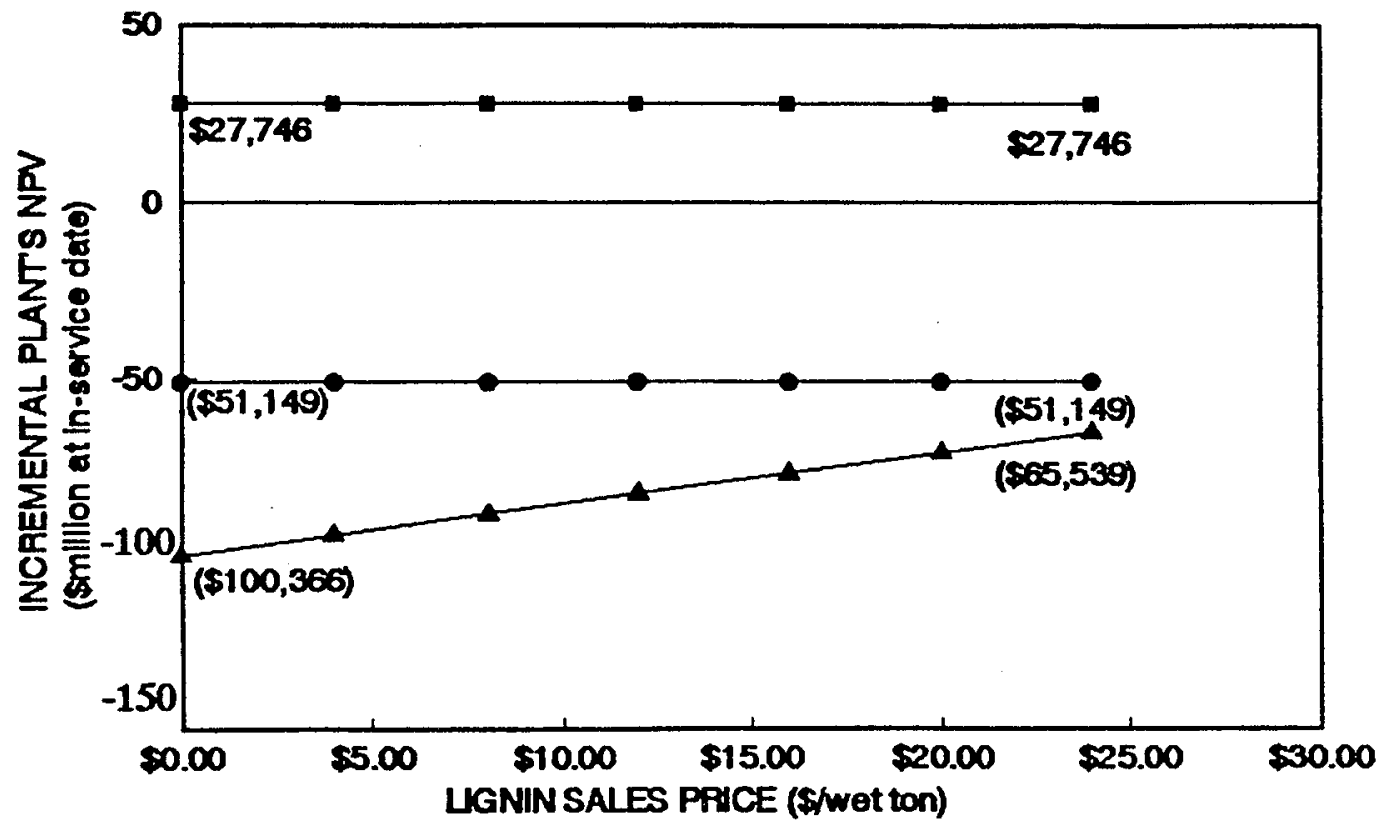

$\rightarrow$ - Option \#2: BGCC vs. Base Case

- Option *3: BGCC+Ethanol Plant vs.Base Case

- Option *4: Boiler Rotrofit + Ethend Plant vs. Base Case

Figure 4-6

NPV - Net Present Value 


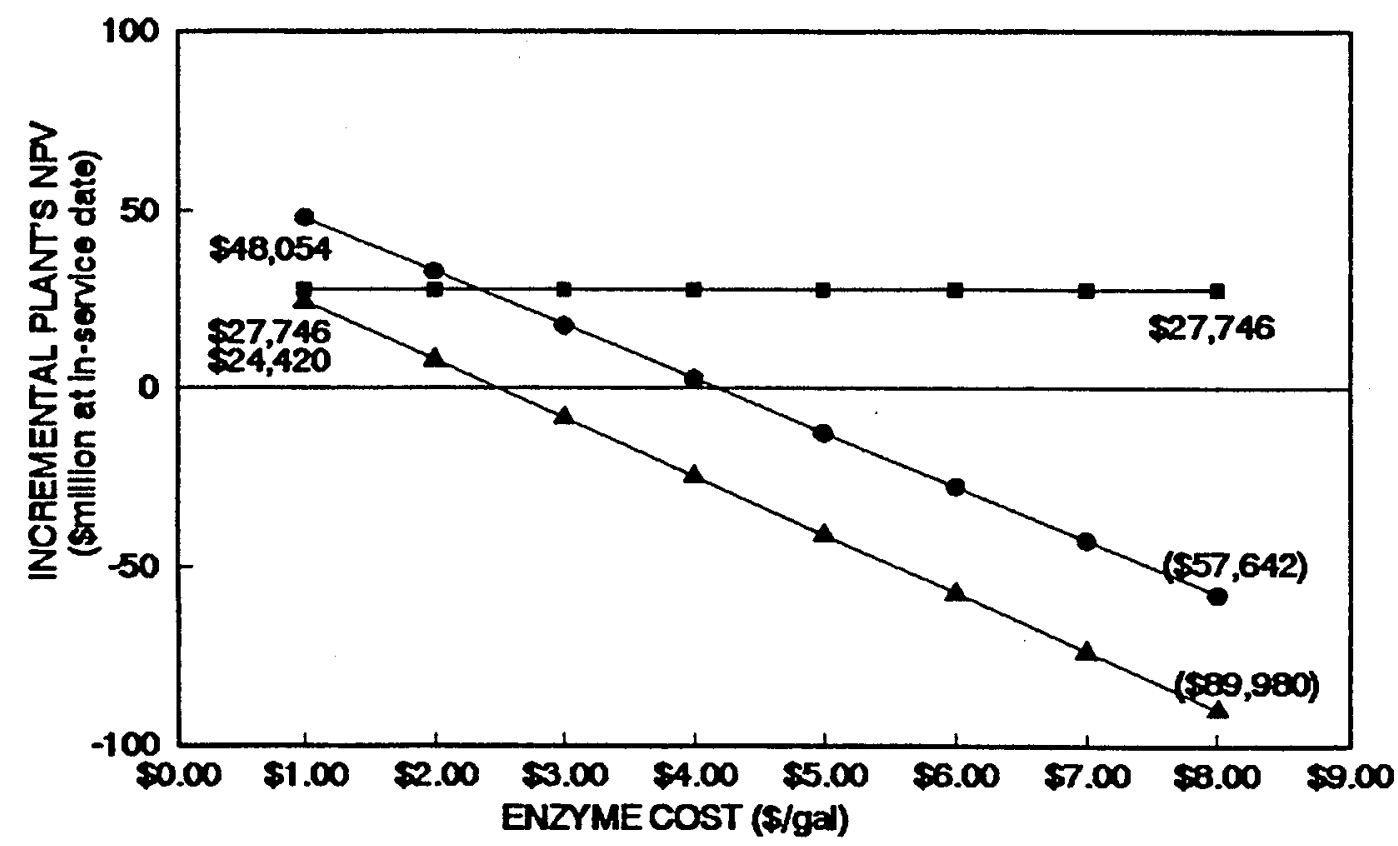

$\rightarrow$ - Option \#2: BGCC vs. Base Case

- Option *3: BGCC+Ethanol Plant vs. Base Case

- Option *4: Boiler Retrofit + Ethand Plant vs. Base Case

NPV - Net Present Vabue

Fgure 4-7

Sensitivity of Incremental Plant's NPV to the Enayme Coet

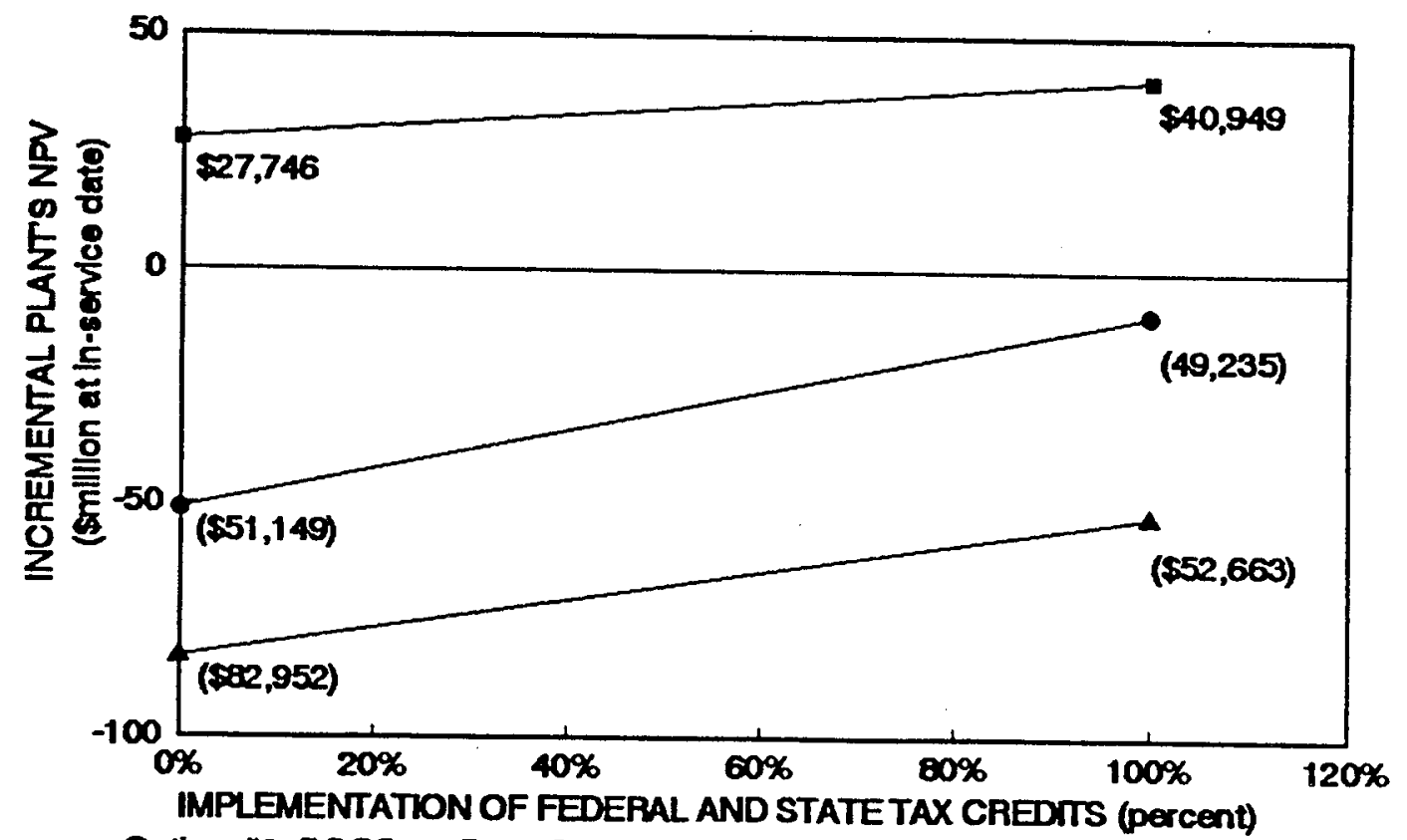

$\rightarrow$ - Option \#2: BGCC vs. Base Case

- Option *3: BGCC+Ethanol Plant vs. Base Case

- Option *4: Boiler Retrofit + Ethand Plant vs. Base Case

NPV - Not Present Value

NOTE: Federal Tax Credit \$0.10/galon ethanol;

State Tax Credit hvestment Tax Credits of 25 to 30 percent

Figure 4-8

Sensitivity of Incremental Plank's NPV to the Tax Crodits 


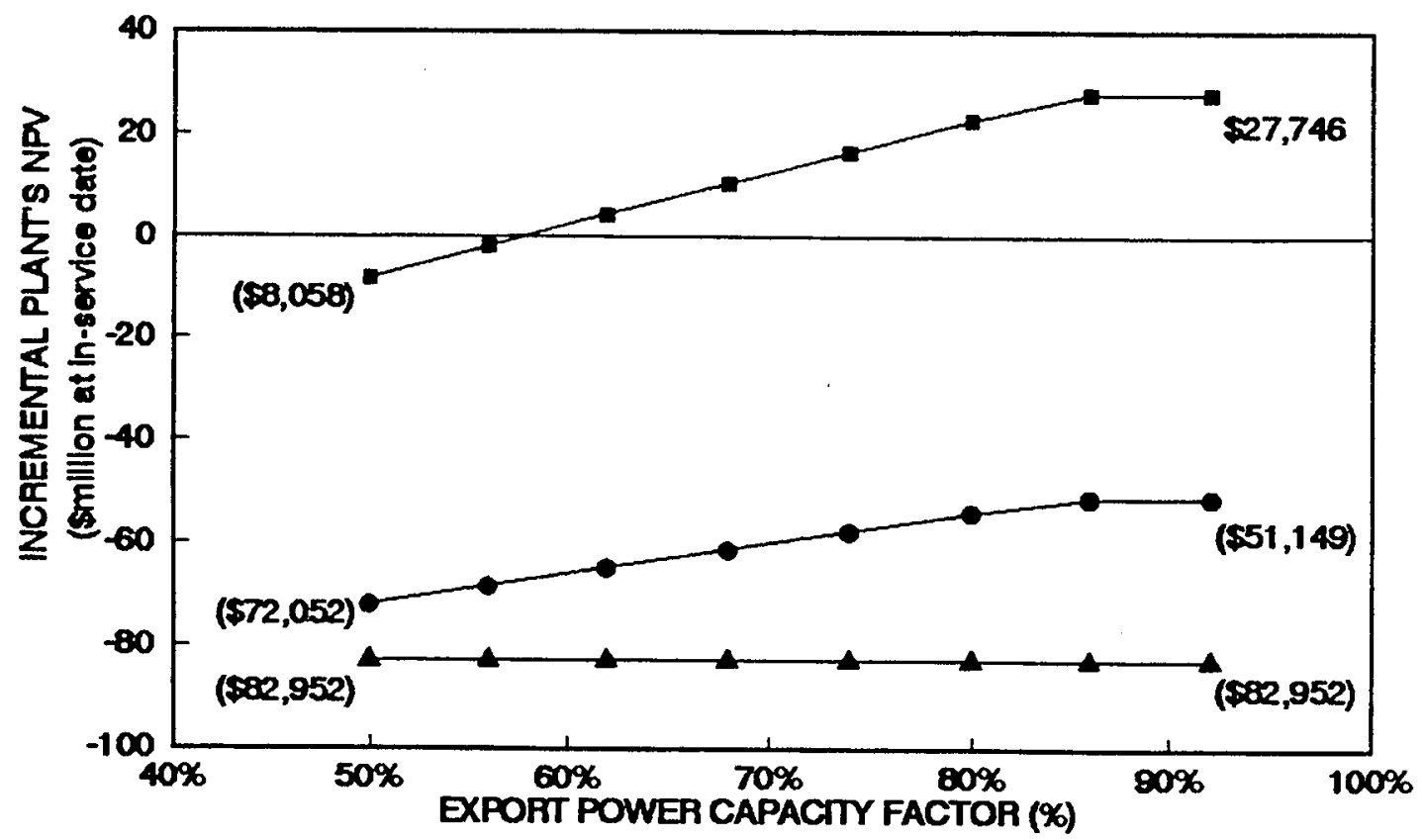

$\rightarrow$ - Option \#2: BGCC vs. Base Case

- - Option *3: BGCC+Ethanol Plant vs. Base Case

- Option *4: Boiler Retrofit + Ethanol Plant vs. Base Case

NPV - NetPresent Value

Export power capacity factor is limitod by the energy

plant capacity factor; thus the curve levels off

Figure 4-9

Sensitivity of Incremental Plant's NPV to the Export Power Capacity Factor

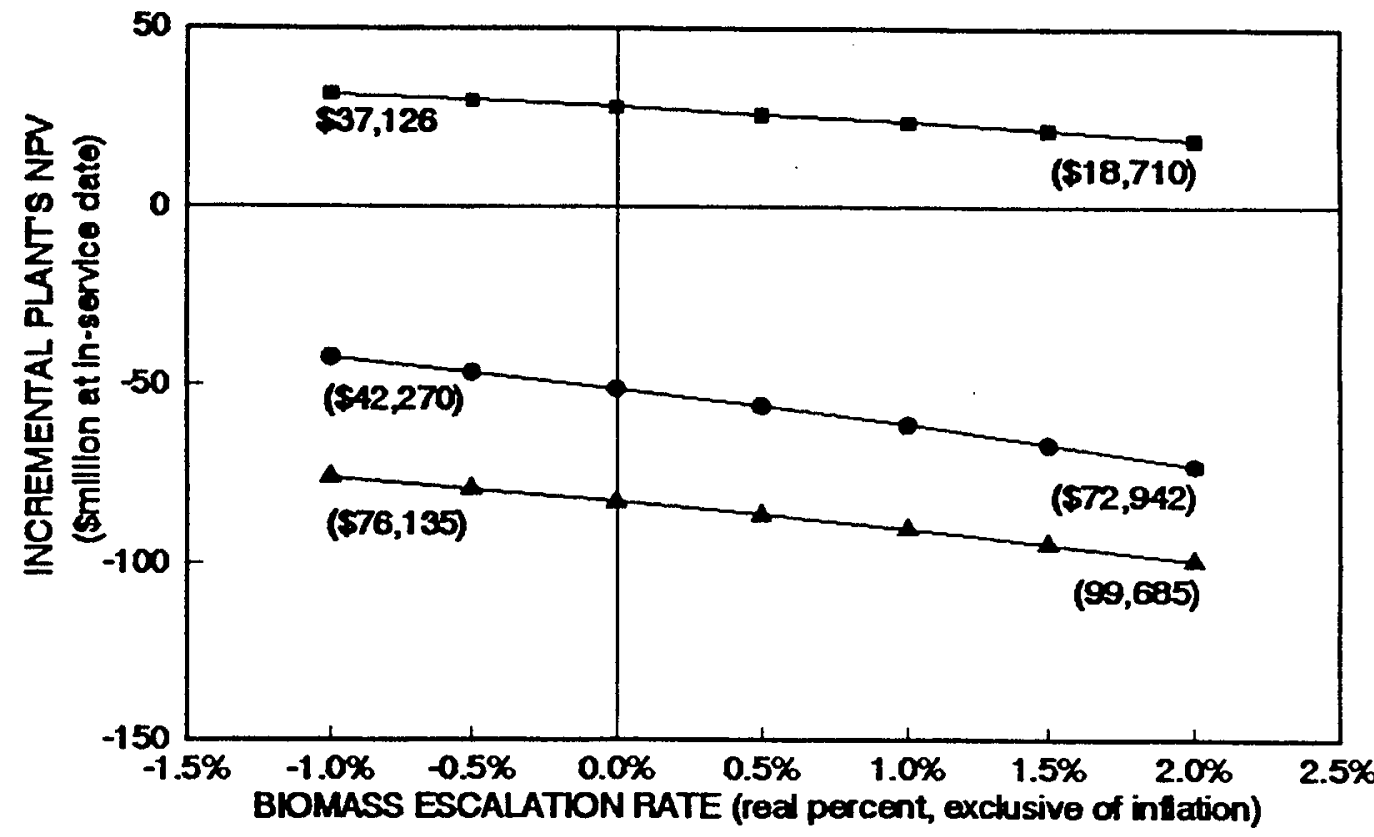

$\rightarrow$ - Option \#2: BGCC vs. Base Case

- Option *3: BGCC+Ethand Plant vs. Base Case

L-Option *4: Boiler Potrofit + Ethanol Plant vs. Base Case

NPV - Net Present Value

Fgure 4-10

Seneitivity of Plant's NPV to the Biomass Escalation Rate 


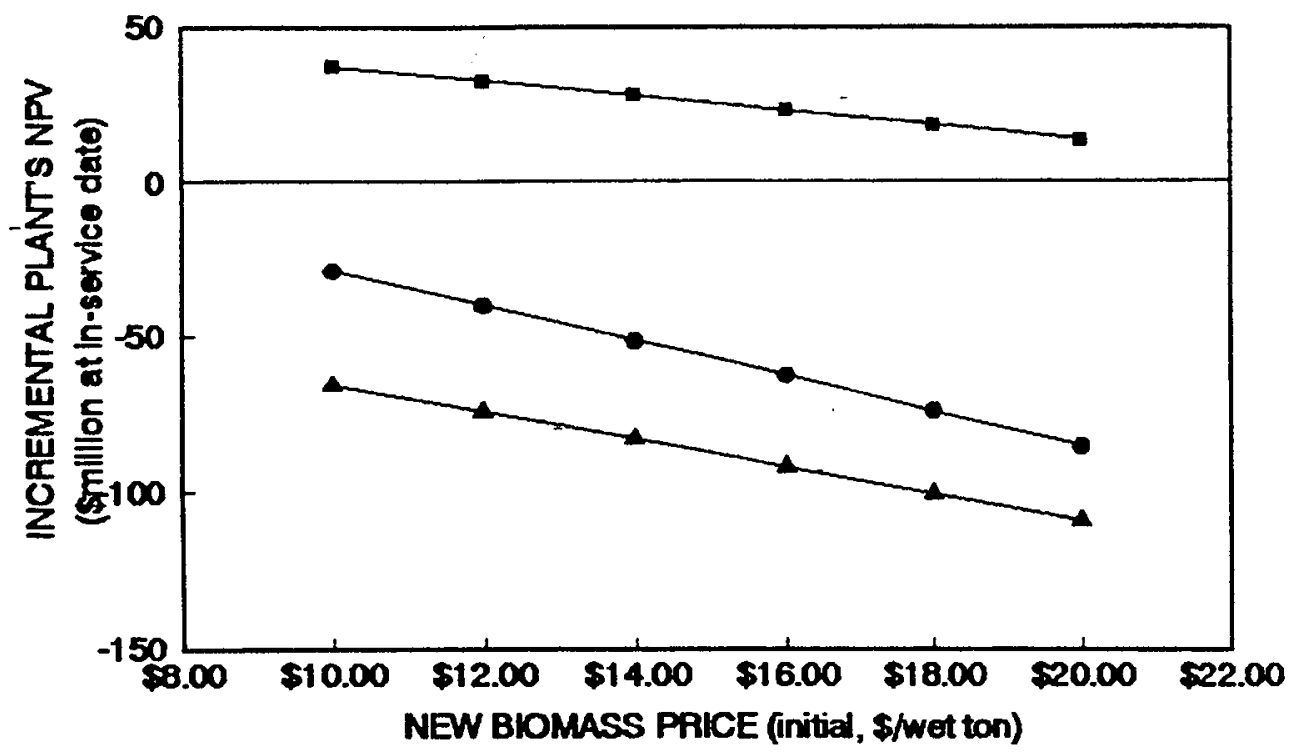

$\rightarrow$ - Option \#2: BGCC vs. Base Case

- Option \#3: BGCC+Ethanol Plant vs.Base Case

- Option *4: Boier Retrofit + Ethanol Plant vs. Base Case

NPV - Net Present Value

The price of mill residual biomass is a

constant percentage of new biomass price

Figure 4-11

Sensitivity of Incremental Pian's

to the Initial Biomass Prico

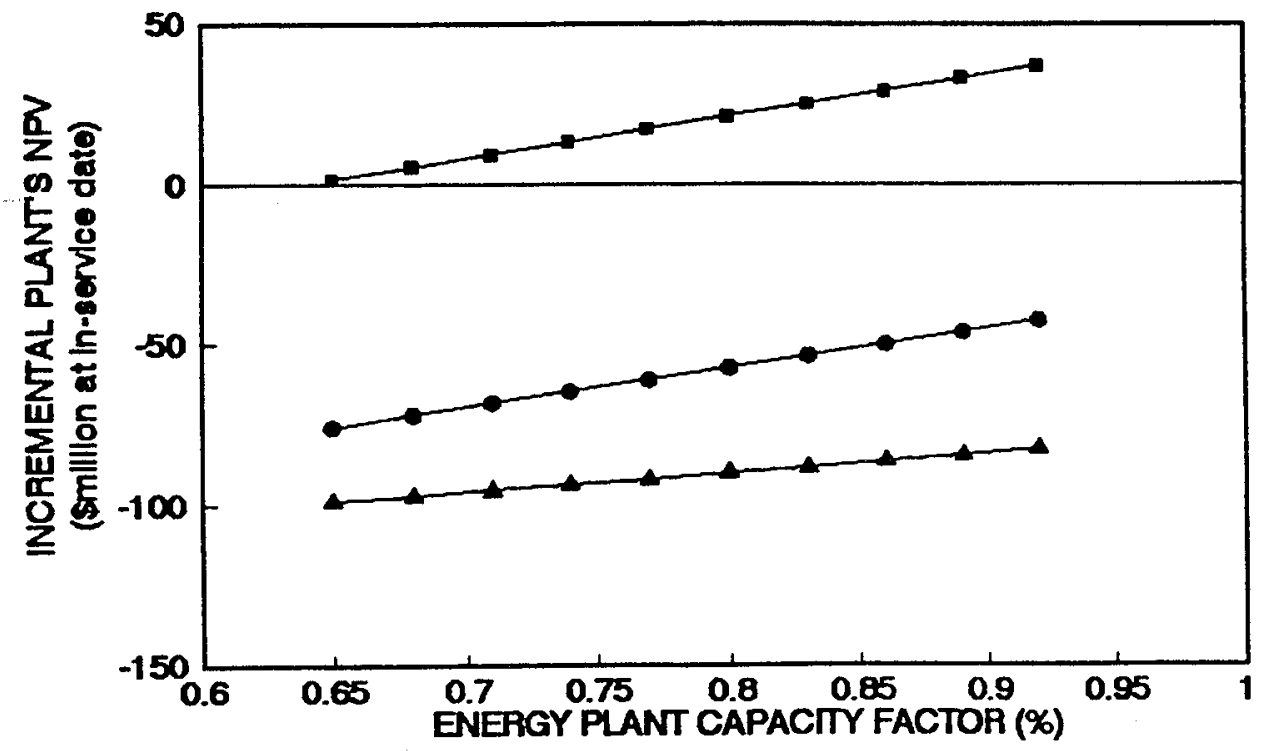

$\rightarrow$ Option \#2: BGCC vs. Base Case

Option \#3: BGCC+Ethanol Plant vs.Base Case

- Option * 4: Boiler Petrofit + Ethanol Plant vs. Base Case

Figure 4-12

NPV - Not Present Value

Sensitivity of Incremental Plant's NPV to the Energy Plant Capacity Factor 


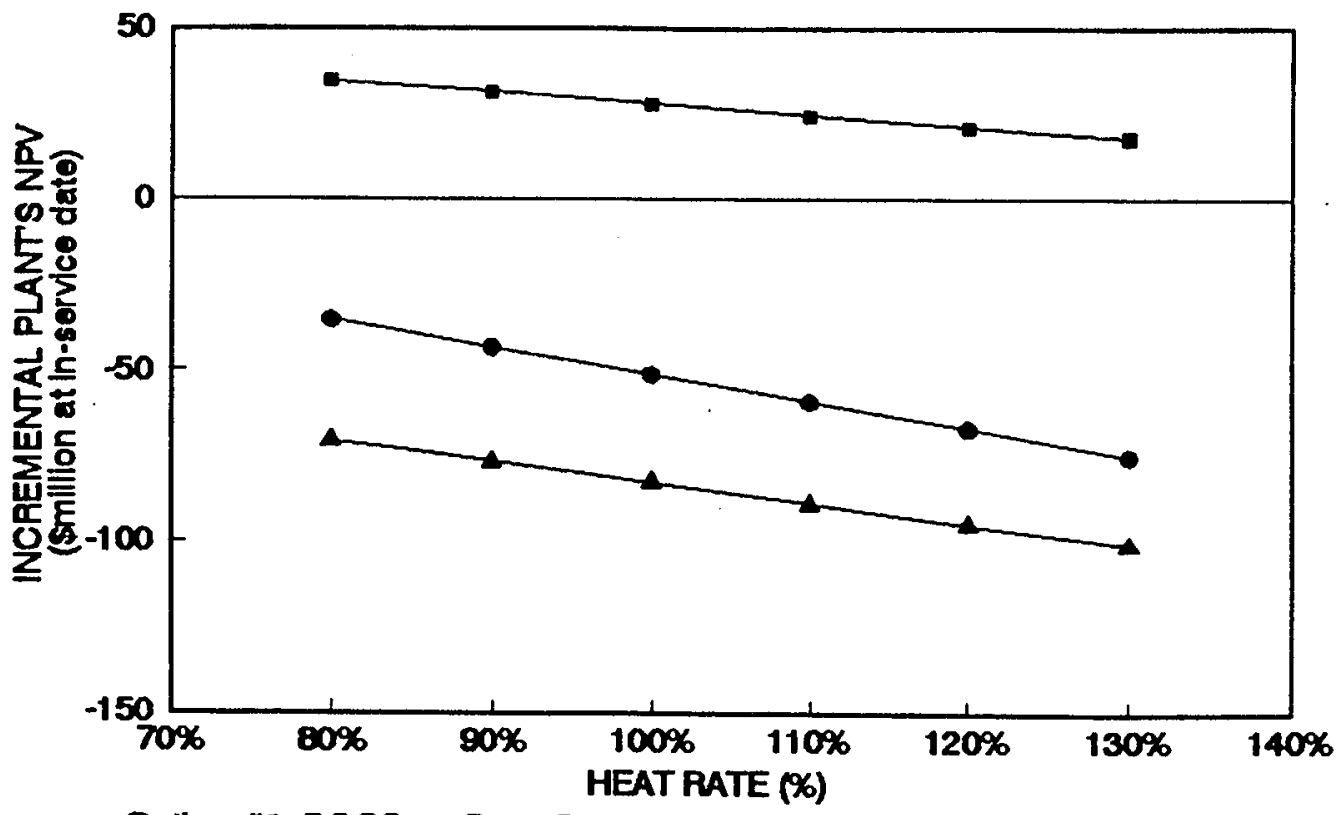

Option 2: BGCC vs. Base Case

- Option *3: BGCC+Ethanol Plant vs. Base Case

- Option *4: Boiler Retrofit + Ethand Plant vs. Base Case

Fgure 4-13

NPV - Not Present Value

Sensitivity of Incremental Plant's NPV to the Plant Performance

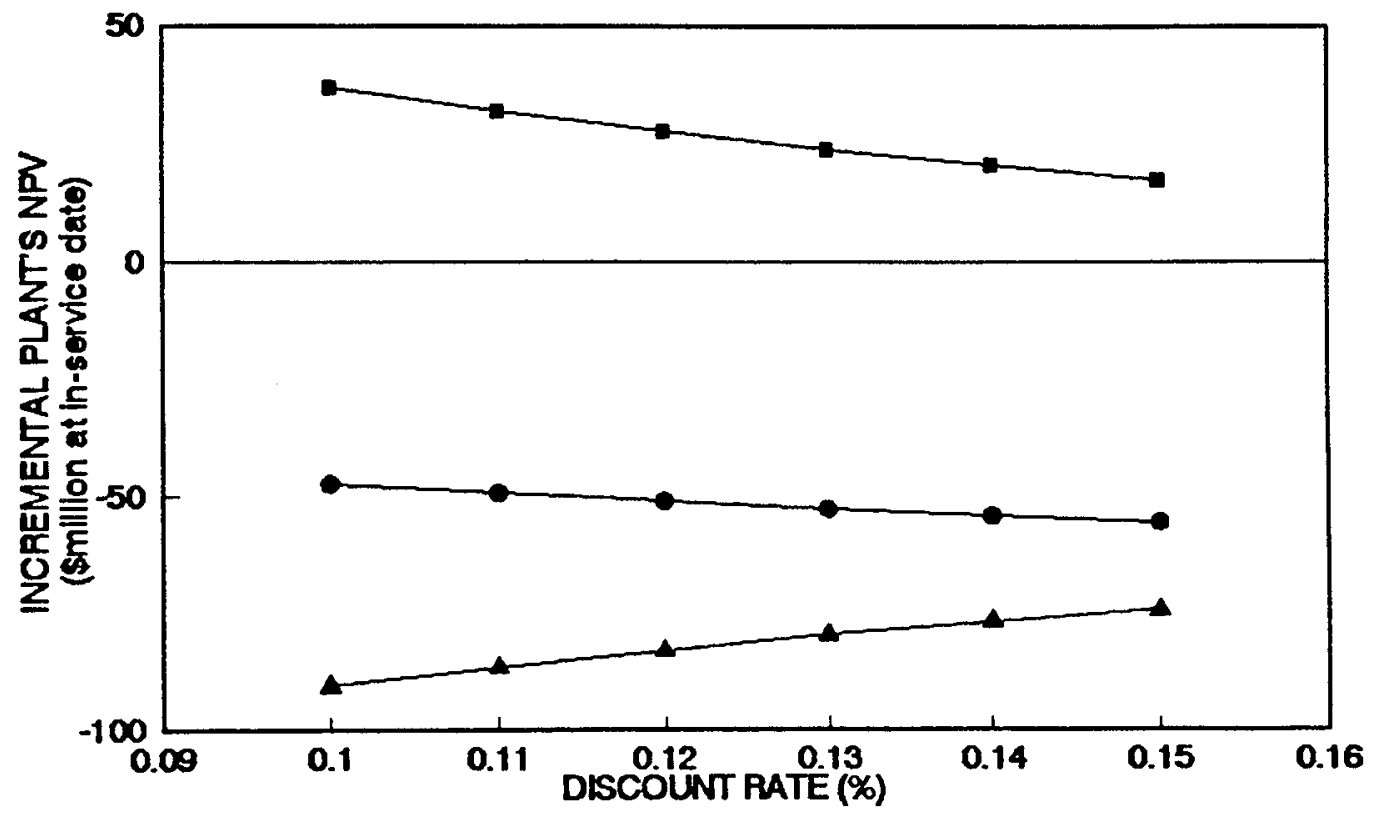

- Option 2: BGCC vs. Base Case

- Option *3: BGCC+Ethanol Plant vs. Base Case

- Option *4: Boiler Rotrofit + Ethanol Plant vs. Base Case

Figure 4-14

NPV - Net Present Vakue 


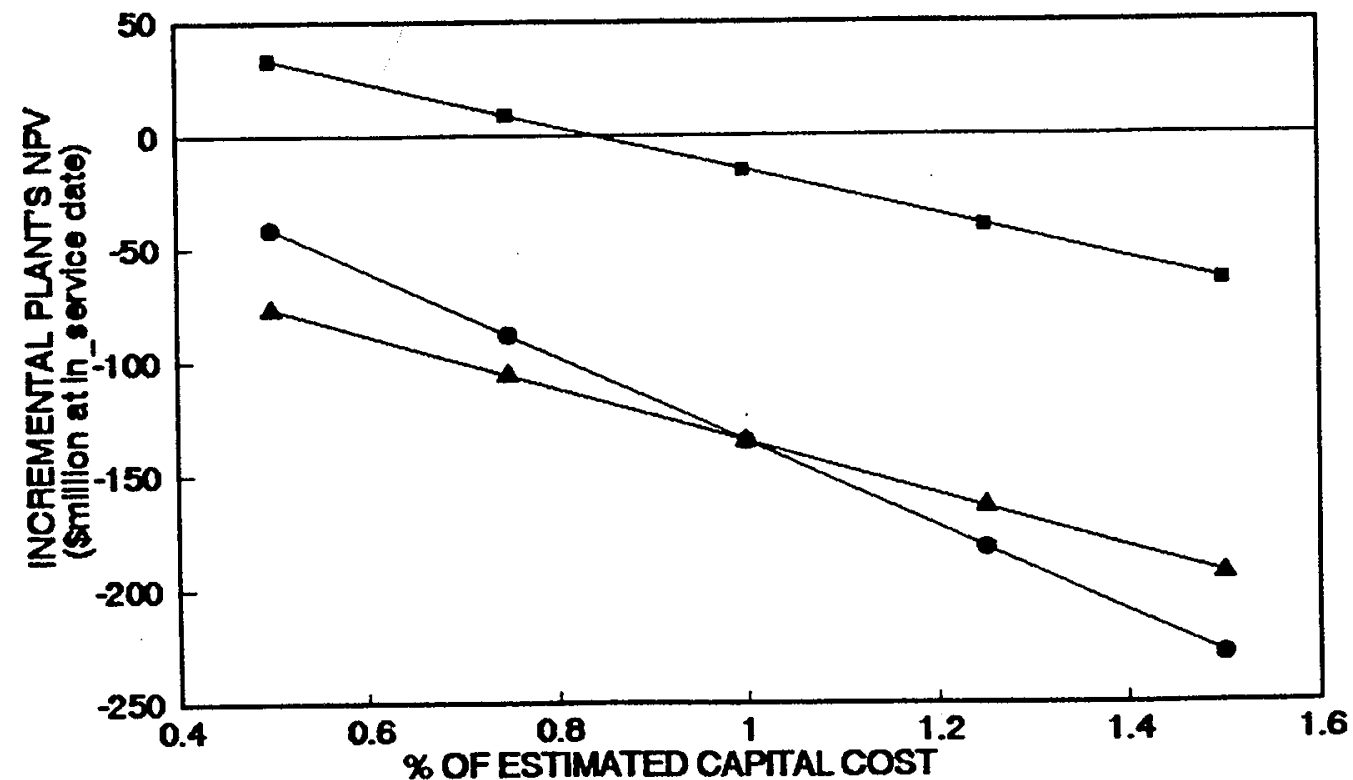

$\rightarrow$ - Option 2: BGCC vs. Base Case

-O Option *3: BGCC+Ethanol Plant vs. Base Case

- Option *4: Boier Retrofit + Ethanol Plant vs. Base Case NPV - Net Present Value

Rgure 4-15

Sensitivity of Incremental Plank's NPV to the Capital Cost

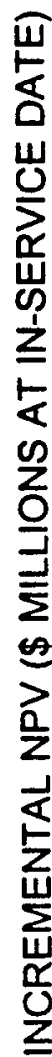

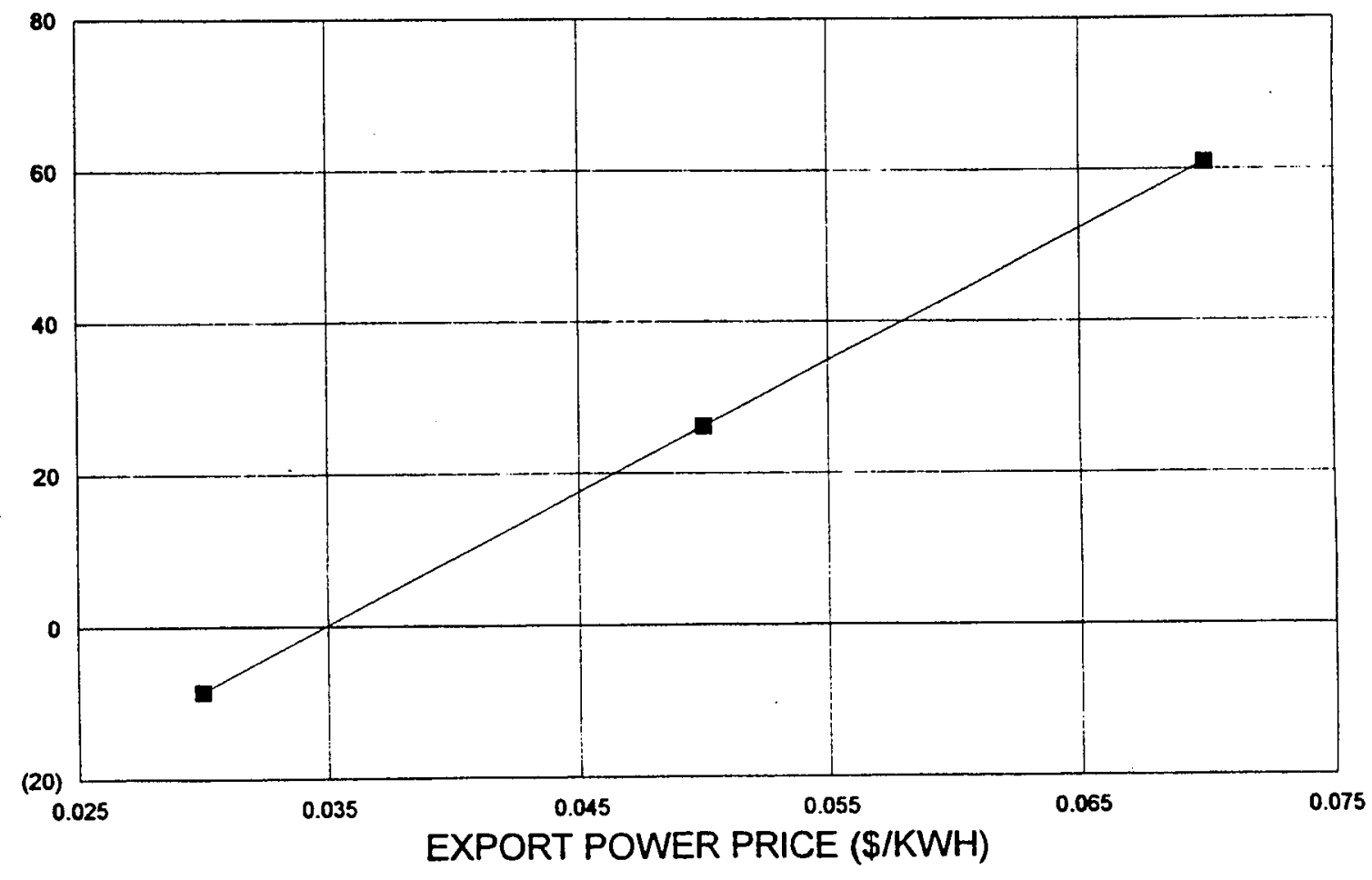

Figure 4-16: BGCC NPV Minus New Boiler NPV vs. Power Sales Price 


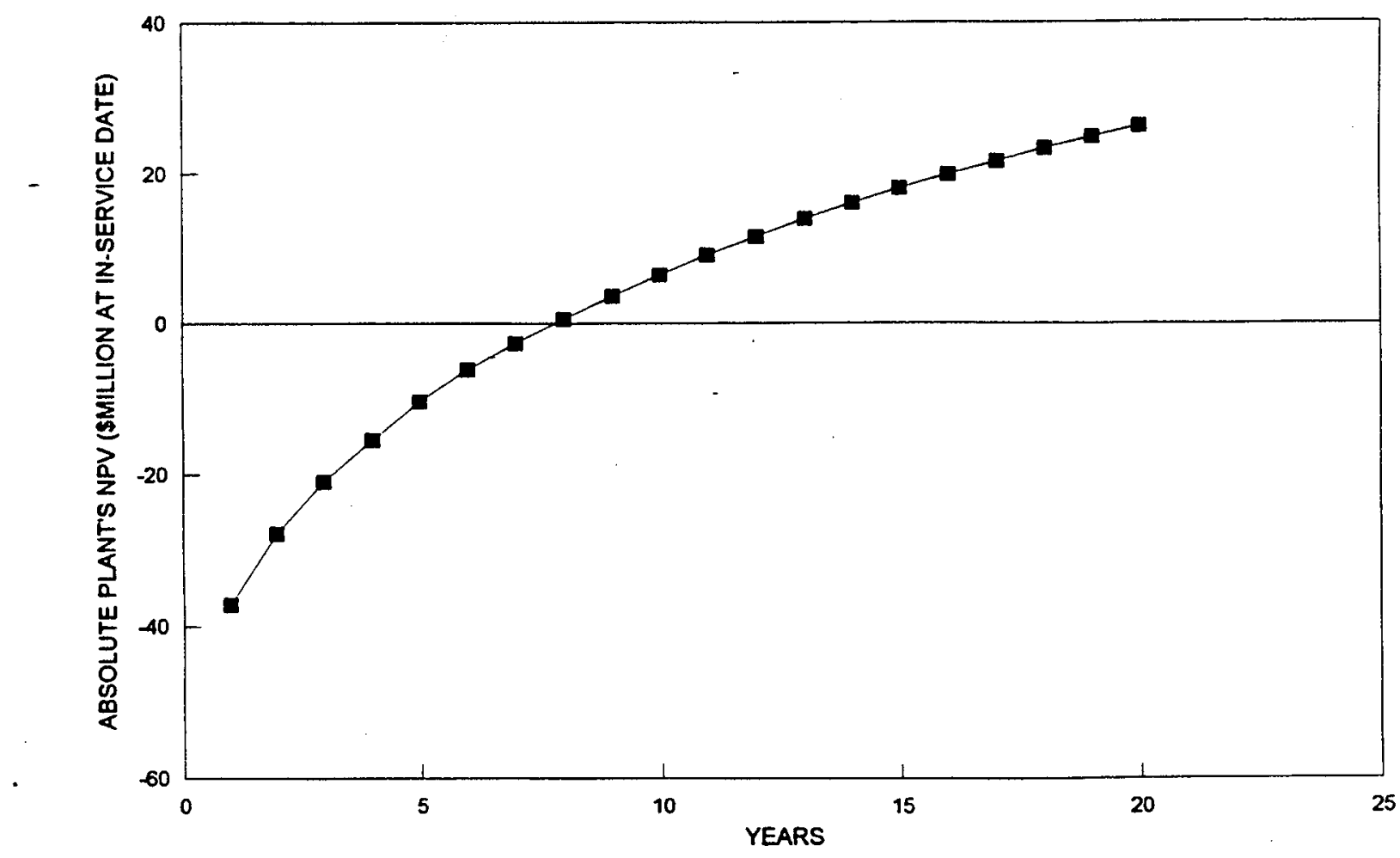

Figure 4-17: BGCC NPV With \$0.05/kWh Power Sales Minus New Boiler NPV Over Project Life

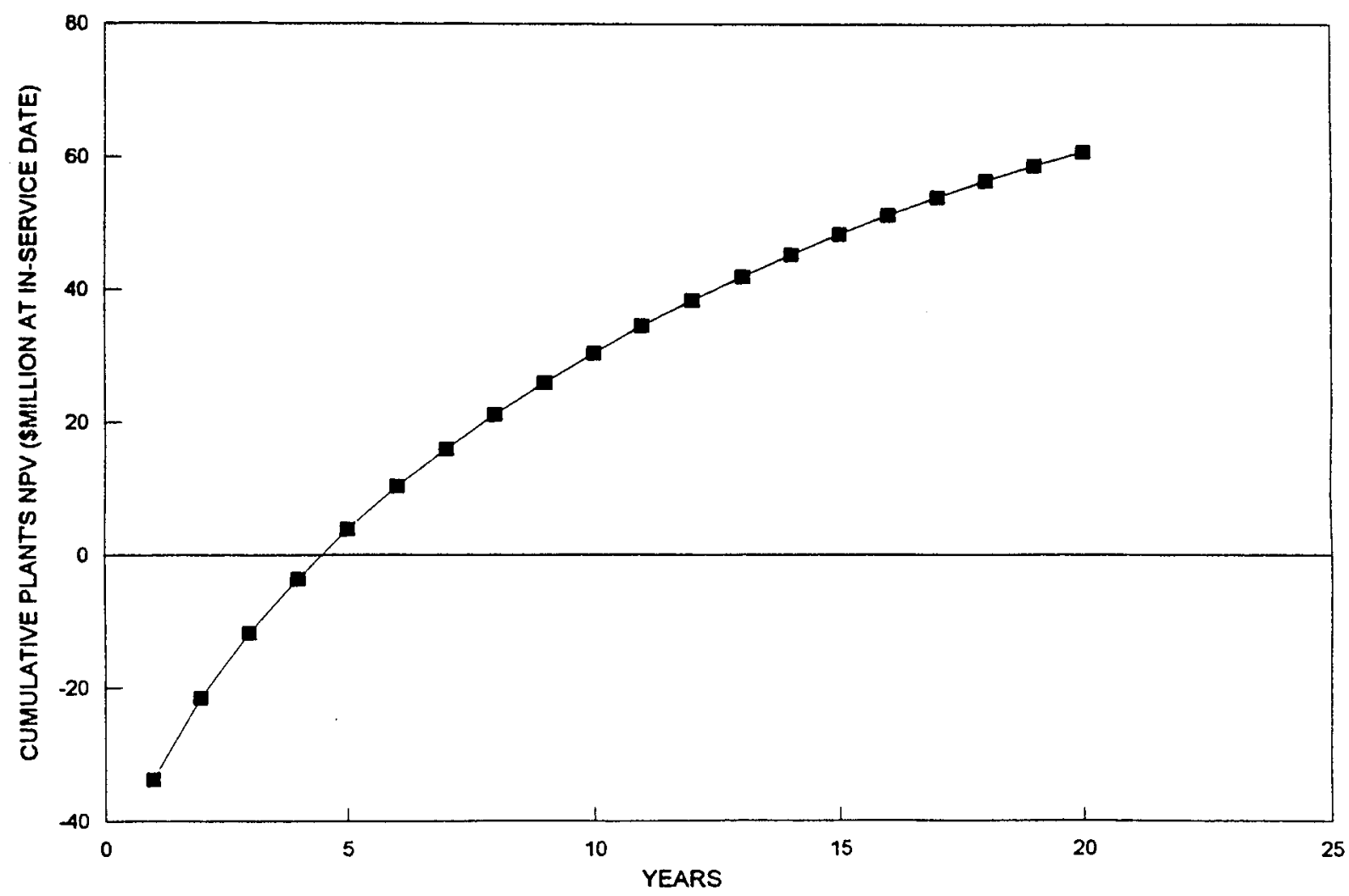

Figure 4-18: BGCC NPV With \$0.07/kWh Power Sales Minus New Boiler NPV Over Project Life 


\section{Section 5}

\section{Environmental Monitoring Plan}

New Bern plant environmental issues have been addressed in discussions in Section 2. Plant related operations are integrated in a comprehensive environmental monitoring program.

\subsection{Timberlands Environmental Monitoring}

This section presents an overview of the Weyerhaeuser forestry' commitment to sustainable forestry, the planned harvest procedures, the policies on which these procedures are based and the audit program at both the corporate and day-to-day operating levels to ensure the environmental quality and health of the forests. These procedures and audit programs are shown to be adequate to serve the additional harvest needs imposed by implementation of a biomass gasification combined cycle facility or a combination biomass combined cycle facility with an ethanol from biomass plant.

Weyerhaeuser is committed to the sustainability of its forestlands and consequently to the environmental quality and health of these forestlands. This is strongly expressed in The Weyerhaeuser Forestry Stewardship Statement. This statement consists of three segments as follows.

Our commitment:

- To continuously improve our performance as responsible stewards of the environmental quality and economic value of the forests we manage.

- To actively listen to and act upon public expectations.

- $\quad$ To communicate consistently to ensure understanding of our forest stewardship goals, practices and accomplishments.

What our commitment means:

We will manage our forestlands for the production of wood. In addition, our goals are to protect, maintain or enhance other important environmental values, such as:

- Water quality and fish habitat.

- Wildlife habitat.

- The productivity of the soil.

- $\quad$ Aesthetics.

- $\quad$ Plant and animal species diversity.

- Culturally or historically unique areas.

We will accomplish this by:

- $\quad$ Practicing sustainable forestry to meet increasing worldwide demand for wood and wood products.

- $\quad$ Performing to standards set for all forestry operations.

- Basing our management processes and practices on scientific research and technology. 
- Leading cooperative efforts with public agencies and other groups interested in forest resources to develop balanced, cost-effective forest practices and regulations based on sound scientific standards.

- $\quad$ Meeting specific resource goals set by our regional Forest Councils.

Weyerhaeuser has for a number of years had a broad-based environmental monitoring program covering forestry, air, and water issues. Monitoring is done by mill and research staff, Corporate and Timberlands R\&D organizations, local universities under contract to Weyerhaeuser, and by the State of North Carolina DNR and U.S. EPA. These studies are for the purposes of determining compliance with existing permits, regulations and standards in order to understand the impacts of our operations on the environment and to identify, understand and assess potential areas of future concern and action.

The Timberlands Environmental Stewardship Audit was implemented in 1988. The purpose of the audit at the corporate level is to provide one more independent check and evaluation of the Weyerhaeuser policies regarding forestry operations. It covers all fee (Weyerhaeuser owned) timberlands in the United States. In the Southern States forest operations are conducted, on a voluntary basis, in accordance to Forestry Best Management Practices (BMP) as promulgated by the North Carolina Division of Forest Resources, Department of Environment, Health and Natural Resources. In addition, internal Weyerhaeuser Forestry standards, developed by the region Forest Councils, complement state regulations and the voluntary state BMP programs. The Corporate Timberlands environmental audit concentrates on assessing compliance with Best Management Practices (BMPs), forest practices regulations and Weyerhaeuser Forestry standards. Nineteen performance areas, checklist items, are currently audited. Point source facilities, such as truck shops, sorting yards, nurseries and seed orchards are audited by a specific facilities audit program.

The Corporate Environmental Stewardship Audit Performance evaluates the following items:

Forest Practices Citations

Forest Council Resource Goals

Smoke Management

Road Construction

Agency Relations

Site Preparation

Chemicals/Fertilizers

Regeneration

Streamside Management

Utilization
Fire Protection

Soils Disturbance

Clearcut Size/"Green-Up"

Housekeeping

Sensitive Areas

Road Maintenance

Wildlife

Waterbars

T\&E Species

Weyerháeuser has also developed an internal timberlands environmental audit procedures policy and program which are provided to all operations. Specific to North Carolina, the purpose of these audit procedures and program are to:

- $\quad$ Promote a high degree of personal responsibility for stewardship among all North Carolina timberlands employees

- Place responsibility for environmental performance as close to the actual operations as possible

- Document and identify areas requiring improvement in environmental performance

- Ensure progress toward zero defects and continuous improvement in environmental performance

- Promote communication, planning and response to unacceptable results throughout the organization. 
General procedures:

- $\quad$ Crew Leader, or Contract Supervisor, will fill out and sign the appropriate Environmental Field Audit Form at the completion of every activity or when moving off of an uncompleted block

- All audit forms will be submitted to the Area Forester with the attached map at the end of every month

- The audit will be entered into the district's computerized spreadsheet

- $\quad$ An exception report of audits which did not pass with zero defects will be created and a copy sent to the Environmental Forester on a monthly basis

- An action plan will be developed for all exception audits and, where feasible, those exceptions will be corrected with 30 days

- As exceptions are corrected, they will be removed from the exception file

- The Environmental Forester, Area Forester, Silvicultural Forester, or Contract Logging Supervisor will conduct a follow-up audit on a small random sample of completed audits to enhance credibility and understanding of Region Standards on a monthly basis

- The audit system will be formally reviewed on an annual basis by the Corporate and Division Audit Team.

Responsibility:

- The Area Forester is responsible for environmental compliance for all activities occurring on fee lands within his district.

- The Raw Materials Manager is ultimately responsible for environmental performance on all stumpage tracts and shares responsibility with the Area Forester for harvesting operations occurring on fee land.

- Every employee is responsible for his or her actions and the actions of contractors under his/her control as these actions impact the environment.

The standards by which all actions are judged on a pass/fail (zero defect) basis are the North Carolina Region Environmental Standards.

Weyerhaeuser Timberlands management and harvesting practices are based upon the Forestry Best Management Practices (BMP) as promulgated by the North Carolina Division of Forest Resources, Department of Environment, Health and Natural Resources. This is the basis for all regulations and practices in the state of North Carolina. Industry does participate in the development of the BMP and updates are made on an as-needed basis. A supplement to this BMP is the Best Management Practices for Forested Wetlands in North Carolina.

BMPs are practices chosen to minimize erosion and prevent or control water pollution resulting from forestry operations. The practices outlined are based on current knowledge and the best judgment of forestry practice experts. BMPs are updated as new methods, techniques and experience are gained from the application of these practices. These practices are designed to assist individuals in meeting the performance standards in Forest Practices Guidelines to Water Quality (15A NCAC 1I .0101 - .0209)

BMPs cover the following activities:

- Runoff and Erosion Control

- Accessing and Harvesting Forest Products

- Site Preparation and Reforestation

- $\quad$ Revegetating Disturbed Areas

- Wildlife Protection 
BMPs for Forested Wetlands prescribes procedures for the following:

- Forested Wetlands

- Road Construction and Maintenance

- Harvesting and Logging Systems

- Regeneration/Reforestation

- $\quad$ Recommended Practices by Wetland Type

- $\quad$ Streamside Management Zones

- Water Management

- Wetland Forestry and Wildlife Management

- $\quad$ Recommended Practices by Wetland Site

Weyerhaeuser has developed a set of Timberland Environmental Management Standards which are based on the BMPs. The Weyerhaeuser standards are more stringent and address more areas. The table of contents provides an excellent overview of these standards which are followed by Weyerhaeuser for managing its North Carolina forests:

- Harvesting

- Configuration/Setting Design

- Utilization

- Performance

- Water Management

- Smoke Management

- Pre-Burn Considerations

- Post-Burn Considerations

- $\quad$ Sensitive Area Management

- $\quad$ Sensitive Areas - Normal Operations

- $\quad$ Sensitive Areas - Region Approval Required

- Road Management

- $\quad$ Spacing and Density

- Construction

- Maintenance

- $\quad$ Streamside management Zones

- $\quad$ Site Preparation and Regeneration

- $\quad$ Plantation Management

- Pre-Commercial Thinning

- Commercial Thinning

- Fertilization

- Prescribed Burning

- Chemical Vegetative Completion/Insect Control

- Wildlife

- Forest Protection

- Fire Protection

- Insect, Disease, and Animal

- Trespass

- Housekeeping

- $\quad$ Land Use

- Environmental Performance Standards

- Long-Term Lease Lands (LTL)

- $\quad$ Private Non-Fee Lands 
Furthermore, in addition to these strong programs, Weyerhaeuser endorses and supports implementation of the American Forest \& Paper Association (AF\&PA) Sustainable Forestry Principles including the Implementation Guidelines. As stated below, twelve objectives are incorporated into these implementation guidelines:

- Broaden the practice of sustainable forestry by employing an array of scientifically, environmentally and economically sound practices in the growth, harvest and use of forests.

- Promptly reforest harvested areas to ensure long-term forest productivity and conservation of forest resources.

- Protect the water quality in streams, lakes and other waterbodies by establishing riparian protection measures based on soil type, terrain, vegetation and other applicable factors and by using EPA-approved Best Management Practices in all forest management operations.

- Enhance the quality of wildlife habitat by developing and implementing measures that promote habitat diversity and the conservation of plant and animal populations found in forest communities.

- Minimize visual impact by designing harvests to blend into the terrain, by restricting clearcut size and/or by using harvest methods, age, classes and judicious placement of harvest units to promote diversity in forest cover.

- Manage company lands of ecological, geological or historical significance in a manner that accounts for their special qualities.

- Contribute to biodiversity by enhancing landscape diversity and providing an array of habitats.

- Continue to improve forest utilization to help ensure the most efficient use of forest resources.

- Continue the prudent use of forest chemicals to improve forest health and growth while protecting employees, neighbors, the public and sensitive areas, including streamcourses and adjacent lands.

- Broaden the practice of sustainable forestry by further involving nonindustrial landowners, loggers, consulting foresters and company employees who are active in wood procurement and landowner assistance programs.

- $\quad$ Publicly report AF\&PA members' progress in fulfilling their commitment to sustainable forestry.

- $\quad$ Provide opportunities for the public and the forestry community to participate in the AF\&PA memberships' commitment to sustainable forestry.

Established harvest guidelines are periodically updated to ensure that harvesting methods and woods operations are balanced in a manner that provides the most complete utilization of timber under the existing marketing conditions. Considerations essential in the planning of harvest/regeneration management units include maximizing harvest and market economics, providing for protection of soil productivity and water quality, habitat diversity, and a good age class distribution throughout the ownership. Monitoring of ongoing harvest activities provides a measure of assurance that the level of performance enhances the long-term interest in the timberland asset in terms of regeneration needs, erosion control, and soil productivity.

\subsection{Environmental Stewardship - General}

Only about 3 percent of the Weyerhaeuser forests are harvested in any year. Site-specific harvest planning begins several years in advance to allow detailed study and maximum flexibility. A variety of factors influence what, when and how the harvest is conducted to ensure safety, efficiency and minimal impact to the environment:

\footnotetext{
- Tree species

- Weather conditions

- Topography and soil stability

- Soil characteristics
} 
- Wildlife habitats and activity

- Watercourse and wetlands conditions

Weyerhaeuser owns or leases approximately 535,000 acres of timberlands in eastern North Carolina with much of these lands surrounding the New Bern manufacturing complex. Several decade-old studies continue in order to understand the soil characteristics and growth rates of forests on our lands. Ongoing soil and tree growth assessments at selected plots are conducted throughout these holdings. These studies serve to permit recognition and documentation of any significant effects of point and nonpoint emissions sources. Long-term fisheries and wildlife studies document biological populations and trends and again serve to identify any significant impacts from our operations.

Managing a forest for wood production supports other values. Managed forests on Weyerhaeuser lands near New Bern, NC, reduce the pressure on other forestlands and provide economic incentives to grow trees instead of converting the land to other uses. Weyerhaeuser manages its forestlands for the production of wood, practicing sustainable forestry to meet the increasing worldwide demand for wood products. The Company uses scientific research and technology to accomplish this while managing other important environmental values - such as soil productivity, water quality, fish and wildlife habitat, and plant and animal species diversity.

Weyerhaeuser has contributed over $\$ 4$ million to organizations such as the Nature Conservancy, the World Wildlife Fund and the Audubon Society, as well as donating or exchanging hundreds of thousands of acres of culturally, biologically or historically unique areas. At the University level research support has been provided to Wayne Skaggs, NCSU, and Bill Kirby-Smith, and Duke among others.

Weyerhaeuser is committed to managing its forestlands for the long-term. For example, in the 1950s soil scientists surveyed and classified all of Weyerhaeuser's lands into nearly 400 different soil types. Coupled with on-going research, this information helps foresters determine which species grows best where. The Company wants to ensure that its forests-including all of the animals, birds, plants and other species that inhabit them-are healthy and vigorous for generations to come. In the 1950s Southern lands were purchased that for decades had been repeatedly logged and burned or used for agricultural purposes. Today nearly all that land supports healthy second- or third-generation forests that are managed on a sustainable basis. After harvesting, trees are planted that are native to the area, primarily loblolly pine which is the dominant natural species in the South. In some areas oak, sweet gum, bald cypress, ash and yellow poplar are also planted.

Even in areas where predominantly one species is planted, the forests are far from being a "monoculture." Shrubs, ferns, grasses and other "wild" species of both hardwood and softwood trees-brought in from surrounding areas by the wind or birds-grow amongst the planted trees. Even though just a few species are hand planted, a great deal of natural regeneration takes place on the Tree Farms. In addition, streamside buffer areas, upland habitat preservation areas and wetland- and wildlifereserve trees provide biological diversity.

Weyerhaeuser protects diversity within species by maintaining the native gene pools of over 70,000 different parent trees. Hundreds of these trees provide seed, pollen or cuttings for the nursery seedlings, potentially providing newly planted areas more genetic diversity than those that regenerate without assistance.

Weyerhaeuser foresters are working continuously to improve the forest health and productivity. By selection of seedlings with improved natural defenses against insects or disease, chemical use can be minimized. Judicious thinning and fertilization heips ensure adequate light, nutrients and moisture as well as providing wood chips for pulp and paper products as the forest grows. Continuous improvements in 
equipment and operating methods are increasing the forest management efficiency while minimizing damage to soil, remaining trees and other vegetation.

Weyerhaeuser Company supports a mosaic of timberland types, from natural bottomland areas (predominately hardwood in nature) through the various successional stages of the intensively managed, even-age pine plantation. Plantations in the younger age classes, 1 to 8 growing seasons, provide excellent forage and browse habitat for many game and non-game wildlife species. The older class plantations under intensive management provide a diversity of both forage and cover habitat. Nonstocked, non-merchantable timberland ownership is mostly marsh and swampland within which thrive a variety of aquatic and animal life. The Company takes responsible actions to protect threatened or endangered species and their habitats on Company landholdings. In all cases, compliance with applicable state and federal regulations will be the minimal accepted standard of performance. Federally endangered species in North Carolina are the red-cockaded woodpecker, bald eagle, cougar (Florida panther), and American alligator. In North Carolina, special consideration is also given to the osprey and the black bear, although neither is an endangered species.

Wildlife habitat areas are maintained in their natural condition along streams and in upland areas. Through cooperative research with universities and public agencies, Weyerhaeuser is continually adding to its knowledge of wildlife habitat. The company has and continues to make numerous voluntary changes in forest management practices to accommodate and be sensitive to special wildlife habitat needs.

In North Carolina the survival of wildlife species adapted to mature forests is assisted by managing the habitat corridors. Such corridors may include hardwoods, pines and marsh. For specific site conditions or habitats, planting stock includes oak, gum, bald cypress, ash and yellow poplar.

Trees left standing along riparian zones and as wildlife reserves in harvested areas will be old trees among younger forest providing homes for a diversity of wildlife.

The development of site-specific Best Management practices (BMP) for safely growing and harvesting trees on most wetlands allows for both productive wood production and wetlands protection.

\subsection{New Bern Pulp Mill Environmental Monitoring}

The impacts of implementing a biomass gasification combined cycle power plant or a combined biomass gasification combined cycle power plant with an ethanol from biomass facility will have no, or at most little, environmental impact on the receiving environments. The aqueous waste biochemical oxygen demand (BOD) load from the ethanol plant will increase by less than ten percent of the current loadings. Particulate air emissions would likely be decreased if this implementation were to replace some existing power boilers.

The National Pollution Discharge Elimination System (NPDES) wastewater and the air emissions permits from the State of North Carolina require daily and monthly environmental reports as defined in the permits. Audits are made by the mill staff to show and to ensure compliance with these permits. Yearly environmental audits are conducted from the Corporate Office of the Environment to ensure Corporate environmental policies are being followed. No changes would be required in these current procedures with the implementation of these facilities.

Point source emissions from the New Bern Pulp Mill complex are monitored daily on aqueous treated effluents being discharged to the receiving environment. Pulp mill discharges are continuously sampled, with 24-hour composites analyzed for $\mathrm{BOD}_{5}$, total suspended solids (TSS) and acidity (pH). Routine 
samples are collected on a periodic basis for color, nutrients, aquatic toxicity, trace organics and organics analyses.

Ambient air quality monitoring is conducted at several sites in the New Bern area by the State of North Carolina and the Craven County Health Department. Particulates and sulfur dioxide are the major parameters of interest. Particulate, sulfur dioxide, nitrogen oxides and opacity measurements are made for many of the combustion and process sources at the New Bern pulp mill. Continuous monitoring is done of NOx on the recovery boilers, power and package boilers, smelt dissolving tanks and TRS on the smelt dissolving tanks and lime kiln. Opacity monitoring is also conducted.

Receiving water studies have been ongoing on the Swift Creek, the Neuse River and its estuary. Routine water quality monitoring is made upstream and downstream of the mill discharge in which the parameters of dissolved oxygen, BOD5, color, nutrients, transparency, trace organics and inorganics are measured. Sediment and fisheries studies are conducted periodically to identify and assess impacts of the pulp mill discharges. National Council for Air and Stream Improvement (NCASI), an industry-sponsored research group, has been conducting studies over the past seventeen years using a series of experimental streams to assess pulp mill effluent discharges on fishery production, the health, survival and reproductive success.

Forestry operations by man can impose an adverse effect on water flowing from forests. These effects are generally classified as sediment, temperature, chemical use, and organic matter. Utilization, environmental performance, road and ditch maintenance, soil management and housekeeping constitute the major areas of measurable performance following the harvest operation.

All harvesting operations conducted by or contracted by Weyerhaeuser Company on fee and non-fee lands shall comply with Chapter 113A, Article 4 of the General Statues of North Carolina entitled, "The Sedimentation Pollution Control Act of 1973." Operations on long-term lease lands will adhere to the North Carolina Region Timberland Environmental Management Standards. Compliance with current federal and state regulations is mandatory. Activities on private non-fee lands will be guided by the goals of the landowner, along with current federal and state regulations and the state best management practices (BMPs).

Surface water management is recognized as a prerequisite to intensive forest management. Forestland ditching has been the silvicultural tool utilized to remove ephemeral surface water and maintain the nearsurface water at a desired level. Water management systems on major tracts are planned and implemented so as to minimize impacts relative to turbidity, sedimentation, downstream landholdings and salinity in downstream areas. Fire protection, growth enhancement and wildlife habitat supplementation are additional benefits derived from a well designed and implemented system.

Forest management activities are planned to minimize potential adverse impacts on water quality, bank integrity, adjacent soils and the related elements of wildlife habitat (both terrestrial and aquatic) within the waterside management zone.

Site preparation and regeneration receives much attention. Site preparation requirements are assessed on a site-by-site basis considering vegetative and soil type characteristics, matching available equipment with existing features of the terrain and soils and scheduling operations under favorable weather conditions. Appropriate procedures and technology are continuously evaluated and updated, as necessary, to ensure that a cost effective, environmentally sound program is maintained.

Plantation management is conducted in a manner sensitive to environmental protection and considerate of the economics of a particular plantation. Well-planned treatments, such as pre-commercial and 
commercial thinning, fertilization, following thinning, prescribed burning and chemical applications for insect and weed control can result in high quality wildlife habitat throughout most of the life of the plantation. 


\section{Section 6}

\section{Market Issues}

\subsection{BGCC/Power Market}

\section{Background}

There are a number of general market issues which must be considered when introducing new technology and products into the commercial market place. While developers are quick to define advantages and benefits of new technologies, potential users are faced with a broad range of risk considerations which in effect become barriers to commercialization. The following are the issues of particular concern to Weyerhaeuser and its team members regarding the decision to employ BGCC technology at the New Bern mill.

- Efficiency and cost of existing energy generation technologies are well defined. The rate at which current operations and technologies may become noncompetitive is not precisely known, but energy systems typically follow relatively long 25 to 30 year life cycles. A decision to pursue a relatively unknown technology over an established one for such a long investment cycle requires strong and compelling evidence, convincing cost projections, and as pointed out in Section 1.1, a timing that fits the industry's normal capital cycle.

- Availability, reliability, and operability of new technology systems may not achieve the required levels for some period of time, thereby denying the user of potential benefits.

- Technology development is a continual process and significant improvements can be identified early in the application cycle. First-of-kind plant users may not achieve the same benefit as follow-on customers who accept much lower levels of risk.

- Incorporation of new technology into existing plants frequently involves design restrictions which may not allow the new system to demonstrate optimum technical and economic performance.

- Plant operational integrity and ability to provide product flexibility is an increasingly important requirement of business decisions. The new technology must demonstrate an improved ability to achieve such flexibility and reliability.

- Competition for capital resources is a continuous process in business. There are significant demands for other plant modernization, capacity additions, and requirements imposed by new regulations or market opportunity. New power system technology must not only demonstrate an ability to improve plant operations but also show significant profitability in order to compete with other possible investments.

- Environmental considerations have become global in character and selection of new plant designs or modifications is strongly influenced by local and other environmental regulations.

In general, there is a significant barrier to the commercial deployment of new, more efficient power generation systems due to competitive pressure and difficulties related to technical and economic risks. There is also considerable concern regarding the economics of current power systems. A combination of factors including successful conservation efforts on the part of consumers, legisiative action to bring 
about a competitive power generation industry, environmental regulatory requirements, and a leveling of real growth in electric demand serve to create this barrier.

Although it is broadly believed that significant increase in dependence on gas may have long-term negative implications on power system reliability and electricity costs, present economic pressures often result in decisions to use gas turbines or combined cycles fueled with gas. Concerns of fuel costs and reliability, despite well known problems in the past, are addressed by expectations that low cost fuel will be available or new technical alternatives will materialize as a result of competitive opportunities when needed. Industries such as the forest product and utility industries which have such an enormous capitalization base simply cannot afford to rely on optimistic projections of low cost high quality fuels upon which to plan future operations. Critical pulp and paper mill operational requirements, such as adjusting power and steam needs in an effective manner, can be better achieved with BGCC technology as pointed out in Background Section 1.1 of this report and if done at the proper scale could also be integrated as a cost effective element of a utility system.

If there was a general need for base loaded power generation capacity, a technology like biomass gasification could more readily be introduced because of its ability to use low cost or residual fuels, ability to be integrated with existing gas turbine systems, and its high efficiency. At the appropriate scale it could be competitive with other technologies such as coal-based power plants, oil- or gas-fueled systems and other new technologies because of the low cost fuel. In addition, biomass gasification has the advantage of being based on a renewable fuel, indigenous to this country, having the potential to significantly reduce oil imports. When all factors are considered, it is believed that this technology is vital to the forest product industry's long-term economic vitality and should be introduced into commercial service employing a shared risk program such as is planned by the Department of Energy with all stakeholders participating.

Biomass gasification offers the opportunity of developing a forest-based chemical industry which may be complementary to existing operations and provide for new revenue streams. The technology also offers the opportunity to replace existing black liquor recovery technology with safer, more efficient and more environmentally compatible pulp mill operations in the future. Collectively, these potential benefits argue strongly in support of biomass gasification technology and for its commercial development.

Other benefits of an increased biomass-to-energy capacity include a decrease in net carbon dioxide release and lower sulfur dioxide emissions. Given that a healthy forest product industry is of significant benefit to North Carolina, it is reasonable to address the various means which could be utilized to distribute the risks associated with the introduction of BGCC technology at New Bern. These risks include:

- For the New Bern project, technical risks of necessity must be borne by equipment suppliers, project developers, constructors, and Weyerhaeuser. Technology developers have already invested significant funds to assure prospective users that reliable and operable systems can be designed and built. The largest risk in this area will be borne by Weyerhaeuser since BGCC system performance impact on plant capacity and, therefore, economic return is unknown until the technology is operationally demonstrated.

- Technology risks are and must be borne by the developers and those who own the rights to use the technology. In the case of BGCC technology, several vendors have progressed to the point of commitment to provide commercial guarantees that provide for capital risk sharing. However, there is little to protect the user from the extra cost of backup systems to avoid operating losses during the startup and commissioning phase. 
- Capital costs associated with first-of-a-kind installations are generally higher than the cost for later applications. In the case of energy processing facilities, it is usual for first-of-a-kind plants to be considerably more expensive because of the high cost of redundant systems to mitigate technical risk. The DOE program to encourage power production from biomass to support rural economic development and similar programs that may be under consideration recognizes this problem and, in - part, provide the mechanism to manage this risk.

- Market risks must also be factored into the decision to use new technology. In the New Bern BGCC plant case, it was determined that additional product and revenue streams could be important in the future for maintaining an economically viable operation. While a biomass gasifier has the potential to solve a number of mill operating problems, no revenue streams result for a mill if the plant is designed to meet only the mill steam, power, and waste disposal requirements. A larger scale facility would allow for the production of additional products from biogas produced by the gasifier. The most compatible of these products, when low Btu air blown gasification is utilized, is electric power. Although there is a projected need for power in the New Bern area, there may be a mismatch between the mill operating regimen and the electric energy demand profiles for a period of time. While plant design can be adjusted to provide for a certain level of dispatchability, capital costs would increase- thereby increasing the financial risk. A risk plan is, therefore, needed in order to distribute additional costs which may accrue if this plant becomes available sooner than is required in the region.

- Environmental benefits that would be realized with use of BGCC technology and increased use of biomass resource are expected to be significant in both a global and a local sense. Atmospheric, land use, and other environmental benefits are projected as a result of utilization of biomass based energy production. Long-term impacts, however, cannot be predicted with certainty; therefore, it must be assumed that there will be concerns expressed regarding implementation of this and any new technology which will impact on the decision process, affect timing of implementation and may have an impact on both project design and costs. This, in turn, will have an impact on the value of the technology in general and the project, specifically. Introduction of the technology on a comparatively small scale in a prudent manner with a reasonably shared and funded risk management plan would serve to safeguard such concerns.

\section{North Carolina Market for Electric Power}

\section{Background Information}

The Carolina Power \& Light Company (CP\&L) electric power system service area covers approximately 30,000 square miles of eastern and central North Carolina, the Asheville area in western North Carolina, and the northeastern quadrant of South Carolina. Rapid growth of the CP\&L service area has created a steady demand for increasing amounts of electric power. CP\&L's existing supply-side resources consist of 5,285 MW of coal, 3,064 MW of nuclear, 1,046 MW of oil/gas, and $218 \mathrm{MW}$ of hydroelectric facilities, as well as 1,596 MW of purchases from other utilities and non-utility generators. All generation additions scheduled through 2004 are relatively low capital cost combustion turbines needed for peaking capacity. The plan also calls for the addition of combined cycle capacity in the 2005 through 2007 timeframe, and the first coal unit is added in 2008. CP\&L's resource plan also incorporates a costeffective mix of DSM programs which have favorable environmental effects and result in improved efficiencies of energy utilizations.

Uncertainty in fuel supply, economic growth, industry regulation, increasing competition in the wholesale power market, and environmental legislation, are complex issues which must be addressed by energy 
system planners. With the current debate over retail competition in the power market, plans must be developed that recognize and are responsive to the uncertainty of future events. Plans must be flexible and must not depend on a specific outcome of future events for them to be successful. To that end, CP\&L emphasizes diversity and flexibility in its Integrated Resource Plan to meet the objective of providing an adequate and reliable power supply to customers at the lowest reasonable cost and with reasonable protection of the environment.

\section{$\underline{\text { Utility Cost Analysis }}$}

A busbar cost analysis was performed to compare the cost of a biomass gasification combined cycle (BGCC) plant to the market cost of electricity for CP\&L service area and conventional supply-side resources that would compete with power from a BGCC facility. The key assumptions in this analysis are:

- Start-up operation in 2000 ;

- Capital and O\&M Cost Estimates as outlined in Sections 2.7.1 and 2.7.2; and allocated for the power export portion of the overall plant on the basis of the export energy to total plant energy ratio.

- 20 year operating life;

- 85 percent capacity factor;

- Department of Energy funding for the project is 50 percent of capital costs.

\section{Cost Analysis of BGCC Plant Without Department of Energy Funding}

Figure 6-1 examines the annual costs of two BGCC configurations without a contribution to capital costs by the Department of Energy (DOE). The two configurations of the BGCC plant include one that provides $33.4 \mathrm{MW}$ of export power as discussed in Section 2 of this report and a similar facility using a larger gasifier and a more efficient combustion turbine which would supply $85.4 \mathrm{MW}$ of export power. The 20-year lifetime cost is also displayed on the graph in terms of a levelized cost per kilowatt-hour in 1995 dollars.

The results of the analysis show that an unsubsidized BGCC $6 \mathrm{~B}$ plant that could export $33.4 \mathrm{MW}$ is not cost competitive with the local utility cost of power until the final years of the 2000-2019 time period. Export of $85.4 \mathrm{MW}$ from the larger, more efficient BGCC $6 \mathrm{~F}$ cogeneration facility does have annual costs that are less than the local utility's costs starting in 2011. However, over the 20-year operating life, this type of facility, with start-up in the year 2000 , is not economical compared to the CP\&L avoided cost of power.

Two of the competing technologies to supply base or intermediate duty power are a $500 \mathrm{MW}$ coal gasification combined cycle plant and a $225 \mathrm{MW}$ combined cycle power plant burning oil or natural gas, respectively. CP\&L resource planning had indicated that an intermediate load duty oil or natural gas fired combined cycle power plant would be required in the 2004 time frame. Intermediate load duty translates to a 50 percent capacity factor at best for this future unit. For a BGCC facility to be selected by the electric utility as the supply technology for capacity expansion, its cost to produce power must be less than these alternative technologies. As Figure 6-1 shows, without DOE funding, neither the 33.4 MW (6B) nor the 85.4 MW (6F) BGCC power export facilities can produce electricity less expensively than a coal gasification combined cycle unit, assuming a start-up in the year 2000 . However, both versions of the BGCC plant can produce power less expensively than an oil-fired combined cycle unit at some point during the study horizon. The $33.4 \mathrm{MW}$ BGCC facility produces power less expensively than an oil-fired combined cycle unit running at a 50 percent capacity factor beginning in 2004 and less than a natural gas-fired combined cycle unit by the year 2011 . Over the 20 year operating life, the cost of the $33.4 \mathrm{MW}$ of export power from the BGCC cogeneration plant without DOE funding 
is less expensive than that from an oil-fired combined cycle unit, but more expensive than power from a natural gas-fired combined cycle unit.

Figure 6-1 shows that without DOE funding the larger 85.4 MW of export power BGCC cogeneration plant produces electricity more cost-effectively over its 20 -year life than a combined cycle plant operating at a 50 percent capacity factor fueled with either oil or natural gas.

\section{Cost Analysis with Department of Energy Funding}

A second analysis was performed in which DOE provides 50 percent funding of the capital costs of a BGCC facility. The results of this evaluation are shown in Figure 6-2. The BGCC 6B cogeneration plant with 33.4 MW of export power starting operation in 2000 is still not economical compared to the CP\&L avoided cost of electricity over the 20 -year operating life. It can, however, produce electricity more economically than a $225 \mathrm{MW}$ combined cycle unit burning oil or natural gas.

Figure 6-2 shows that the larger version of the BGCC cogeneration facility based on a General Electric 6F turbine, while more costly during the first five years, can produce electricity at a cost that is less than the CP\&L avoided cost over the 20 year operating life. The cost of electricity for this plant is less than a $225 \mathrm{MW}$ combined cycle fueled with either natural gas or oil and also $500 \mathrm{MW}$ coal gasification combined cycle plant. The BGCC cogeneration plant that is based on a General Electric 6B turbine does not produce electricity that can be sold to the grid economically over its 20 -year life. Such a configuration also generates more expensive electricity that a $500 \mathrm{MW}$ coal gasification combined cycle plant.

\section{Sensitivity Analysis on Startup Date}

One conclusion from the analysis discussed above is that, with the exception of a larger, more efficient BGCC cogeneration facility based on a GE 6F turbine with DOE funding, a BGCC plant operational in 2000 cannot provide economical electricity to the local utility over its 20-year operating life with or without DOE funding. Therefore, such a facility should not be developed prior to 2000 . However, to determine whether such a facility would be economical if installed in a later year, an analysis was performed in which the start-up year was varied. The analysis examined the $33.4 \mathrm{MW}$ and $85.4 \mathrm{MW}$ export power BGCC cogeneration facilities previously described.

The analysis was performed comparing the 20-year levelized cost of electricity of the BGCC plant to the market price of electricity using start-up years as late as 2020 for facilities both with and without DOE co-funding. The analysis found that a $33.4 \mathrm{MW}$ export power BGCC cogeneration plant is not economical if operation begins prior to 2020 either with or without DOE funding. Therefore, it is unlikely that such a facility would ever be able to produce economical electricity for export to the local utility. As discussed above, the BGCC cogeneration facility based on the GE 6F turbine with DOE co-funding is economical over a 20-year life with operation starting in 2000. Without DOE funding, such a facility is not economical if operational prior to 2020.

This assessment confirms that a small scale solid fuel plant has difficulty in competing with large scale existing utility plants when a power sales contract is essential, even though the plant has an efficiency better than the overall utility system through its integration with a viable manufacturing operation.

Given the substantial sensitivity of the BGCC plant to both capital and fuel costs, both will need to move in a positive direction before wide spread use of this technology occurs within the forest products industry. Although it is difficult to predict what may happen to the capital cost as the technology matures, it is believed that a $10-30$ percent reduction is possible for the plant. It is somewhat easier to speculate on what the potential may be for decreasing fuel costs. Although it is unlikely that the cost of 
residual biomass from wood products manufacturing and harvesting operations will decrease over the next 10-20 years, it is equally likely that the advances in harvesting technology and forest plantation management practices will offset any upward pressures on price and that the fuel cost projections contained in this report will be consistent over time.

The real opportunity will occur in 8-10 years and beyond when black liquor gasification combined cycle becomes a reality. In this case, not only will the size of the gas turbine plants potentially double (thus, taking advantage of economy of scale), the availability of half or more of the biogas from black liquor processing will have a significant dilution factor on the real cost of fuel going to these combined facilities. Although this impact needs to be studied further, it is believed that when it is taken into account the average fuel cost will be significantly less than $\$ 1.00 / \mathrm{MBtu}$ and could be as low as $70-80 \mathrm{c} / \mathrm{MBtu}$.

As the industry moves in this direction, there is considerable flexibility, particularly with larger mills, to utilize internally much or all of the power generated. Other possibilities will be to retail wheel the power to other facilities owned by the same company; and, of course, in regions where an attractive power contract can be obtained, these facilities can be optimized for maximum use of the low cost black liquor and biomass fuel. When these facilities are optimized in this way, there will be some locations where as much as 200-250 MW of power can be realistically produced. Weyerhaeuser's North Carolina region surrounding New Bern and Plymouth represents such an opportunity. 


\section{No DOE Contribution}

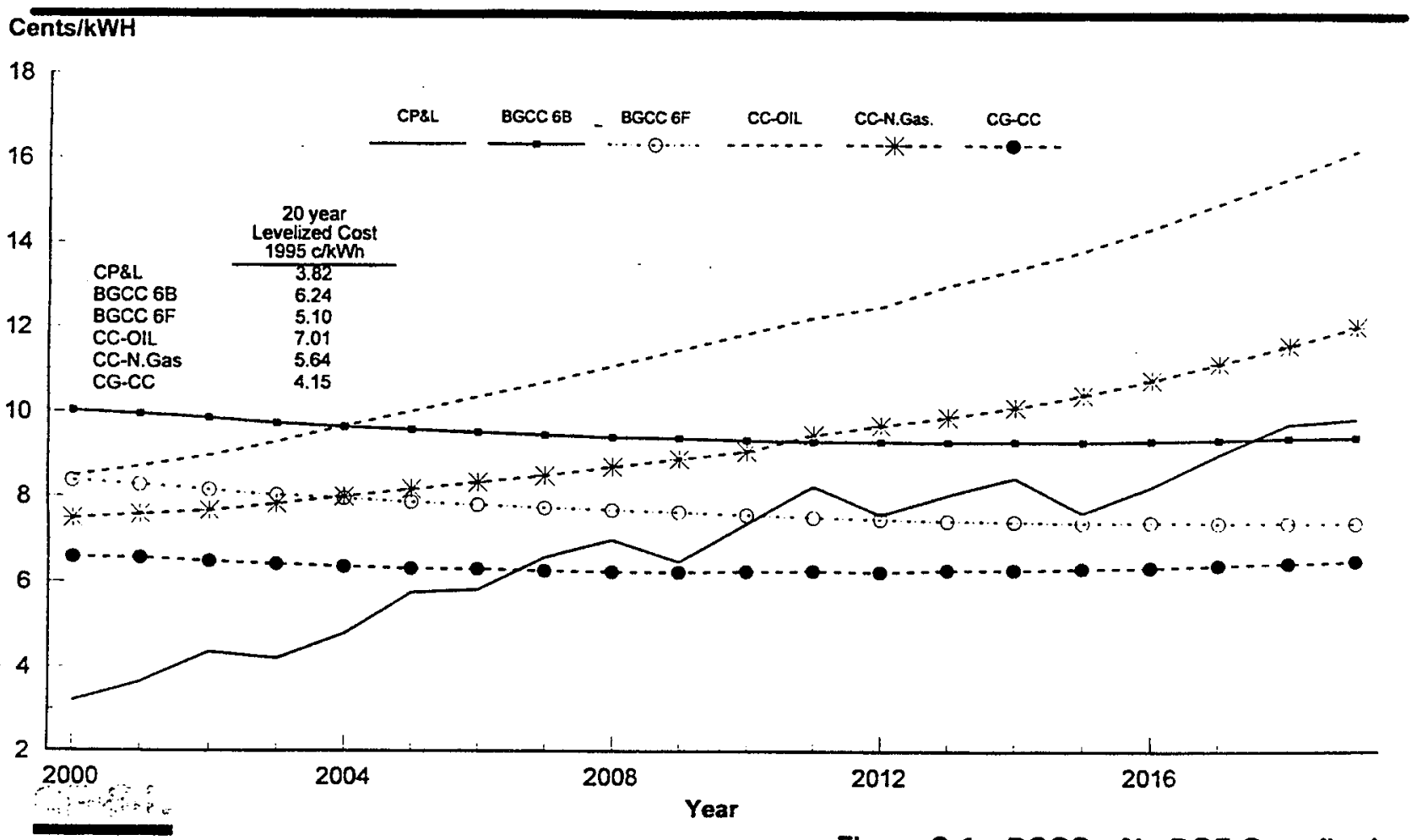

Figure 6-1: BGCC - No DOE Contribution

\section{With DOE Contribution}

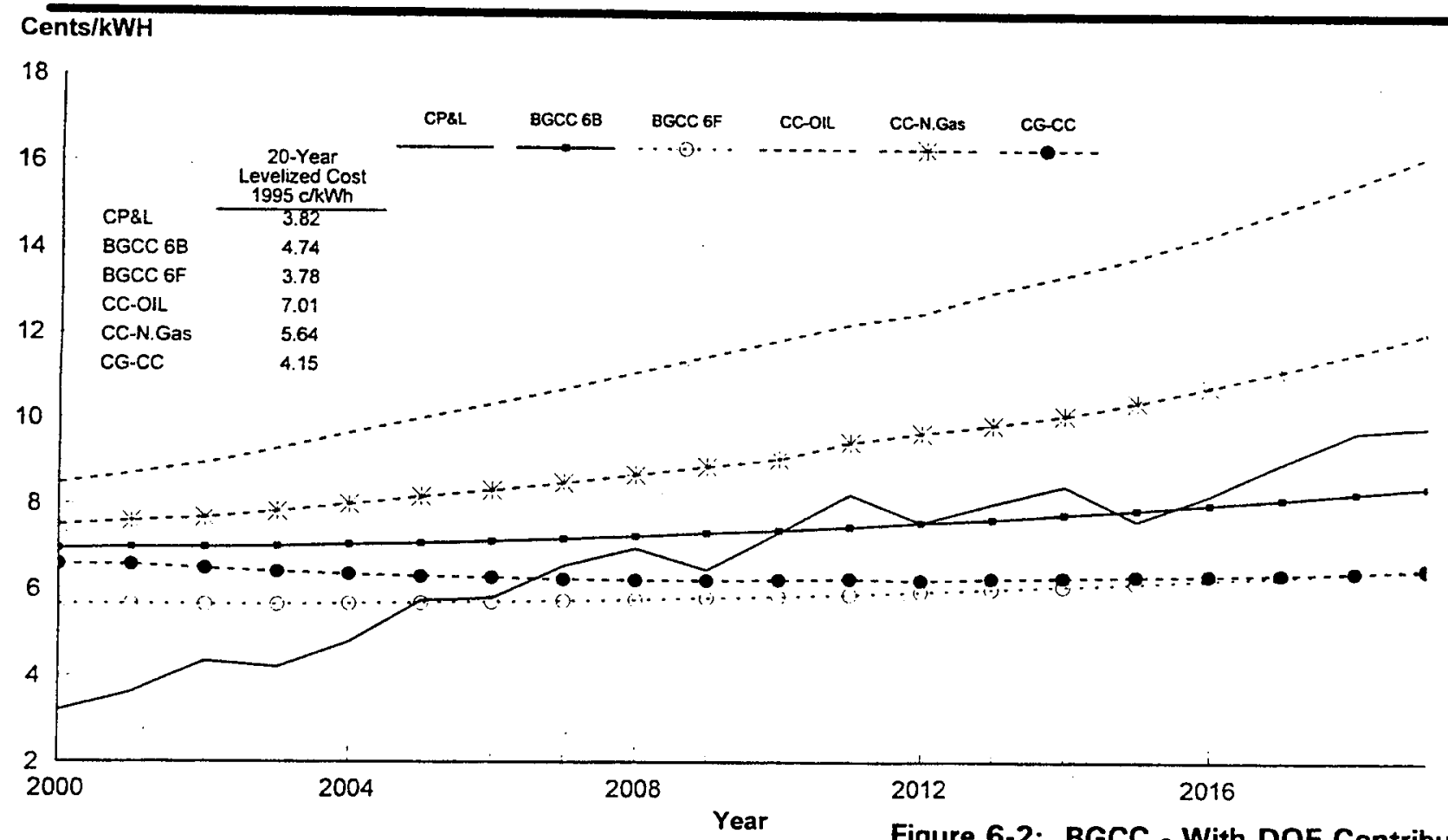

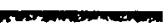

Figure 6-2: BGCC - With DOE Contribution 


\subsection{Fuel/Ethanol Market}

\section{Background}

United States East Coast (PAD-I) motor gasoline demand is 41 billion gallons based on 1993 market data. Of this amount, 1.4 billion gallons, or 3.4 percent, is sold as gasoline/ethanol blends. Assuming these blends are 10 percent ethanol, East Coast ethanol demand is 140 million gallons, annually, or 10 percent of the total U.S. fuel ethanol supply. As explained in a later section, a subset of this market was selected for the New Bern study. This subset, or model market, has an estimated ethanol demand of $120,000,000 \mathrm{gal} / \mathrm{yr}$. The envisioned New Bern Biomass to Ethanol facility can produce $27,000,000 \mathrm{gal} / \mathrm{yr}$, or 22 percent of the model market demand figure.

The minimum permissible ethanol blending percentages for oxygenated fuels and reformulated gasoline (RFG) are actually lower than 10 percent. Based on the available federal excise tax credit for ethanolgasoline blends, and the value of the ethanol, including its octane and its Reid vapor pressure, the optimum concentration of ethanol might be in the range of 7.5 percent. However, blends of ethanol and gasoline containing less than 10 percent ethanol do not quality for the federal ethanol blending credit, which is an alternative subsidy for using ethanol. The excise tax credit has no value to large company blenders who already have such large deductions that they must pay the Alternative Minimum Income Tax. By blending at 10 percent, these companies qualify for the ethanol blending credit.

Presently, there are no ethanol fuel manufacturing facilities in the East Coast region. The three nearest ethanol manufacturing facilities are between 500 and 1,000 miles away. That the region receives distant supply today indicates there is significant infrastructure in place to transport fuel ethanol to terminals in the selected model marketing area. Ethanol produced at a New Bern facility can utilize this same product transportation infrastructure.

About 65 percent of the New Bern ethanol product is expected to enjoy a transportation cost advantage within its model ethanol market over ethanol shipped from the three nearest ethanol production locations in Tennessee, Ohio, and Indiana. This transportation cost advantage encompasses a marketing area from New Bern north through the Baltimore region.

Ethanol produced at a New Bern facility will need to be priced competitively with other fuel oxygenates including ethanol supplied from outside the model marketing area. A review of fuel ethanol price history from 1992 to the present shows prices for selected markets ranging from $\$ 0.94$ to $\$ 1.45$ per gallon and averaging $\$ 1.17$ per gallon. The low end of the price range likely is indicative of the cash costs for conventional ethanol plants. Likewise, the high end of the price range likely is indicative of the "switching" price, or the price at which consumers switch to oxygenate alternatives.

Ethanol produced at a New Bern facility will be eligible for the federal ethanol blending credit of $\$ 0.54$ per gallon under today's legislation. In addition, the state of North Carolina allows a tax credit up to 30 percent of a plant's construction cost. The economic justification of a New Bern ethanol facility will depend on many factors, including ethanol market prices and tax credits.

\section{United States Ethanol Manufacturing Capacity}

To provide perspective, this section compares the capacity of the envisioned New Bern ethanol plant with that of conventional ethanol facilities. 


\section{U.S. Fuel Ethanol Plants and Capacity}

U.S. fuel ethanol annual manufacturing capacity is about 1.4 billion gallons [1]. As of 1993 there were 37 facilities, most of which produce ethanol from corn and are located in the Midwest. A much smaller number of facilities are located in the West. U.S. fuel ethanol manufacturing facilities in place as of 1993 are listed in Table 6-1.

\section{Comparison of New Bern and Conventional Ethanol Plants}

If implemented as described in this study, the New Bern biomass to ethanol facility, with an annual capacity of 27,000,000 gallons, would rank 13th and would increase today's fuel ethanol capacity by 2 percent. A review of fuel ethanol plant statistics shown in Table 6-2 and Table 6-3, shows that the capacity of New Bern facility is about three-quarters the size of the average sized facility in the U.S.

\section{Table 6-2: Selected Capacity Statistics for U.S. Fuel Ethanol Plants}

\begin{tabular}{|l|r|r|r|}
\hline & All Plants & Plants < 10 MM Gal & Plants > 10 MM Gal \\
\hline Number & 37 & 18 & 19 \\
\hline Total Capacity & $1,393,300,000$ & $51,900,000$ & $1,341,400,000$ \\
\hline Average Capacity, Gallons/Yr. & $37,700,000$ & $2,900,000$ & $70,600,000$ \\
\hline Median Capacity & $10,000,000$ & $2,300,000$ & $30,000,000$ \\
\hline Total Capacity, Percent of All Plants & - & $4 \%$ & $96 \%$ \\
\hline
\end{tabular}

Table 6-3: Comparison of New Bern Ethanol Plant Capacity Statistics

\begin{tabular}{|l|r|r|r|}
\hline \multicolumn{4}{|c|}{ New Bern Fuel Ethanol Plant Capacity Vs All Ethanol Plants } \\
\hline & All Plants & Plants < 10 MM Gal & Plants > 10 MM Gal \\
\hline New Bern Capacity Vs Total Capacity & $2 \%$ & $54 \%$ & $2 \%$ \\
\hline New Bern Capacity Vs Average & $74 \%$ & $971 \%$ & $40 \%$ \\
\hline New Bern Capacity Vs Median & $280 \%$ & $1217 \%$ & $93 \%$ \\
\hline
\end{tabular}

\section{New Bern Ethanol Plant Marketing Model}

A New Bern Ethanol Plant Marketing Model was developed considering several factors including federal clean fuels requirements, present ethanol demand, estimated future demand, and transportation costs. The following describes how each of these areas was considered when building the ethanol marketing model.

\section{The New Bern Ethanol Plant Model Marketing Area}

New federal clean fuel requirements are intended to reduce, or limit, motor fuel combustion emissions of ozone and of carbon monoxide (CO) in "ozone non-attainment" and "CO non-attainment" areas of the United States. Federal regulations require fuel marketers to provide oxygenated, and/or, reformulated fuels in these regions [3]. Materials which can be added to gasoline formulations to meet the federal regulations include ethanol, MTBE, ETBE, and TAME, to name a few. 
Table 6-1: U.S. Fuel Ethanol Plants and Capacity [1]

\begin{tabular}{|c|c|c|c|c|}
\hline Company & City & State & Gal/Yr. & Rank \\
\hline Archer Daniels Midland & Decatur & Illinois & $330,000,000$ & 1 \\
\hline Archer Daniels Midland & Peoria & Illinois & $200,000,000$ & 2 \\
\hline Archer Daniels Midland & Cedar Rapids & Iowa & $170,000,000$ & 3 \\
\hline Archer Daniels Midland & Clinton & Iowa & $140,000,000$ & 4 \\
\hline Pekin Energy Company & Pekin & Illinois & $100,000,000$ & 5 \\
\hline New Energy Company of Indiana & South Bend & Indiana & $75,000,000$ & 6 \\
\hline South Point Ethanol & South Point & Ohio & $65,000,000$ & 7 \\
\hline A.E. Staley Manufacturing Co. & Loudon & Tennessee & $40,000,000$ & 8 \\
\hline Minnesota Corn Processors & Marshall & Minnesota & $32,000,000$ & 9 \\
\hline Cargill, Inc. & Eddyville & lowa & $30,000,000$ & 10 \\
\hline Minnesota Corn Processors & Columbus & Nebraska & $30,000,000$ & 11 \\
\hline Chief Ethanol Fueis, Inc. & Hastings & Nebraska & $28,500,000$ & 12 \\
\hline High Plains Corporation & Colwich & Kansas & $20,900,000$ & 13 \\
\hline The Hubinger Company & Keokuk & Iowa & $18,000,000$ & 14 \\
\hline Archer Daniels Midland & Walhalla & North Dakota & $16,000,000$ & 15 \\
\hline Alchem Limited & Grafton & North Dakota & $12,000,000$ & 16 \\
\hline Giant Refining, Inc. & Portales & New Mexico & $12,000,000$ & 17 \\
\hline Midwest Grain Products, Inc. & Pekin & Illinois & $12,000,000$ & 18 \\
\hline Grain Processing Corporation & Muscatine & Iowa & $10,000,000$ & 19 \\
\hline Reeve Agri Energy, Inc. & Garden City & Kansas & $7,500,000$ & 20 \\
\hline Manildra Energy, Inc. & Hamburg & Iowa & $6,000,000$ & 21 \\
\hline Midwest Grain Products, Inc. & Atchison & Kansas & $6,000,000$ & 22 \\
\hline Heartland Grain Fuels & Aberdeen & South Dakota & $5,000,000$ & 23 \\
\hline Morris Ag-Energy Co., Inc. & Morris & Minnesota & $4,500,000$ & 24 \\
\hline J.R. Simplot Co. & Caldwell & Idaho & $4,000,000$ & 25 \\
\hline Georgia Pacific Corp. & Bellingham & Washington & $3,500,000$ & 26 \\
\hline J.R. Simplot Co. & Burly & Idaho & $3,000,000$ & 27 \\
\hline Golden Cheese of California & Corona & California & $2,600,000$ & 28 \\
\hline Alcotech, Inc. & Ringling & Montana & $2,000,000$ & 29 \\
\hline Parallel Products & Cucamonga & California & $2,000,000$ & 30 \\
\hline Kraft, Inc. & Melrose & Minnesota & $1,200,000$ & 31 \\
\hline Minnesota Clean Fuels & Dundas & Minnesota & $1,200,000$ & 32 \\
\hline Broin Enterprises, Inc. & Scotland & South Dakota & $1,000,000$ & 33 \\
\hline Dairymen's Cooperative & Tulare & California & 700,000 & 34 \\
\hline Pabst Brewing Company & Olympia & Washington & 700,000 & 35 \\
\hline ESE Alcohol, Inc. & Leoti & Kansas & 500,000 & 36 \\
\hline Vienna Correctional Center & Vienna & Illinois & 500,000 & 37 \\
\hline \begin{tabular}{|c|} 
Total Ethanol Capacity \\
\end{tabular} & & & $1,393,300,000$ & \\
\hline
\end{tabular}


Table 6-4 below, lists the PAD-1 states, including the District of Columbia, and their "ozone non-attainment" and/or "CO non-attainment" designation. Also tabulated is which of the PAD-I states have regions requiring oxygenated, RFG (reformulated gasoline), and/or combination oxygenated/RFG fuels. The New Bern ethanol plant model marketing area includes only those states which have regions requiring oxygenated, RFG, and/or combination oxygenated/RFG fuels.

Oxygenated fuels are required to contain, on average, about 2.1 weight percent oxygen, while RFG fuels are required to contain, on average, about 2.7 weight percent oxygen [3]. The ethanol volume which can be blended into the finished gasoline/ethanol fuel product to meet the oxygen weight specification depends on several factors. By way of example, to attain a 2.1 weight percent oxygen specification, gasoline/ethanol blends may contain 5 to 7 volume percent ethanol. Likewise, to attain the 2.7 weight percent specification, blends may contain about 10 volume percent ethanol. Ethanol can be blended year-round in RFG and oxygenated gasolines. In CO nonattainment areas, oxygenated gasoline blends must be marketed during a designated (nominally winter) season.

Table 6-4: New Bern Ethanol Plant Model Market Area

\begin{tabular}{|l|c|c|c|c|c|c|}
\hline & Ozone & Co & \multicolumn{2}{c|}{$\begin{array}{c}\text { States Having Area Fuel } \\
\text { Requirements for }\end{array}$} & $\begin{array}{c}\text { New Bern } \\
\text { Model }\end{array}$ \\
\hline State & Nonattainment & Nonattainment & Oxygenated & RFG & Oxygenated/RFG & Market Area \\
\hline & & & & & & \\
\hline North Carolina & Opt-In & Yes & Yes & & & Yes \\
\hline Virginia & Yes & Yes & & Yes & & Yes \\
\hline $\begin{array}{l}\text { Dist. of } \\
\text { Columbia }\end{array}$ & Yes & Yes & & & Yes & Yes \\
\hline Maryland & Yes & Yes & & Yes & Yes & Yes \\
\hline Delaware & Yes & & & Yes & & Yes \\
\hline Pennsylvania & Yes & Yes & & Yes & Yes & Yes \\
\hline New Jersey & Yes & Yes & & Yes & Yes & Yes \\
\hline Connecticut & Yes & Yes & & Yes & Yes & Yes \\
\hline New York & Yes & Yes & Yes & Yes & Yes & Yes \\
\hline Massachusetts & Yes & & & Yes & Yes & Yes \\
\hline Rhode Island & Yes & & & Yes & & Yes \\
\hline New Hampshire & Yes & & & Yes & & Yes \\
\hline Maine & Yes & & & Yes & & Yes \\
\hline Vermont & Yes & & & Yes & & Yes \\
\hline West Virginia & Opt-ln & Yes & No & No & No & No \\
\hline Florida & Opt-In & & No & No & No & No \\
\hline Georgia & Opt-ln & & No & No & No & No \\
\hline South Carolina & Opt-ln & & No & No & No & No \\
\hline
\end{tabular}

\section{Model Market Area Fuel Demand}

Gasoline and gasoline/ethanol blend demand for the states in the New Bern Ethanol Plant marketing model are listed in Table 6-5, below. The listed data is for the year 1993, and it is taken from reference [1]. Included in the table is an estimate of the present ethanol demand, assuming the gasoline/ethanol blends are 10 volume percent ethanol. 
Table 6-5: Ethanol Plant Model Market Area Fuel Demand

\begin{tabular}{|l|r|r|r|r|}
\hline State & $\begin{array}{c}\text { Gasoline } \\
\mathbf{0 0 0} \text { gallons }\end{array}$ & $\begin{array}{c}\text { Gasoline/Ethanol Blends } \\
\mathbf{0 0 0} \text { gallons }\end{array}$ & $\begin{array}{c}\text { Estimated } \\
\text { Present Ethanol } \\
\text { 000 gallons }\end{array}$ & $\begin{array}{c}\text { Sensitivity: } \\
\text { Ethanol w/RFG } \\
\text { 000 gallons }\end{array}$ \\
\hline North Carolina & $3,371,311$ & 25,689 & 2,569 & 117,996 \\
\hline Virginia & $3,093,817$ & 155,691 & 15,569 & 108,284 \\
\hline Washington, DC & 176,379 & 10,000 & 1,000 & 6,173 \\
\hline Maryland & $2,126,585$ & 22,675 & 2,268 & 74,430 \\
\hline Delaware & 353,051 & 25,119 & 2,512 & 12,357 \\
\hline Pennsylvania & $4,701,894$ & 400,100 & 40,010 & 164,566 \\
\hline New Jersey & $3,369,892$ & 0 & 0 & 117,946 \\
\hline Connecticut & $1,411,172$ & 52,695 & 5,270 & 49,391 \\
\hline New York & $5,653,256$ & 461,198 & 46,120 & 197,864 \\
\hline Massachusetts & $2,413,073$ & 30,111 & 3,011 & 84,458 \\
\hline Rhode Island & 382,557 & 0 & 0 & 13,389 \\
\hline New Hampshire & 527,725 & 0 & 0 & 18,470 \\
\hline Maine & 612,500 & 8,000 & 800 & 21,438 \\
\hline Vermont & 299,543 & 400 & 40 & 10,484 \\
\hline \multicolumn{1}{|c|}{ Totals } & $28,492,755$ & $1,191,678$ & 119,169 & 997,246 \\
\hline
\end{tabular}

The estimated ethanol demand volume of $119,000,000$ gallons represents approximately 9 percent of the total United States ethanol production capacity. The importance of this ethanol demand figure is that it demonstrates that there is ethanol fuel blend marketing infrastructure across much of the model marketing area. Furthermore, the New Bern ethanol plant is sized to produce approximately $28,000,000$ gallons annually of fuel grade ethanol. This production figure is about 23 percent of the estimated present ethanol demand volume of $119,000,000$ gallons, indicating that ethanol produced at the New Bern plant likely can be readily absorbed in the model marketing area.

Also listed in the Table 6-5 is an estimate of the level of ethanol demand with RFG. This ethanol demand sensitivity assumes that approximately one-third of the total gasoline demand in the marketing area is RFG, and that RFG requirements are met exclusively with gasoline/ethanol blends. The purpose of this demand sensitivity is discussed in a later section dealing with New Bern ethanol market penetration.

\section{New Bern Ethanol Transportation Cost Model}

For each of the states listed in the New Bern ethanol plant model marketing area, a single city or region within the state was arbitrarily assigned as the "centroid" of the state's ethanol demand. The distance from the New Bern ethanol plant for each of these ethanol demand "centroids" is listed in Table 6, below. Also listed is the approximate railroad freight cost from New Bern to the demand "centroid." 
Table 6-6: New Bern Ethanol Transportation Cost Model

\begin{tabular}{|l|l|r|r|}
\hline State & \multicolumn{1}{|c|}{$\begin{array}{c}\text { Arbitrary } \\
\text { Demand Centroid }\end{array}$} & $\begin{array}{c}\text { Approximate Distance } \\
\text { from New Bern, miles }\end{array}$ & $\begin{array}{c}\text { Approximate Freight to } \\
\text { Market, Cents/gallon }\end{array}$ \\
\hline North Carolina & Raleigh/Durham & 129 & 0.031 \\
\hline Virginia & Richmond & 448 & 0.054 \\
\hline Washington, DC & Washington & 498 & 0.058 \\
\hline Maryland & Baltimore & 538 & 0.066 \\
\hline Delaware & Wilmington & 605 & 0.075 \\
\hline Pennsylvania & Philadelphia & 637 & 0.075 \\
\hline New Jersey & Trenton & 669 & 0.078 \\
\hline Connecticut & Hartford & 1,097 & 0.122 \\
\hline New York & New York & 1,103 & 0.122 \\
\hline Massachusetts & Boston & 1,169 & 0.125 \\
\hline Rhode Island & Providence & 1,171 & 0.128 \\
\hline New Hampshire & Portsmouth & 1,226 & 0.130 \\
\hline Maine & Portland & 1,276 & 0.135 \\
\hline Vermont & Montpelier & 1,293 & 0.137 \\
\hline
\end{tabular}

Railroad freight costs were determined using a transportation model which assumes the use of 30,000 gallon railroad tank cars [4]. The model includes both a tank car cost element and a mileage cost element. As Table 6-6 shows, ethanol freight costs across the model marketing area may range from approximately 3 to 14 cents per gallon of ethanol. Ethanol truck transportation costs can be examined in a future study.

The above three marketing area, ethanol demand, and transportation costs models are combined in Table 6-7, the New Bern Biomass to Ethanol Plant Marketing Model.

\section{New Bern Ethanol Plant Market Penetration}

Included in the New Bern Biomass to Ethanol Plant Marketing Model, Table 6-7, are three sensitivities of the New Bern plant's ethanol market penetration. The first market penetration sensitivity assumes ethanol at the plant will capture 100 percent market share up to a total of $28,000,000$ gallons, the plant's annual manufacturing output. At the present model marketing area ethanol demand level of $119,000,000$ gallons, the ethanol produced at the New Bern plant can meet 100 percent of the volumetric ethanol demand within 600 miles north of New Bern. The single largest supply volume meets the demand of the "centroid" designated as Richmond, Virginia, which is 450 miles north of New Bern. Freight costs in this demand scenario, range from 3 to 7 cents per gallon.

The second market penetration sensitivity assumes that ethanol produced at the New Bern plant will capture no more than 24 percent of the present ethanol demand. Under this scenario, ethanol is transported up to 1300 miles from New Bern. The bulk of the ethanol is marketed in the Richmond, Philadelphia, and New York "centroids". Freight costs for the bulk of the ethanol range from 3 to 12 cents per gallon. 
Table 6-7: New Bern Biomass to Ethanol Plant Marketing Model

\begin{tabular}{|c|c|c|c|c|c|c|c|c|c|c|c|c|}
\hline \multirow{4}{*}{ State } & \multicolumn{9}{|c|}{ New Bern Biomass to Ethanol Plant Market Model } & & & \\
\hline & \multirow{3}{*}{$\begin{array}{l}\text { Arbitrary } \\
\text { Demand Centroid }\end{array}$} & \multirow{3}{*}{$\begin{array}{c}\text { Approx. } \\
\text { Miles From } \\
\text { New Bern }\end{array}$} & \multirow{3}{*}{$\begin{array}{l}\text { Approx. } \\
\text { Freight to } \\
\text { Market }\end{array}$} & \multicolumn{9}{|c|}{000 Gallons / Year } \\
\hline & & & & \multicolumn{2}{|c|}{ Fuel Demand } & \multicolumn{4}{|c|}{ Ethanol Demand } & \multicolumn{3}{|c|}{$\begin{array}{l}\text { New Bern Ethanol } \\
\text { Market Penetration }\end{array}$} \\
\hline & & & & Gasoline & $\begin{array}{l}\text { Ethanol } \\
\text { Blends }\end{array}$ & $\begin{array}{c}\text { Estimated } \\
\text { Present }\end{array}$ & $\begin{array}{c}\text { Sensitivity } \\
\text { w/RFG }\end{array}$ & $\begin{array}{c}\text { at } 23.5 \% \\
\text { Present }\end{array}$ & $\begin{array}{l}\text { at } 5.0 \% \\
\text { w/RFG }\end{array}$ & $\begin{array}{c}100 \% \\
\text { Present }\end{array}$ & $\begin{array}{l}\text { 23.5\% } \\
\text { Present }\end{array}$ & $\begin{array}{c}5 . \overline{0 \%} \\
\text { w/RFG }\end{array}$ \\
\hline North Carolina & Raleigh/Durham & 129 & 0.031 & $3,371,3 \pi$ & 25,689 & 2,569 & Tा7,996 & 604 & 5,900 & 2,569 & 604 & 5,900 \\
\hline Virginia & Richmond & 448 & 0.054 & $3,093,817$ & 155,691 & 15,569 & 108,284 & 3,658 & 5,414 & 15,569 & 3,658 & 5,414 \\
\hline Dist. of Columbia & Washington & 498 & 0.058 & 176,379 & 10,000 & 1,000 & 6,173 & 235 & 309 & 1,000 & 235 & 309 \\
\hline Maryland & Baltimore & 538 & 0.066 & $2,126,585$ & 22,675 & 2,268 & 74,430 & 533 & 3,722 & 2,268 & 533 & 3,722 \\
\hline Delaware & Wilmington & 605 & 0.075 & 353,051 & 25,119 & 2,512 & 12,357 & 590 & 618 & 2,512 & 590 & 618 \\
\hline Pennsylvania & Philadelphia & 637 & 0.075 & $4,701,894$ & 400,100 & 40,010 & 164,566 & 9,401 & 8,228 & 4,083 & 9,401 & 8,228 \\
\hline New Jersey & Trenton & 669 & 0.078 & $3,369,892$ & 0 & 0 & 117,946 & 0 & 5,897 & 0 & 0 & 3,810 \\
\hline Connecticut & Hartford & 1097 & 0.122 & $1,411,172$ & 52,695 & 5,270 & 49,391 & 1,238 & 2,470 & 0 & 1,238 & 0 \\
\hline New York & New York & 1103 & 0.122 & $5,653,256$ & 461,198 & 46,120 & 197,864 & 10,836 & 9,893 & of & $.10,836$ & 0 \\
\hline Massachusetts & Boston & 1169 & 0.125 & $2,413,073$ & 30,111 & 3,011 & 84,458 & 707 & 4,223 & $\overline{0}$ & 707 & 0 \\
\hline Rhode Island & Providence & 1171 & 0.128 & 382,557 & 0 & 0 & 13,389 & 0 & 669 & 0 & 0 & 0 \\
\hline New Hampshire & Portsmouth & 7226 & 0.130 & 527,725 & 0 & 0 & 18,470 & 0 & 924 & 0 & 0 & 0 \\
\hline Maine & Portland & T276 & 0.135 & 612,500 & 8,000 & 800 & 21,438 & 188 & 1,072 & 0 & 188 & 0 \\
\hline Vermont & Montpelier & 1293 & 0.137 & 299,543 & 400 & 40 & 10,484 & 9 & 524 & 0 & 9 & 0 \\
\hline Totals & & & & $28,492,755$ & $1,191,678$ & 119,168 & 997,246 & 28,000 & 49,862 & 28,000 & 28,000 & 28,000 \\
\hline
\end{tabular}


The third market penetration sensitivity assumes ethanol is blended into all RFG fuels and that ethanol produced at the New Bern plant captures 5 percent of this market in each demand "centroid". Under this scenario, ethanol is transported up to 669 miles from New Bern. Freight costs range from 3 to 8 cents per gallon.

\section{Moving New Bern Ethanol to Market - General Approach}

\section{New Bern Ethanol Storage and Transport Rationale}

Ethanol storage at the New Bern facility is sized to accommodate approximately 10 day's ethanol production of about 750,000 gallons (18,000 barrels). This capacity level ensures there is sufficient tankage to accommodate periodic loading cycle delays [4]. It further ensures that loading delays will not cause a reduction in the plant's daily product output.

Rail is the likely method of ethanol transport [4]. The New Bern site has an existing rail spur which can be modified to accommodate the loading of two to three 30,000 gallon rail tank cars daily. Rail maps show two short lines serve the New Bern area. These tie into the CSX and Norfolk and Southern railroads, which in turn feed into Conrail and others further north along the East Coast. As discussed earlier, the ethanol marketing area assumed for this study now receives $119,000,000$ gallons, annually. Therefore, it can be assumed that there is sufficient rail transport and receiving infrastructure to move ethanol from the New Bern site to blending terminals. A more detailed infrastructure analysis is required, but it is beyond the scope of this study.

Although it is anticipated that most of the product ethanol will be freighted by rail, it is likely that small quantities will be supplied by truck to blending terminals within 100 miles of New Bern. Therefore, a truck loading rack is included in the plant's design. Because only a relatively.small portion of ethanol product is anticipated to move within 100 miles of New Bern, the transportation cost model discussed earlier is based solely on rail transport to the more distant receiving locations.

Weyerhaeuser's New Bern mill site has barge docking facilities which are presently used to receive fuel oil. However, given the complexity of determining which blending terminals can receive barge quantities of fuel ethanol, this transport option was not examined further in this study. Future studies can address this transport option more closely.

\section{Marketing Logistics}

Today, most fuel ethanol is blended into gasoline motor fuel by motor fuel marketers at their distribution terminals. This terminal blending technique ensures product quality of the gasoline/ethanol blends prior to their shipment to retail stations. Other than the very small quantities used as a denaturant, it is not necessary for a fuel ethanol producer to blend the ethanol with gasoline at the ethanol manufacturing site. Thus, to market fuel ethanol, it is necessary only to ship the ethanol from its manufacturing site to a gasoline blending and distribution terminal. The ethanol producer can ship the ethanol to the distribution terminal for sale on a delivered, or CIF, basis to the motor fuel distributor. Alternatively, the ethanol producer can sell the ethanol product at the manufacturing site, FOB, where it is loaded into distributorprovided tank cars.

Midwest-produced ethanol is marketed today in the same market the New Bern ethanol plant is envisioned to serve $[1,4]$. The implication is that there is an existing commercial distribution network in place, obviating the need to establish ethanol distribution infrastructure. 
For the scope of this study, it is assumed that contract sales and/or trades of ethanol from New Bern likely can be executed by existing, experienced industry oxygenate traders, perhaps through mutually agreeable service arrangements. An extensive listing of motor fuel oxygenate contacts appears in reference [2].

\section{Fuel Ethanol Market Price History -}

The degree of market penetration of ethanol produced at the New Bern site is largely one of economics. Competing products include ethanol produced from existing plants and other oxygenates such as MTBE, ETBE, and TAME.

A review of ethanol price history from 1992 through 1994 listed in Table 6-8 shows ethanol prices for selected markets ranging from a minimum of $\$ 0.94$ per gallon to a maximum of $\$ 1.45$ per gallon [6]. The average price in the sample was per gallon with a standard deviation of $\$ 0.09$ per gallon. A detailed listing of the fuel ethanol prices for these selected markets is shown in Tables 6-9, 6-10, and 6-11, for 1992,1993 , and 1994, respectively.

Table 6-8: Summary of Selected Historical Fuel Ethanol Prices (1992 - 1994)

\begin{tabular}{|l|c|c|c|c|c|c|c|}
\hline & Richmond, VA & Pekin, II & $\begin{array}{c}\text { Indianapolis, } \\
\mathbf{I N}\end{array}$ & $\begin{array}{c}\text { Upstate, } \\
\mathbf{N Y}\end{array}$ & $\begin{array}{c}\text { South Point, } \\
\mathbf{O H}\end{array}$ & $\begin{array}{c}\text { Nashville, } \\
\text { TN }\end{array}$ & Sample \\
\hline Average & $\$ 1.18$ & $\$ 1.17$ & $\$ 1.14$ & $\$ 1.20$ & $\$ 1.19$ & $\$ 1.16$ & $\$ 1.17$ \\
\hline Maximum & $\$ 1.38$ & $\$ 1.38$ & $\$ 1.35$ & $\$ 1.45$ & $\$ 1.40$ & $\$ 1.38$ & $\$ 1.45$ \\
\hline Minimum & $\$ 1.00$ & $\$ 0.97$ & $\$ 0.94$ & $\$ 1.00$ & $\$ 1.03$ & $\$ 0.96$ & $\$ 0.94$ \\
\hline Std Dev & $\$ 0.08$ & $\$ 0.09$ & $\$ 0.09$ & $\$ 0.09$ & $\$ 0.09$ & $\$ 0.09$ & $\$ 0.09$ \\
\hline Median & $\$ 1.18$ & $\$ 1.16$ & $\$ 1.13$ & $\$ 1.19$ & $\$ 1.16$ & $\$ 1.15$ & $\$ 1.16$ \\
\hline Mode & $\$ 1.12$ & $\$ 1.15$ & $\$ 1.13$ & $\$ 1.15$ & $\$ 1.15$ & $\$ 1.15$ & $\$ 1.15$ \\
\hline
\end{tabular}

Fuel ethanol produced at the New Bern facility likely will sell into the market at these price levels, adjusted for transport costs. The low price in the range likely is representative of the cash costs for competing conventional ethanol plants. Likewise, the high price in the range likely is representative of the "switching" price, or the price at which consumers switch to oxygenate alternatives. To the extent that ethanol did not capture 100 percent of the oxygenate requirements of the selected markets, the selected ethanol price history likely reflects the price of competing oxygenates.

\section{Ethanol Credits}

The historical market prices quoted here do not include the federal fuel ethanol credit because this credit accrues to the ethanol blender, not the ethanol manufacturer. Blenders purchasing ethanol produced at the New Bern facility would be eligible for the federal credit [4].

The state of North Carolina provides for a income tax credit up to 30 percent of the fuel ethanol plant's cost [5]. This credit consists of two components. The first is a tax credit up to 20 percent of the plant's installation and construction costs. The second component provides an additional 10 percent tax credit for the construction of new fuel ethanol plants using forestry products as feedstocks. The value of these credits on ethanol production cost is discussed in Section 4. 


\subsection{New Bern BGCC Plant Ownership Options}

The technical and economic assessments which have been performed for the New Bern BGCC plant have confirmed that the technology has the potential to improve the efficiencies of both forest and plant operations. Although there are projected economic gains from the use of BGCC, it is apparent that special consideration must be given to identifying the most effective plant design and site to assure that the technology is demonstrated in a manner that will achieve its promise with acceptable economic risk. While the New Bern mill offers an excellent site to achieve the technical objectives, market and other business considerations in the New Bern area dictate that ownership arrangements must be reviewed to establish a risk management plan which supports the BGCC commercialization effort with acceptable risk. 
Table 6-9: 1992 Ethanol Prices for Selected Markets [6]

\begin{tabular}{|c|c|c|c|c|c|c|}
\hline DATE & Richmond, VA & Pekin, IL & Indianapolis, IN & Upstate, NY & South Point, OH & Nashville, TN \\
\hline $1 / 6 / 92$ & $\$ 1.13$ & $\$ 1.16$ & $\$ 1.13$ & $\$ 1.15$ & $\$ 1.15$ & $\$ 1.15$ \\
\hline $1 / 13 / 92$ & $\$ 1.16$ & $\$ 1.15$ & $\$ 1.12$ & $\$ 1.14$ & $\$ 1.13$ & $\$ 1.14$ \\
\hline $1 / 20 / 92$ & $\$ 1.15$ & $\$ 1.13$ & $\$ 1.11$ & $\$ 1.12$ & $\$ 1.11$ & $\$ 1.13$ \\
\hline $1 / 27 / 92$ & $\$ 1.17$ & $\$ 1.15$ & $\$ 1.15$ & $\$ 1.14$ & $\$ 1.13$ & $\$ 1.15$ \\
\hline $2 / 3 / 92$ & $\$ 1.17$ & $\$ 1.15$ & $\$ 1.13$ & $\$ 1.13$ & $\$ 1.14$ & $\$ 1.12$ \\
\hline $2 / 10 / 92$ & $\$ 1.16$ & $\$ 1.14$ & $\$ 1.11$ & $\$ 1.13$ & $\$ 1.15$ & $\$ 1.11$ \\
\hline $2 / 17 / 92$ & $\$ 1.21$ & $\$ 1.18$ & $\$ 1.15$ & $\$ 1.16$ & $\$ 1.19$ & $\$ 1.15$ \\
\hline $2 / 24 / 92$ & $\$ 1.18$ & $\$ 1.16$ & $\$ 1.13$ & $\$ 1.15$ & $\$ 1.17$ & $\$ 1.13$ \\
\hline $3 / 2 / 92$ & $\$ 1.19$ & $\$ 1.16$ & $\$ 1.12$ & $\$ 1.18$ & $\$ 1.19$ & $\$ 1.14$ \\
\hline $3 / 9 / 92$ & $\$ 1.19$ & $\$ 1.16$ & $\$ 1.13$ & $\$ 1.20$ & $\$ 1.22$ & $\$ 1.14$ \\
\hline $3 / 16 / 92$ & $\$ 1.18$ & $\$ 1.15$ & $\$ 1.12$ & $\$ 1.19$ & $\$ 1.22$ & $\$ 1.14$ \\
\hline $3 / 23 / 92$ & $\$ 1.19$ & $\$ 1.17$ & $\$ 1.13$ & $\$ 1.19$ & $\$ 1.23$ & $\$ 1.16$ \\
\hline $3 / 30 / 92$ & $\$ 1.19$ & $\$ 1.17$ & $\$ 1.13$ & $\$ 1.20$ & $\$ 1.23$ & $\$ 1.17$ \\
\hline $4 / 6 / 92$ & $\$ 1.22$ & $\$ 1.21$ & $\$ 1.18$ & $\$ 1.22$ & $\$ 1.26$ & $\$ 1.21$ \\
\hline $4 / 13 / 92$ & $\$ 1.21$ & $\$ 1.21$ & $\$ 1.18$ & $\$ 1.21$ & $\$ 1.27$ & $\$ 1.21$ \\
\hline $4 / 20 / 92$ & $\$ 1.22$ & $\$ 1.21$ & $\$ 1.19$ & $\$ 1.21$ & $\$ 1.28$ & $\$ 1.21$ \\
\hline $4 / 27 / 92$ & $\$ 1.23$ & $\$ 1.23$ & $\$ 1.20$ & $\$ 1.22$ & $\$ 1.30$ & $\$ 1.22$ \\
\hline $5 / 4 / 92$ & $\$ 1.23$ & $\$ 1.24$ & $\$ 1.20$ & $\$ 1.22$ & $\$ 1.30$ & $\$ 1.22$ \\
\hline $5 / 11 / 92$ & $\$ 1.23$ & $\$ 1.24$ & $\$ 1.20$ & $\$ 1.22$ & $\$ 1.30$ & $\$ 1.22$ \\
\hline $5 / 18 / 92$ & $\$ 1.25$ & $\$ 1.26$ & $\$ 1.22$ & $\$ 1.24$ & $\$ 1.34$ & $\$ 1.23$ \\
\hline $5 / 25 / 92$ & $\$ 1.25$ & $\$ 1.26$ & $\$ 1.23$ & $\$ 1.26$ & $\$ 1.35$ & $\$ 1.23$ \\
\hline $6 / 1 / 92$ & $\$ 1.25$ & $\$ 1.26$ & $\$ 1.23$ & $\$ 1.26$ & $\$ 1.35$ & $\$ 1.23$ \\
\hline $6 / 8 / 92$ & $\$ 1.26$ & $\$ 1.26$ & $\$ 1.24$ & $\$ 1.27$ & $\$ 1.37$ & $\$ 1.24$ \\
\hline $6 / 15 / 92$ & $\$ 1.25$ & $\$ 1.26$ & $\$ 1.24$ & $\$ 1.27$ & $\$ 1.35$ & $\$ 1.24$ \\
\hline $6 / 22 / 92$ & $\$ 1.25$ & $\$ 1.25$ & $\$ 1.23$ & $\$ 1.26$ & $\$ 1.34$ & $\$ 1.24$ \\
\hline $6 / 29 / 92$ & $\$ 1.25$ & $\$ 1.25$ & $\$ 1.23$ & $\$ 1.26$ & $\$ 1.34$ & $\$ 1.24$ \\
\hline $7 / 6 / 92$ & $\$ 1.24$ & $\$ 1.25$ & $\$ 1.21$ & $\$ 1.25$ & $\$ 1.32$ & $\$ 1.22$ \\
\hline $7 / 13 / 92$ & $\$ 1.24$ & $\$ 1.25$ & $\$ 1.21$ & $\$ 1.25$ & $\$ 1.32$ & $\$ 1.22$ \\
\hline $7 / 20 / 92$ & $\$ 1.25$ & $\$ 1.27$ & $\$ 1.24$ & $\$ 1.27$ & $\$ 1.32$ & $\$ 1.26$ \\
\hline $7 / 27 / 92$ & $\$ 1.29$ & $\$ 1.29$ & $\$ 1.27$ & $\$ 1.30$ & $\$ 1.34$ & $\$ 1.28$ \\
\hline $8 / 3 / 92$ & $\$ 1.31$ & $\$ 1.30$ & $\$ 1.28$ & $\$ 1.32$ & $\$ 1.35$ & $\$ 1.29$ \\
\hline $8 / 10 / 92$ & $\$ 1.31$ & $\$ 1.30$ & $\$ 1.26$ & $\$ 1.31$ & $\$ 1.35$ & $\$ 1.29$ \\
\hline $8 / 17 / 92$ & $\$ 1.31$ & $\$ 1.30$ & $\$ 1.26$ & $\$ 1.31$ & $\$ 1.35$ & $\$ 1.29$ \\
\hline $8 / 24 / 92$ & $\$ 1.31$ & $\$ 1.31$ & $\$ 1.28$ & $\$ 1.32$ & $\$ 1.35$ & $\$ 1.30$ \\
\hline $8 / 31 / 92$ & $\$ 1.31$ & $\$ 1.31$ & $\$ 1.28$ & $\$ 1.32$ & $\$ 1.35$ & $\$ 1.30$ \\
\hline $9 / 7 / 92$ & $\$ 1.32$ & $\$ 1.32$ & $\$ 1.29$ & $\$ 1.33$ & $\$ 1.35$ & $\$ 1.31$ \\
\hline $9 / 14 / 92$ & $\$ 1.32$ & $\$ 1.32$ & $\$ 1.29$ & $\$ 1.33$ & $\$ 1.35$ & $\$ 1.30$ \\
\hline $9 / 21 / 92$ & $\$ 1.31$ & $\$ 1.32$ & $\$ 1.29$ & $\$ 1.33$ & $\$ 1.34$ & $\$ 1.30$ \\
\hline $9 / 28 / 92$ & $\$ 1.33$ & $\$ 1.32$ & $\$ 1.30$ & $\$ 1.34$ & $\$ 1.34$ & $\$ 1.31$ \\
\hline $10 / 5 / 92$ & $\$ 1.33$ & $\$ 1.32$ & $\$ 1.30$ & $\$ 1.34$ & $\$ 1.34$ & $\$ 1.31$ \\
\hline $10 / 12 / 92$ & $\$ 1.33$ & $\$ 1.34$ & $\$ 1.31$ & $\$ 1.36$ & $\$ 1.35$ & $\$ 1.32$ \\
\hline $10 / 19 / 92$ & $\$ 1.35$ & $\$ 1.35$ & $\$ 1.33$ & $\$ 1.38$ & $\$ 1.35$ & $\$ 1.34$ \\
\hline $10 / 26 / 92$ & $\$ 1.36$ & $\$ 1.37$ & $\$ 1.34$ & $\$ 1.40$ & $\$ 1.35$ & $\$ 1.35$ \\
\hline $11 / 2 / 92$ & $\$ 1.38$ & $\$ 1.38$ & $\$ 1.35$ & $\$ 1.45$ & $\$ 1.40$ & $\$ 1.38$ \\
\hline $11 / 9 / 92$ & $\$ 1.38$ & $\$ 1.38$ & $\$ 1.35$ & $\$ 1.45$ & $\$ 1.40$ & $\$ 1.38$ \\
\hline $11 / 16 / 92$ & $\$ 1.32$ & $\$ 1.31$ & $\$ 1.28$ & $\$ 1.38$ & $\$ 1.29$ & $\$ 1.29$ \\
\hline $11 / 23 / 92$ & $\$ 1.32$ & $\$ 1.31$ & $\$ 1.28$ & $\$ 1.37$ & $\$ 1.29$ & $\$ 1.29$ \\
\hline $11 / 30 / 92$ & $\$ 1.26$ & $\$ 1.28$ & $\$ 1.26$ & $\$ 1.35$ & $\$ 1.25$ & $\$ 1.26$ \\
\hline
\end{tabular}




\begin{tabular}{|c|c|c|c|c|c|c|}
\hline DATE & Richmond, VA & Pekin, II & Indianapolis, IN & Upstate, NY & South Point, OH & Nashville, TN \\
\hline $12 / 7 / 92$ & $\$ 1.30$ & $\$ 1.25$ & $\$ 1.25$ & $\$ 1.34$ & $\$ 1.24$ & $\$ 1.23$ \\
\hline $12 / 14 / 92$ & $\$ 1.28$ & $\$ 1.23$ & $\$ 1.28$ & $\$ 1.31$ & $\$ 1.16$ & $\$ 1.21$ \\
\hline $12 / 21 / 92$ & $\$ 1.28$ & $\$ 1.22$ & $\$ 1.27$ & $\$ 1.31$ & $\$ 1.16$ & $\$ 1.20$ \\
\hline $12 / 28 / 92$ & $\$ 1.27$ & $\$ 1.22$ & $\$ 1.23$ & $\$ 1.30$ & $\$ 1.16$ & $\$ 1.20$ \\
\hline
\end{tabular}


Table 6-10: 1993 Ethanol Prices for Selected Markets [6]

\begin{tabular}{|c|c|c|c|c|c|c|}
\hline DATE & Richmond, VA & Pekin, $\mathbf{I}$ & Indianapolis, IN & Upstate, NY & South Point, $\mathrm{OH}$ & Nashville, TN \\
\hline $1 / 11 / 93$ & $\$ 1.21$ & $\$ 1.19$ & $\$ 1.17$ & $\$ 1.26$ & $\$ 1.14$ & $\$ 1.17$ \\
\hline $1 / 18 / 93$ & $\$ 1.18$ & $\$ 1.17$ & $\$ 1.15$ & $\$ 1.24$ & $\$ 1.13$ & $\$ 1.15$ \\
\hline $1 / 25 / 93$ & $\$ 1.16$ & $\$ 1.15$ & $\$ 1.13$ & $\$ 1.22$ & $\$ 1.13$ & $\$ 1.14$ \\
\hline $2 / 1 / 93$ & $\$ 1.15$ & $\$ 1.13$ & $\$ 1.12$ & $\$ 1.21$ & $\$ 1.12$ & $\$ 1.12$ \\
\hline $2 / 8 / 93$ & $\$ 1.15$ & $\$ 1.13$ & $\$ 1.12$ & $\$ 1.22$ & $\$ 1.16$ & $\$ 1.14$ \\
\hline $2 / 15 / 93$ & $\$ 1.15$ & $\$ 1.13$ & $\$ 1.12$ & $\$ 1.21$ & $\$ 1.15$ & $\$ 1.14$ \\
\hline $2 / 22 / 93$ & $\$ 1.14$ & $\$ 1.13$ & $\$ 1.10$ & $\$ 1.19$ & $\$ 1.09$ & $\$ 1.13$ \\
\hline $3 / 1 / 93$ & $\$ 1.13$ & $\$ 1.11$ & $\$ 1.08$ & $\$ 1.16$ & $\$ 1.09$ & $\$ 1.11$ \\
\hline $3 / 8 / 93$ & $\$ 1.12$ & $\$ 1.10$ & $\$ 1.07$ & $\$ 1.15$ & $\$ 1.09$ & $\$ 1.10$ \\
\hline $3 / 15 / 93$ & $\$ 1.16$ & $\$ 1.14$ & $\$ 1.10$ & $\$ 1.17$ & $\$ 1.16$ & $\$ 1.12$ \\
\hline $3 / 22 / 93$ & $\$ 1.16$ & $\$ 1.15$ & $\$ 1.11$ & $\$ 1.18$ & $\$ 1.16$ & $\$ 1.13$ \\
\hline $3 / 29 / 93$ & $\$ 1.16$ & $\$ 1.13$ & $\$ 1.08$ & $\$ 1.16$ & $\$ 1.13$ & $\$ 1.11$ \\
\hline $4 / 5 / 93$ & $\$ 1.17$ & $\$ 1.14$ & $\$ 1.09$ & $\$ 1.18$ & $\$ 1.14$ & $\$ 1.13$ \\
\hline $4 / 12 / 93$ & $\$ 1.15$ & $\$ 1.13$ & $\$ 1.09$ & $\$ 1.16$ & $\$ 1.13$ & $\$ 1.12$ \\
\hline $4 / 19 / 93$ & $\$ 1.17$ & $\$ 1.14$ & $\$ 1.11$ & $\$ 1.17$ & $\$ 1.14$ & $\$ 1.15$ \\
\hline $4 / 26 / 93$ & $\$ 1.18$ & $\$ 1.15$ & $\$ 1.12$ & $\$ 1.17$ & $\$ 1.14$ & $\$ 1.15$ \\
\hline $5 / 3 / 93$ & $\$ 1.20$ & $\$ 1.16$ & $\$ 1.13$ & $\$ 1.19$ & $\$ 1.16$ & $\$ 1.16$ \\
\hline $5 / 10 / 93$ & $\$ 1.21$ & $\$ 1.17$ & $\$ 1.14$ & $\$ 1.21$ & $\$ 1.16$ & $\$ 1.16$ \\
\hline $5 / 17 / 93$ & $\$ 1.21$ & $\$ 1.17$ & $\$ 1.14$ & $\$ 1.22$ & $\$ 1.19$ & $\$ 1.16$ \\
\hline $5 / 24 / 93$ & $\$ 1.22$ & $\$ 1.17$ & $\$ 1.15$ & $\$ 1.23$ & $\$ 1.19$ & $\$ 1.16$ \\
\hline $5 / 31 / 93$ & $\$ 1.22$ & $\$ 1.17$ & $\$ 1.15$ & $\$ 1.23$ & $\$ 1.19$ & $\$ 1.16$ \\
\hline $6 / 7 / 93$ & $\$ 1.22$ & $\$ 1.18$ & $\$ 1.15$ & $\$ 1.24$ & $\$ 1.19$ & $\$ 1.16$ \\
\hline $6 / 14 / 93$ & $\$ 1.22$ & $\$ 1.17$ & $\$ 1.14$ & $\$ 1.25$ & $\$ 1.18$ & $\$ 1.16$ \\
\hline $6 / 21 / 93$ & $\$ 1.21$ & $\$ 1.16$ & $\$ 1.13$ & $\$ 1.20$ & $\$ 1.16$ & $\$ 1.14$ \\
\hline $7 / 12 / 93$ & $\$ 1.15$ & $\$ 1.16$ & $\$ 1.08$ & $\$ 1.14$ & $\$ 1.10$ & $\$ 1.09$ \\
\hline $7 / 19 / 93$ & $\$ 1.13$ & $\$ 1.14$ & $\$ 1.05$ & $\$ 1.14$ & $\$ 1.07$ & $\$ 1.08$ \\
\hline $7 / 26 / 93$ & $\$ 1.12$ & $\$ 1.13$ & $\$ 1.05$ & $\$ 1.14$ & $\$ 1.06$ & $\$ 1.08$ \\
\hline $8 / 2 / 93$ & $\$ 1.10$ & $\$ 1.10$ & $\$ 1.04$ & $\$ 1.12$ & $\$ 1.05$ & $\$ 1.06$ \\
\hline $8 / 9 / 93$ & $\$ 1.10$ & $\$ 1.10$ & $\$ 1.04$ & $\$ 1.12$ & $\$ 1.05$ & $\$ 1.06$ \\
\hline $8 / 16 / 93$ & $\$ 1.12$ & $\$ 1.09$ & $\$ 1.07$ & $\$ 1.14$ & $\$ 1.09$ & $\$ 1.07$ \\
\hline $8 / 23 / 93$ & $\$ 1.12$ & $\$ 1.09$ & $\$ 1.08$ & $\$ 1.14$ & $\$ 1.10$ & $\$ 1.08$ \\
\hline $8 / 30 / 93$ & $\$ 1.13$ & $\$ 1.09$ & $\$ 1.09$ & $\$ 1.15$ & $\$ 1.11$ & $\$ 1.10$ \\
\hline $9 / 6 / 93$ & $\$ 1.13$ & $\$ 1.09$ & $\$ 1.09$ & $\$ 1.15$ & $\$ 1.11$ & $\$ 1.10$ \\
\hline 9/13/93 & $\$ 1.11$ & $\$ 1.07$ & $\$ 1.07$ & $\$ 1.14$ & $\$ 1.09$ & $\$ 1.08$ \\
\hline 9/20/93 & $\$ 1.10$ & $\$ 1.07$ & $\$ 1.05$ & $\$ 1.11$ & $\$ 1.08$ & $\$ 1.07$ \\
\hline $9 / 27 / 93$ & $\$ 1.10$ & $\$ 1.07$ & $\$ 1.05$ & $\$ 1.10$ & $\$ 1.08$ & $\$ 1.07$ \\
\hline $10 / 4 / 93$ & $\$ 1.10$ & $\$ 1.07$ & $\$ 1.06$ & $\$ 1.12$ & $\$ 1.08$ & $\$ 1.07$ \\
\hline $10 / 11 / 93$ & $\$ 1.12$ & $\$ 1.09$ & $\$ 1.08$ & $\$ 1.14$ & $\$ 1.11$ & $\$ 1.09$ \\
\hline $10 / 18 / 93$ & $\$ 1.12$ & $\$ 1.10$ & $\$ 1.08$ & $\$ 1.14$ & $\$ 1.12$ & $\$ 1.09$ \\
\hline $10 / 25 / 93$ & $\$ 1.05$ & $\$ 1.09$ & $\$ 1.06$ & $\$ 1.13$ & $\$ 1.08$ & $\$ 1.07$ \\
\hline $11 / 1 / 93$ & $\$ 1.08$ & $\$ 1.08$ & $\$ 1.06$ & $\$ 1.11$ & $\$ 1.05$ & $\$ 1.05$ \\
\hline $11 / 8 / 93$ & $\$ 1.07$ & $\$ 1.07$ & $\$ 1.05$ & $\$ 1.10$ & $\$ 1.04$ & $\$ 1.04$ \\
\hline
\end{tabular}




\begin{tabular}{|c|c|c|c|c|c|c|}
\hline DATE & Richmond, VA & Pekin, IL & Indianapolis, IN & Upstate, NY & South Point, OH & Nashville, TN \\
\hline $11 / 15 / 93$ & $\$ 1.05$ & $\$ 1.04$ & $\$ 1.03$ & $\$ 1.08$ & $\$ 1.03$ & $\$ 1.03$ \\
\hline $11 / 22 / 93$ & $\$ 1.05$ & $\$ 1.03$ & $\$ 1.01$ & $\$ 1.05$ & $\$ 1.03$ & $\$ 1.03$ \\
\hline $11 / 29 / 93$ & $\$ 1.05$ & $\$ 1.02$ & $\$ 0.99$ & $\$ 1.05$ & $\$ 1.03$ & $\$ 1.03$ \\
\hline $12 / 6 / 93$ & $\$ 1.05$ & $\$ 1.02$ & $\$ 0.98$ & $\$ 1.04$ & $\$ 1.12$ & $\$ 1.02$ \\
\hline $12 / 13 / 93$ & $\$ 1.01$ & $\$ 1.00$ & $\$ 0.96$ & $\$ 1.01$ & $\$ 1.15$ & $\$ 0.98$ \\
\hline $12 / 20 / 93$ & $\$ 1.00$ & $\$ 0.97$ & $\$ 0.94$ & $\$ 1.00$ & $\$ 1.13$ & $\$ 0.96$ \\
\hline $12 / 27 / 93$ & $\$ 1.00$ & $\$ 0.97$ & $\$ 0.94$ & $\$ 1.00$ & $\$ 1.13$ & $\$ 0.96$ \\
\hline
\end{tabular}


Table 6-11: 1994 Ethanol Prices for Selected Markets [6]

\begin{tabular}{|c|c|c|c|c|c|c|}
\hline DATE & Richmond, VA & Pekin, IL & Indianapolis, IN & Upstate, NY & South Point, OH & Nashville, TN \\
\hline $1 / 10 / 94$ & $\$ 1.00$ & $\$ 0.98$ & $\$ 0.96$ & $\$ 1.04$ & $\$ 1.15$ & $\$ 0.99$ \\
\hline $1 / 24 / 94$ & $\$ 1.05$ & $\$ 1.04$ & $\$ 1.01$ & $\$ 1.08$ & $\$ 1.15$ & $\$ 1.03$ \\
\hline $1 / 31 / 94$ & $\$ 1.07$ & $\$ 1.07$ & $\$ 1.03$ & $\$ 1.11$ & $\$ 1.05$ & $\$ 1.04$ \\
\hline $2 / 7 / 94$ & $\$ 1.12$ & $\$ 1.12$ & $\$ 1.09$ & $\$ 1.14$ & $\$ 1.15$ & $\$ 1.09$ \\
\hline $2 / 14 / 94$ & $\$ 1.12$ & $\$ 1.12$ & $\$ 1.08$ & $\$ 1.14$ & $\$ 1.14$ & $\$ 1.09$ \\
\hline $2 / 21 / 94$ & $\$ 1.13$ & $\$ 1.12$ & & $\$ 1.15$ & $\$ 1.15$ & $\$ 1.10$ \\
\hline $2 / 28 / 94$ & $\$ 1.13$ & $\$ 1.12$ & $\$ 1.10$ & $\$ 1.15$ & $\$ 1.15$ & $\$ 1.10$ \\
\hline $3 / 7 / 94$ & $\$ 1.13$ & $\$ 1.11$ & $\$ 1.09$ & $\$ 1.15$ & $\$ 1.15$ & $\$ 1.09$ \\
\hline $3 / 14 / 94$ & $\$ 1.10$ & $\$ 1.10$ & $\$ 1.06$ & $\$ 1.12$ & $\$ 1.13$ & $\$ 1.07$ \\
\hline $3 / 21 / 94$ & $\$ 1.11$ & $\$ 1.10$ & $\$ 1.06$ & $\$ 1.13$ & $\$ 1.14$ & $\$ 1.08$ \\
\hline $3 / 28 / 94$ & $\$ 1.12$ & $\$ 1.09$ & $\$ 1.06$ & $\$ 1.13$ & $\$ 1.14$ & $\$ 1.08$ \\
\hline $4 / 4 / 94$ & $\$ 1.11$ & $\$ 1.09$ & $\$ 1.06$ & $\$ 1.12$ & $\$ 1.14$ & $\$ 1.07$ \\
\hline $4 / 11 / 94$ & $\$ 1.11$ & $\$ 1.10$ & $\$ 1.07$ & $\$ 1.13$ & $\$ 1.15$ & $\$ 1.08$ \\
\hline $4 / 18 / 94$ & $\$ 1.10$ & $\$ 1.09$ & $\$ 1.06$ & $\$ 1.11$ & $\$ 1.15$ & $\$ 1.07$ \\
\hline $4 / 25 / 94$ & $\$ 1.09$ & $\$ 1.08$ & $\$ 1.05$ & $\$ 1.11$ & $\$ 1.15$ & $\$ 1.06$ \\
\hline $5 / 2 / 94$ & $\$ 1.09$ & $\$ 1.10$ & $\$ 1.06$ & $\$ 1.13$ & $\$ 1.15$ & $\$ 1.07$ \\
\hline $5 / 9794$ & $\$ 1.09$ & $\$ 1.11$ & $\$ 1.06$ & $\$ 1.15$ & $\$ 1.15$ & $\$ 1.07$ \\
\hline $5 / 16 / 94$ & $\$ 1.10$ & $\$ 1.11$ & $\$ 1.07$ & $\$ 1.15$ & $\$ 1.15$ & $\$ 1.08$ \\
\hline $5 / 23 / 94$ & $\$ 1.12$ & $\$ 1.11$ & $\$ 1.08$ & $\$ 1.15$ & $\$ 1.15$ & $\$ 1.09$ \\
\hline $5 / 30 / 94$ & $\$ 1.14$ & $\$ 1.12$ & $\$ 1.09$ & $\$ 1.15$ & $\$ 1.11$ & $\$ 1.11$ \\
\hline $6 / 6 / 94$ & $\$ 1.16$ & $\$ 1.13$ & $\$ 1.13$ & $\$ 1.16$ & $\$ 1.15$ & $\$ 1.12$ \\
\hline $6 / 13 / 94$ & $\$ 1.15$ & $\$ 1.12$ & $\$ 1.10$ & $\$ 1.15$ & $\$ 1.15$ & $\$ 1.12$ \\
\hline $6 / 20 / 94$ & $\$ 1.17$ & $\$ 1.15$ & $\$ 1.12$ & $\$ 1.15$ & $\$ 1.15$ & $\$ 1.13$ \\
\hline $6 / 27 / 94$ & $\$ 1.17$ & $\$ 1.15$ & $\$ 1.12$ & $5: \overline{5}$ & $\$ 1.15$ & $\$ 1.13$ \\
\hline $7 / 4 / 94$ & $\$ 1.18$ & $\$ 1.16$ & $\$ 1.13$ & $\$ 1.16$ & $\$ 1.18$ & $\$ 1.15$ \\
\hline $7 / 11 / 94$ & $\$ 1.18$ & $\$ 1.16$ & $\$ 1.13$ & $\$ 1.16$ & $\$ 1.18$ & $\$ 1.15$ \\
\hline $7 / 18 / 94$ & $\$ 1.20$ & $\$ 1.18$ & $\$ 1.15$ & $\$ 1.20$ & $\$ 1.21$ & $\$ 1.17$ \\
\hline $7 / 25 / 94$ & $\$ 1.20$ & $\$ 1.20$ & $\$ 1.16$ & $\$ 1.21$ & $\$ 1.22$ & $\$ 1.18$ \\
\hline $8 / 1 / 94$ & $\$ 1.21$ & $\$ 1.22$ & $\$ 1.18$ & $\$ 1.22$ & $\$ 1.24$ & $\$ 1.19$ \\
\hline $8 / 8 / 94$ & $\$ 1.25$ & $\$ 1.25$ & $\$ 1.20$ & $\$ 1.25$ & $\$ 1.26$ & $\$ 1.22$ \\
\hline $8 / 15 / 94$ & $\$ 1.26$ & $\$ 1.25$ & $\$ 1.21$ & $\$ 1.25$ & $\$ 1.26$ & $\$ 1.22$ \\
\hline $8 / 22 / 94$ & $\$ 1.23$ & $\$ 1.23$ & $\$ 1.19$ & $\$ 1.25$ & $\$ 1.26$ & $\$ 1.20$ \\
\hline $8 / 29 / 94$ & $\$ 1.20$ & $\$ 1.20$ & $\$ 1.15$ & $\$ 1.22$ & $\$ 1.22$ & $\$ 1.16$ \\
\hline $9 / 12 / 94$ & $\$ 1.23$ & $\$ 1.22$ & $\$ 1.19$ & $\$ 1.25$ & $\$ 1.25$ & $\$ 1.20$ \\
\hline $9 / 19 / 94$ & $\$ 1.20$ & $\$ 1.20$ & $\$ 1.15$ & $\$ 1.25$ & $\$ 1.25$ & $\$ 1.18$ \\
\hline $9 / 26 / 94$ & $\$ 1.20$ & $\$ 1.21$ & $\$ 1.15$ & $\$ 1.25$ & $\$ 1.25$ & $\$ 1.18$ \\
\hline $10 / 3 / 94$ & $\$ 1.18$ & $\$ 1.17$ & $\$ 1.11$ & $\$ 1.25$ & $\$ 1.22$ & $\$ 1.15$ \\
\hline $10 / 10 / 94$ & $\$ 1.17$ & $\$ 1.15$ & $\$ 1.09$ & $\$ 1.25$ & $\$ 1.23$ & $\$ 1.15$ \\
\hline $10 / 17 / 94$ & $\$ 1.20$ & $\$ 1.18$ & $\$ 1.11$ & $\$ 1.30$ & $\$ 1.24$ & $\$ 1.18$ \\
\hline $10 / 24 / 94$ & $\$ 1.21$ & $\$ 1.19$ & $\$ 1.11$ & $\$ 1.30$ & $\$ 1.25$ & $\$ 1.18$ \\
\hline $10 / 31 / 94$ & $\$ 1.22$ & $\$ 1.20$ & $\$ 1.12$ & $\$ 1.30$ & $\$ 1.26$ & $\$ 1.19$ \\
\hline $11 / 7 / 94$ & $\$ 1.22$ & $\$ 1.19$ & $\$ 1.11$ & $\$ 1.30$ & $\$ 1.25$ & $\$ 1.19$ \\
\hline $11 / 14 / 94$ & $\$ 1.24$ & $\$ 1.19$ & $\$ 1.13$ & $\$ 1.30$ & $\$ 1.24$ & $\$ 1.19$ \\
\hline
\end{tabular}


The original plan was for Weyerhaeuser to be the sole owner. Under this arrangement, a power sales agreement for the plant life would have to be negotiated with Carolina Power \& Light or some other power purchaser. With the CP\&L position of valuing the power at its calculated avoided cost with no need for base load power until the middle of the next decade, the project is not economically attractive. However, the New Bern BGCC project could be the basis of a response to the regional Rural Electric Authority (REA) which has announced its intention to solicit bids for replacement of $600 \mathrm{MW}$ of base load power which it currently purchases from CP\&L. A larger, more efficient BGCC plant based on a General Electric 6FA gas turbine with export power of about $100 \mathrm{MW}$ would satisfy a portion of that load, and could match well with other bids likely to be based on gas fired combined cycles nominally 250 MW in size. The BGCC plant would represent supply diversity and, assuming DOE support, would have roughly comparable costs. This REA initiative further complicates the supply issue since it would result in even more CP\&L capacity becoming available and CP\&L may choose to negate the initiative by reducing electricity costs.

Nonetheless, the REA could decide to be a partner in the New Bern BGCC plant. It has determined that an alternate source of power is needed. It has a vested interest in the local communities, access to low cost money, and a need to support competitive power. This response to increasing energy costs is of concern to power companies and regulatory groups because of the potential to lead to stranded investment in utility capacity. An obvious outcome could be negotiated rate settlements at the Utility Commission level as a less costly solution to the general rate payer.

If the BGCC plant were designed to meet only the mill power and steam needs, the technology would not be portrayed in its best economic light but such an approach could serve the purpose of technology demonstration. Due to the smaller size equipment, power efficiency gain would be minimal and unit costs would be high. More cost-effective solutions to mill needs using conventional technologies may be available at lower risk. Establishing the plant as an industry owned facility as a means of commercial scale demonstration of BGCC technology benefits may be achievable because the industry has an interest in improving power system efficiencies. The industry would provide some level of cost share and would participate in assessment of the new technology benefits. The risk exposure of Weyerhaeuser would be reduced and the plant would be sized for internal use only, thereby avoiding conflicts with power producers. Although the plant would be too small to fully achieve potential efficiency gains, it would provide operating experience and an indication of the performance and reliability achieved by the BGCC power system design.

The range of support for such a demonstration could be broadened to incorporate the local and state communities. Weyerhaeuser, with industry support, could convince the state government and local communities of the value of the technology to the New Bern plant, the economic health of the forest products industry, the potential economic and environmental benefits to the region and the modest cost impact of supporting the demonstration.

\section{References}

[1] 1995 United States Fuel Reformulation Map, Hart/IRI Fuels Information Services, 1995.

[2] The World Reformulated Gasoline Directory, Fuel Reformulation, Hart Publications, Inc., July August, Vol. IV, No. 4, 1994.

[3] Washecheck, D. M., Amoco Petroleum Products Marketing Sector, personal communication, February, 24, 1995. 
[4] Shale, J. H., et. al., Amoco Petroleum Products Supply Logistics, personal communication, September 19, 1994.

[5] Clean Fuels Report, J. E. Sinor Consultants, Inc, Vol. 6, No. 2, April, 1994.

[6] Oxy-Fuel News Price Report, Oxy-Fuel News, Hart Publications, Inc., Vols. IV (1992), V (1993), VI (1994). 


\section{Section 7}

\section{Socioeconomic and Environmental Evaluation}

This section presents an overview of the impact of this project on the region with regard to the potential for new employment, industrial expansion, and development of a strengthened rural economy.

Two scenarios were considered for analysis of the direct staffing needs. For the first scenario, the Biomass Gasification Combined Cycle plant proposed in this project, permanent full time employment would increase by 46: to operate the plant 18 people would be added, while 28 people would be added to supply the wood. For the second scenario, the addition of a Biomass to Ethanol plant to the Biomass Gasification Combined Cycle plant, the employment total would increase to 113, comprised of 36 for plant operation and 77 for wood procurement. In addition, direct jobs equivalent to 103 and 258 persons/day, respectively for the two scenarios would be created during the construction phase.

The determination of the impact of these two proposed scenarios on employment in the area was also made using a computer model, "A Method for the Assessment of Site-Specific Economic Impacts of Commercial and Industrial Biomass Energy Facilities," developed by Resource Systems Group, Inc. for the Southeastern Regional Biomass Energy Program administered by the Tennessee Valley Authority. This program uses the feedstock information, capital and operating costs and factors developed for each state to estimate direct and indirect incomes as well as direct and indirect jobs.

Based on this model the number of direct jobs created by the Biomass Gasification Combined Cycle plant would be 129 . This total is greater than the 46 determined by the Weyerhaeuser project team. The difference appears to be a result of the method of calculating the direct jobs created by the purpose of wood chips (harvested wood). In the TVA program the tonnage of this wood is factored to determine the number of persons required to harvest the wood. Similarly for the addition of a Biomass to Ethanol plant to the Biomass Gasification Combined Cycle plant the computer program projected 319 direct jobs would be created, which is greater than the project team's projection of 113. Again this difference is associated with the wood harvest. The project team believes its estimates to be more realistic based upon experience. However, this discrepancy needs to be understood and should be addressed if the project goes forward.

Based on the model results, indirect jobs created as a result of these two projects are predicted to be 157 and 811 , respectively. 


\section{Section 8}

\section{Plan for Phase II of the New Bern Project}

The information summarized in this report demonstrates the availability of reasonable cost feedstock to support either a BGCC or an ethanol facility in the New Bern region. At ethanol prices of over $\sim \$ 1.40$ /gallon or enzyme costs of less than $\sim \$ 4.00 /$ gallon, the ethanol plant has the potential for attractive economics. However, the current status of development of the ethanol technology precludes commercialization at the scale studied here at this time. Several design issues need to be resolved and the economics revisited before a large scale commercial demonstration can be proposed.

As a result, the most attractive technology to carry forward to commercialization at New Bern or other similar sites is BGCC. The attractiveness of the BGCC technology is significantly impacted by the value of power produced and the capital cost of the plant. Given that likely reductions in capital cost of 2030 percent are achievable as subsequent facilities are cost engineered and built-and that power values of $5 \mathrm{c} / \mathrm{kWh}$ and greater are realizable through power contracts or displacement of purchased power-the results of this study demonstrate that biomass gasification combined cycle technology has significant potential for achieving improved pulp mill operations and biomass utilization efficiency. It also has the potential for developing additional product revenue streams which could enhance forest product industry economic productivity.

For these reasons, Weyerhaeuser has decided to proceed with the next stage of a biomass gasification project. The costs and risk of the first U.S. commercial BGCC system are such that significant cost sharing from the DOE or other sources will be essential to make this step feasible. Given the availability of this cost sharing to establish the commercial viability of BGCC technology, long-range plans for many Weyerhaeuser and industry pulp mills should include biomass gasification and black liquor gasification technology to satisfy energy, process and environmental requirements. Over time, effective use of these technologies will result in improved integration opportunities in pulp mill design and operational needs in addition to possible markets for added energy products that could result from the use of biomass gasification systems.

Weyerhaeuser believes that the advancement of this technology to a commercially-proven status is important to the industry and is consistent with the goals and objectives reviewed with the DOE and documented in the industry's "compact" with DOE which is based on the industry's vision of the future, "Agenda 2020".

For its New Bern mill, Weyerhaeuser has developed a detailed plan for implementing biomass gasification which is consistent with projected mill energy requirements, the technology evaluations presented in this report, technical assessments performed by Weyerhaeuser in parallel with this work, and market conditions prevailing in the New Bern area for biomass, electric power, and other potential products. Figure 8-1 shows the decision tree associated with the BGCC selection process.

The project design which minimizes capital cost and, therefore, risk is the use of an atmospheric pressure gasifier to provide a fuel gas which would displace the oil currently fired in the bark boiler and could also displace oil fired in the mill's lime kiln. This boiler retrofitting project will yield $40 \mathrm{MW}$ of biomass based power capacity through an existing back pressure and new condensing turbine, as well as reducing operating costs by essentially eliminating oil use and power purchase at the mill in the first phase of implementation. In a later phase, as black liquor gasification technology becomes available and power 
or liquid fuel values justify, the combined cycle plant will be added and biomass gasification will be expanded.

Specific elements of the project include:

- $\quad$ - $\quad$ Retrofitting of the existing $30 \mathrm{MW}$ oil-fired boiler to allow use of fuel gas in place of oil

- $\quad$ Addition of a $10 \mathrm{MW}$ condensing steam turbine

- $\quad$ Fuel gas conversion of the lime kiln

- $\quad$ Upgrade of biomass handling system to support gasifier operation

- $\quad$ Detailed engineering and cost estimates required for funding approvals

- $\quad$ Environmental permitting

- $\quad$ Scheduled construction start January, 1997

- $\quad$ Scheduled initial operation November, 1998

This project design has been determined to be the least costly manner of incorporating biomass gasification technology and its associated benefits into the New Bern mill. Economic risks related to introduction of this new technology into a pulp mill environment will be effectively managed by minimizing capital expenditures. Operational experience and understanding of the best means to integrate a full-scale gasification system into the New Bern mill operations will be achieved by this least costly approach, which will allow for future additional gasifiers which could be used for power or liquid fuel production from biomass available in the New Bern area. Demonstration of this technology at the New Bern mill in this manner provides significant life extension of existing plant facilities, increased use of biomass and plant wastes within the mill, and will confirm that technical requirements for commercial biomass gasification combined cycle power plants can be achieved. As Figure 8-1 shows, the alternatives to a gasification approach utilize fully commercial, low-risk technology. Shared funding will be necessary to offset the higher risk of gasification. 


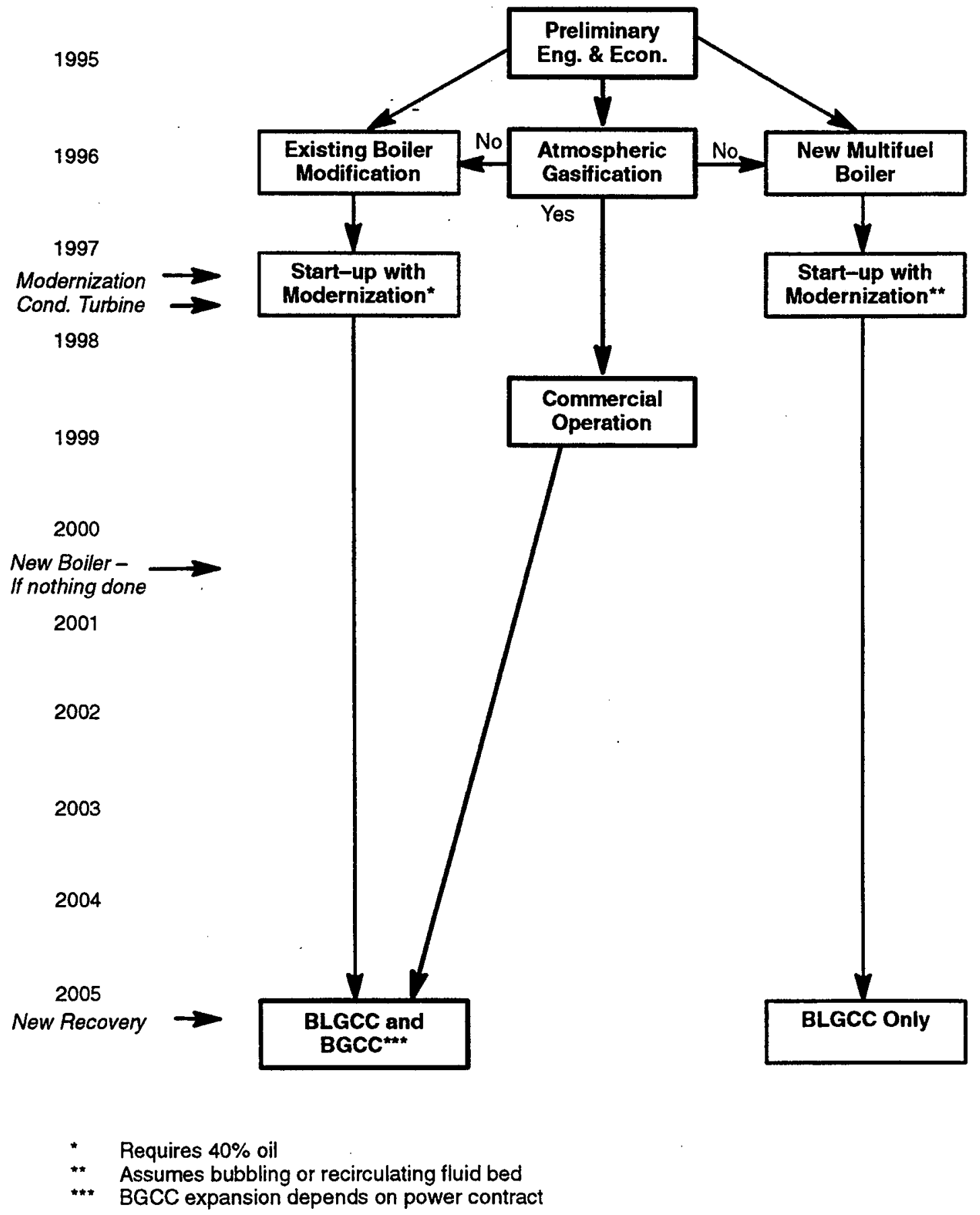

Figure 8-1: Power Island Alternatives for a

Sustained Competitive Future with Government Funding 


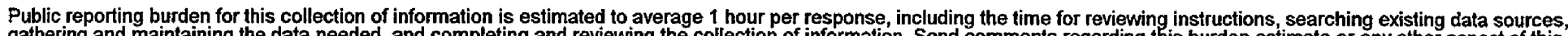

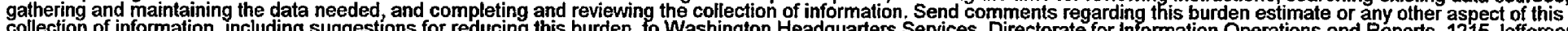

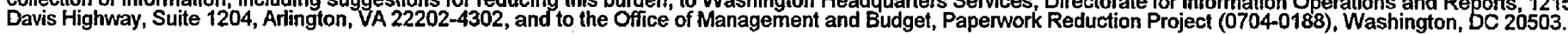

\section{AGENCY USE ONLY (Leave blank) 2. REPORT DATE October 1995 \\ 3. REPORT TYPE AND DATES COVERED \\ Subcontract Report}

\section{TITLE AND SUBTITLE}

New Bern Biomass to Energy Poject Phase I: Feasibility Study

5. FUNDING NUMBERS

(C) CAE-3-13383-01

(TA) BF521002

\section{AUTHOR(S)}

Stone \& Webster, Weyerhauser, Amoco, and Carolina Power \& Light

\section{PERFORMING ORGANIZATION NAME(S) AND ADDRESS(ES)}

Same as 6

8. PERFORMING ORGANIZATION REPORT NUMBER

\section{SPONSORING/MONITORING AGENCY NAME(S) AND ADDRESS(ES)}

National Renewable Energy Laboratory

1617 Cole Boulevard

Golden, CO 80401-3393

NA

10. SPONSORING/MONITORING AGENCY REPORT NUMBER

NREUTP-421-7942

\section{SUPPLEMENTARY NOTES}

\section{2a. DISTRIBUTION/AVAILABILITY STATEMENT}

National Technical Information Service

U.S. Department of Commerce

5285 Port Royal Road

Springfield, VA 22161 12b. DISTRIBUTION CODE

UC-1503

\section{ABSTRACT (Maximum 200 words)}

The concept of this project is to define a specific dedicated feedstock supply system for serving an advanced biomass-to-energy conversion process located at Weyerhauser's market pulp mill in New Bern, North Carolina. It is a feasibility study of the capital cost, operating economics, and regional impact of two technologies: biomass gasification combined cycle and biomass to ethanol.

\section{SUBJECT TERMS}

biomass, dedicated feedstock supply system, gasification

15. NUMBER OF PAGES 200

16. PRICE CODE

17. SECURITY CLASSIFICATION OF REPORT
18. SECURITY CLASSIFICATION OF THIS PAGE
19. SECURITY CLASSIFICATION OF ABSTRACT
20. LIMITATION OF ABSTRACT 